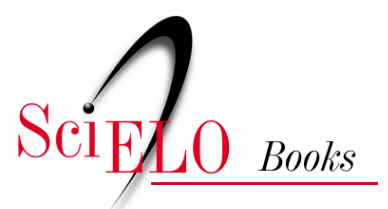

\title{
History of Health in Rio de Janeiro
}

institutions and architectural heritage

\author{
Ângela Porto \\ Gisele Sanglard \\ Maria Rachel Fróes da Fonseca \\ Renato da Gama-Rosa Costa \\ (orgs.)
}

\section{SciELO Books / SciELO Livros / SciELO Libros}

PORTO, Â., SANGLARD, G., FONSECA, M.R.F., and COSTA, R.G.R., orgs. History of Health in Rio de Janeiro: institutions and architectural heritage: História da saúde no Rio de Janeiro: instituições e patrimônio arquitetônico (1808-1958) [online]. Rio de Janeiro: Editora FIOCRUZ, 2008, 167 p. ISBN: 978-85-7541-599-3. Available from: doi: 10.7476/9788575415993.0011. Also available in ePUB from: http://books.scielo.org/id/7f83x/epub/porto-9788575415993.epub.

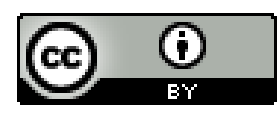

All the contents of this work, except where otherwise noted, is licensed under a Creative Commons Attribution $\underline{4.0 \text { International license. }}$

Todo o conteúdo deste trabalho, exceto quando houver ressalva, é publicado sob a licença Creative Commons Atribição 4.0. 


\section{Introduction}

"História da Saúde no Rio de Janeiro: instituições e patrimônio arquitetônico (1808-1958)" [History of Health in Rio de Janeiro: institutions and architectural heritage] comes from a collective project whose main objective was to identify and publicize the heritage of constructed assets that compose the health-related cultural heritage of the city. By researching the institutional and architectural history of hospitals, medical care facilities and scientific research institutes created from the beginning of $19^{\text {th }}$ to mid- $20^{\text {th }}$ century, we wanted to contribute for the preservation of health-related scientific and cultural heritage. Many institutions here depicted already had their buildings preserved by the Federal Government, while others' preservation processes are still at work. However, that does not imply a full preservation. Most of them have not achieved it yet, being unprotected or losing their original features; others, like the Medical School at Praia Vermelha, were transferred to someplace else, since its original building no longer exists.

This research came from a survey made on 1994 by architect Benedito Tadeu de Oliveira (Departamento de Patrimônio Histórico da Casa de Oswaldo Cruz [Casa de Oswaldo Cruz Historical Heritage Department]), Jaime Benchimol, and me (Departamento de Pesquisa da Casa de Oswaldo Cruz [Casa de Oswaldo Cruz Research Department]). Back then, we wanted to list and identify health-related buildings which were preserved or about to be preserved at Rio de Janeiro on federal, statewide and municipal levels, specially the unprotected ones. This primary survey was proposed by Mr. Paulo José Pardal, scholar, member of Instituto Histórico e Geográfico Brasileiro [Brazilian Geographic and Historical Institute] and of Instituto Estadual de Patrimônio Cultural [State Institute of Cultural Heritage] - Inepac/RJ. Mr. Pardal was a relentless guardian of Rio de Janeiro's Historical Heritage. This work is dedicated to his loving memory.

Other buildings were added to this primary list. They were identified on a survey developed by Renato da Gama-Rosa Costa and Gisele Sanglard that studied the creation of Public Assistance [Assistência Pública] at the federal capital during Brazilian Old Republic [República Velha], as well as the works of Divisão de Obras do Ministério da Saúde [Health Department Building Division] post-1930. We also found institutions, especially science academies, on the Dicionário Histórico-Biográfico das Ciências da Saúde no Brasil [Historical and Biographical Dictionary of Brazilian Health Sciences] (1832-1930), organized by Maria Rachel Fróes da Fonseca.

With no intent to finish the huge list that we imposed on ourselves, or even try to make a final study about all institutions and constructed heritages, we present for now an expressive amount of institutions, as well as the main buildings that compose the Health Architectural Heritage at Rio de Janeiro County. Our objective is to publicize and give them a long deserved acknowledgement. 
We wanted to highlight several categories representing the cultural and scientific heritage of health in Rio de Janeiro: medical facilities, hospitals, hospital centers, leprosarium and other facilities for infectious diseases, hospices and mental institutions, research facilities, laboratories, medical teaching and therapeutical institutions, government agencies, as well as medical and scientific academies and associations. Once we identified the core institutions and their relevant buildings for the history of city health, we gathered information and images at archives and libraries that kept referential collections on the subject. Not all institutions accepted to join this research; others did not have enough documents to recover their history, but opened their doors to our team. This might give the reader a false impression of heterogeneous content when comparing entries about different institutions, or noticing the lack of well-known institutions. Those facts were neither planned nor controlled by us. Therefore, it should not be taken as research negligence.

Going through the history of these institutions allowed us to get a deeper knowledge on the history of health in Brazil, especially when it comes to its features and how health care has changed over the $19^{\text {th }}$ and $20^{\text {th }}$ centuries. The architecture reflects this process, since it reveals not only the medical knowledge of that era but also the relationship between health and disease. The architectural styles adopted to build hospitals unveil the ideas and means to treat an illness at a given time. Thus, the pavilion structure is replaced by in block architecture, uniting in a single space patients formerly doomed to isolation. Medicine, science, and society are connected and define both health policies and how those policies apply themselves on a practical level.

All institutions here presented had their facilities fully or partially preserved. Some of them had several head offices over time. By recovering their history and images, we propose a route over the History of Health in Rio de Janeiro.

Due to its dimensions, this work comes in two forms: a book and an attached CD-ROM. The first contains essays about the history of health in Rio de Janeiro. This history, presented on five parts, goes through different times and contexts. Working as an introduction, part one: "Memória, História e Patrimônio Cultural da Saúde: uma história possível [Health Memory, History and Cultural Heritage: a possible history]", by Gisele Sanglard \& Renato da Gama-Rosa Costa, approaches history, memory, and heritage concepts, as well as the relationship between them and preservative actions - both public and private. The following parts analyze the three large periods on which this research was divided. "A saúde pública no Rio de Janeiro imperial [Public health at Rio de Janeiro during the empire years]", de Maria Rachel Fróes da Fonseca offers a view on health facilities in 19th century, back to their colonial origins; "A Primeira República e a constituição de uma rede hospitalar no Distrito Federal [Brazilian First Republic and the formation of a hospital network at Federal District", by Gisele Sanglard, deals with institutions and facilities built during Brazilian Old Republic, where public health care on Federal Capital suffered noticeable transformations; "Política e Saúde: Diretrizes Nacionais e Assistência Médica no Distrito Federal pós-30 [Politics and Health: National Guidelines and Medical Assistance at Federal District post-1930]", by Cristina M. Oliveira Fonseca, analyzes the period, stressing the opening of hospitals during Pedro Ernesto government as mayor and Gustavo Capanema period at the Ministério da Educação e Saúde [Department of Education and Health] (MES). Finally, "Arquitetura e saúde no Rio de Janeiro [Architecture and Health at Rio de Janeiro]" 
describes the architectural history of health facilities during the period analyzed on this study. All parts are followed by images.

The included CD-ROM has entries about institutions and facilities containing history, location, features, current use, and architectural data. Each entry is followed by selected images from the past and present. The CD-ROM contains both English and Spanish languages translations of the essays and the entries.

The period between 1808 and 1958 was chosen because we wanted to work with the year when Portuguese Royal Family arrived and the transformations that followed. Of course, we also wanted to celebrate the bicentennial of such arrival, which happens this year. Our research follows a 150 year period, ending at 1958. The fifties were chosen as the final landmark since it points out both the strengthening of hospital architecture and the moment on which the architect fully assumes the hospital building projects.

We would like to thank everyone who opened out their houses, facilities, and collections, hereby represented by the following institutions: Maternidade de Laranjeiras [Laranjeiras Maternity Hospital], Casa de Portugal: Hospital e Maternidade [House of Portugal: Maternity and General Hospital], Hospital do Amparo Feminino [Female Care Hospital], Sociedade Beneficente Israelita do Rio de Janeiro [Israeli Beneficent Society on Rio de Janeiro], Hospital Evangélico [Protestant Hospital], Hospital Central da Aeronáutica [Brazilian Air Force Central Hospital]; Hospital de Ipanema [Ipanema Hospital], HospitalMaternidade Herculano Pinheiro [Maternity and General Hospital Herculano Pinheiro], Maternidade Alexander Fleming [Alexander Fleming Maternity Hospital], Hospital São Lucas [São Lucas Hospital], Instituto Nacional de Educação de Surdos [Educational National Institute for the Hearing-Impaired] (INES), Serviço de Documentação da Marinha [Navy Documentation Service], e Instituto de Hematologia Arthur Siqueira de Cavalcanti [Hematology Institute Arthur Siqueira de Cavalcanti] (HEMORIO); and we would also like to thank the invaluable support provided by Vera Wanderley (Pro-Matre), Luiz Guilherme Romano (Casa de Saúde Sta. Lúcia [Sta. Lucia Nursing Home]), Olga de Fátima Barros (Beneficência Portuguesa [Portuguese Charity Hospital]), Everson Sofiste (Museu dos Bombeiros [Fire Department Museum]), Dásio Lopes Simões e Elizabeth Bittencourt Constantino (Hospital do Andaraí [Andaraí Hospital]), Alexandre Estelito Mourão e Mello e Fladenor Belfort Leite (Casa de Portugal [House of Portugal]), e Coronel Hélio Gouveia Prado (5ª Divisão de Levantamento do Exército [Brazilian Army $5^{\text {th }}$ Survey Division]).

Finally, thanks to Luíza Andrea from SPCOC, for her dedication to obtain funds to make this project possible, as well as Cobra Tecnologia for its financial support. 


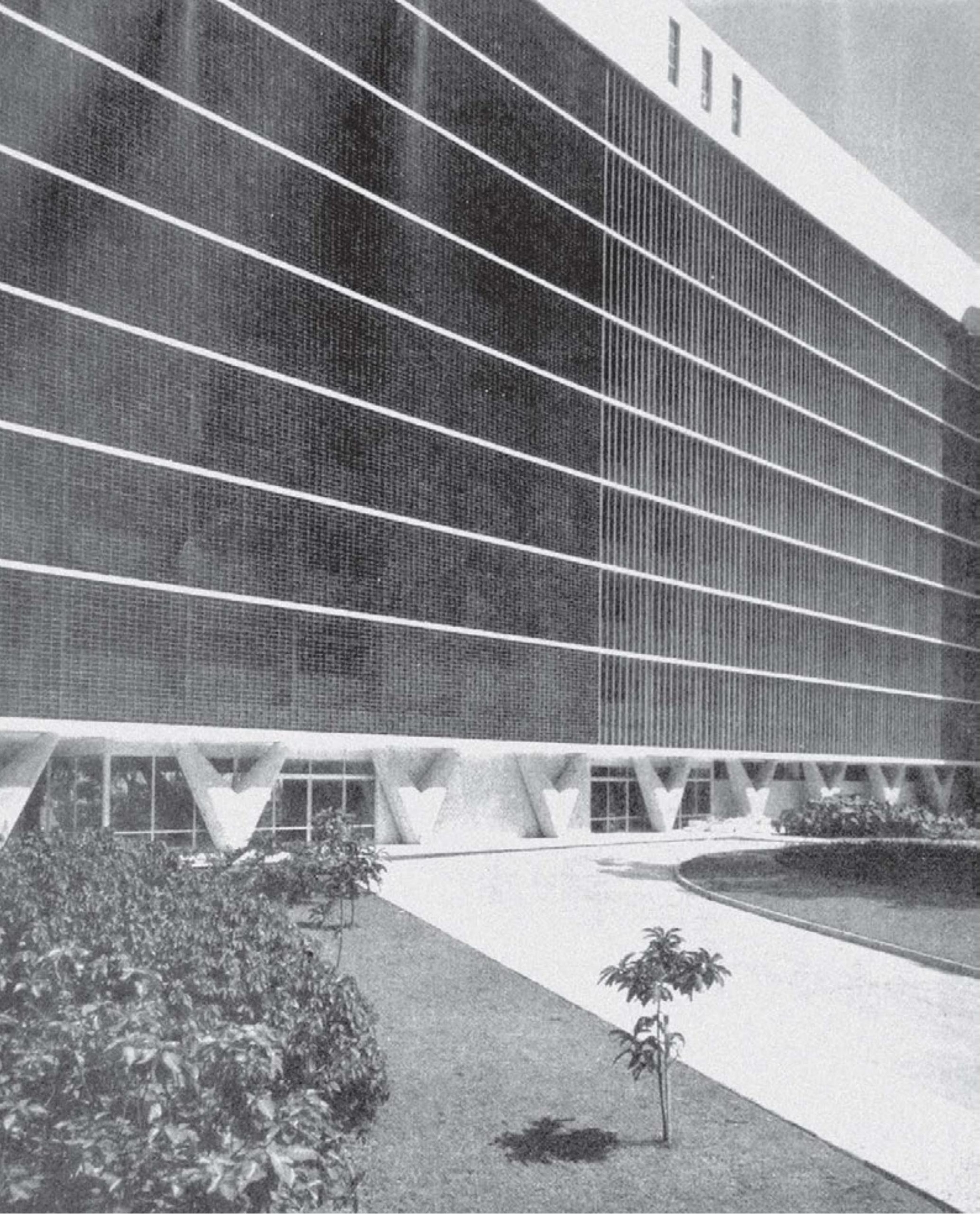




\section{Memory, History and Cultural heritage of health care: a possible history}

Gisele Sanglard

Renato da Gama-Rosa Costa 


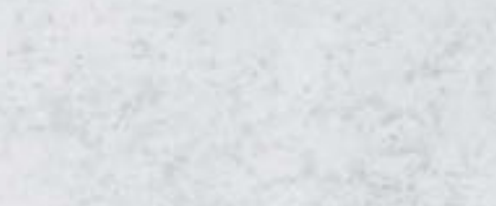

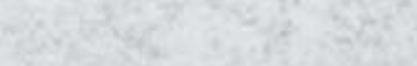


This book is a product of an initial effort made by researchers from the Casa de Oswaldo Cruz/ Fiocruz to deepen studies on work which have been going on for many years at the Institution and looks to relate historical aspects with the identification and appreciation of the health care heritage in Rio de Janeiro. The last decade has shown a large growth in the number of studies related to the history of health care, which has added new objects and approaches, such as, for example, the study of the hospitals and the architecture for health care.

In this proposal we intend to demonstrate the architectural heritage of health care institutions which, although they are part of everyday life, have not been given the proper recognition yet; or in other cases, as their original usage has been changed, the buildings have lost their identity and usage. In this perspective, we will examine representative aspects of health care heritage in Rio de Janeiro.

The chronological cross section to be examined considers two important landmarks in the History of Health Care in Brazil: on the one hand, the year 1808 goes back to the arrival of the Portuguese Royal Family and to the context of transformations which followed. With the arrival of the Court, Brazil became the administrative center of the Kingdom and important administrative, economic and cultural measures were implemented, which had an impact on the development of medicine in Brazil, such as the foundation of the first medical and surgical educational institutions in the cities of Salvador and Rio de Janeiro. The School of Surgical, in Salvador, and the Anatomic, Surgical and Medical School in Rio de Janeiro, created in 1808, were aimed at preparing the professionals to perform the essential public services at that time.

On the other side of history, much more recently, the decade of 1950 represented also a landmark in terms of institutional development in medicine and public health in Brazil, with the creation, in 1953, of the Ministry of Health - something physicians had been wishing for since the beginning of that century. This moment in history was characterized by the consolidation of the single structure type of hospital architecture, as well as a time when professional architects started to assume responsibility for hospital construction projects. It is important to mention, until the decade of 1940, that doctors still had considerable control over project and moreover it was engineers, sometimes sanitary engineers, who had technical responsibility for the projects. With modern architecture, the architect began to use the hospital program as a way to exercise to the fullest his or her ability to put together scientific knowledge complexes into a civil construction. The preparation of a hospital construction project 
always depends on a multi-disciplinary team made up of doctors and specialists from different areas. Architects began to coordinate the entire process and, starting in the 1960s, projects began to take on standardization both in terms of type and architectural form.

\section{The places for memory, history and heritage}

This book makes us reflect on the relations between history, memory and heritage - concepts which are apparently far apart from one another, but are closely connected. Since the publication of the work coordinated by French historian Pierre Nora, Les Lieux de Mémoire (1984), studies involving memory and history started to win historians all over the world and, particularly, in France. After this study many others followed attempting to think about the relation between these concepts and applying them in case studies, many of them dedicated to reflect about the history of France and the memory of the Jews who survived the Shoah (Joutard, 1993; Todorov, 1995; Ricour, 2000; Yates, 1975; Detienne, 1988; Bosi, 1987; Lowenthal, 1988; Rossi, 1991).

The work of Pierre Nora however, was not the first of its kind. Among the classics should be mentioned the works of Henri Bergson (1990) and Maurice Halbwachs (1990) - published for the first time, respectively, in 1896 and in the first quarter of the $20^{\text {th }}$ century. And between the years of 1977 and 1982, Jacques Le Goff, also a historian and Nora's partner in the Faire de l'histoire collection, published a series of articles in the Einaudi Encyclopedia, published together shortly afterwards - 1986 - in a work entitled Histoire et Mémoire. Among the articles written by Le Goff should be mentioned "History", "Memory" and "Document/Monument" - where memory is understood to be a crucial concept, as it is a living storage place of history, despite its mobility, and rich in files and in documents/monuments, besides being considered as "a sounding echo (and a living one) of historical work" (1992: 475). And documents and monuments are two kinds of materials applied to the collective memory, and to what Le Goff called "its scientific form" (p. 535), history. The document is a product of the society which created it and only the analysis "of the document as a monument allows the collective memory to recover it and the historian to use it scientifically" (p. 545). In this sense every document is a monument, and every monument is a document which can be analyzed by the historian.

In Brazil, still during the same decade, we can mention publication $\mathrm{n}^{\circ} 87$ (Memory and History), from 1986, from the Tempo Brasileiro Magazine, from the Colégio do Brasil; and the Estudos Históricos Magazine, no 3 (1989/1), published by the Research and Documentation Center of the Fundação Getúlio Vargas (CPDOC/FGV), dedicated to the theme of "Memória" (Memory), and brought texts of the sociologist Michel Pollack, "Memória e Esquecimento" (Memory and Forgetfulness)"; by anthropologist Hugo Lovissolo, "Memória e formação dos homens" ("Memory and the Formation of Man") and historian Myriam Moraes Lins de Barros "Memória e família" ("Memory and Family") - which shows the importance of this discussion in Brazilian academic circles ${ }^{1}$. It is important to mention the works of historian Ulpiano Bezerra de Menezes (1999) about memory, history and heritage and his concern about the value given to heritage. For him, "the direction and effectiveness of work involving cultural heritage depends, in the very essence, on our form of society, of the type of relationships we wish to establish between men" (1992:194).

Pierre Nora (1984) calls attention to the fact that the concepts of memory and history are opposites. Memory - the goddess Mnemosine goddess -, made up of equal parts of memory and forgetfulness, is 
alive, is in constant change and subject to manipulations; history - the muse Clio, Mnemosin's daughter - is the imperfect reconstruction of that which no longer exists, or in other words: memory is rooted in concrete, in what is tangible - in a specific space, in a gesture or object, in the absolute; while history is connected to the temporal continuities, in evolution and in the relation between things, working in the realm of relativization (Nora, 1984: XIX). And Le Goff highlights that time, essential category for historical studies, records memory in history. Memory is also, and, chiefly, "an essential element of what it is usually called identity, individual or collective, the search of which is one of the essential activities of individuals and modern day societies..." (Le Goff, 1992: 476).

Thus, to talk about memory is to talk about group identity and the memory places would be the spaces where the memory congeals and hides itself. It can be found in files, statues, cemeteries, dictionaries and anywhere else. The need to go to these "places" is because the means by which the memory is transmitted do not exist anymore - oral tradition. For Walter Benjamin (1993) the end of the storyteller as a key figure in transmitting memory comes from the loss of a collective experience and the increase in individuality, typical of his time. Pierre Nora (1997) highlights that, in the specific case of France, the cult to memory is linked to Europe's unification process and this movement thus could be understood as a reflection of the identity crisis which France underwent at the end of the last century. The destruction of traditional identities, in addition to the need for a collective identity, was, in part, one of the factors responsible for the cult to memory. Todorov (1995) adds that only by putting together a common past that it will be possible to gain the recognition of the group.

One of the consequences of this movement is the fever of celebrations: the national dates, the big events, or even events that interconnect a smaller group. The celebrations themselves have become objects of analysis, in places of memory (lugares de memória), as a way to control the phenomenon, but that wound up being absorbed by the "commemorative bulimy", as Paul Ricœur (2000) defined the celebration fever that took place first in France, but later reached other countries.

This fever opened the way for another phenomenon, totally connected to the cult to the memory: the promotion of heritage and its crystallization as the "historical monument". By heritage we mean a whole set of legends, memories, language and even crucial peculiarities of nature, in other words, which designate certain essential conditions for the existence of a nation (Chastel, 1997: 1433), always assuming the idea of continuity and a function of feeding cultural identity (Menezes, 2006: 182). Monuments can be divided in three different classes: those classified as "intentional" having been created to commemorate a specific event; historical - which have been given this characteristic using subjective criteria; and ancient - those which have survived to the action of time. It is precisely this attribution of historic value to an artistic category, especially when connected to patriot and national interests, that protects the monument. Or as Dominique Poulot says, mentioning A. Riegl, protection only becomes effective when the entire population considers their ancestors' works as part of their own creative activity (Poulot, 1997: 1534). Thus, heritage is situated between memory and history (Le Goff, 1997) and

Memory has given to heritage its life, dynamics and vigor. But its emancipating work is finished. The problems associated with heritage are now firmly installed in the heart of contemporaneous societies. As for its rate of growth, its firm rooting in the long term, the most profound reasons for its existence and its future, it is, however history, and only history, that can and must provide them: by the choice 
it dictates, by the priorities which it suggests or imposes, by the scale of value it can support, by the discipline which it represents. (Nora, 1997: 397, our italics)

It is history's role to study it and thus make possible its knowledge over time. Thus, the concepts of history, memory and heritage, are very intimately interconnected, we would even say, that they cannot be separated. It is through historical studies that people will become conscience about the importance of heritage and the need to preserve it - it is only through knowledge that its defense can be constructed. Thus, heritage must be the object of knowledge which it has to stimulate. For Jacques Le Goff it is a must to transform heritage into an object of knowledge (1997: 119) and for Ulpiano Bezerra de Menezes

Different types of testimony about "old times" must be considered as informational support about change, its processes, its scope. Therefore we must not consider them only as products, but also investigate the contexts in which they are produced and consumed. (Menezes, 2006: 186)

In this regard, France is an example of what can be done in terms of actions and policies of preservation of the national heritage - whether in architecture, museums, the arts or archives. It is no wonder that museums, archives, libraries, medals, cemeteries, cenotaphs, national festivals, historic monuments, national symbols are considered as memory places (lugares de memória) for the French people. The health care heritage also enters into the list of these special places such as the Hôtel-Dieu in Beaune (Bourgogne), which has been transformed into a museum and recreating the scenario of the end of the 15th century, when it was built; or Musée de l'Assistance Publique-Hôpitaux from Paris, that keeps a big museum collection, made up of items from Paris hospitals²; or the Archives de l'Assistance Publique-Hôpitaux in Paris ${ }^{3}$.

In the area of real estate preservation, it should be noted the movement to preserve the French sanatoriums, built in the period between the world wars to fight tuberculosis. The insertion of these buildings in the list of monuments faces difficulties which involve the collective memory of different players, as tuberculosis was the big scourge of French society of the end of the 19th century and beginning of the 20th lasting until the end of the First World War. These buildings became, for most French families, a symbol of the past, still very vivid in the memory, where a relative or friend was admitted in a system similar to a concentration camp, in a place of death. In the medical imagination, under the surface these institutions brought the idea of an illusion, a therapeutic failure, as these 'hotel-hospitals' did not bring about a complete total cure, which only became possible with the discovery of antibiotics. For those wanting to use these installations for other purposes, these sanatoriums, built to be isolated and large in size, are difficult to insert into city economies, which is an obstacle for public and private sectors investments (Cremnitzer, 2005). Transforming this negative, or at least uncomfortable remembrance, into something positive, allowing these buildings to become "places of memory" of medicine and health care, is a movement that architects, doctors and students of heritage have implemented in France.

\section{The heritage question in Latin America and in Brazil}

As stated by Françoise Choay (2001) the idea of historical monuments and the practices of preservation were restricted to Europe until the end of the 19 th century and the first decade of the $20^{\text {th }}$ century. The international conferences for the Conservation of Historical Monuments, held in Athens, in 1931 and 
in Venice, in 1964, although involving a massive participation by Europeans, as observed by Choay, they were certainly important in spreading the discussed concepts in the conferences all over the rest of the world. For Funari and Pelegrini, the emphasis on national heritage on a worldwide level occurred between the two World Wars (2006), due to losses brought about by the conflicts, reflecting on the rest of the world. In the case of Brazil, other factors were considered, as we shall see later on.

The construction of heritage and worldwide preservation actions were to occur on three fronts: in the understanding as to its value as a monument and symbol; on the understanding of what should be considered as heritage and the creation of organs and institutions whose mission is to preserve. At the heart of these actions is the discussion and choice of what can be considered as heritage and how to act to preserve and safeguard it for future generations.

The holding of the seventh meeting of Entretiens du Patrimoine - seminary organized by the Heritage Board of Directors - in 1998, to celebrate the 30 years of the publication of the National Heritage Inventory, confirms the relevance of these discussions still today. The seminary, which received the subtitle Science and Heritage Consciousness, was attended by historians, geographers, architects, preservers, and other professionals involved in the discussion about heritage; besides politicians. Supervision of the work, done by Pierre Nora, made very clear the close connection between history and heritage or as stated by Maurice Agulhon, to justify his presence in the seminary: every dated object is related to time and everything that is related to time is of interest to historians. Therefore, objects of art and related items are of interest to historians (Agulhon, 1997: 31-38).

The idea of heritage, constructed over a long period of time in Europe since the French Revolution, arose in Brazil in connection with activities during the Estado Novo period and to the modern concept of patrimony, that was understood as being: "no longer in the private or religious scope of ancient and medieval traditions, but of an entire civilization, with a single language, origin and territory" (Funari e Pelegrini, 2006: 17). This statement, directed by the authors to the Italian example, could very easily be inserted into the context of the first government of President Getúlio Vargas (1930-1945) and his policies of the formation of the Brazilian State, associated to the construction of a national identity. We remind that this subject was present in Brazil since the decade of 1920, involving arts and the constitution of a national esthetics solidly based on the rereading of the colonial origins. In the 1930s, this national identity would gain well defined directions, in search of an esthetics that would look to the future, while at the same time trying to keep a dialogue with the past.

When we talk about identity and nationality we are dealing with ideas and concepts constructed over time and which in Brazil it have assumed contradictory characteristics, when discussing subjects like origin, past, tradition and future. When we talk about Brazilian heritage, we must be aware that this heritage was not built up naturally; in other words, this heritage was constructed, accepted and shared, by institutions, intellectuals and technicians participating in the discussions about a national memory. Only in the 1930s did the question of memory in Brazil start to grow. Maria Cecília Londres Fonseca (2005) points out that the year 1934 marked the beginning of this process. In this year the constitution defined the responsibility of protecting natural beauties and monuments with a historic or artistic value as belonging to the Federal and State governments. It is not surprising that in the same year the colonial city of Ouro Preto (MG) was chosen as national monument. 
Fonseca (2005) points out two peculiarities in the establishment, in Brazil, of an organ specifically focused on the preservation of the historical and artistic national heritage. First, while the European countries looked at types of individual assets, in Brazil the approach was more "widespread and coordinated", proposing "a single institution to protect the whole universe of cultural assets" (Fonseca, 2005: 97). Secondly, the involvement of intellectuals in the project gave a clearly more innovative posture, principally, in the use of the historic monument concept and in the process of choosing the objects from the past which were to be safeguarded, in line with the indication of the Athens Letter, of $1933^{4}$.

The Ministry of Health and Education, established in 1934, would take on the task of creating this organ to itself, organizing the National Historical and Artistic Heritage Service (SPHAN) and linking it to a wider understanding about heritage and memory, adding them to a notion of art and culture. A culture that expressed itself as a synthesis of the Ministry's three focuses of action: education, public health and social assistance. As stated by Gustavo Capanema, Education and Health minister between 1934 and 1945, these actions would have a single objective: the formation of the Brazilian culture (Amora, 2006: 17).

The idea of culture would wind up prevailing and SPHAN would go on to report to the Ministry of Culture, starting in the 1980s. As stated by Maria Cecilia Londres Fonseca, between the end of the 1970s and the beginning of the 1980s, the ministry chose to prioritize not only the cultural needs of the groups excluded from the benefits of the cultural policies implemented thus far, but also to meet their economic and social needs. More than this: "these communities needed to start participating in the building and management of Brazilian cultural production, including cultural heritage" (Fonseca, 2005: 158).

Indeed, as an essential attribute of the exercise of citizenship and of the responsibility of the State, this decade saw initiatives aimed at recovering memory, attributing value and rights to information. More specifically in Brazil, the 'memory fever', as discussed in the work of the Nora and Le Goff group, reached files and the historical documentation. These, in a way, benefited from the "memory fever" that started to appear not only as a subject of study among specialists, but that also showed itself to be - in that context - a support to the processes of construction of a national identity, of group demands and of the expression of desires of different social segments that returned with strength to the center of the political process. We can identify a similar situation in other countries in the Americas, in a context of recovery, consolidation and extension of the conditions of free expression and social participation.

In this regards, the document presented by the Group of Historical Work and Cultural Heritage of the Health Care Sector, joined during the 4th Meeting of the Regional Coordination of the Virtual Health Care Library (BVS) / 7th, within the Regional Information Congress on Health Sciences (CRICS), held in the city of Salvador, in the year of 2005, that we can understand as a milestone in the discussion of history, memory and heritage of health care in Brazil, considered" the Cultural Heritage in the Health Care area as a combination of material and symbolic goods built up socially, which express the process of the individual and collective health in its scientific, historic and cultural dimensions" 5 .

When discussing work with Health Care Cultural Heritage, first we will define an overall concept and which will allow for accompanying the transformations which health care has undergone since the beginning of the Portuguese colonization. "Health Care" is not a piece of data, but a historical and social construction whose definitions, cultural meanings and political arrangements can change over 
time. This diversity is what we plan to identify and catalog. Thus, we are recording this work in the formula proposed by Pierre Nora and Jacques Le Goff, where heritage is located between memory and history and where it is the latter's job to analyze it.

Attempts to safeguard health care heritage have been appearing on the international scene over the last years, connected directly to the symbolic value assigned to it by the communities in which it is inserted. Examples in Netherlands, India, England and France ${ }^{6}$, can be added to the case of pioneering experiences in Chile. Arising from the mobilization of the population and of its employees against the demolition of the ancient San José Hospital, this experience allowed for the Chilean Ministry of Education to forbid its demolition and, more than this, led to the foundation of the Unit of Health Care Cultural Heritage, linked to the Ministry of Health, serving as inspiration for the establishment of the Latin American network to which we have been registered since 2005.

This movement is going on at the same time to a new evaluation that historiography is making of hospitals which are not only being studied as places for the practice of medicine, to be included in the historical analysis - inserted in the context of the history of health care and the social history. The space that the study of hospitals is occupying can may be seen from the academic congresses, as the Jornadas Peruanas de Historia de la Ciencia, la Tecnología y la Salud Medicina Social e Inclusión Social en Perspectiva Histórica (Peruvian Congress on the History of Science, Technology and Social Medical health and Social Inclusion), which took place in September/2007, in Lima/Peru. At this seminar there was a round table discussion on the subject - Hospitales en perspectiva historica (Hospitals in a Historical Perspective) that has the participation of Peruvian Antonio Coello, American Brian Bauer (Evidencias arqueológicas del Hospital de San Andrés) (Archaeological Evidence of the San Andrés Hospital) and Mexican María Rosa Gudiño (Hospitales y Pintura mural. Salud y Modernización en México 1944-1958) (Hospitals and Mural Painting, Health and Modernization in México 1944-1958).

In Europe, seminars such Bispos, Cabidos e Assistência na Península Ibérica (séculos XVI-XVIII) (Bishops, Ecclesiastical Officials and Social Work on the Iberian Peninsula in the $16^{\text {th }}$ through $18^{\text {th }}$ Centuries), held at the University of Évora, Portugal, resulted in a book compiled by Laurinda Abreu (2004), aimed at discussing the role of the hospital in those societies. At this seminar, specifically, the subjects of social work, the Church and secular authorities were discussed by historians from Brazil, Portugal and Spain emphasizing the actions of Charitable Institutions and the connection of the Hospital with the Church in the Modern period, and other related subjects. The same can be said about the (a) thematic session Assistência e caridade como estratégias de intervenção social: igreja, estado e comunidade (Península Ibérica, séculos $X V-X X$ ) (Social work and charity as strategies of intervention in society: church, state and the community (Iberian Peninsula, $15^{\text {th }}$ to the $20^{\text {th }}$ Century))-, which took place at the $25^{\text {th }}$ Meeting of the Portuguese Association of Social and Economic History, in 2005, also at Évora. From this second event came the book, organized by Laurinda Abreu (2007), with the same name as the thematic session which originated it. With the participation of Portuguese and Spanish historians, the book allows to draw a panorama of the hospital on the Iberian Peninsula, over an extended period.

In this regard, the opening of museums dedicated to health care, inside universities and hospitals, in different countries of Latin America - strongly marked by cultural diversity -, seems to point to a direction that makes us relive the memory fever of the 1980s, but this time including the health care heritage, creating spaces for thinking, spreading the word and teaching. The most important examples 
are those from the School of Medical Sciences of the National University of Córdoba and the museums dedicated to hospitals, in Argentina, such as the Historic Museum Hospital B. Rivadavia, that holds meetings about the Cultural Heritage of hospitals, in partnership with the Commission of Historical Cultural Heritage Preservation of the Argentine Ministry of Culture?

In Brazil, there are still only a few studies about the history of hospitals, as well as the preservation actions of the buildings linked to them, as some of the 'Public Charity Hospitals' (Santas Casas da Misericórdia). We could mention the Emílio Ribas Museum as the pioneer, installed where the old State Disinfectory used to operate, or even the Medical History Museum of Rio Grande do Sul, installed at the Beneficiência Portuguesa Hopsital in Porto Alegre, founded at the end of last year (2007), in partnership with the Physicians' Association of Rio Grande do Sul. An important example is the Fundação Oswaldo Cruz (Oswaldo Cruz Foundation) in Rio de Janeiro, on which a complex of buildings constructed at the beginning of the 20th Century for research labs, teaching and production in health care products, was protected from possible demolition by an act of the IPHAN, receiving continuous investments since then for its conservation. On the other hand, there is no organized tool with systematic information that allows students on the subject, much less lay persons to recover the history of health care in the country through its monuments.

With this book we intend to continue these discussions and hope that this work can serve as a reference for preservation actions of the organs responsible in the three spheres of government: federal, statewide and municipal. It is our desire that the information obtained can help in the process of registering other assets for preservation adding to the (few) objects related of health care already registered

and that these can be valued using a broader cultural view, associating them to history of health care and of its institutions and collections.

Finally, we intend to show the professionals who have worked on architectural projects, including architects, engineers and builders, in an attempt to recover their work, often times, forgotten by the history of the Brazilian architecture. We insist that such history has been give special attention to the investigation of hospital programs, and when it does, it seeks to concentrate on the individual actions of the professionals, not considering, to a certain degree, the political and administrative structure that allowed the massive construction of public buildings all over Brazil, principally after the 1930s, and especially during the first Vargas government.

This work has as objective to turn public this valuable source of information on the history of health care and biomedical sciences in Brazil, which, in addition to the identification of its archival, bibliographic and museum collections, will make possible new investigations and generation of knowledge.

The legacy received from those coming before us helps to understand our history and makes clear the values which characterize the group to which we belong. The disappearance of the most important references of a group or place, such as architectural landmarks, landscape or cultural expression, makes that individual lose his or her identification with the environment where he or she lives and his or her history. 


\section{Notes}

${ }^{1}$ The organization of the Mémoire et Histoire International Forum which took place in May/1998, at UNESCO and the Sorbonne is another example of how the subject of memory and history began to be critical for the historiography. And as Elie Wessel said in the publication foreword, "To remember, is to allow man to claim that time has left traces and scars on the surface of history, that all events are connected to each other, just like living beings. Without memory, nothing is possible, nothing can be projected." (Pourquoi se souvenir?, 1999, p. 10-11). It is important to mention that the Forum was organized by the Académie Universelle de Culture (was) founded by Elie Wessel in 1992, in Paris, with the objective of thinking about the $21^{\text {st }}$ Century.

${ }^{2}$ Among these objects may be mentioned the priest vestments of Saint Vincent de Paul, the turnstile of the foundlings ("a roda dos expostos"), the collection of baby bottles, the pharmacy jars,

${ }^{3}$ The institution has maintained the hospital administrative files and even of the Assistance Publique, since the XIII century (registries of entrance or exit, births and deaths, etc.); medical files (medical records, etc.); iconographic material (photographs, blueprints, anatomic diagrams, etc.) and library containing books since the 16th century and periodicals.

${ }^{4}$ In the Athens Letter, past testimonies must go through a selection process: "Not everything that is past has, by definition, the right to be made lasting; it is important to choose wisely what must be respected", what justified in large part the participation of intellectuals. (Athens Letter: 25-26).

${ }^{5}$ Health Care History and Cultural Heritage. Organization term of the Latin American Network of Health Care History and Cultural Heritage. This document was originally prepared and presented as Term of Reference by the Brazilian Ministry of Health / Home of Oswaldo Cruz - Fiocruz and Chilean Ministry of Health / Health Care Cultural Heritage Unit, to direct the discussions of the Group of Historical Work and Cultural Heritage of Health Care that met during the $4^{\text {th }}$ Meeting of Regional Coordination of the Virtual Health Library (BVS) / 7th. Regional Congress of Information on Health Sciences (CRICS), in the city of Salvador (BA). 2005: 4-6. This text was published in Spanish for the Chilean Annals of Medicine History 2006; 16: 237-242, for example Historia y patrimônio cultural de salud: propuesta para la creación de uma biblioteca virtual latinoamericana.

${ }^{6}$ France, that already has a large inventory of its "healing spaces", lately has been pointing out the difficulty to adding cultural value to the sanatoriums built between the wars. One of the specific actions, initiated by architects and art historians, would be to remedy the absence of these buildings from the list of work of art lists of the Modern Movement and, thus, to initiate a process of recovery and appreciation of this collection of assets. Cremnitzer, Jean-Bernard. Architecture et Santé. Les temps du sanatorium en France et Europe. Éditions A. et J. Picard, 2005. In India, there is also an effort going on to preserve the last sanatorium of the solarium type remaining in the world. In England, the sanatorium for people affected by tuberculosis of Sully Glamorgan is being rebuilt for residential use, with the objective of bringing about its restoration. Finally, it should be remembered that in the Netherlands, the imminence of the destruction of the Zonnestraal sanatorium led to the creation of the Docomomo (International Committee for Documentation and Conservation of Sites, Buildings and Neighbourhood of Modern Mouvement) in 1988, and brought the attention of the world of how the modern movement in general was suffering with the devaluation, the effects of time, decadence and improper use.

${ }^{7}$ A second event, held in May/2007, Brazil was represented, through the actions performed by the Oswaldo Cruz/Fiocruz Foundation.

\section{Bibliography}

ABREU, L. (Ed.) Igreja, Caridade e Assistência na Península Ibérica (sécs. XVI-XVIII). Évora: Edições Colibri/ Cidehus, Universidade de Évora, 2004.

ABREU, L. (Ed.) Asistencia y Caridad como Estrategias de Invervención Social: Iglesia, Estado y comunidad (s. XVXX). Bilbao: Universidad del País Vasco, 2007.

AGULHON, M. L'historien et la rencontre de l'objet: l'exemple de la République en sculpture. In: NORA, P. Science et Conscience du Patrimoine: actes des Entretiens du Patrimoine. Paris: Fayard, Éditions du Patrimoine, 1997.

AMORA, A. O Nacional e o Moderno: arquitetura e saúde no Estado Novo nas cidades catarinenses, 2006. Tese de Doutorado, Rio de Janeiro: Programa de Pós-Graduação do Instituto de Pesquisa e Planejamento Urbano e Regional da Universidade Federal do Rio de Janeiro (Ippur/UFRJ).

BENJAMIN, W. O narrador. In: BENJAMIN, W. Obras Escolhidas: magia e técnica, arte e política. 5. ed. São Paulo: Brasiliense, 1993. 
BERGSON, H. Memória e Matéria. São Paulo: Martins Fontes, 1990.

BOSI, E. Memória e Sociedade: lembranças de velhos. São Paulo: T. A. Queiroz, Edusp, 1987.

CHASTEL, A. La notion de patrimoine. In: NORA, P. Les Lieux de Mémoire. 3 v. La République, La Nation, Les Frances. Paris: Quarto, Gallimard, 1997.

CREMNITZER, J-B. Architecture et Santé : les temps du sanatorium en France et Europe. Paris : Éditions A. et J. Picard, 2005.

CHOAY, F. A Alegoria do Patrimônio. São Paulo: Estação Liberdade, Editora da Unesp, 2001.

DETIENNE, M. Os Mestres da Verdade na Grécia Arcaica. Rio de Janeiro: Jorge Zahar, 1988.

FONSECA, M. C. L. O Patrimônio em Processo: trajetória da política federal de preservação no Brasil. 2. ed. Rio de Janeiro: Editora UFRJ, Iphan, 2005.

FUNARI, P. \& PELEGRINI, S. Patrimônio Histórico e Cultural. Rio de Janeiro: Jorge Zahar, 2006.

HALBWACHS, M. A Memória Coletiva. São Paulo: Vértice, 1990.

História e Patrimônio Cultural da Saúde. Termo de constituição da Rede Latino-Americana de História e Patrimônio Cultural da Saúde. Termo de Referência. Ministério da Saúde do Brasil/Casa de Oswaldo Cruz/Fiocruz e Ministério da Saúde do Chile/Unidade do Patrimônio Cultural da Saúde.

Historia y patrimônio cultural de salud: propuesta para la creación de uma biblioteca virtual latinoamericana. Anais Chilenos de Historia da Medicina, 16: 237-242, 2006.

JOUTARD, P. Mémoire, une passion française: 1'histoire. In: BOURGUIÈRE, A. \& REVEL, J. Histoire de la France : choix culturels et mémoire. Paris: Seuil, 1993. (Folio, 2000)

LE GOFF, J. Reflexões sobre a História. Lisboa: Edições 70, 1982.

LE GOFF, J. História e Memória. São Paulo: Unicamp, 1992.

LE GOFF, J. "Conclusion de já journée du 28 novembre" IN: NORA, P. Science et Conscience du Patrimoine: actes des Entretiens du Patrimoine. Paris: Fayard, Éditions du Patrimoine, 1997, p. 117-123.

LOWENTHAL, D. The Past is a Foreign Country. Cambridge: Cambridge University Press, 1988.

MENEZES, U. B. de. O patrimônio cultural entre o público e o privado. In: Direito à Memória: patrimônio histórico e cidadania. São Paulo: Departamento do Patrimônio Histórico, 1992.

MENEZES, U. B. de. A crise da memória, história e documento: reflexões para um tempo de transformações. In: SILVA, Z. (Org.) Arquivos, Patrimônio e Memória: trajetórias e perspctivas. São Paulo: Editora Unesp, 1999.

MENEZES, U. B. de. Identidade coletiva e arqueologia. In: BOSI, A. Cultura Brasileira: temas e situações. 4 . ed. Rio de Janeiro: Ática, 2006.

NORA, P. Les Lieux de Mémoire. Paris: Gallimard, 1984. v. 1 - La République.

NORA, P. Science et Conscience du Patrimoine: actes des Entretiens du Patrimoine. Paris: Fayard, Éditions du Patrimoine, 1997.

POULOT, D. Alexandre Lenoir et les musées des Monuments français. In : NORA, P. Les Lieux de mémoire République, La Nation, Les Frances. Paris : Quarto, Gallimard, 1997.

POURQUOI se Souvenir? Paris: Grasset, 1999.

RICCEUR, P. La mémoire, l'Histoire et l'Oubli. Paris: Seuil, 2000.

ROSSI, P. Il Passato, la Memoria, l’Oblio. Bologna: Il Mulino, 1991.

TODOROV, T. Les Abus de la Mémoire. Paris: Arléa, 1995.

YATES, F. L'Art de la Mémoire. Paris: Gallimard, 1975. 


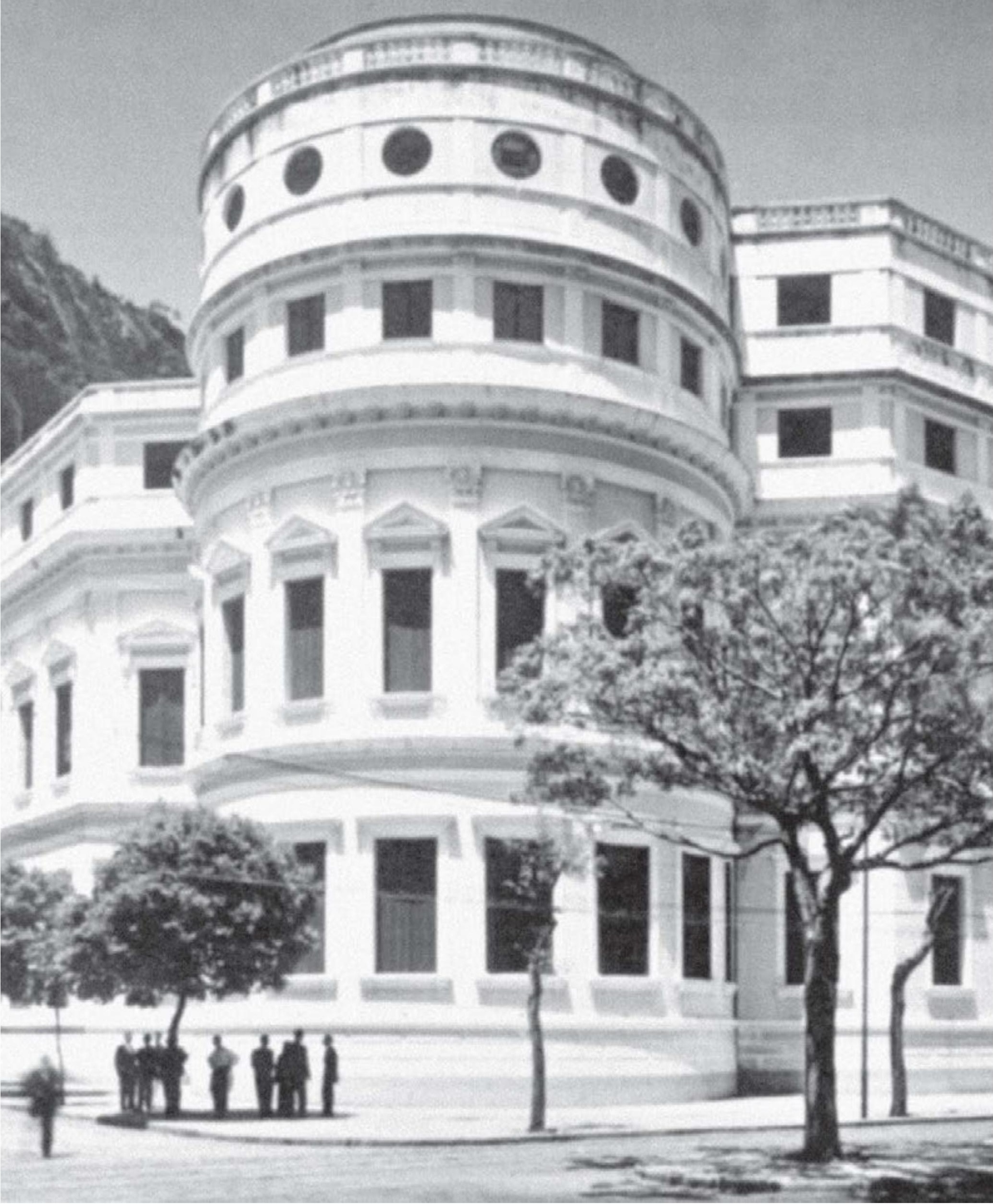




\section{2 \\ Public health in Imperial Rio de Janeiro}

Maria Rachel Fróes da Fonseca 


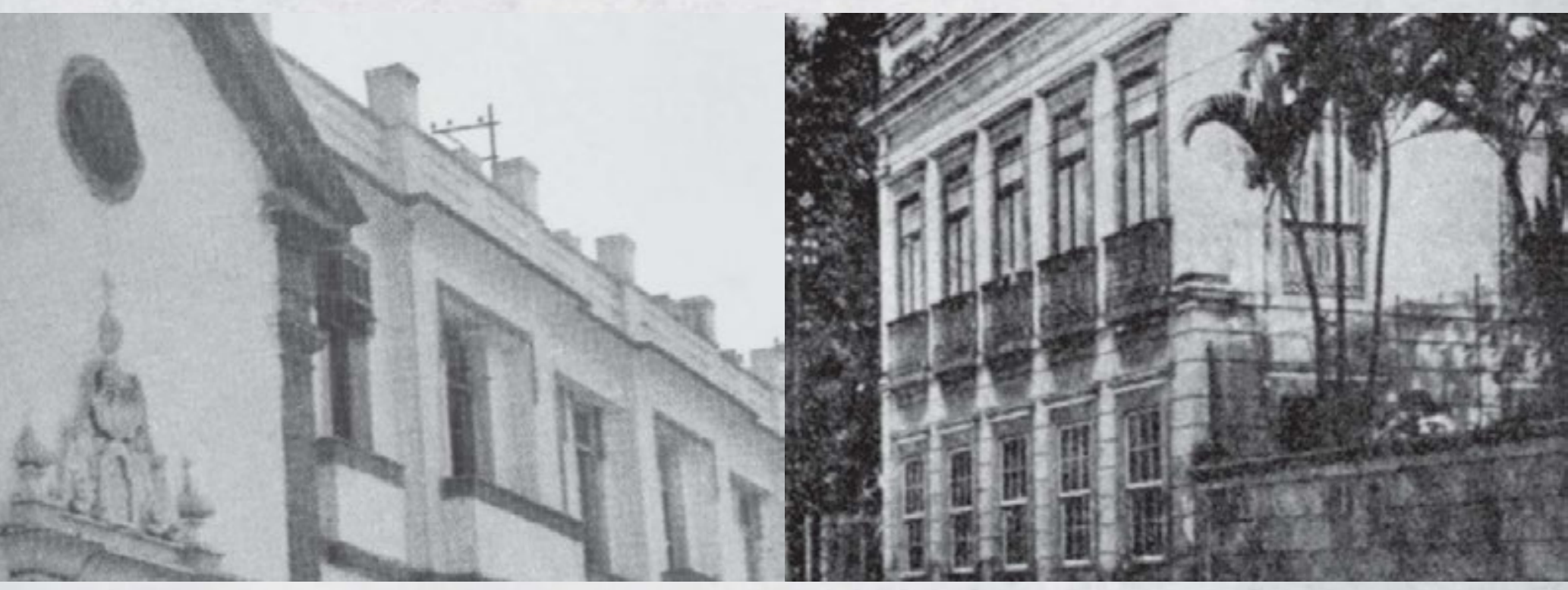




\section{Hygiene and health defense in the colonial city}

During the colonial period it was principally the responsibility of the Municipal Council to determine and adopt measures in defense of hygiene and health conditions in colonial cities, such as Rio de Janeiro. Until the foundation of the Protomedicato Council, in 1782, the Lead Physicist and Lead Surgeon Commissioners had the responsibility of monitoring the adoption of such measures, including also monitoring professional activities (Medicine and Pharmacy) and the sale of drugs. Until the beginning of the 19th century, physicists or licentiates, barber-surgeons, approved-surgeons and examined-surgeons, were the professionals practicing medicine in Brazil. Bleeders, healers, and midwives were also part of the healing art, to whom Lead Physicists issued licenses. There was a hierarchy among all these categories, as pointed out by Tânia Salgado Pimenta (2004: p. 68), in which "the doctors would take the most privileged positions while the midwives and bleeders, for instance, the less privileged".

The pharmacists, equally considered to be practitioners of a secondary art, sought local medical knowledge, of native and African origins, in the making of pharmacopeias, as highlighted by Vera Regina Beltrão Marques (1999). The medical practices of the 18th century were fundamentally the result of experiences engaged by the European, African and Native Americans (Ribeiro, 1997).

The main guidelines on public health would follow the rules of the home country Portugal, and were enforced in the colony by the abovementioned commissioners. The rules that determined the creation of Lead Physicist and Lead Surgeon are dated, respectively, 1476 and 1448.

Nevertheless these determinations were not widely applied in the first centuries of colonization, as there were still places without commissioners to monitor the enforcement of these measures. In the late $18^{\text {th }}$ century, however, these measures became effective in more cities. The responsibilities attributed to these colonial officials were: inspection of pharmacies and hospitals, monitoring of medical practices, determination of public health measures, examination of candidates to medical-related professions (barber, barber-surgeon, bleeder, midwife, pharmacy apprentice) and annulment of diploma and the other licenses. Among the measures in the public health area there was the determination that residents should keep their backyards and the streets clean, getting rid of trash and other refuse.

Other measures of a more immediate nature were adopted by the general-captains and by the provincial governors, to whom the port health service providers and health inspectors were subordinated. In order to control the epidemics, they would isolate people with contagious diseases and install military hospitals 
and Public Charity Hospitals. These port health service providers and health inspectors would promote the public health vigilance, monitoring the arrival of ships, through the so-called "health inspections", and disembarkation of infected people.

With the creation of the Protomedicato Council, in the late 18th century, there was an effort to reorganize the various functions regarding the public health assistance in the colonies. The functions, until then attributed to the Lead Physicist and Lead Surgeon, became part of this Council's responsibility, a Council which was made up of seven members (physicists and surgeons), two secretaries and a doorman. Its activities included the certification of diplomas of those who graduated from foreign schools, given the fact that that were no medical schools in Brazil. Nevertheless, the existence of the Protomedicato was relatively short-lived, and, in 1809, the positions of Lead Physicist and Lead Surgeon were reestablished.

Thus, regularization of public health was, once again, subject to the Lead Physicist and Lead Surgeon's activities, whose responsibility included naming the representatives that would monitor public health in the provinces. Also among their attributions were the determination of local public health measures, such as clearing of land and cleaning streets, and establishing rules for the use of certain product (notably alcoholic beverages).

The various public health regulations implemented during the colonial period were ineffective, meaning that they were only hygienic measures, not enough to be properly called a public health policy.

Ever since the colonial period, medical-hospital assistance was performed, fundamentally, at the Misericórdia Public Charity Hospitals (Santas Casas da Misericórdia), like the Santa Casa da Misericórdia Hospital of Rio de Janeiro, at the hospitals Ordens Terceira dos Mínimos de São Francisco de Paula, Nossa Senhora do Monte do Carmo, and São Francisco da Penitência Hospitals. Santa Casa da Misericórdia Hospital of Rio de Janeiro served as the central military hospital for a long time, and in 1763, vice-king D. Antônio Alvares da Cunha (Conde da Cunha), trying to fix the situation of the military medical service, founded an infirmary ward at the Quartel das Guarnições das Naus, on the slope of São Bento hill. This infirmary ward was later transferred from that Barracks to the old Colégio dos Jesuitas building, on Castelo hill, originating the Real Militar e Ultramar Hospital, in 1769, the first military hospital founded in Rio de Janeiro.

Evaluation of the precarious state of health care in the country, and of the inefficacy of the means used so far, was shared by many intellectuals, and sometimes sent to official or representative organs, with the objective of solving those deficiencies. In this sense, the correspondence sent to José Luis de Castro, Vice-King and Count of Resende by botanist Manuel Joaquim de Sousa Ferraz in 1795 was very illustrative:

"Since public health care is the first State social law; and me seeing that unfortunately the means that work towards this end for the art of health are inert and insufficient, in the fertile and pleasant continent of Brazil, using old, corrupted and adulterated drugs, ordered from Europe at high prices, and being able to use unspeakable benefit and advantages of the marvelous and very virtuous plants that the benign providence used to enrich this famous province of the West Indies, as stated by the general authority of Botanists and world travelers, and for the stupendous cures that empirical amateurs and savages operate routinely, administering effective medicines extracted from native plants; being persuaded and certified of what I just mentioned by information and experiences that I have been using and by botanical digressions that I have been doing in the suburbs of this city, I would fail to 
fulfill my duty as a patriot and a good servant, and the obligation of my ministry as a botanist and a doctor,...." (Ferraz, 1975: 97-99)

In this same direction, in 1798, the Senate of Rio de Janeiro proposed the preparation of a questionnaire about the city's public health conditions. It is believed that such initiative, the questionnaire, was a result of the verification of the precarious situation of the city's health conditions, due to a high incidence of endemic diseases such as scabies, erysipelas, tetter, tuberculosis, yaws, leprosy, elephantiasis, chigoes, leucorrhea, dyspepsia, hemorrhoids and leg edema. Among the diseases with an epidemic nature there was the occurrence of intermittent fevers and the Bladder epidemics (smallpox).

The questionnaire asked the main physicians in the city for their opinions on the possible influences of climate, diet and personal habits on the incidence of these diseases, in the following way:

1st - Which are the endemic diseases in the city of Rio de Janeiro, and which are the epidemic ones?

2nd - Is the excessively humid and hot climate one of the principal causes of endemic diseases and of the lack of success in the epidemic diseases?

3rd - Are the causes of the humidity. 1st, the very low level of the pavement in the city as compared to the sea and bays (...); 2nd, the poor drainage of the water from heavy rains principally in the summer (...); $3^{\text {rd }}$ the poor circulation of the air on the city streets and inside buildings.

4 th - If the causes of heat are: 1 st, the blockage to the entry of daily morning or land winds $(\ldots) ; 2^{\text {nd }}$, the direction of the streets (...).

5 th - If the causes of these diseases are: 1 st, filth, that remains in the city, $2^{\text {nd }}$, the stagnant waters on its outskirts (...)

6th - How much should the City's pavements and buildings be elevated to remediate the moisture to solve the filth problem?

7 th - What are the other moral and food related causes for the abovementioned diseases?. (No ano de 1789 se propôs..., 1813)

Doctors Bernardino Antonio Gomes, Antonio Joaquim de Medeiros and Manuel Joaquim Marreiros answered the criteria proposed by the City Council. The texts prepared in answer to the questionnaire, and published in $1813^{1}$ in the "O Patriota" magazine, present the medical conceptions at that time, especially the approaches referring to the question concerning the causes of the diseases. Manoel Joaquim Marreiros began his comments pointing to inadequacy of the area's topography which interfered in the circulation of air. The soil was impregnated with water, hydrogen, coming from the swamps, which had considerable moisture, making people vulnerable to disease (erysipelas, tetter, scabies, edemas, remittent and nervous fevers). He added other more specific causes such as the direction and layout of some streets making the breeze more difficult; inadequate house construction which blocked the entry of external air; the wet land on which buildings were constructed; and the lack of cleanliness of the city squares because of refuse left there.

Among the measures he proposed, Marreiros highlighted the importance of tree conservation that represented important reservoirs of breathing air. He also pointed how improper diets, such as the harmful use of fish, easily perishable, and "stimulating" mixtures, that would increase voracity. The physical and moral constitution of individuals could also be affected by the lack of jobs, especially among women. 
Marreiros stated that some infirmities, very common in other regions, acquired their own symptoms, as to its form and duration. Among the most effective measures to reverse the chaotic state of public health, he suggested that some parts of the city be elevated, house constructions changed and refuse eliminated. He also pointed out the necessity of the police to act efficiently regarding the numerous families living unworthily on the city's streets.

Doctor Bernardino Antonio Gomes separated, initially, the endemic and epidemic diseases, stating that many diseases spread epidemically in other countries, but did not act the same way here. He admitted the occurrence of occasional or extraordinary epidemics, such as the Smallpox case in 1797. they characterized the group of diseases (endemic or epidemic) that occur here as atony diseases, "and that by consequence must be classified in the order of its causes all that tends to enervate the physical constitution of inhabitants, and to produce miasma, that are known nowadays because of the intermittent and remittent fevers, and mainly the epidemic ones" (Gomes, 1813: 57).

He pointed out the warm and humid climate as one of the principal causes of the incidence of diseases, that favored the decaying of animal and plant substances, and consequently promoted production of miasmas. The topographical conditions, both low elevation and proximity to hills were obstacles to an ideal circulation of breezes, promoting air stagnation and excessive warmth, highly harmful to human physical conditions. The existence of stagnant water and swampy soil was seen as a true source of vapor and, thus, of miasma.

Other less notable causes, but just as pernicious, were, according to Bernardino Antonio Gomes, the filth that existed principally due to slavery, which led to grouping of too many people in small rooms, menacing the quality of the breathing air.

In the question of diet, the doctor from Portugal pointed the improperness of certain foods that made the first tracts inactive due to mucus, such as bananas, sweet cassavas, yams, potatoes (of some kinds), manioc flour, mate and tea. A sedentary life style, especially among women, was also understood as being a cause of illness, as exercise would be the main basis for health. Prostitution originated, according to Gomes, from leisure time and easy wealth, damaged health, though its practice, and by consequence its harmful effects, were greater in Europe than in Brazil. Another practice that weakened Brazilians would be the daily use of tepid baths, due to the perspiration it produced, that increases the looseness of the exhaling veins.

The last doctor to answer the official questionnaire, Antonio Joaquim de Medeiros, agreed with the idea that the infirmities could affect any person regardless of his/her age, gender and residence. On the other hand, he believed that an unfavorable topographical situation and inadequate house construction increased the possibility of a precarious public health condition.

He affirmed that the main cause of endemic diseases and epidemic dimensions was found in this kind of climate, warm and humid. The excessive humidity and poor air quality were a result of the low height of city's pavements, poor water drainage, inadequate layout of streets and buildings and the location of hills, that did not allow for a proper exchange of air. The filth found on the city streets and the existence of stagnant water, together with the abovementioned aspects, made for a very precarious scenario.

The quality of water for consumption, which was previously identified as a cause of illness was referred to by Medeiros as being good, based on experiments made by doctors who were members of the Literary Society of Rio de Janeiro, created in Rio de Janeiro in 1786. 
Antonio Joaquim de Medeiros highlighted the causes as being of a moral or dietary nature, pointing out that "the opulence of this respectable City introduced luxury, and luxury immoral behavior, in a way that inside the City there was no lack of public houses, where youths would ruin their health, and corrupt the behavior learned from a good education, contracting new illnesses and causing many." (Medeiros, 1813: p. 10-11)

Regarding other social habits, he also identified a sedentary life style and excessive consumption of food and beverages as being responsible for the occurrence of various chronic diseases.

The precarious public health condition of Rio de Janeiro was evaluated not only as being harmful to the population as a whole, but also as a generator of government expenditures, as occurred during the Smallpox epidemics of 1797 . He would, thus, suggest specifically for the Smallpox case, the creation of an Inoculation Hospital, like the one in Lisbon, where everyone could be inoculated, including slaves. In order to improve the general public health conditions of the city, he proposed the demolition of Castelo and Santo Antonio hills, demolition of some buildings, construction of houses under the supervision of engineers or the City Council, the creation of large squares, elimination of filth centers and drainage of stagnant water locations, and the proper care with beef cattle (to avoid deterioration of meat to be consumed).

The observations and considerations presented by doctors, as a reply to the City Council questionnaire, were based mainly on the miasmic theory. It was stated that inhalation and contact with contaminated air, with decaying organic material, could result in an imbalance of gases, the miasmas, which would cause the incidence of diseases. Thus, it was understood that the cause of diseases was directly related to environmental conditions. It was, then, imperative to clean the environment, city, drying up the swamps, cleaning streets and relocating cemeteries.

\section{Medicine and health in the Court municipality}

Until the first decades of the 19th century, the exercise of medicine was assigned exclusively to physicists and surgeons with a certificate of qualification by the Kingdom's lead surgeon, as determined by the regulation of May 23, 1800. Its part was restricted to bloodletting, to application of leeches, to healing wounds and fractures, being forbidden the administration of internal medicine, that was a privilege only for the doctors who had graduated from Coimbra.

With the arrival of the Royal Family to Brazil, turning it into administrative center of the Empire, important administrative, economic and cultural of impact measures on health and medicine issues were adopted in the country. In this context of transformation, the city of Rio de Janeiro would be stage of various cultural and scientific initiatives such as the Royal Press, National Library, the first periodicals, medical and teaching institutions.

The creation of the first university level teaching establishments was ordered to address the need of formation of professionals to provide the essential public services at that time. In this perspective, in 1808, two establishments of medical surgeon teaching were created, the Surgery School, in Salvador and the Anatomy, Surgery and Medical School in Rio de Janeiro, the only official centers of medical graduation of practically the entire $19^{\text {th }}$ Century. The curricular proposal, that initially only included 
knowledge in surgery and anatomy, now covered subjects of anatomy and physiology, therapeutic surgical and private, surgical medicine and obstetrics, medicine, chemistry and elements of medical and pharmacy subjects.

With the opening of Brazilian ports to foreign trade, in 1808, it became essential to adopt measures that could promote urban public health, especially in the municipality where the Royal Family was located, in light of the risk of contamination by diseases that would arrive from ports. To define these actions, a study was requested by the counselors that were part of Regent Prince D.João's entourage upon their arrival to Brazil. And among these were Paulo Fernandes Viana (1758-1821), José Corrêa Picanço (1745-1823), responsible for the creation of medical surgeons schools in Bahia and Rio de Janeiro, and Manoel Vieira da Silva (1753-1826). The latter was the author of a study entitled "Reflections on some of the proposed ways to lead to an improved climate in the City of Rio de Janeiro", published in 1808 and considered to be the first on this subject ever printed in Brazil (Lima, 1900). In this work were discussed the causes and solutions for the virulent condition in the city of Rio de Janeiro, including topographical and climate factors, the location of cemeteries, the slaughterhouse situation, the medicine matter and recommended the creation of pest houses to quarter those who disembarked here infected or suspected of being infected by diseases. Manoel Vieira da Silva was named, in 1809, Lead Provider of the Court and Brazilian States Health, responsible for monitoring the health conditions of ship crews. At this time was created, at the boat anchorage of Bom Jesus Island, the first temporary pest house.

On April 4, 1811, knowing about the city's chaotic public health condition, Regent Prince D. João created the Vaccination Institution Council of the Court, subordinated to the Lead Physicist, with the responsibility of preparing an anti-Smallpox vaccine that would be administered throughout the Court municipality and the other provinces of the Empire. The hygienic and public health services were still precarious and the anti-Smallpox vaccination worked as one of few resources presenting some efficiency. In Rio de Janeiro, from 1811 to 1835, the Vaccination Court Council, then known as the Central Vaccination Council, vaccinated 102,719 people. In 1846 the Council was restructured and became the Imperial Vaccination Institute, also knows as Vaccination Institute of the Court.

The combat against infirmities also concerned doctors outside of official institutions, and was object of different medical studies in the D.João period, with special mention of those of Bernardino Antonio Gomes ("Medical and Botanical Observation of some Brazilian plants", 1812), Caetano José Cardoso ("List of many indigenous plants in the province of Minas Gerais and its medical products", 1813), and José Maria Bomtempo ("Concerning some infirmities in Rio de Janeiro, and especially about the general abuse, and pernicious effect of precious application of Peruvian bark, or quinine", 1814), and Francisco de Melo Franco ("Hygienic Elements", 1814).

Only in the first decades of the 19th Century did some proprietary hospitals start to be installed in the city of Rio de Janeiro, most of which were private establishments owned by doctors. Among the first ones we can mention the hospital of surgeon Antonio José Peixoto (1816-1864), installed in 1845 on Gamboa hill. Ten years later, the same surgeon established a new hospital, on Olinda Street, in Botafogo neighborhood which with his passing was acquired by Manoel Joaquim Fernandes Eiras (1828-1889), who transformed it into the Dr. Eiras Hospital.

With the Act of August 30, 1828, that eliminated the functions of Lead Provider and positions of Lead Physicist and Lead Surgeon from the Empire, the City Council was given the responsibility for the 
services in hygiene and public health, which until then had been the Lead Physicist's responsibility. Thus began, therefore, the decentralization process of the imperial government, mostly due to local relations dominated by the nobility. By Municipal Ordinances we mean, the City Councils began to regulate several matters related to public health conditions in the city of Rio de Janeiro, proposing rules on everything concerning city public health, such as illumination and cleaning of streets and squares, preservation of buildings, conditions of sidewalks, aqueducts and fountains, swamp drainage, cemetery location, animal traffic, slaughterhouses and road repair. In the "Ordinance of the City Council of Rio de Janeiro in 1832", in its section "Vaccines and Exposed Population", was established the obligation of vaccination in the city, determining that all people that had a child under their care, had to take them to the "vaccine house to be vaccinated" (apud Falcão, 1978a: 48), under penalty of a pecuniary fine for non-compliance. However, such a position was not effectively adopted.

The decree of January 17, 1829 created a special commission named Public Health Inspection of Rio de Janeiro Port, which would be made up of a health service manager, elected by the City Council, a health professor, an interpreter as a secretary and by guards.

Hygiene and public health services remained under responsibility of the City Councils until 1843, when it was defined that these could no longer intervene in the public health inspections of the ports, nor in naming of its respective employees, and that such attributions would be the responsibility of the Imperial Cabinet. From then on, and until the end of the Monarchy in Brazil, all health and hygiene departments, the Public Hygiene Council, the quarantined pest houses, the Imperial Vaccination Institute, the Medical Schools of Rio de Janeiro and Bahia and all organs connected to public health were now subordinated to the City Secretariat of Imperial Affairs.

Hygiene and public health institutionalization in Brazil is equally related to the history of the Medical Society of Rio de Janeiro (current the National Academy of Medicine), on 30th June of 1829 created with the objective of making possible the increase of different medical areas and to extend the participation of these professionals participation in the Imperial Government, especially in matters regarding hygiene and public health policies. Among their founders were Joaquim Cândido Soares de Meirelles (1797-1868), Francisco Freire Allemão de Cysneiros (1797-1874), José Martins da Cruz Jobim (1802-1878), Francisco de Paula Cândido (1805-1864), and the frenchman José Francisco Xavier Sigaud (1796-1856), author of the work "Du Climat et des Maladies du Brésil" (1844), considered a synthesis of the hygienist thinking in Brazil in the first half of the $19^{\text {th }}$ Century. The Medical Society of Rio de Janeiro was initially installed at the Clergy House of Rosário Church, operating at other locations in the city, and in 1861 was transferred to the Court Municipal Palace, located near Campo de Santana. Only in 1953 did the construction of its own and current headquarters begin, at Av.General Justo, no 365.

The installation of hospitals dedicated especially to the care of alienated people happened only in the middle of the 19th Century, highlighting the creation, in 1841, by José Clemente Pereira, president of the Mercy Public Charity Hospital of Rio de Janeiro, Pedro II Asylum, located at Praia Vermelha, in a building where now is located the Federal University of Rio de Janeiro. 


\section{Epidemics and the health regularization in the Empire}

In the second half of the 19th Century, public health in Brazil faced several problems, beginning with the appearance, in 1849, of yellow fever in Bahia and afterwards in all ports of the north and finally in Rio de Janeiro. Before the yellow fever threat a temporary pest house was installed on Bom Jesus dos Frades Island, to where were transferred seamen, and those that were already sick were sent to Mercy Public Charity Hospital of Rio de Janeiro. Also established were the Nossa Senhora do Livramento and Marítimo de Santa Izabel hospitals, located in Jurujuba bay at port entrance and several infirmaries at various locations in the city.

In 1849, knowing the dangers of yellow fever, the Imperial Government created a Central Public Health Commission, made up of doctors affiliated to the Imperial Academy of Medicine: Cândido Borges Monteiro (president), Manoel de Valadão Pimentel, Roberto Jorge Hadock Lobo, Antonio Felix Martins, José Maria Noronha Feital, José Bento da Rosa, José Pereira Rego, Luiz Vicente Simoni, José Francisco Sigaud and Joaquim José da Silva. For a more effective combat against epidemics, Paroquial Commissions were also created, that would be subordinated to this Commission, and that would also be made up of PhDs in medicine. The formed commissions had the objective of making sure that the laws, orders and measures related to public health were observed and to visit free of charges all the sick and poor people in its area.

Despite all these measures, statistics of that time still indicated high levels of mortality from yellow fever. In the summer of 1849-1850 the yellow fever epidemic in Rio de Janeiro was controlled, but the Imperial Government, seeking to prevent new epidemics, created through decree $\mathrm{n}^{\circ} 598$ of September 14, 1850, the Public Hygiene Council, with the following responsibility:

In order to propose to the government all the measures, judged as necessary or convenient to the well being of public health, and inform about those pointed by the government. To understand in the effective execution of the City Councils Ordinances related to public health, and indicate measures judged as necessary or convenient so that they may be made into Ordinances, calling for help from the government (...) whenever this does not happen; To enforce medical policy on visits of ship heretofore assigned to the Port Health inspection, and in those that must be done in pharmacies, drugstores, markets, warehouses and all places, establishments and houses in general where damage to Public Health may occur. (Brasil,1951)

The Public Hygiene Council, that would operate in the Imperial capital, the city of Rio de Janeiro, would be constituted by a president, named by the Imperial government, two lead surgeons of the Fleet and Army, an inspector of the Empire Vaccination Institute and Port Health superintendent. At this time a Commission of Engineers was created, made up of four officials chosen by the government to whom was given the function of drawing blueprints and proposing work budgets and services necessary to improve health condition in the city, and help the Public Hygiene Council. The first composition of the Public Hygiene Council had Francisco de Paula Cândido (President), Joaquim Cândido Soares de Meirelles, Antonio José Ramos (Lead Fleet Surgeon), Jacintho Rodrigues Pereira Reis (Lead Army Surgeon), Antônio Felix Martins (Lead Port Health Superintendent) and Ernesto Augusto Lassance Cunha (Secretary).

The Council, that would be initially a Consulting Council, ended up as the responsible for Public Health service in the Empire, working mainly in times of yellow fever, cholera morbus and smallpox 
epidemics. The Council included the services of Port Health Inspection and Vaccination Institute and was responsible for hygiene and public health on land and sea.

This Public Hygiene Council model was adopted in other Imperial provinces such as Pará, Maranhão, Pernambuco, Bahia and Rio Grande do Sul, where Public Hygiene Commissions were also established. In 1851 Public Hygiene Council was renamed the Public Hygiene Central Council, concentrating all public health services of the Empire, and exercising its authority in other provinces through commissions and providers that were under its guardianship. The Port Health Inspection and Vaccination Inspection were definitively incorporated under the leadership of the Council.

President Francisco de Paula Cândido, working to prevent a future epidemic, in 1851 rented a house to receive the sick, on the Caju península, in Jurujuba cove. Given the poor conditions of the accommodations of this pest house, a decree was issued on January 3, 1853 which established the foundation of a Hospital which would receive the name of the Santa Izabel Marine Hospital, later the Paula Cândido Hospital.

In 1857 it was determined that the Public Hygiene Councils, created earlier in the provinces, would be eliminated and substituted by public health inspectors, a name which was also given to the superintendents.

A decree of the Imperial Government in 1859 gave a new set of rules for Port Health Inspection, substituting that of 1843, which, according to the Imperial Government no longer served the functions and needs of Inspection, as it had been created before the yellow fever and morbo cholera epidemics. However, the new decree did not achieve its proposed purpose, and, in 1861, other resolutions were presented, establishing norms for the Santa Izabel marine Hospital and other pest houses in the Empire, which could only receive the sick when the government considered it essential or when the ports were threatened by some epidemic which could not be treated in the charity establishments.

With the impact of the Paraguay War, begun in 1864, important measures or legislation were not implemented during this period. In 1876 the Imperial Government refocused its attention on the issue of public health, naming a commission with the responsibility of studying in particular the reasons which had caused the persistence and increase of yellow fever in recent years, and to propose better ways to eradicate it. The president of this commission was José Pereira Rego (the Baron of Lavradio), who, at the time, was also president of the Central Public Hygiene Board, and made up of equally well renowned doctors such as Antônio Corrêa de Souza Costa, João Vicente Torres Homem, Vicente Cândido Figueira de Sabóia, Hilário Soares de Gouvêa and João Baptista dos Santos. With this makeup the important role of doctors in defining public health actions and measures was reinforced. The Commission sent to the Imperial Government two reports and projects presenting the actions to be taken, and indicating measures that would improve the city's hygienic conditions, like attacking unhealthy locations and reorganizing the land and maritime public health services in all the Empire. Among the proposed preventive measures, which were later converted into Ordinances by the Municipal Council were the prohibition of throwing trash on beaches, landfills and other places, and the establishment of hospitals. The Municipal Ordinance dated October 6, 1876 prohibited the establishment of new public and private hospitals, or expansion of those already in existence, within the defined zone, "beginning at the ocean, next to Glória hill, proceeding along Lapa Street, Mangueiras Street, Riachuelo Street, Frei Caneca Street, Estácio de Sá 
Street, Estácio de Sá Square, São Christovão Street, Lázaros Street, ending at the ocean" (apud FALCÃO, 1978a: p.216). The same Municipal Ordinance also determined that in the general public and private hospitals, that is, establishments which received patients with all kinds of ailments, no one with yellow fever, small pox, cholera or other epidemic or contagious disease could be treated.

Imperial decree $\mathrm{n}^{\circ} 6.376$, of November 15,1876 , tried to address the need to take action related to the influx and increase of contagious and infectious-contagious diseases in several ports and seaside cities of the Empire, taking into account the opinion of the Commission which had been names earlier by the Imperial Government with this purpose. Among the terms was the determination that the Central Public Hygiene Board would be assisted by specialized doctors, names by the Ministry of Imperial Affairs, and that a temporary floating pest house would be created close to the Santa Izabel Maritime Hospital for quarantining of passengers coming from ports where there was yellow fever, cholera and other diseases. The pest house would be under the responsibility of the Port Health inspector, who would gain four assistants. The Provincial Hygiene Commissions were re-established in the provinces of Bahia, Pernambuco, Maranhão, Pará, São Paulo and Rio Grande do Sul. The vaccination stations in urban districts were closed, and urban parishes were divided into districts, called public health districts, run by the corresponding doctors. The distribution of the parishes was as follows: Nossa Senhora da Conceição do Engenho Novo and Nossa Senhora da Candelária, one district; Santíssimo Sacramento, São José, Santo Antônio, Divino Espírito, São Francisco Xavier do Engenho Velho and São Cristóvão, with two districts; Nossa Senhora da Glória, Santana and Santa Rita, with three districts. São João Batista da Lagoa and Nossa Senhora da Conceição da Gávea would form a single district.

Also in 1876, another imperial decree established instructions related to public health services, which were divided between city and port services. The services which the Central Public Hygiene Board would be responsible for were:

1) Study of the epidemics, prevalent diseases and murrains, and the means to prevent and fight them. Inspection of pharmacies, drugstores and manufacturers of mineral water and medical drugs. Registration of doctors and pharmacists, and monitoring of the medical and pharmacist professional activity. 2) Inspection of foods and beverages displayed for sale, as well as establishments and places where they are manufactured, prepared or sold. Supervision on the way water is supplied to the city, garbage collection and urban sanitation and irrigation of streets and squares, as related to healthy conditions for the general public. 3) Study of the hygienic conditions of public and private buildings to be built. Sanitization of tenement rows or inns and public restrooms. 4) First aid administration to the poor. Inspection of factories, workshops, laboratories and other private establishments. Of places which may be harmful to public health, and places where animals are kept. 5) Vigilances on hygienic conditions of barracks, arsenals, nursing homes, and other public establishments. Sanitary inspection of cemeteries and morgues. (Brasil, 1978).

On April 5, 1878 the Imperial Government authorizes the naming of Parish Commissions to help the Central Public Hygiene Board in the services to improve health and hygiene conditions in the city of Rio de Janeiro. Once again, the Board was put in charge of organizing the new plan of improvements to preserve the city from epidemics. New decrees were issued, determining the measures to be adopted in the case of imminence of any epidemic, such as the transfer of suspected or confirmed cases to the Maritime Hospital, and, if necessary, to a floating hospital in the same Jurujuba cove, and permission 
from the public health authority to order ships to move away from the shore for the period it deemed convenient.

From 1876 to 1879 , there were no important actions related to public health, however, between 1881 and 1886, the Imperial Government made some reforms in public health services. On February 19, 1881 the Imperial Government removed the Baron of Lavradio as Board president, director of the vaccination Institute and Port Health Inspection, and named João Baptista dos Santos (1828-1911) to the Central Public Hygiene Board, Nuno Ferreira de Andrade (1851-1922) to the Port Health Inspection and Peregrino José Leite to the Vaccination Institute. In this same year other actions were taken related to assistance and health care, such as:

1st: authorizing the Hygiene Board to organize the disinfection services; 2nd recommend administrators, directors and owners of public and private hospitals not to receive patients with infectious or contagious disease which they did sporadically; 3rd requesting the superintendent of the Mercy Public Charity Hospital to forbid burial of indigents in the São João Batista cemetery, the establishment of new areas in the abovementioned cemetery of the drainage system that would meet the hygienic conditions required by public health authorities, raining the height of the wall of the above cemetery next to the place known as Izabelópolis, and planting eucalyptus and other appropriate trees in that place. (Barbosa \& Rezende, 1909: 81)

By decree $\mathrm{n}^{\circ}$ 8.387, of January 19th, 1882, the responsibilities of the Central Public Hygiene Board were reaffirmed for everything related to public health, proposing the creation of a Public Hygiene Commission, in every parish of the municipality of the Court, of a Hygiene Board in the capital of each one of the provinces of Pará, Maranhão, Pernambuco, Bahia and Rio Grande do Sul and, the establishment of a public hygiene inspector in the other provinces (Brasil, 1889a).

The smallpox epidemics worsened in 1883, worrying the authorities with relation to the vaccination of the population. On December $19^{\text {th }}$ of the same year, two Vaccination-Public Health Commissions were established to aid the Board and the Vaccination Institute.

On December 22, 1883 rules were established for the operation of the Hygiene Laboratory of the Medical School of Rio de Janeiro, designed not only for students of hygiene at that institution but also for the performing of drug, beverage and food analyses in the interest of public health, under the orientation of the Central Public Hygiene Board.

In 1884 Imperial Minister, Felippe Franco de Sá, determined the construction of a quarantine pest house, which had been suggested earlier by Nuno Ferreira de Andrade, to be built on Ilha Grande. The pest house, which was completed in 1886, was considered one of the best of its kind with the capacity for 1500 people.

The health care situation of the city of Rio de Janeiro, despite all the abovementioned measures, had not change much, still with a large number of people with yellow fever and smallpox. With decree $\mathrm{n}^{\circ}$ 9.554, of February 3, 1886, the Imperial public health service was reorganized, encompassing from then on land public health service and port public health service. The former was subordinated to the General Hygiene Inspectorship, and the latter, to the General Port Health Inspectorship, both headquarted in the capital of the Empire.

The General Hygiene Inspectorship was responsible for all land-based public health services, with these attributions: 
I. Monitoring of the medical and pharmacist professional activity; II. The study of epidemics, murrains and prevalent diseases; III Management of the vaccination service and study of the ways to improve and develop it; IV. Management of public health assistance to the needy; V. Responsibility for public health policy on everything that, directly or indirectly, involves the health of the inhabitants of the cities, towns and villages of the Empire; VI. Organization of the demographic and public health statistics; VII. Organization and improvement of the Brazilian Pharmaceutical Code. (Brasil, 1886)

To the General Hygiene Inspectorship was given the responsibility to take care of the services related to the hygienic and public health well-being: monitoring garbage collection and city cleaning services; examination of water for human consumption; study of all projects, plans and proposals of public constructions with regard to health and public hygiene issues as well as hygienic conditions of already existing buildings and public establishment, examination of the hygiene of already established industries; granting or denial of licenses to sell medicinal substances and for installation of private hospitals, health clinics and maternities, and organizations of public assistance plans and active vigilance on public health services.

The Port Health Inspectorship created to promote maritime health services, would have the following responsibilities: "I. Managing medical assistance to seamen; II. Enforcement of public health policies on ships, docks and on the shoreline; III. The service of maritime quarantines; VI. The study of all questions related to improving public health condition in the ports." (Brasil, 1886).

In addition the General Port Health Inspectorship would be responsible for the services of enforcing public health policy on the shoreline, docks and ships; the granting or denial of licenses, in times of epidemics; the division of the quarantine services and management of the maritime hospital and pest house; and issuing instructions to the provincial Port Heath Inspectors.

The 1886 decree also established the creation, in the Court, of a Supreme Public Health Council, responsible for consultation on questions of hygiene and general health, every time the Imperial Government needed such assistance. It would be made up of the people responsible for two important health institutions, the President of the Imperial Academy of Medicine and the director of the Medical School of Rio de Janeiro.

Also in 1886, was organized a Rio de Janeiro Sanitation Commission, led by British engineer Jules Jean Revy, which would be responsible for performing studies on the origin and nature of swampy land, on the works of drainage, drying or land filling, regime of the rivers, and on the works of canalization needed for the sanitation system of Rio de Janeiro, and the organization of a sewage improvement plan.

In 1889, based on the proposal sent by Benjamin Antônio da Rocha Faria (1853-1936), full professor of hygiene of the Medical School of Rio de Janeiro, to Vicente Cândido Figueira de Sabóia, director of the institution, the service of analysis and testing was separated from the Hygiene Laboratory, and created the Hygiene Institute of the Medical School of Rio de Janeiro. These modifications were approved by decree $\mathrm{n}^{\circ} 10.230$ of April 13, 1889, which defined and the objectives of the Institute the instruction of students of hygiene, the study of epidemics and murrains, specialized in hygiene instruction for teachers in primary schools and students of Teacher Preparatory School (Escola Normal), and the dissemination of essential notions of personal and home hygiene for the population of the municipality of the Court. On the other hand, the service of analysis and examination of beverages, food substances and other 
substances of interest to public health would be performed by a specific laboratory, the Laboratory of the State, created by the same 1889 decree.

This establishment, which would later become National Analysis Laboratory, operated in a Customs building. Decree $n^{\circ} 6.418$, of October 30, 1889, the last act of the Imperial Government related to public health, organized and regulated anti-carbuncular vaccination service, under the responsibility of the Experimental Physiology Laboratory of the National Museum, created in 1880, during the administration of Ladislau de Souza Mello Netto (1838-1894).

In 1890 , decree $\mathrm{n}^{\circ} 169$ defined the establishment of a public health council and the reorganization of the land-based public health services of the Republic. The land-based public health service would be run by the General Hygiene Inspectorship headquartered in the city of Rio de Janeiro, then the nation's capital. The Inspectorship would be responsible for studying questions of public hygiene, sanitation systems, adoption of preventive measures against epidemics and endemics, the organization of public assistance, management of vaccination services, health inspection of school, factories, hospitals, asylums and other collective buildings monitoring of public food programs. Monitoring of the medical profession, definition of public health policy, organization of demographic and public health statistics, and health monitoring of cemeteries and other constructions which might cause problems to public health. Among the responsibilities of the hygiene commissioners was the monitoring of the physical conditions and operations of hospitals and health clinics.

The execution of the services would be done based on the authority of the General Hygiene Inspectorship, of its hygiene commissioner in the nation's capital, and the Hygiene Inspectorships and respective commissioners in the States. This decree also determined the creation of Public Health Council, also headquartered in the nation's capital, and which would be "given the responsibility of issuing opinions related to questions of hygiene and general health related to questions posed to it by the Government" (apud Falcão, 1978b: 715).

Throughout the $19^{\text {th }}$ Century there was a growing concern among administrators and doctors regarding the health conditions of the city, as expressed in the ample legislation, creation of public organs, and preparation of numerous studies. The medical and hospital care in the city of Rio de Janeiro was performed, throughout this whole period notably in charitable institutions, both lay and confessional. This way, they tried to combat the diseases that affected the city, and thus make it more healthy and "civilized".

With the Republic and the publication of the Constitution of 1891, a reorganization of the attributions and division of responsibilities between the municipal and federal governments took place. If before actions in the field of assistance and health care were characterized by the lack of a more effective government action, now in the republic, public health was now controlled by the State, in terms of its organization and places of action.

Note

${ }^{1}$ The primary and secondary sources consulted which discuss the administering of this questionnaire, do not explain the reason why the answers to the questionnaire were published only in 1813. 


\section{References}

BARBOSA, P. \& REZENDE, C. B. de. Os Serviços de Saúde Pública do Brasil, especialmente na Cidade do Rio de Janeiro de 1808 a 1907: esboço histórico e legislação. Rio de Janeiro: Imprensa Nacional, 1909.

BRASIL. Decreto n. 9.554 de 03 de fevereiro de 1886. In: Colleção de Leis do Império do Brazil de 1886, Tomo XXXIII, parte I. Actos do Poder Executivo. Rio de Janeiro: Typographia Nacional, 1886.

BRASIL. Decreto n. 8.387 de 19 de janeiro de 1882. In: Colleção de Leis do Brazil de 1882, Tomo XXIX, parte II. Tomo XLV. Rio de Janeiro: Typographia Nacional, 1889a.

BRASIL. Decreto n. 10.232 de 13 de abril de 1889. In: Colleção das Leis do Império do Brazil de 1889, Parte I, Tomo XXXVI, v. I. Rio de Janeiro: Imprensa Nacional, $1889 \mathrm{~b}$.

BRASIL. Decreto n. 598 de 14 de setembro de 1850. In: Colleção de Leis do Brasil, 1850, Tomo XI, parte I. Rio de Janeiro: Typographia Nacional, 1951.

BRASIL. Decreto n. 828 de 29 de setembro de 1851. In: Colleção de Leis do Império do Brazil, 1851, Tomo XIV, parte II, secção 59ª Rio de Janeiro: Typographia Nacional, 1952.

BRASIL. Decreto n. 6.406 de 13 de dezembro de 1876. In: FALCÃO, E. de C. Brasilliensia Documenta, VI, Osvaldo Cruz Monumenta Histórica, Tomo IV (II). Os Serviços de Saúde Pública no Brasil (1808-1907): legislação. São Paulo: s. n., 1978.

FALCÃO, E. C. Brasilliensia Documenta, VI, Osvaldo Cruz Monumenta Histórica, Tomo IV (I). Os Serviços de Saúde Pública no Brasil (1808-1907): legislação. São Paulo: s. n., 1978a.

FALCÃO, E. C. Brasilliensia Documenta, VI, Osvaldo Cruz Monumenta Histórica, Tomo IV (II). Os Serviços de Saúde Pública no Brasil (1808-1907): legislação. São Paulo: s. n., 1978 b.

FERRAZ, Manuel Joaquim de Sousa. Correspondência ao Conde de Resende. 9 dezembro 1795. In: VARNHAGEN. História Geral do Brasil. Tomo V. São Paulo: Cia. Melhoramentos de São Paulo, 1975.

GOMES, B. A. Resposta que deu o Doutor Bernardino Antonio Gomes ao Programa da Câmara desta Cidade, que vem no $\mathrm{n}^{\circ}$ 1. O Patriota, Rio de Janeiro, n. 2, p. 56-58, fev. 1813.

LIMA, A. J. S. Parte segunda 1808-1900. In: Livro do Centenário. Rio de Janeiro, Imprensa Nacional, 1900. v. 2.

MARQUES, V. R. B. Natureza em Boiões: medicinas e boticários no Brasil setecentista. Campinas: Editora da Unicamp, 1999.

MARREIROS, M. J. Resposta, que deu o Doutor Manoel Joaquim Marreiros aos quesitos precedentes. O Patriota, Rio de Janeiro, n. 1, p. 60-67, jan. 1813.

MEDEIROS, A. J. Resposta, que ao Programma da Câmara annunciado no No1 pag.58, deu o Doutor Antonio Joaquim Medeiros. O Patriota, n. 3, p. 3-15, mar. 1813.

NO ANO DE 1798 se propôs por Acordo da Câmara desta Cidade a vários Médicos, um programa que tinha por objeto os quesitos seguintes. O Patriota, n. 1, p. 58-59, jan. 1813.

PIMENTA, T. S. Transformações no exercício das artes de curar no Rio de Janeiro durante a primeira metade do Oitocentos. História, Ciências, Saúde-Manguinhos, 11 (supl. 1): 67-92, 2004.

RIBEIRO, M. M. A Ciência dos Trópicos: a arte médica no Brasil do século XVIII. São Paulo: Hucitec, 1997. 
3

\section{The First Republic and the establishment of a hospital network in the Federal District}

Gisele Sanglard 


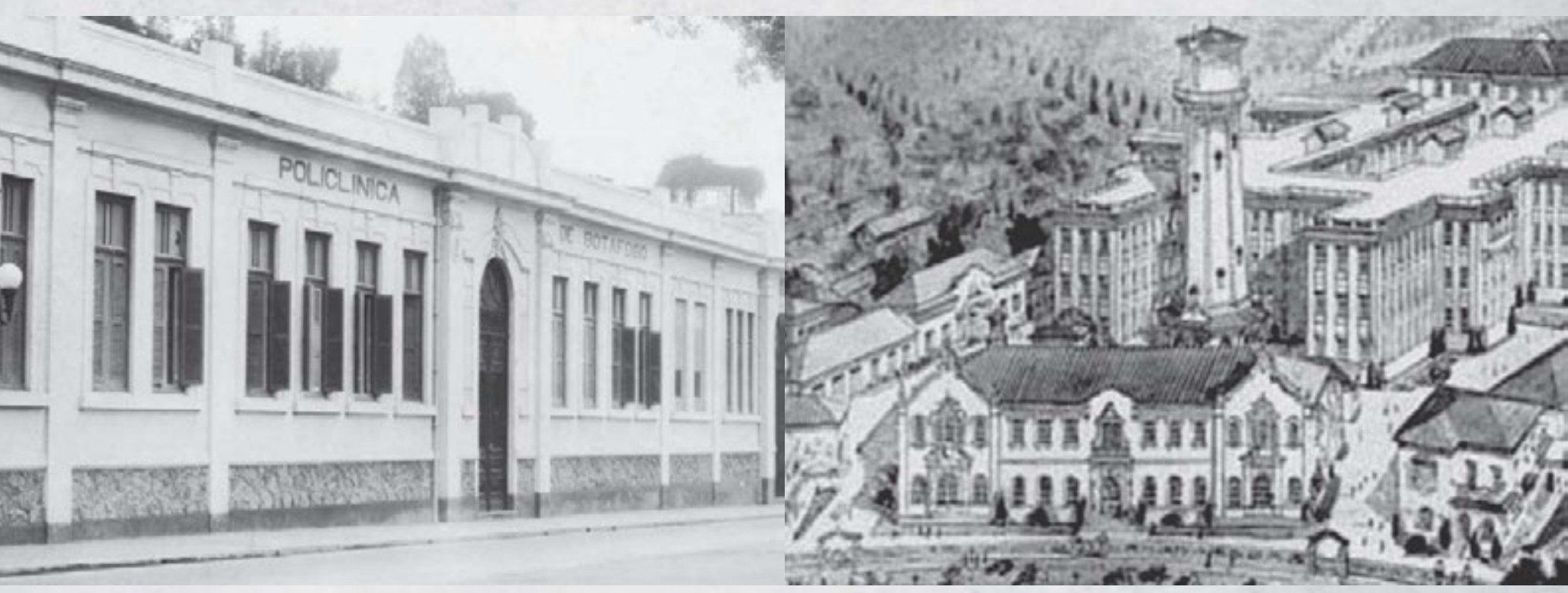


This chapter goes back to the beginning of the Republic, more specifically between the years 19061929, when an evident contrast is perceived in regards to the current conceptions on health care, as well as on the proper sphere of action of the State. The analysis will concentrate on the ideas and proposals regarding the constitution of the hospital network in the city of Rio de Janeiro, then Federal District, present in the debate that lasted throughout that period, involving doctors, hygienists and philanthropists. It draws attention in this debate the definition of public assistance, which has no similarity with the current meaning of medical care, although it was about the rendering of certain medical services to the population. Public assistance was understood as a vast and comprehensive array of actions to which was attributed a public nature - from infant and maternity care, care of the elderly and mental illness -, and that involved a number of public and private institutions, lay and religious hospitals, nursing homes, orphanages, colonies, day-care centers, leagues, medical posts, maternities, asylums, dispensaries, polyclinics -, where limits of action were tenuous and permeable.

When analyzing the changes undergone in public assistance, from the discussions and proposals presented by doctors and representatives of the elite. It is possible to define this period as a transition between the liberal state, as structured by the 1889 Constitution, and a welfare state, which characterized what has been called the Vargas era (1930-1945), which will be covered in the next chapter, with the questioning and uncertainties that surrounded the liberalism of the developing Republic being perceived at that moment. There it can be identified the origin of proposals and actions that would be implemented during the decade of 1930 .

This chapter is divided in four different parts. The first, "The hospital and its public", discusses the transformations in the hospital - from a place for charity to a space for therapeutics. This theme relates to the perception of the society on the impoverished, to whom this space was destined throughout the centuries, and the origin of the labor force, that requires another structure of assistance. The second part, "Assistance in Brazil: first organizations", seeks to highlight the characteristic of assistance in the country, centered in the pious actions of the Sisterhood of Mercy and the changes occurred with the proclamation of the Republic.

The third part, "Rethinking Public Assistance (1900-1918)", leaves the word to the doctors and philanthropists that presented their projects for Public Assistance in the Federal District - still based on the non-intervention of the State. These men defended the participation of the philanthropy in the 
organization of Assistance. Finally, the last part, "the crisis of hospital beds and the changes in Assistance (1918-1919)", indicates the transition from the liberal state to the welfare state. The year of 1922 marks the last breath of liberal assistance; while doctors and politicians defended their projects, now calling for the participation in the creation and management of the public hospital network in the city. Transition period, where the doctors' saying makes clear the uncertainty that marked that decade.

\section{The hospital and its public}

The hospital is where one resorts to at times of illness, for clinical and surgical treatment. However, the relationship between men and hospitals was not always like that, having gone through major transformations throughout the centuries. It was the place of the impoverished, where one went to look for food for the body and soul.

In the Middle Ages, hospitals - whose etymology is associated to the act of sheltering - were open to all human suffering: the mad, women in labor, foundlings, old and sick people. These institutions represented the place, par excellence, for charity, even if at some moments of its history they have been used for public order.

From its origins, the hospital can be characterized for its notably religious character and as social center for care to the unaided population - and it will be difficult to extract this mark to it, even because the poverty and the care to the impoverished are central issues in Christianity. At the beginning, worries about salvation and compassion with the patient had motivated great part of the donations to the hospital institutions. The periods of epidemics marked an increase in contributions, which could be made under the form of bequeaths and donations or for the collection of alms. It must be noted that, at that time, the poor were covered with a sacred mantle, they were God's poor, and to the act of sheltering was attributed an equally sacred character. In time, the questions associated with the material world started to predominate in the relations between the society and these establishments, slowly transforming them. From the $16^{\text {th }}$ century, it was mostly a new perspective about the poor and poverty that changed the character of hospitals. The sanctified mantle was put aside, giving place to the idea of that an agglomeration of the poor represented a potential social hazard.

Early in the $18^{\text {th }}$ century, garbage, dirt, stagnant water, fumes from decaying material started being considered as propitious environments for the dissemination of diseases. As a result, the unhealthy city streets, cemeteries and houses became targets of hygienists' attention and action. In many countries public health organizations were established, aiming to control epidemics and plagues, whose more visible actions were directed towards such environments (Bourdelais, 2001, P. 10 et seq.; Corbain, 1986). To this new scenario, others would be added, such as the concern with the circulation, the cities and living conditions (feeding, housing, etc.) and labor. Hospitals did not remain oblivious to this environment and became one of the main focuses of the problem, having been opened a crusade against the agglomeration that characterized them (occupation of the beds and infirmaries, localization of the rooms, etc.) in favor of ventilation and sunlight - two concepts fond to the hygienists ${ }^{1}$. However, from this reform process, it was converted into an essential part in the public health and demographic policy adopted in Europe throughout the nineteenth century, not only due to the availability of better 
equipment, but mostly because the formation of a medical body. It was only in the hospital and in the daily practice that medical knowledge could be acquired, reaffirming its medical equipment role.

Since the beginning of the nineteenth century, the use of public health terminology could be heard among doctors and the elite, mostly when referring to and intervening in situations defined as social, and the poor were, for them, the main focus of the city problems. However, in this period, parallel to the industrialization process, a new player entered the scene: the laborer. The poor were no longer the object of attention of hygienists and philanthropists, but laborers and their living and housing conditions. It was on the laborer that the English Law of the Poor ${ }^{2}$ (1834) was centered; and the various philanthropic and legislative actions that had been adopted in France - along with the social movements which marked the nineteenth century and the origin of the socialist thinking.

It is in this picture that emerge the social reformers, as they called themselves, formed by intellectuals, doctors, moguls and politicians who proposed to elaborate a new social pact for France. They were opposites to the philanthropists, to whom it was attributed an ineffective response to social needs, at a moment where the boundaries were redefined between the public and private spheres, as the laborer, and no longer the poor, were taken as the object of action, beginning a long debate on the legitimacy of the role of the State in the industrial society. These reformers had as an objective to achieve social peace, in a moment marked by social turmoil. The actions proposed by them were directed towards the creation of healthy residences for the workers, which demonstrated a strong influence of the hygienist creed, through the creation of a protective legislation and of incentives to the labor circles, organized in the factories and seeking civic education and leisure (cf. Duprat, 1993). They had been defenders of societies of mutual assistance, considered as a necessity of the working world and that aimed at providing assistance in case of illness, accidents, aging, maternity or death. Mutuality was perceived as complementary structure, for the organization of the laborers - proposed in line with the current liberal practice (Horne, 2004).

The needs of the 'working world' brought changes in the dynamics of the assistance, forcing it to adjust to the matrix of modern life and culture - the industry and its consequences: labor accidents, unemployment, inadequate living conditions, etc. It is in this context that emerged, in the nineteenth century, a new form of assistance: the mutual assistance houses, linked to professional categories. Along with the hospital services, the sanitary education became part of the actions of the houses of aid, turning these institutions, in the words of Olivier Faure (1993, P. 120), into "instruments of hygienic cleansing" of both moral and physical health of the poor laborer. A space for socialization of classes, medical care, social security and savings, the mutual aid houses had become, in the eyes of the elite, the place par excellence for the moral development of the working classes.

It was in this context of change that Brazilian doctors and philanthropists had thought and reflected on the topic of Assistance in Brazil - even if only for Rio de Janeiro.

\section{Assistance in Brazil: first organizations}

Assistance in Brazil was characterized, from the early days of colonization, by dependence on the actions of the Sisterhood of the Mercy. The Sisterhood of Our Lady, Madre de Deus, Virgin Mary of Mercy, or simply Mercy, was created in Portugal at the end of the fifteenth century, under the auspices 
of Queen D. Leonor, which granted it prestige and regal protection, differentiating it from other organizations created at the same time. Its works (Hospital, House of the Wheel, Housing of Orphans) were supported by alms, pious donations of the religious, bequests, and government endowments, being it the Portuguese Crown, the imperial government, or the republican (cf. entry of the Mercy Public Charity Hospital (Santa Casa de Misericórdia do Rio De Janeiro).

The concentration of the assistance in the Mercy Hospital, since the beginning of the sixteenth century, was part of a set of actions adopted by the Portuguese Crown that "launched the foundations of a social support system, relatively uniform, based on an explicit logic of a division of labor, which sought to include prisoners, unsupported children, the poor and the sick." (Abreu, 2004: 13). It was this same standardization of the system that expanded throughout the Portuguese overseas empire, where many times the Mercy Hospitals represented the colonial power, mixing, in its actions, constantly, the public and the private.

The Sisterhood of Mercy assumed, in the Colony, the role of a public institution, not only for receiving the regal clergy, but also due to two issues. First, tied directly with the organization of the Imperial State, which in 1828 delegated to the provinces and the cities health care actions - reassuming control of the actions after the outbreak of the first yellow fever epidemic in the Court, in the summer of 1849-1850 - while the Imperial government only had responsibility for acting in times of epidemics, in the maintenance of the isolation hospitals (Maritime of Santa Isabel ${ }^{3}$ and, starting in 1886, the São Sebastião Hospital), in the health care of the ports and the monitoring of medical and pharmacy practices.

The second issue relates to, specifically, the perception of the boundaries between the public and the private, in the Imperial period, as well as that covered in this chapter. Although apparently acting in opposing fields, the actions of the different agents involved with assistance were, many times, complementary. The institution could have a private character, but its action was public. Or worded differently:

"Very different indeed, were the management forms of the many kinds of welfare institutions; the guardianships that they exerted; the denominations - or the meanings of similar denominations -; the times of intervention of institutional powers. Interaction was also common, as well as complementary actions of different organizations involved in assistance, even when positioned in opposing fields". (Abreu, 2004: 11)

Public or private, lay or confessional, assistance in Rio de Janeiro, and in Brazil, was performed by many welfare institutions and denominations, which at a time of need, focused on helping the poor.

As far as hospital care itself is concerned, the city of Rio de Janeiro had a great number of hospitals, polyclinics and nursing homes - that no matter how many beds reserved to philanthropy, little was changed in the general availability of beds for the poor. The absence of a hospital managed by the municipality seemed strange to the foreigners who arrived here, as the case with Frenchman Emille Allain, who visited the city at the end of the Imperial period, although he considered that the service of public assistance was very well organized, thanks to the action of the Santa Casa da Misericórdia (Allain, 1886: 231-2).

In 1889 , the advent of the Republic greatly modified the organization of the municipal and federal authority. What until then were attributions of the central power, became functions of the municipality, as previously highlighted. In such a way, it was the responsibility of the Federal District to manage all 
urban sanity actions. Among the various measures taken by the city, it can be cited the razing of the "Cabeça de Porco" tenement house in downtown Rio de Janeiro, in February of 1893 - exactly one year after the promulgation of a law that gave the municipality authority to act on behalf of the city's hygiene 4 . Thus, the destruction of the "Cabeça de Porco" during the administration of doctor and mayor Barata Ribeiro (1892-1893), strengthened the victory of the hygienist policy, on the one hand, and opened the period of strong intervention which the city would go through also in the administration of Mayor Pereira Passos (1902-1906) - the Rio of the "tear it down". The demolishing action culminated with the razing of Castelo hill, during the administration of Mayor Carlos Sampaio (1920-1922), all measures seeking to improve the hygienic and sanitary conditions of the city.

If on the one hand the measures of the municipal government were concentrated on the urban question, with its improvements in the public health conditions and beautification, in the other, the first years of the Republic little modified the hospital care structure in the Capital. The Santa Casa da Misericórdia remained the only hospital destined to treat the poor, but relied on the help of the General Polyclinic of Rio de Janeiro (1881) and of the Polyclinic of Botafogo (1899) - philanthropic institutions that provided ambulatory, clinical and surgical care to the poor.

However, early in the century this structure was not yet a problem for the doctors, as Luiz Barbosa expressed (1869-1949). In his opinion, the Capital did not lack, in 1908, assistance institutions, but rather a coherent form of organization and management. The doctor highlighted in his writings on the Services of Assistance in Rio de Janeiro, of 1908, that the classification of the institutions as "official" federal and municipal - and "private" - religious and civil - could be considered artificial, but was fully acceptable for the development of his book and in any case all the establishments, institutes, associations and assistance services worked in favor of the public assistance in the city. (Barbosa, 1908).

It is worth noting that one of the main characteristics of the first Republic was federalism, which transferred to the states responsibility for actions to maintain the public order and provide protection, opposite to the centralization of power during the Empire. This federalism was legitimized by the liberal practice that advocated non- intervention by the State, and supported local government. And as it relates to assistance, the liberal practice ended up maintaining the structure inherited from colonial times, managed by the Mercy Hospital. Hence, the State would only be responsible for acting in times of public calamity, when order was in danger, that is, during the epidemics; and in the monitoring of the ports and of the professional practice.

\section{Rethinking Public Assistance (1900-1918)}

The first years of the Twentieth Century were marked by the intervention of the Federal District municipal government in the public health conditions of the city and maintaining the same actions of assistance as during the Empire. During the administration of President Rodrigues Alves (1902-1906), modernizing reforms in the federal capital had been undertaken, on three fronts of action that overlapped: on one side, the Port and on the other, the city and its public health problems.

These three fronts pointed to an issue related to the public order: the old houses of downtown which had been transformed into collective housing for dock workers. These were mainly occupied by 
blacks who came from the farms, who came to the city after the abolition of the slavery in search of work, and found it at the docks, where their manpower was absorbed in the loading and unloading of ships that arrived in increasing numbers. They came, therefore, in the eyes of the authorities, to increase the already numerous contingent of former slaves and free men who circulated in the city. Thus, the innumerable tenements that existed were considered as a public threat to the order, safety, morality, public health, and as such had to be controlled and fought. It seems that, in the eyes of the republicans, the poor had become dangerous, as they put it in risk the plans of building a tropical civilized and industrial nation (Benchimol, 1992; Chalhoub, 2004).

The Public Health Reform was configured, at the same time, as object of action and justification to the project of modernizing (Benchimol, 2001). Doctor Oswaldo Cruz was put in charge to lead the General Management of Public Health (DGSP), agency that concentrated the actions of public health in the Capital. Oswaldo Cruz was given police powers, which allowed him to order breaking into homes, and commercial and industrial establishments, in order to identify sources of epidemics, as well as adopting the necessary prophylactic measures.

One of the consequences of this reform was the loss, by the Federal District Municipal Government ${ }^{5}$, of most of its attributions, which were centralized in the federal sphere, with the exception of emergency medical assistance. Despite lamenting this measure, the doctor Luiz Barbosa recognized that although the obligation of the Municipal Government was to establish, direct and organize the assistance stations and the obligation to provide emergency care in case of accidents on the streets and beach areas, little had been done. It was initiative of the municipality to create, in 1903, the General Office of Assistance, which would seek to organize the various philanthropic assistance initiatives spread throughout the city and in the following year, the first attempt to organize emergency services. The first measure was not implemented, and the second, in the opinion of the doctor, brought old problems, notably for having been installed in inadequate buildings, and for having enough material for the clinical and administrative functions. However, the emergency assistance went a different direction, with the inauguration, on November $1^{\text {st }} 1907$, of the Municipal Assistance Station, on Camerino Street - currently the Souza Aguiar Municipal Hospital.

Parallel to the rearrangement of the actions and authorities of the municipal and federal governments in the city of Rio de Janeiro, the first years of the Twentieth Century saw the emergence of various congresses dedicated to the theme of Public and Private Assistance, where doctors and philanthropists found the ideal stage to defend their ideas on the topic. This discussion was in direct accord with the ideas debated all over the Western world, when, as it was previously highlighted, the role of the State in society was being debated and challenged (Polanyi, 2000). It was in this context of rearticulating and redefining the social roles that had been elaborated proposals for the Public and Private Assistance - a subject very dear to the liberals. This discussion did not occur, however, at the same time in all countries, they endured through the entire nineteenth century and early twentieth century, and were directly related to the historical moments lived by the national States ${ }^{6}$.

Among the players who had presented proposals for the organization of the assistance in the Brazilian Capital, special mention should be made about doctors Luiz Barbosa; Carlos Arthur Moncorvo de Figueiredo Filho (Moncorvo Filho); Antonio Fernandes Figueira; Garfield de Almeida; and philanthropist Ataulfo Nápoles de Paiva. 
Luiz Barbosa presented, in his already mentioned writings of 1908, how public assistance should be organized by the municipal government. He defended the application, in the capital, of a health care system similar to that of Buenos Aires, where the city was divided by districts and ambulances were driven by medical students. The comparison between the two South American capitals was quite unfavorable to Rio de Janeiro, where the transport of the ill and wounded was performed using borrowed stretchers or police vehicles, in most cases, without medical examination. And this suggested the need of an agreement with the federal government, to establish their posts in the health stations and taking advantage of the Polyclinics as additional resources to emergency services. It is worth noting that Luiz Barbosa was the creator of the Polyclinic of Botafogo, in addition to managing Municipal Public Assistance, in the period.

In 1907, Moncorvo Filho (1871-1944) published the brochure Public Assistance in Rio de Janeiro and particularly Assistance to Children, from his communication in the IV International Congress of Public and Private Assistance, held in Milan, in the previous year, where he analyzed of the situation of the assistance in Rio de Janeiro and proposed measures to better organize it. He affirmed that, according to "modern doctrines", the municipalities were responsible for organizing assistance services, and the Federal Government was responsible for establishing general laws of assistance and the organization of the central agency, which would have to direct the overall initiative, guiding the various services, of private or national nature.

Moncorvo briefly described the situation of private institutions ${ }^{7}$, with more emphasis on the Santa Casa da Misericórdia, to which he attributed serious problems, some considered as due to its "origin" or the fact of being a charity institution - and other due to the numerous sick people that it was forced to accept, "underneath of its charitable ceiling", as well as the emergency services (street accidents and others), for which it was not prepared and which should be provided by the Municipality; or even due to layout of the building, considered obsolete and which put infirmary wards too close together. All these factors had contributed to the problems in the service at the Santa Casa. He concluded with the assertion that the gaps left in the service at Santa Casa were fully acceptable given to the countless services and responsibilities it supported. (Moncorvo Filho, 1907)

A similar opinion was expressed by doctor Antonio Fernandes Figueira, in 1902, in the pages of the Brazil-Doctor magazine. In his opinion, hospital service improvement was urgent in the city which regard to treatment of children, to the issue of the quarantining, and as it relates to hospital facilities, especially when adding infirmaries to clinical services. Even if there was a movement for the establishment of hospitals by the municipality, he believed that most important thing was the introduction of reforms "in the casas santas, which will have the sick poor" (Figueira, 1902: 3311-12); besides separating children and adults, and having better defined quarantining areas, in order not to mix inpatients with people with tuberculosis and plagues. Fernandes Figueira considered that this would be the greatest work which the Maintaining Organization of the Casa Santa could do.

As will be covered later on, the argument of the overuse of the Santa Casa de Misericórdia was common among the doctors, even if the Sisterhood maintained various other hospitals or sought to open new institutions to meet demands from doctors themselves, such as the opening of the Child Polyclinic, in 1909, and the São Zaccharias Hospital, in 1916, both destined to fetal and child care. 
Back to the ideas defended by Moncorvo Filho at the 1906 Congress, he proposed, in a perspective similar to the French approach - centered in the action of the municipal bureau of hygiene (Bourdelais, 2005) - the creation of a Superior Council of Public Assistance and of a Service of Public Assistance that would be an autonomous branch of the public administration, with specific funding. Its action was toward home care services those rendered in hospitals, asylums, dispensaries, polyclinics etc., under the jurisdiction of the Ministry of Justice and Interior Affairs.

In the specific case of the Federal Capital, Moncorvo Filho defended the establishment of a Central Bureau, where the headquarters of the Public Assistance would operate. In each district, Beneficence Offices would be established, which would have medical-surgical stations, equipped for emergency service, day and night, and street accidents. The Offices would also be responsible for the organization of the lists of beggars and poor in the area, and to provide home care.

As a practical measure and aiming at the proper work of the structure, Moncorvo Filho foresaw the use of widely recognized institutions of assistance such as Assistance Stations - the General (Rio de Janeiro) and Botafogo Polyclinics, and the Hospital of the Santa Casa de Misericórdia. The Institute of Protection and Assistance to Infants (IPAI) would be reserved to the Assistance to Infancy, including exams and certified wet nurses, milk supply to poor newborns and home care for poor pregnant women. The women who could not be admitted to the IPAI would be directed to the Maternity of Laranjeiras or to the Santa Casa. Patients with tuberculosis would be directed to the Brazilian Anti-Tuberculosis League.

Once again, the Polyclinics emerged as resources to be added to the Public Assistance. It is worth noting that, as Luiz Barbosa, Moncorvo Filho was closely connected with the philanthropic project of the Polyclinics, as his father was one of the founders of the General Polyclinic of Rio de Janeiro, and himself the creator of the IPAI. Both doctors strongly believed in the alliance between philanthropy and Public Assistance, as well as in the proposal of assistance defended by these institutions.

In 1908, the Federal District, under the administration of Francisco Marcelino de Souza Aguiar (1906-1909), held a National Congress of Public and Private Assistance, held during the commemorative Exposition of the Centennial of the Opening of the Ports. The indicated Organizing Commission was formed by doctors Benjamin da Rocha Faria and Antônio Fernandes Figueira, by jurist and philanthropist Ataulfo Naples de Paiva, by poet Olavo Bilac, besides João Carneiro de Souza Bandeira; Alfredo da Graça Couto and Jose de Medeiros e Albuquerque. Invitations were sent to scientific societies, Medical Universities, public and private hospitals, the endowment societies and all those concerned about the problem of Assistance.

The Congress was divided into four sessions: Medical Assistance; General Public Assistance; Assistance to Infancy; and External Assistance. Among the various theories defended in Congress and published in the Medical Brazil of 1908, the theories of Antônio Fernandes Figueira and Garfield de Almeida should be given special mention.

The report presented by Fernandes Figueira for the session Public Assistance - assistance to infancy and particularly in what concerns to the measures to be adopted against infant mortality. Education of handicapped children indicated the following measures: organization, by the public power, of a body of doctorinspectors for the monitoring of the nursing babies; obligation of the assistance institutions to accept breast-feeding of children until age six months; extinction of the abandoned children "wheels" 
substituted by the "free registers"; urgency in the establishment of home care societies for the poor and of protection to breast-feeding; the creation of the largest possible number of "clinics for nursing babies" in cities and villages; the monitoring by the public power, of the milk destined to the consumption by children (Figueira, 1908).

Garfield de Almeidam(1908), in the other hand, criticized the hospital services offered in the Capital, besides endorsing the notion of that the city of Rio de Janeiro was behind in terms of Public Assistance. His conclusions pointed to a way to solve the problems: the construction, with urgency, of a public hospital, which would have to be established on unused public property, in special using one of the pavilions of the 1908 Exposition itself. The adopted system would be "pavilion-like", with 40 beds each, adding up to 14 pavilions and 540 beds, separating the sick into the three (sic) genders (men, women and children). It would have a smaller pavilion, for observation; a pavilion with double infirmary wards, with 40 beds, for tuberculosis inpatients; a pavilion of convalescents in addition to a clinic with 10 services. Another main point for him was the expansion of the S. Francisco de Assis Nursing Home, which would be better used when transformed into a hospital-nursing home.

Jurist Ataulfo de Paiva, in turn, defended the proposal for the creation of a Central Office of Assistance, of private character, made up of representatives from private institutions. His project aimed to organize the direct action of government in what it referred to the execution and to supply coverage to the poor in general. It proposed the creation of a General Direction of Public Assistance, under whose attributions was the governmental aid services. (Paiva, 1916: 325)

The Central Office of Assistance, organized by the central government, would seek to congregate and harmonize the interests of the public assistance, and private when performing its activities few of charge. This agency would have to preserve the autonomy and administration of associations, "pious houses", nursing homes, societies and other institutions that provided private assistance. Only in such a way, it would the government be qualified to direct and resolve the "great and capital issues that affect[ed]s the exercise of assistance in general" (Paiva, 1916: 321).

The general conclusions of the Congress, with regard to Hospital and Emergency Care, help to understand the discussions that took over the agenda of doctors and philanthropists. For the first, the congressmen decided that it was the responsibility of municipal governments, that all cities, industrialized or with large population, should have an emergency service and that the Central Assistance Station of Rio de Janeiro was considered as model to be applied in other cities. However, the emergency services in Rio de Janeiro were still restricted to those places where they could be executed properly, and that the creation of other emergency stations in the urban municipal sanitary districts was necessary. The Congress reaffirmed the centralization of actions, proposed by the Public Health Reform of 1904, while praising the work carried through by the Federal District administration in favor of the emergency assistance even if it still had to improve somewhat.

Regarding Hospital Care, Congress concluded that it was urgent to build a hospital for the municipality of Rio de Janeiro; that the expansion of the S. Francisco de Assis Hospital was essential, as well as the creation of a hospital-nursing home for incurable patients with capacity of 200 beds, 100 for each sex. With this, a demand came to the forefront which dominated most part of the discussion on the assistance in the following decades: the need to build public hospitals in the Federal Capital - this 
subject became even more troubling starting in 1918, with the outbreak of the epidemic of Spanish flu, which highlighted the inefficiency of the Capital's assistance services.

Eight years after this Congress, Ataulfo de Paiva's book, Justice and Assistance, was published, where he assembled various articles of his authorship, on subjects associated with justice and assistance, discussing also on the subject of the mutualism and social assistance, besides presenting his preface to his book Public and Private Assistance in Rio de Janeiro, which was only published in 1922 as part of the celebrations of the Centennial of Independence. His work in charge of the Brazilian Anti-Tuberculosis League gave him the credentials to participate in all congresses on the subject of Assistance, making him a reference in the theme. In this work, the jurist and philanthropist reaffirmed his project defended in the National Congress of Public and Private Assistance of 1908, by going back to the foundations of his concept of assistance, strongly inspired by the French experience. The French model was based in the role of the communes, departments and of the Nation in the organization of the services of Assistance; where philanthropy exerted an important role in assistance, especially due to the presence of countless philanthropists who defended their ideals in the Constitutional Assembly (Faure, 1993).

In this preface, Ataulfo de Paiva made an x-ray of the public assistance in Brazil, while presenting its constituent foundations ${ }^{9}$. Among these items it is worth noting that, regarding infant care, Paiva defended the ideas proposed by Moncorvo Filho; for women the issue with assistance was directly related to the work force and the conditions of infant care - and social assistance would be translated in the creation of maternities, which would save baby and mother.

As for the hospital assistance, his analysis was also based on the French experience and the discussion occurred there since the end of eighteenth century, which would last through the nineteenth century, on the subject, concentrating on charity associations and philanthropic societies (Duprat, 1993,1996; Faure, 1993; Sanglard, 2008). These organizations, in addition to distributing bread, wine and clothing, also made home visits and medical appointments. About the hospital itself, besides having discussed the changes in the hospital architecture, this of Tenon ${ }^{10}$, and highlighting the model of the French Hospital of Lariboisière, Ataulfo de Paiva mentioned that Rio de Janeiro's Mercy Public Charity Hospital had reached its limit and that there was the need to build a public hospital in the Capital; he brought back the words of Garfield de Almeida in the Congress in 1908, affirming that according to the doctor's calculations, the hospital model, here, would need 800 beds. Finally, he ended the session with a sentence that summarized, in a great way, the expectation of the time concerning the construction of a public hospital in Rio de Janeiro: "Of this company, however, and to this date, this has not yet been though of in government circles. Nor will it come soon to fill another of the great and notable gaps in public and private assistance in Rio de Janeiro" (Paiva, 1916: 219).

\section{The crisis of beds and the changes in Assistance (1918-1929)}

The period between 1917 and 1918 was marked by two factors that ended up influencing and redirecting the debates concerning Assistance, in a general sense, and specifically with the hospital: on the one hand, the outbreak of labor strikes in Rio de Janeiro and São Paulo which brought to the House of Representatives the discussions on feminine and child labor, labor accidents and social security (Gomes, 
1979); and, on the other hand, the pandemic of Spanish Fluturned, in the summer of 1918-1919, that drew attention to a chronic problem of the great urban centers: the lack of centers of aid for the poor population. As Ataulfo de Paiva pointed out, no initiative by the municipality or the federal government had been implemented, with regard to increasing the number of hospital beds.

The Spanish Fluturned the hospital assistance issue into one of the flagships of the Carlos Chagas (1919-1926) administration in charge of the recently created National Department of Public Health $(\mathrm{DNSP})^{11}$. In this period, several hospitals were built in Rio de Janeiro, such as the Pedro II Hospital (1920), São Francisco de Assis Hospital (1922), Gaffrée e Guinle Hospital (1924-1929) and the Arthur Bernardes Shelter Hospital (1924); e initiated the construction of the Hospital of Cancer (1927-1935) and the Arthur Bernardes Hospital of Clinics of the Medicine College (1926-1934), which would change the Public Assistance in Rio de Janeiro, not to mention the establishment of the Juliano Moreira (1924) and Curupaity (1922-1928) farm colonies. It is worth noting that these hospitals were all beneficiaries for the DNSP and tied to Carlos Chagas' policy, two of them having been built at the expense of the philanthropy of the Guinle family ${ }^{12}$ (cf. Sanglard, 2008).

The debate around the lack of beds in the city was amply covered by the press. One of the most present doctors was José de Mendonça, who had space in the Correio da Manhã, for publishing his thoughts. In 1918, soon after the arrival of the Spanish, he proposed the construction of four hospitals with a thousand beds each; established in the regions of Botafogo (near the College), Andaraí, São Cristóvão (in the coastal part of the area, to assist sailors), and Méier or Cascadura (next the Central rail line). He defended the theory, supported by other doctors, that Hospital care should not be free, but proportional to each patient's ability to pay and, in case of total incapacity to pay, it would be up to the municipality to cover all costs.

In this same year, Carlos Chagas stated, during a tribute to doctors from Bahia at Rio de Janeiro's Jockey Club, that Brazil needed new and modern hospitals, aiming at to taking care of the 'usual health treatment places' and, in some cases, the epidemics. In his speech he reiterated that the Mercy Hospital could no longer be expanded to take care of to the needs of public assistance. (1919, Virtual Library Carlos Chagas, captured in 02 May 2003).

In 1920, a similar proposal would be defended in the Chamber of Deputies, by the doctor from Southern Brazil Domingos Mascarenhas, who was able to turn into decree his bill for the construction of three hospitals in the Federal District, all with capacity of over a thousand beds, one of which close to the Medicine College, and all managed by the DNSP and following the German model of hospital architecture. In this project, free service was granted to beggars, and others would pay in proportion to their financial conditions. This project was greatly inspired by the ideas of José de Mendonça (Brazil, 1920) and widely discussed and debated in the Chamber of Deputies with the presence of the doctormembers of the house of representatives - Palmeira Ripper, Zoroastro Alvarenga, Domingos Mascarenhas, Alexandrino Rocha, Raul Barroso, Dionysio Bentes, Rodrigues Lima and Teixeira Brandão - and had also the participation of Carlos Chagas and Luiz Barbosa. However, the proximity of the celebrations of the Centennial of Independence prevented the Mascarenhas Project, as was known, from being established, adding to the intensification of criticism (Brazil, 1923). This project was re-written, with alterations, but never executed. 
Of the discussions concerning this project it is worth noting some thoughts. Carlos Chagas, who argued that it had been over 50 years since any improvement had been made in hospital assistance, despite the ever increasing growth of the population and consequently of the patients who used it, reiterated the fact that the Santa Casa was operating at its limit as well as the São Sebastião Hospital. Teixeira Brandão highlighted the urgent need to build a hospital for the education of the clinics for the Medicine College, defended the construction of hospitals for the municipal employees, which would relieve the congestion in the federal hospital assistance and the creation of home assistance. Domingos Mascarenhas, in his turn, made a negative comparison between Rio de Janeiro and Buenos Aires (Mendonça, 1920), recurrent theme among doctors and intellectuals of the time (Sanglard, 2007).

As part of the celebrations of the Centennial of Independence, two events drew attention to the issue related to the city's Public Assistance. The first was the already mentioned publication by the municipal government of the Public and Private Assistance in Rio de Janeiro - which presented the history and statistics of all existing institutions and associations providing resources to public assistance and the ones yet to be created, as the Hospital Gaffrée and Guinle. The second was the National Congress of Practicing Professionals held at the General Polyclinic, which had one of its sessions dedicated to the subject of the Public Assistance. Among the various communications of the Congress, it is worth noting: "the true hospital organization and its administrative structure"; "autonomy of the hospitals; doctors and nurses"; "the hospital as means of practical instruction" - headed by Irineu Malagueta; "Reflections on the Hospital Assistance", by José de Mendonça; "Public and Private Assistance - relation and regulation", by Moncorvo Filho; "the abuse in free hospitalization, the reasonable verification of poverty, and the modest hospital fees", by Miguel Couto; and "hospital assistance is the duty of the municipalities", by Luiz Barbosa.

The reports presented recalled many of the discussions that crossed the latest decades, with the same players, and making room for new proposals. José de Mendonça, one of great defenders of the creation of public hospitals in the city, used its space to announce his support for the project of representative Amaral Carvalho, of 1921, which recalled, almost in its entirety, the Mascarenhas project - with the exception of the adopted architectural model, which became the single block, and the name of the Hospital of Clinics which would be Pedro II, in homage to the Emperor (Brazil, 1921). Others, such as Irineu Malagueta, brought up again the discussion on who would be in charge of the construction of the hospitals: the municipality or the federation? To Luiz Barbosa, this would be a function of the City... Miguel Couto launched the public debate on the issue of the free nature of the services. It was praised by José de Mendonça in what it referred to as the defense of opening hospitals, and criticized with regards to observing poverty verification, which he considered as necessary. This caused Luiz Barbosa to defend the verification of the assistance service by the Municipal Government. Alvaro Ozório, in his turn, considered as "defective" the socialization of assistance services and defended as indispensable the establishment of a compulsory health insurance (Actas e Trabalhos, 1923).

In 1924 José Mendonça published an article in Revista do Brasil, later transcribed in the Brazil Médico magazine of the same year, in which he reiterated the proposal to build four hospitals, with a thousand beds each (Mendonça 1924) ${ }^{13}$. The concept of hospital organization of this doctor was greatly inspired in the Austrian model. Thus, for Mendonça, in the cities, where land was more expensive, should be 
placed those hospitals destined to take care of victims of accidents (street and work), the "ProntosSocorros" (Emergency Services); "the curable" sick (short internments), the Polyclinics; and the laboring women, the Maternities. In the countryside, where land was cheaper, should be established the houses of convalescents, the sanatoriums for tuberculosis inpatients, the hospitals of the mentally ill, and the sanatoriums for "nervous and addicted people", using the words of the author. With regards to the free nature of the services, he proposed a law which required companies (State owned, industrial, commercial or rural) to contribute proportionally to the number of employees.

In this scenario the project for the establishment of the five hospitals in the decade of 1920 was highlighted. Two of them - the Gaffrée and Guinle Hospital, and the Hospital of the Cancer - were built thanks to the philanthropic action of Guillermo Guinle (1882-1960), whose constructions were directly connected with Carlos Chagas' project, and of doctors linked to the Inspectorship of Leprosy and Venereal diseases.

The projects of the Gaffree and Guinle Hospital and the Hospital of the Cancer became relevant for having been undertaken due to the actions of the carioca industrial Guillermo Guinle. At the time, the participation of the Brazilian elite in the construction/maintenance of hospitals/dispensaries was considered inexistent for its contemporaries, to the point of Guinle's attitude to be considered "exemplary" (Sanglard: 2008). This exemplary character, very widely publicized at the time corroborates the words of José Mendonça (1924); the doctor, much earlier, had stated the individual wealth to be rare, which would hinder the participation of these in philanthropic initiatives and, as a consequence, would make the government the only agent able to executive works of this size.

Along with these projects was also the establishment in 1924 of the Arthur Bernardes Shelter-Hospital, in the Botafogo neighborhood, destined for pediatric clinical work and surgery, and connected to the actions of the Inspectorship of Infant Hygiene - under the responsibility of Doctor Antônio Fernandes Figueira. The original project also included, besides assistance to infants, the establishment of the Maternity of the College of Medicine (Livro de Atas: jul 10 1923).'

During the administration of president Washington Luiz the change in public policy toward hospital assistance was indicative with the creation, in 1926, of the Hospital Assistance, agency independent of the DNSP, responsible for the management of the São Francisco de Assis and Pedro II Hospitals, as well as supervision of the other hospitals of the capital (Brasil 1930: 69). The management of the Hospital Assistance was given to João Marino, professor at the Medicine College. The agency had a Hospital Board, made up of Ataulfo de Paiva, Carlos Chagas, Guillerme Guinle, Clementino Fraga, Abreu Fialho and Miguel de Carvalho. The board was responsible to advise the director in the most ambitious project of the agency: the construction of a hospital - Arthur Bernardes Hospital of Clinics - for the Medicine College, with capacity to admit as many as 1,800 patients (Sanglard, 2007). The construction of this hospital met two objectives: to provide the Rio de Janeiro Medical School with its own hospital, and to increase the availability of beds in the city. Thereby, this project systemized all others that had circulated throughout the past 25 years.

The land chosen was expropriated in January of 1926; in the region of Mangueira. One of the area's appeals, and one of the justifications presented for its choice, was the easy access of the poor population, especially those in the suburbs - it was located at the Mangueira station, near the Central do Brazil and the Leopoldina Railways, and reachable by streetcar and automobiles (Brasil, 1956). 
Considered by the Carioca press as a "Notable Enterprise", but also as a "last minute initiative", the hospital's project had its management marked by a series of divergences. The architectural project had already been chosen, when João Marinho took charge of the agency. It was ordered with Porto d'Ave the same architect responsible for the Gaffrée and Guinle Hospital, and Hospital of Cancer projects soon after the selection of the land; its foundation stone was laid on June $19^{\text {th }} 1926$ (Notável Empreendimento, 1926).

For the confection of the architectural project, Porto d'Ave was advised by university professors of the Medical School. The chief technician responsible was Professor Rocha Vaz, then manager of the College. According to the plan presented by Rocha Vaz to the government, in June of 1926, the Hospital of Clinics would be built by German technique, "pavilion like", but it would maintain the American internal organization - which differed from the final proposals, as already mentioned.

It was not easy to reach an agreement between the professors of the College, the Hospital Assistance and Porto d'Ave with regards to the Hospital's project; and the disputes were notorious between João Marinho and Porto d'Ave, besides the several quarrels between professors of the Medicine College published in medical periodicals, such as the Folha Médica, Rio de Janeiro's Medicine and Surgery Society's official agency, as well as general press.

Among the disputed points was the planned proximity with a greatly populated area. However, some critics would like the new hospital to be located closer to the College's building, in the Praia Vermelha area, in order to facilitate to the locomotion of students and professors; for others, the localization would have to be close to the São Francisco Hospital, transforming the Mangue region into a big health center - there, also, was already installed the Ana Nery College of Nurses -, besides the fact of being downtown. This last group also called for the construction of a new building for the College in the region.

What really happened is that in 1931 the construction of the hospital was interrupted during the administration of President Getúlio Vargas and submitted to internal investigation. The press, which had both criticized, praised, or supported, when the construction seemed almost at a standstill, did not lose hope to see the project built the project, even when it published the alleged reasons by the director of the Hospital Assistance, Doctor Peter Ernesto, to call for the embargo of the construction: excessive and uncontrolled expenditures. In 1934, the construction was definitively abandoned. Over time its skeleton was busy - originating the slum quarter of the Skeleton -, and in the 1970's the State University of Rio de Janeiro was installed there.

And so the decade of 1920 ended without the resolution of one of Public Assistance's biggest problems.

\section{The legacy of the 1920's: health care between philanthropy and government action}

The advent of the Republic, in 1889, caused changes in the field of Public Assistance, and also a rearrangement of the forces that marked the First Republic. If in the first years, public health issues of the city dominated the political agenda, the question of the organization of the Assistance then started to gain space in the concerns of doctors and philanthropists.

One of the issues that continued throughout the period was related to the responsibility for health care actions in the Federal District. The main point of this discussion was the construction of "official" 
hospitals. Who would be in charge: the municipal or the federal government? This question endured throughout the entire period, without a defined answer.

It is certain that the perception of the involved in the discussions changed over that time. In 1902 the construction of hospitals by the government was not considered. The majority of the audience in the National Congress of Public and Private Assistance, in 1908, believed that the best solution for the Public Assistance was to join efforts with the Private Assistance - that which performed a public activity. In 1916, this idea was still valid, as Ataulfo de Paiva alerted. This unification did not eliminate, however, the need to build hospitals, considered as official ones, but was heavily supported in the actions of the philanthropic institutions, notably the General Polyclinic of Rio De Janeiro, the Botafogo Polyclinic, and the IPAI.

This period was also marked by the defense of the Assistance to the Woman and the Assistance to Infancy, where a great concern with the future of the nation was perceived, as children were considered as such. The institutions directed toward the women, in its turn, displayed a concern with the motherwoman, mostly female laborers, granting them the conditions of care with their children and the return to work. In both assistance forms, poverty and infancy were closely connected.

It was under these principles that many philanthropic institutions were created, targeting this public: the already cited IPAI, philanthropic institution directed toward maternal-infantile education and assistance campaigns, strongly inspired in French organizations such as the Goûttes de Lait; the Polyclinic of the Children (1909) and the São Zaccharias Hospital (1916), both created and maintained by the Santa Casa da Misericórdia, and destined, respectively, to the children of the city's North and South Zones, and with very similar objectives as those of the IPAI; and the PRO-MATRE (1918), philanthropic maternity to the poor woman. In all these institutions, doctors and philanthropists joined efforts in favor of the assistance to the woman and the infant. In the same period the Maternity of Laranjeiras was also created, first as a private institution, with philanthropic character, and then it became semiofficial as the Maternity-School of the College of Medicine, in 1918.

Another point to be observed is that many of these institutions directed toward the care of the mother and the infant were located in the city suburbs, following the expansion of the city, and where the working class population lived. It was in the suburbs of Rio de Janeiro where the philanthropic institutions were established, kept by important players in the Rio de Janeiro political and industrial scene, and by beneficent associations. Districts such as São Cristóvão and Cascadura were the object of attention of these philanthropists.

From 1918 the approach changed. It was no longer the combination of philanthropy and public policy that was being defended and spread by the doctors, but the setup and construction of hospitals by government, specifically the Federal Government. Carlos Chagas clearly stated so in the already mentioned speech of 1918, not to mention the several articles published by José de Mendonça on the topic, and discussions in the House of Representatives, concerning the construction of hospitals in Rio de Janeiro. It was noted mostly a greater union of doctors around the issue, as well as the perception that the Union's actions concerning opening new hospitals should not be restricted to the Federal District, as discussed in the Congress of Practioners of 1922 and even in the speech of doctor and representative Antônio Austregésilo (Actas e Trabalhos, 1923; Brasil, 1923). 
However, the transition from projects to reality was much harder. Carlos Chagas, as manager of the DNSP, was in charge of the establishment of six hospitals and two colonies: three adapted in existing building (Pedro II, 1920; São Francisco de Assis, 1922 and Shelter-Hospital Arthur Bernardes, 1924); two constructed thanks to the charitable actions of the Guinle family (Gaffrée and Guinle, 1924-1929, and Cancer, unfinished); the Hospital of Clinics of the College of Medicine (just started); and colonies Juliano Moreira (1924), for the mentally ill, and of Curupaity (1922-1928), for lepers. Of the above mentioned, five were directly tied to public policies adopted at the moment: Shelter-Hospital, linked to the Inspectorship of Infantile Hygiene; the two funded by the Guinles and the Colony of Crupaity, to the Inspectorship of Prophylaxis of Leprosy and Venereal diseases; and the Juliano Moreira Colony, associated to the admittance of Psychopaths.

Undoubtedly, the 1920s represented progress in the organization of the Public Assistance in the Federal Capital, but in spite of the statements' call for the government to be responsible for the Hospital Care in the city, resorting to philanthropy proved to be the viable and ideal solution for the expansion of the Public Assistance.

This period was also marked by the emergence of many hospitals linked to the Beneficent Societies (Evangelical Hospital, Spanish Beneficence, Albert Sabin Hospital, and Feminine Shelter), that exerted a public function, by freely admitting members, relieving the nurseries in the Santa Casa. It was also noted the emerging of measures to establish a social security in Brazil, as a response to the labor strikes of 1917 and 1918, in Rio de Janeiro and São Paulo (Oliveira \& Teixeira, 1986). The concern with the health of workers started to appear in the doctors' speeches, in the proposals for funding the worker hospitalization, in the public hospitals, through the companies (Mendonça, 1924), among other proposals.

Finally, the period covered here draws attention to the changes that took place in the speech of the doctors: the publication of Public and Private Assistance in Rio De Janeiro (1922) was the last libel in defense of a standard for liberal assistance. Since the beginning of the decade, and ever more, the presence of the State was called upon to solve and direct the welfare in Rio de Janeiro. However, the government still used philanthropy as a resource for organizing hospital assistance, only that, in the case of the actions of Guillerme Guinle in health care, it represented a support and an investment in the policy of Carlos Chagas, to the extent that the Guinle family funded the projects of the Inspectorship of Prophylaxis of Leprosy and the Venereal diseases, where the maintenance of the hospitals was in charge of the DNSP.

It was only in the 1930's that the construction and the maintenance of hospitals all around the city became public policy, and through the two spheres of power: the municipal and the federal. However, it was a different political context. 
The First Republic and the establishment of a hospital network in the Federal District

\section{Notes}

${ }^{1}$ In a time where public health rules gained strength, the intervention of the authorities started to have decisive role, mostly in places known as privileged focus of diseases: jails, ports, vessels and general hospitals. In this new picture the traditional hospital lost space. It was necessary to transform it physically and conceptually, and eliminate its welfare character in benefit of therapeutic care.

${ }^{2}$ This Law of the Poor, strongly inspired by the hygienist theories of the end of the eighteenth century, understood that London's poor neighborhoods were the focus of the main epidemics, thus justifying the public health intervention measures in these sites. The dirt, the lack of draining of the swamps, and the absence of sewage had been the main problems noted, and as a solution a piping system was installed which brought drinking water to all cities, as well as a sewage system, that took waste waters far away from the urban perimeter (Bourdelais, 2003).

${ }^{3}$ This hospital, later called Hospital Paula Cândido, was destined to the quarantining of the maritime (immigrants and sailors) infected with contagious diseases. It was located in Jurujuba, Niterói, and was decommissioned in the Twentieth Century.

${ }^{4}$ Tenements were considered, since the Imperial times, as places of disorder and infection, and there were numerous attempts to destroy them, or prevent their construction. However, issues related to private property - so dear to the Imperial Government, as it might create a precedent as it relates to the possession of slaves - prevented the demolitions and ways were always found to get around government inspections. (Chalhoub, 2004).

${ }^{5}$ The 1891 Constitution transferred health management to the states. In the case of the Federal District, the municipal government was in charge of managing and organizing the service. Thus, in 1893, Rio de Janeiro's General Management for Public Health and Assistance was created, which sought to organize, manage and distribute, in the city of Rio de Janeiro, free medical care services in both "normal" times, and in those of epidemic outbreaks; of accidents and disasters in public places, among others (Barbosa, 1908).

${ }^{6}$ For example, France felt behind in this discussion, comparing to their neighbors; England had been discussing the issue since early in nineteenth century, which resulted in the reform of the Law of the Poor; and in Portugal, liberalism started to be adopted since the return of Dom Pedro to the Kingdom. The transfer of São José Hospital , the oldest in Lisbon, to governmental administration dates back to 1834 and to 1851, the definitive break with the Sisterhood of Mercy.

${ }^{7}$ These "private" hospitals were those maintained by third Sisterhoods and Orders; the Laranjeiras Maternity, of a semi-official status; the São Luis Nursing Home; the Brazilian Anti-Tuberculosis League; and the Polyclinics: General of Rio de Janeiro, and Botafogo.

${ }^{8}$ The "wheels" were where abandoned children were placed, bringing them to inside the sheltering institution - in the case of Rio de Janeiro, the House of the Exposed (or of the Wheel) in the Santa Casa da Misericórdia, currently Educandário Romão Duarte. Its mechanism allowed the identity of the mother to be preserved. Its goal was to try to rescue abandoned -or exposed - children by providing milk and education, so they could be integrated to society. (Gandelman, 2001).

${ }_{9}^{9}$ These would be: assistance to infancy - delinquent and abandoned children and child care; assistance to the elderly; assistance to women; assistance to foreigners; assistance through work - professional medicine (criminal issue); home and hospital assistance; assistance to the alienated; assistance to those infected with tuberculosis; assistance to lepers; to alcoholism; to people with syphilis; and methodic assistance - practical means to obtain an alliance between public and private assistance; Brazil's problem.

${ }^{10}$ French architect who launched the foundations of the French hospital, in 1788. See chapter 5.

11 DNSP was created in 1919 and established in the following year. It was constituted by a General Management, and three managing areas, the Terrestrial Sanitary Services in the federal capital, Maritime and Fluvial Sanitary Defense, and the Rural Sanitary and Prophylaxis; besides ten special inspection units, including: Public Health Engineering; Tuberculosis Prophylaxis; DemographicSanitary Statistics; Supervision of Medicine, Pharmacy, Dental Arts, and Obstetrics Practices; Prophylaxis of Leper and Sexual Transmitted Diseases; and Maritime Prophylaxis. (Hochman, 1998)

12 The Cancer (currently Barata Ribeiro Municipal Hospital) Hospital, and the Gafrée and Guinle Hospital were funded by the Guinle family.

${ }^{13}$ It is worth noting that the foundations of the Mascarenhas project were defended, in 1923, in the Editorial of Brasil Médico magazine. 
Bibliography

ACTAS e Trabalhos do Primeiro Congresso Nacional dos Práticos: em comemoração do centenário do Brasil. Rio de Janeiro: Publicações Scientíficas, 1923.

ABREU, L. (Ed.) Igreja, Caridade e Assistência na Península Ibérica (sécs. XVI-XVIII). Évora: Edições Colibri, Cidehus/Universidade de Évora, 2004.

ASSISTÊNCIA pública e privada no Rio de Janeiro (Brasil): história e estatística. Rio de Janeiro: Prefeitura do Distrito Federal, 1922.

ALMEIDA, G. Assistência Hospitalar: memória apresentada ao Congresso Nacional de Assistência Pública e Privada do Rio de Janeiro. Rio de Janeiro: Typographia Jornal do Commercio, 1908.

ALLAIN, E. Rio de Janeiro: quelques données sur la capitale et sur l'administration du Brésil. Paris, Rio de Janeiro: L. Firenze et Cie Éditeurs, Lachaud et Cie, 1886.

BARBOSA, L. Serviços de Assistência no Rio de Janeiro. Rio de Janeiro: Typographia Ao Luzeiro, 1908.

BENCHIMOL, J. Pereira Passos: um Haussmann tropical. Rio de Janeiro: Secretaria Municipal de Cultura, Turismo e Esportes/Departamento Geral de Documentação e Informação Cultural, 1992. (Biblioteca Carioca)

BENCHIMOL, J. (Coord.) Febre Amarela: a doença e a vacina, uma história inacabada. Rio de Janeiro: BioManguinhos, Editora Fiocruz, 2001.

BOURDELAIS, Patrice. «Les logiques du développement de l'hygièbe publique » IN : BOURDELAIS, Patrice (dir.). Les higiénistes, enjeux, modèles et pratiques (XVIIIe - XXe sciecles). Paris: Belin; 2001.

BOURDELAIS, P. Les épidemies terrassées - une histoire des pays riches. Paris, Editions de la Martinière; 2003.

BOURDELAIS, P. Les bureaux d'hygiène municipaux (1879-1900): connaître, décider, innover, assister, convaincre e diffuser . In: BOURDELAIS, P. \& FAURE, O. Les Nouvelles Pratiques de Santé, XVIII ${ }^{e}-X X^{e}$ sciècles. Paris: Belin, 2005.

BRASIL. Anais da Câmara dos Deputados. Rio de Janeiro: Imprensa Nacional, 1920.

BRASIL. Anais da Câmara dos Deputados. Rio de Janeiro: Imprensa Nacional, 1921.

BRASIL. Anais da Câmara dos Deputados. Rio de Janeiro: Imprensa Nacional, 1923.

BRASIL. Mensagens ao Congresso: Obras Completas de Epitácio Pessoa. Rio de Janeiro: INL, 1956. v. XVII.

BRASIL. Mensagens ao Congresso: Washington Luis P. de Sousa. Rio de Janeiro: Imprensa Nacional, 1930.

CHAGAS, C. Discurso do Dr. Carlos Chagas no banquete offerecido pela classe medica do Rio de Janeiro, no Edifício do Derby-Club, em homenagem aos medicos bahianos, em 9 de dezembro de 1918. Rio de Janeiro: Typ. Jornal do Commercio, de Rodrigues, 1919. Biblioteca Virtual Carlos Chagas <http://www4.prossiga.br/chagas/>. Acesso em: 2 maio 2003.

CHALHOUB, S. Cidade Febril: cortiços e epidemias na corte imperial. 3. ed. São Paulo: Companhia das Letras, 2004. CORBAIN, A. Le Miasme et la Jonquille. Paris: Flammarion, 1986.

DUMONT, M-J. Le Logement Social à Paris (1850-1930) : les habitations à bon marché. Liège: Mardaga, 1991.

DUPRAT, C. Pour l'Amour de l'Humanité - Le Temps des Philantropes: la philantropie parisienne des Lumières à la monarchie de Julliet. Paris: Éditions CTHS, 1993. T. 1.

DUPRAT, C. Usage et Pratiques de la Philantropie: pauvreté, action sociale et lien social, à Paris, au cour du premier XIX ${ }^{e}$ sciècle. Paris: Comité d'Histoire de la Sécurité Sociale, 1996. v. 1 et 2.

FAURE, O. Les Français et leur Médecine aux XIX ${ }^{e}$ siècle. Paris: Belin , 1993.

FIGUEIRA, A. Reforma dos hospitais. Brasil Médico, 15 ago. 1902, p. 311-312.

FIGUEIRA, A. Assistência pública: assistência à infância e particularmente o que se refere às medidas a adotar contra a mortalidade infantil. Educação das crianças deficientes. Relatório apresentado ao Congresso Nacional de Assistência Pública e Privada. Brazil-Médico, 1 e 8 nov. 1908, p. 401-405, 411-415, 419-420.

GANDELMAN, L. M. A Santa Casa da Misericórdia do Rio de Janeiro nos séculos XVI a XIX. História, Ciência, Saúde-Manguinhos, 8(3): 613-630, dez. 2001.

GOMES, A. Burguesia e Trabalho. Rio de Janeiro: Editora Campus, 1979.

HOCHMAN, G. A Era do Saneamento. São Paulo: Hucitec, Anpocs, 1998.

HORNE, J. Le Musée Social: aux origines de l'État providence. Paris: Belin, 2004. 
LIVRO de ofícios da Faculdade de Medicina do Rio de Janeiro para o ano de 1923. (Mimeo.)

MENDONÇA, J. Assistência hospitalar no Rio de Janeiro. Correio da Manhã, 14 jun. 1920, p. 2.

MENDONÇA, J. A organização econômica do hospital moderno. Revista do Brasil, XXVI(101): 8-15, maio 1924.

MONCORVO FILHO. Assistência pública no Rio de Janeiro e particularmente da assistência à infância. Comunicação enviada ao IV Congresso Internacional de Assistência Pública e Privada, realizado em Milão em 1906. Rio de Janeiro: Imprensa Nacional, 1907.

NOTÁVEL empreendimento - Hospital de Clínicas 'Arthur Bernardes', o lançamento de sua pedra fundamental (1926). Vida Doméstica - Revista da Família e da Mulher, 101, jul. 1926.

OLIVEIRA, J. \& TEIXEIRA, S. (IM)Previdência Social: 60 anos de história da previdência social no Brasil. Petrópolis, Rio de Janeiro: Vozes, Abrasco, 1986.

PAIVA, A. Justiça e Assistência. Rio de Janeiro: Typographia do Jornal do Commercio, 1916.

POLANYI, K. A Grande Transformação: as origens da nossa época. São Paulo: Campus, 2000.

SANGLARD, G. Entre os salões e o laboratório: Guilherme Guinle, a saúde e a ciência no Rio de Janeiro. Rio de Janeiro: Editora Fiocruz; 2008.

SANGLARD, G. Da Misericórdia ao Estado: questões de saúde no Brasil na primeira metade do século XX. In: PRIEGO, N. \& LOZANO, S. (Orgs.) Paradigmas, Culturas y Saberes: la transmisión del conocimiento científico a Latinoamérica. Madrid: Editorial Iberoamericana, 2007. 

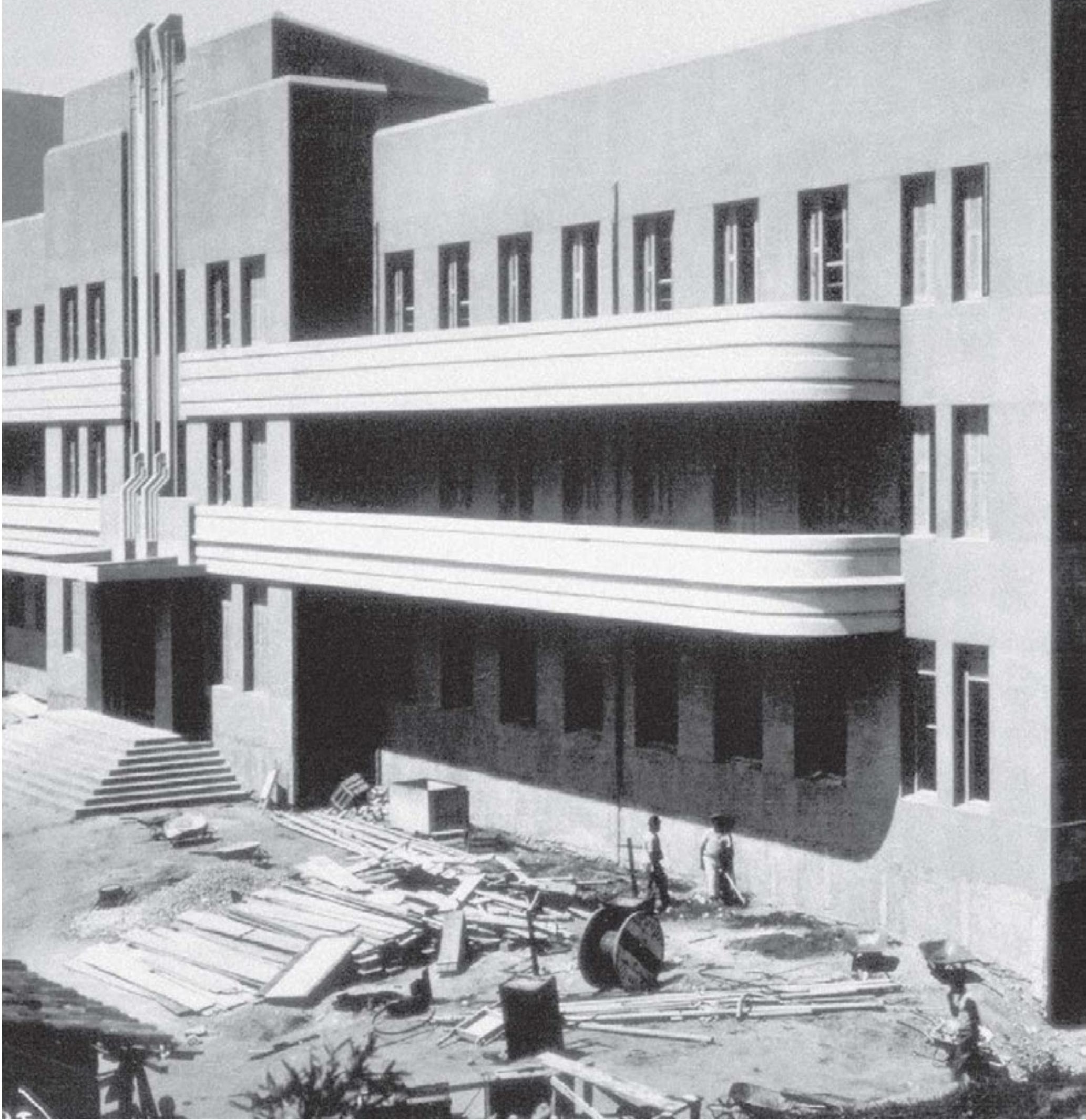
4

\section{Politics and Health: National Guidelines and Medical Care in the Federal District after 1930}

Cristina M. Oliveira Fonseca 
Health care, in the first decades of the 20th Century had already become a public good. In this regards it carries with it an intrinsic political dimension. Therefore, to understand the characteristics presented by health care starting in the 1930s, one must understand that the adoption of a particular institutional model to provide health care services is in itself a political option, in the choice of direction, priorities and definition of strategies to reach the objectives. On the other hand, the institutional structure adopted by the government in a specific political context, also expresses a kind of relationship in the public area between government entities and the population, who will use this collective good, expressing another dimension of this political role of health care.

In the case of health care, starting in the 1930s, two aspects are essential in order to understand the characteristics which this institutional structure took on and its interactions in the public area: the relations between the federal government and the states and municipalities; the relationship between public health and health care, and how these two dimensions of providing services were defined. Analyzing these relations is fundamental to situating a question which remaining unresolved through the 20th Century and continues present to this day, in the debates about public policies related to health in Brazil: what are the specific responsibilities of each sphere of the executive- municipal, state and federal - in the definition of the authorities and responsibilities to provide health services to the Brazilian population?

Along this line of thinking, we need to emphasize that the transformations which took place in the institutional organization of health care in the Federal District, starting in the 1930s, can only be understood in dialogue with the transformations taking place in health care policies at the federal level. This dialogue takes place on the one hand in its political dimension, present in the relation of local leaders - such as Pedro Ernesto - with the Vargas government, and the attributions defined for the Nation's capital. On the other hand, this relationship is expressed in its organizational dimension, when a series of norms and rules began to be adopted and imposed guidelines to the operations of the public health service in the whole country, with impacts on the Federal District (where the city of Rio de Janeiro was located), up to that time the priority area of federal actions and investments in the health area.

With such references as a starting point, in this chapter I will try to analyze some aspects of the health care policy implemented in the first government of Getúlio Vargas. First I will trace a rapid panorama of the political situation at the time, stressing the instability in the period after 1930, the 
interests in play at this moment of transition and some of the ideological guidelines which oriented political debates and health policy. Without understanding the national political context, it will not be possible to understand the transformations underway in the nation's capital.

Next, I highlight the principal characteristics of the institutional changes implemented in the area of health, directed by the need to guarantee the expansion of government authority in the whole country, leading to the adoption, by the National Health Department (Departamento Nacional de Saúde), of a management model characterized by a centralized administration and a decentralized executive. I will seek to present the basic principles which directed the organization and management of health care in the whole country and how the health care services in the Federal District fit into this debate.

In the third part I will concentrate on the principal characteristics of the health care structure of the Federal District, calling attention to the specific aspects that its condition as the Nation's capital gave it. The services in the Federal District earned their own dimension, because they were not federal, but neither were they in the same conditions as state services; they were governed by specific norms, that its condition as the seat of the federal government assured it. This is, therefore, a new moment of redefinition of the attributes of the federal government, when the federal government's need to expand its actions to the rest of the country, and strengthen its presence politically in the states, also implied changes in public health policy in the city of Rio de Janeiro.

\section{Characteristics of the Brazilian Political Context}

In the period immediately after the 1930 revolution, the period covered by the Provisional Government (1930-34), was marked by great political instability, due to, among other things, the heterogeneous natures of the forces which had allied themselves during the revolutionary process. In this political context, it became clear that the agricultural export sector was undergoing a hegemony crisis, mainly identified by dissidences at the regional level. As the remaining sectors of society- in this case, rural groups not connected with coffee production and the emerging urban groups - were not sufficiently organized to become a dominant political force, the repercussions of the October movement were subject to political disputes between the different factions which had come together in the Liberal Alliance (Aliança Liberal), particularly between lieutenants and dissident oligarchies. (Gomes, 1980: 27). The oligarchic structure inherited from the Old Republic (República Velha) brought in itself important differences which had marked political disputes and which now had become more intense. Considering what was described by Werneck Vianna (1976) characterized, starting with Lima Sobrinho (1975), as exclusive liberalism of the First Republic, the rural oligarchy had segments which were opposed to the agricultural export wings and who resisted the directions taken by the movement of 1930 . The unequal relationship between the states marked the First Republic, translating a conception of federalism oriented by notions of privileges and exclusion. The discrimination could be observed in the policy of presidential selection, where the states were classified into three classes, according to their level of importance in taking decisions.

Specifically, the first class States, qualified to claim the Brazilian Presidency were only two: São Paulo e Minas Gerais. The second class states, who could dispute the Vice Presidency were Bahia, Pernambuco 
and Rio de Janeiro. The other states made up a third class, the "luggage rack" of the Federation, who only by chance would receive the opportunity to indicate someone different, which never occurred due to the strength of the State, but by the friendships and political prestige of the men who deserved such a great distinction. (Lima Sobrinho apud Vianna, 1976: 102) ${ }^{1}$

It was the breaking of the agreement between the two main states which represented one of the factors which brought about the revolutionary movement of 1930, putting Minas Gerais and Rio de Janeiro as allies against São Paulo (Schwartzman, 1982: 106). On the political scene, the regional differences were followed by economic interests, which diversified in the same proportion, as Diniz demonstrated (1981). For the author, the 1930s were characterized by significant changes in the economic area, highlighted by the important industrial surge taking place between 1929 and 1939, pointing to the substitution of agricultural activities in certain regions of the country. Thus, the economic changes would be translated into the movement of production for export to production for the domestic market, including industrial activity. (Diniz, 1981: 91). With the diversification of the economy, new interests emerged and pressured the old order and its power structure. The opposition parties were concentrated within the structure of the political organization in place, which did not allow for the participation of emerging social forces. In other words, the loss of hegemony of the coffee sector helped stimulate regional differences. However, none of the groups involved in the confrontation were able to impose their will on the others, which led to a reformulation in the scheme of alliances between the dominant groups. This may explain why there was no uniformity in the economic policy implemented, and measures favorable to industrialization coexisted with others which were designed to support traditional rural interests. (Boris Fausto apud Diniz, 1981: 90).

The lieutenants, supported in a strong criticism to liberalism - here associated with a political practice implemented during the Old Republic -, defended a government model which was clearly centralizing and interventionary. Those principles had already been indicated in the 3 de Outubro ('October $3^{\text {rd') }}$ Club, who defended "a strong Executive, technical councils and an administrative structure focused on national interests" (Camargo et al., 1989: 23). The dissident oligarchic sectors, on the other hand, fought for federalism as a model of the ideal State, because in that model they could maintain the autonomy at the state level and restrict the interference of the Federal Government. The debate between centralization and federalism represented the synthesis of the basic differences between the two groups, symbolizing "the touchstone around which all other questions came together" (Gomes,1980: 29).

The process of building and consolidating a bureaucratic and institutional framework in the area of public health, in this period, however, came up against these changes in the composition of power between the federal government and local leaders, coming from a gradual structuring of a centralized regime although with a format different from that present during the Imperial period. Soon, the objectives designed for the social health policy would become immersed in these political, economic and social relations referred to by the authors mentioned. This policy would be designed based on the changes in this composition of interests between colonels, government bureaucrats, state governors and the central government, coming out from the new power arrangements which had been established. It is not by chance that one of the most frequent subjects, in the debates related to health services starting in 1935, had to do with the development of norms for the relations between the States and the Federal 
Government. Therefore, it was in this scenario of political instability, that Getúlio Vargas was looking for mechanisms to consolidate himself in power, reinforcing the ideals of a National Government that was centralizing and interventionary, which went on during the early years of his government. Gradually a new model of health care management and strategies for implementation were defined, following, in this institutional reform process, the different political contexts which marked the fifteen years of the Vargas government.

\section{Changes in the Health area: Institutional Reorganization}

The first significant change in the institutional structure in the health care area occurred in 1930, when the Ministry of Education and Public Health (MESP) and the Labor, Industry and Commerce Ministry (MTIC) were created. In its institutional dimension, the public health actions followed the distinctions established between the MTIC and the MESP. On the one hand, the legal and material framework for individual government health care was established, developed in the MTIC, which over the years would become one of the main references for providing public health care services. It was designed for those who were inserted in the formal labor market and supported by corporate principles which defined those recognized as citizens, characterizing what was defined by Wanderley Guilherme dos Santos as "regulated citizenship" (Santos, 1998). On the other hand, in MESP, connected to education, was public health. In other words, all that dealt with the health of the population and which was not within the realm of public health care. It was MESP's responsibility to provide services to those identified as "pre-citizens"; the poor, the unemployed, those who worked informally, that is, all those who were not entitled to use the services offered by the corporate community chests and public welfare institutes. ${ }^{2}$ This would be the new configuration of federal actions in the health area, within whose scope would be activities related to health care.

In January 1931, the new organizational structure of MESP was defined, where, in addition to a Federal Secretariat, the new ministry would be made up of seven divisions and four independent national departments: Education, Public Health, Experimental Medicine and Public Assistance. Despite the fact that three of these involved the area of health, its make up did not imply immediate substantial changes in the institutional structure in effect. Effective changes in this area would only occur gradually in the following years, following the changes in the ministries.

The National Department of Experimental Medicine (Departamento Nacional de Medicina Experimental) would be made up by the Oswaldo Cruz Institute (Instituto Oswaldo Cruz (IOC)) and by other institutions which could be created to develop similar activities. However, the department remained restricted to the IOC, which in October 1932 regained its original name. The National Department of Public Assistance ( Departamento Nacional de Assistência Pública) took charge of providing hospital services and was directed by Pedro Ernesto Batista. This existed as a department only until October 1931, when it was transformed into a directory of the DNSP. However, two months later, on December 30, 1931, the directory was eliminated due to the end of the special fund destined to provide hospital services and the consequent lack of resources to expand the services of public assistance on a national level. The hospitals which were part of this structure, São Francisco de Assis and Pedro II, remained the responsibility of the DNSP 
(Decree. 20.890 of December 30, 1931). ${ }^{3}$ Also within the regulations of January, 1931, the DNSP would not suffer any changes at that moment, confirming what earlier decrees had already indicated. That is, the department was incorporated to MESP as of November, 1930 maintaining its organization and assuring its autonomy as the organ responsible for actions of public health. Its structure was made up of three directories: Health Services of the Federal District; Maritime and River Public Health Defense; Sanitation and Rural Prophylaxis. (note that the Federal District always has its own structure, different from those of the other states).

Differences of opinion about the political future of the country also impacted the future of the recently created ministry. The institutional format given to it should obviously be compatible with the prevailing political project out of the disputes which began after the 1930 Revolution. However, just like the debates which took place in the sphere of national politics, the first years of the MESP were marked by a lack of definition and inconstancy of proposals and projects. One of the evidences of this lack of political definition can be found in the alternation of ministers in charge of the organ, which in its first four years was directed successively by Francisco Campos, Belisário Pena and Washington Pires. ${ }^{4}$

The latter, as soon as he took over, worked on implementing changes which reflected a new strategy of public actions in the health area, and presented a proposal which implied changes in the DNSP and created the National Directory of Health and Medical and Social Assistance (DNSAMS), which was approved in June, 1934, only one month after the new Constitution went into effect. With small variations, the large majority of the services which made up the DNSP remained in the new structure, but regrouped into two large general technical sections of Public Health and Social Health Care, and in five new directories: Public Health Defense of the Nation's Capital and Internationally (Defesa Sanitária Internacional e da Capital da República); of State Public Health Services (Serviços Sanitários nos Estados); of Protection to Motherhood and Infancy ( Proteção à Maternidade e à Infância); of Psychopathic Assistance and Mental Prophylaxis (Assistência Psicopatas e de Profilaxia Mental); and Hospital Assistance (Assistência Hospitalar). ${ }^{5}$ The latter included in its organizational structure the following organs: Assistance and Screening Center (Centro de Assistência e de Triagem); São Francisco de Assis Hospital; Pedro II Hospital; Paula Candido Preventorium; Curupaity Hospital-Colony. The Directory of Public Health Defense of the Nation's Capital and Internationally now had the following structure: Merchant Marine and Port Inspectorship (Inspetoria da Marinha Mercante e dos Portos), Health Center Inspectorship (Inspetoria dos Centros de Saúde), Professional Qualification Monitoring Inspectorship (Inspetoria da Fiscalização do Exercício Profissional), Food Inspectorship (Inspetoria de Alimentação), Public Health Laboratory (Laboratório de Saúde Pública), São Sebastião Isolation Hospital and Anna Nery School . 6

The new institutional design demonstrated the priorities in the new government with the emphasis on children, mental health, medical and hospital assistance and the expansion and reinforcement of federal government presence in the states, in response to the demands of no longer concentrating federal health services in the Federal District. According to João de Barros Barreto - an important leader in the health area and future director of the National Health Department (Departamento Nacional de Saúde DNS) - it was in fact starting in 1934, with the organization of the new organ, that expansion of services outside the Federal District began in a coordinated way: 
But only in 1934 did the beginning of the restructuring which the progress of techniques of public health organization and the Brazilian situation had been demanding actually occur, by formally determining that the actions of the Federal Government would no longer be concentrated in Rio de Janeiro. Thus, in that year a technical command organ was created for several services in the health care that were spread out in the new ministry. For the first time there was a specialized command of the general hospitals maintained by the Federal Government; remodeling, fundamentally the public health organization of the Federal District, establishing the modern and ideal system of Health Center; and extending federal actions to the States. (Barreto, 1942b: 170)

At the end of the Provisional Government, therefore, the MESP was at the beginning of an administrative restructuring process, without the time in effect for it to be consolidated. The scenario of instability and substitutions of ministers which characterized the first four years of the ministry's existence, would change substantially starting in July 1934, when Gustavo Capanema took office as the new and principal administrator in the area of education and health. Capanema inherited the recently approved structure left by Washington Pires, affirming that Pires had been important because he reorganized the services of hospital assistance, which initially had had secondary importance and expand the actions of MESP in the area of social assistance. So, the Ministry was then made up of three types of services: national education, public health and social assistance (Gustavo Capanema/Cpdoc/FGV File, GC 34.06.21, F 07).

With Gustavo Capanema a new moment in the institutional history in the country began, and a new series of reforms would be implemented, consolidating a new administrative structure for public health that would last, with few changes, until the creation in 1953 of the Ministry of Health. The changes which the new ministry proposed, in a bill presented in November of 1935, would change the institutional structure defined by the recent reform of Washington Pires, approved in June 1934. During the year of 1935, while the new reform bill was being prepared, the main activities in the health area were divided between those defined by the new structure of the DNSAMS and the changes underway in the services in the Federal District. In the Nation's capital the highlight was the creation of the health centers - which absorbed the services of the old Directory of Public Health Services of the Federal District and the Directory of Rural Sanitation — and the specialized inspectorships. At the end of 1935 the city was divided into 12 districts, which already had nine health centers. ${ }^{7}$

Both the explanation of the reasons which accompanied the bill sent to the president, and the bill itself reaffirmed two guidelines regarding federal actions in the states. On the one hand it maintained the procedure that had been adopted in Brazil for several decades, which delegated to the Federal Government a supplementary role, with participation concentrated on providing financial resources to the public and private health organs through agreements signed with the states. Direct action by the Federal Government would be exercised only in the case of endemic diseases or epidemics of serious consequences, where the state government would not be able to combat it, which shows the concern in maintaining local autonomy. In his explanation, Capanema expressed the predominant view on this issue, making it clear his intention to protect the activities of the states in this area and, thus avoid possible political and managerial conflicts, affirming that the supplementary action of the Federal Government should be done indirectly.(Capanema, 1935: 50). The minister, therefore, defended a different position with regard to the Nation's capital when he stated that: 
"In fact, it is not merely a local interest, but above all of national interest that the city, which is the seat of the organs of national sovereignty, which is the center of all the political life of the country, which is where representatives of foreign nations live, has the defense of its public health, supplied with all its resources under the direct responsibility of the Federal Government. It is the Federal Government's responsibility to organize, finance and manage it. Public health is treated the same way as the police. In the Federal District, this is the Federal Government's responsibility." (Capanema, 1935: 23)

This line of interpretation which stressed the specific conditions of the Federal District, when it dealt with defining attributions and models of providing health care services, would also appear in the debates which occurred during the voting process of the Capanema Reform bill.

\section{Health Services in the Federal District in the Debate of the Capanema Reform Bill}

Concerning the health services in the Federal District, three points were at the heart of the debate about article 56 of the bill, in which were defined the public health services that would be performed by the Public Health Service of the Federal District. ${ }^{8}$

The first of them dealt with an old topic of discussion: the heavy concentration of federal services in the Nation's capital in detriment of the other regions of the country. In a speech made in the session of December 15, 1936, congressman Agostinho Monteiro criticized the almost complete application of public health funds in the Federal District, based on the budget of 1933. He also defended that health care be given priority. Congressmen Xavier de Oliveira and Lino Machado agreed with Monteiro's observation, but criticized the model established by Carlos Chagas, who had, in their opinion, given a secondary importance to medical and hospital care. Xavier de Oliveira argued:

“(...) it is an error that is being repeated now, an error made when the DNSP was created by Carlos Chagas, a time when rural prophylaxis was also established. Then it was the prophylaxis, called the Leitmotiv of the public health technicians for Brazil at the time, totally forgetting hospital care". (Diários do Poder Legislativo, 18 dez. 1936: 23623)

The arguments of the congressmen was based on the relation between public health and medical care and the assumption that there is an antagonism between these areas, as if placing priority on one of them would necessarily mean precluding the other. In the interpretation of the congressmen, investing in public health meant neglecting medical care, as if it were not possible to put both of them into a public health service.

At the moment a new structure for public health was being defined, this question arose in connection with the discussion about whether or not the Federal Government should interfere in the states. In this case the autonomy of the state health services presented some peculiarities: when talking about actions to take place in the Nation's capital, it was difficult to distinguish between federal and local authority ${ }^{9}$

The second point which came out in the debate on the services of the Federal District had to do with the controversy between the adoption of a district model, represented by the health centers, and the preservation of the organization which had existed until then, based on the specialized inspectorships.

According to Raul de Almeida Magalhães — director of the DNSP while Washington Pires was minister —, in an exposition made to the Public Health Commission, there were two schools of guidelines for modern public health: one which criticized technical services based on autonomous inspectorships and recommended the district system, organized in health centers which concentrated all activities; and 
another which recognized the importance of the health centers, but which did not consider them incompatible with the inspectorship system. Defending the second school, he reminded that the modern tendency was towards specialization and that the inspector of the health centers, responsible in the district system for providing guidelines for all public health activities, could not have solid knowledge in so many diverse areas of knowledge, in so many different specialties. At the same time, as he believed that certain public health activities should not be part of the health centers, he defended the autonomy of the service of transmittable diseases under a single organ: "With the service split up into 10 centers for lack of qualified personnel and for lack of leadership, notifications of transmittable diseases cannot be communicated with the proper speed." (Public Health Organization, June 14, 1936)

Pointing out once again that the health center system did not exclude the need for inspectorships, he described the district system adopted in New York, which at the time had a director and sub-director of health, with inspectorships in the following areas: general administration, nursing, child hygiene, transmittable diseases, tuberculosis, venereal diseases, public health policies, foods and drugs and laboratories. The directors of the health centers followed instructions from the specialized inspectorships, and the district authorities were mere executors of the services to receive technical instructions from the inspectorships.

In the structure approved with the reform and its consequences a conciliatory model prevailed which confirmed the observations of Raul de Almeida Magalhães. The health centers were consolidated as models of reference in the public health organization - not only in the Federal District but all over the country -, making up the apex of a hierarchy formed by the public health clinics (postos de saúde) and sub-clinics, classified according to the complexity of the activities performed and the profile of the existing professionals. Gradually the inspectorships gave way to the specialized services, which also grew and expanded, principally after the creation of the National Services (Serviços Nacionais) in 1941, confirming the interpretation that the district model was not compatible with a structure of specialized services.

The third point to be mentioned in the debate about the health area in the Federal District referred to whether or not an autonomous service for the maternity-child area should be created, which had already appeared as a specialized area of public action. The prominent role and relevance given to the services of care in the maternity-child care area in the administrative structure of the government was also a subject of criticism and differences of opinion. Some professionals felt that this service should be performed by the health centers; for others it was absurd to put children and people with transmittable diseases in the same place.

The controversy continued during several sessions of the Chamber of Deputies and commission meetings, reflecting different conceptions concerning the activities of the health centers, their importance as a space for prophylaxis and public health education and emphasizing the differences between these activities and those of clinical medical care. It also brought about comments on contagious diseases and their differences in relation to transmittable diseases. The final version of the text showed that the opinion that maternity and child care services deserved a specific directory prevailed. The creation of the Directory of Maternity and Child Care strengthened the area from an institutional perspective, which became one of the priorities of the Vargas government's social policy, expanding its scope of action beyond the Federal District. These guidelines would be confirmed with the creation, in 1940, of the 
National Department for Children ( Departamento Nacional da Criança (DNCr)), with the same hierarchical level as the DNS, which assured to it a greater coverage and autonomy in the management of actions in the maternity and child care area. ${ }^{10}$

\section{The New Model as of 1937}

On January 13, 1937, the act which reorganized the structure of what was known then as the Ministry of Education and Health (Ministério de Educação e Saúde (MES)) went into effect. The changes proposed in the reform bill specified basically three major areas of public health services. In the act approved in 1937, the section relating to these services was divided as follows: those dedicated to investigation, health services in the Federal District and those of a national scope. This format specified the logic which oriented the administrative organization in the field of public health, separating the services of the Nation's capital from those destined for the other states of Brazil.

The articles which specifically defined the organization of the activities and services of the Federal District, indicated that they were now to be organized through the Federal District Public Health Service and the Federal District Hospital Care Service. The former included the following organs: Public Health Laboratory, Food Inspectorship, Health Center Inspectorship, Special Services Inspectorship and the Public Health Engineering Inspectorship. The latter, designed to meet the hospital care needs in the Federal District, was made up of the Estácio de Sá Hospital, the São Francisco de Assis Hospital, and the Pedro II Hospital. A single paragraph indicated the creation of a Cancer Center, destined for the prophylaxis and treatment of cancer. (Brasil, 1937, Act (Lei) 378)

The same act delegated to the DNS the responsibility for public health activities in Brazil. So it was decided that this organ would be made up of four Divisions: Public Health, Hospital Care, Psychopathic Care and Maternity and Child Care. The responsibility for directing hospital care services on a national level was delegated to the Division of Hospital Care, as well as those of a local nature which were also delegated to the Federal Government. Article 54 of the same act also created the National Child Care Institute, with the objective of performing studies, surveys and research on problems related to maternity and child health. ${ }^{11}$

João de Barros Barreto was named as its director making him a direct assistant to Capanema in the management of issues related to health. Starting then, a period of intense activity began working of preparing norms, laws, regulations and public health codes, with the objective of standardizing the activities of different health services in the state down to the minimum details, following the process of bureaucratization of the Government, which was increasing. The new guidelines were adjusted in many ways to the proposals which had been debated in international forums, developed and applied especially in the United States, incorporating the priorities defined for government actions in health in the agendas of congresses and conferences sponsored by the Pan American Health Organization (OPAS). A standard for government action was established combining centralized norms and decentralized execution channeling to the state government level the management of public health services, under the guidance of the central government.

The strengthening of the state level as the place for political control was so clear that, among the measures foreseen to implement the district system, more specifically in the establishment of 
responsibilities, the central government raised the possibility of not having any public health services maintained by municipalities. This orientation would not preclude, however, participation of municipalities in the financial costs of installing and maintaining the health services. Reproducing the model of the Caixas de Fundos (Community Chests) established in 1938 in Rio de Janeiro, while Mário Pinotti was director of the Federal District Health Department, municipalities should contribute with $5 \%$ of all revenues received for public health and health care services. This model would be used as a standard reference for the rest of the country, defining the form of financing in the new form of public health management (cf. decrees published respectively on December 31, 1937 and April 26, 1938, apud Barreto 1938b: 300).

Four years later, in 1941, already under the regime of the Estado Novo (New State), Gustavo Capanema would add to the changes begun in 1937, making important alterations in the DNS in order to further centralize federal participation in health care management. This time, without Congressional participation, closed since November, 1937, when the dictatorial regime was established. At this moment the National Services and two new divisions were created - the Division of Public Health Organization (Divisão de Organização Sanitária (DOS)) and the Division of Hospital Organization (Divisão de Organização Hospitalar $(\mathrm{DOH})$ ) - which incorporated functions which, until then, had been exercised by the old Divisions of Public Health and Hospital Care of the DNS. With this reorganization the divisions also widened their range of action, characterizing themselves as "elements which direct the overall structuring of health care organizations in Brasil" (Barreto, 1942b: 174).

\section{The activities of the Hospital Organization Division}

Just like the DOS, the DOH was created with the objective of standardizing, creating norms and controlling actions related to medical and social assistances in all states of Brazil. In this sense, it because the "arms" of the federal government administration in the states in the hospital care area. Under the direction of doctor Teófilo de Almeida, it was made up of the Sections of Buildings and Installations, Organization and Administration and Assistance and Health Insurance.

Its responsibilities, in light of the priorities in the area, were debated during the $1^{\text {st }}$ National Health Conference, held in 1941, when the following directives for the sector were defined: the creation of regional hospitals, outpatient clinics and urgent medical care facilities following the system of district division and meeting minimum requirements, in rural areas of two beds for every 1,000 people for general hospitals and one doctor for every four thousand inhabitants. In the decree of 1942 which established the functions of the $\mathrm{DOH}$, these included, among others, organizing a general assistance plan, including a network of hospitals covering the whole country, establishing norms and standards for installation, organization and operation of the several technical and administrative services of different types of hospitals and organizing and maintaining updated a registry of all the hospitals in the country. ${ }^{12}$

In its first year of activity, the DOH dedicate special attention to putting together a hospital registry in the whole country, with a detailed questionnaire which covered information "from the most complete hospital to the most modest charity establishment" (Barreto, 1942a: 79). The total number of known establishments in all the states was 1,173, and in 1941, 358 institutions were registered. Done between November 1941 and November 1942, it was the first one of its kind in Brazil performed with that 
objective. In it information related to the Federal District showed that the city had, at that time, 84 establishments, of which 59 were registered. ${ }^{13}$

The information obtained with the registry was the starting point for the building of a national network of regional hospitals which were designed to take care of the problem of medical and surgical care. The network was to encompass Federal, state and municipal resources and would also have the help of the private sector, of charitable organizations, associations, besides institutes and health associations subordinated to the Labor, Industry and Commerce Ministry, industries, rural establishments and, especially the Brazilian Red Cross. The health care policy designed for the hospital area, from that moment on, went back to preparing a plan aimed at creating a Brazilian network of hospitals starting in the states of the North and Northeast. The plan covered general and specialized hospitals, except those specialized in maternity, mental illness, tuberculosis and leprosy, all of which had special plans prepared by the corresponding federal services. It gained a priority status for the year 1942, in light of Brazil's participation in the Second World War.

In November of this same year a note explaining the proposal to build a Brazilian Hospital Network was sent to the Minister of Education and Health, in which the parameters which would guide its structuring were explained. It was destined initially to the states of the North and Northeast, covering the states from Pará to Sergipe. In its item 9 it indicated:

What is important in equipping the medical and surgical care activity, an integral part of the national organization, is not only the beds for the charity or the very poor, but beds which are convenient or available for all levels of society, with the cooperation, overall technical guidance and control of the State. Under this point of view, equal attention should be given to free beds or those belonging to industries, cooperatives or sisterhoods, and even those to paying patients, that is for non-profit and forprofit purposes: the latter relieving the expenses of the former and the heavy cost of the federal, state and municipal, in that which, in the realm of public health care or social assistance, is government's responsibility, where private funds are not sufficient or lacking. (Barreto, 1943: 179; my italics)

The proposal reveals which profile was defined for state responsibility, at the moment in which there was, on the part of the government administrators, a formal demand that the State recognize as its obligation providing health care services regardless of social group. The execution of the plan would be supervised by $\mathrm{DOH}$, whose technical orientation was based on principles conceived by American organizations like the American College of Surgeons and the American Association of Hospitals, who defined hospital organization as a specialty. These principles helped DOH to spread information about what it considered to be a modern hospital consciousness. The American influence on the proposed format for public health policy in the hospital area, can essentially be attributed to the visit of DOH Director Teófilo de Almeida to the United States which took place during his first months in the position, and to the interests and needs arising as a result of the Second World War.

At the same time as the measures to execute the Brazilian Hospital Network plan, minister Gustavo Capanema presented an initial proposal of a decree-act that would establish norms and general principles to regulate medical and social care services in Brazil. Article one, which defined its purpose determined:

The control of medical and social assistance for the sick, handicapped and people without financial or family support is hereby established in the whole country, relating to a technical systematizing of this service, with the objective of creating a national network of hospital and social assistance institutions, 
appropriately equipped to serve all Brazilians in accordance with local and regional needs. (Apud Barros Barreto, 1943: 186; our italics)

The initial project also established norms and principles for classification and operation of hospital and semi-hospital establishments, concerned about assuring that the standardization and supervision of these guidelines in the whole country were the responsibility of the $\mathrm{DOH}$. The classification defined several distinctions which included the number of beds, the type and physical capacity of the buildings, the type of clinical activity, the type of property and how the institution was maintained (government, philanthropic and private) and specific information about its directors and administration. The DOH was following here the same strategy adopted within the scope of the DOS, by seeking to standardize the different forms of services provided as can be seen in Attachment 2.

In the early years of the 1940s, besides the investment in defining rules and controlling hospital activities, concentrated principally on collecting information for the hospital registry and the establishment of a hospital network, the DOH dedicated itself to training professionals for the sector. In 1943, for the first time in Brazil, it put on a training course on organization and hospital administration led by the division director and some of its technicians. The course was maintained in following years, as in 1944 Barros Barreto (1945: 381) reported that Brazil had the preference to administer courses in specialization and additional training in hospital organization and administration.

Like other sectors which were targeted with public policies, actions in medical care within the MES were marked by the concern to build a truly national and coordinated service, with centralized guidelines and standardized general norms. Although not discussed in details here, one can mention, for example, the gradual process of professionalization and specialization - accompanying therefore the specific activities of public health - through the administration of courses in hospital administration, technician training and specialization courses for nurses. the bases were also created for the actual implementation of a system of hospital care in the whole country, with the specific items pertinent to that end. That is, effective measures were taken to organize services nationally with the purpose of institutionalizing and consolidating the area of medical care. And what is very important: with wide-ranging, non-restrictive characteristics explicitly aimed at serving the whole Brazilian population. In this regard, this field of government activity was institutionalized as a service for all and, associated to the services related to DOS, aimed at building a large network of public health assistance, combining preventive and curative medicine.

Within this general scenario, it is important to observe how health care services in the Federal District interacted with these institutional changes implemented in the federal health structures. What transformations occurred in the existing services in the city, how was the organizational structure of medical care in the Federal District rethought, what were the similarities and differences in relation to the political and institutional model which was being adopted in the rest of the country? 


\section{Health Care in the Federal District: Construction and consolidation of an Institutional Inheritance}

The changes in management of health policies in the Federal District starting in the 1930s are intimately related to the Brazilian political context and the guidelines adopted by the federal government for this sector of government actions. On the other hand, they are also directly associated to the actions of Pedro Ernesto Batista, who assumed the local political leadership, as a result of his direct participation in the revolutionary movement, as he was named intervener in the Federal District, then director of Hospital Care in the Federal District, and later, the city's mayor. Considered an important contact between the local and federal government, he showed an affinity of principles and guidelines in the administration of health policies adopted during this period. In particular the field of medical care was the stage of innumerable changes in a short period of time, leaving for the city of Rio de Janeiro a significant institutional inheritance in the area of health care. In a speech at the inauguration ceremony of the Jesus Hospital, he described this affinity of principles and concern in emphasizing the responsibility of the State:

"The direction of the revolution were affirmed through administrative integrity, the seat of justice, recognition of the equality of all Brazilians and for an anguishing expectation of the public services that the State is responsibility for providing for the well being of the population" (Cpdoc File, apud Vieira, p. 326)

With this political logic his administration would be marked with intense activity in the area of medical care, beginning construction of a large number of hospitals and dispensaries, some of which were inaugurated during his administration. Medical care was highlighted as one of the areas of special attention by government, institutionally strengthening a model to provide health care services as a responsibility of the State, emphasizing curative action, which was destined for the whole population, without restriction of access. To the profile of government intervention which formalized the obligation of government to guarantee health care to the entire city's population, on the other hand, there were the IAPs who, connected to the MTIC, and included in the area of health insurance and pensions, also built their hospitals aimed at providing medical care to those holding their insurance. ${ }^{14}$

Despite the disrupting political events which led to the departure of Pedro Ernesto and his imprisonment in 1937, the process of reformulation in the institutional structure of the health sector would proceed, consolidating a hierarchical and regionalized model, which definitively broke with the logic which until then had been giving preferential treatment to emergency medical services. (Vieira, 1982:440) In the following year, in 1938 the General health Care and Assistance Secretariat was reorganized ${ }^{15}$ and in 1939 an important legal alteration would strengthen even more the institutional autonomy of the Federal District in the health area. Through Decree-Act 1.040 (of January 11, 1939) the maintenance and administration of local health services were definitively transferred to the Federal District. Thus the institutional bases of medical care in the city of Rio de Janeiro were established, for the following decades. Significant changes would occur only in the 1950s, especially in 1953 with the creation of the Health Ministry and in 1956, with the charges in the DNS and creation of the National Department of Rural Endemic Diseases (DNERu). 
This was because, with Vargas leaving the government in 1945, the holding of elections and the enactment of a new Constitution in 1946, a new arrangement between organized political forces took place. In the new context, party policies took on for the first time, starting in 1946, a national character without, however, breaking its traditional historical ties with local politics, a mark of the origin of our political system. In this sense the Federal District preserved its specific characteristics as the Nation's capital conciliating its local political power with national interests. The health area would be involved in this political game, something which could be observed with the creation of the Health Ministry.

The first minister of Health, named by Getúlio Vargas in December of 1953, was Miguel Couto Filho, who carried as credentials the fact that he was the son of a famous doctor and putting together his professional career and performance in public life, helped him to operate in the sphere of the game of party politics. On the other hand, the press at the time pointed out that his nomination would have been the fruit of a political agreement between Vargas and Ernani do Amaral Peixoto, leader of the PSD party in the state of Rio de Janeiro, who wanted to see his political protégé as the next state Governor. The political agreement was aimed at strengthening the candidacy of Miguel Couto Filho, built around the most immediate interests of the PSD in the state of Rio de Janeiro, supported by the relations and historical agreements of the party of Amaral Peixoto with Getúlio Vargas. That is, the regional political forces tied to the state of Rio de Janeiro demonstrated that they would maintain the capacity of connection and interference in the national political scene, directing the results according to their interests and in this case with direct impact on the health area. ${ }^{16}$

The institutional history of health in Rio de Janeiro, however, cannot be observed and analyzed without understanding its peculiarities and specific conditions related to the fact that this city was the nation's capital, the center of national political power. It was not only a place for government activity, of government intervention and institutional creation, it was also stage for public debate, scene of the decision process, where national political disputes took place and agreements made. This configuration, however, would suffer in the decades following, the impact of the creation of Brasília and the transfer of the center of political power to central Brazil.

From then on, in this new context, the institutional relations continued to be changed gradually. The local health policy would face the challenge of having to answer (or not to) to the demands of the population and accompany the national guidelines for this sector, except that now, in this new scenario, as just another state in the federation and no longer with the special status as the nation's capital. For this it would have a long institutional legacy it inherited from prior periods, which it should maintain efficiently, with a capacity to adjust it to population growth, to technological advances and the complexities of the medical care system. In this regard, this is still a great challenge to be faced. 
Notes

1 Rio Grande do Sul kept itself on the side, acting as a rebel force and representing a threat to the agreements made.

2 For a comprehensive analysis of the history of government health care, please see Oliveira \& Teixeira (1986).

3 The services of hospital assistance included the following institutions: São Francisco de Assis Hospital; Pedro II Hospital; Service of Assistance to Psychopaths (formerly subordinated to the Ministry of Justice and Internal Affairs); Hospital de Clínica; and the General Hospital Inspectorships (Gama e Silva \& Marques, 1955: 10).

4 The substitution of ministers was in the following sequence: Francisco Campos (Nov. 18, 1930 to Sept., 1931); Belisário Pena (Sept. 1931 to Dec. 1931); Francisco Campos (Jan., 1932 to Sept., 1932); and Washington Pires (Sept,. 1932 to Jul., 1934).

5 According to the new act, the participation of the Federal Government in the states should be done through the Directory of Public Health Defense of the Nation's Capital and Internationally and the Directory of Public Health Services in the States.

6 According to Decree 24.814 of July 14,1934 , which established the general organizational plan of the public health and social health care services, in accordance with Decree 24.438, of June, 1934.

7 The creation of the health centers was defined by Decree 24.814, of July 14, 1934 (see also Gustavo Capanema/ Cpdoc/FGV File ).

8 This service was made up of the following organs, among others: Public Health Laboratory; Food Inspectorship; Health Center Inspectorship; Special Service Inspectorship (malaria and plague); and the Public Health Engineering Inspectorship.

9 The result of this debate can be observed in the structure defined for the ministry in January 1937. The first proposal presented by Capanema argued in favor of transferring services to the Federal District which, at the time, were the responsibility of the Federal Government. As mentioned earlier, the minister started to defend in 1936, inversely, maintenance of Federal services in the states, with the objective of expanding federal actions. However, in 1939 the services were transferred to the Federal District Municipal Government, which led Barros Barreto to ask to resign from his position as director of the DNS.

10 For a detailed analysis about the DNCr, please see Pereira (1992).

11 Once the Clinicas Hospital of the Universidade do Brasil was installed, the Maternity Hospital in the Laranjeiras District because part of the Federal District Child Care Service.

12 The other responsibilities given to the DOH were: "taking care of studies and the solution of problems related to social and medical assistance to sick people, the handicapped and those without financial or family; give opinions regarding the procedures of federal funding to institutions providing medical and social assistance; take care of problems related to medical and social assistance to the blind and deaf mutes, the very poor, elderly, abandoned, crippled and other abnormalities and handicapped; organize the national plan for insurance against disease and promote, together with the DOS, the systematic institution of periodic health exams" (Decree. 8.674, of Feb. 4, 1942).

13 According to the report presented by Barros Barreto (1943: 178) in the following year, the registry was done exclusively by medical officials who traveled to all the municipalities for the related inspection, visited the institutions and filled out the special forms.

14 Among the institutions created during Pedro Ernesto's administration we can mention: the Regional Polyclinical Hospital of Campo Grande (now known as Rocha Faria); the Regional Peripheral Hospital of Marechal Hermes (currently Carlos Chagas); Gavea Peripheral Hospital (currently Miguel Couto); Jesus Hospital; Pedro Ernesto Hospital; Getúlio Vargas Hospital; Campo Grande Dispensary (currently Rocha Faria); Dispensary of the llha (currently Paulino Werneck Hospital); Dispensary of Méier, (currently Salgado Filho); Dispensary of Sapê (currently Carmela Dutra Hospital); Dispensary of Paquetá (cuurently Manoel Arthur Villaboim Hospital); Dispensary of Cascadura (currently Herculano Pinheiro State Maternity) Vieira (1982: 443) Within the scope of the IAPS were the cases of the Bancários Hospital (currently Lagoa Hospital); the Comerciários Hospital (currently the Ipanema Hospital and Laranjeiras Cardiology Hospital) Transport Employees' Hospital (currently Bonsucesso Hospital), Marítimos Hospital (currently Andaraí Hospital) among others.

15 In the Department of Hospital Care were the following hospitals: Emergency (Pronto Socorro), Carlos Chagas, Getúlio Vargas, Miguel Couto, Jesús, the Dispensaries of Cascadura, Meyer, Governador, Sapê, Campo Grande, llha de Postos de Vargem Grande, Guaratiba and Rescue Services. See Brasil, Decree Act 871 of Nov. 18, 1938.

16 For a more detailed analysis on the creation of the MS, please see Hamilton \& Fonseca, 2003. 


\section{Bibliography}

BRASIL. Decreto n. 24.438, de 21 de junho de 1934. Dispõe sobre a reorganização, sem aumento de despesa, da Secretaria de Estado de Educação e Saúde Pública e das repartições dependentes, e dá outras providências.

BRASIL. Decreto n. 24.814, de 14 de julho de 1934. Estabelece, na conformidade do decreto 24.438, de 21 de junho último, o Plano Geral de Organização dos Serviços de Saúde Pública e Assistência Médico Social, e dá outras providências, sem aumento de despesa.

BRASIL. Lei n. 378, 13 de janeiro de 1937. Dá nova organização ao Ministério da Educação e Saúde Pública.

BRASIL. Decreto-lei 871 de 18 de novembro de 1938.

BARRETO, J. B. Normas para uma organização estadual de saúde pública. Arquivos de Higiene, 7(2): 339, 1937.

BARRETO, J. B. Saúde pública no Brasil. Arquivos de Higiene, 8(2): 289-304, 1938b.

BARRETO, J. B. Medicina curativa em meio rural e suas relações com os serviços de saúde pública. Arquivos de Higiene, 9(1): 5-29, 1939.

BARRETO, J. B. As realizações do Departamento Nacional de Saúde em 1941. Arquivos de Higiene, 12(1), 1942a.

BARRETO, J. B. A Organização da saúde pública no Brasil. Arquivo de Higiene, 12(2): 169-215, 1942b.

BARRETO, J. B. As realizações do Departamento Nacional de Saúde em 1942. Arquivos de Higiene, 13(1), 1943.

BARRETO, J. B. O Departamento Nacional de Saúde em 1943. Arquivos de Higiene, 14(1, 2), 1944a.

BARRETO, J. B. A V Conferência Pan-americana dos Diretores Nacionais de Saúde. Arquivos de Higiene, 14(3): 183-200, 1944b.

BARRETO, J. B. As realizações do Departamento Nacional de Saúde em 1944. Arquivos de Higiene, 15(1, 2), 1945.

CAMARGO, A. et al. O Golpe Silencioso. Rio de Janeiro: Rio Fundo Editora, 1989.

CAPANEMA, G. Plano de Reorganização do Mesp Apresentado ao Poder Legislativo pelo Presidente da República. Rio de Janeiro: Imprensa Nacional, 1935.

DINIZ, E. O Estado Novo: estrutura de poder e relação de classes. In: FAUSTO, B. (Org.) História Geral da Civilização Brasileira, tomo III, v. 3. São Paulo: Difel, 1981.

FONSECA, C. Saúde no Governo Vargas: dualidade institucional de um bem público. Rio de Janeiro: Editora Fiocruz, 2007.

GAMA e SILVA, J. \& MARQUES, L. Evolução do Ministério da Educação e Saúde. Rio de Janeiro: Divisão de Pesquisas do Instituto Brasileiro de Administração/Fundação Getulio Vargas, 1955.

GOMES, A. (Coord.) Regionalismo e Centralização Política: partidos e Constituinte nos anos 30. Rio de Janeiro: Nova Fronteira, 1980.

HAMILTON, W. \& FONSECA, C. Políticas, atores e interesses no processo de mudança institucional: a criação do Ministério da Saúde em 1953. História, Ciências, Saúde-Manguinhos, 10(3): 791-826, dez. 2003.

HOCHMAN, G. A Era do Saneamento: as bases da política de saúde pública no Brasil. Rio de Janeiro: Hucitec, Anpocs, 1998.

HOCHMAN, G. \& FONSECA, C. A I Conferência Nacional de Saúde: reformas, políticas e saúde pública em debate no Estado Novo. In: GOMES, A. (Org.) Capanema: o ministro e o seu ministério. Rio de Janeiro: Editora FGV, 2000.

LIMA SOBRINHO, B. A Verdade sobre a Revolução de Outubro. 2. ed. São Paulo: Alfa-Ômega, 1975.

OLIVEIRA, J. \& TEIXEIRA, S. (Im)Previdência Social: 60 anos de história da previdência no Brasil. Petrópolis, Rio de Janeiro: Vozes, Abrasco, 1986.

ORGANIZAÇÃO da saúde pública. Jornal do Commercio, Rio de Janeiro, p. 6., 14 jun. 1936.

PEREIRA, A. Políticas Sociais e Corporativismo no Brasil: o Departamento Nacional da Criança no Estado Novo, 1992. Dissertação de Mestrado, Niterói: Departamento de História, Universidade Federal Fluminense.

SANTOS, W. G. Cidadania e Justiça: a política social na ordem brasileira. Rio de Janeiro: Campus, 1987.

SANTOS, W. G. Décadas de Espanto e uma Apologia Democrática. Rio de Janeiro: Rocco, 1998. 
SANTOS, W. G. O Ex-Leviatã Brasileiro: do voto disperso ao clientelismo concentrado. Rio de Janeiro: Civilização Brasileira, 2006.

SCHWARTZMAN, S. As Bases do Autoritarismo Brasileiro. Brasília: Editora Universidade de Brasília, 1982.

VIANNA, L. W. Liberalismo e Sindicato no Brasil. Rio de Janeiro: Paz e Terra, 1976.

VIEIRA, P.E.G. Assistência Médica no Rio de Janeiro (1920-1937): reformas institucionais e transformações da prática médica, 1982. Dissertação de Mestrado, Rio de Janeiro: Instituto de Medicina Social da Universidade do Estado do Rio de Janeiro.

Classification Table of Medical and Social Care in 1943

Fonte: Arquivos de Higiene, vol. 13, 1943.

Cadastro da Divisão de Organização Hospitalar

Source: Arquivos de Higiene, vol 12(1), 1942. 
Addendum 1

Cadastre of the Division of Hospital Organization

FICMA DE INSTITUIÇ̃̃o

MINISTÉRIO DA EDUCACX̃O E SAUDE DEPARTAMENTO NACIONAL DE SAUDE DIVISÃo DE ORGANIZACX̃o HOSPITALAR

FICHA N.

\begin{tabular}{|c|c|c|}
\hline ESTADO & (Nome da Inatituicio) & FUNDADA EM \\
\hline MUNICIPIO & LOCALIDADE & S. $\quad P \quad D$. \\
\hline DISTRITO & RUA & DATA, 194 \\
\hline
\end{tabular}

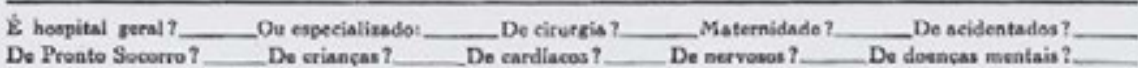
De tubercalose? De lepra? De isolamento? De ol _ Dos, garganta, nariz, ouvides?

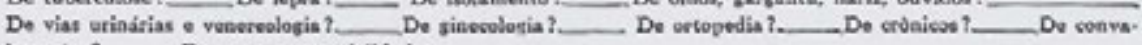
lencentes? _ De outras escrcialidades

Nome do diretor__ Do administrados____ D

ATENCÃO: 1) Responder, no máximo postivel, com alsarismos ou com "sim" ou "ñ̄o".

2) As informagðes, aqui pedidas, se referem ao ano de 1940 .

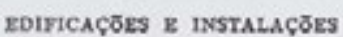

É de construçăo moderna? Na zona urba na? Tem parque? jardim? $\hat{E}$ do tipo "mono-bloco"? Ou tipo "pavilionar"? Quantos pavilhões De quantos pavimentos? Quantas edificacðes anexas? Quantas enfermarias? Número de leitos? nas maiores? nas médilis? nas menores?

Capacidade total de leitos nas enfermarias? Quantos guartos particulares? Total de leitos nos mesmos? Quantas salas de operaçio? sépticas? assépticas? Quantas para anestevia? Para curativos? Para consultas? Para parto? Instalação de ortopedia? radiologia? sendo: para diagnós tico? para tratamento? Instalaçĭo para eletroterapia? hidroterapia? helioterapia? Para oto-rino-laringologia? oftalmologia? cardiologia? Quantos gabinetes dentírios? Quartos para médicos-internos? Para cstudantes? Para enfermeiros? Gabinete fotográfico? Farmáeia? Com laboratório anexo? Laboratório clínico? bacteriológico? anátomo-patológico? sorológico? Tem necrotério? Sala de capela? Sala para leitura? Para cursos? Para reunizes? Para projeçio? Aparelhos de "projeçăo fixa"? de cinema $16 \mathrm{~mm}$ ? de $35 \mathrm{~mm}$ ? Quantos refeitórios para doentes? Para médicos e administração?

Para auxiliares e subalternos? Tem instalaçăo elé. trica? de gás? de vapor? Aque- cimento interno? Refrigeradores elétricos? a gás? Camaras frigorificas? Tem ar condicionado? S6 filtrado? Esterilizado? Há inter-comunicaçs̃o telefónica? de alta voz? de sinal-som? de sinal-luminoso? Receptores de rádio? Rede interna de recepçio radiofónica? Há reservatório d'água? de quantos litros? A água é depurada? Quantas cozinhas? sendo diet6ticas? Há lavandaria mecånica? Forno para incinerặto de lixo? Quantos aparelhos sanitários? Destino do esgoto: rede geral? curso d'água? Fossa? O efluente da fossa é tratado? Clorado? Quantas ambulancias? Elevadores? Carros térmicos para conduzir comida? Outros véfculos? Há outras construçdes e insta-

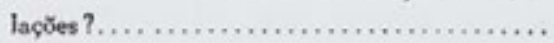

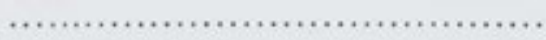

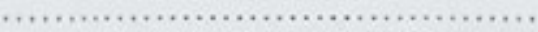
(Queiram juntar plantas, fotografins e quaisquer outros documentos referentes i instituiçđ̃o).

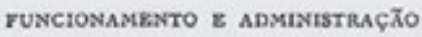

Doentes internados em $1 / 1 / 40$ ? Homens? Mulheres? Crianças? Quantos entrados durante 1940? Homens? Mulheres? Crianças? Quantos gratuitos em 1940? Homens? Mulheres? Crianças? Pensionistas ou contribuintes? Homens? Mulheres? Criancas? 


\title{
Addendum 2
}

Addendum Classification Picture of Assistance Medico-Social, at 1943

\section{DIVISÃO DE ORGANIZAÇÃO HOSPITALAR}

\author{
ASSISTENCIA MÉdiCA E SOCtAL
}

COMPREENDENDO: ASSISTENCIA HOSPITALAR E ASSISTENCIA PARA-HOSPITALAR

CONTROLE

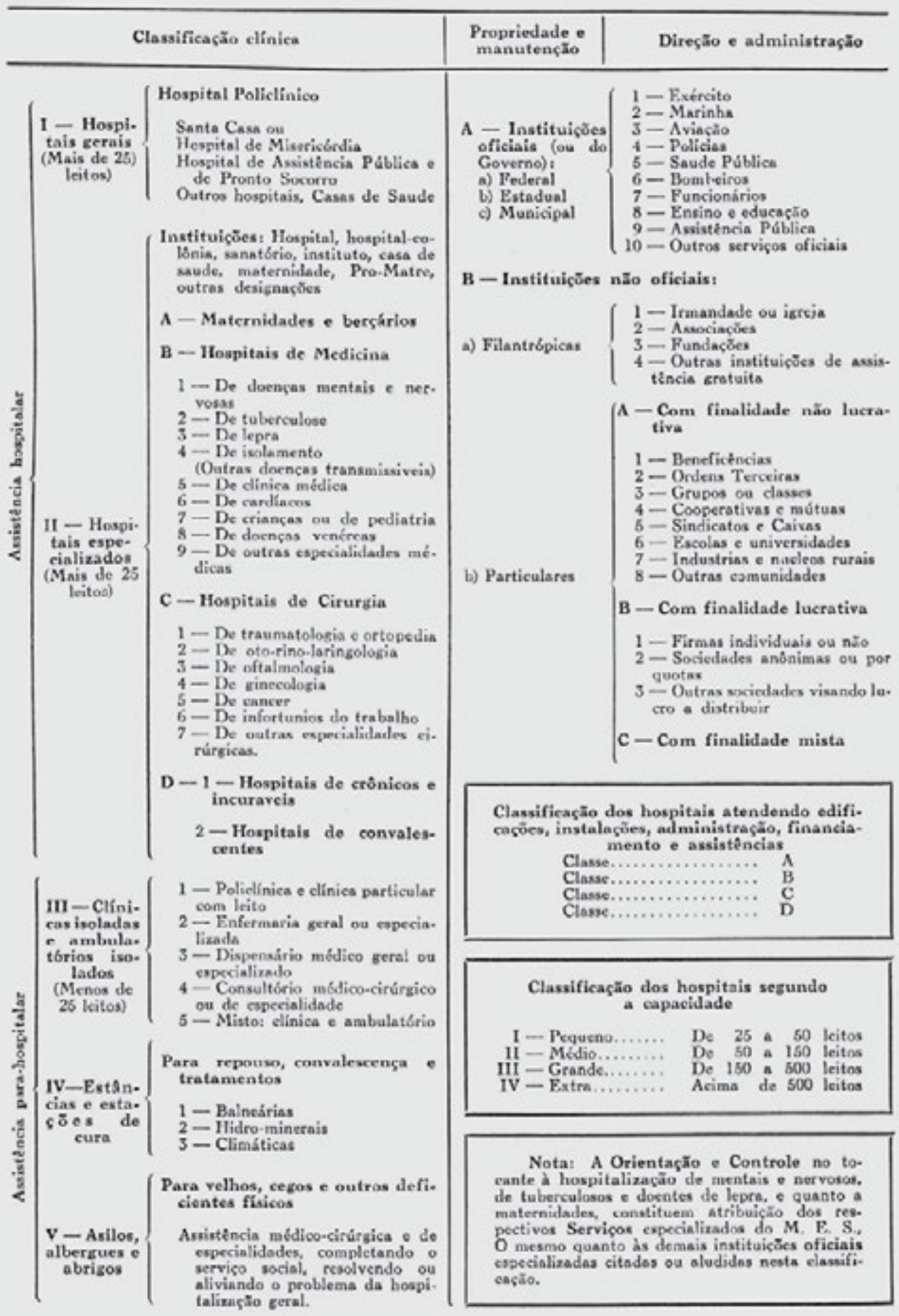



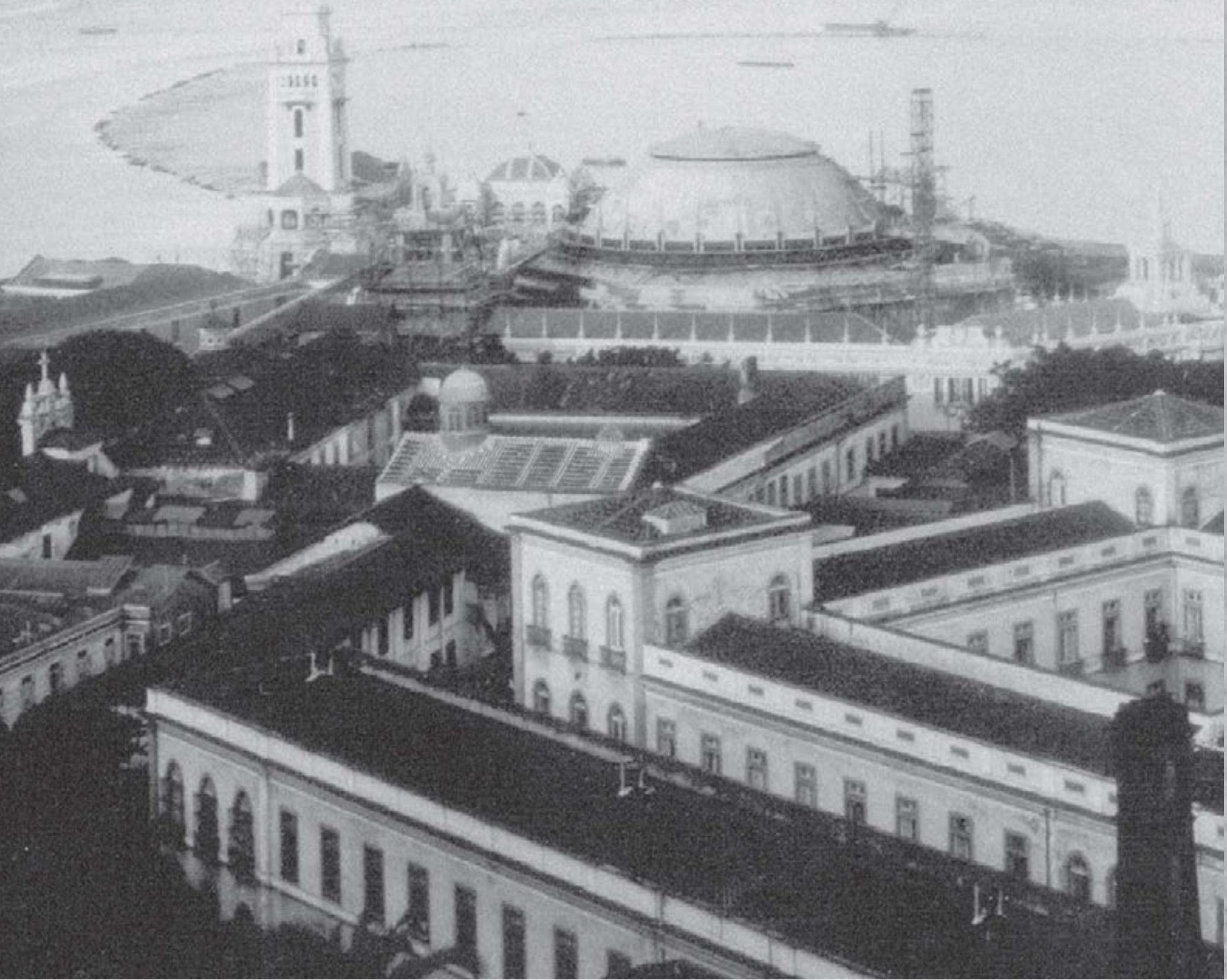
5

\title{
Architecture and health in Rio de Janeiro
}

\author{
Renato da Gama-Rosa Costa
}




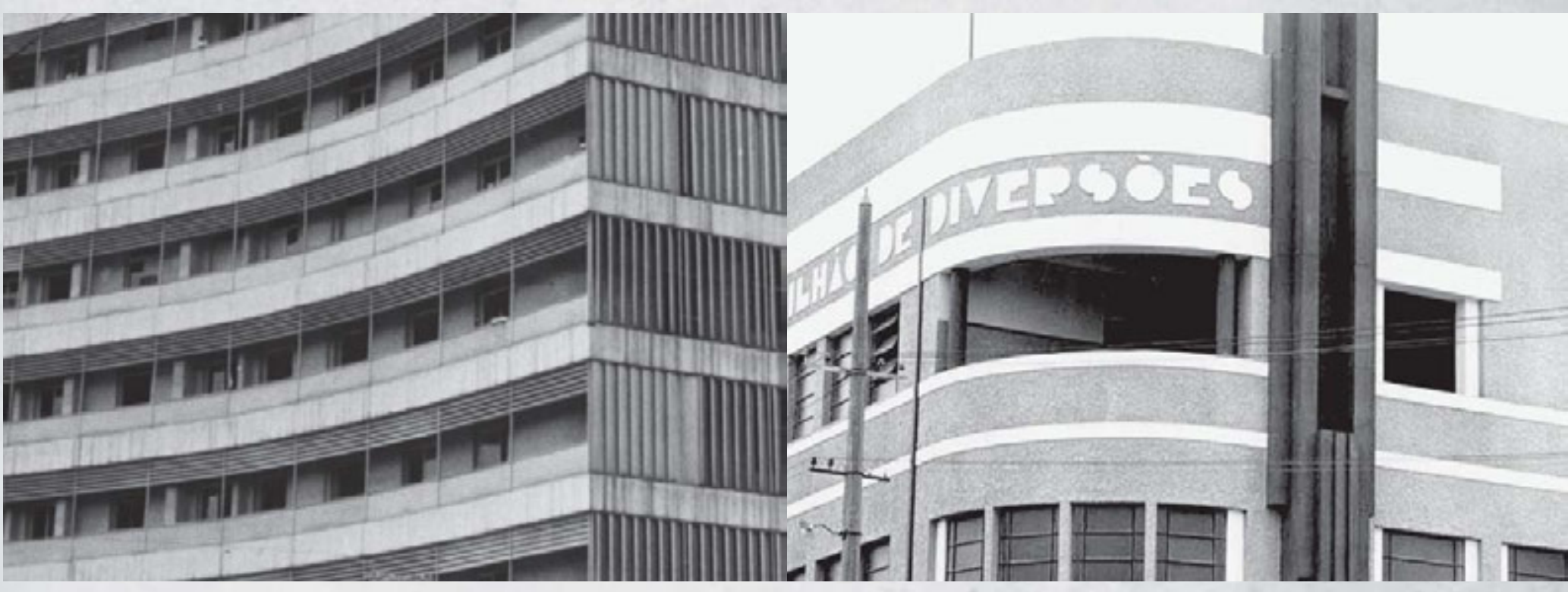


The history of hospitals has some classic studies developed, but investigations on hospital architecture are still fruitful. In Brazil, with the exception of pioneering studies carried out by Miquelin (1992), Bittencourt (2000) and more recently, Toledo (2006), this theme still searches for those who are willing to tell the history of hospital architecture through case studies. This is one of this book's objectives, and what this chapter in particular aims at.

According to Foucault (1999), hospitals while instruments of cure are a recent invention from the end of the $18^{\text {th }}$ century. This is the case because, according to him, hospitals were not a place for medical practice, and doctors didn't see them as objects for the performance or the improvement of their therapeutical studies. Hospitals were a place for religious people and their fraternities, aiming at supporting the poor until their death. The reconstruction of Hôtel-Dieu in Paris, between 1772 and 1788, after a fire, would defeat the raising of awareness on the deplorable status of hygiene conditions in old charity hospitals. The traditional use of hospitals for different purposes and for the care of patients with the most varied types of infection, along with wounded patients, parturients and kids, allied to a new conception of room ventilation and aeration, questioned the old hospitals' usual square or cross plant, adopting the pavillion shape.

To rebuild the hospital, French surgeon Jacques Tenon was called - he, along with Englishman Howard and the Austrian Hunczovsky carried out, since 1760, comparative studies trying to statistically demonstrate the relationship among mortality rates, certain medical practices and the hospitals' internal spaces, having as their inspiration Hospital Stonehouse, from Plymouth, projected by engineer Roverhead, in that year (Mignot, 1983). Such hospital would then be the model used as a reference for the reconstruction of the Parisian hospital and of other French hospitals, being approved by that country's Science Academy, in 1786. The Commission proposed, in summary, 1200 beds for the hospitals, more isolation, disposition and openings in each room, aiming at better renewing the air, organizing the isolation pavillions in a more orderly manner, disposed in parallel and more favorably oriented in the north-south direction, and, in their majority, composed by one to two pavements, with rare concessions to three floors.

However, such model wouldn't be fully applied before 1830-1850, with the construction of the Renaissance Hospice, in Garches, or even before 1874, with the construction of Hospital Lariboisière. To a certain extent, the subsequent nationalization of France's clerical properties would have contributed 
with this delay (Mignot, 1983). Along the second half of the $19^{\text {th }}$ century, hospitals managed by churches would give place to hospitals organized by doctors, and the architecture of health spaces would start being understood as an instrument of cure as much as a "food diet, a sangria and a medical gesture" (Foucault, 1999: 109).

In order for this to occur, the promulgation of French republican law dated July 15, 1893, which instituted the free medical care, was decisive. This law made it possible for communes to finance the hospitalization of citizens who didn't have resources and forced hospitals to care for them. This way, public authorities started requiring that patient admissions were performed by doctors, taking this prerogative away from the nuns. In this regard, hospitals would gradually become managed by doctors, caring for all types of city residents, were they venereal patients or parturient women. These changes would bring deep alterations in hospital architecture (Faure, 1994), and it would never be the same.

In this chapter we plan on analyzing how such changes were translated in hospital constructions in the city of Rio de Janeiro, perceiving similarities and particularities, and examining the choices of language and shape adopted, including the Santa Casa hospital and even monoblock hospitals. In other words, this analysis includes the architecture that served the religious cult's needs to the architecture that followed hygiene precepts or from the challet architecture to the functionalist architecture.

Another aspect that we will approach is related to the gradual performance of architects, which started taking over the role of main articulators in a hospital's project, from the second half of the $20^{\text {th }}$ century on, with the advent of the so called modern architecture. Modern architecture would use such type of program as a way to exercise to the maximum its ability of articulating complex uses and scientific information in a civil construction (Anelli, 2001) According to architect Rino Levi (1901-1965), born in São Paulo and author of seven hospital projects performed between 1945 and 1960 in Brazil and in Latin America ${ }^{1}$, the development of a hospital project depends on a multidisciplinary team composed by doctors and specialists from various areas, and the architect is the coordinator who's able to reunite contributions from each one of the professionals involved (Anelli, 2001)

However, such methodology for the construction of hospitals would have other results. The decades of 1960 and 1970 would watch a predominance of technique over architecture in the use of the monoblock typology, a construction which reunited, in one single construction, diseases previously separated by pavillions. In search of extreme functionality, what can be noticed is that, from then on, the technology of construction would be more and more predominant, in detriment of higher creative ability coming from the architects. Not by chance, we decided to end our research in 1958, a period preceding these two decades.

What's important to make clear is that the evolution of architecture for health does not present a linearity, which could make it seem that a subsequent solution would be better than the previous solution, two or more models co-existed at the same time. In reality, what can be noticed is that this discipline attempted to respond, the best way possible, to the challenges imposed in the interdependent relationship with medicine along the centuries, which on its turn, didn't follow in a linear and progressive manner either. 


\section{Care for the poor, and religious hospitals}

Roberto Machado (1978) and Russel-Wood (1981) were some of the few scholars that carried out deeper investigations on Mercy house hospitals, bringing the theme to the Brazilian particularity. According to Russel-Wood, in the entire Hispanic America, hospital services were not municipal responsibility. The Church and religious orders assumed such task, which in Brazil would belong to the Mercy fraternity, the most active one in this regard, even if with limits.

The first Santa Casa hospital in Rio de Janeiro, founded in 1582, was part of a set of charity actions offered by the mercy houses, divided in seven spiritual and seven corporal actions. The hospital's responsibility was, certainly, to cure the ill; cover those who were naked; feed the starved; provide water to the thirsty; give shelter to wanderers and the poor; bury the dead. To Machado, "hospital care at the Santa Casa in Rio de Janeiro was limited, in the beginning of the 18th century, to only two doctors, a surgeon and a nurse assisted by a helper and two slaves, for a population of more or less two hundred and fifty sick people" (Machado, 1978: 59).

The establishment of the Portuguese Court, in 1808, in Rio de Janeiro, would bring significant changes in this relationship. In 1813, it was established that the Medical-Surgical Academy had its program conducted at the Santa Casa hospital. This would continue even after Rio de Janeiro's Medical School was created, in 1832. Teaming with this school was essential for Mercy to become the stage of transformations in the exercise of curing arts, and not only death support. The presence of academic medicine in that environment, as well as the increasing number of patients assisted made the building's physical structure problems evident - it was considered inappropriate for the treatment of the ill, according to medical conceptions at the time. Besides, discussions in the 1823 Constituent Meeting, questioning Santa Casa's spaces, considered insalubrious, led to the creation of a report that pointed to the construction of a new hospital for Santa Casa, accomplished in 1854, already within hygiene precepts, as we'll see ahead. This report also indicated other improvements in the health area, such as the construction of special buildings for the madmen, for the exposed and for orphan girls.

A closer look at the architecture of Hospital dos Lázaros reveals the level of complicity felt at a certain moment between architecture, medicine and religion. The hospital was built between 1748 and 1752, constituting a square plant, with internal patios and a central chapel. This disposition was maintained even after it was adapted to receive the leprous, in 1766. The jesuits' cells, used as rooms for the patients, thus remained until 1892, when they were finally destroyed, transforming the space into infirmarysalons (Porto \& Oliveira, 1996). The presence of a doctor was rare; patients were assisted by a surgeon and cared for by nurses and the religious.

Attempting to keep up with advances in the patients' treatment and comfort, and to comply with hygiene precepts, the lazaretto went through many reforms, especially in the last quarter of the 19th century. Reforms continued in the following century, between 1917 and 1920, and made it possible for its installations to become a model of hygiene, encouraging other improvements, precursor of what would be required for hospital construction in the subsequent years. In formal terms, Hospital dos Lázaros tried to maintain lines closer to the religious architecture, adopting the neo-gothic as main element of language and style. Along the reforms, constructions in the lazaretto incorporated aesthetic 
and neoclassic elements, eclectic elements, and art nouveau elements, without, however, leaving the religious reference behind.

Architectural projects of isolation spaces for the madmen, such as the mendicity asylum, built between 1884 and 1889, were developed in compositions that followed the same principles of prison institutions in Europe, such as "Bentham's Panooptic". The asylum's architectural party ${ }^{2}$, current Hospital São Francisco, adopted the volumetric configuration formed by a central body and 5 overlapped poles, in two pavements. This radial solution, that induced confinement and control, was also the object of projects for hospitals, finding very few models in Brazil - one of the most prominent is the Belém Sanatorium, located in an area far from the city of Porto Alegre. ${ }^{3}$ In the transformation of the old asylum to a general-hospital, the wards' original structure was reused as a "pavillion hospital" - an adaptation for infirmary-salons, creation of a separate consultations' office, rationalization of the hygiene and circulation system. A chapel located in the building's central body was part of the original project, making evident how much tradition owed to religion for the treatment of its patients.

\section{From the hygienist architecture to the pavillion architecture}

Hygiene would be responsible for the transformation in the first hospitals' architectural shape, especially after the epidemies that devastated Rio de Janeiro in the second half of the $19^{\text {th }}$ century. Such precepts were translated into investments in the separation of wards for the patients, independent but interconnected by corridors that were underground at times; in the isolation of big urban concentrations, and in the attention to aeration benefits and humidity control.

The new hospital for Santa Casa de Misericórdia complied with these principles, raising, between 1840 and 1852, a big construction with neoclassic features, distributed in 10 wards and six internal patios, symmetric and square, projected by architect-engineer José Domingos Monteiro, a former member of the Imperial Body of Engineers and Chamber architect. Monteiro was designated as the architect for Santa Casa's works by the Institution's provider, José Clemente Pereira, who pointed out defects in the old installations, at the time in disagreement with the Eight Hundred's hygiene rules: irregular architecture; nursing rooms located underground, humid and deprived of the required air circulation; infirmaries that were too small for women; phthisics were not isolated, as well as the persons infected with smallpox; and the madmen's accomodations were like prisons. These conditions were worsened by infiltrations, leaks and caving threats in some parts of the building.

A travel report produced at the time (1868-1870) by the expedition of Bourdel-Roncière, a French doctor who was responsible for the health care aboard one of the French vessels that responded to the interests of the medical geography and the European colonization (Morais, 2007), attested Santa Casa's unfavorable situation under the hygiene point of view. Reports like this legitimized the authority of European doctors and their diagnosis on a country, essential for the progress of the colonialist company.

"Their opinions on the hospitals' general conditions, the most common diseases, the number of employees available - doctors, pharmacists and nurses -, hospital expenses, the building's architecture and the treatments currently used by the local medical communities, were used as guides for the governmental authorities and, consequently, for other exploring doctors" (Morais, 2007: 47) ${ }^{4}$. 
According to the report, the architecture in the Santa Casa building was considered to be as good as the best European establishments, especially the French ones, which were considered models. Equally praised were the generous space between beds, the corridors' size and the existence of gardens, essential elements in hospital salubrity. Despite all praises regarding materials employed in its construction granites and noble woods -, revealing the effort undertaken by Monteiro and Pereira, the hospital hygiene was very deficient. Its location at the base of Morro do Castelo was considered inappropriate from the hygienic point of view, "(...) due to the hill's near perpendicularity in relation to the winds, which represented an obstacle to the ventilation" (Morais, 2007:49). We know how much the location of a hospital was important to maintain its salubrious conditions.

In fact, in the same period, Hospice Pedro II was built. Following precepts that suggest providing "calmness, tranquility and space" to the madmen (Tundis e Costa, 1990: 38), the hospice's building was built at Praia Vermelha, a site away from the city and very ventilated. The difficult access guaranteed the patients' isolation, as well as protection against eventual escapes. The party adopted for the isolation hospice was pavillion-shaped, presenting six internal patios. Its configuration followed a program that was common to Paris' hospital establishments, confirming Hôtel-Dieu as a great model to be used as inspiration all over the world - its program is constituted by infirmaries, pharmacy, salons and a chapel.

Until the end of the 20th century, the following were built: Hospital da Beneficência Portuguesa, Hospital São Sebastião and Hospital Evangélico. What can be perceived as common to these hospitals' architecture is the attempt to respond, with constructive quality, to issues imposed by hygiene: the use of isolation pavillions to shelter infecto-contagious diseases or the separation by gender; the use of internal patios and big windows to facilitate the rooms' aeration and ventilation. In the case of the São Sebastião Hospital, the urban network was also isolated.

As for the architectural language, the neoclassic style is used, combined with the challet style in decoration and in the use of constructive materials. In general, the neoclassic style appears in the main buildings of the complex, with emphasis to access façades, leaving the challet language to the interior of buildings or for isolation pavillions. In the case of Hospital Beneficência Portuguesa, its main building, built between 1848 and 1853, presents the only model of arched pediment with Rio de Janeiro's classic style, an element that would be repeated in the pavillion built forty years later.

The neoclassic and challet languages would still appear in some hospitals in the first decade of the 20th century, although already inserted in the new reading provided by the architectural eclectism movement, such as in the Red Cross Hospital, the Manguinhos Hospital and in the hospital built for the National Institute for the Education of the Deaf. At this time, new medical discoveries, such as the transmission of diseases by germs, and the work of French engineer Casimir Tollet, in 1892, presenting a permanent solution for the renewal of air in the infirmaries, which consisted in the construction of environments with high walls, with an arched section and an opening in the ceiling, near the roofs, which allowed the exit of dirty air through the upper portion of the environment. This system would allow a new kind of insertion of the hospital in the urban environment, without the requirement of spaces around the building for ventilation and air renewal at the windows' level.

The Manguinhos hospital project, by Luiz Moraes Jr., built during the last living years of Oswaldo Cruz, between 1912 and 1917, still followed recommendations for a hygienic hospital: large terraces, 
high headway and refrigeration system, which facilitated the aeration and more comfort in the rooms. The guiding program, however, was bacteriology, where each disease was fought separately, that is, in each pavillion. Its original project estimated the construction of another five pavillions. This undertaking was not successful, given the scientist's premature death - the only pavillion built was used for the treatment of tropical diseases, such as the Chagas disease, the yellow fever, the visceral and tegumental leishmaniosis, the Lutz disease and the pemphigus foliaceous.

The discoveries made, especially by Pasteur and his followers, and the progressive individualization of infecto-contagious diseases, associating a microorganism to a disease and its symptoms, would lead to a review of the isolation therapy. For diseases that would still require withdrawing the patient from the rest of the society, the isolation hospital was still the model to be followed. In terms of architecture, the sanatoriums experienced a series of constructive references and shapes, becoming labs for aesthetic and constructive research.

To conduct other treatments that did not require isolation, and for other illnesses that would appear with the modernity of the $20^{\text {th }}$ century, such as people wounded in the war and those hurt at work or in traffic, already appearing, general hospitals and emergency rooms would be built. They started occupying more centralized urban areas.

To a certain extent, this was felt in the creation of Red Cross hospitals. Their purpose was to care for those wounded in the many conflict episodes in the 20th century, thus stimulating, since 1863, the work of the International Committee to help wounded military personnel. On December 5th, 1908, the Brazilian Red Cross was founded as an agency for public and private assistance in Rio de Janeiro, with the aim of establishing, in the country, a hospital care body similar to those created in other cities around the world, located right at the heart of the city. In a certain way, the inauguration of the Hospital de Pronto Socorro (Emergency Room Hospital, current Hospital Municipal Souza Aguiar), in 1925, aimed at caring for those who suffered accidents, and was located at the Praça da República.

\section{The twentieth years and the transition architecture, between the hygienist, the pavillion and the monoblock model}

The decade of 1920, in Rio de Janeiro, represented a period for the search of new treatments and therapies, situated between the tradition of mercy houses and the modernity brought by bacteriology studies, which were being imposed more and more. These years' production was concentrated in the projects of engineer-geographer Adelstano Porto d'Ave, at the service of the sanitary reform undertaken by Carlos Chagas, before the Public Health's National Department, and the Guinle family's philanthropic activities. Similar to what had occurred with architect Luiz Moraes, who had assisted Oswaldo Cruz during his administration as General Director of the Public Health and at Institute Oswaldo Cruz, executing the constructions' projects by request of the scientist, including a good number of hospital projects, his family ties with the Guinle family made it possible for Porto d'Ave to develop the projects of three hospitals built by Carlos Chagas, under the direction of the Public Health National Department ${ }^{5}$

Then, Hospital Gaffrée e Guinle, Hospital do Câncer and the Medical School's Hospital das Clínicas were designed, at a time when Santa Casa showed signs of exhaustion in the public assistance, and a 
hospital network, with the aim of attacking cases of epidemy of diseases not treated at Santa Casa, especially lepra and venereal diseases, had to be built with the participation of private companies. From these hospitals, only the first was built in its integrity.

The project for Hospital Gaffrée e Guinle was developed by Porto d'Ave and his partner Haering, between 1923 and 1929, date of its inauguration. It was created to hospitalize 320 people and counted on a main building with four pavements and an elevator - the fourth floor was destined to the solarium -, where several services and a medical station were located. It is observed that the typology of Hospital Gaffrée e Guinle followed that of a hygienist hospital, with its infirmaries detached from the central building, according to the traditional concern with the correct ventilation and insulation in the patients' treatment. To a certain extent, its architecture was preparing for the typology that appeared in the United States and that would become hegemonic in the following decades: the monoblock typology.

The architectural aesthetic followed the separation of two typologies: the neocolonial language, predominant in Brazil at the time, dominates the main façade's body and the smaller buildings, such as the chapel. Now the four pavillion block presented an aesthetic that was closer to a German classicism.

In the other projects, Porto d'Ave would make an effort to comply with what he understood, at the time, as being a modern hospital, which in its conception translated into a hospital with an eminent socio-educational role, located in a location with easy access and (sic) happy and attractive (Sanglard \& Costa, 2004). Besides, the engineer's references were no longer the French models, but the German and the North American ones. The challenge imposed to Porto d'Ave is not surprising: until the decade of 1930, the pavillion hospital typology prevailed - soon after it would be supplanted by the monblock type. Hospital projects in the 1920s were, therefore, facing a transition period, when even the doctors hesitated between one model and the other. France itself was split between adopting one or the other: the North American model, constituted by pavillion installations similar to tents (the tent-houses), in wood, inheritors of shelter-like installations from campaign hospitals, to be burned every year, and the German model, formed by one only long shape construction, equipped with counters and curing galleries, more permanent. Common to both typologies was the fact that these constructions were implanted in a huge park, almost garden-cities.

Porto d'Ave developed two projects for Hospital do Câncer (currently Municipal Hospital Barata Ribeiro), one for the location closer to the Porto wharf and another one for the current location, at Mangueira. In both the idea of making pavillions from one to four pavements prevailed, maintaining the architectural language of classic lines. During the land exchange, the installations gained even more generous dimensions, accentuating the " $\mathrm{U}$ " plant, so common in hospital constructions at the time. Unfortunately, little was left from this project.

Hospital das Clínicas would have an even worse destiny, becoming the victim of arguments on hospital modernity from the end of the decade of 1920. Again Porto d'Ave would make a series of projects, trying to satisfy the requirements imposed, mainly by João Marinho, who at the time was the Hospital Care Director. The first plan presented in 1926 estimated that the hospital would be build according to the German school, adopting buildings divided into clinics, lodged in pavillions interconnected by underground passages, but whose internal organization would follow the logic of 
North American infirmaries. The project suffered from severe criticism by supporters of the monoblock system, who preferred to reunite the pavillions in one single construction. More criticism was offered regarding its location, because some wanted it far from the urban agglomeration, certainly tied to the most traditional hygienic issues, which required big pieces of surrounding land to ventilate the air, ignoring the contribution of Tollet, and others preferred land at the Mangue, near Hospital São Francisco and Nursing School Anna Nery. Another point of discussion was if the maternity should be inside or outside the construction's main body.

But the main issue was that, to be a truly modern hospital, it should adopt, without any restrictions, the single block model. Marinho had as references Hospital das Clínicas de São Paulo and the Rochester Hospital, in New York. Porto d'Ave, on his turn, would try to adopt the architecture from the Johns Hopkins Hospital, in Baltimore, copied in its asymmetric plant disposition and in its verticality. In the midst of disagreements, the hospital was started in 1929, but the work was permanently halted in 1934, becoming a big skeleton with an iron frame, and being subsequently occupied by low income residents, turning into a slum.

Another trend would be established starting on the decade of 1920: the eminent separation between the general hospital and isolation hospital categories. This separation would not concern only treatment therapies, but it would be equally reflected in its urban insertion and in its architectural shape and language. The treatment of tuberculosis people in the second half of the $19^{\text {th }}$ century required isolation hospitals and guaranteed its use still during the prevalence of monoblock hospitals, in the following century, especially for patients considered dangerous, such as patients with lepra (Bittencourt, 2000:83).

José Messias do Carmo, on his 1948 work, wrote about the definition, the characteristics and the organization of isolation hospitals. Two hospitals were a model of this at the time: Hospital Pasteur in Paris, and the Providence City Hospital, in Rhode Island, USA. To the author, it was still necessary to build a big isolation hospital for the Federal District, because only the São Sebastião, the São Francisco de Assis and Hospital Evandro Chagas (old Hospital de Manguinhos) fulfilled such role. The number of beds should reach 1000 or 1500, but divided into constructions with 500 beds each, located in urban and suburban areas. Above this number, according to Carmos, the productivity of the hospital started suffering and the administration became strenuous (1948:139).

The author, however, did not consider, in his statistics, rural colonies created in Rio de Janeiro for the treatment of ill people who needed isolation - they were implanted in the region of Jacarepaguá in the decades of 1910 and 1920, as it was the case with colonies Juliano Moreira, for madmen, and Curupaity, for those patients with lepra. It is worth pointing out the relevance of the Jacarepaguá region in the construction of these isolation hospitals, similar to what happened with the Caju and São Cristóvão neighborhoods in the previous centuries. Around Morro Dois Irmãos, which belongs to Maciço da Pedra Branca, and in the middle of Mata Atlântica's primitive reserve, the following would still be inaugurated: the Santa Maria Sanatorium, in the decade of 1940, and the Curicica sanatorium, the following decade.

Therapy for the treatment of this diseases tried to minimize the feeling of loss of citizenship, moving the patients away from the society, which translated in the creation of small urban environments, with the reproduction of typical elements from a city, such as the square, family residences and the leisure 
and entertaining space, expressed by the installation of movie theaters, clubs, ballrooms, among others. The architecture tried to follow this attempt to create a family environment, adopting a more plain and traditional language, close to our Portuguese colonial roots, with one pavement and elevated basement constructions, making use of gable roofs, walls with coating in low relief, generally in white, and wooden frames. The aesthetic ecstasy was left to constructions that sheltered curing, administrative and leisure spaces: the language used was art déco, whose most relevant model is present in Curupaity's movie theater.

From the decade of 1930 on, it would be the North American's responsibility to develop primacy in the monoblock system, here mentioned, rehearsed by the German in their long shape constructions, interconnected as a single construction. This system, which expressed itself in the separation of diseases through the various pavements of the same building, and in the rationalization of personnel circulation and traffic, of ill people and of infected material, would be fully adopted here in Brazil, at least for the general hospitals inserted in the urban network. We can mention as an example, the German Colony's Hospital (1934), current Aeronautics' Hospital, or even the Servers' Hospital, from 1934, whose project passed by Porto d'Ave's hands, who saw in it the chance of projecting a legitimate one-piece hospital ${ }^{6}$. The isolation hospitals would continue not to opt for a single typology, creating a repertoire rich in architecture for health, which needs more attention from history makers.

\section{Years 1930 - 1940: hospital architecture between two typologies and the search for formal cleanness}

In the decades of 1930 and 1940, discussions on hygienist hospitals, isolation hospitals and European models took a path of uniformity: the isolation pavillion typology would be maintained for diseases such as tuberculosis, lepra and those of mental origin; and the monoblock typology would be adopted by general hospitals, that should care for the various types of disease, according to the North American standard.

What was said at the time was that pavillion hospitals required a high number of employees and high installation and maintenance costs - they had to be restricted to certain treatments, such as the treatment for tuberculous people, which had preference over vertical hospitals, because their green and spacious areas helped in the patients' recovery. However, the pavillions, in their great majority formed by one pavement, would be more subject to the harmful effects of contact with dust from the streets. Regarding the therapeutical issue, its installations did not correspond to the growing specialization of diseases, being restricted to those who needed isolation. Finally, no advantage could be perceived from isolating those who were not contagious.

In fact, the one-piece system presented many advantages over the pavillion type, such as the reduction in the cost of buying the land and the installations; the savings in transportation, commutes and time of circulation from the administrative personnel, the medical and the nursing body, made possible by the vertical dislocation provided by elevators; the concentration of the administration, internal discipline and surveillance; the concentration of hydraulic, sewage and electricity installations; more distance from noises and dust in more elevated floors, among others (Brazil, 1965). In summary, a hybrid solution which adopted both models should then be the best option to be followed. 
Two public policies for the construction of hospitals and sanatoriums are important for us to understand what's to be analyzed in this chapter. One of them refers to actions from Mayor Pedro Ernesto, occurred during the first half of the 1930 decade, and another one concerns the national policy developed by Getúlio Vargas in his first administration, between 1937 and 1945. While the first policy would focus on the construction of hospitals and dispensaries, the second one, world trend perceived in the in-between-war period, would use sanatoriums as the main elements to attack diseases that depended on isolation as a therapy. In aesthetic terms, the modern architecture presented by the sanatoriums would adopt, without parsimony, the standards of North American art déco, ignoring the hegemony that the modern aesthetics of French Le Corbusier (1887-1965) would reach among architects from the modernist generation (1930-1960).

In parallel, the reading of decree 6000, launched by the Federal District in July of 1937, points to other elements for the analysis of construction proposals for curing spaces in Brazil. In the decree, the hospitals are separated into three big categories: general hospitals; asylums, which included hospitals for the madmen, for chronic diseases, tuberculosis and mental patients; and 'free' hospitals, maybe referring to assistance and first aid stations. The zoning of the city did not allow the construction of new hospitals and health centers in mainly industrial, port and commercial areas; it was possible to do so in some residential, rural and farm areas.

The asylums were required to, mandatorily, have installations for the administration, which was composed by a direction, secretary and reception; for the assistance, with medical and dental offices and an infirmary; a place where the madmen could stay, with working, reading and entertainment areas; lodgings, separated for the many classes of patients, nurses or janitors and service personnel; cafeterias, equally with the same separations; general services, comprising the pantry, kitchen, storeroom, laundry room, garbage incinerator, etc; and a vigil room. For children's asylums, field installations for games and gymnasiums were also required. The decree dictated the dimensions of internal spaces, the headways' height $(3.20 \mathrm{~m})$ and what should be included in each infirmary: rooms for wound dressing, treatments and medical services; a pantry; a linen room; a small pharmacy, sanitary installations and washrooms.

For the hospitals, it was mandatory that the program counted on a kitchen, laundry room, morgue and garbage incinerators. The decree, besides establishing guidelines regarding the size of headways, a little shorter than those established for sanatoriums - $3.00 \mathrm{~m} \mathrm{-,}$ of corridors and internal spaces, required the use of resistant, impermeable and washable materials, such as ceramics and tiles, in floors and walls, up to the height of 1.50, for circulation corridors, washrooms and kitchens. For constructions with more than two pavements, elevators had to be installed. Dormitories for the ill had to observe the best direction of the sun, protecting the gaps, such as windows and doors, from the incidence of the sun, making use of terraces, marquises and natural shields, such as vegetation, or artificial shields, such as blinds. The constructions also had to allow the permanent ventilation of dormitories, making use of the best direction of the winds provided by the land. The Decree thus translated and reunited centuries of experience in the construction of curing spaces, preparing for modernity in a more organized manner.

Pedro Ernesto's administration, during his time as mayor of the Federal District, adopted a plan for the construction of regional policlinic hospitals and of dispensaries, between the years of 1931 and 1934. Ahead the construction of these hospitals was Luiz Moraes Jr., the same builder for Manguinhos. 
His Companhia Industrial Construtora do Rio de Janeiro (Rio de Janeiro's Industrial Building Company), in partnership with Archimedes d'Arthagnam Saldanha, executed most of the works.

The plastic language adopted in these buildings searched for a modernity that was still embryonic, with strong references to the art déco originated in North America, being identified as protomodernism, attempting to, its own way, break the 'styles' adopted until then for hospital constructions, which then made references to the German gothic, the neoclassic and the French romanticism. The attempt was to create formal cleanness, with emphasis to the terraces, without totally abandoning the use of corners and detached access paths, of ornaments (minimally reduced to stylized pediments), and of cubist markings and lines.

On its turn, the Ministry of Health and Education's Works Division developed activities between 1934 and 1977 in the construction of buildings for the entire country, being responsible for the elaboration of architectural programs and projects, for the organization of specifications and budget plans, for the execution and the inspection of the works (Oliveira et al, 2003). During this period, the team projected and built, with the ministry's resources, between 13 to 19 big sanatoriums in practically every state of the nation, including the one in Santa Maria, Jacarepaguá (1937-1943) ${ }^{7}$. In Porto Alegre, it built Hospital Sanatório Belém, in partnership with the philanthropic society that carries the same name. This strategy for the creation of beds for the treatment of people with tuberculosis counted on specialized hospitals and hospitals that maintained beds for people with tuberculosis, among private and public units, which was characterized as the 'Sanitary Crusade of the Getúlio Vargas Era'. The architectural language, depending on the author of the project - among them, certainly, Jorge Ferreira -, was more audacious, adopting the aesthetics proposed by Le Corbusier: absence of ornaments, apparent structure, free plant, the idea of a prototype and the possibility of industrial reproduction (Cavalcanti, 2006).

Another team was the Engineering and Architecture office for the National Campaign Against Tuberculosis (CNCT - Campanha Nacional Contra a Tuberculose), created in 1946, under the guidance and the inspection of the National Tuberculosis Service, from the National Health Department, Ministry of Health and Education. This team had architects like Sérgio Bernardes and Jorge Machado Moreira, who, like Jorge Ferreira, adopted more clearly the corbusian aesthetics.

The campaign acted mainly in the combat of bone, surgical and pulmonary tuberculosis. For each disease there was a model of therapy, with special reflex in the architecture. It was recommended that bone tuberculosis was treated with heliotherapy, which consisted basically in the exposure of the ill person to the sun, for various hours during the day. And to treat pulmonary tuberculosis, the most important was air and ventilation. So that we can compare one model against the other, let's take as examples the Santa Maria Sanatorium, for the first case, and the Curicica Sanatorium for the second. The Santa Maria Sanatorium was projected by the Works Division team, between 1937 and 1943, and the Curicica Sanatorium by CNCT's engineering and architecture office, between 1949 and 1952, headed by Sérgio Bernardes.

The monoblock construction, located in a wide green area, was adopted in the Santa Maria Sanatorium. Its plant consists in the junction of two ' $y$ 's, a common scheme to these sanatoriums, which at the time also used plants in ' $V$ ' as a way to avoid strong wind effects which, in this case, were harmful to the treatment (Bittencourt, 2000). The curing terraces were positioned by the Ys legs, and in 
the center were the common areas, such as the administration, surgery rooms, kitchen, laundry room, etc. The terraces are the building's main location: places for sun exposure and contemplation of the surrounding site.

The Curicica Sanatorium, on its turn, had the traditional one pavement pavillion system, spread through a wide green area, even though this system was not being used around the world anymore. This typology presented an important factor for the treatment of pulmonary tuberculosis, besides avoiding the reclusion status, noticed in patients hospitalized in vertical monoblocks sanatoriums, leading the Campaign to project the sanatorium complex with those characteristics.

The architectural program followed the technical premises developed by the National Tuberculosis Service, previously approved by the Ministry of Education and Health, whose general recommendations followed the study and the standardization of Campaign-type sanatoriums and dispensaries: efficiency, low cost and economic maintenance, without, however, sacrificing their technical, functional and architectural qualities. It was equally necessary to prepare its installations with spaces that favored the professional training and social coexistence of the ill, through workshops, areas for leisure, religious cults and entertainment.

As we observed, along the decade of 1930 until the years of 1950, the pavillion and monoblock systems fought for the preference of doctors and architects in modern constructions for the health, with predominance of the first, even before the great diversity of hospital categories provided by contemporaneity ${ }^{8}$. The year of 1967 , however, would be decisive for the change in this scenario.

\section{Years 1950-60: the technological hospital and the triumphant monoblock vertical architecture}

The decade of 1950 was a model in the discussion of what would be considered a modern hospital, this time led by architects. We used as a basis the 1954 publication from the Hospital Planning Commission of the Brazilian Institute of Architects, São Paulo department. This publication, under the title of Hospital Planning, was a result of the classes and the debates carried out on occasion of the Hospital Planning Program offered by the institute between April 13 and 17, 1953, in São Paulo, in which architects, engineers, doctors, nurses and students in the respective areas took part.

The objectives of this course, according to the publication's introduction, were, among others, “(...) to disclose conquers in the hospital planning field, to analyze the essential elements for a sane and scientific project, to make it possible to build efficient hospitals (...), to bring interested parties closer, and to stimulate the exchange of information and research (...)" (1954: 13 and 14).

The bigger the architect's contribution, Rino Levi, one of the participants in the course, had conscience that it would actually occur during the project's final plastic shape, as in any other architectural project. But, in the case of hospitals, aesthetics was allied to a desire to organize a service that, in his opinion, contributed for a more extensive scientific investigation, in place of controversies and of personal and empirical criteria in the planning of one of the most complex programs (Levi, 1954: 40).

For participants in general, modern architecture's big contribution would be to transform the hospital into a one-piece construction, where one could demonstrate all the rigor of a solid and grand construction, 
worthy of a rational architecture, well planned and well built. A construction that worried about the location in the existing urban network, with the insulation, the ventilation, the circulations, the flows, the structure, the installations and the details.

The monoblock hospital buildings built in Rio de Janeiro in the 1950s would try to follow such recommendations with the following hospitals, which turned out to be good projects: Hospital da Lagoa; Hospital dos Radialistas; Hospital do Câncer, at Praça da Cruz Vermelha; Hospital de Ipanema; Hospital de Andaraí and the Medical School's Hospital das Clínicas.

Hospital da Lagoa, designed by Oscar Niemeyer and Hélio Uchoa, with Burle Marx's landscaping, enters Brazilian history as a great expression of hospitals with the modern period's vertical monoblock typology. Its architectural details, such as the "V" pillar and the auditorium's block arched structure; reveal great technical and aesthetic refinement. Especially important, the pillar, Niemeyer's creation based on the formal repertoire launched by the International Modernism, was first used in this hospital, deserving the attention of French historian Yves Bruand. It is one of the few modern models preserved by an asset protection organism, and this hospital's relevance lies in the rigor with which the precepts of a modern one-piece hospital were applied.

The diseases were separated through its 10 pavements; the circulation of ill people, personnel and services was facilitated by the construction of wide corridors and of a vertical circulation prism, detached from the main block. Areas destined to the social coexistence were located in the first floor. The patients' rooms, the doctors' offices and the operation rooms were positioned for better insulation and better view, facing Lagoa Rodrigo de Freitas. Service rooms faced the Jardim Botânico Street, adopting, as protection against the sun, leaked bricks and vertical brise-soleis.

In 1957, under the command of Jorge Machado Moreira, Universidade do Brasil's Technical Office (ETBU) developed the project of Hospital Universitário Clementino Fraga Filho, for Hospital das Clínicas at Universidade do Brasil. Designed to meet the program requirements of a school-hospital with 2000 beds, a magnificent $220,000 \mathrm{~m}^{2}$ was built, adopting the one-piece hospital typology. But until today half of its installations are still active, located at Ilha do Fundão.

This project would be a great reference for vertical monoblock hospitals in Rio de Janeiro and in Brazil, along with Hospital das Clínicas in São Paulo and Porto Alegre, both by Moreira. One of the authors of the Plan's Commission at Universidade do Brasil, and subsequently Minister of Education, Ernesto de Souza Campos declared, in reissue preface of the História e Evolução dos Hospitais (Hospitals' History and Evolution, 1965), that the decade of 1950, using Moreira's projects as a reference, were a period of hospital renovation, forcing architects, especially, to debate the issue. Published for the first time in 1944, under the responsibility of the National Health Department's Hospital Organization Division, this work would bring important contributions for the debate, opening a field of thoughts on the construction of hospitals and its specialized and extremely functional architecture. Created in 1941, based on the American College of Surgeons' model, the division became a reference for the theme, especially during the two subsequent decades, by offering Hospital Organization and Administration courses, as the Institute of Architects would do in 1953/1954.

For architect Jarbas Karman, director of the course offered by the IAB, modern hospitals were “(...) one of the most complex, dynamic and specialized institutions. Daily, new applications, researches and 
discoveries have been transforming it. Slowly, what is still empirical and traditional will be replaced by the scientific and the rational". (Karman, 1954: 175)

Karman based his impressions in studies from the Hospital Division of the United States' Public Health Service (U.S. Public Health Service). In his text, the architect was concerned not only with the final plastic solution, a combination of formal elements from several types of architectural plants (shaped as I, L, V, U, X, Y), but also with the internal disposition of each device, room, medical and surgical center, associated to the detailing of each unit's and circulation areas' measures - vertical and horizontal, flows - clean areas with dirty areas, social and service areas, general infirmaries and isolation infirmaries, even the detailing of cabinets, doors, ventilation systems, installations, etc., demonstrating the extreme complexity of a hospital construction contemporaneous to the time at issue.

In 1967, the Federal Government prohibited the creation of new beds for people with tuberculosis, and the general hospitals started offering this type of treatment, which required reforms and expansions in their installations, in their great majority, obsolete. These reforms focused on the construction of monoblocks that were annex to or that replaced the previous buildings, great vertical layers with five, seven or ten pavements. We can mention five examples: hospitals Salgado Filho, Rocha Faria, Getúlio Vargas, Miguel Couto, Souza Aguiar, Pedro II and Carlos Chagas.

Discussions from the previous decade would be fully used, and the vertical monoblock system finally reigned, absolute.

\section{Architecture and medicine: between the theory and the practice.}

As we tried to make evident in this chapter, there is still much more to think about regarding architecture and health. Architecture may be understood as the materialization of the human culture evolution, along with the sculpture, expressing itself through its built shapes and spaces. In health, the biggest challenges were imposed in the attempt to ally medicine's precepts with the constructive materials used at the time, geography, the climate and the plastic expression. From constructions resembling churches and religious temples to compact and extremely functional buildings, built in the heart of cities or outside them, invested by charity or sanitary and hygienic missions, the health spaces, particularly the hospitals, were always permeated by their political, social, economic, medical and architectural context.

What we planned on analyzing in this chapter was how the architects, engineers and builders, associated to the doctors up to a certain moment, tried to respond, between the practice and the theory and with reason and ingenuity, to the challenges imposed by the construction of health spaces in Rio de Janeiro. As we could observe, the salubrity of the waters, the air and the place were always determining for a good architecture. Especially for hospitals, health homes and sanatoriums, the formula of a good architecture adds to the dialogue established with medical theories.

In common with other cities in the new world, the hospital architecture history started among us in the complicity relationship, first with religiosity. Little by little, at the same time that the spaces transformed from death environments into curing environments, they started gaining autonomy, also formally. Subordinated to the search for wide spaces, external and internal, and trying to contribute in 
the combat of the increasingly higher individualization of diseases and their treatments, health spaces tried to multiply and improve the curing spaces, aiming for therapeutical excellence.

Architecture showed itself willing to follow these challenges. When the role of the hospital was to support the patient until death, architecture expressed itself as legitimate monasteries, with solid and robust construction, a place for retreat and contemplation. Based on the need to search for better conditions for the recovery and cure of its patients, hospital architecture tried to become freer, opening gaps and patios, increasing the height of internal headways, discovering and adopting materials and constructive manners to better use the air and the healthy sun. In Rio de Janeiro, hospitals had to follow the NNE and NNO directions, the most satisfactory direction - summer and winter - to protect from insulation, a fact that was known since Vicente Licínio Cardoso's first studies, carried out in the decade of 1920 about hospital architecture ${ }^{9}$.

The aesthetic response initially appeared in the orderly and harmonious shape of classic architecture, combined with the challets' French architecture: rhythm and austerity coexisting with lacing, blinds, wall-tiles, hydraulic floor-tiles and decorative panels. Afterwards, with modernity imposing more and more effective responses, health locations started rejecting refinements, adopting the slogan "less is more"10, and concentrating on the efficiency of its spaces and on the purpose of its constructions, always allied to the dialogue with medical indications, in the case of hospital constructions. If the treatment required more contact with the sun, sanatoriums with wide terraces were built. If the objective was enjoying more the healthy air, pavillions spread through big green areas were maintained. If the sun needed to be controlled, exaggerated exposure was avoided, using the following resources: blinds, leaked bricks, marquises, natural vegetation. If the idea was to avoid dust and noise from the streets, the construction was elevated - true health skyscrapers.

Architectural languages were expressed in the most varied shapes, going from a reference to the classic culture, to the elegant lifestyle of French homes, from the Portuguese colonialism to German cityhospitals and perennial American tent-houses, from the American protomodernism to the European rationalism, without this representing, we insist, a linear and progressive evolution. Today it is recognized that the soft spot of vertical and compact hospitals is in not making better use of the contact with the external environment, always depending on artificial mechanisms. There's an attempt to go back using gardens and fresh air for the patients' better recovery.

The city of Rio de Janeiro counts on good examples of real estate properties related to health registered in preservation books for its historical and/or architectural value, encompassing various languages and constructive periods. Thanks to the actions of the three layers of protection - federal, state and municipal - we have been protecting Santa Casa da Misericórdia main and children hospital, Fiocruz's Historical Center, the complex of old Colony Juliano Moreira, hospitals São Francisco de Assis, Moncorvo Filho, da Cruz Vermelha, da Lagoa, Gafrée and Guinle, Frei Antonio, Ordem Terceira da Penitência, the Beneficência Portuguesa complex, a Ana Nery's Nursing School, Caixa de Socorro D. Pedro V, the National Institute for the Education of the Deaf and Casa de Saúde Dr Eiras.

This repertoire, not fully diffused to a great extent, added to what was studied in this publication, needs to have its due value recognized and transformed into a cultural asset in the city of Rio de Janeiro. 
Notes

1 Rino Levi (1901-1965) executed, in São Paulo, the following projects: the São Paulo University Maternity, in 1945; Hospital Central do Câncer (Cancer Central Hospital), 1947; Hospital da Cruzada Pró-Infância (Pro-Childhood Crusade Hospital), 1950; Hospital Albert Einstein, 1958; and in Venezuela, Caracas' Central Hospital, 1959, Maiquetia's Central Hospital, 1959 and Puerto Cabello's Central Hospital, 1960. (ANELLI, GUERRE and NELSON, 2001)

2 An architectural party is a set of guidelines that direct the creation of architecture projects, including the aesthetic option, definition of use, constructive elements, resources, etc.

3 According to the architectural description developed by Inês El-Jaick Andrade for Hospital São Francisco de Assis' note, for this publication.

4 The author refers to exploring doctors as those who participated in trips undertaken on behalf of colonialist European companies, that used these professionals for the creation of an extensive nosographic map on countries located in the colonies, the so called medical geography.

5 Luiz Moraes jr. would become a great reference in architecture for health in Rio de Janeiro, in the first half of the 20th century. His approach to the area was due to Oswaldo Cruz's invitation for the execution of projects for the buildings of Instituto Soroterápico (1905-1917). The architect's relationship with the institute was maintained during Carlos Chagas' administration (1917-1934). For works beyond those in Manguinhos, Moraes would be responsible for the project and the construction of Policlínica da Avenida Central (1904), Desinfectório de Botafogo (current Hospital Rocha Maia, 1905), for reforms at Hospital do Engenho de Dentro (1908), for new pavillion projects, for the reform and construction of pavillions at Hospital São Sebastião (1908) and Hospital Jurujuba (1909). Now, the insertion of Porto d'Ave in hospital architecture was due to Guilherme Guinle's patronage. Their approximation was facilitated by the fact that his sister-in-law Gilda had been married with Carlos Guinle, Guilherme's brother. In the decade of 1920, Guilherme Guinle financed the construction of three hospitals for public health, during the administration of Carlos Chagas at the DNSP (Sanglard, Costa \& Mello. 2007).

6 Porto D'Ave was the winner of an architecture contest carried out in 1934 for the Servers' Hospital. However, the construction of the hospital dragged for a decade and the project built suffered modifications - its author was engineer Dulphe Pinheiro Machado, with the collaboration of doctor Felix Lamela (Sanglard \& Costa, 2007).

7 According to data from the Gustavo Capanema Fund, and Fundação Getulio Vargas' CPDOC, sanatoriums for people with tuberculosis were projected in the states of the Federal District (Sanatório de Santa Maria, in Jacarepaguá), Pará (Sanatório de Belém - 1938), Pernambuco (Sanatório Otávio de Freitas, in Recife - 1939-1946), Ceará (Sanatório de Fortaleza - 1938), Espírito Santo (Sanatório Getúlio Vargas, in Vitória - 1938-1942), Rio de Janeiro (Sanatório Azevedo Lima, in Niterói - 1939-1946), Rio Grande do Norte (Sanatório de Natal - 1939), Maranhão (Sanatório de São Luis - 1939), Sergipe (Sanatório de Aracaju - 1939-1941), Alagoas (Sanatório General Severiano da Fonseca, in Maceió - 1939-1946), São Paulo (Sanatório de Mandaqui - 1939), Paraíba (Sanatório Clementino Fraga 1941-1946), Piauí (annex to Hospital Getúlio Vargas - 1941-1944), Minas Gerais (Sanatório Getúlio Vargas - projected, but not built), Mato Grosso (Sanatório de Campo Grande - projected, but not built), Bahia (Sanatório São Gonçalo dos Campos - projected, but not built), Goiás (projected, but not built), Amazônia (projected, but not built) e Acre (projected, but not built).

8 In the 1954 publication (Hospital Planning, Brazilian Institute of Architects in São Paulo, 1954), the hospital assistance was divided between general and specialized hospitals. Other than these, they were considered special, hospitals of the following types: colony, village, asylum, sanatorium, prison, emergency, mobile, teaching and ship. The same publication proposed a new and simpler classification in hospitals of the following types: clinic or policlinic, dispensary, first aid station, curing station, asylum, shelter, hostel, hydromineral, thermal, balnearium and climatic. For specialized hospitals, however, it proposed a detailed classification that comprised thirty different items, among cardiac diseases, transmissible diseases, cancer, mental diseases, throat, nose and ear diseases, diseases of the elderly, kids, deaf, impaired, etc.

9 I mention Vicente Licínio Cardoso's work, during thesis presented in the selection process for teachers of the Politechnical School, in the official Architecture and Civil Construction chair that, in 1927, writes the Hospital Hygiene General Modern Principles, where he outlines, in the course of the text, the evolution of modern hospitals from 1786 on, with the appearance of pavillion hospitals in 
France, as a reaction to the types inherited from the Middle Age and the Renaissance, until the best examples of hospitals in the United States, to the point of specifically analyzing constructions in Rio de Janeiro.

10 This slogan was preconized by Adolf Loos, in 1908, when its publication Ornament and Crime was published - in it, he develops the principles of modernism that led to the rejection of ornaments as composing and formal elements.

\section{Bibliogrphy}

ANELLI, R.; GUERRA, A. \& NELSON, K. Rino Levi: arquitetura e cidade. São Paulo: Romano Guerra Editora, 2001.

BITTENCOURT, T. Peste Branca, Arquitetura Branca: os sanatórios de tuberculose no Brasil na primeira metade do século vinte, 2000. Dissertação de Mestrado, São Carlos: Instituto Escola de Engenharia, Universidade de São Carlos.

BRASIL. Código de Obras e Legislação Complementar. Decreto 6.000, de 1 de julho de 1937.

BRASIL. Ministério da Saúde. Departamento Nacional de Saúde. Divisão de Organização Hospitalar. História e evolução dos hospitais. Rio de Janeiro, 1944. Reedição, 1965.

CARDOSO, V. À Margem da Arquitetura Grega e Romana e Princípios Geraes Modernos de Hygiene Hospitalar. Rio de Janeiro: Typographia do Anuário do Brasil, 1927.

CARMO, J. Contribuição ao Estudo da Evolução do Hospital em Higiene Pública, 1948. Tese apresentada para concurso de professor catedrático de higiene e legislação farmacêutica na Faculdade Nacional de Farmácia da Universidade do Brasil.

CAVALCANTI, L. Moderno e Brasileiro: a história de uma nova linguagem na arquitetura (1930-1960). Rio de Janeiro: Jorge Zahar, 2006.

COSTA, R. "Healthcare in Brazil. 1930-1960. Preserving the modern architectural legacy". Docomomo Journal. No 37. September 2007.

CREMNITZER, J-B. Architecture et Santé. Les temps du sanatorium en France et Europe. Éditions A. et J. Picard, 2005.

DESAI, M. Docomomo Journal, n. 35, set. 2006, p. 11.

FAURE, O. Histoire Sociale de la Médecine (XVIII -XXeè siècles). Paris: Anthropos Histhoriques, 1994.

FOUCAULT, M. Microfísica do Poder. 17. ed. Rio de Janeiro: Graal, 1999.

História e Patrimônio Cultural da Saúde. Termo de constituição da Rede de História e Patrimônio Cultural da Saúde. Casa de Oswaldo Cruz. Rio de Janeiro, set. 2006. (Mimeo.)

KARMAN, J. B. Unidade de centro cirúrgico e centro de material e de esterilização. In: PRADO, A. C.; KARMAN, J. B. \& LEVI, R. Planejamento de Hospitais. São Paulo: IAB-SP, 1954.

LEVI, R. Planejamento de hospitais sob o ponto de vista do arquiteto. In: PRADO, A. C.; KARMAN, J. B. \& LEVI, R. Planejamento de Hospitais. São Paulo: IAB-SP, 1954.

MACHADO, R. et al. Danação da Norma: medicina social e constituição da psiquiatria no Brasil. Rio de Janeiro: Graal, 1978.

MIQUELIN, L. C. Anatomia dos Edifícios Hospitalares. São Paulo: Cedas, 1992.

MIGNOT, C. Architecture of the $19^{\text {th }}$ Century. Colônia: Evergreen, 1983.

MORAIS, R. A geografia médica e as expedições francesas para o Brasil: uma descrição da estação naval do Brasil e da Prata (1868-1870). História,Ciências, Saúde-Manguinhos [on-line], 14(1): 39-62, 2007. Disponível em: <http://www.scielo.br/scielo.php?script=sci_arttext\&pid=S0104-59702007000100003\&lng =pt\&nrm =iso $>$. Acesso em: 13 nov. 2007.

NASCIMENTO, D.; COSTA, R.; PESSOA, A.; MELLO, E. Sanatório de Curicica: um Sérgio Bernardes pouco conhecido. In www.vitruvius.com.br, 2003.

OLIVEIRA, B.; COSTA, R.; PESSOA, A. Um Lugar para a Ciência: a formação do campus de Manguinhos. Rio de Janeiro: Editora Fiocruz, 2003. 
PÔRTO, A. \& OLIVEIRA, B. Edifício colonial construído pelos jesuítas é lazareto desde 1752 no Rio de Janeiro. História, Ciências, Saúde - Manguinhos [on-line], 2(3): 171-174, 1996. Disponível em: <http://www.scielo.br/ scielo.php?script=sci_arttext\&pid=S0104-59701996000400009\&lng=pt\&nrm=iso>. Acesso em: 13 nov. 2007.

PRADO, A. C.; KARMAN, J. B.; LEVI, R. Planejamento de Hospitais. São Paulo: Instituto de Arquitetos do Brasil de São Paulo, 1954.

RIBEIRO, L. A luta contra a tuberculose no Brasil (apontamentos para a sua história). Rio de Janeiro: Editorial SulAmericana, 1956.

RUSSEL-WOOD, A. Fidalgos e Filantropos: a Santa Casa da Misericórdia da Bahia, 1550-1755. Brasília: Editora UnB, 1981.

SANGLARD, G. \& COSTA, R. G. R. Direções e traçados da assistência hospitalar no Rio de Janeiro, 1923-1931. História, Ciências, Saúde - Manguinhos, 11(1):107-141, 2004.

SANGLARD, G. \& COSTA, R. G. R. (Orgs.) Porto d'Ave: projetos para a saúde. Catálogo exposição, 2007.

SANGLARD, G.; COSTA, R. G. R. \& MELLO, M. T. B. A coleção Porto d’Ave e a assistência hospitalar no Rio de Janeiro - 1920. Revista do Instituto Histórico e Geográfico Brasileiro, v. 435, p. 195-208, 2007.

SEGAWA, H. "Arquitetura na Era Vargas: o avesso da unidade pretendida". In: PESSOA, J.; VASCONCELLOS, E.; REIS, E.; LOBO, M. (orgs). Moderno e Nacional. Niterói: EDUFF, 2006.

TOLEDO, L. Feitos para Curar: arquitetura hospitalar e processo projetural no Brasil. Rio de Janeiro: ABDEH, 2006. TUNDIS, S. \& COSTA, N. Cidadania e Loucura: políticas de saúde mental no Brasil. Rio de Janeiro: Vozes, 1990. 


\section{Beneficência Portuguesa Hospital}

Location: Glória.

Address: Rua Santo Amaro, 80.

Category: General Hospital

Period of construction: 1859 (São João de Deus Hospital); 1922-1927 (Visconde de Morais Hospital) and 1972 (Santa Maria Hospital).

Proprietor: Real e Benemérita Sociedade Portuguesa de Beneficência do Rio de Janeiro.

Author/constructor: Luiz Hosxe (São João de Deus Hospital); Luiz Moraes Junior (adaptation of the Palacete Fialho to house the Visconde de Morais Hospital) and Roberto Nadalutti (Santa Maria Hospital).

\section{History:}

The history of this hospital is intrinsically tied to the creation of an institution of mutual assistance linked to the Portuguese colony at the capital of the Empire - the Real e Benemérita Sociedade Portuguesa de Beneficência do Rio de Janeiro - founded on May $17^{\text {th }}, 1840$ with the goal to provide assistance care to the Portuguese residents and immigrants of that nation.

In 1848, the associate member of the society, João Nunes de Andrade, has the idea to build a hospital. In the following year, during the first prominent yellow fever epidemic that ravaged the capital of the Empire in the summer of 18491850, an infirmary is inaugurated on March $1^{\text {st }}, 1850$, under the protection of São Vicente de Paulo, to care for the indigent Portuguese affected by the epidemic. This infirmary was administered by the homeopathic doctor João Vicente Martins.

In subsequent years, a commission comprised by Francisco da Silva Melo Soares de Sá, José Joaquim de França and Henrique Pereira Leite Bastos was nominated to study the sketch of the first project of the hospital. The architectonic project was commissioned to the architect Luiz Hosxe. In December 1853 the cornerstone was laid and construction work begins soon after. In spite of the expectation of being complete in two years, the Hospital was inaugurated on September $16^{\text {th }}, 1858$, date of the birthday of King D. Pedro V, of Portugal. Yet it was only open to the public in January of the following year $(01 / 07 / 1859)$.

In the following decade, already in the administration of Viscount de Souto (1864-1866), an infirmary was inaugurated - Jerônimo da Costa Jácome, in tribute to the benefactor that helped build it -, in a lot annexed the hospital's, destined for the isolation of contagious diseases, notably smallpox.

The period from 1867 to 1871 is considered as the consolidation of the hospital. Under the administration of Viscount of São Mamede (two biannual) the pharmacy was built and inaugurated, located on the ground floor of the infirmaries facing toward Santo Amaro Street, and the mortuary chapel - on the back of the hospital; in addition to acquiring property contiguous the hospital. This period is marked by the receipt of a great number of donations and legacies; in addition to the realization of various subscription lists and festivals with earnings going to the Beneficência.

Once the hospital was consolidated and financial difficulties had been overcome, there was new expansion with the contracting of a project to build a new hospital, under the presidency of the Viscount of São Salvador dos Matosinhos (1874-1876), João José dos Rios. However, it was only during the following administration (1877-78), under commendator, Joaquim José Rodrigues Guimarães that construction works on the new infirmaries began, leveling the land of the new building, whose cornerstone was laid on September $16^{\text {th }}, 1877$. Three years later, on December $19^{\text {th }}, 1880$, during the second term of the Count of S. Salvador de Matosinhos (1878-87), the new building was inaugurated, where three infirmaries were established: homeopathy; dosimetry and ophthalmology.

Under the administration of the Baron of Santa Leocádia (1888-90) a special infirmary was built for the treatment of mentally ill associates. 
In 1884, the Asylum of Professional Instruction was inaugurated, destined to provide professional education to the destitute minors, children of the associates. Considered too costly and incompatible with the hospital activities of the Beneficência, the asylum was gradually deactivated in the beginning of the 1890's, to be extinct under the administration of José Gonçalves da Mota (1895-1896). In the building where the Asylum had operated, a quarantine hospital was installed, destined for the treatment of infectious-contagious diseases, inaugurated on September $26^{\text {th }}, 1897$, when the adaptation construction works finished.

Still under the administration of Commendator Antônio Gomes de Avellar (1896-98) the quarantine hospital was inaugurated; in addition to the expansion of the infirmary of S. Antônio destined to the asylum of disabled associates, admitting up to 20 patients; and of the renovation of numerous rooms of the hospital.

The beginning of the XX century brought forth new modifications to the Beneficência Portuguesa, most notably under the long lasting administration of José Júlio de Morais, Viscount de Morais (1923-31). It is in this period that an issue that had been discussed over the course of many administrations is resolved: the transfer of the disabled and of the elderly, in addition to the installation of the tuberculous and of the neuropsychiatric to another property outside the hospital and away from the urban area. The elderly and disabled had begun to over occupy the hospital on Santo Amaro Street, as well as the presence of the tuberculous imposed the need to transfer them to a place where the climate and topographic conditions allowed for more favorable chances of a cure. With this in mind, the property senator Lauro Müller located in Jacarepaguá at rua Florianópolis, no 112 was acquired on October, 1923, for the installation of the Retreat for the Elderly, named Retiro Jaime Sotto Maior; and the Pavilion Zeferino de Oliveira for the tuberculous.

On April 17 ${ }^{\text {th }}, 1927$ the Visconde de Morais Hospital was inaugurated dedicated for women and installed at Palacete Fialho - building bordering the Beneficência Portuguesa Hospital and acquired in 1898. This hospital had the technical management of Jorge Monjardino with the collaboration of Jaime Lino Soto Maior and Francisco Pereira dos Santos and composes the hospital complex of Santo Amaro Street.

As of the administration of the commendator Frankllin Ceppas (1956-1958) the structure of the hospital began to be questioned since it no longer accommodated the surge in its social commitments. And on December 1t, 1960 the cornerstone of the third hospital of the Beneficência Portuguesa hospital complex was laid in Glória - the Santa Maria Hospital - in attendance of Juscelino Kubitcheck, then the President of the Republic. The Santa Maria Hospital was inaugurated on April 23 $3^{\text {rd }}, 1972$ by the President of Portugal, Américo Thomaz. It was equipped with 473 beds, along with modern infirmaries, apartments and private rooms. The medical staff had at its disposal hundreds of consultation rooms, surgical center, laboratories, rooms of radiotherapy and rehabilitation; in addition to an amphitheater, center of studies and library. The planning of the new hospital was commissioned to Odair Pacheco Pedroso, a native of the interior of São Paulo.

The construction of this pavilion, already in the molds of a single-block hospital, increased to 1300 the availability of rooms at the institution, a number superior to its clientele which consisted of associate and private members. During this moment management opens the doors to covenants. Later, infrastructure services (laundry, kitchen, among others) of the hospital undergo modernization. Its pharmacy is also adapted for the new requirements.

Currently, although in dire financial straits, the hospital continues to offer its services to associates, as well as private members and covenants.

\section{Architectonic description:}

The hospital campus of Beneficência Portuguesa is a showcase of the architecture from Rio de Janeiro of the XIX and XX centuries. The oldest component of the complex is the São João de Deus Pavilion located on the left side of the property. The block on the right, erected 40 years later, reproduces the project of the earlier pavilion. The originality of such architecture is evidenced on the low arched frontage - the only reminiscent example of the neoclassical from Rio de Janeiro. Both blocks are united by an elevated walkway which communicates with the street via a scenic staircase of eclectic composition. The workmanship of the ironwork and the masonry of the frontal fence are noticeable. 


\section{IMPERIAL TIMES}

In its own accord, the Santa Maria Pavilion, of Roberto Nadalutti - architect who graduated from the University of Brazil and would end up specializing in hospital planning -, represents the modern, single-block, hospital architecture produced in Brazil as of the 1950's.

\section{Register of Preservation:}

City Hall of the City of Rio de Janeiro, September 1990, decree 9636/90.

\section{Sources:}

A BENEFICIÊNCIA Portuguesa do Rio de Janeiro. Revista Paulista de Hospitais, São Paulo, dez. 1960, p. 18, il. ASSISTÊNCIA Pública e Privada no Rio de Janeiro (Brasil) - História e Estatística. Comemoração do Centenário da Independência Nacional. Rio de Janeiro: Typographia do Annuario do Brasil; 1922.

BENCHIMOL, J. (Coord.). Manguinhos do sonho à vida. A ciência na Belle Époque. Rio de Janeiro: Casa de Oswaldo Cruz; 1990.

LOUREIRO, A. História da Beneficência Portuguesa do Rio de Janeiro (1840/1955). Rio de Janeiro; [s.n (Graf.Olimpica Ed.)]; 1960.

OLIVEIRA, B.; COSTA, R.; PESSOA, A. Um Lugar para a Ciência: a formação do campus de Manguinhos. Rio de Janeiro: Editora Fiocruz; 2003.

Credits: Renato Pereira da Silva, Felipe Abdala and Leonardo Rodrigues (research); Gisele Sanglard (text); and Renato da Gama-Rosa Costa (architectonic description). 


\section{IMPERIAL TIMES}

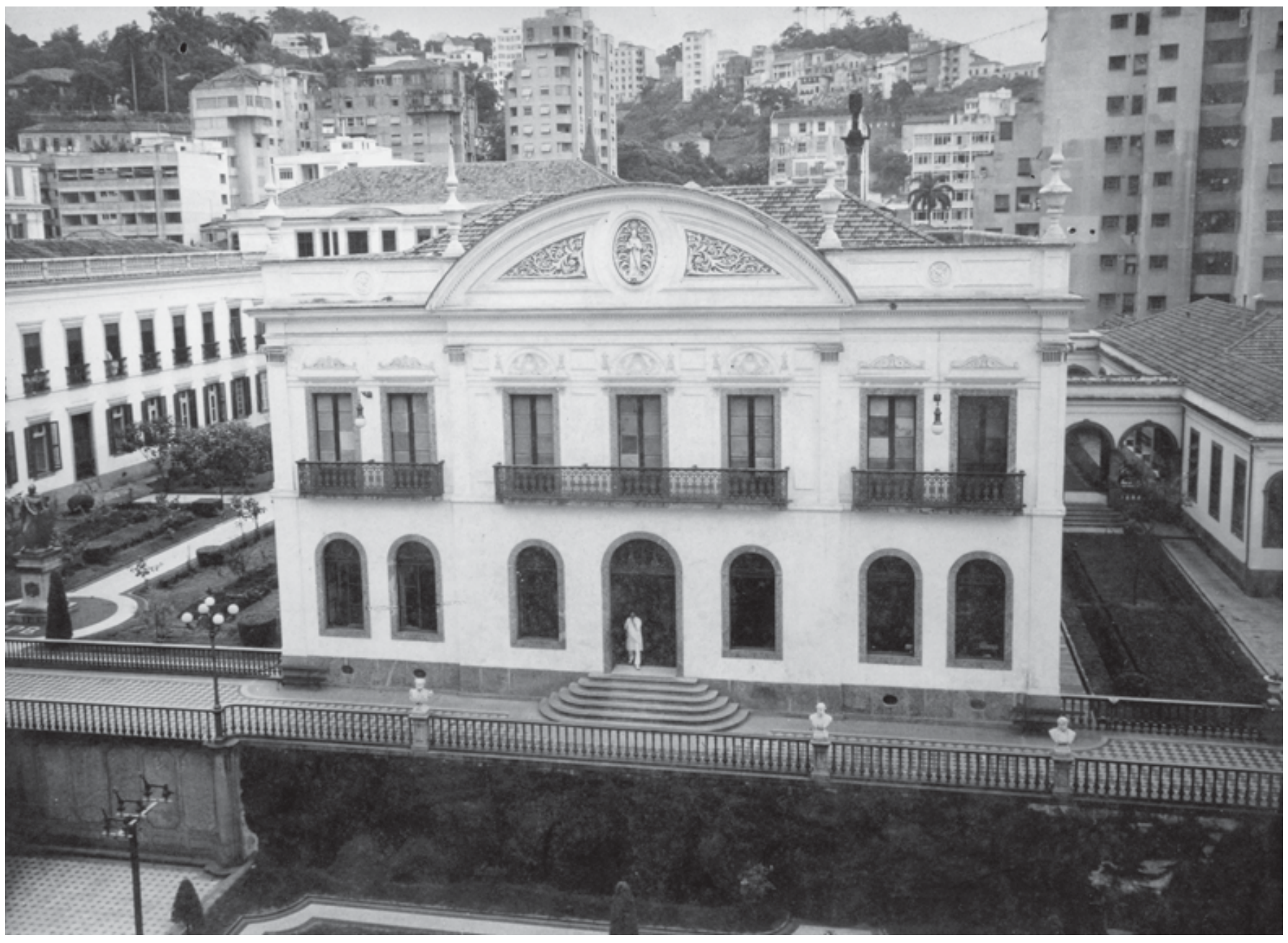

Beneficência Portuguesa Hospital, [s.d.]. Real e Benemérita Sociedade Portuguesa de Beneficência do Rio de Janeiro Archives

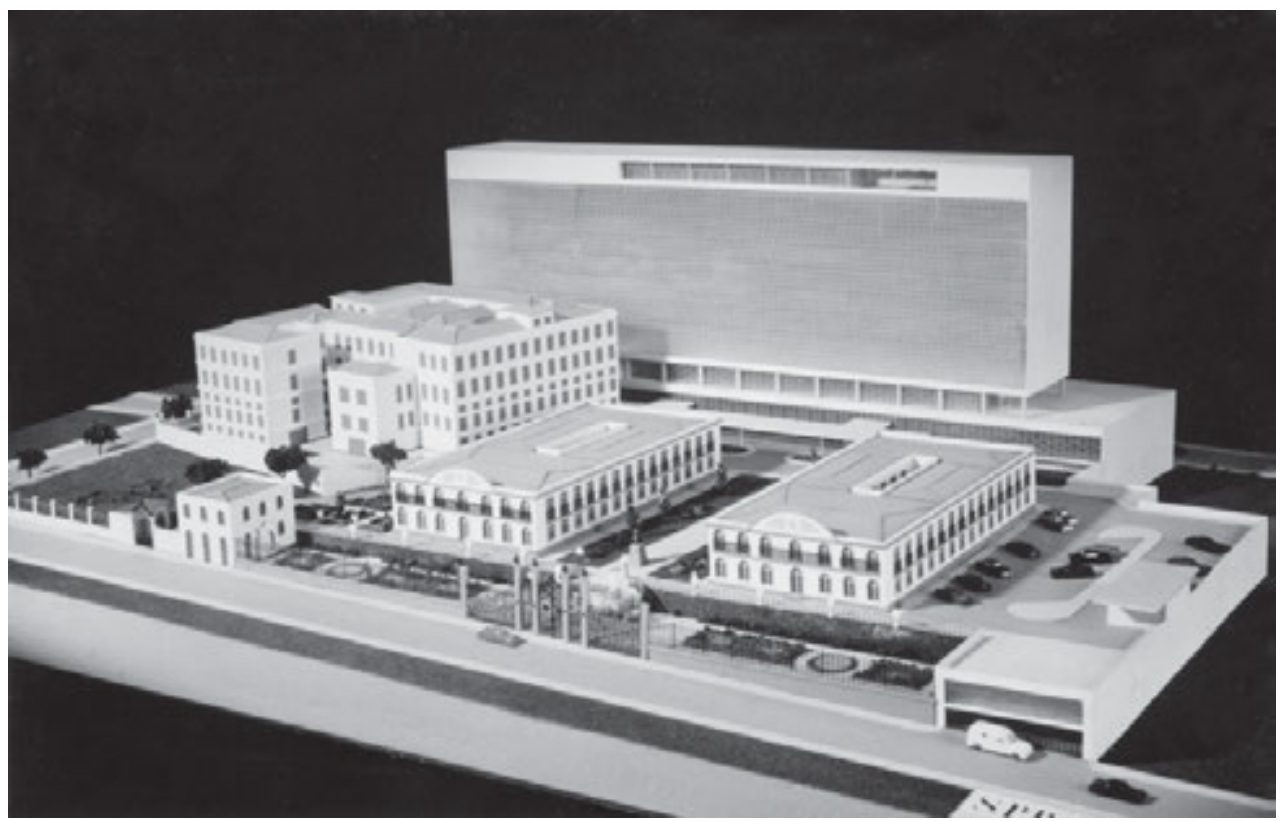

Beneficência Portuguesa Hospital

Maquette, [s.d.]. Real e Benemérita

Sociedade Portuguesa de Beneficência do Rio de Janeiro Archives 
IMPERIAL TIMES

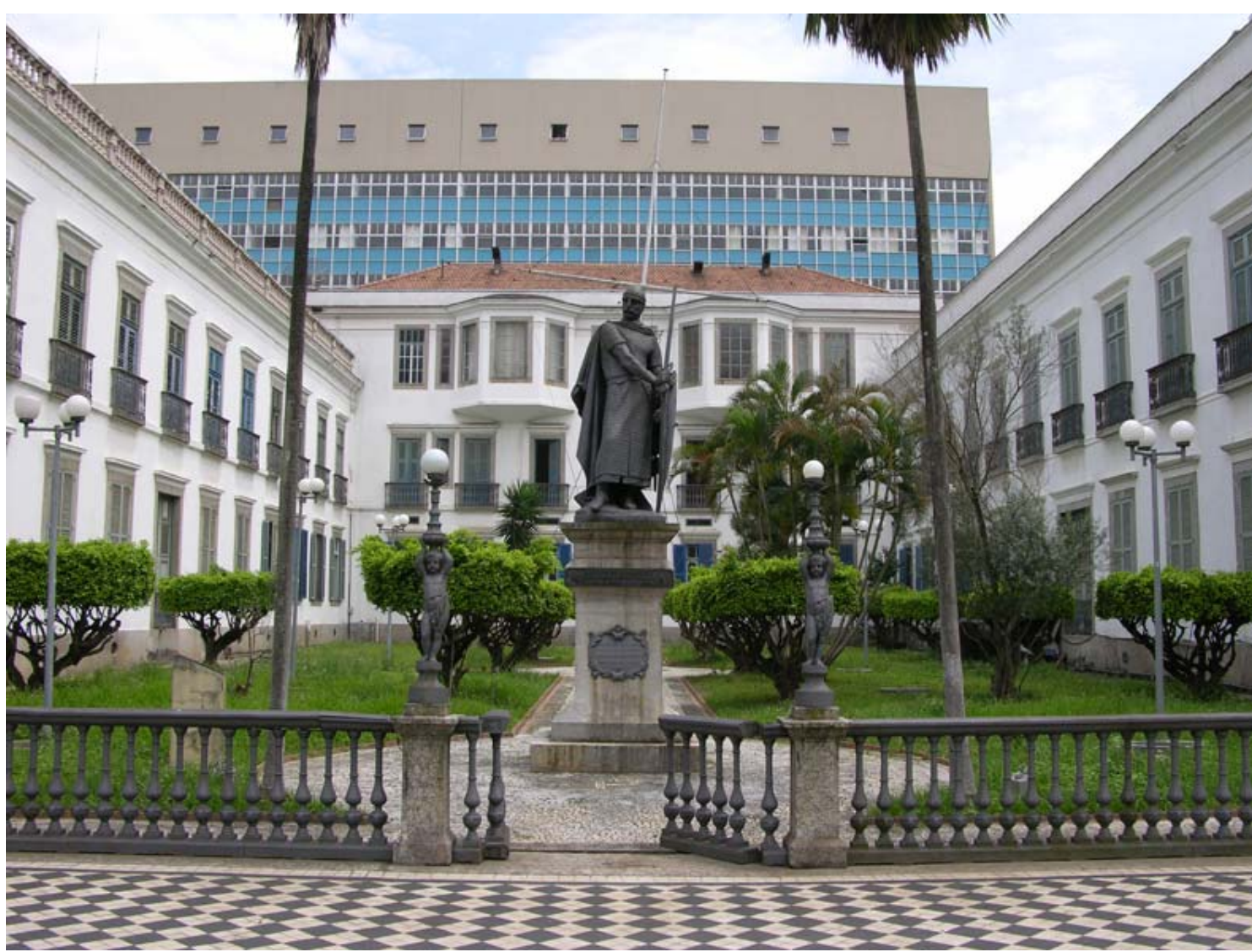

Beneficência

Portuguesa Hospital. Photo Roberto Jesus Oscar \& Vinícius Pequeno de Souza, 2007. Casa de Oswaldo Cruz Archives

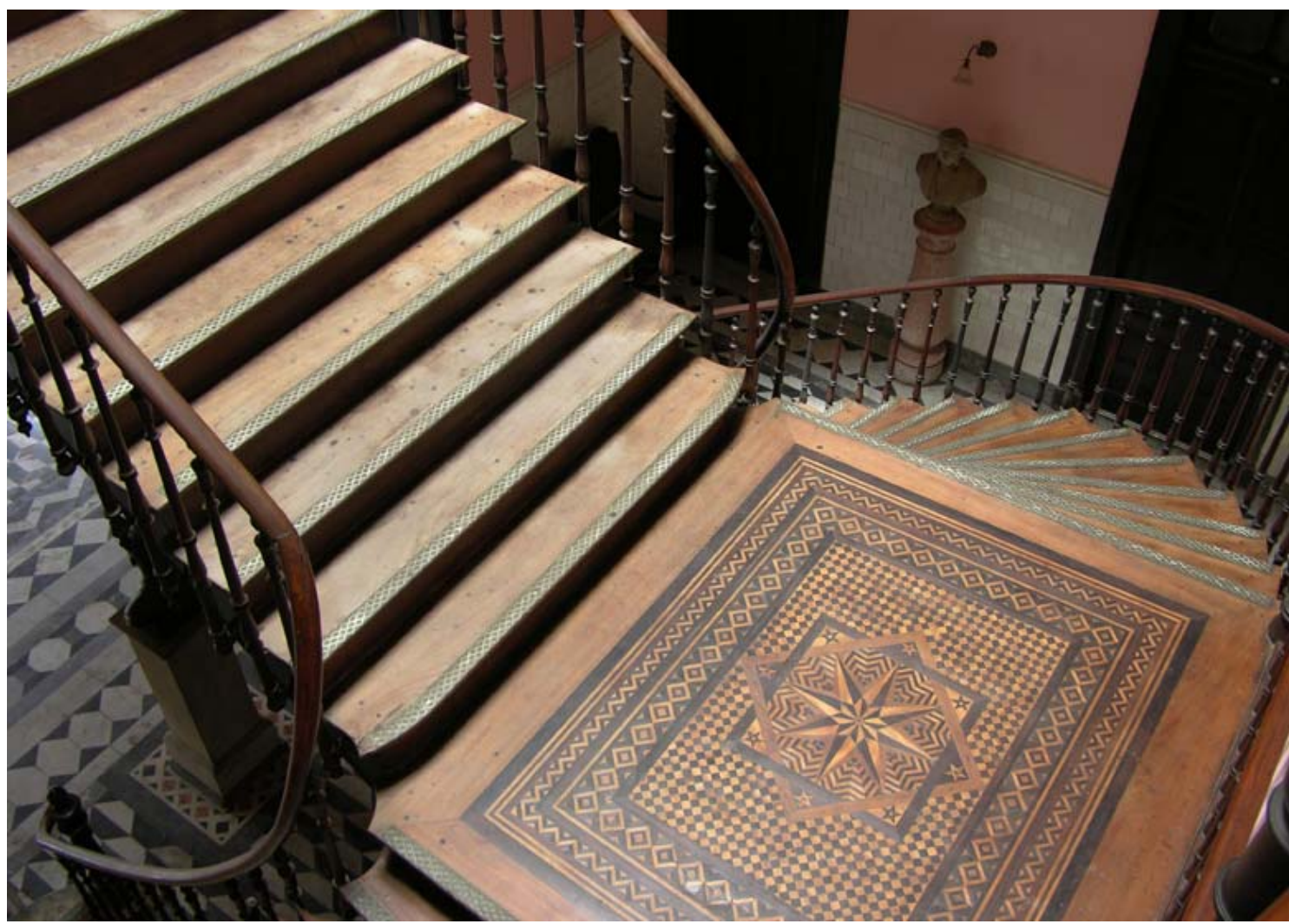

Beneficência Portuguesa Hospital. Photo Roberto Jesus Oscar \& Vinícius Pequeno de Souza, 2007. Casa de Oswaldo Cruz Archives 


\section{Benjamin Constant Institute}

Other denominations: Imperial Instituto dos Meninos Cegos (Imperial Institute for Blind Boys) (1854); Instituto dos Meninos Cegos (Institute for Blind Boys) (1889); Instituto Nacional dos Cegos (National Institute of the Blind) (1890); Benjamin Constant Institute (1891-present day).

Location: Urca

Address: Avenida Pasteur, no. 350/368.

Category: Welfare Institution

Period of construction: 1872-1944

Proprietor: Benjamin Constant Institute

Author / Constructor: Benjamin Constant Botelho de Magalhães (author), Carlos Araújo Ledo Neves (engineer), Torquato Martins Ribeiro (constructor)

\section{History:}

The creation of an establishment directed towards the education of the blind in Brazil had as its inspiration the visually disabled person, José Alvares de Azevedo, born in Rio de Janeiro. Educated at the Institution Impériale de Jeunes Aveugles, in Paris, on returning to the Court in 1852, he occupied himself in disseminating the methods that he had learned for the education of the blind, going on to teach children with this disability. He had as his first pupil, the daughter of the doctor of the Imperial Palace, José Francisco Xavier Sigaud, whose name was Adéle Marie Louise Sigaud, and he taught her how to read using the Braille system.

Due to the success obtained with the education of Adéle, José Francisco Xavier Sigaud suggested to the Minister, Luiz Pedreira do Couto Ferraz (Viscount of Bom Retiro) that he present José Alvares to D. Pedro II. Enthused by the possibility of access to knowledge about writing and reading for the blind, the Emperor supported the foundation of an institution capable of implanting these methodologies into the educational system, directing them to make a formal request for the appreciation of the Ministry of the Affairs of the Empire.

Its creation was approved by imperial decree no. 1.428, of /09/12/1854, and the Imperial Institute for Blind Boys was inaugurated on September $17^{\text {th }}$ of the following year, however, without the presence of José Alvares de Azevedo, who had died in March of that year. It was inaugurated with 30 vacancies, 10 of them offered for free. Its first director was Sigaud, who tried to extend such help to the female sex as well, alleging that the number of girls afflicted with blindness was greater than that of boys, however his attempt did not achieve success. He directed the institution for just two years for he died in 1856.

The Institute was initially located at Rua do Lazareto da Gamboa, no. 3, in a country house on Morro da Saúde, in a dwelling called the Casa dos Coqueiros (House of the Coconut Palms). It was transferred in the 1860's to the Praça da Aclamação, no. 127 (present Praça da República), during the administration of the director, Cláudio Luiz da Costa. His administration was marked by the publication of the first book in braille in Brazil, the Chronological History of the Imperial Institute for Blind Boys, in 1863, which he wrote, narrating the first two administrative periods of the Institute, in three volumes.

Benjamin Constant Botelho de Magalhães, a mathematics and natural sciences teacher in the Institute since 1861, occupied the position of director on May $28^{\text {th }}, 1869$, at the time of the death of Cláudio Luiz da Costa. He re-organized it and was behind its transfer to its own headquarters at Avenida Pasteur, no. 350/368, on privately owned land donated by the Emperor D. Pedro II. The construction work began on June $2^{9}$ th 1872 , when the foundation stone was officially laid. It was actually transferred in 1890, when the first stage of the project was concluded. Upon the death of Benjamin Constant, in 1891, the Institute was named after him. 
On November 16th, 1911, by virtue of decree no. 9.026, the new statutes of the Benjamin Constant Institute were approved which entered into force on the following January $01^{\text {st }}$. This decree established the commitments of the entity toward the blind people it received: to provide them with primary and secondary level education; to promote the teaching of theoretical, vocal and instrumental music; to provide teaching of the arts and useful skills. This educational side was divided into two courses: literary and professional. The former was sub-divided into primary and secondary level in a total of eight years of study, covering all the school disciplines. The practical professional instruction included: a complete study of music; book-binding; the manufacture of brooms, dusters and brushes; straw-work furniture; the tuning of instruments and handicrafts. This instruction was given over a period of eight years of primary and secondary level studies.

The students would pay or be accepted without charge, depending on the financial situation of the family, and they had to have an age range of 8 to 14 years old. Many stayed on beyond the age limit due to a lack of having somewhere to live and a family or because, due to the good results in their studies, they began to work in the workshops of practical professional teaching in the mode in which they excelled. Besides this, later, some became teachers, masters or foremen of the institution itself, due to their good conduct and their results of full approval in all the subjects of the literary course. The Institute provided all the instruments and study materials. Admission as a blind person accepted by the Institute depended on the approval of the Home Office, due to the subordination of the Institute to this Department.

The Benjamin Constant Institute was closed in 1937 for the conclusion of the last stage of the works, begun in the previous century, re-opening only in 1944. In the following year, its junior school course was inaugurated, being granted equivalence to the Pedro II School in 1946. This fact made it possible for the blind to have access to secondary and upper level education.

Up to 1926, the Benjamin Constant Institute was the only institution destined to the education of the blind in Brazil, for it was in this year that the São Rafael Institute was founded in Belo Horizonte (MG). The only blind director up to that time, was the teacher Renato Monard da Gama Malcher, whose administration ran from 1970 to 1972.

Subordinate to the Ministry of Education (MEC), it at present receives boys and girls up to 13 years old, instructing them in the Braille method of reading, created by Louis Braille (1809-1952). Scientific advances in this method and new technologies for the instruction of the blind are widely published in the Benjamin Constant Magazine, created to serve as a vehicle of information and dissemination of scientific knowledge of the area. It also offers services of rehabilitation, medical assistance, personal training, research and publicity.

The Benjamin Constant Institute is considered to be a center of reference for the study, treatment and education of the visually disabled, offering support to similar institutions.

\section{Register of Preservation:}

Building listed by IPHAN on July $11^{\text {th }}, 1972$. Temporary preservation order bestowed by the INEPAC, on August $14^{\text {th }}$, 2001.

\section{Sources:}

ASSISTÊNCIA Pública e Privada no Rio de Janeiro (Brasil) - História e Estatística. Comemoração do Centenário da Independência Nacional. Rio de Janeiro: Typographia do Annuario do Brasil; 1922.

FLEIUSS, M. História administrativa do Brasil. São Paulo: Companhia Melhoramentos de S. Paulo; 1922.

INSTITUTO Benjamin Constant. Como tudo começou... Capturado em 06 de jun. 2007. Online. Disponível na Internet: http://www.ibc.gov.br/?catid=13\&blogid=1\&itemid=89

LEMOS, F.; FERREIRA, P. Instituto Benjamin Constant - uma história centenária. Capturado em 13 de jun. 2007. Online. Disponível na Internet:

http://216.239.51.104/search?q=cache:GmVBBd8-IlIJ:200.156.28.7/Nucleus/media/common/Downloads_Historia_I BC.doc+\%22francisco+mendes+lemos\%22+benjamin+constant\&hl=pt-BR\&ct=clnk\&cd=1\&gl=br

Credits: Atiele Azevedo de Lima Lopes (research and text) 


\section{IMPERIAL TIMES}

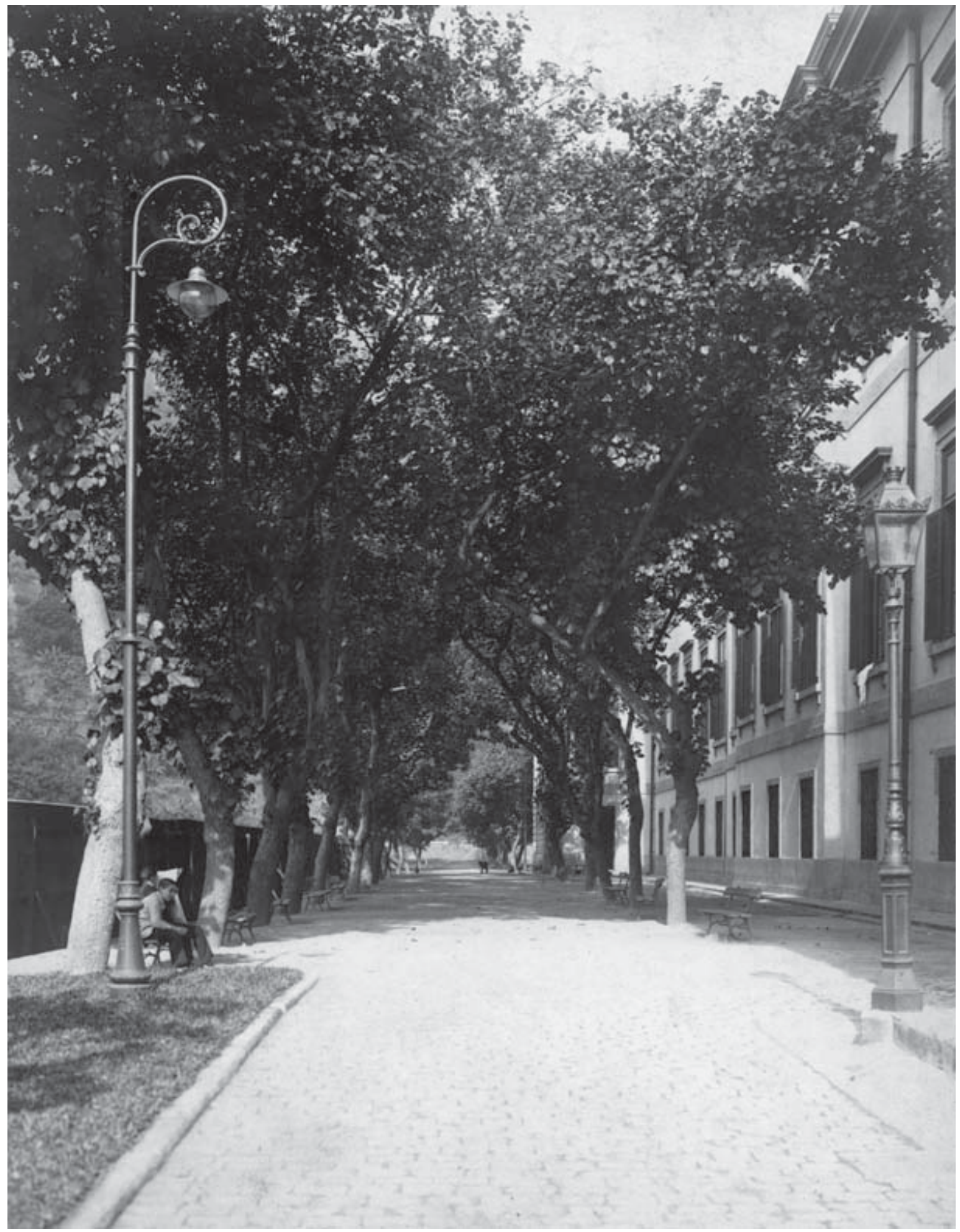

Lateral view of Benjamin Constant Institute, [s.d.]. Museu da Imagem e do Som - RJ Archives 

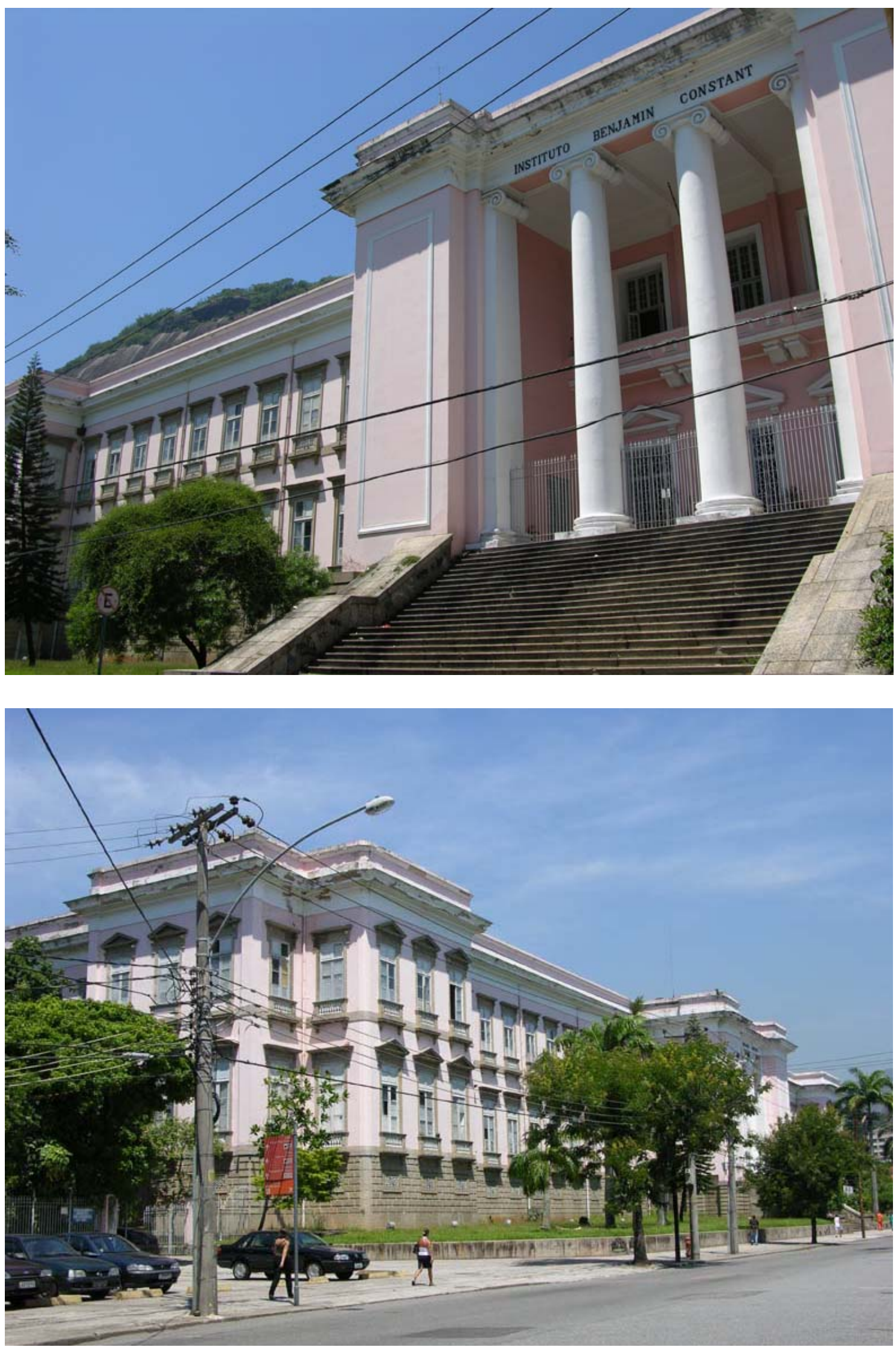

Benjamin Constant Institute - façade. Photo Roberto Jesus Oscar \& Vinícius Pequeno de Souza, 2008. Casa de Oswaldo Cruz Archives
Benjamin Constant Institute. Photo Roberto Jesus Oscar \& Vinícius Pequeno de Souza, 2008. Casa de Oswaldo Cruz Archives 


\title{
Casa de Banhos de D.João VI. (Bath House of D.João VI)
}

\author{
Other denominations: Solar da Família Tavares Guerra (Manor house of the Tavares Guerra Family)
}

Location: Caju

Address: Praia do Caju, 385 (old 115).

Category: Museum of Urban Cleaning.

Period of Construction: 1817.

Proprietor: City Hall of the City of Rio de Janeiro / Comlurb.

Author / Constructor: unknown

History:

Praia do Caju was located in the Royal Estate of Caju, which had been acquired by the Imperial Family in 1817 . With the arrival of the Royal Family in 1808, the city of Rio de Janeiro was transformed into the headquarters of the Portuguese government, which brought about profound changes of a political nature, an expansion of the trade and port functions of the city, and a re-organization of the urban space. In this context, the region of Praia do Caju became a bathing resort, with various farmsteads and residences. On lands near to the beach there was the manor house of the family of Antonio Tavares Guerra, an important coffee trader, who later, in 1859, would found the company, "Empresa Imperial Companhia de Navegação a Vapor São Cristóvão e Caju" (São Cristóvão and Caju Imperial Steam Navigation Company).

It is believed that this house was offered to the then Prince-Regent D. João (proclaimed as D. João VI only in 1818) as a place of support, a dressing room, for bathing in the sea as recommended by his doctors. It is reported that, in 1811, the Prince-Regent, when he was resting at the Royal Farm of Santa Cruz had been bitten by lice on his left leg, and that the wound had become infected, it having been recommended to him to thoroughly wash the said wound. There was a certain reduction in the pain and the wound, but some years later, the pain returned and the condition developed into erysipelas, and, after another consultation, it was recommended to him, by the Palace doctor, to take complete baths, by immersion. At the time, the idea of the capacity of sea-water to cure and act as a tonic was back in vogue, especially for certain infirmities. According to Rose de Saulces de Freycinet (1794-1832), author of Journal du Voyage autour du Monde à borde de l'Uranie (1817-182), a traveller who was in Rio de Janeiro in 1817, D. João started, then, to bathe in the sea at Praia do Caju, and to use the house of the Tavares Guerra family to change his clothing. Also according to the reports, D. João took his bath inside a tub with holes in it, because he was afraid of the crabs. The sea-water baths, according to reports, made his infection recede, curing his leg, and thus D. João journeyed to the Chapel of São Roque, on the Ilha de Paquetá (Paquetá Island), to give thanks for the cure.

This taking of baths in the sea was considered, by Victor Andrade de Melo, as marking the change of the relationship of the city of Rio de Janeiro with the sea. The house, as a result of the tradition of this usage by D.João, came to be known as "Casa de Banhos de D. João VI".

At present there are no longer any traces of the beach at Caju, for a large part of the area was buried for the construction of the port and later the Rio-Niterói Bridge. The borough of Caju covered the area from Mangue de São Diogo (now the region of the Gasometer, headquarters of CEG (gas company)), passing along the Praia de São Cristóvão (at present Rua São Cristóvão, Praça Padre Seve, Rua da Igrejinha, Rua Monsenhor Manuel Gomes), going on to Praia do Caju (the whole length of Rua Monsenhor Gomes, now known as the street of the cemeteries).

In 1937, the manor house was inspected by the architect Carlos Leão, who indicated its preservation, and, in 1938 it was preserved by SPHAN. During the government of Carlos Lacerda the manor was expropriated, and with this it began to function as a deposit of the Department of Urban Cleaning. The Bath House of D. João VI was restored, in 1996, by the Municipal Company of Urban Cleaning - COMLURB, and at present houses the Museum of Urban Cleaning. 


\section{IMPERIAL TIMES}

\section{Architectonic description:}

The manor house of the Tavares Guerra family, known later as the Bath House of D. João VI, has 210m², and presents a square ground plan, typical of rural dwellings at the end of XVIII ${ }^{\text {th }}$ century in Brazil. Evelyn Furquim Werneck Lima (2000) highlights the simplicity of its construction, made of brick and stone with cornices and wooden window frames, with a roof at four levels, and pillars with corners and lintels in a lowered arch over the windows. The manor house, also according to Werneck Lima, can be considered as a construction characteristic of the transition between the urban and the rural.

\section{Register of Preservation:}

Preserved by IPHAN. Book of Fine Arts (Register 038 - 04/20/1938); Record Book (register 017 - 04/20/1938). No. of the process: 0026-T-38.

\section{Sources:}

Assessoria de Comunicação Social da Comlurb. Casa de Banho D.João VI. Museu da Limpeza Urbana. Capturado em 11 nov. 2007. Online. Disponível na Internet: http://www.rio.rj.gov.br/pcrj/destaques/museu_limpeza_urbana.htm

Caju (Cidade do Rio de Janeiro). In: Wikipédia. A Enciclopédia Livre. Capturado em 15 nov. 2007. Online. Disponível na Internet: http://pt.wikipedia.org/wiki/Caju_(Rio_de_Janeiro)

Casa de banhos de D. João VI - Rua Praia do Caju, 385. Capturado em 12 nov. 2007. Online. Disponível na Internet: http:// www.sindegtur.org.br/2006/arquivos/arqcolrio.pdf.

Casa de Banhos de D. João VI (Rio e Janeiro, RJ). Capturado em 10 nov. 2007. Online. Disponível na Internet: http:// www.iphan.gov.br/ans.net/tema_consulta.asp?Linha=tc_hist.gif\&Cod=1698

COMLURB. Museu. Capturado em 12 nov. 2007. Online. Disponível na Internet: http://comlurb.rio.rj.gov.br/emp_ museu.htm

LIMA, E. Uma Herança Cultural no Cenário carioca: arquitetura de D. João VI). In: TOSTES, V. (ed.). Anais do Seminário Internacional. D. João VI: um Rei Aclamado na América. Rio de Janeiro: Museu Histórico Nacional; 2000, p. 302-314.

MELO, V. Mar e o Remo no Rio de Janeiro do século XIX. Capturado em 16 nov. 2007. Online. Disponível na Internet: http:/ /www.cpdoc.fgv.br/revista/arq/258.pdf

TEIXEIRA, M. Botafogo Histórico. O Rei não está nu. O Manequinho. Jornal da Associação de Moradores e Amigos de Botafogo - $A M A B$, Rio de Janeiro, ano V, n.24, p.10, abr./mai. 2006.

VELTMAN, H. O Caju. Boletim ASA, n.108, set-out/2007. Capturado em 12 nov. 2007. Online. Disponível na Internet: http://www.asa.org.br/boletim/108/108_h7.htm

Credits: Maria Rachel Fróes da Fonseca (research, text and architectural description). 
IMPERIAL TIMES 


\section{Hospital Central do Exército (Central Army Hospital)}

Other denominations: Hospital Real Militar e Ultramar - 1768-1831 (Royal Military and Overseas Hospital); Hospital Regimental do Campo - 1832-1844 (Regimental Field Hospital); Hospital Militar de Guarnição da Corte - 1844-1890 (Court Garrison Military Hospital); Hospital Central do Exército - 1890-present day (Central Army Hospital ).

Location: Benfica

Address: Rua Francisco Manuel, 126.

Period of Construction: 1892-1902

Proprietor: Brazilian Army.

Author / Constructor: Francisco Marcelino de Souza Aguiar (military engineer).

\section{History:}

In 1702, the King of Portugal, Pedro II, because of the precariousness of the medical services given to military personnel in Brazil, issued a Royal Letter ordering the construction of a military hospital in Rio de Janeiro. Between 1766 and 1767, under the command of the viceroy D. Antônio Alvares da Cunha (Count da Cunha), the old Jesuits College, situated on the Castelo hill, was reformed, in order to serve as an official residence for him, because the building had been unoccupied since the expulsion of the Jesuits from Brazil (1759). The building was large, being more than two hundred meters in length, and having four floors. Before his move to the new residence, he was substituted in the office by D. Antônio Rolim de Moura Tavares, Count of Azambuja (1767-1769), who preferred to live in the old official residence, Paço dos Governadores (Governor's Palace), in the present day November XV square, the referred to building of the Jesuit College continuing unoccupied. At the decision of the new viceroy, this was renovated and to it were transferred some of the infirmaries, in an attempt to bring all the sick together into a single facility, since they were attended to in a small infirmary belonging to the Barracks of the Garrisons of the Fleet (Quartel das Guarnições das Naus), and at the Santa Casa da Misericórdia Hospital of Rio de Janeiro. Thus, the infirmary was transferred from the Fleet Barracks (Quartel das Naus) to the building of the old Jesuit College, marking the origin of the Royal Military and Overseas Hospital (Hospital Real Militar e Ultramar) the first military hospital founded in Rio de Janeiro. Its administration was handed over to the head surgeon Teotonio dos Santos de Almeida. The exact date of its foundation is unknown, but there is a reference in an official letter written by the viceroy to the Portuguese metropolis, dated January $22^{\text {nd }}, 1769$.

The School of Anatomy, Surgery and Medicine of Rio de Janeiro was created in 1808, in the buildings of the Royal Military and Overseas Hospital. On April 02 ${ }^{\text {nd }}$, of that year, the Prince Regent, D. João VI nominated the surgeon Joaquim da Rocha Mazarém not only as master of the anatomy chair but also designated him to offer a course on ligatures, childbirth and surgical operations in it. Up to the year 1856, the referred to School, transformed in 1832 into the Faculty of Medicine of Rio de Janeiro, was based, in part, in the building of the Royal Military and Overseas Hospital.

The decree of Regency, of February $17^{\text {th }}, 1832$, extinguished the Military Hospitals and created the Regimental Hospitals. In Rio de Janeiro one was set up at Campo da Aclamação - the present Praça da República - and another at the Deposit of Praia Vermelha, besides a small military infirmary at Fortaleza de São João. The hospital only changed its name and address - from on top of the Morro do Castelo to Praça da Aclamação - because the administrators, professionals and problems continued just the same. Denominated the Regimental Field Hospital, it also did not serve the growing clientele of the Court, and could not be compared to the Regimental Hospitals of the Provinces, where the military staff was much smaller. It was in fact an authentic general hospital.

Facing various difficulties, the Regimental Hospitals, which lasted for a further twelve years, were closed by decree no. 397, of November $25^{\text {th }}, 1844$. A Comission, formed by doctors Fidelis Martins Bastos, Cristóvão José dos Santos and Honório José da Cunha Gurgel, was created to organize a regulation project that would come to establish the uniting of 
all the Regimental Hospitals into one, under the denomination of the Court Garrison Military Hospital (Hospital Militar da Guarnição da Corte), to serve land-based forces. The Hospital returned to the Morro do Castelo, with the denomination of Court Garrison Military Hospital. The date of September $5^{\text {th }}, 1867$ marks the signing of a contract between the Ministry of War and the Congregação das Filhas de São Vicente de Paula for the employment of the nuns, who entered into service the following year.

The hospital was the stage for important facts for the history of medicine in the country. The first narcosis in Brazil using ether was performed there, by doctors Roberto Jorge Haddock Lobo and Domingos Marinho de Azevedo Americano, in 1847; and also the first use of chloroform, by Manoel Feliciano Pereira de Carvalho, in 1848. In the field of vascular surgery, the first extraperitoneal ligature of the abdominal aorta was performed by Cândido Borges Monteiro (Viscount of Itaúna) in 1842, and, in 1868, Augusto Cândido Fortes de Bustamante e Sá performed the first ligature of the primitive iliac artery in the country, on the patient Francisco Gomes de Mendonça.

With the Proclamation of the Republic, the Head of the Provisional Government, Marshal Manoel Deodoro da Fonseca, on regulating the Sanitary Service of the Army, created the Central Army Hospital (decrees no. 277, of 03/22/1890, and no. 307, of 04/07/1890), that remained at the Morro do Castelo until 1902. In view of the very poor conditions of the facilities, it was decided that the hospital would be transferred to another location. On March $20^{\text {th }}, 1892$, the foundation stone was laid in a large area of 78,960 square meters in the district of Benfica, acquired from the Jóquei Clube. The project presented by the military engineer Francisco Marcellino de Souza Aguiar, designated by Marshal Floriano Peixoto, the then President of the Republic, was soon put into operation. The project included eight isolated pavilions, of the Tollet type for infirmaries, and a large building for administration of general services, besides other buildings for isolation infirmaries and other services, with a capacity for 500 beds. Ten years later, on June $21^{\text {st }}, 1902$, the Central Army Hospital was inaugurated at its present address, in Benfica, with only three pavilions finished, of the eight initially planned, with three infirmaries each, and which were denominated as follows:

$1^{\text {st }}$ Pavilion: "Duque de Caxias" - $1^{\text {st }}$ infirmary: "Varques", $2^{\text {nd }}$ infirmary: "Moura", $3^{\text {rd }}$ infirmary: "João Severiano";

$2^{\text {nd }}$ Pavilion: "Osório" $-4^{\text {th }}$ infirmary: "Bayma", $5^{\text {th }}$ infirmary: "Mallet", $6^{\text {th }}$ infirmary: "Argollo";

$3^{\text {rd }}$ Pavilion: "Deodoro" $-7^{\text {th }}$ infirmary: "Enéas Galvão", $8^{\text {th }}$ infirmary: "Cantuária", $9^{\text {th }}$ infirmary: "Carlos Machado".

On August 11 ${ }^{\text {th }}, 1905$, Ismael da Rocha, then director of the Central Army Hospital, inaugurated three new pavilions: "Rodrigues Alves", destined to the electrotherapy department, physiotherapy, microscopy analysis laboratory and to bacteriology; "Marcellino Aguiar", with two infirmaries for prisoners; and "Benjamin Aguiar", for the nuns. He also inaugurated the buildings destined to the medical staff, the clothing store and to the transport animals, and re-inaugurated the "Cantuária" infirmary that had been destroyed by a fire. In the administration of Ismael da Rocha, surgical instrumentation was acquired, modern metallic beds and standard uniforms for nurses and domestic staff, a course for the instruction of nurses and stretcher bearers was started, and a homeopathic clinic was installed which occupied a special infirmary. The "Floriano Peixoto" Pavilion, concluded in 1912 in the center of the area occupied by the hospital, was destined to administrative services, a secretary's office, first-aid room, medical consultation room, pharmacy, store, library and archive. This central area also contained a dispensary, a kitchen, the sleeping quarters of the nuns and a chapel. In these new buildings of the Central Army Hospital the Medical-Military Application School began to function, created by decree no. 2.232, of January $6^{\text {th }}, 1910$, as one of the agencies of the Army Health Service. However, this course, as that of the nurses and stretcher bearers, was only regulated by decree no. 10.402, of August $20^{\text {th }}, 1913$, signed by the Minister of War, General Vespasiano Gonçalves de Albuquerque e Silva, and by the President of the Republic, Hermes Rodrigues da Fonseca. This decree stated that the application course had as its objectives, the perfecting of the medical and surgical knowledge of the doctors applying for inclusion in the Army Health Corps, and the teaching of administration and of tactics related to the health service in times of peace and war.

The architectural group designed by Souza Aguiar was completed around 1922. However, about 60 years after its conclusion, the pavilions built according to the Tollet system were considered outdated for the new requirements of the modern hospital. The option was the demolition of the old pavilions and the construction of new blocks, the first having been - Brigadier General Antônio Carlos Pires de Carvalho e Albuquerque - destined to a clinic, odontological service and emergency treatment. 
After that, the Industrial blocks were inaugurated - composed of the kitchen, mess halls, boiler room, laundry and sterilization unit - and Internment - with a capacity of 360 beds, a surgical center, an area of support for diagnosis, an intensive care unit, an auditorium, classrooms, a library and information center.

The new hospital unit is also composed of another four wards set aside for geriatric medicine, infectious/contagious diseases, oncology, pediatrics and obstetrics.

At present it offers 630 beds, besides developing research and offering courses related to the medical area.

\section{Architectural Description:}

The project of Francisco Marcellino de Souza Aguiar for the Central Army Hospital was based on the Model developed by the French military engineer Casimir Tollet, author of "Les hôpitaux modernes au XIXe siècle. Description des principaux hôpitaux français et étrangers les plus récemment édifiés" (1892) - (Modern hospitals of the 19th century. Description of the principal most recently built French and foreign hospitals), which was widely circulated throughout the whole of Europe at the turn of the $19^{\text {th }}$ century to the $20^{\text {th }}$ century. Tollet proposed new sanitary bases for the construction of hospitals, according to which the hospital should be placed at a distance from urban agglomerations, in areas bathed by the sun. The land area would increase in relation to the number of collective accommodations (ex.: $100 \mathrm{~m}$ for every 100 beds; $150 \mathrm{~m}$ for every 600 beds), the buildings should be spread out over the whole surface of the land and the various buildings should be in parallel with each other. He also proposed that the infirmaries should have arched walls to promote the circulation of the air.

This system became known as the pavilion style, which, in harmony with the hygienic precepts of the period gave priority to the isolation of the sick, according to their diseases, in the hospital space. It is characterized by buildings with at the maximum two floors, which occupied a large area and in it ruled the principal of isolation where each disease and each patient was isolated in the interior of the Pavilion. One of the few examples in Brazil, of a project based on the Tollet system, the Central Army Hospital represented an important role in the history of hospital architecture in Brazil.

\section{Register of Preservation:}

It is not listed.

\section{Sources:}

ARAÚJO, A. A Assistência Médica Hospitalar no Rio de Janeiro no século XIX. Rio de Janeiro: Ministério da Educação e Cultura/ Conselho Federal de Cultura; 1982.

CARVALHO, P. Histórico da Hospitalização Militar no Brasil. Revista do Instituto Histórico e Geográfico Brasileiro, tomo especial consagrado ao Primeiro Congresso de História Nacional (7 - 16 de setembro de 1914), parte V. Rio de Janeiro: Imprensa Nacional; 1917.

CORRESPONDÊNCIA, Conde de Azambuja. Revista do Instituto Histórico e Geográfico Brasileiro, Rio de Janeiro, v. $255,1962$.

MITCHELL, G. História do Serviço de Saúde do Exército Brasileiro. Rio de Janeiro: Escola de Saúde do Exército, 1963.

PONDÉ, F. História Administrativa do Brasil. Organização e Administração do Ministério da Guerra no Império. Rio de Janeiro: Biblioteca de Exército Editora; Funcep; 1986.

SOUZA, L. A hospitalização militar no Rio de Janeiro e o Patrono do Serviço de Saúde do Exército. Separata da Revista Brasileira de Medicina, Rio de Janeiro, volume 29, número 5, maio 1972.

. O Hospital Central do Exército: Berço do Ensino Médico. Revista do Instituto Histórico e Geográfico Brasileiro, Rio de Janeiro, v. 354.357, jan./dez. 1987.

Credits: Maria Elizabeth Bueno de Godoy (research); Maria Rachel Fróes da Fonseca (research and text) and Gisele Sanglard (architectural description). 


\section{IMPERIAL TIMES}

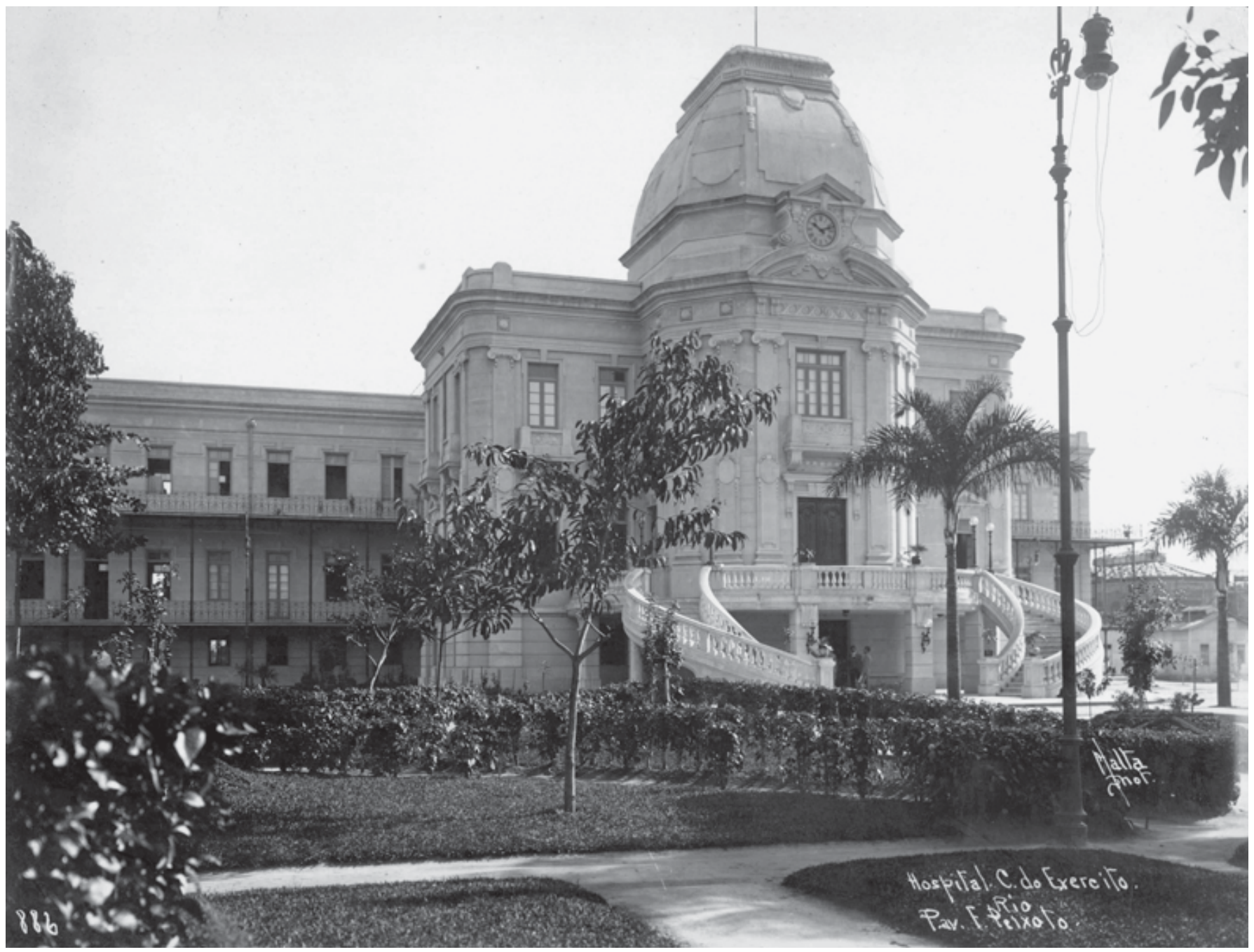

Central Army Hospital - façade, [s.d.]. Photo Augusto Malta. Museu da Imagem e do Som - RJ Archives 


\section{Central Hospital of the Military Police}

Other denominations: Police Brigade Hospital (1848- ); Military Police Hospital (1942).

Location: Estácio.

Address: Rua Estácio de Sá, 20.

Category: General Hospital.

Period of Construction: 1848.

Proprietor: Military Police of the State of Rio de Janeiro.

Author/Constructor: Paulo Neves de Moraes Gomide (military engineer, re-modeling, 1912); José Ribeiro de Almeida (constructor of the medical infirmary, 1912); Ladislau Cunha \& Co. (construction of the three pavilions, 1913); Firmino Pinto (entrepreneur, construction of the wall, 1913); José Teixeira de Motta (wrought iron fencing, 1913); Dossani \& Co. (constructor, surgery ward, operating theater, special ward for prisoners, and kitchen, 1914); Miguel Calmon du Pin e Almeida (reform, 1942).

\section{History:}

The old Police Brigade Hospital, today known as the Central Hospital of the Military Police (HCPM), came into existence during the administration (1844-1846) of Commander Manoel Muniz Tavares. The idea of constructing a hospital for the soldiers of the Military Police corps, started with José Joaquim Fernandes Torres, Minister and Secretary of State for Justice. The cost of the work was budgeted at three thousand, three hundred Réis (currency of the period), and the construction of the Hospital, on Morro de Santo Antonio (Santo Antonio hill), was only begun in 1848, under the command of Lieutenant-Colonel Polydoro da Fonseca Quintanilha Jordão.

The works on one of the wards were interdicted, in 1890, by the Company of Improvements of Brazil, and were only re-started in 1894, when Commander, Colonel Francisco Agostinho de Souza Menezes obtained authorization from the Company to conclude the works and to construct one more pavilion style ward.

During the period of command of Sylvestre Rodrigues da Silva Travassos, between 1894 and 1898, new annexes were built and improvements were made to the Hospital, that had medical and surgical wards, special compartments for officers and lower ranks, two isolation annexes for the treatment of tuberculosis and patients with other infecto-contagious diseases. Under the administration (1906-1909) of the Commander of the Military Brigade, General Antônio Geraldo de Souza Aguiar, a reform was undertaken of the Police Brigade Hospital, based on a plan of reform of the institution approved by the Government to be carried out when the financial conditions of the country permitted it. While such an opportunity was awaited, works of conservation and improvement were performed, and also some works of a preparatory nature in expectation of the re-modeling work, such as the construction an electric inclined elevator that would lead from Rua Evaristo da Veiga up to the Hospital, on Morro de the Santo Antonio.

The Report of Commander General José da Silva Pessoa, presented in 1910, stated that the facilities of the Hospital were poor, the number of beds insufficient, the conditions inadequate and favorable to promiscuity, the inexistence of an operating theater equipped according to surgical advances - in short, an inadequate scenario to care for the number of police officers who sought care there. Because of this, José da Silva Pessoa repeated the claim for the need to construct two more wards, an operating theater and other annexes for administration and health care. Together with this Report, a remodeling plan was prepared by the military engineer, Paulo Neves de Moraes Gomide. On December 23 ${ }^{\text {rd }}, 1911$, decree no. 2.159 approved the contract with the constructor José Ribeiro de Almeida for the construction of a medical ward. The work on this ward was only completed in 1912 , and inaugurated on May $12^{\text {th }}$, of that year.

In 1912, still under the administration of General José da Silva Pessoa, it was decided to make a survey of a three pavilion project, on the slope of Morro de Santo Antonio, one being a tuberculosis ward, another for isolation of police officers affected by skin diseases, and the third ward for the observation of suspicious illnesses. The project was approved, 
and the work put out for bid, and the proposal of the company, Ladislau Cunha \& Co., was accepted and the contract approved by the Government. These new pavilions were inaugurated on May $12^{\text {th }}, 1913$. In that same year, the entrepreneur Firmino Pinto was also hired for the construction of a sustaining wall with stone steps, making it possible to access the homes of the officers located on Morro de Santo Antonio. On the wall facing the medical ward, a wrought iron fence was installed, for which José Teixeira de Motta was hired. A reinforced concrete wall was also constructed to separate the lands of the Hospital from the neighbors. Still other annexes were added, with the construction of a surgical ward, an operating theater, a special ward for the treatment of prisoners, and a kitchen. These works were executed by the company, Dossani \& Co., and inaugurated on March 30 1914.

In the 1940`s, during the government of Getúlio Vargas, as a result of the need for expansion of the Frei Caneca Penitentiary Complex, the hospital facilities were transferred to the old Estácio de Sá Hospital, connected, at the time to the City Hall of the Federal District. Due to the influence of the Military Brigade General, Odylio Denys, the transfer was carried out in 1942, and the reform on the old hospital was directed by Lieutenant-Colonel, doctor, Miguel Calmon Du Pin e Almeida. With this change, the hospital came to be denominated the Military Police Hospital.

On January $17^{\text {th }}, 1992$, it came to be called the Central Hospital of the Military Police, a name which it has maintained up to the present day. The hospital, that is still located at Rua Estácio de Sá, no. 20, operates in two buildings: the old one, which was the Estácio de Sá Hospital itself - whose structure, despite being precariously conserved, is in a better state than the other and newer facilities; and the new one.

\section{Architectonic description:}

The facilities that the Military Police Hospital have occupied since 1942 present the characteristics of hospitals built in the 1930s, still inspired by a newly established modernism and, therefore, a period of transition. Its general lines show influence of a more traditional architecture in the use of edges, ceramic tile roofing protected by external horizontal lines, windows with leaves as Persian blinds and plant in cross. The walls that mark the entrance of the hospital resemble a fortress, as if affirming the location of a military institution.

The construction of the annex brought the architecture of a more contemporary hospital, with cloths of glass and brushed steel, whose wear due to time is more pronounce than the older hospital, which received ceramic tile in the façade, hiding the original revetment in mica powder, typical of the proto-modern constructions.

\section{Register of Preservation:}

It is not listed.

\section{Observations:}

The documentation referring to the history of the Central Hospital of the Military Police, which is preserved, is made up of only a few documents, of various administrative rulings referring to the changes in administration and the transfer of the headquarters.

\section{Sources:}

ASSISTÊNCIA Pública e Privada no Rio de Janeiro (Brasil) - História e Estatística. Comemoração do Centenário da Independência Nacional. Rio de Janeiro: Typographia do Annuario do Brasil; 1922.

Credits: Maria Elizabeth Bueno de Godoy and Maria Rachel Fróes da Fonseca (research and text). 

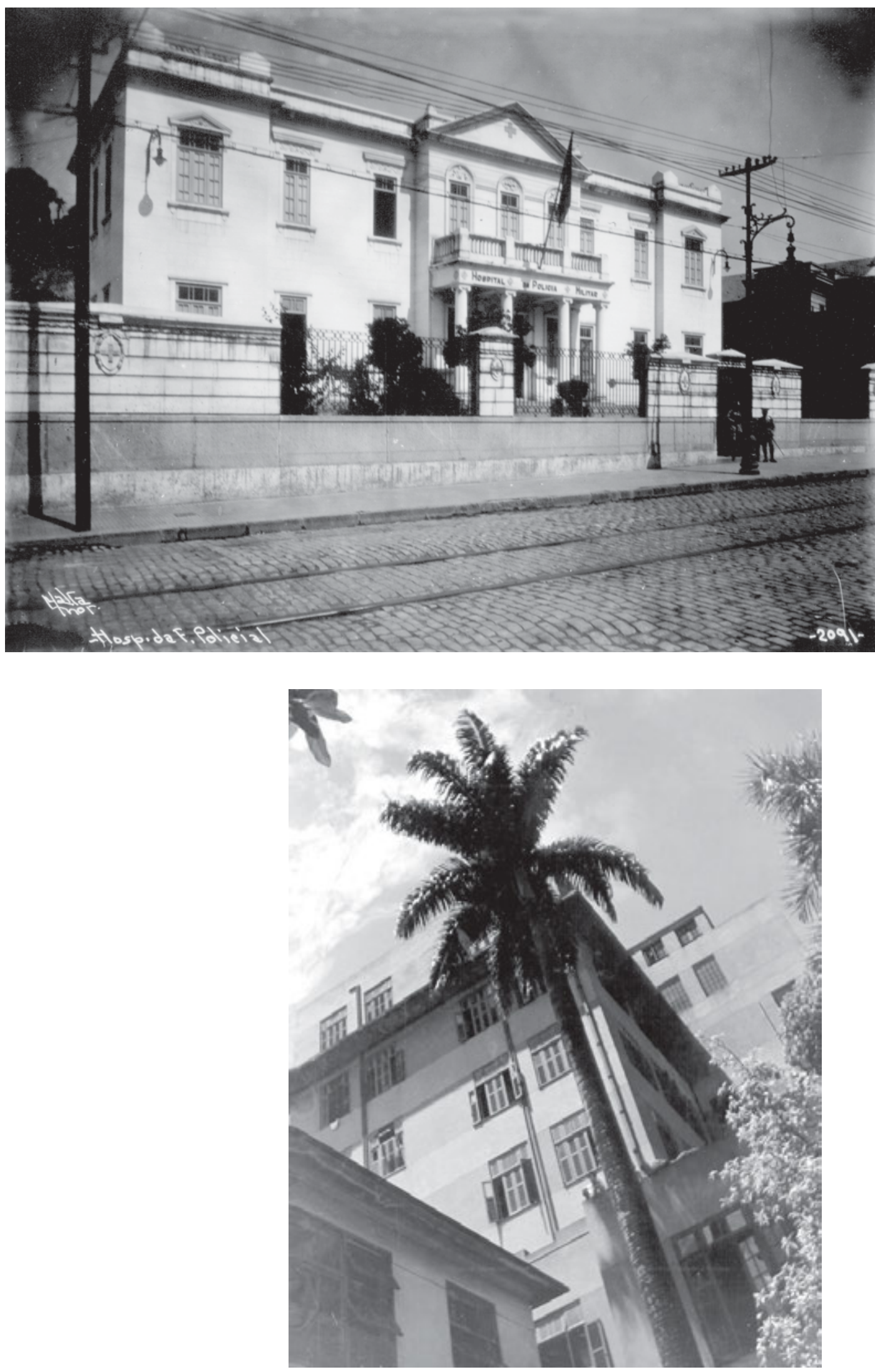

Estácio de Sá Hospital, [1930-1945]. CPDOC/FGV Archives
Força Policial Hospital, [s.d.]. Photo Augusto Malta. City of Rio de Janeiro General Archives 


\section{Central Navy Hospital}

Other denominations: Rua dos Quartéis das Naus Hospital (1727-1768); Royal Military and Overseas Hospital (17681834); Fleet Hospital (1834-1853); Court Navy Hospital (1853-1890); Navy Hospital of the Federal Capital (1890-1908); Central Navy Hospital (1908-present day).

Location: Downtown.

Address: Ilha das Cobras, w/n.

Category: General Hospital.

Period of construction: 1809.

Proprietor: Brazilian Navy

Author / Constructor: unknown

\section{History:}

The history of the Central Navy Hospital has its origins in the XVI century, a period in which the Portuguese America - above the coastal strip denominated "seascape" - was the center of disputes with France and Holland. And it was for this reason that Portugal decided to send military forces and war ships for the defense and policing of this 'seascape'. At that time, as no hospital establishment existed, the soldiers and sailors that arrived sick were placed in private residences. With the Royal Letter of March $21^{\text {st }}, 1702$, a specific establishment for the treatment of the garrison troops was created in Rua dos Quartéis da Armada (later called Rua de Bragança, and afterwards Rua Conselheiro Saraiva). In 1727 the soldiers of the City Garrison, those of the Warship Garrisons and sick prisoners were cared for at this location, then known as Rua dos Quartéis das Naus Hospital. But in view of the fact that it was located at the side of Morro de São Bento (São Bento Hill), an area that was very hot and inappropriate for a hospital, D. Antonio Rolim de Moura Tavares, the Count of Azambuja, decided, in 1768, to transfer it to the old mansion of Morro do Castelo (Castelo Hill), which was once again vacant. The building, previously occupied by the College of Jesuits, would afterwards be totally occupied by the hospital, then denominated the Royal Military and Overseas Hospital. In August of 1797, in Portugal, a rule was established for military hospitals in which the attributions of the surgeons and head-physicians were specified. On February $17^{\text {th }}, 1831$, the Military Hospitals were decreed extinct and Regimental Hospitals were created. Between the years 1809 and 1810, for economic reasons and for the better working of the Anatomic, Surgical and Medical School of Rio de Janeiro, then installed in the Military Hospital, the order was given to install a number of infirmaries on Ilha das Cobras (Snakes Island). Up to this time, the history of this Hospital was intertwined with that of the Central Hospital of the Army, whose origin had been the same.

Decree no. 122, of December $9^{\text {th }}, 1833$, established a specific regulation for the Fleet Hospital, and on March $03^{\text {rd }}, 1834$ the Hospital was definitively installed in front of the Artillery Barracks of the Fort of São José of Ilha das Cobras. In 1834, under the direction of the head-surgeon, Francisco Julio Xavier, chief of the Fleet Health Corps, the Fleet Hospital, on Ilha das Cobras, was, then inaugurated, directed toward caring for the soldiers of the Fleet and of the Artillery Corps of the Navy. The Hospital had 60 beds, two infirmaries, a room for officers, a house for a pharmacy, operations, dressings, surgical material and autopsies, a bedroom for the surgeon of the day, and clothes store, kitchen and dispensary.

Between the years of 1836 and 1851 the infirmaries were enlarged, and a building was constructed for the Corporation of the Disabled, due to the epidemics, such as yellow fever and morbid cholera, which demonstrated the need for a special infirmary for the treatment of the sick with contagious diseases.

On January $03^{\text {rd }}, 1853$, through decree no. 1.104, the institution came to be denominated the Court Navy Hospital, and maintained its objective of treating the sick, both from the ships of the Fleet, as well as the attached corps, and of the Arsenal. This same decree also established that the Hospital should have two infirmaries for the treatment of contagious 
diseases, three rooms (an office and for the conferences of the physicians; for major surgery and autopsies; and as a mortuary), six houses (office and file store; deposit for the instruments, surgical equipment, and objects for daily dressing; collection of the clothing and utensils necessary for the treatment of the sick; storage of the clothing of the sick; for baths, stone tubs being preferred; for a pharmacy). In 1866 there were already new buildings prepared to receive the injured arriving from the Paraguay War, and at the end of this conflict, in 1870 the Hospital had 12 wards with 250 beds.

In 1890, decree no. 429 re-organized the activities of the Hospital, which then came to be called Navy Hospital of the Federal Capital, and it defined that this would continue to render treatment to the officers of Fleet Corps and related classes, sailors of the navy corps and other employees of the naval establishments.

Due to being located at a strategic site, that is to say, the São José Fort, at Ilha das Cobras, the Navy Hospital of the Federal Capital suffered serious damage at the time of the Revolt of the Fleet (September $06^{\text {th }}, 1893$ to March 13 ${ }^{\text {th }}, 1894$ ). It was exactly in this hospital that Admiral Saldanha da Gama wrote his manifesto of December $7^{\text {th }}$, 1893, with which he joined the said revolt, and which led the government to include him in the list of deserters by decree no. 1.560 of 1893 , which also established the destitution of institutions that supported the revolt.

Decree no. 1697-A, of April 25 ${ }^{\text {th }}, 1894$, transferred the Forts of Ilha das Cobras and of Villegaignon from the port of Janeiro to the jurisdiction of the Ministry of War, thus facilitating their occupation by the forces of the Army. In 1895 it returned to the jurisdiction of the Navy, but in January of 1897 the activities of the Navy Hospital of the Federal Capital were suspended. Later, its mission and organization were altered by successive decrees that would confer a new organization to the hospital service of the navy.

From 1906 to 1910 various improvements were made to the Hospital, including the operating room, physiotherapy rooms, a homeopathic ward, electric lighting, a new mortuary, a library, a 200,000 liter water reservoir, an oven for incinerating garbage and a steam kitchen. Decree no. 7203, of December 03 ${ }^{\text {rd }}, 1908$, approved a regulation for the hospital service of the Navy, and established that the hospital would become known as the Central Navy Hospital, and that in this would be created a homeopathic ward.

On November $22^{\text {nd }}, 1910$, with the revolt of the sailors, known as the "Chibata Revolt", Ilha das Cobras once again came under fire. And in view of the threat of bombing of the Naval Battalion, which was located in the fort of Ilha das Cobras, the Government decided that the patients of the Hospital should be transferred to the Central Hospital of the Army. And these remained there and only returned to the hospital of Ilha das Cobras on November $28^{\text {th }}, 1910$. On December $9^{\text {th }}$, the Naval Battalion itself rebelled, causing everyone, patients and employees, to abandon the Hospital, which had already been hit. Some of the patients and employees were transferred to the Navy's beri-beri Infirmary, in Copacabana, and others to the Central Hospital of the Army and to Santa Casa da Misericórdia Hospital. The Central Navy Hospital then began to operate precariously in the Navy Infirmary, in Copacabana.

The reconstruction work of the Hospital, on Ilha das Cobras, began in 1912, and was concluded on June $30^{\text {th }}, 1913$. On July 03 ${ }^{\text {rd }}, 1913$ the Central Navy Hospital, already re-constructed, was re-inaugurated, under the administration of Rear-Admiral Joaquim de Siqueira Balcão. On October $24^{\text {th }}, 1917$, ten nuns from the Order of São Vicente de Paulo were contracted, to help out in the services of the infirmaries of the Hospital.

In 1933, work on the construction of the tuberculosis hospital in Nova Friburgo was started, the first that the Navy would come to have specially set aside for the treatment of tuberculosis, and to where the patients who were in the Auxiliary Infirmary in Copacabana would be transferred, which was de-activated at that time, for its patients had been transferred to the Sanatorium of Nova Friburgo. Also at that time it was established that in Casa de Marcílio Dias (House of Marcílio Dias), a philanthropic institution founded in 1926 for Navy officer's wives, situated in Méier, would function the installations of a future hospital for contagious diseases. Thus the embryo of the future Marcílio Dias Naval Hospital came into being, that would be inaugurated in 1939.

Other decrees in 1946, 1947 and 1948, re-organized the activities of the Central Navy Hospital. In 1972, with decree no. 71.511, the Central Navy Hospital began to be administered under the rules established for the Navy Hospitals.

The mission of the Central Navy Hospital today, due to administrative ruling no. 0064, of May 04 ${ }^{\text {th }}, 1995$, is defined as Medical-Outpatient and Odontological Assistance rendered to the military personnel of the Brazilian Navy, for those 


\section{IMPERIAL TIMES}

serving and in the reserves, being part of, in this manner the Navy Health System. The Hospital began to function, from January $01^{\text {st }}, 1998$, as a Military Organization Rendering Hospital Services, in fulfillment of Ministerial Instruction.

From March $12^{\text {th }}, 2004$, the Central Navy Hospital was included in the Navy's itinerary of cultural interest, and is also part of the tourist program "Get to know Rio on Foot" of Riotur.

\section{Architectural description:}

Since the beginning of the XVI century fortified buildings were constructed on Ilha das Cobras, previously denominated Ilha de Paranapecu or das Madeiras (Wood or Paranapecu Island), due to it being a strategic point for the defense of the city. As from 1735 the permanent forts were built, which received the general name of São José Fort, after the chapel that was constructed at the same location, at present annexed to the Central Hospital da Armada. For this chapel there was sent from Portugal the frontispiece of lioz stone, a work of the master-worker Manoel Vicente, following the design of the chief engineer of the Kingdom, Manoel de Azevedo Fortes (1660-1749). This frontispiece and also the old gate of the fort, worked in granite, are the only elements that remain of the old fortifications.

\section{Register of Preservation:}

Fort of São José - gate and frontispiece of São José Chapel : the chapel was annexed to the Central Navy Hospital. IPHAN - Inscription: 297; Date: 11/7/1952; No. of the process: 0466-T.

\section{Sources:}

Arquivo Noronha Santos/IPHAN. Capturado em 20 nov. 2007. Online. Disponível na Internet: http://www2.iphan.gov.br/ ans/inicial.htm

ASSISTÊNCIA Pública e Privada no Rio de Janeiro (Brasil) - História e Estatística. Comemoração do Centenário da Independência Nacional. Rio de Janeiro: Typographia do Annuario do Brasil; 1922.

HOSPITAL CENTRAL DA MARINHA. Histórico. Capturado em 20 nov. 2007. Online. Disponível na Internet: https:// www.mar.mil.br/hcm/

Credits: Maria Elizabeth Bueno de Godoy; Maria Rachel Fróes da Fonseca (research and text). 


\section{IMPERIAL TIMES}

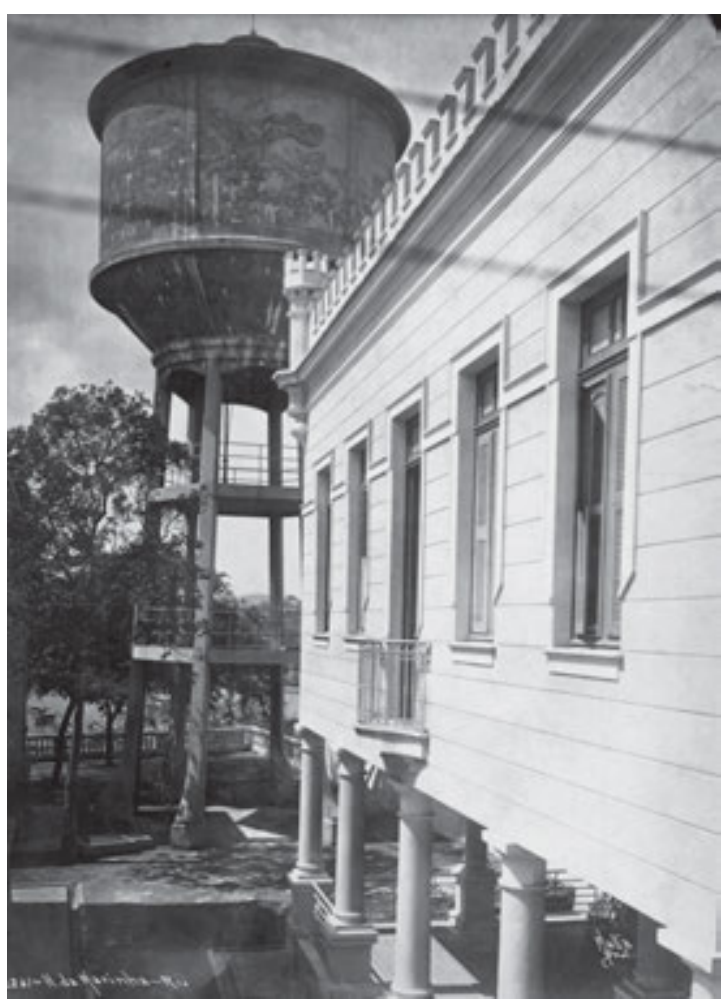

Central Navy Hospital - façade, [s.d.]. Photo Augusto Malta. Museu da Imagem e do Som - RJ Archives

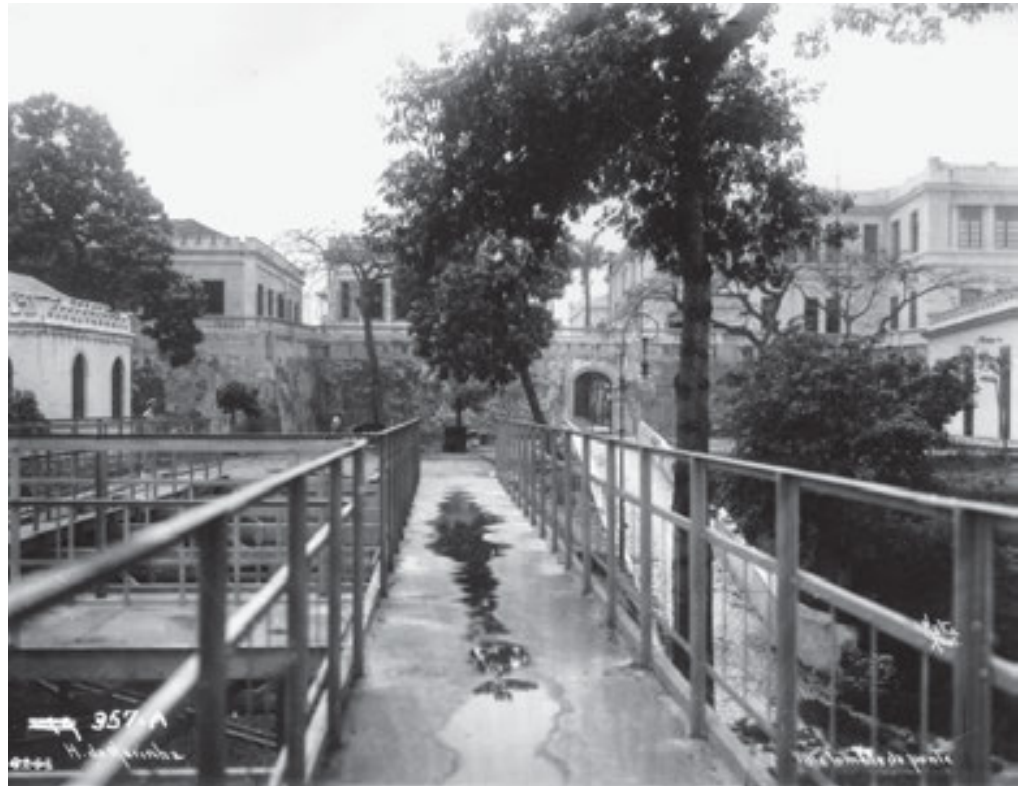

Central Navy Hospital, [s.d.]. Photo Augusto Malta. City of Rio de Janeiro General Archives

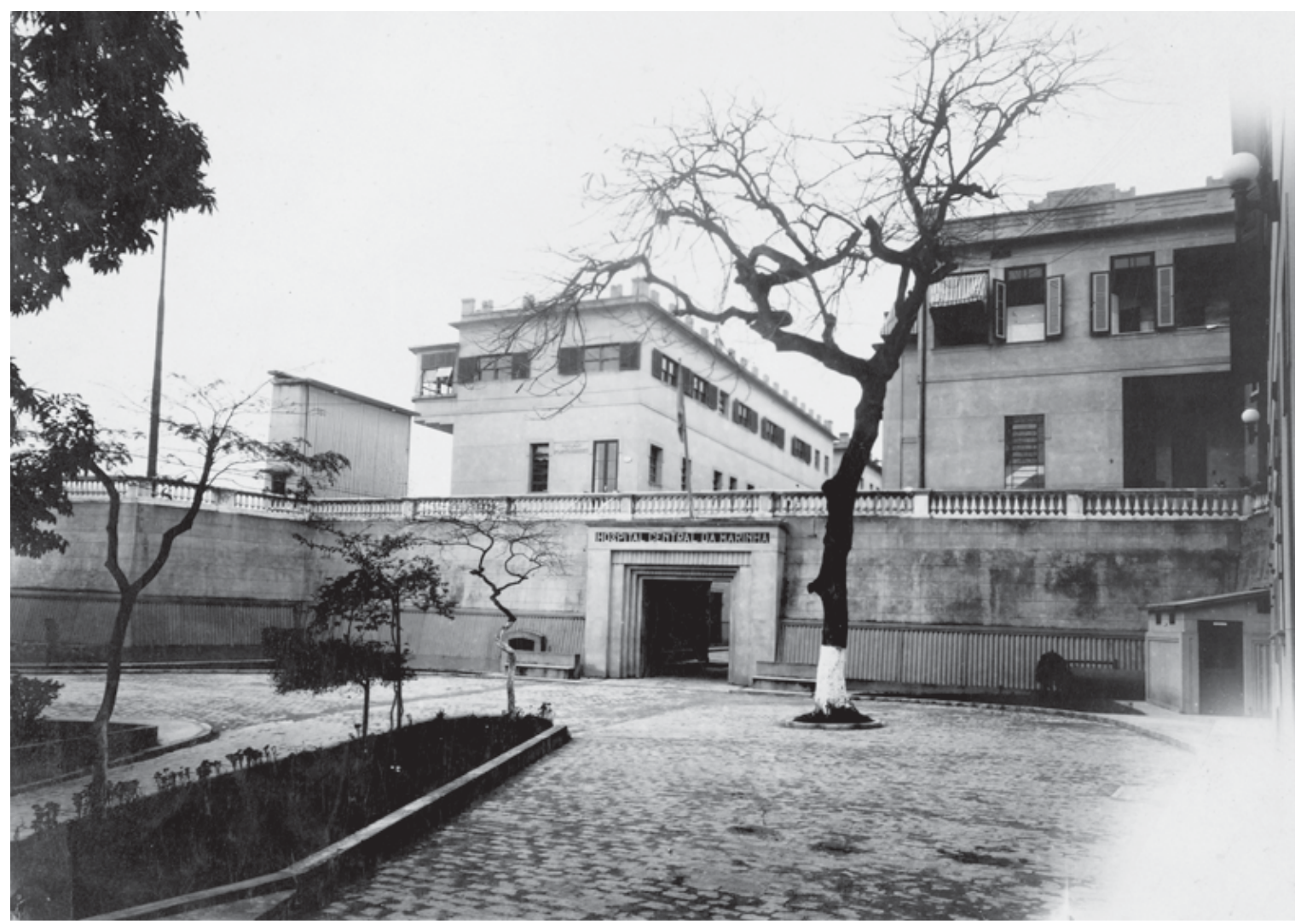

Central Navy

Hospital, [s.d.].

Photo Augusto Malta. City of Rio de Janeiro General Archives 


\section{IMPERIAL TIMES}
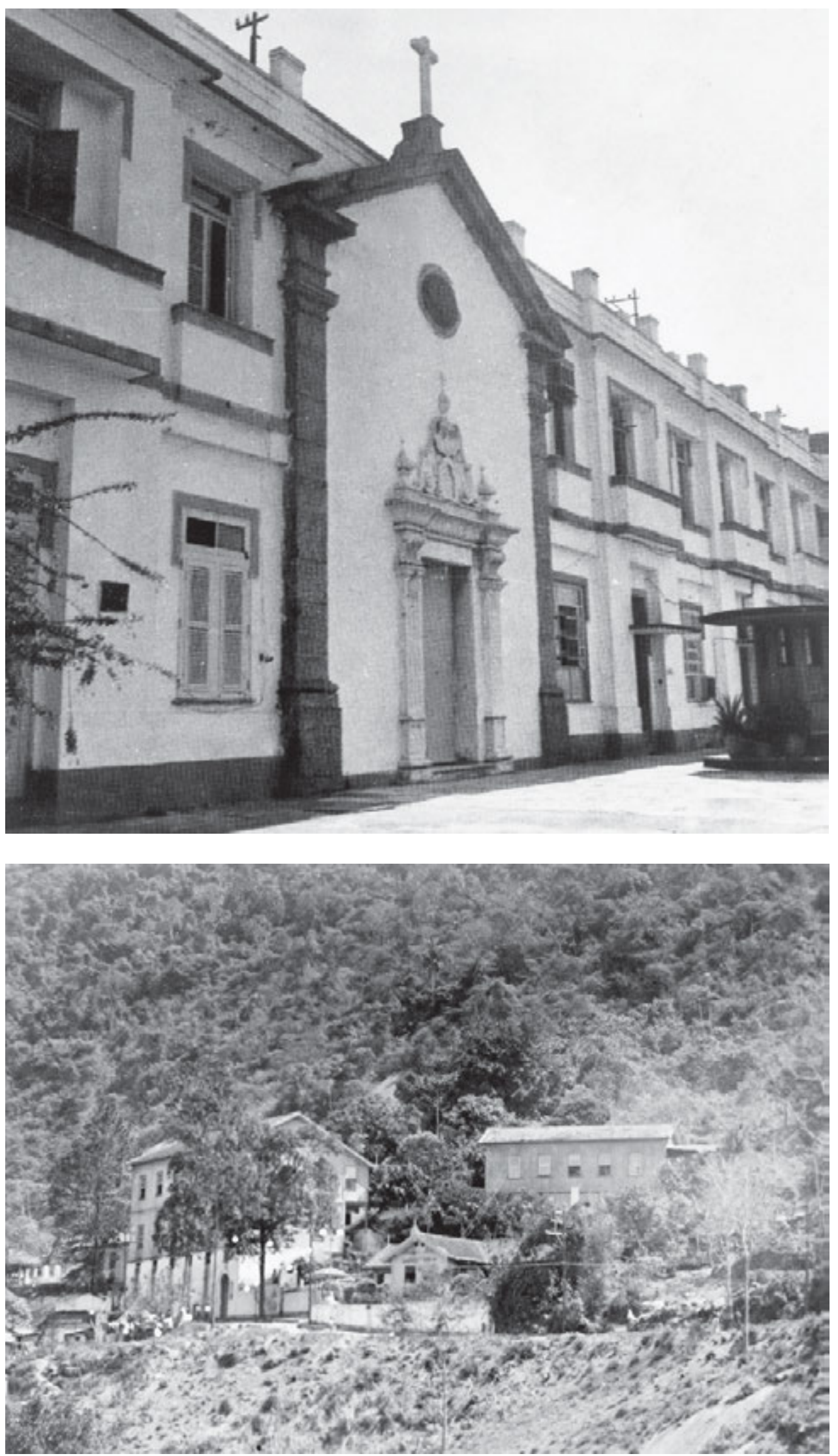

Central Navy Hospital - lateral, with São José Chapel, [s.d.]. Serviço de Documentação da Marinha Archives
Copacabana Beriberi's infirmary, [s.d.] Serviço de Documentação da Marinha Archives 


\section{IMPERIAL TIMES}

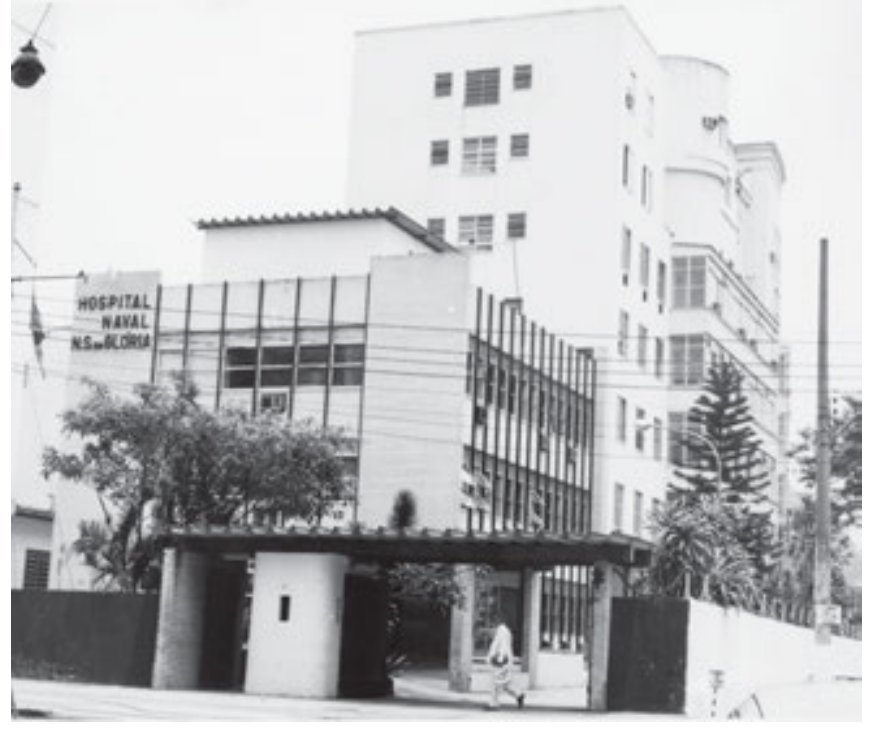

Nossa Senhora da Glória Navy Hospital, Tijuca, [s.d]. Serviço de Documentação da Marinha Archives

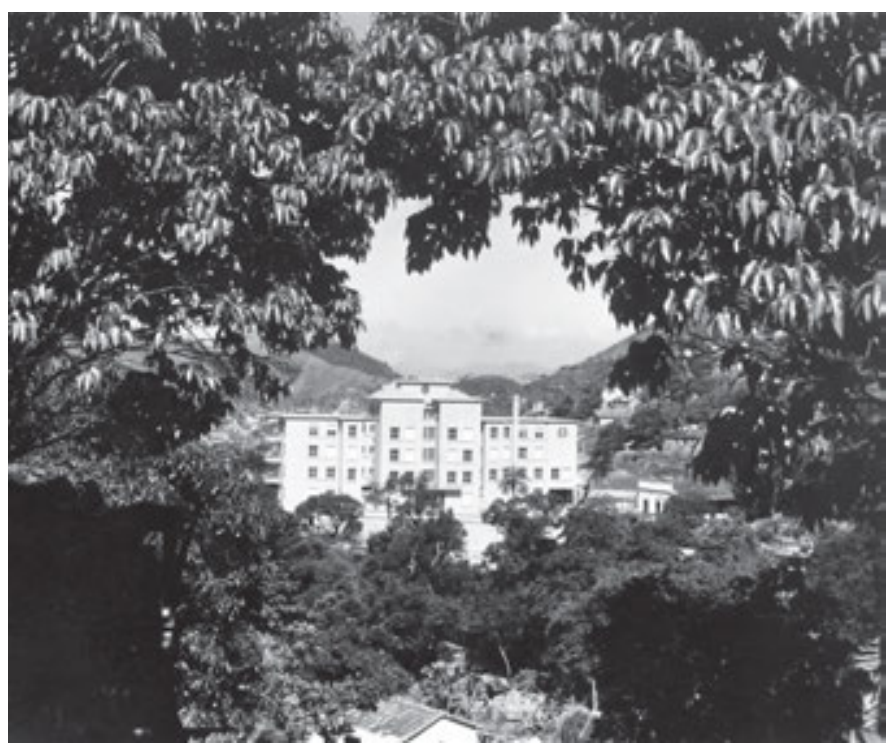

Marcílio Dias Navy Hospital, Lins de Vasconcelos, [s.f]. Serviço de Documentação da Marinha Archives

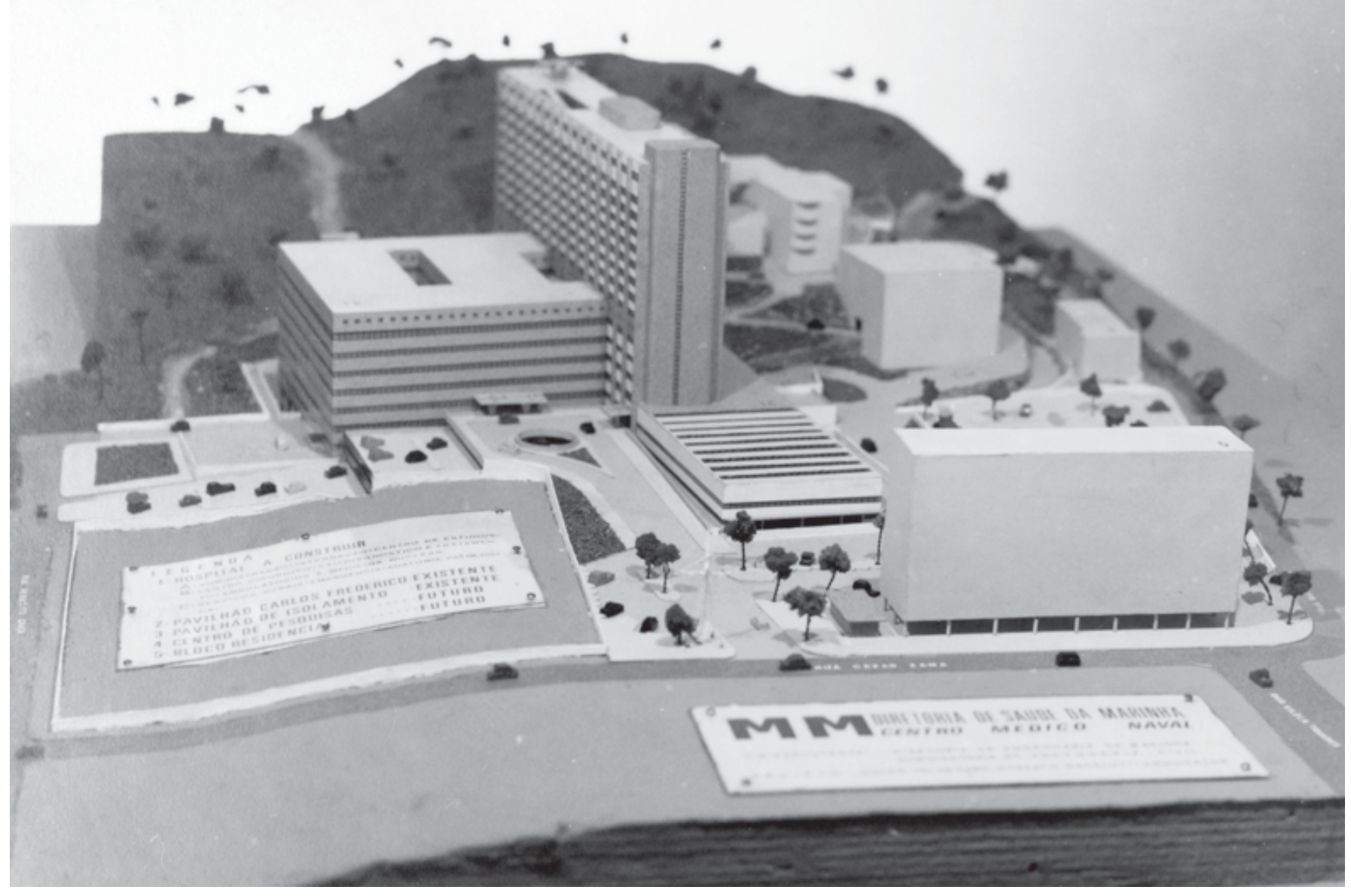

Maquette of the Marcílio Dias Navy Hospital, Lins de Vasconcelos, [s.f.]. Serviço de Documentação da Marinha Archives 


\section{IMPERIAL TIMES}

\section{José Carlos Rodrigues Hospital}

Other denominations: Children's Hospital Polyclinic; Dr. “J. C. Rodrigues” Children's Hospital Polyclinic; José Carlos Rodrigues Hospital.

Location: São Cristóvão

Address: Rua Mário de Frias, no. 57 (main entrance) and Rua de São Cristóvão nº 70.

Category: Institution of assistance care

Period of Construction: 1905-1909

Proprietor: Prefeitura da Cidade do Rio de Janeiro

Author / Constructor: José Carlos Rodrigues (design), Antonio Januzzi, Irmão \& C. (construction)

\section{History:}

Until the beginning of the XX century there was not a hospital destined exclusively for children in the city of Rio de Janeiro. The pioneering feat was performed by Santa Casa da Misericórdia of Rio de Janeiro through the intermediation of its General Hospital administrator, José Carlos Rodrigues (Cantagalo [RJ] 07/19/1844-Paris 06/28/1923). He occupied this position since 1902 and also was director of the Jornal do Commercio between 1890 and 1915.

The initiative to set up an establishment that could serve such purpose originated from the evidence that the health care service to poor children of the city was deficient and should be specialized. J. C. Rodrigues proposed to Santa Casa's Presidency, which was represented by Miguel Joaquim Ribeiro de Carvalho, to construct and incorporate it to the patrimony of the entity. In order to raise starting capital, indispensable for construction work preparation, he sold his extensive library, which included rare books in several languages.

Within a year in the administration, J. C. Rodrigues suggested to Santa Casa to exchange the real state in Flamengo, located at Rua Marquês de Abrantes no. 20, under its ownership, for a property in the São Cristóvão neighborhood. The small farm in Flamengo was then destined to be Casa dos Expostos, which had to leave Rua Evaristo da Veiga due to an expropriation process by the Federal Government. The administrator preferred the north side district since it concentrated working class families and liberal workers, in addition to many industries that were establishing themselves there. Thus the hospital would fulfill its role of providing assistance care to low income people, needy of health care services.

In 1905, in order to initiate the installation of the hospital, a small farm at Rua São Cristóvão no. 52 was acquired along with small houses and lots on Rua Miguel de Frias, between nos. 49 and 55. Such areas were chosen because they were accessible to the population who used the streetcar routes which crossed the communities of São Cristóvão, Andaraí, Praia Formosa, Estácio, Tijuca and Mangue.

In 1906, the merchant Alberto Barth moved to Europe and there died a short while later, leaving in his will real estate and properties in the south side of the city to construct with his proceeds a patrimony for the Children's Hospital. Aiming the same patrimony expansion, in 1910, a plan called "Fund for the Construction of the Santa Casa Children's Hospital" would be executed; a kind of subscription for market merchants and other potential benefactors, which, however, was still not enough for the undertaking.

Following his own design plan, José Carlos Rodrigues sent the construction proposal to the firm Antonio Januzzi, Irmão \& C. Although the project contemplated the architectonic plan of a Hospital, the amount of money destined for the construction of the entire beneficent complex was insufficient for its realization. So being, the construction of a smaller Polyclinic, adequate for the provisioning of all medical clinics was chosen.

Finally, on May $08^{\text {th }}, 1909$, Children's Hospital Polyclinic was inaugurated, attended by several political and civic authorities and constituents of the Sisterhood of Santa Casa da Misericórdia of Rio de Janeiro. It started operating on the 


\section{IMPERIAL TIMES}

following May $10^{\text {th }}$, making available orthopedic gymnastics room; homeopathic consultation room; pharmacy; cabinets of consultation and odontology and other clinics. In the year of its inauguration alone the Polyclinic rendered care to 4,280 children, because there was no other similar institution in the vicinity. J. C. Rodrigues entrusted the organization and administration of the Polyclinic onto Doctor Antônio Fernandes Figueira, who had been appointed to him by the renowned Dr. Hutinel, director of the Hôpital des Enfants Malade, in Paris, whom he had sought for a respectable name.

After a short time of operation, Children's Polyclinic already conducted respectable field studies for scholars whose specialty was pediatrics. Innumerous theses of the College of Medicine in Rio de Janeiro were elaborated around the clinical experiences of this establishment.

In 1914, another children's hospital was established linked to the Santa Casa, São Zacharias Hospital in Botafogo, which provided service care to children from the south side district. Around this time, Children's Hospital Polyclinic could no longer accommodate the large number of children coming from all over the city who sought assistance there.

In the 20s, the Polyclinic had surgery cabinet, children's hygiene service, laboratory, consultation rooms of otorhinolaryngology, dermatology, electrotherapy, hydrotherapy, odontology cabinet, medical clinic, ophthalmology and gynecology consultation room. At the end of the decade, in September, 1928, it underwent a regulation which suppressed services of gynecology, dermatology and house calls. Aiming to balance the budget, it joined the cabinets of hydrotherapy and electrotherapy under a single service of physiotherapy. Yet, the cost cutting objective did not allow for the daily distribution of 100 liters of milk to go extinct.

On May 14 ${ }^{\text {th }}, 1930$, during the presidency of Miguel Joaquim Ribeiro de Carvalho, Nursery Visconde de São Francisco was inaugurated, adjacent the Polyclinic, by testamentary indication of benefactor Irene de Miranda Pacheco. It was destined to house children whose mothers did not have where to leave them during their work shift.

In the 40s, its clinical staff, medical services and number of hospital beds increased affording it dimensions of a real Hospital. In 1945 a pre-natal service was set up which offered treatment, medicines and counseling to pregnant women during the entire gestation.

The following years were characterized by budgetary deficits for Santa Casa da Misericórdia of Rio de Janeiro, and, in the middle of the 50s, at least one of its units ceased activities - São João Batista Asylum. José Carlos Rodrigues Hospital may have suffered the same process given the hardship of bearing the high onus associated to the maintenance of several establishments, because the information about its history is only available until the referred to decade.

\section{Notes:}

There is no information of official changes in its denomination, being referred by the variations cited within the same year, for example.

\section{Register of Preservation:}

Listed. Prefeitura da Cidade do Rio de Janeiro, Decreto no. 15502/97, de 31/01/1997.

\section{Sources:}

A POLICLÍNICA de Crianças Pobres da S. C. da Misericórdia fundada e doada pelo Dr. José Carlos Rodrigues e inaugurada pelo Presidente Affonso Penna a 08 de maio de 1909.

ASSISTÊNCIA Pública e Privada no Rio de Janeiro (Brasil) - História e Estatística. Comemoração do Centenário da Independência Nacional. Rio de Janeiro: Typographia do Annuario do Brasil, 1922.

Retrospecto de onze annos de serviços sob a direção do Dr. Fernandes Figueira. Rio de Janeiro: Typ. do Jornal do Commercio, de Rodrigues \& C., 1920. 


\section{IMPERIAL TIMES}

CARDIM, Elmano. José Carlos Rodrigues: sua vida e sua obra. Revista do IHGB, Rio de Janeiro, nº 185, out./dez., 1944. pp. 126-157.

FREITAS, B. Hospital de Crianças. In: CARVALHO, M. (org.). Notícia dos diversos estabelecimentos mantidos pela Santa Casa da Misericórdia da cidade de S. Sebastião do Rio de Janeiro. Rio de Janeiro: Typographia do "Jornal do Commercio" de Rodrigues \& C., 1908.

HOSPITAL de Crianças da Santa Casa da Misericórdia do Rio de Janeiro. Documentos Diversos. IHGB. (1905-1916)

Credits: Atiele Azevedo de Lima Lopes (research and text) 


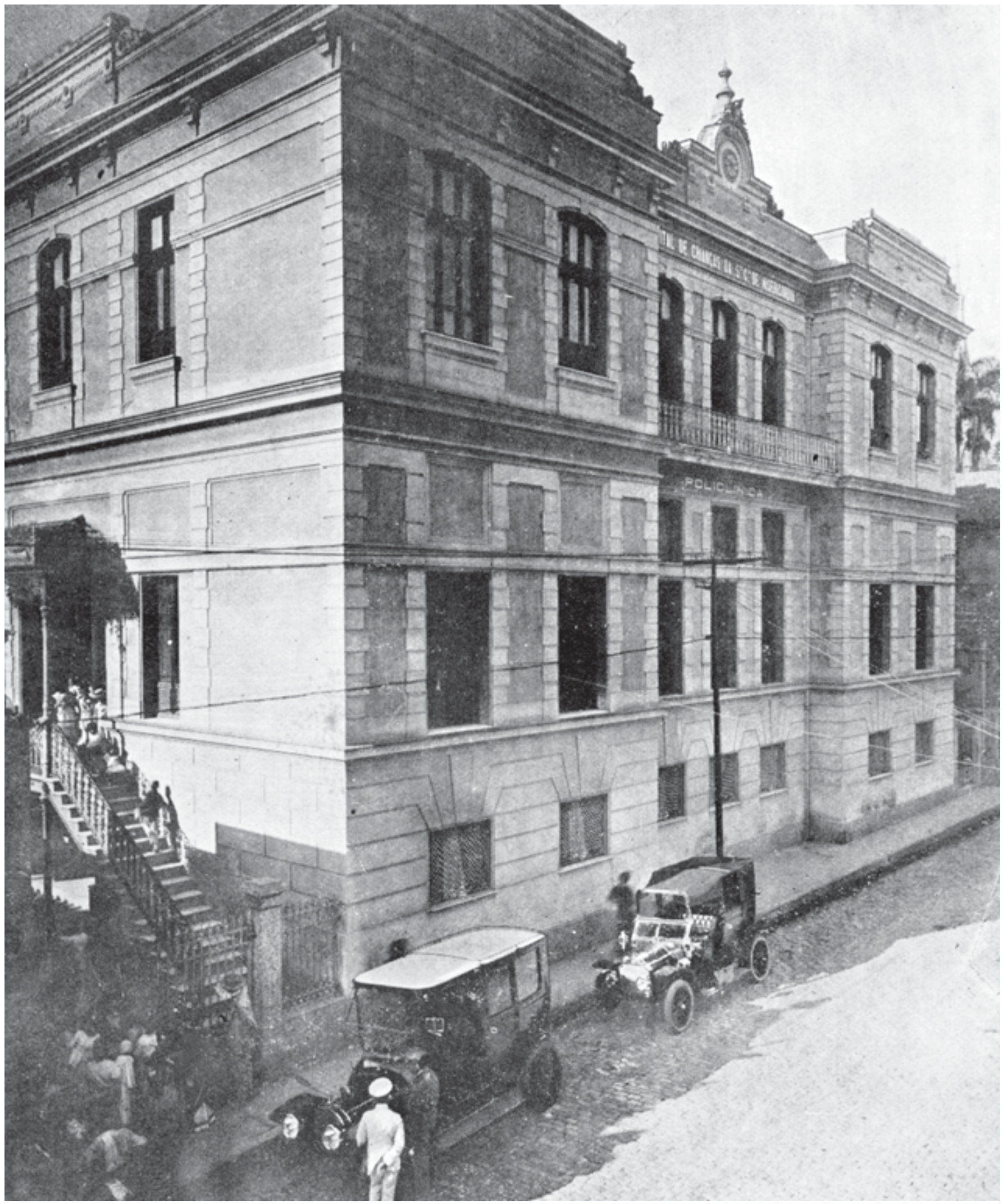

Children Policlinic, [s.d.]. Source: Assistência, 1922 


\section{IMPERIAL TIMES}

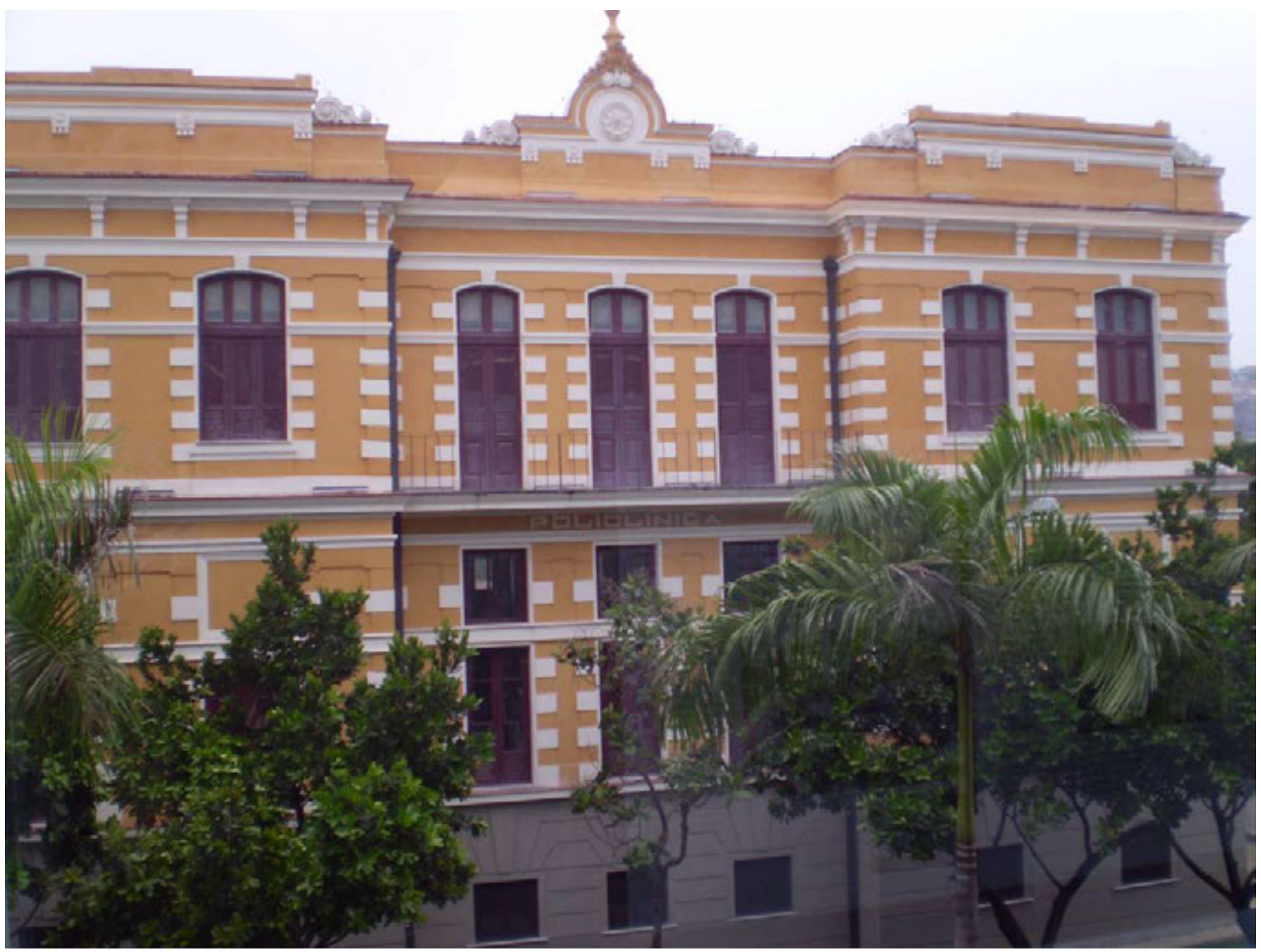

José Carlos Rodrigues Hospital, 2008. Photo Gisele Sanglard 


\section{College of Medicine of the Federal University of Rio de Janeiro}

Other denominations: Anatomic, Surgical and Medical School of Rio de Janeiro (1808); Medical-Surgical Academy of Rio de Janeiro (1813); College of Medicine of Rio de Janeiro (1832); College of Medicine and Pharmacy of Rio de Janeiro (1891); College of Medicine of Rio de Janeiro (1901); College of Medicine of the University of Rio de Janeiro (1920); National College of Medicine of the University of Brazil (1937); College of Medicine of the Federal University of Rio de Janeiro (1965-present day).

Location: Cidade Universitária, Ilha do Fundão.

Address: Ilha do Fundão, s/n.

Category: Institution of higher education.

Period of construction: 1916-1918 (Praia Vermelha building).

Proprietor: The Federal University of Rio de Janeiro.

Author / Constructor: Luiz Moraes Jr. (architect) and Antônio Januzzi (constructor), to the Praia Vermelha building.

\section{History:}

Until the beginning of the $19^{\text {th }}$ century, medicine in Brazil was practiced by physicists, barber-surgeons, approvedsurgeons and examined-surgeons that presented a qualification certificate and by licensees of the surgeon-general of the Kingdom. At this time, the only examples of educational establishments were schools and seminaries run by the Jesuits.

When the Portuguese Royal Family came to Brazil (1808), Brazil became the headquarters of the Empire, ushering a period of advances in relation to the founding of scientific and cultural establishments, including the implementation of the first schools of higher education.

According to Lycurgo de Castro Santos Filho (1991), April $2^{\text {nd }}, 1808$, marks the inaugural founding of the Anatomic, Surgical and Medical School of Rio de Janeiro. The date indicates the beginning of the anatomy classes administered by Joaquim da Rocha Mazarém in the accommodations of the Royal Military Hospital (former School of the Jesuits - Morro do Castelo).

In accordance with the program, it should have also been responsible for the cathedrae of ligatures, parturition and operations. It was in virtue of this initiative that the course of surgery was established in Rio de Janeiro, embryo of the Anatomic, Surgical and Medical School of Rio de Janeiro. The proposal for the curriculum was expanded including the disciplines of anatomy and physiology, private and surgical therapy, surgical medicine and obstetrics, medicine, chemistry and elements of a medical and pharmacy nature.

Confronting the inexistence of its own bylaws, the new institution, as well as its congener from Bahia, the School of Surgery of Bahia, also created in 1808, was governed by the school bylaws of the University of Coimbra, Portugal.

The establishments of higher education in medicine underwent several educational reforms throughout their institutional trajectory. In 1813, the Manoel Luiz Álvares de Carvalho reform approved the "Plan of Surgery Studies", by Manuel Luiz Álvares de Carvalho, Director of the Studies of Medicine and Surgery in the Royal Court, which among other provisions, altered the denomination to the Medical-Surgical Academy of Rio de Janeiro. The institution receives halls next to the Santa Casa da Misericórdia Hospital of Rio de Janeiro, at Santa Luzia beach. Admission requirements for the course were not very strict, the applicant only had to know how to read and write and understand French and English. Disciplines used to be distributed in a five-year program. On December 1820, by means of a reform, new bylaws elaborated by José Maria Bomtempo were adopted, which changed the sequencing of the disciplines at the Medical-Surgical Academy of Rio de Janeiro, and redefined administrative issues regarding the duties of the director, obligations of the professors, secretary, archive and other employees; and the duties and privileges of the students. The Act of September $9^{\text {th }}, 1826$ promoted the autonomy of the medical-surgical academies of Rio de Janeiro and Bahia, allowing them to effectively 
grant two types of diplomas, the diplomas of surgeon and graduate surgeon, ending the proceedings in effect until then, which were subordinate to the physicist-general and surgeon-general of the Empire.

The Reform Act of 1832 (10/03/1832) was the result of the "Plan for the Organization of the Medical Schools of the Empire", elaborated at the Society of Medicine of Rio de Janeiro, after a proposal sent by the House of Representatives, aiming to remedy the deficiency and delay that courses of medicine still faced in relation to their congeners in the rest of the world, benefiting those who graduated in Europe, specially Coimbra. Among the changes in the administrative and pedagogic structure, under this reform the Academies of Medicine became designated Colleges of Medicine and were temporarily governed by the bylaws of the College of Medicine of Paris, while their own were being organized.

The Bom Retiro Reform, also known as Reforma Couto Ferraz, implemented by decree no. 1.387 of 04/28/1854, reorganized the two colleges of Medicine of the Empire, of Rio de Janeiro and Bahia, and marked an important effort in the organization of the medical education in the country, which until then was under the provisory control of the regulations from 1832. On April 19 ${ }^{\text {th }}, 1879$, by decree no. 7.247 the reform which became known as Reforma Leônica de Carvalho was approved. Inspired in the German universities, this reform instituted the non-mandatory attendance of classes, the creation of non-official courses in the confines of the colleges, the compulsoriness of the practical tests, and for the first time women were allowed to graduate in several courses of the colleges. On October $25^{\text {th }}, 1884$, by means of decree no. 9.311, new bylaws were established for those colleges of medicine, which maintained to a great extent the plan of Leôncio de Carvalho. Known as the Sabóia Reform, due to the accomplishments of the director of the College of Medicine of Rio de Janeiro at the time, Vicente Cândido Figueira de Sabóia, who determined that each college should administer a course of Medical and Surgical Sciences and three more annexed ones, Pharmacy, Obstetrics and Gynecology, and Odontology, in three, two and three years, respectively.

From 1813 to 1832, given the lack of its own headquarters, the School of Medicine occupied areas of the Santa Casa da Misericórdia of Rio de Janeiro. As of this date, it was based in several locations, including simultaneously. In 1844, for example, it was divided among the Military Hospital, a two-story house at Praia de Santa Luiza and halls conceded by the Santa Casa. In 1850, some of its cathedrae and administrative areas operated at Rua dos Barbonos (currently Evaristo da Veiga), in 1856, transferred along with the library to the old Recolhimento de Órfãs da Irmandade da Misericórdia, at Rua de Santa Luzia.

Still in the $19^{\text {th }}$ century, several attempts to construct a headquarters for the College of Medicine of Rio de Janeiro were carried out, many of which were concocted by members of its Faculty, important names of the medical teaching establishment such as, Antonio Correia de Souza Costa, Joaquim Monteiro Caminhoá, Domingos José Freire Junior, Nuno Ferreira de Andrade and Cláudio Velho da Motta Maia. At the end of the $19^{\text {th }}$ century, the project of the engineer Antonio de Paula Freitas for the construction of a building for the College of Medicine of Rio de Janeiro was approved, to be constructed in the grounds of Praia da Saudade (later known as Praia Vermelha), near the Pedro II Hospice. The cornerstone was laid on February $13^{\text {th }}, 1881$, however construction was interrupted only to resume in 1908 for the construction of one of the pavilions for the centennial commemorative Exposition of the Opening of the Ports (1908), which later housed the National Department of Mineral Production.

With the Proclamation of the Republic on November $15^{\text {th }}, 1889$ and the forming of the Provisional Government, the institutions of medical education underwent new organization. The first was the Benjamin Constant Reform (decree no. 1.270 of 01/10/1891). Under this decree the schools of medicine became colleges of medicine and pharmacy, denomination which did not last very long. Once the Code of 1901 was instituted, by means of decree no. 3.890 of 01/01/1901, a new working system was implemented for the Official Institutes of Higher and Secondary Education dependents of the Ministry of Justice and Internal Affairs. Soon later, followed decree no. 3.902, of 01/12/1901, reestablishing the denomination of College of Medicine of Rio de Janeiro.

On May $4^{\text {th }}, 1916$ the contract between the College of Medicine of Rio de Janeiro and the architecture firm of Antonio Januzzi was drawn up commissioning the construction of the new building at the old Praia da Saudade. The approved project was of the engineer Luiz de Moraes Junior and, based on the plan, anticipated the construction of three buildings, oriented by the sanitation doctor Oswaldo Cruz (DOYLE MALA, 1996:94). Only one of the buildings proposed in the plan was constructed, and on 10/12/1918 the building of the College of Medicine was inaugurated. 
In virtue of decree no. 14.343, of 09/07/1920 the University of Rio de Janeiro was created, composed of the colleges of Medicine, Law and by the Polytechnic School of Rio de Janeiro. Such effect once again changed the denomination of the institution to the College of Medicine of the University of Rio de Janeiro, remaining as such until 1937, when under decree no. 452 of July $5^{\text {th }}$ the referred to University was renamed University of Brazil, consequently altering the denomination of its medicine unit to the National College of Medicine of the University of Brazil.

In accordance with decree no. 4.831, of 11/05/1965, the University of Brazil became the Federal University of Rio de Janeiro, and the College of Medicine once again had its name changed to the College of Medicine of the Federal University of Rio de Janeiro, denomination which remains until today. In this period the Center of Health Sciences was constituted housing the colleges of Medicine, Odontology, Pharmacy; the institutes of Biology, Nutrition, Biophysics, Microbiology and Biomedical Sciences. This Center is the keeper of the historic records of the College - its library and archive.

The building at Praia Vermelha was the headquarters of the College of Medicine until January 1973, when the institution was transferred to the university campus of the Federal University of Rio de Janeiro, at Ilha do Fundão. The old building at Praia Vermelha was demolished in 1975.

In 1978, the Clementino Fraga Filho University Hospital was inaugurated, putting an end to the long struggle of the institution in search of an exclusive hospital for the practical classes of its students.

\section{Architectonic Description:}

The College of Medicine of Rio de Janeiro always tried to have its own buildings and hospitals. Throughout the $19^{\text {th }}$ century, two projects for the College of Medicine were formulated, one by Manoel de Araújo Porto-Alegre in 1860, in an area at rua Santa Luzia; and another by the engineer Antônio de Paula Freitas, in 1881, that designs a complex of buildings at Praia da Saudade. The cornerstone would be laid with great ostentation. But, the construction work would drag on for two decades. The most frustrating thing for the scientific community, who longed a headquarters for the College of Medicine, was not the delay in the construction work, but its final destination to house one of the pavilions of the Commemorative Exposition of the Opening of the Ports in 1908.

In 1916, during the Administration of Wenceslau Braz, the project of the engineer-architect Luiz Moraes Jr was finally contracted, with Antônio Jannuzzi as constructor, this would be the definitive headquarters of the entity, in a location near the project of Paula Freitas, now at Praia Vermelha. The contract included the project for two other buildings in the vicinity for the College, which did not move ahead.

In terms of the architectonic language, Moraes' project sought inspiration from the primitive project of Paula Freitas, using as reference, for example, the low arched frontage. This arch marked the main entrance of Moraes' building, architectonic element characteristic of other hospital constructions, such as the Beneficência Portuguesa, which is considered the only example of the neoclassic architecture of Rio de Janeiro today.

The scheme of the classicist eclectic composition was developed from a decentralized volume, composed by a set of four beaten and cadenced blocks, by column and windows of traditional disposition, finished up by four well marked lateral cylindrical bastions. Internally, the decoration included stained glass windows with allegories of medicine (a mythic figure of Aesculapius) and of wisdom. Two staircases led to the main courtyard of octagonal format and full of trees, paved and decorated by mosaics of Portuguese stone.

The building originally had two pavements, but around 1940 it received the progressive increment of three more new pavements, profoundly changing its spatiality and ornamentation, specially the low arched frontage. The College remained in this location until January 1973, when it was transferred to the university campus at Ilha do Fundão, being installed in several sectors of the Center of Health Sciences (CCS). In 1975 the building at Av. Pasteur was demolished and the land was not used, it currently belongs to the University of Rio de Janeiro (UNIRIO).

If the wish to have its own headquarters was achieved in 1918, the dream to have its own hospital was realized in 1926, when the cornerstone of the Arthur Bernardes Clinics Hospital was laid, with capacity to hospitalize about 2000 people, in a lot where today the State University of Rio de Janeiro is located, at the region of Mangueira. The project of the 
architect Porto d'Ave was highly criticized until works finally started in 1929, but were suspended in 1931, to be abandoned definitively in 1934. Two years later, in 1936, the construction of another building to serve as a Clinics Hospital to the College was considered, while works of the Cidade Universitária were not concluded and which later would be reverted to the municipality. This idea, which was defended by some professors, did not achieve great success and the College had to wait a few decades until a project of a Clinics Hospital was accomplished.

In 1957, the Technical office of the University of Brazil (ETBU), under the management of Jorge Machado Moreira, developed the project of the Clinics Hospital of the University of Brazil, already at the Ilha do Fundão, Clementino Fraga Filho University Hospital. Designed to serve the program of a school-hospital with 2.000 beds, a grandiose structure of $220.000 \mathrm{~m}^{2}$ was constructed, adopting the typology of the mono-block hospital. This construction dragged on for almost two decades given the innumerous difficulties which the work underwent. In 1970, the Committee of Implantation of the Cidade Universitária decided that the Hospital would occupy only half of the total area of the structure. Work on the Hospital resumed on January $22^{\text {nd }}, 1971$, and in 1972, given a lack of resources slowed down once again and came to a halt. Work resumed under the administration of Hélio Fraga. On September, 1973, he took over the Presidency and, on June $25^{\text {th }}, 1974$, decided to reorganize the Committee, limiting it only to the implantation of the University Hospital. On November 1974, the Council of Social Development approved the concession of the initial budget to resume the project. However, as of today only half of its facilities are functioning.

\section{Register of Preservation:}

It is not listed .

\section{Sources:}

AZEVEDO, M. A Faculdade de Medicina do Rio de Janeiro. Revista do Instituto Histórico e Geográfico Brasileiro, Rio de Janeiro, tomo 30, $2^{\text {a }}$ parte, p.39-418, 1867.

CASTRO-SANTOS FILHO, L. História Geral da Medicina Brasileira. São Paulo: HUCITEC/EDUSP, 1991. v. 2.

FACULDADE DE MEDICINA DA UFRJ. Museu Virtual. Online. Disponível na Internet: http://www.museuvirtual. medicina.ufrj.br:81/

LACAZ, C. Contribuição da Faculdade de Medicina da Universidade Federal do Rio de Janeiro para o desenvolvimento da pesquisa, do ensino e da prática médica no Brasil. In: UNIVERSIDADE FEDERAL DO RIO DE JANEIRO. Centro de Ciências da Saúde. Sesquicentenário da Faculdade de Medicina da Universidade Federal do Rio de Janeiro. Rio de Janeiro: [UFRJ].

MAGALHÃES, F. O Centenário da Faculdade de Medicina 1832-1932. Rio de Janeiro: Tip. A . P. Barthel, 1932.

MAIA, G. Biografia de uma Faculdade: História e Estórias da Faculdade de Medicina da Praia Vermelha. São Paulo: Ed. Atheneu, 1996.

PEREIRA, R.; MAURO, F. Boletim Eletrônico da Faculdade de Medicina da UFRJ. Um pouco de História. Número 109 - Ano IV - 13/1/06. Online. Disponível na Internet: http://www.medicina.ufrj.br/noticiasAntDet.asp? TipoConsulta=0\&id_ boletim $=170$

SILVA, A. Quadro Histórico da Fundação da Escola de Medicina do Rio de Janeiro. Revista do Instituto Histórico e Geográfico Brasileiro, Rio de Janeiro, t.74, 2a parte, p.263-276, 1911.

TEREMOS afinal, um Hospital das Clínicas? Correio da Manhã, Rio de Janeiro, 19 de abril de 1936.

Credits: Atiele Azevedo de Lima Lopes (research and text); Inês El-Jaick Andrade and Renato da Gama-Rosa Costa (architectonic description). 


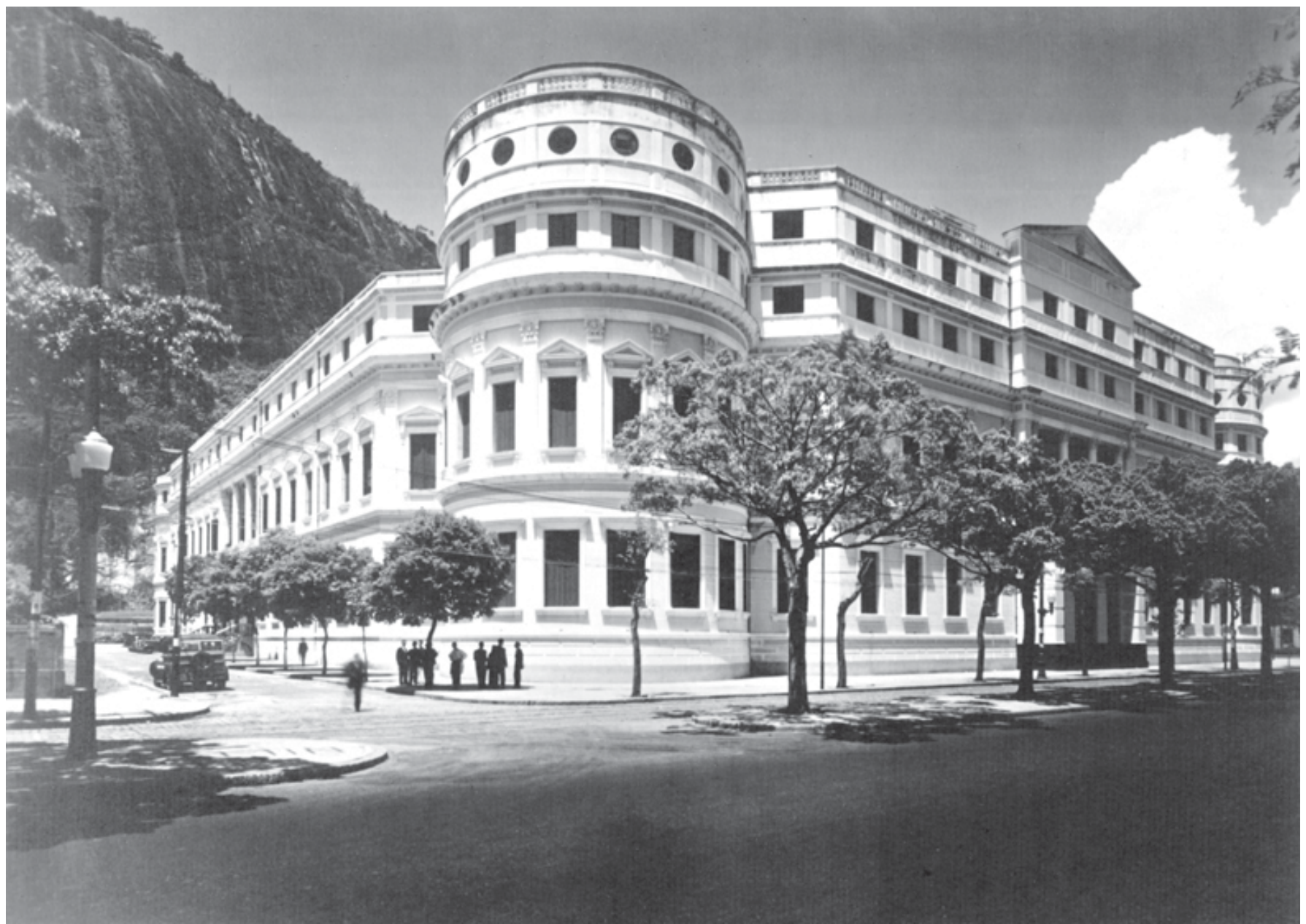

College of Medicine, Praia Vermelha - Chemistry Laboratory, [s.d.] Centro de Ciências da Saúde/ Federal University of Rio de Janeiro Archives

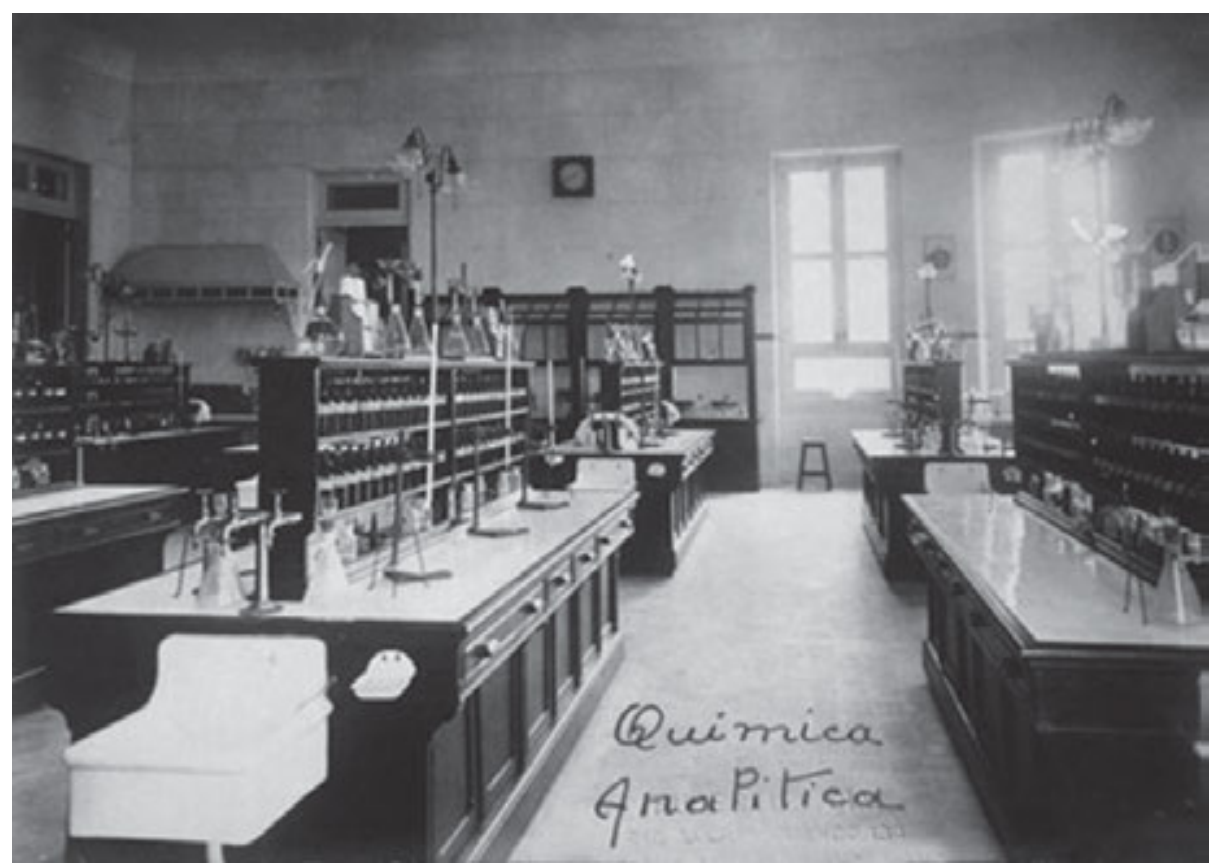

College of Medicine, Praia Vermelha Practical Classes Laboratory, 1918. Centro de Ciências da Saúde/ Federal University of Rio de Janeiro Archives 


\section{IMPERIAL TIMES}

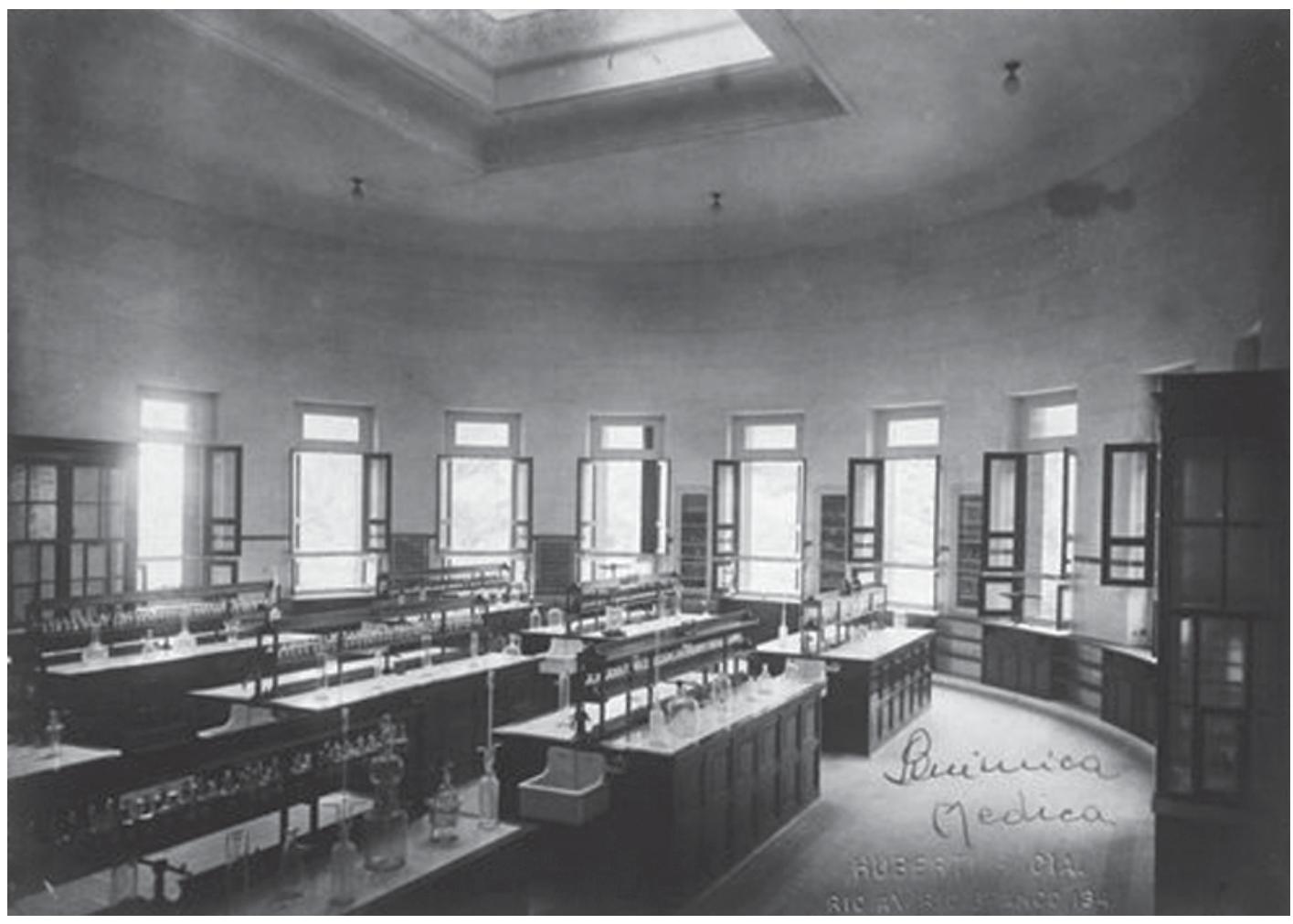

College of Medicine, Praia Vermelha - Practical Classes Laboratory, 1918. Centro de Ciências da Saúde/ Federal University of Rio de Janeiro Archives

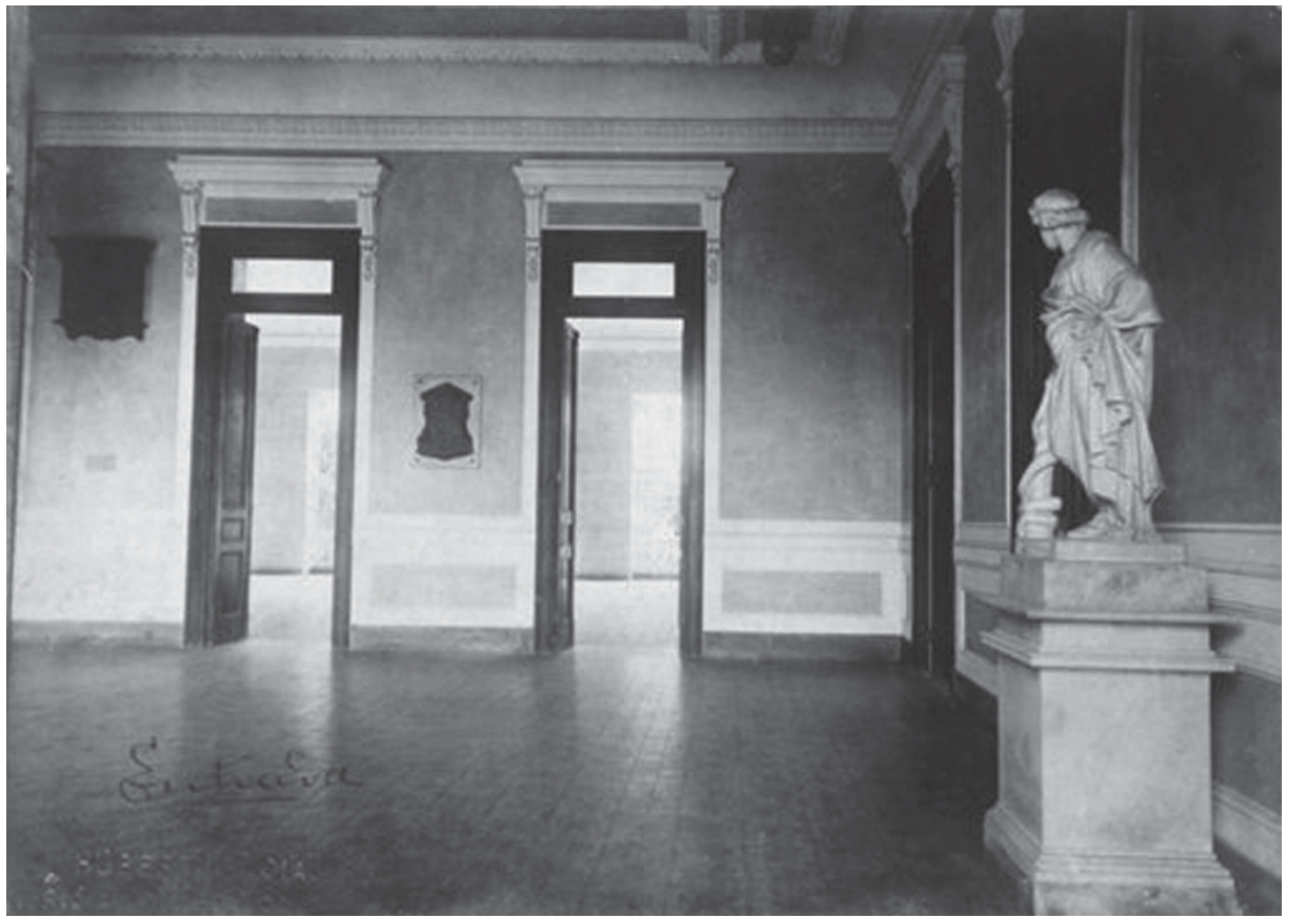

College of Medicine, Praia Vermelha - Entrance Hall, [s.d.] Centro de Ciências da Saúde/ Federal University of Rio de Janeiro Archives 


\section{IMPERIAL TIMES}

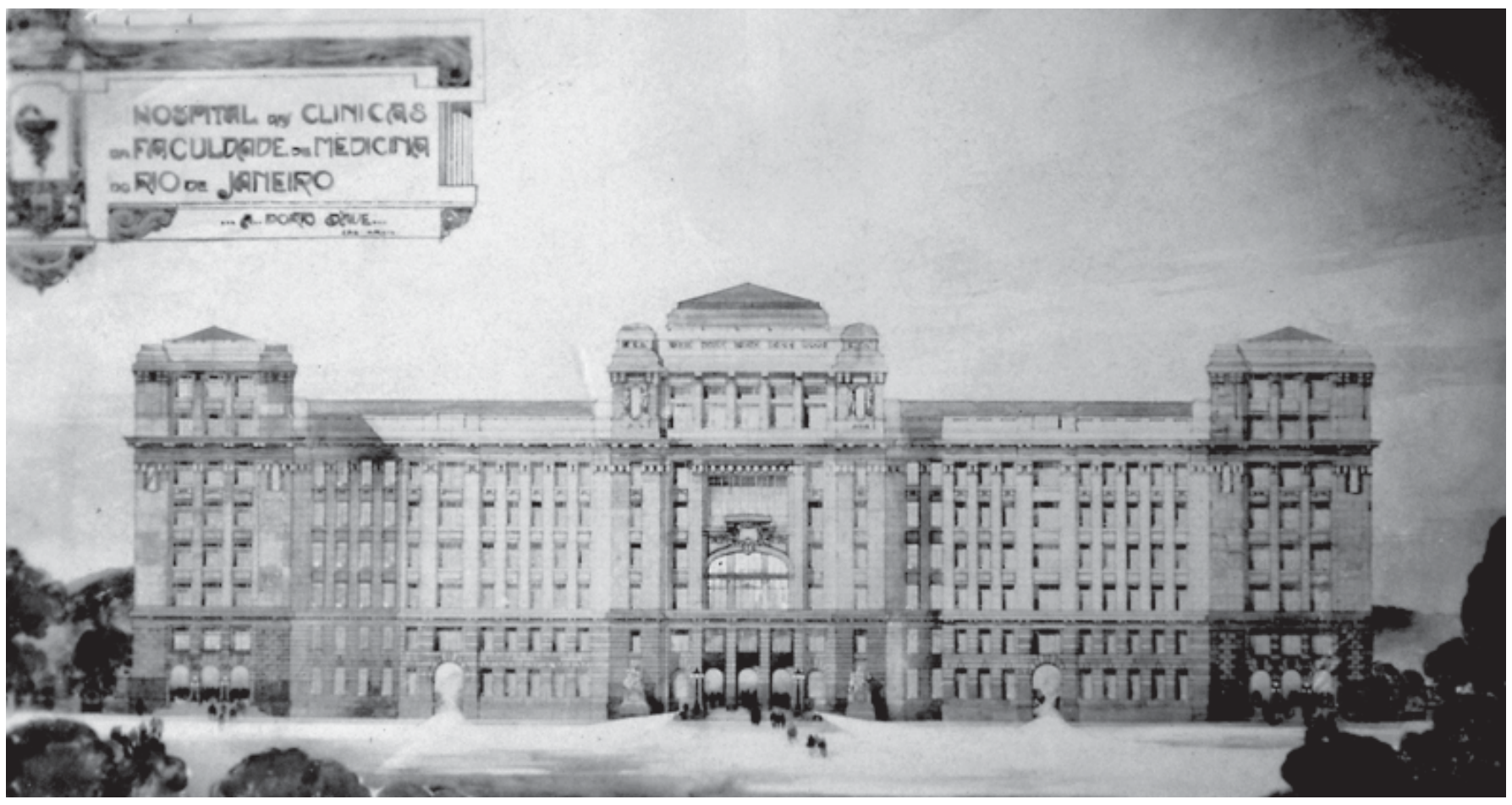

College of Medicine Hospital, Porto d'Ave project [1926-1934]. Instituto Histórico e Geográfico Brasileiro Archives 


\section{IMPERIAL TIMES}

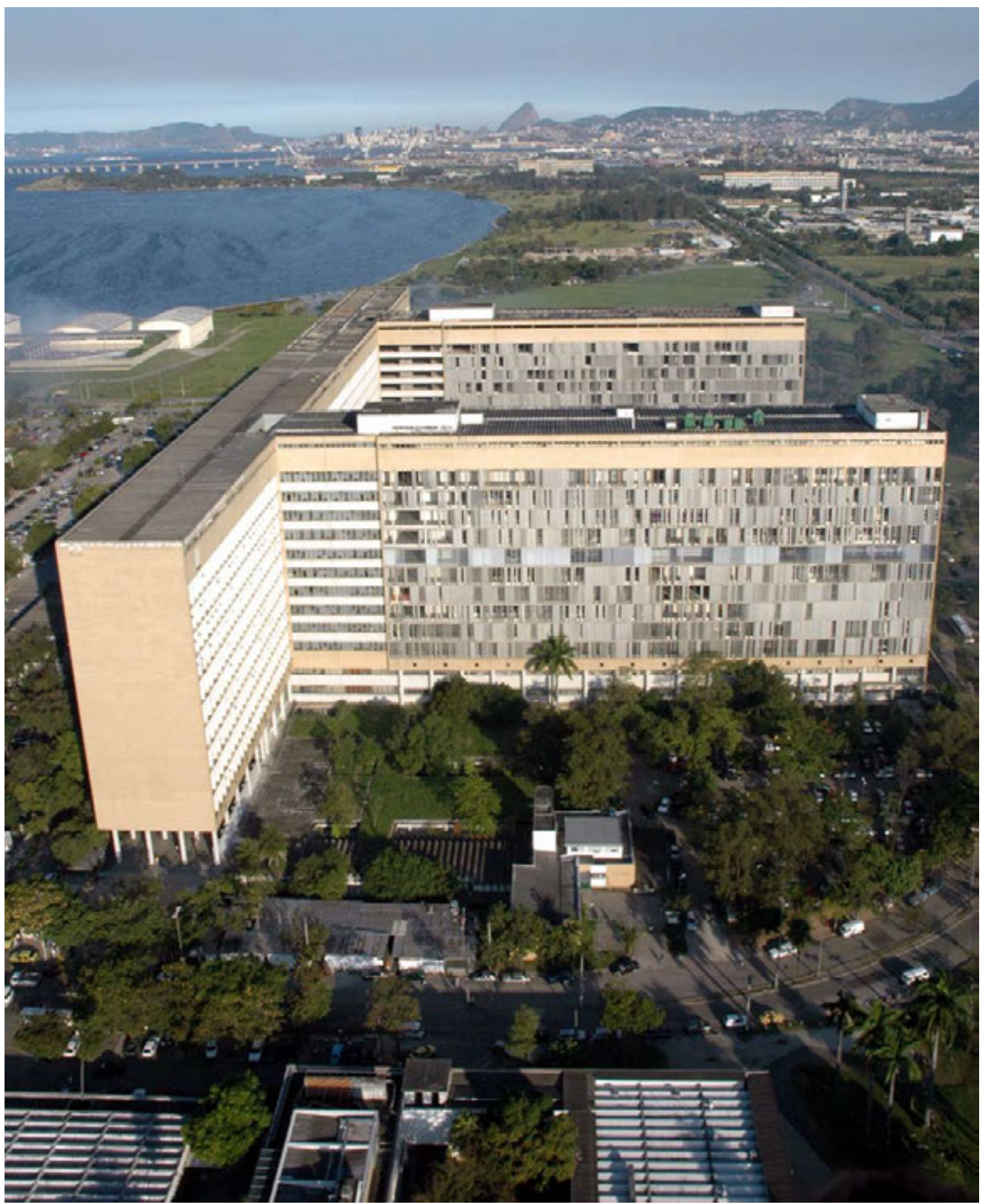

University Hospital, [s.d.]. Universidade Federal do Rio de Janeiro Archives 


\section{Instituto Nacional de Educação de Surdos (Deaf Education National Institute) - INES}

Other denominations: Deaf-Mute Imperial Institute (Imperial Instituto dos Surdos Mudos) (1856-1889); Deaf-Mute Institute (Instituto dos Surdos Mudos) (1889-1902); Deaf-Mute National Institute (Instituto Nacional de Surdos-Mudos) (1904-1957); Deaf Education National Institute (Instituto Nacional de Educação de Surdos) (1957-present day).

Location: Laranjeiras

Address: Rua das Laranjeiras, no. 232

Category: Teaching Institution

Period of construction: 1913-1915

Proprietor: Institute of the Deaf-Mutes.

Author / Constructor: Gustav Lully (architect); Poley Ferreira \& C. (constructor).

\section{History:}

The first establishment in Brazil destined to the instruction of deaf-mutes was created by the Frenchman Ernest Hüet, director and teacher of the Bourges Institute. Already in Brazil in 1855, he made known to the Emperor D. Pedro II, his objective of opening up a similar type of establishment in Rio de Janeiro. The initiative was welcomed and the Emperor saw to it that the Vassimon School, situated at Rua Municipal no. 8 (at the present day Mayrink Veiga), in the borough of Laranjeiras, received the teacher and two students with the financial support of the Imperial Government.

Due to the results obtained with the education of these students, it was decided to create a committee to plan and build an educational institute for deaf-mutes. For this, a building was leased at Ladeira do Livramento no. 29, in the borough of Saúde, to where the students received by the Vassimon School were transferred. This was the embryo of the foundation, in October of 1856, of the Imperial Institute of the Deaf-Mutes.

The Institute was officially established by means of Law no. 839 , of September $26^{\text {th }}, 1857$, and offered instruction for both sexes, the girls being cared for by Ernest Hüet's wife.

After some years as director of the entity, Hüet was substituted by Manoel de Magalhães Couto, hired by Prime Minister, Pedro de Araújo Lima (Marquis of Olinda) directly from France, where he had concluded his studies, taking up office on August $01^{\text {st }}, 1862$. On August $10^{\text {th }}, 1868$, Tobias Rabello Leite assumed the position, remaining for four years as temporary director. In his administration, made effective in 1872, he extinguished the feminine section of the Institute, alleging that it was not possible to maintain morality in the establishment while caring for both sexes. Besides this, he was charged with elaborating a project for the re-writing the statutes with provisions adapted to the results of the measures adopted with success during his administration. This project was approved and converted into regulation by means of decree no. 5.435, of October $15^{\text {th }}, 1873$.

By the new resolutions, the course was extended from five to six years and included the primary school curriculum. The studies of mathematics, geography, Brazilian history and drawing were introduced into the curriculum. The establishment began to accept the inscription of paying students, previously offered freely to orphans and to the children of civil professionals and military personnel. To be accepted as a student it was necessary to be within the age limits (from 9 to 14 years old), undergo an evaluation made by the director and not to be suffering from any incurable disease.

The written method of teaching was used, based on the deaf-mute teaching programs of J.J. Valade Gabel. The practical method of teaching the Portuguese language was based on the book "Lessons of Portuguese language", compiling and adapting various methods in use in the principal European institutes.

With the new regulations there was also created the discipline of articulated language for the students that were not completely deaf, but it was not offered until 1883 for the lack of a qualified professional. As the oral method was in 
fashion in Europe, the Imperial Government decided that it would send the teacher, Menezes Vieira to learn about the new techniques of teaching. On his return to Brazil, the oral method was put into practice, but without achieving satisfactory results, this discipline being extinguished in 1890 .

Up to the construction of the new building, begun in July of 1913 and concluded in 1915, the teaching was offered exclusively for the male sex. However, when the Institution was transferred to its own building, at Rua das Laranjeiras no. 95 (present 232), the admittance of women was possible, approved by decree no. 9.198, of December $12^{\text {th }}, 1911$ The dimensions of the new building, designed by thg architect Gustavo Lully, also made it possible to expand the school curriculum, making available professional technical courses, physical education and sports.

In 1951 the first regular course for the training of teachers specialized in cases of deafness was created and, after thirty years, an advanced course was established in the entity for the same purpose. The latter, presently called the Additional Studies Course, trains agents from all over the country, with the objective not only of instructing them in the education of deaf people, but also with the purpose of expanding methodological and scientific knowledge in the area.

Receiving at the present time the denomination of National Institute for the Education of the Deaf (since June $06^{\text {th }}$, 1957), it is an entity subordinate to the Ministry of Education (MEC). Since 1993, with the change in its internal regulations, it occupies the position of national reference in the educational field for deaf people. Besides this, it is involved in the socialization, training and insertion into the work market of individuals bearing this disability.

\section{Architectonic Description:}

The current building that houses the INES, which completed 150 years in 2007, replaced the former neoclassical facilities of 1881. According to Noronha Santos (apud, Rocha, 2007),

"on March $18^{\text {th }}, 1881$, the institute was transferred to a building on rua das Laranjeiras. The building had two pavements. The $1^{\text {st }}$ pavement had ten windows facing the street. The second consisted of a central structure superposed on the four windows of the $1^{\text {st }}$ pavement's center, having the same number of balcony windows. In 1891, construction work to add two lateral structures was concluded, and, in each one of them, three parapet windows were constructed."

On the other hand, the new and current headquarters, which was erected between 1913 and 1915, was designed within the architectonic eclectic movement. It is very similar to the building of the Museu Nacional de Belas Artes (National Museum of Fine Arts), especially regarding the symmetric composition of the main façade along with lateral bastions and a central structure connected by intermediary structures with balconies. The building's main access gains prominence because of a beautiful marble staircase, a clock and a dome originally covered with copper plates. The dome, french design, originated more precisely from one of the pavilions from the Louvre Museum in Paris, as well as total inspiration in French Renascence art, is also evident in both of the projects.

The opening rhythm of empty spaces adheres to the proportion 1-3-5-7, affording the project a volumetric rigor which makes it stand out from the urban scene. In the interior of the first floor, the building displays great halls. Access to the other pavements, to be used by the students, is performed by means of two lateral staircases of iron structure and marble steps. The controversy regarding this project is because of two lateral structures and a central one, belonging to a pavement, which originally housed areas of support and a cafeteria. Until today these "annexes" or "volutes" stir up doubts among employees over their year of construction, whether it was in 1915 or during the reform of 1937-42, given that the reform did create other facilities to house gymnasiums and an auditorium and second and third floors where none existed originally. Over the institution's years other buildings were bought and annexed such as the mansions which stood laterally to the main building. The Centro de Memória (Memorial Center), which houses the library and historical collection, occupies one of these mansions, and is a beautiful example of Art Nouveau, probably from the first decade of the XX century. 


\section{IMPERIAL TIMES}

\section{Register of Preservation:}

The preservation process has been requested by the Residents Association of Laranjeiras (AMAL), however, it still hasn’t been granted.

\section{Sources:}

ASSISTÊNCIA Pública e Privada no Rio de Janeiro (Brasil) - História e Estatística. Comemoração do Centenário da Independência Nacional. Rio de Janeiro: Typographia do Annuario do Brasil; 1922.

INSTITUTO NACIONAL DE EDUCAÇÃO DE SURDOS. 150 anos de História. Capturado em 05 de jun. 2007. Online. Disponível na Internet: http://www.ines.org.br/Paginas/historico.asp

LEITE, T. Notícia do Instituto dos Surdos Mudos do Rio de Janeiro. Rio de Janeiro: Typographia Universal de E. \& H. Laemmert, 1877.

ROCHA, S. O INES e a educação de surdos no Brasil. Aspectos da trajetória do Instituto Nacional de Educação de Surdos em seu percurso de 150 anos. Rio de Janeiro: MEC/INES, 2007.

Credits: Atiele Azevedo de Lima Lopes (research and text) and Renato da Gama-Rosa Costa (Architectonic Description) 


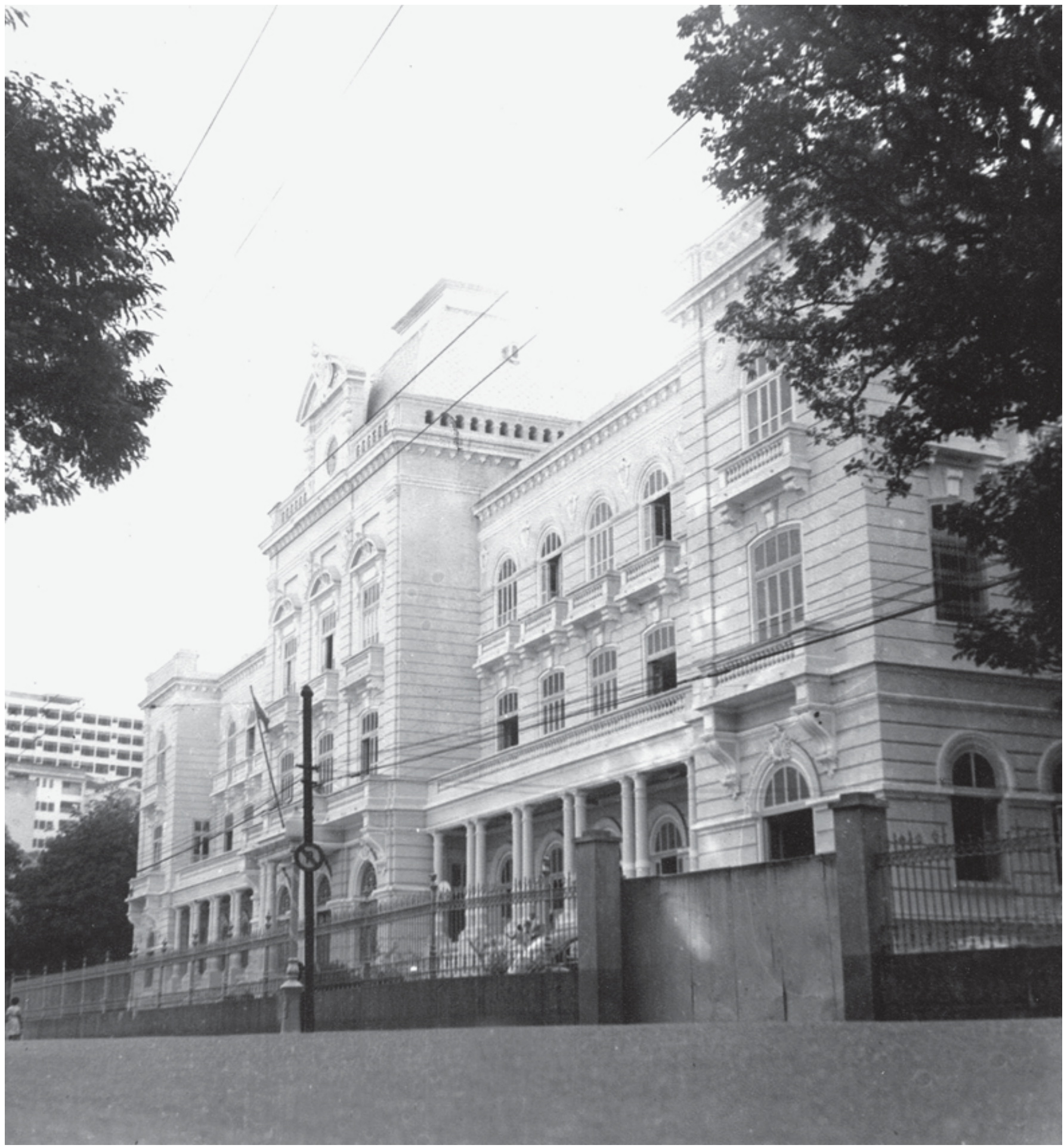

National Institute of Deaf Education, [s.d.]. INES Archives 


\section{IMPERIAL TIMES}

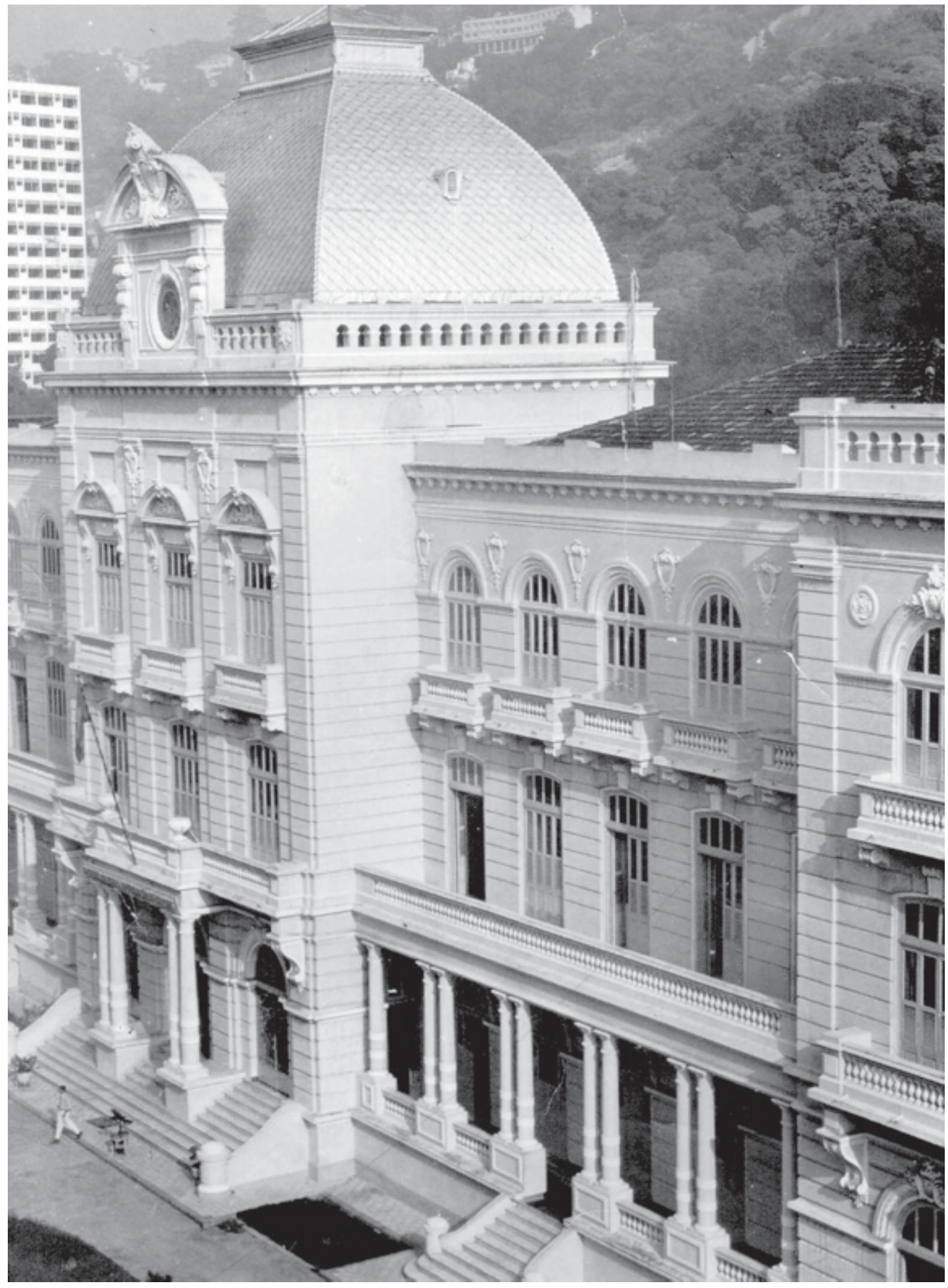

National Institute of Deaf Education - façade [s.d.]. INES Archives 


\section{Dr. Erias Hospital}

Other Denominations: Dr. Peixoto Hospital (1855-186?); Convalescença e Saúde Hospital (186?-1877); Dr. Erias Hospital (1877-)

Location: Botafogo

Address: Rua Assunção, $\mathrm{n}^{\circ} 2$.

Denomination: Dr. Erias Hospital

Period of Construction: XIX ${ }^{\text {th }}$ Century

Proprietor: Palais d'Olinda Condominium

Author / Constructor: unknown

\section{History:}

On August $8^{\text {th }}, 1840$, the Doctor in surgery from the Faculté de Médecine of Montpellier and medicine from the Faculté de Médecine of Paris, Antônio José Peixoto (1816-1864), delivered a Representation to Emperor D. Pedro II with a project for a Hospital following the European model. In such document he justified his proposal as follows: "Your Excellence - The insufficiency of the only hospital, which exists in this Royal Court to shelter the sick in need which solicit the philanthropic generosity of the Government, well recognized of Your Imperial Majesty, excused is to show circumstantially the need and utility of a Hospital similar to Maison Royale de Santé, of Paris, where can be admitted, not only the people which the Government deems convenient to treat, but those which, lacking adequate means, are unable to treat themselves in private hospitals, and are rejected from admittance in hospitals of charity."

Along with such document, Antônio José Peixoto presented a contract proposal, in which he affirmed the intention of establishing, within a year, a Hospital denominated "Imperial Hospital and Orthopedic Gymnastics Institute" with 100 hospital beds, of which 12 would be dedicated to the treatment of vertebral column, legs, arms, etc. illnesses, and making available a great hall with gymnastics equipment, and an amphitheater for 50 people, where courses of surgical clinic and operations medicine would be offered and operations would be performed on patients of that Hospital.

According to Achilles Ribeiro de Araújo, this proposal was delivered by the Emperor to the Imperial Academy of Medicine for analysis. The Academy nominated a commission composed of members from that association for the elaboration of an opinion in respect to the proposal. It was discussed in the session of April $1^{\text {st }}, 1841$, and its content published in Revista Médica Brasileira (tome X, p.96, 1841-1842). The commission approved the proposal, only recommending alterations in the number of doctors at the establishment, and suggesting that Antônio José Peixoto bring from Europe a competent professor in the art of orthopedics. In relation to the courses which he intended to perform in such establishment, the opinion of the commission affirmed that this initiative would violate the act promulgated in 1832, which regulated the medical teaching in the country. On April $29^{\text {th }}, 1841$, the proposal was once again debated at the Imperial Academy of Medicine, stirring great controversy between the debaters, and the final opinion was to reject the proposal of the creation of such hospital.

In 1843, Antônio José Peixoto obtained success in another one of his projects, Dr. Peixoto Hospital, established in a property at the Alto do Morro do Forno do Cal, in the district of Gamboa, which was a precursor in the service of orthopedics in Brazil. Considered as the first Hospital in the city of Rio de Janeiro, Dr. Peixoto Hospital was installed in two buildings, with various annexes, and became known as the "Yellow House" in reference to its yellow color. During the first years of operations, Dr. Peixoto Hospital hospitalized almost solely the transient ill, traveling salespersons, ambulant merchants and mariners, and people affected by non-surgical illnesses, such as yellow fever. It underwent reforms between 1848 and 1849, which provided it with a greater number of beds for hospitalizations, promoted an improvement in the rendering of services and conferred upon the establishment an honorary distinction, the title of 
"Maison de Santé de la Marine Française". On November 15 ${ }^{\text {th }}, 1852$ the Chief Commander of the French Naval Base in Brazil and Rio da Prata, Rear Admiral of Suin, conferred upon the establishment the title of "Hôpital de la Marine Française". At this time, among some of the changes which occurred at the Hospital, stand out the creation of the religious assistance service, the permission to hospitalize slaves, the supplying of clothes and laundry and the authorization of paying for costs with foreign currency. In the second half of the XIX century, José Clemente Pereira, then Head of the Santa Casa da Misericórdia of Rio de Janeiro, suggested to the Central Commission of Health, the expropriation of the Dr. Peixoto Hospital, so that in its place could be installed an emergency infirmary to combat epidemics. On 04/27/1853, the Head of the Santa Casa acquired from Dr. Peixoto the improvements, pharmacy, surgical arsenal, furniture, 4 slaves, and on 07/ 02/1853 the Hospital was already a dependency of the Santa Casa under the name Infirmary of Gamboa.

Antônio José Peixoto, after the sale of his establishment, traveled to Europe for retreat and to study, however with the goal that upon returning he would inaugurate another Hospital. With this in mind, upon traveling he authorized Jules Boquet, by means of a power of attorney, to purchase a small farm, with an ample building and annexes, located at Rua da Olinda no. 2, in Botafogo, which belonged to the Marquis of Olinda. In Europe, he acquired a new surgical instrument, and upon returning to the country the new Hospital was undergoing adaptations, however it began operations in January, 1855.

This new Hospital, which retained the title "Hôpital de la Marine Française" that had been conferred previously to the other establishment, was equipped with more comfortable facilities than the previous one and also had a Hydrotherapy Establishment in annex. In spite of the improvements in the establishment, its financial situation was declining, and in 1864, with the worsening of Antônio José Peixoto's health, he handed over the direction of the Hospital to Pedro Autran da Matta e Albuquerque Filho, his collaborator at the time. Later, at the end of 1865, the Hospital on Rua da Olinda was acquired by Manoel Joaquim Fernandes Eiras (1828-1889), a general physician who later dedicated himself to otorhinolaryngology and became denominated Dr. Eiras. Hospital

Worth mentioning that Manoel Joaquim Eiras was a renowned clinician established in the Royal Court, and had been the owner of two clinics - Nossa Senhora da Ajuda Hospital located at Rua da Ajuda no. 66 and 68 and the Imperial Hospital and Operations Medicine at Praia de Botafogo no. 26 - prior to acquiring Dr. Peixoto Hospital

For a brief period, Dr. Eiras Hospital became known as Convalescença e Saúde Hospital and on its ads used to add the former title Peixoto Hospital which was only removed in 1877. Since it was acquired by Dr. Eiras, the hospital had specialized in the treatment of the mentally ill and the direction was the responsibility of its proprietors: from 1865 to 1889, the very own Manoel Joaquim Fernandes Eiras; from 1889 to 1920, his son Carlos Eiras; from 1920 to 1940 Waldemar Schiller, a psychiatrist who had already collaborated with the establishment prior to becoming its proprietor, succeeded by his son, Maurício Schiller until 1943; from 1943 to 1986, Leonel Tavares Miranda de Albuquerque, who was a representative of the group of doctors which acquired the Hospital and, finally, his son Carlos Gross Miranda, in 1991, its last director.

Still, at the end of XIX century, an enlargement and modernization process begins at the facilities of the Dr. Eiras Hospital to satisfy the increasing demand for hospitalizations in the treatment of psychiatric patients. In 1889, the Santana, Santa Clarice and N.S. das Graças Pavilions of Medical Clinic (with a primitive pharmacy) are built next to the Olinda Chalet. Reference to catholic saints in the pavilions was a result of the presence of the nuns of the Daughters of Santana order, who dedicated themselves to the care of patients.

In the 1950's, it undergoes profound modification in the physical structure and health care area, under the command of Doctor Leonel Tavares Miranda de Albuquerque. The project by the architect Oscar Niemeyer designs and builds the following: the Santa Tereza Pavilion, with ten floors, dedicated for male patients; the N.S. de Fátima Pavilion, with five floors, for the rendering of services to female patients; and, later, the São José Pavilion, thus complementing this hospital complex. Expansions and modernization of the Hospital facilities were necessary as a result of the innumerous accords which increased the demand for medical and hospital services. In 1962, also aiming to cater to the demand, Dr. Eiras Hospital is created in the state municipality of Paracambi.

The shutting down of the centenary institution due to financial problems at the end of the 1990's, resulted in the sale of the property to a Real Estate Company which is building a luxury condominium of 10 buildings in the lot, where the Olinda Chalet, the only endowed real estate, will be part of the social area of the Condominium. 


\section{IMPERIAL TIMES}

\section{Architectonic Description:}

The Olinda Chalet, built to be the residence of the Marquis of Olinda, presents an eclectic architectonic complex following the French romantic model, much adored at the time, and is composed of: a central body with two pavements and flanked by buildings with one pavement, its façade with beautiful windows and balconies complement its style, and in the front a garden with symmetric walkways, following the French model.

The architectonic complex of the Dr. Eiras Hospital encompasses: the older part, composed of the Olinda Chalet and Santana Pavilion and the new part, composed of the Santa Tereza, N.S. de Fátima and São José Pavilions, encompassing a developed area of $18.000 \mathrm{~m}^{2}$, within a property of $42.000 \mathrm{~m}^{2}$, which it still retains in Morro Mundo Novo. The older part of this complex was temporarily endowed by City Hall of the City of Rio de Janeiro on September $30^{\text {th }}, 1967$ by means of decree no. 6.934; the procedure compliments the Chalet, describing the beautiful works of stonecutting and metalworking, the central door in full arch and the windows in low arch, which yields great beauty to the whole of its façade, the construction is characterized as romantic in taste, with three pavements, whose internal access, completely modified to service the conditions of a hospital establishment, is done by a staircase or elevator; decorative architectonic elements on the façade complement this historic building. There is nothing relevant recognized in the Santana Pavilion. On October $30^{\text {th }}, 1993$, by means of decree no. 12.224 , the definitive endowment, only considers the Olinda Chalet as a building of historical value.

\section{Register of Preservation:}

Preserved by the City Hall of Rio de Janeiro, on October $30^{\text {th }}$, 1993. Decree no. 12224.

\section{Sources:}

ARAÚJO, A. Da enjeitada Imperial Casa de Saúde e Instituto Ginástico Ortopédico do Doutor Antonio José Peixoto à Primeira Casa de Saúde do Rio de Janeiro. In: Anais do Congresso de História do Segundo Reinado. Comissão de História Científica, 1975. v.1. Rio de Janeiro: IHGB, 1984. p.7-58.

Casa de Saúde Dr. Eiras. Acessado em 20 de jul. 2007. Online. Disponível na Internet: http://www.hmattos.kit.net/ historiadacasadesaude.html

Universidade de Chicago. Acessado em 20 de jul. 2007. Online. Disponível na Internet: http://www.crl.edu/content/ pindex.htm

Credits: Maria Elizabeth Bueno de Godoy (research and architectonic description), Ângela Porto and Maria Rachel Fróes da Fonseca (text). 


\section{Frei Antônio Hospital}

Other denominations: São Cristóvão Lazars' Hospital (1741 - 1823); Imperial Lazars' Hospital (1823 - 1889); Lazars' Hospital (1832 - 1941); Frei Antônio Hospital (1941 - present day).

Location: São Cristóvão

Address: Rua São Cristóvão, No. 870

Category: Assistance Institution

Period of construction: [1840]

Proprietor: Brotherhood of the Holiest Sacrament of Our Lady of Candelária

Author / Construction: unknown

\section{History:}

The Lázaros Hospital was created by initiative of the General Governor of Rio de Janeiro Gomes Freire de Andrade (Count of Bobadella) in 1741, in the hillside of a hill in the neighborhood of São Cristóvão, in lands belonging to the Company of Jesus. Its intent was to collect some people taken ill with Hansen's disease (leprosy) who wandered about the city with without any care or hygiene and place them under the care of nurses (Franciscan friars of Santo Antônio), aided by slaves arrested for grave crime, configuring a modest assistance service.

After the death of Gomes Freire, the lepers were delivered to state of total abandonment, living in precarious conditions, since it was the General Governor who watched over the Hospital's maintenance. In 1763, by request of the Bishop Dom Friar Antônio do Desterro, a member of the triumvirate which took over the Government of Rio de Janeiro, this encumbrance became the responsibility of the Brotherhood of the Candelária annexed to the Holiest Sacrament of the Parish of Candelária.

Dom Antônio, inquisitor of the Jesuits expelled from Brazil in 1759, pleaded with the vice-roy Francisco Xavier de Mendonça Furtado (Count of Cunha) to intercede before the King of Portugal for the transfer of the lepers to the House of Jesuits, probably built between 1748 e 1752 and already confiscated by the Portuguese Crown due to the inadequacy of the facilities they were submitted to. This request was conjugated to the Resolution of August $27^{\text {th }}, 1760$, which authorized the Municipal Chamber of Rio de Janeiro to establish a lazaretto for the people afflicted with Hansen's disease (leprosy), named St. Lazarus.

Once the request was accepted, the Hospital was delivered to the lazars - as the carriers of this disease were called - on January $31^{\text {st }}, 1765$ by order of the Court of Lisbon. The entity obtained a regulation dated February $17^{\text {th }}, 1766$, put into execution on March $13^{\text {th }}$ next. From this year, the Brotherhood of Candelária carried out reformations in the building, putting its entrance at the (square) Praça dos Lázaros (present Praça Mario Nazareth). It had at the time 6 infirmaries with 60 beds, which maintenance came from a new tax, collected by the Brotherhood itself in the parishes.

In 1808, with the coming of the Portuguese Royal Family to Rio de Janeiro, the Lazars' Hospital received the initials "P.R." (Royal Property), being expropriated.

In the subsequent decades, the Brotherhood's administration is contested several times, due to the inconstancy and insufficiency of its cares for the lepers. On account of this fact, in 1814, the Prince of Beira (son of D. João VI), appoints a superintendent to inspect the Hospital's management, a situation which extends until the end of the XIX century.

By the ministerial decree of October $03^{\text {rd }}, 1817$ the lazars were transferred to the Isle of Enxadas, to be give room to a military troop coming from Portugal. By order of D. Pedro I, on February $03^{\text {rd }}, 1823$, they were transferred to the Isle of Bom Jesus (Frades). And by virtue of the decree of August $25^{\text {th }}, 1832$, the restitution of the Imperial Hospital to the Lazars was authorized, which would undergo reformations and expansions to receive them again. 


\section{IMPERIAL TIMES}

Up to then, the Hospital was maintained by alms from families residing in the city, established by criteria of financial situation, provisioned by regulation. Later, it started to receive a monthly pension from the government, from the Law of October $24^{\text {th }}, 1832$.

After the Proclamation of the Republic in 1889, the Brotherhood of Candelária is exempt of rendering accounts to the Public Treasury, as a result from the separation between the Church and the State, undertaking exclusively the administration of the Lazars' Hospital, without any official interventions.

The end of the XIX century inaugurates a period $\mathrm{f}$ intense reformations in the Hospital, seeking to transform it into a de facto hospital establishment, seen that many premises still maintained traces of a religious institution. From 1893, when the Bench Room is created for investigating the cases suspected of this disease, the Hospital starts to count with an experimental laboratory, library, laundry and steam greenhouse, a new mess hall and a hydrotherapeutic cabinet. In 1900, an Isolation Hospital is built in an annex, named Santo Otávio, destined to the infectious-contagious diseases.

In 1914, the Hospital purveyor's office is passed to the hands of the engineer Mário da Silva Nazareth, who initiates a propitious period of improvements in the institutions, transforming it in a reference of hygiene in hospital establishments. In the following administration, in 1924, the nursing services of the sisters of São Vicente de Paulo are introduced, used for more than sixty years in the Hospital.

In homage to the two hundred years of the Hospital, in 1941, its denomination was changed to Friar Antônio Hospital, remitting to Dom Friar Antônio do Desterro, responsible for installing the lepers in this location.

In 1947, the Friar Antônio Hospital worked as core of systematic studies about leprosy, by means of a covenant entered into between the National Leprosy Service and the Brotherhood of the Holiest Sacrament of Candelária. In 1952, the head office pavilion of the Leprology Institute of said Service was inaugurated, which worked annexed to the Hospital until 1976, when it was taken over by the Oswaldo Cruz Institute.

The Friar Antônio Hospital currently works at the same address, conserving its centenary internal relics, such as tiles, ironwork, timber in ashlars, furniture and laundry equipment from the beginning of the XX century. Follow the few interns at the care of the Brotherhood of the Holiest Sacrament of Candelária.

\section{Architectural Description:}

The institution works in an eclectic story house, with the implementation in the center of a terrain with landscaping treated as a romantic garden (1881). The edification presents a composition with a central body in relief and two lateral wings slightly receded.

The original architectural party followed the principles of the therapeutic hospital - maintenance of the separation and exclusion structure with no preventive worry or the notion of visit and systematic observation (1766-1892); the successive changes from the second half of the XIX century suggest the engagement with the "pavilion hospital" ideology - old cells are transformed into halls-infirmaries, creation of the isolated doctor's office for examination of the suspected cases of leprosy, rationalization of the hygiene and circulation system and the construction of an isolation hospital in the same terrain with two infirmaries for the contagious cases, the Santo Otávio Hospital - (1892-2007).

On the course of its existence, the hospital edification program had, in addition to the infirmaries, a central chapel, a mortuary chapel, bath house, library, laundry, greenhouse for disinfecting clothing, mess hall, hydrotherapeutic cabin, cinema and theater.

\section{Notes:}

The project of the chapel of St. Peter, today St. Lazarus, is attributed to the Jesuits Friar Inácio da Silva and Brother Francisco do Rêgo de Caminha. 


\section{IMPERIAL TIMES}

\section{Register of Preservation:}

Listed as a historical site by the Municipality on January 10 1985.

\section{Sources:}

DOCUMENTOS relativos à fundação do Hospital dos Lázaros do Rio de Janeiro. Revista Trimestral do Instituto Histórico, Geográfico e Ethnographico do Brasil, Rio de Janeiro, tomo XXIII, primeiro trimestre, vol. 23, 1860. pp. 431-438.

GUIA do Acervo da Casa de Oswaldo Cruz. Seção Departamento de Medicina Tropical. Capturado em 23 de ago. 2007. Online. Disponível na Internet: http://www.coc.fiocruz.br/areas/dad/guia_acervo/arq_institucional/fundo_ioc_tropical.htm

PORTO, A.; OLIVEIRA, B. Edifício colonial construído pelos jesuítas é Lazareto desde 1752 no Rio de Janeiro. Revista História, Ciências, Saúde: Manguinhos, Rio de Janeiro, vol. 2, nº 3, fev. 1996, pp. 171-174.

RELATÓRIO do Imperial Hospital dos Lázaros apresentado pelo escrivão João Antonio da silva Guimarães por ocasião da posse da nova administração em março de 1874. Rio de Janeiro: Typographia Americana, 1874.

Credits: Atiele Azevedo de Lima Lopes (research and text) and Inês El-Jaick Andrade (architectural description). 


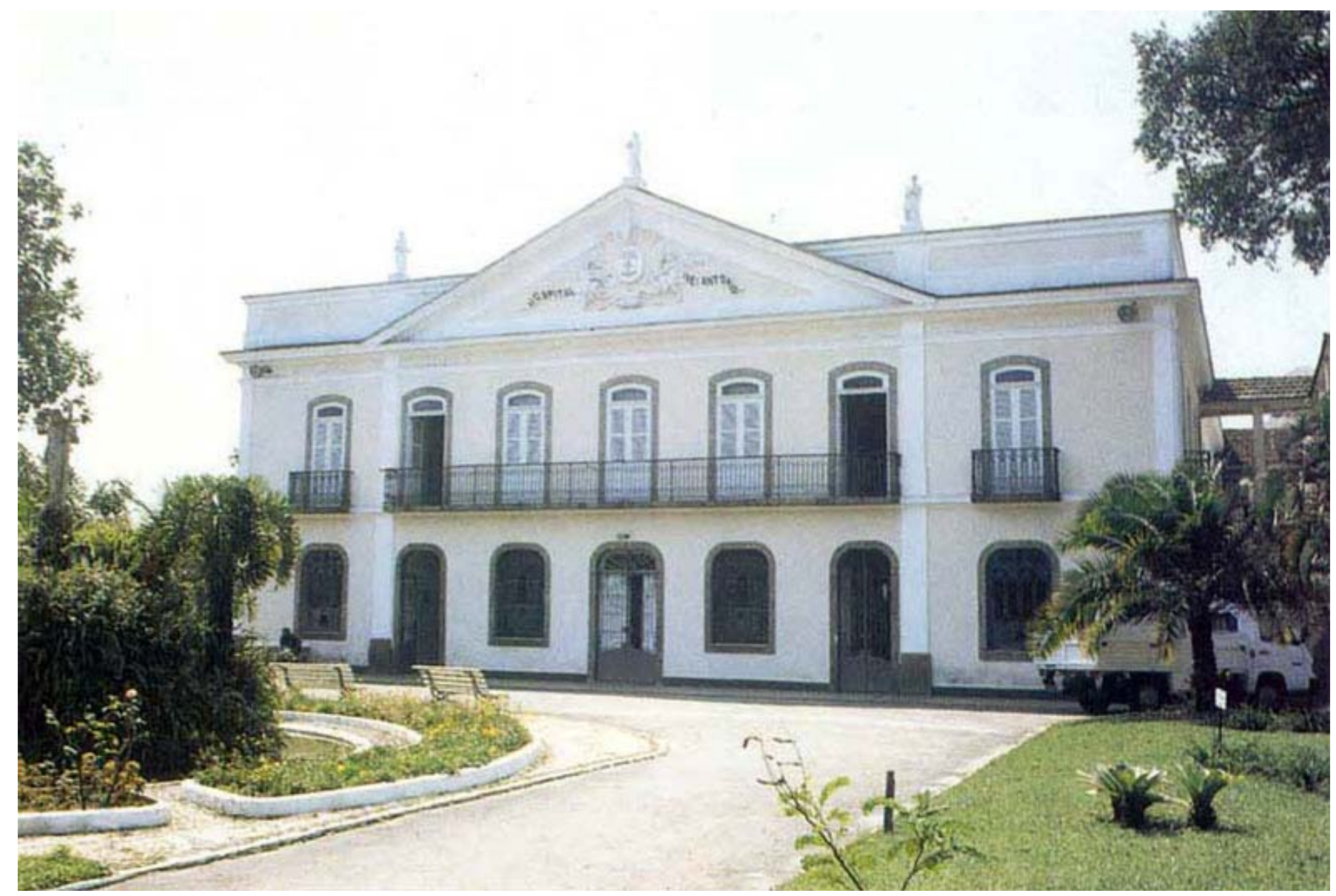

Frei Antônio Hospital, 1996. Photo Nelson Rivera Monteiro. Source: Porto \& Oliveira. 1996

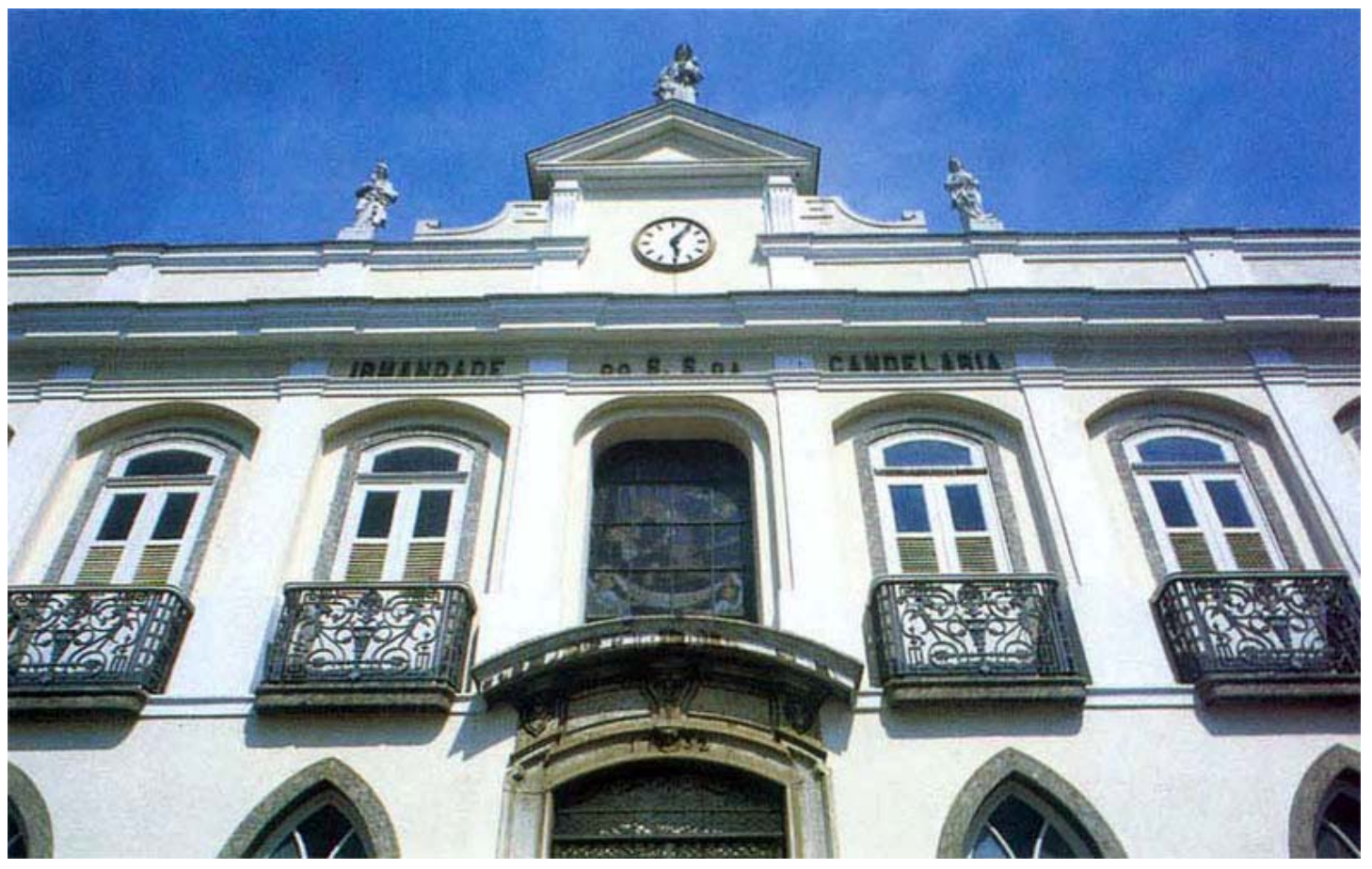

Frei Antônio Hospital, 1996. Photo Nelson Rivera Monteiro. Source: Porto \& Oliveira. 1996 


\section{General Polyclinic of Rio de Janeiro}

Location: Castelo

Address: Avenida Nilo Peçanha, no. 38.

Category: Health Care Institution

Period of construction: 1939

Proprietor: General Polyclinic of Rio de Janeiro.

Author / Constructor: Luiz Moraes Jr. (Av. Central building); unknown (current).

History:

The emergence of the General Polyclinic of Rio de Janeiro is closely related to the trajectory of Doctor Carlos Arthur Moncorvo de Figueiredo, who fought, at the end of the $19^{\text {th }}$ century for the improvement of scientific theory and practice of pediatrics. For that, he defended the establishment of an institution which merged education/research and health care, contemplating their social aspects bringing together students, professionals and population. After being aired by the magazine União Médica, the idea was embraced by a group of doctors (among them João Pizarro Gabizzo, Antônio Loureiro de Sampaio) and supported by the Imperial Government and by benefactor partners (traders, landlords, politicians), who guaranteed the financial health and the institutional development of the entity.

Founded on December $10^{\text {th }}, 1881$, the General Polyclinic of Rio de Janeiro received by assignment, the ground floor of the building of the Public Instruction Department, former building of the Public Archive, located at Rua dos Ourives, no. 1 (currently Miguel Couto and Rodrigo Silva). In the following year, the institution would be officially considered philanthropic as from the approval of its bylaws, which determined the undertaking of providing free health care to the population in need. Furthermore, its main purpose was to treat the diseased in their residence, as a way of avoiding the contamination to which the patient is exposed in hospital facilities.

With the presence of Emperor D. Pedro II, it started its activities on August $1^{\text {st }}, 1882$ with an inaugural class administered by Carlos Arthur Moncorvo de Figueiredo, considered the first class on pediatrics on record in Brazil.

At the time of its foundation the Polyclinic had the following services: Intertropical Pathology (Julio Rodrigues de Moura and Francisco Borges de Souza Dantas); Pneumocardiopathology (Henrique Carlos da Rocha Lima); Nervous System Diseases (Domingos de Almeida Martins Costa and João Carlos Teixeira Brandão); Surgical Practice (Pedro Severiano de Magalhães); Ophthalmology (José Cardoso de Moura Brasil); Gynecology (José Rodrigues dos Santos and Carlos Pires Ramos); Odontology, Laryngology and Rhinology (Cipriano Barbosa Bettamio); Syphilitic Diseases and of the Epidermis (Antonio José Pereira da Silva Araújo); Children's Diseases (Carlos Artur Moncorvo de Figueiredo); and the Laboratory of Medical Analysis, under responsibility of the chemist José Pereira Lopes.

In 1904, in the course of processes of urban reforms in the city of Rio de Janeiro, the director of the Polyclinic at the time, José Cardoso de Moura Brazil, obtained from the Federal Government the assignment of an area of land at the newly inaugurated Avenida Central (currently Avenida Rio Branco) no. 167/171, for the construction of its own headquarters for the first time. The construction works continued until 1909, when on February $10^{\text {th }}$ the new building was inaugurated, with the design of the engineer-architect Luiz Moraes Junior.

In 1934, due to transformations in the urbanistic plan of the city, once again the General Polyclinic of Rio de Janeiro had to change its address. An exchange of the land occupied by the headquarters for other land located at Avenida Nilo Peçanha was agreed to with the Federal Government. This new undertaking had its cornerstone laid on February $14^{\text {th }}$, 1937 and was inaugurated in January, 1939 by the director Gabriel de Andrade. With 13 floors, the occupation of the new headquarters permitted a significant increase of services and a greater utilization of the physical space to develop the areas of research and medical instruction.

Over a period of almost 30 years, the General Polyclinic of Rio de Janeiro was declared as an institution of public utility at the three governmental levels: State (law no. 752, of 01/28/1965); Federal (decree no. 68,497, of 04/12/1971) and Municipal (law no. 2,223, of 10/07/1994). 


\section{IMPERIAL TIMES}

On April $5^{\text {th }}, 1976$, the Polyclinic obtained under the scheme of a lease, the donation of the land at Avenida Nilo Peçanha no. 38, due to decree no. 77,381.

Having private management under municipal administration, it still operates as a beneficent entity and continues the clinic service for the various surgical medical specializations. In parallel with its assistance program, it regularly holds post-graduation courses in its facilities.

\section{Architectonic Description:}

Since 1902, the Deliberative Council of the Polyclinic discussed the need to offer better facilities to serve the increasing number of patients in its out-patient departments. The first idea would be to reform the old building at Rua dos Ourives. In 1904, Luiz Moraes Jr. was asked to take part in the discussions, invited by Salles Guerra and certainly indicated by Oswaldo Cruz - responsible for the bacteriological exams of the Polyclinic - and who by that time had already begun the projects for Manguinhos, under the responsibility of the engineer-architect. Actually, Moraes managed to convince the Council to construct a new headquarters. The construction works began on August $10^{\text {th }}$ of the same year. Between 1908 and 1909 the building received the finishing touches and ornamentation, the installation of equipment and electric and hydraulic systems.

The Polyclinic was transferred to the new headquarters on February $10^{\text {th }}, 1909$, with construction works still in progress. The building occupied three numbers of Avenida Central (nos. 167, 169 and 171), and half a block between the streets, São José and Ajuda. The architectonic language was inspired by the German renascence, exploring classic elements, such as frontages above the windows of the main corner and the double row of columns that surpassed the two intermediary pavements. The prominence of its architecture was directed to the internal yard, which had a polygonal shape and facilitated the ventilation and lightening adequate to clinics and laboratories and to corners. To delimit them, Moraes used elegant mansards on the cover. At the façade of the ground floor facing the Avenue, the Polyclinic opened commercial establishments, which was a solution common to other buildings.

With the move to Avenida Nilo Peçanha, the entity came to have a building with 13 floors, inserted in blocks, following the urbanistic logic proposed by the alignment project of the French Donat-Alfred Agache (1927), without great architectonic qualities.

\section{Register of Preservation:}

It is not listed.

\section{Sources:}

ANNAES da Policlínica Geral do Rio de Janeiro, Rio de Janeiro: Imprensa Nacional, ano I, $\mathrm{n}^{\circ}$ 1, mai., 1916.

ARAÚJo, A. Policlínica Geral do Rio de Janeiro. Discurso inaugural proferido no dia 28 de junho de 1882. Rio de Janeiro: Imprensa Industrial, $2^{\mathrm{a}}$ ed., 1882.

ASSISTÊNCIA Pública e Privada no Rio de Janeiro (Brasil) - História e Estatística. Comemoração do Centenário da Independência Nacional. Rio de Janeiro: Typographia do Annuario do Brasil, 1922.

CINQÜENTA anos ininterruptos de reuniões semanais na Clínica de Reumatologia da Policlínica Geral do Rio de Janeiro. Boletim da Sociedade de Reumatologia do Rio de Janeiro, Rio de Janeiro, vol. 30, nº 103, jan.-mar., 2002. p. 23. Capturado em 12 de mai. 2006. Online. Disponível na Internet: http://www.reumatorj.com.br/boletim/bol103.pdf

FUNDAÇÃO LEGIÃO BRASILEIRA DE ASSISTÊNCIA. Policlínica Geral do Rio de Janeiro. Memória da Assistência Social 5. Rio de Janeiro: Fundação Legião Brasileira de Assistência, 1980.

O ÁLBUM da Avenida Central. São Paulo: Editora Ex-libris, 1983.

POLICLÍNICA Geral do Rio de Janeiro, Annuario Médico Brasileiro, Rio de Janeiro: Imprensa a vapor H. Lombaerts \& Cia, ano II $-1887,1888$. 


\section{IMPERIAL TIMES}

POLICLÍNICA Geral do Rio de Janeiro, Archivos Brasileiros de Medicina, Rio de Janeiro, ano X, 1920.

VALVERDE, B. (org.). Cinqüentenário da Policlínica Geral do Rio de Janeiro. Rio de Janeiro: Imprensa Nacional, 1932.

Credits: Atiele Lopes (research and text) and Renato da Gama-Rosa Costa (architectonic description). 


\section{IMPERIAL TIMES}

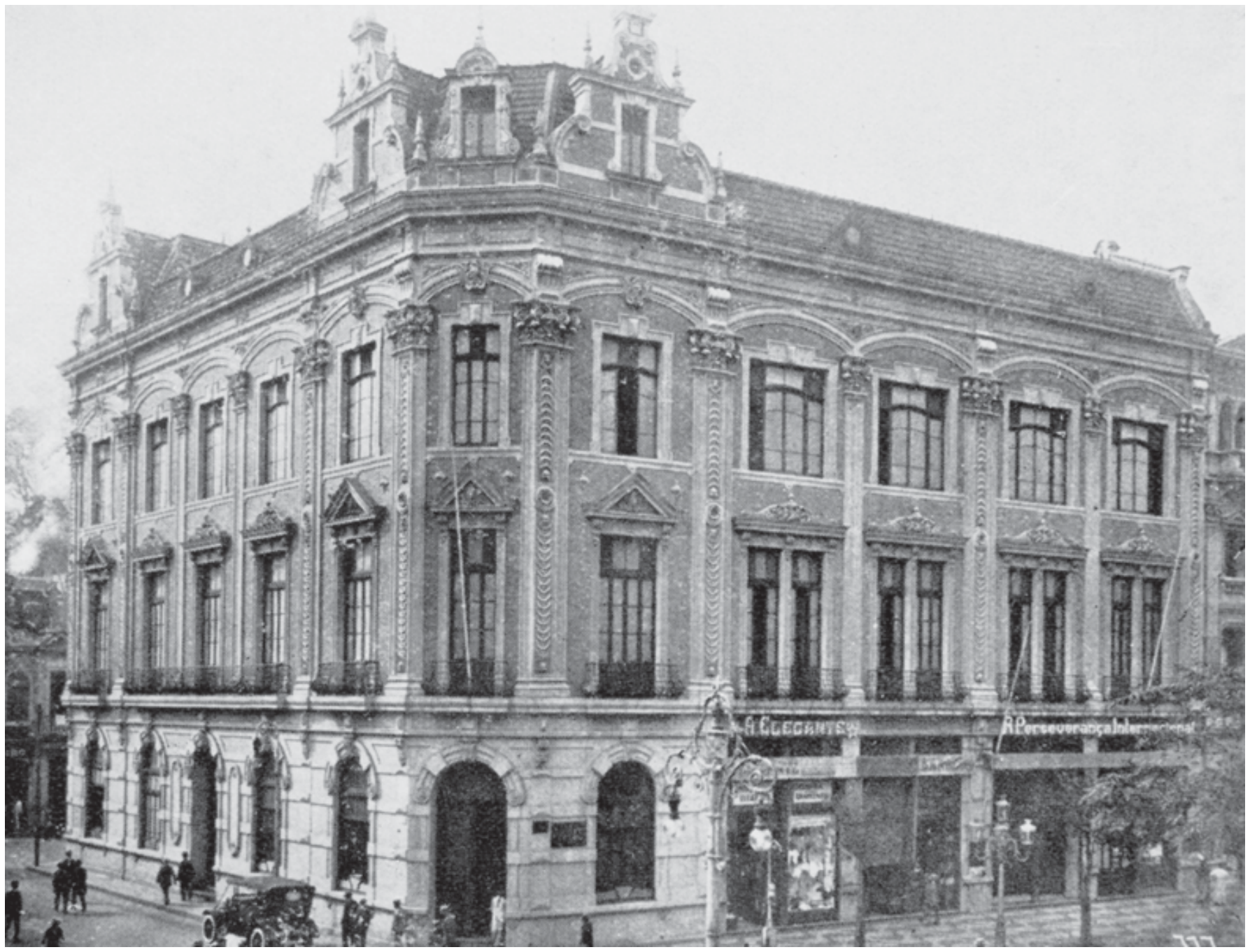

Rio de Janeiro General Polyclinic, [s.d]. Source: Assistência, 1922 


\section{Hahnemanniano Institute Of Brazil}

Location: Downtown

Address: R. Frei Caneca, 940

Category: Institution of education and medical assistance

Period of construction: decade of 1950

Proprietor: Hahnemanniano Institute of Brazil

Author / Constructor: Octávio Reis Cantanhede Almeida (engineer)

\section{History:}

The Hahnemanniano Institute of Brazil (IHB), located at 94 Rua Frei Caneca, recognizes 1859 as the date of its creation. However, for many authors, the IHB founded in 1859 should not be mistaken with its homonymous which "still exists today" and was created in 1880. According to such authors, the first had an ephemeral existence and was marked by dissidence among its members. Part of the dissidents reassembled, sometime between 1875 and 1876, and created the Hahnemanniano Fluminense Institute, changing its name to Hanemanniano Institute of Brazil in 1880. As an official symbol of the entity, the Institute adopts the emblem of the former Homeopathic Institute of Brazil, founded by the introducer of homeopathic medicine in Brazil, Frenchman Benoît Mure, in 1843. The emblem consists of a figure of a cacique over a region of land which represents Brazil, grasping a cross, symbol of the faith propagated all over the Brazilian territory and, in the background, Hahnemann's eagle with Galen's serpent in its beak. This symbol remains until today. IHB seems to have always searched, in the past as well as in the present, for a more remote origin which would grant it ballast.

The institution was created with the purpose to promote the propagation of the medical doctrine founded by Hahnemann, homeopathy. The means to be used to divulge the doctrine were a newspaper and the establishment of a school. The first entity of divulgence was the Annaes de Medicina Homeopathica, publication which began in 1882. In spite of the irregular circulation, IHB never stopped maintaining a periodical. Today, Revista Homeopatia Brasileira is dedicated to the divulgence of the scientific material on homeopathy, in the areas of medicine, pharmacy, veterinary medicine and odontology.

In reference to the teaching of homeopathic medicine, since 1881, the Institute submitted a requirement to the Imperial Government soliciting the creation of two chairs - clinic and homeopathic medical material - at the College of Medicine of Rio de Janeiro, however, without any success. Only in 1912, Hahnemanniana College is created, and Dr. Licínio Cardoso is elected its director, and also director of IHB. The name Hahnemanniana College was used from 1912 to 1924 when it became known as the School of Medicine and Surgery of IHB. Today, homeopathy instruction is under the responsibility of the Federal University of the State of Rio de Janeiro (UNIRIO), under the auspices of IHB on Rua Frei Caneca.

During the administration of Licínio Cardoso, considered the golden period of homeopathy, IHB receives by Decree 11.473 of March $3^{\text {rd }}, 1915$, the property on Rua Frei Caneca, which had belonged to the Baron of Vista Alegre, where it still remains today. In the same year, the Pharmacy was inaugurated under the directorship of Dr. João Vicente de Souza Martins.

In 1916, Hahnemanniano Hospital was installed in the building which had been the small palace of the Baron of Vista Alegre. The Hospital had as director Dr. Theodoro Gomes and probably functioned there until the demolishment of the buildings and construction of the current IHB building. Octávio Reis Cantanhede Almeida was the engineer responsible for the construction, as evident in Proceeding 3085 approved on May $5^{\text {th }}, 1951$.

There is no registration of the dates on the conclusion of activities of Hahnemanniana Hospital and Pharmacy. The current Pharmacy was inaugurated on April 10 ${ }^{\text {th }}, 1992$, which is the birth date of Hahnemann, under the presidency of Prof. Alfredo Eugenio Vervloet. 


\section{IMPERIAL TIMES}

Today, the IHB building houses the Pharmacy School Prof. José Barros da Silva, and the Polyclinic School Dr. Kamil Curi, in addition to undergraduate courses and specialization in homeopathy. The polyclinic has medical and odontology service on location and renders veterinary service at the Municipal Institute of Veterinary Medicine Jorge Vaitsmann, in São Cristóvão, and/or of large animals, at the Veterinary Hospital of the Rural Federal University of Rio de Janeiro (Seropédica).

\section{Register of Preservation:}

It is not listed.

\section{Sources:}

Credits: Ângela Pôrto (research and text) 


\section{IMPERIAL TIMES}
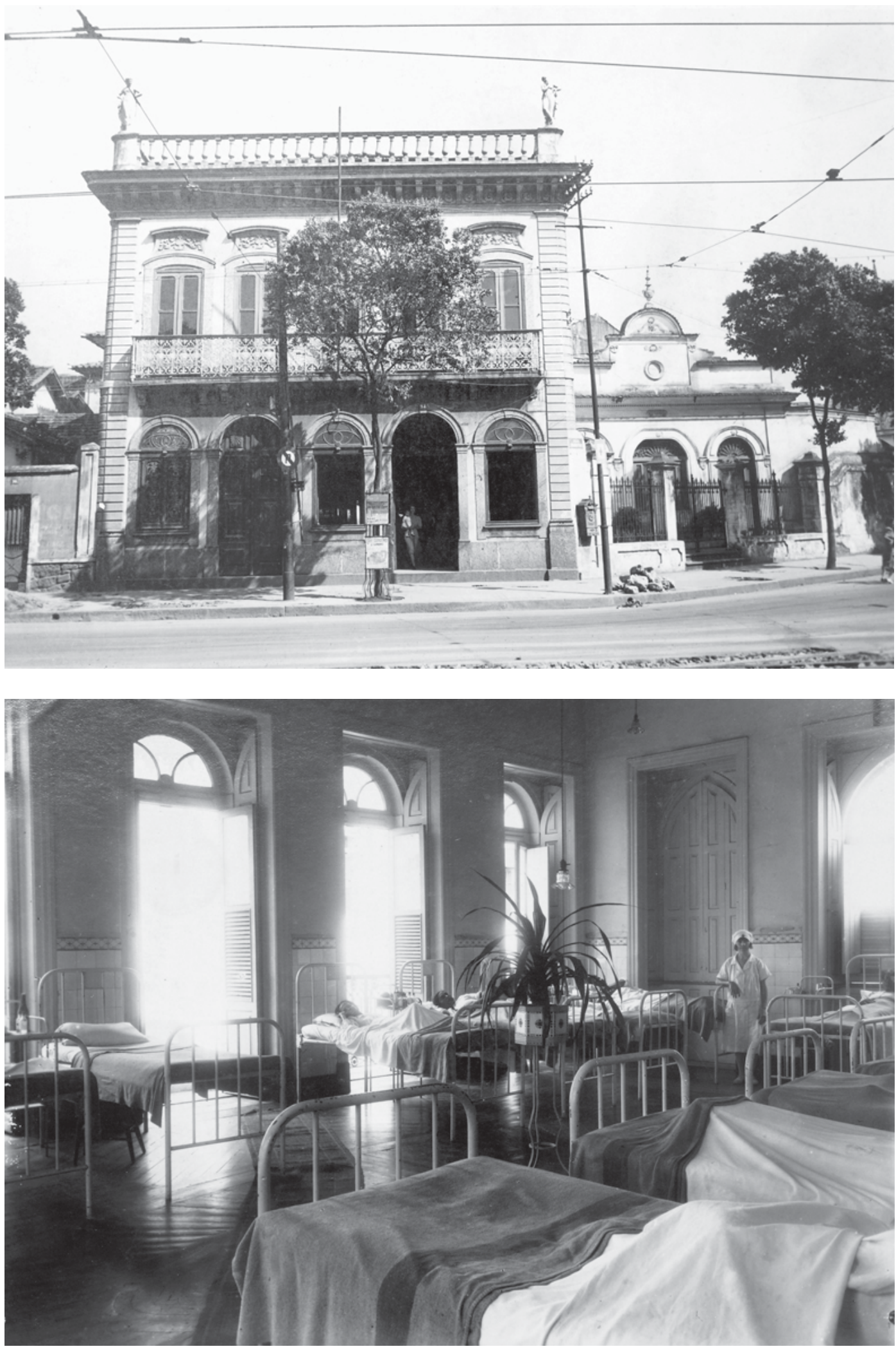

First building of

Hahnemannian Institute of Brazil. [s.d.]. Instituto Hahnemanniano do Brasil Archives

mannian Institute of Brazil - infirmary. [s.d.].

Instituto Hahnemanniano do Brasil Archives 


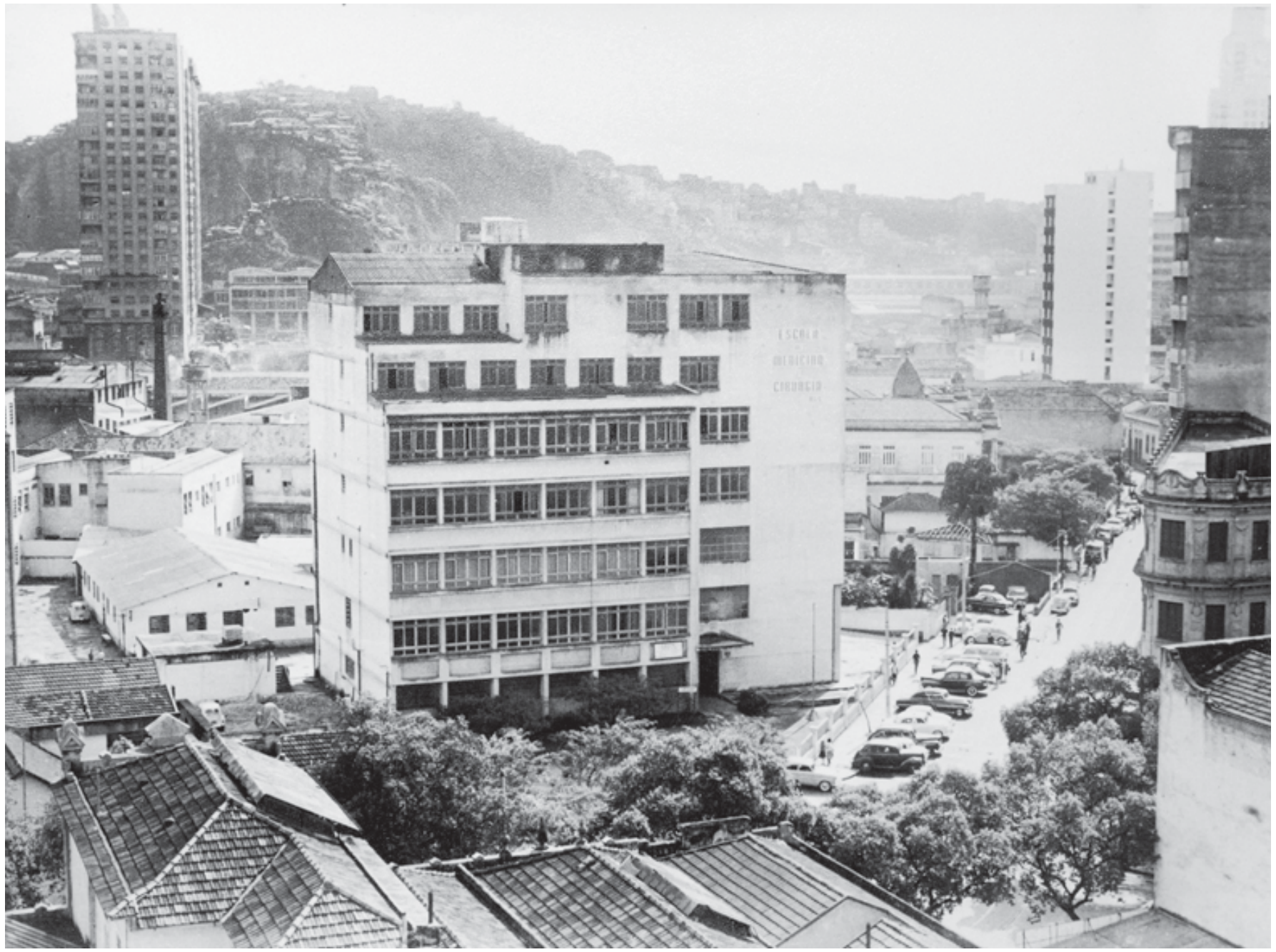

Hahnemannian Institute of Brazil. [s.d.]. Instituto Hahnemanniano do Brasil Archives 


\section{IMPERIAL TIMES}

\section{National Academy of Medicine}

Other denominations: The Society of Medicine of Rio de Janeiro (1829); Imperial Academy of Medicine (1835); National Academy of Medicine (1889-present day).

Location: Downtown

Address: Avenida General Justo, no. 365

Denomination: Professional and Scientific Association

Period of construction: 1958

Proprietor: National Academy of Medicine

Author/constructor: unknown

\section{History:}

The Society of Medicine of Rio de Janeiro was born on June $30^{\text {th }}, 1829$ with the mission to assemble professionals connected to medicine in order to promote debates involving medical science and of the role of the doctor while its health care provider. In addition, the Society had the mission to channel discussions, which previously had been dispersed, related to policy actions in benefit of public health thus developing a unified stance on behalf of the medical community and magnifying the representation of these professionals before the Imperial Government.

Its founding was preceded by numerous meetings at the residences of the doctors José Francisco Xavier Sigaud on Rua do Rosário no. 185, and Joaquim Cândido Soares de Meirelles on Rua da Cadeia no. 161 (currently Rua da Assembléia), and later at the old Rua Larga de São Joaquim no. 170. During these first meetings the norms of the statutes were debated and the composition of the founding officials deliberated: Joaquim Cândido Soares de Meirelles, Luís Vicente De Simoni, José Francisco Xavier Sigaud, José Martins da Cruz Jobim, João Maurício Faivre, Jacintho Rodrigues Pereira Reis, Antônio Américo D’Urzedo, Octaviano Maria da Rosa, Cristóvão José dos Santos, Antônio Martins Pinheiro, Antônio Joaquim da Costa Sampaio, José Maria Cambuci do Valle, José Augusto Cezar de Menezes, João Alves Carneiro, Fidélis Martins Bastos, Joaquim José da Silva and José Mariano da Silva.

The abovementioned statutes were fully based upon the model of the Paris Academy of Medicine due to the strong influence of the founding fathers, Joaquim Cândido Soares de Meirelles, Francisco Freire Allemão Cisneiros, José Martins da Cruz Jobim and Francisco de Paula Cândido, who were all graduates of the College of Medicine in Paris, in addition to the Frenchman, José Francisco Xavier Sigaud, who graduated from Strausburg. The main focuses of the regiment of the referred Academy were issues related to sanitary inspections. For this reason, the regulation of the Society of Medicine of Rio de Janeiro projected its division into four sections: vaccination, gratuitous consultations, repugnant diseases and general hygiene of the city.

The solemn public inauguration occurred on April 24 $4^{\text {th }}, 1830$, in an area of the Ordem Terceira de São Francisco de Paula Hospital and was attended by diverse political and ecclesiastic authorities, including Emperor Pedro I, who was an ardent attendee of the commemorative sessions of the newly-inaugurated association. During this period, the Society was headquartered on Rua do Rosário no. 240. Later, on December $30^{\text {th }}$, it was transferred to Casa do Consistório da Igreja do Rosário where it remained until 1834, year in which it began to occupy some of the accommodations of the Royal Military Academy.

One of the accomplishments that most indicated the prestige of the association was the consult on behalf of the Government in 1832, on the occasion of the implementation of the "Plan for the Organization of the Medical Schools of the Empire", according to which the medical-surgical academies of Rio de Janeiro and Bahia became colleges of medicine the only two institutes of higher education in medicine in Brazil until then. This fact demonstrated the scientific authority and institutional faculty that supported the Society of Medicine of Rio de Janeiro in matters related to the medical area. 


\section{IMPERIAL TIMES}

As of 1835, in addition to changing its denomination to the Imperial Academy of Medicine, the entity began to have only three sections: medicine, surgery and pharmacy. For each one of them there was a session of debates dealing with relevant matters for the referred area.

Ever since the regency period up to 1850, any decisions regarding sanitary legislation and public health policies were scrutinized by the members of the Academy, which had become a sort of official consultant for the Imperial Government. In the same year, this task became the responsibility of the Central Council of Public Hygiene, an agency with direct ties to the Ministry of the Empire.

The lack of its own headquarters constituted a major impediment to the sequence of works performed by the scholars. In 1861, it left the Royal Military Academy and was transferred to the Municipal Chamber of the Court, in the vicinity of Campo de Santana. In 1874, it was ceded to it the ground floor of the Recolhimento do Parto, where it remained until 1899. In the same year, it moved to the old building of the Pedagogium (Museum of the Pedagogue), located on Rua do Passeio. During this period, already under the Republican government (established in 1889), it was denominated National Academy of Medicine.

Since then, targeting to maintain itself as a legitimate and autonomous institution in respect to the State, it explored ways to magnify the divulgence of its works through numerous news outlets, such as research in specialized periodicals and major newspapers. Nevertheless, since its founding, the entity kept various scientific studies and political-institutional debates open to the public through periodicals such as: Semanário de Saúde Pública (1831-1833); Revista Médica Fluminense (1835-1841); Revista Médica Brasileira (1841-1843); Annaes de Medicina Brasiliense (1845-1849); Annaes Brasilienses de Medicina (1849-1885); Annaes da Academia de Medicina (1885-1906) and Boletim da Academia Nacional de Medicina (1885-1897).

In the beginning of the XX century, it occupied a great hall of the Liceu de Artes e Ofícios located on Rua Treze de Maio. Yet in 1903, while works on the building of the dock of Lapa (Rua Augusto Severo no. 04) had not been concluded, it operated in a large hall of the Colégio Pedro II, and later occupied it on June $30^{\text {th }}$, 1904. In 1958, it left the building of the Silogeu Brasileiro and, finally, on November $06^{\text {th }}$, moved to its current address on Avenida General Justo no. 365, in construction as of 1953.

There have been great names in national medicine among the presidents that headed the National Academy of Medicine during the XIX and first decades of the XX century: Joaquim Cândido Soares de Meirelles; José Francisco Xavier Sigaud; José Martins da Cruz Jobim; Francisco Freire Allemão Cisneiros; Joaquim Vicente Torres Homem; Francisco de Paula Cândido; José Pereira Rego (Barão de Lavradio); Vicente Cândido Figueira de Sabóia (Visconde de Sabóia); Nuno Ferreira de Andrade; Antonio Fernandes Figueira; Miguel da Silva Pereira; Carlos Seidl; Miguel de Oliveira Couto.

\section{Notes:}

There is a project at the IPHAN to inventory the collection of the Academy.

\section{Register of Preservation:}

It is not listed.

\section{Sources:}

ACADEMIA NACIONAL DE MEDICINA. Em comemoração do ensino médico. Rio de Janeiro, Jornal do Commercio, 1908. CASTRO, S. A Academia Nacional de Medicina e a política sanitarista do governo Rodrigues Alves. Rio de Janeiro, 1996. Dissertação (Mestrado em Ciências Sociais) - Instituto de Filosofia e Ciências Sociais, UFRJ, 1986.

EDLER, F. As Reformas do Ensino Médico e a Profissionalização da Medicina na Corte do Rio de Janeiro (1854-1884). São Paulo: Faculdade de Filosofia, Letras e Ciências Humanas, USP; 1992. (Dissertação de mestrado)

FERNANDES, R. O Conselheiro Jobim e o espírito da medicina do seu tempo. Brasília: Ed. do Senado Federal; 1982. 


\section{IMPERIAL TIMES}

NASCIMENTO, A. O centenário da Academia Nacional de medicina do Rio de Janeiro, 1829-1929: primórdios e evolução da medicina no Brasil. Rio de Janeiro: Imp. Nacional, 1929.

RIBEIRO, L. Academia Nacional de Medicina. Rio de Janeiro, Sintra Gráfica e Editora Ltda, 1984.

SANT' ANNA, A. Academia Nacional de Medicina: Resenha Histórica. Rio de Janeiro, 1979.

Credits: Atiele Azevedo de Lima Lopes (research and text). 


\section{IMPERIAL TIMES}

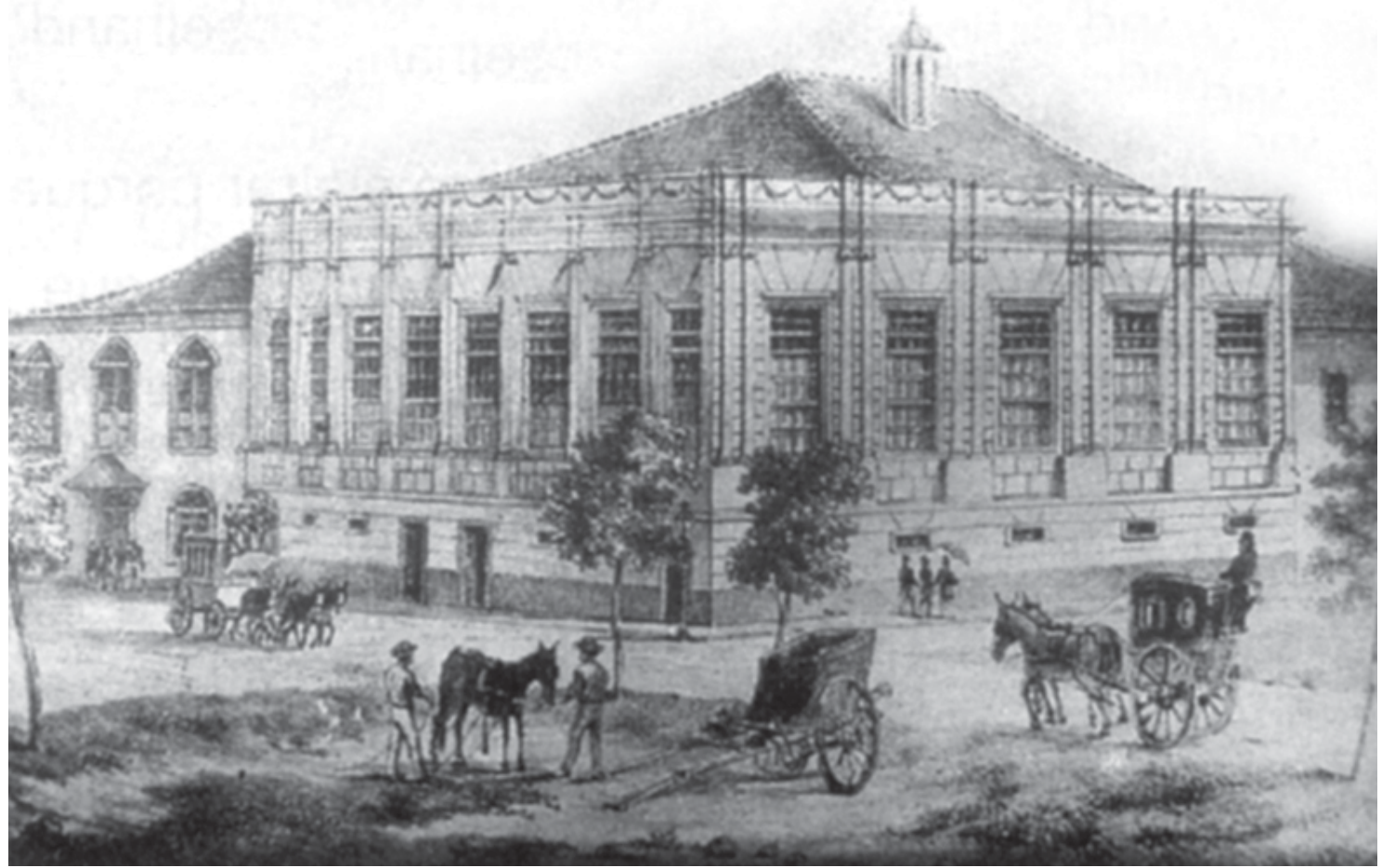

National Academy of

Medicine, Campo de Santana, [1861-1874]

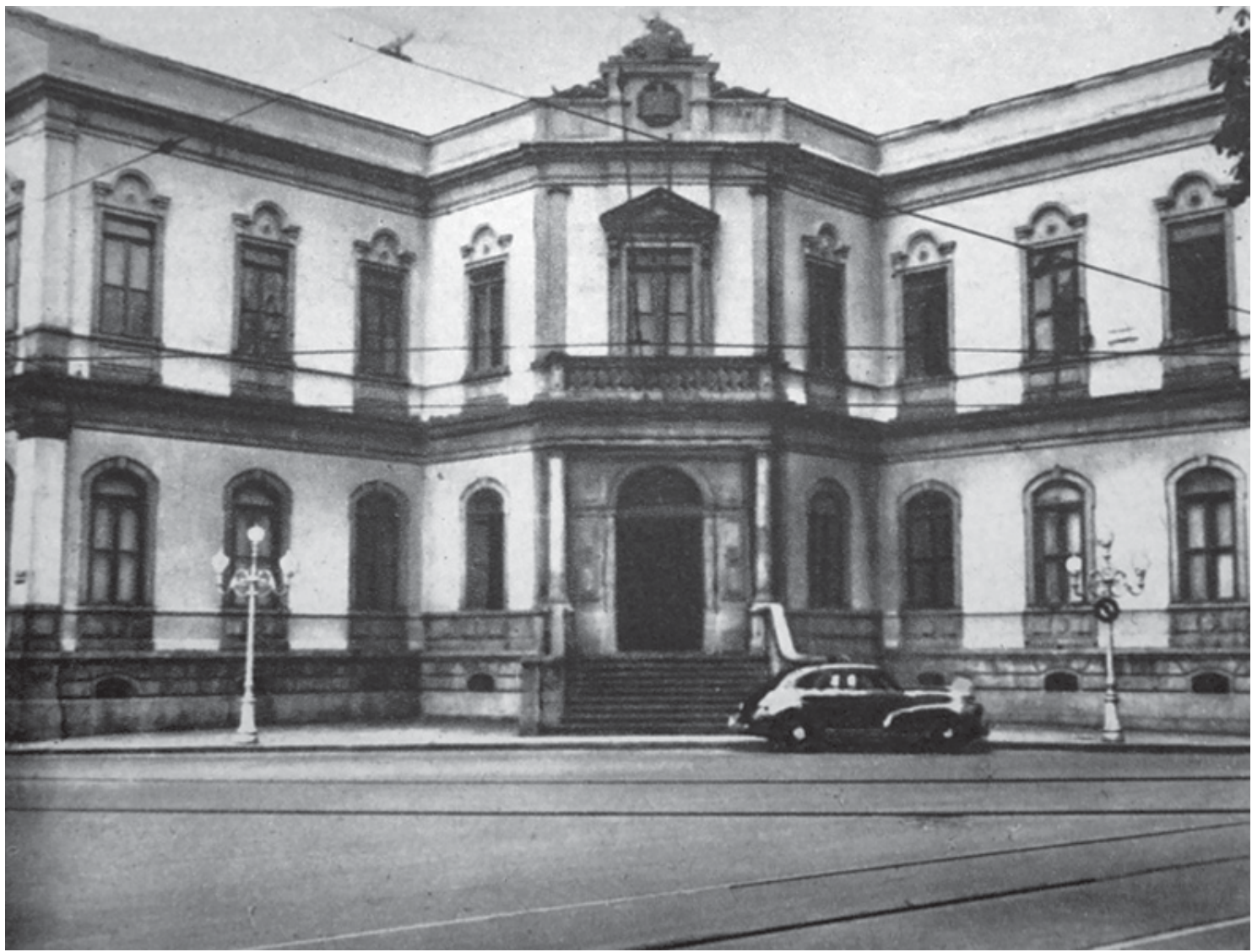

National Academy of Medicine, Lapa Beach (1904-1958). National Academy of Medicine Archive 


\section{Nossa Senhora da Saúde Hospital}

Other denominations: Infirmary of Gamboa (1853-1856); Nossa Senhora da Saúde Asylum (1856); Nossa Senhora da Saúde Hospital (currently).

Location: Santo Cristo

Address: Rua da Gamboa no. 303

Category: General Hospital

Period of construction: 1840

Proprietor: Santa Casa da Misericórdia of Rio de Janeiro

Author / Constructor: unknown

\section{History:}

The first yellow fever epidemic which occurred in the city of Rio de Janeiro, in the summer of 1849-1850, stimulated the promulgation of Act no. 583 of September $5^{\text {th }}, 1850$, allowing the Imperial Government to expropriate properties for the installation of infirmaries and cemeteries. In virtue of the sanitation state of affairs of the monarchy, it was ordered the realization of a public bidding for the establishment of two cemeteries outside of the urban perimeter of the city of Rio de Janeiro. One of the clauses regulated the mandatory installation of three hospitals, by the winning entity, catered to the care of the victims of the epidemics that raged in the city.

Under the presidency of José Clemente Pereira, the Santa Casa da Misericórdia of Rio de Janeiro won this bidding and, in order to fulfill such obligation, it acquired by lease, in 1853, the Dr. Peixoto Hospital, at Morro da Gamboa, for the organization of one of these hospitals. The building and the land of the old small farm, rented by Doctor Antonio José Peixoto, were property of Commendator Manoel Machado Coelho. Besides the land with the building, he also leased the surgical arsenal, furniture, grocery store and four slaves. This acquisition was possible with the authorization of the Central Council of Public Hygiene, who was consulted upon the salubrious conditions of the location. The favorable opinion, assessed by director Francisco de Paula Cândido, was given due to the propitious winds coming from Guanabara Bay and because the small farm was distant from the urban center, which made it ideal for the isolation of patients.

Thus, on July $2^{\text {nd }} 1853$, the referred to Casa de Saúde, which demanded full restoration due to its precarious state, was transformed into Hospital of Gamboa, expanded and equipped to receive individuals infected with yellow fever, specially the ones coming from the port zone of the city.

Initially, it was called Infirmary of Gamboa, this hospital establishment received the first patients on the day of its inauguration. The clinical service was under the responsibility of Francisco Xavier da Veiga. With the increasing rates of smallpox and yellow fever contamination, another doctor was designated, Francisco Augusto dos Santos. The sisters of charity from Ordem de São Vicente de Paula in Paris, who arrived in Rio de Janeiro on September $26^{\text {th }}, 1852$ by means of negotiations between José Clemente Pereira and the mentioned Ordem, would provide support to the doctors. They were soon spread among the hospitals of Santa Casa.

In January of 1856, with the increase in the number of individuals infected with cholera morbus, the regent Honório Hermeto Carneiro Leão (Marquis of Paraná) determined the creation of more four infirmaries. During this year, the Infirmary underwent reorganization, being constituted as Nossa Senhora da Saúde Asylum, not linked to the Santa Casa da Misericórdia of Rio de Janeiro General Hospital.

On September $1^{\text {st }}$, 1865, during the presidency of Miguel Calmon du Pin e Almeida (Marquis of Abrantes) at Santa Casa, occurred the final possession of the land which housed the Asylum, through the effective purchase of the small farm from the heirs of Manoel Machado Coelho.

In the property of the small farm, in tribute to the Saint after whom the Asylum was named, the chapel of Nossa Senhora da Saúde began to be constructed in 1868. The chapel was only finished in 1871, although it was solemnly 


\section{IMPERIAL TIMES}

inaugurated in the Christmas celebrations of 1869. The gothic styled chapel was reconstructed between 1888 and 1889 by Ernesto da Cunha de Araujo Vianna, engineer of Santa Casa and adjacent divisions, because the former had been destroyed.

Under the initiative of Regent Zacharias de Góes e Vasconcellos, N. S. da Saúde Asylum underwent a vast process of restorations in its physical structure as of 1871, inaugurating new infirmaries and private rooms. Also, during this year, annexed the Asylum, a Provisional Asylum for Orphans was created, which sheltered children who accompanied their ill mothers, the children were able to stay permanently in the event that the mothers passed away. In subsequent years, improvements continued: construction of a cadaver storage and a laundry room, kitchen restoration, clothes closet, bathrooms and water and sewage piping.

As of 1888, under an initiative of Regent José Maurício Wanderley (Baron of Cotegipe), the individuals infected were transferred to quarantine hospitals which had been created by the Imperial Government in the previous decades. The assistance care to female tuberculosis patients was transferred to Nossa Senhora das Dores Asylum in Cascadura, specialized in the treatment of tuberculosis patients. In 1890, the girls from the asylum were transferred to the Misericórdia Asylum, recently created by Regent Jerônimo José Teixeira Júnior (Viscount of Cruzeiro). Only girls over 16 could live in the N. S. da Saúde Asylum in order to help with household chores.

On October 19 $9^{\text {th }}, 1901$ an agreement between the Presidency of Santa Casa da Misericórdia of Rio de Janeiro and City Hall of the Federal District was signed, extending for another 50 years the maintenance of the establishments connected to it: Nossa Senhora da Saúde Asylum, São João Baptista Asylum and Nossa Senhora do Socorro Asylum.

From 1904 to 1906, during the presidency of Miguel Joaquim Ribeiro de Carvalho, in the vicinity of N. S. da Saúde Asylum, a quarantine pavilion was constructed for cases of suspected illnesses and also special infirmaries for soldiers from the Army, Navy and Police, infected by contagious maladies. There was also a no-cost treatment for the students of the Casa de São José and Quinze de Novembro Correctional School in the Asylum.

Around 1907, nursing classes were introduced in the Asylum under the responsibility of the surgeon, with the objective to qualify a labor force for services at the very same institution or to meet the demands of Santa Casa da Misericórdia of Rio de Janeiro.

The first operating room was inaugurated in 1909, under the clinical responsibility of Dr. Nabuco de Gouveia.

During the first Vargas administration, Nossa Senhora da Saúde Hospital was threatened to close in virtue of its state of abandonment. Given its historical importance it continued working, undergoing vast physical and institutional restoration in 1960, implemented by Afrânio Coutinho Costa regent of Santa Casa. Since then, the Hospital of Gamboa, as it is commonly known, provides assistance care to the people of the city offering clinical services in several medical specializations.

\section{Register of Preservation:}

It is listed by the Municipality since August $23^{\text {rd }}, 1986$, by means of decree no 6.057.

\section{Sources:}

ARAÚJO, A. A Assistência Médica Hospitalar no Rio de Janeiro no século XIX. Rio de Janeiro: Ministério da Educação e Cultura/ Conselho Federal de Cultura; 1982.

DORIA, E. O Hospital da Gamboa, Revista da Semana, Rio de Janeiro, nº 49, ano XXVII, 27/11/1926.

SOARES, O. Hospício de N. Senhora da Saúde - Gamboa. In: CARVALHO, M. (org.). Notícia dos diversos estabelecimentos mantidos pela Santa Casa da Misericórdia da cidade de S. Sebastião do Rio de Janeiro. Rio de Janeiro: Typographia do "Jornal do Commercio" de Rodrigues \& C., 1908.

ZARUR, D. Hospital N. S. da Saúde. 2a ed. Rio de Janeiro: Binus Artes Gráficas LTDA., 1996.

Credits: Atiele Azevedo de Lima Lopes (research and text) 


\section{IMPERIAL TIMES}

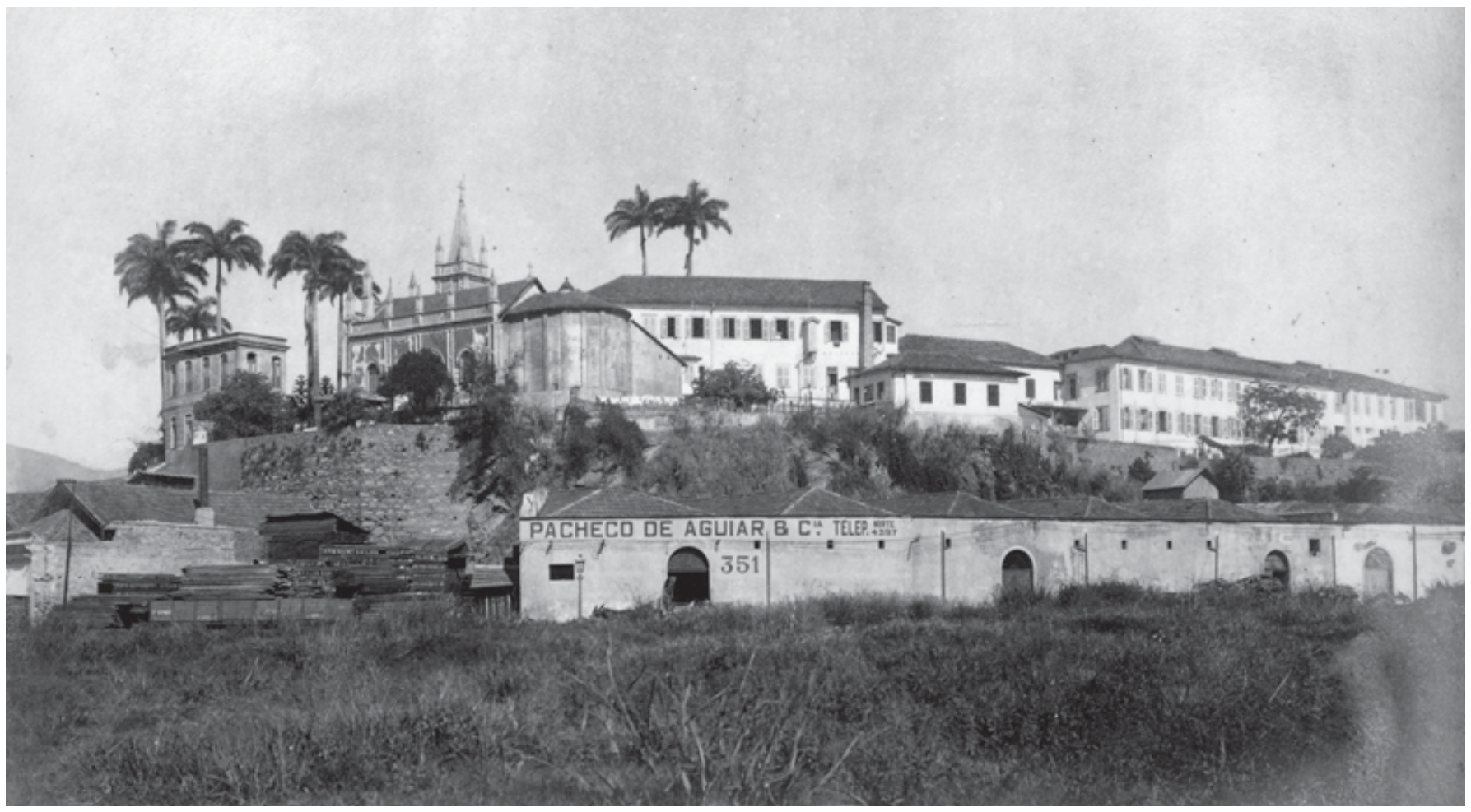

N. Sra. da Saúde Hospital, [s.d.]. Instituto Hahnemanniano of Brasil Archives

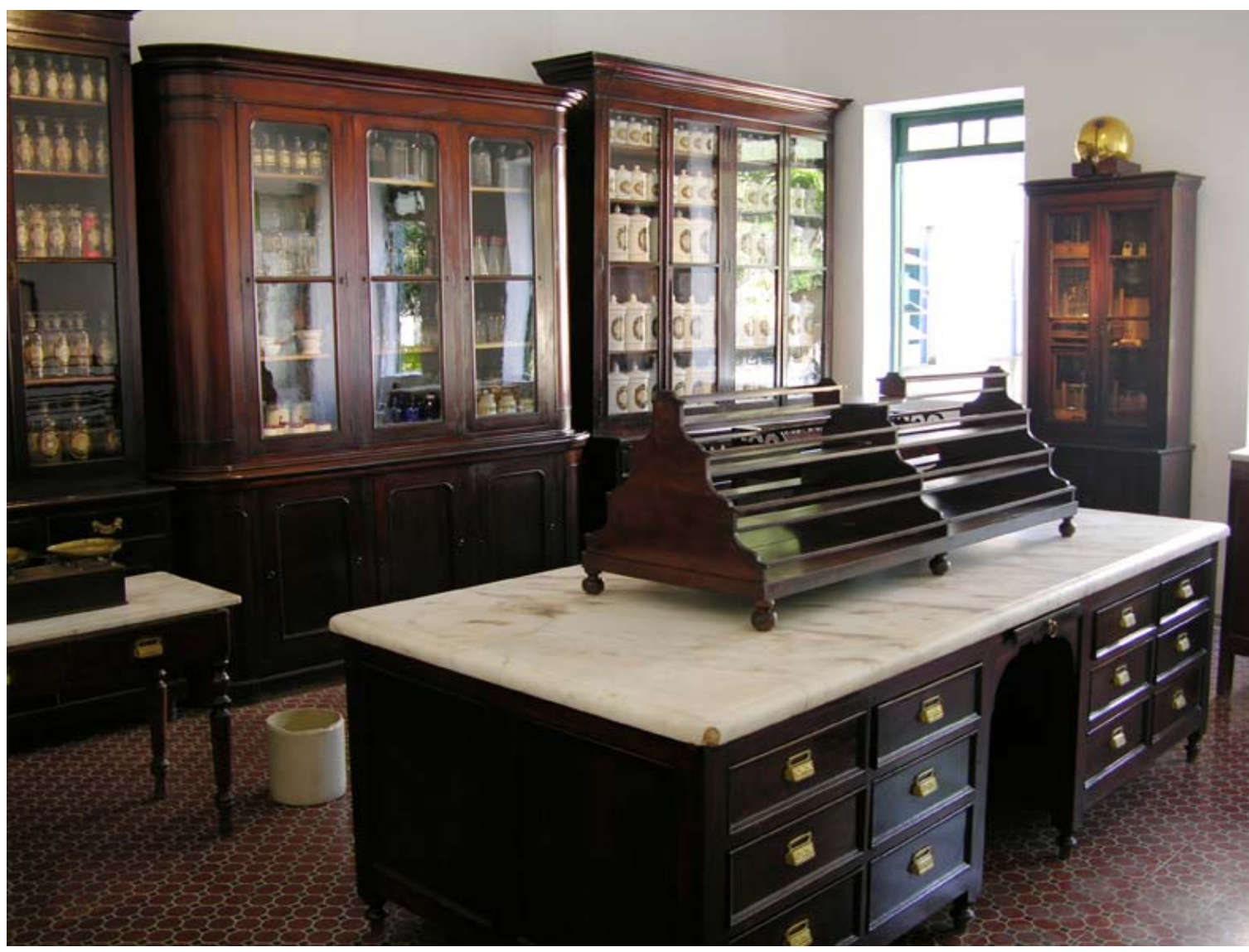

N. Sra. da Saúde

Hospital - Museum

Photo Roberto Jesus

Oscar \& Vinícius

Pequeno de Souza,

2008. Casa de

Oswaldo Cruz

Archives 


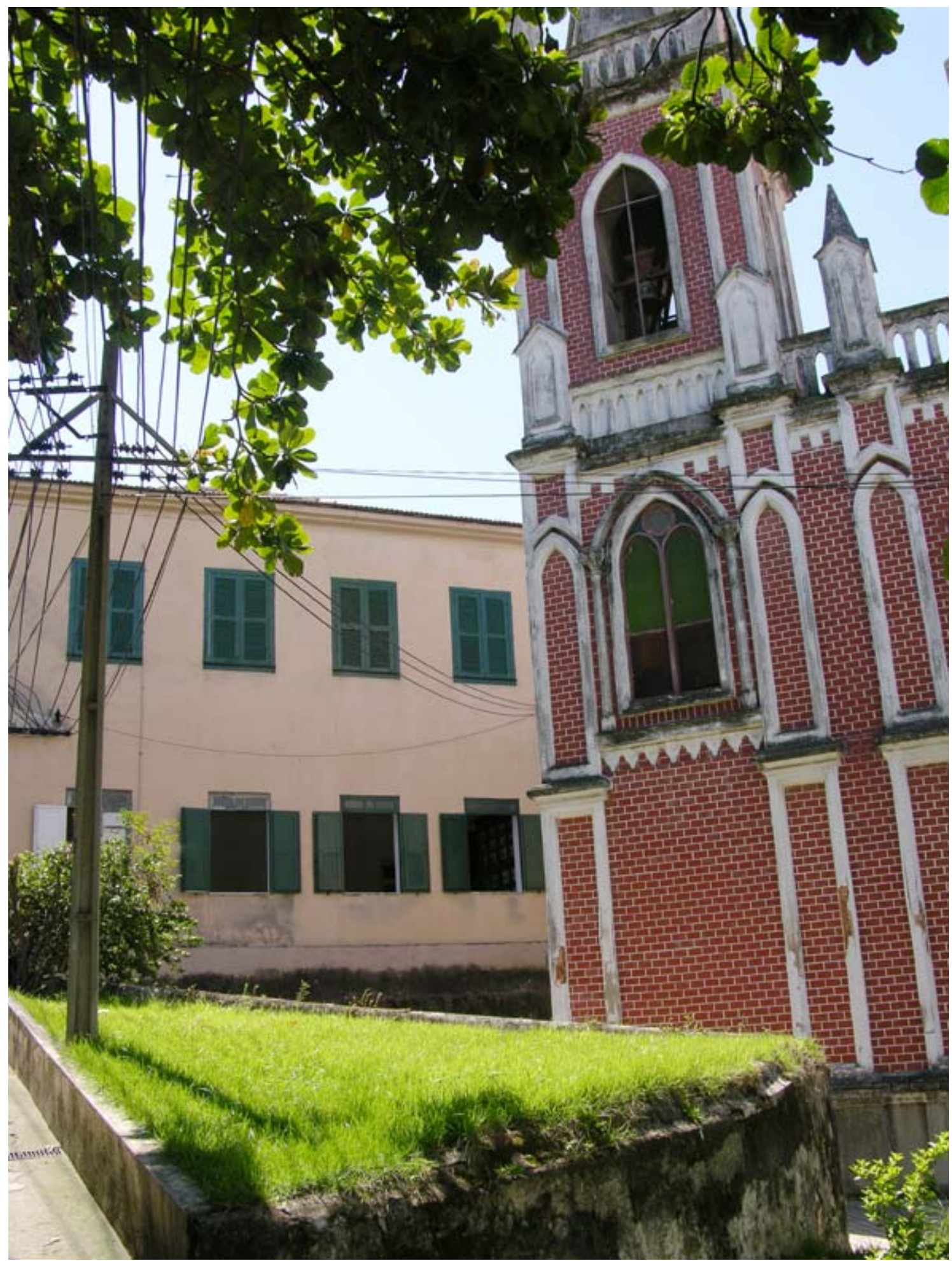

N. Sra. da Saúde Hospital - façade. Photo Roberto Jesus Oscar \& Vinícius Pequeno de Souza, 2008. Casa de Oswaldo Cruz Archives 


\section{IMPERIAL TIMES}

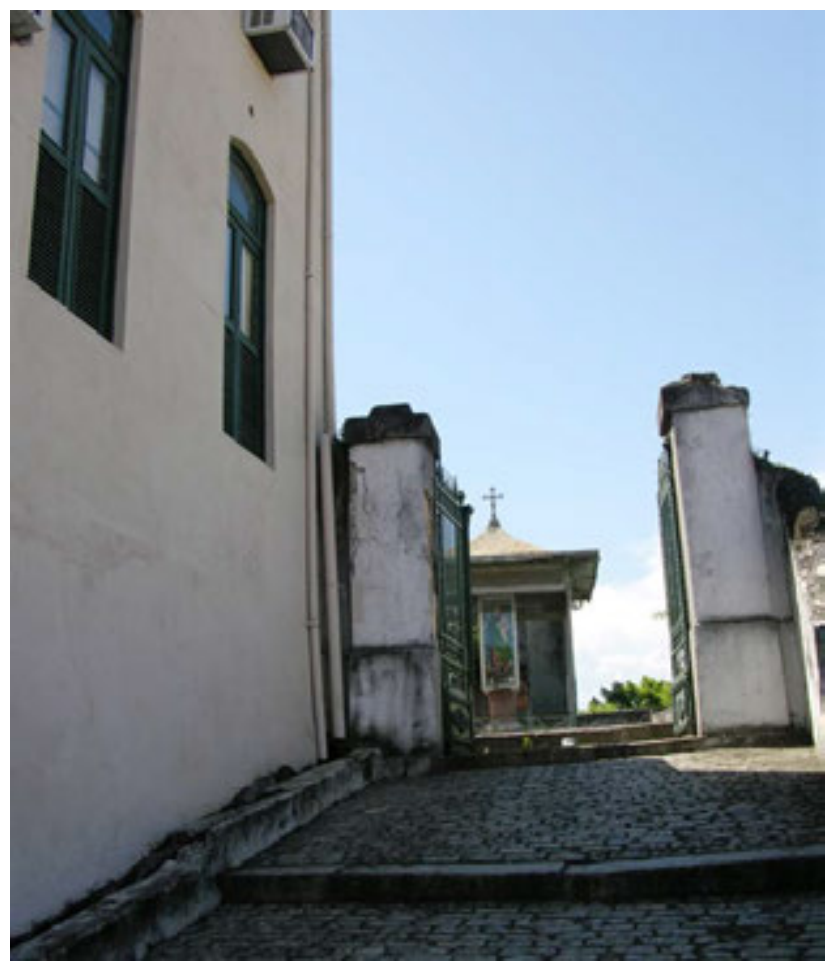

N. Sra. da Saúde Hospital - entrance gate. Photo Roberto Jesus Oscar \& Vinícius Pequeno de Souza, 2008. Casa de Oswaldo Cruz Archives.

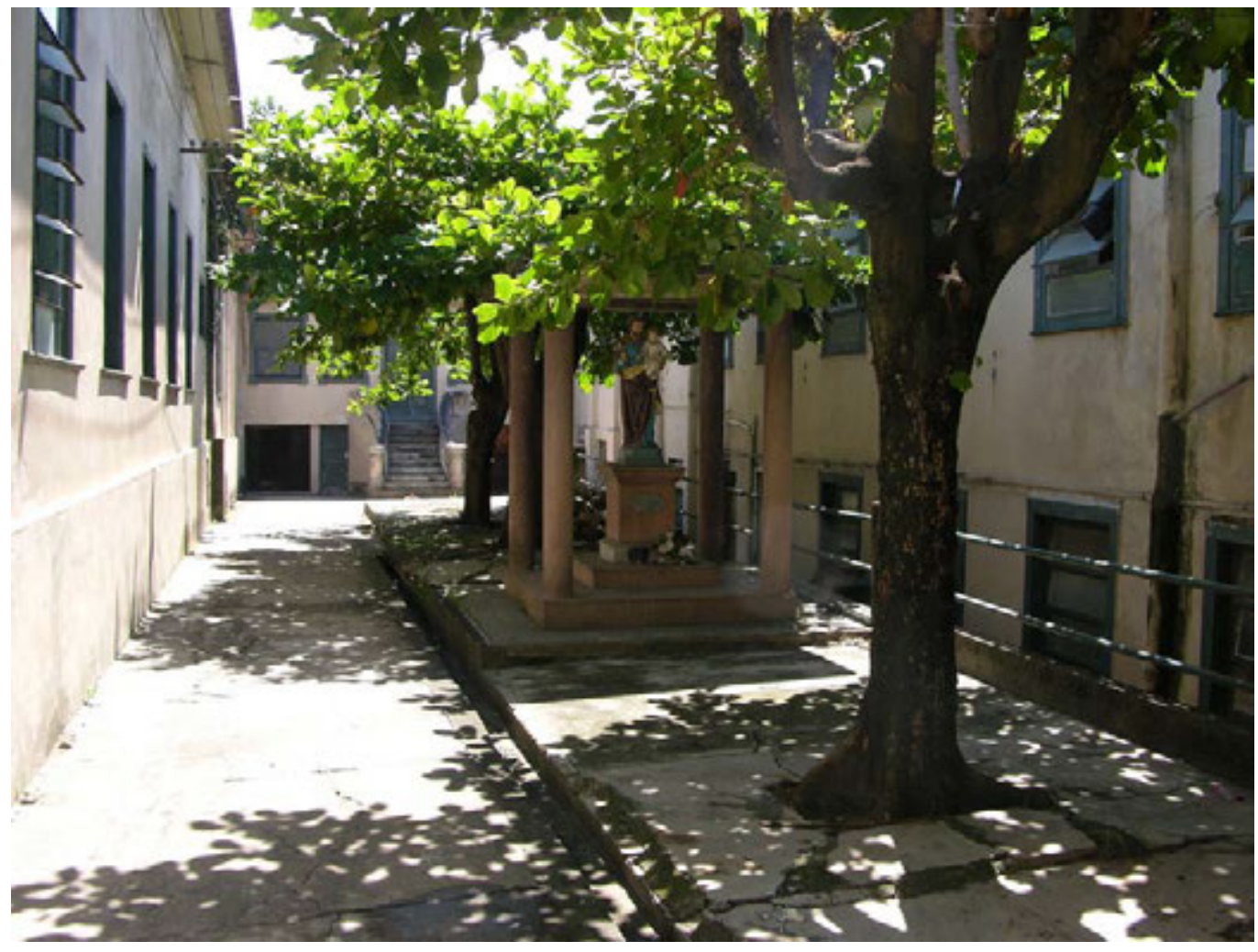

N. Sra. da Saúde Hospital - interior garden. Photo Roberto Jesus Oscar \& Vinícius Pequeno de Souza, 2008. Casa de Oswaldo Cruz Archives 


\section{IMPERIAL TIMES}

\section{Nossa Senhora das Dores Hospital}

Other denominations: Nossa Senhora das Dores Asylum (1884-1914); Nossa Senhora das Dores Hospital (1914present day)

Location: Cascadura

Address: Avenida Ernani Cardoso No. 21

Denomination: Institution of assistance care

Period of construction: 1884

Proprietor: Santa Casa da Misericórdia of Rio de Janeiro

Author / Constructor: unkown

\section{History:}

The origin of the Nossa Senhora das Dores Asylum dates back to 1839, when an infirmary for the tuberculous was created in Morro do Castelo (Castelo Hill), aiming to separate them from close living proximity with other patients of the Santa Casa da Misericórdia of Rio de Janeiro General Hospital. Later, the patients were transferred to an infirmary on Praia Vermelha (Red Beach), which soon became insufficient given the enormous number of hospitalized patients and returned to the Santa Casa. Over time and due to the constant epidemics, the volume of the tuberculous cared for at General Hospital was increasing, jeopardizing the adequate functioning of the infirmaries given the imminent risk for contamination.

Soon after the discovery of the tuberculosis bacillus (1882) by German bacteriologist Robert Koch, the idea of transferring the tuberculous to a separate hospital was discussed. During the presidency of João Maurício Wanderley (Baron of Cotegipe) at Santa Casa a location in the suburb of Cascadura was leased for such a purpose - the former Ferraz Rural Estate, on September $13^{\text {th }}, 1884$. The property already came equipped with a herd of cattle and a small plantation, which were later used to feed the future patients. In this period, Cascadura was completely rural, regarded as a place of rest for wealthy families.

Considered as the first pthysiology hospital in Brazil, the Nossa Senhora das Dores Asylum was inaugurated at Rua do Coronel Rangel no. 1 (former Rua do Campinho) on December $08^{\text {th }}, 1884$. The goal was to care for the needy tuberculous of the region, who were deprived of any type of medical assistance care. Its first director was Francisco José Xavier, a specialist in the treatment of tuberculosis. In addition to rendering service care for such a specialty, the entity still possessed clinics of surgery, gynecology, obstetrics, otorhinolaryngology, odontology, hydrotherapy and laboratories for the exams of X-rays.

Given the financial constraints that the Asylum was experiencing, council member Paulino José Soares de Souza suggested to the Baron of Cotegipe to provide the Asylum with a new direction. Thus, in 1896, it began to receive girls from the Recolhimento de Órfãs (Gathering of Orphans) and from various others asylums under the custody of the Santa Casa, predisposed to or already infected with tuberculosis.

Upon assuming the presidency of the Santa Casa da Misericórdia of Rio de Janeiro in 1890, Paulino José Soares de Souza, under proposal of the Asylum's administration, implemented a consultation room to provide service care for the low-income population in 1899, initiating operations on May $02^{\text {nd }}$. The increase in the volume of rendered service care led to the separation of the consultation room from the Asylum, thus creating the Dispensary.

In 1906, the president who succeeded Paulino Soares, Miguel Joaquim Ribeiro de Carvalho, arranged for a visit by the sanitation doctor Oswaldo Cruz, at the time the General Director of Public Health, and the Minister of Justice Felix Gaspar to the Asylum, as a way to call attention to the urgency on maintenance and expansion construction works. Then, in 1910, construction work was authorized thus beginning the expansion of its service-rendering capacity, since 


\section{IMPERIAL TIMES}

the demand for tuberculosis treatment had reached great proportions. The construction works, which employed the most modern technical equipment in the civil construction of hospitals, received a gold medal at the International Hygiene Exposition of Rome, in 1912.

Gradually, the amount spent with the construction works began to surpass the financial reality of the Santa Casa da Misericórdia of Rio de Janeiro, which prompted an assistance petition to Congress in the form of a supplemental budget. The improvements undertaken extended from 1910 to 1913, resulting in a new building with six pavilions, annexed the original building of the Asylum, which was re-inaugurated on June $25^{\text {th }}, 1914$ already under the denomination of Hospital. The institution underwent new expansion in 1921 with the construction of new facilities: 12 infirmaries each with 16 beds.

On November $23^{\text {rd }}, 1925$, the Hospital received its regulations, still under the presidency of Miguel de Carvalho. The provisions, in addition to regulating the adequate functioning of the clinics and Dispensary, also regulated the care services rendered by the sisters of charity to the patients, already in existence since its foundation.

As of the 1930's, with the advent of mass radiography (1936) as a diagnostic method in the prevention of tuberculosis, the number of patients and fatal victims decreased at Nossa Senhora das Dores Hospital, as well as in all of the establishments where such medical science innovations were present.

Under the proposal of the Hospital administrator, on July $30^{\text {th }}, 1960$, it was suggested for the utilization of its adjacent rooms by the College of Medicine of the University Gama Filho, under the premise that students perform the practical part of their medical training there. This request was accepted and authorized on August 02 ${ }^{\text {nd }}, 1936$, initial measure for the signing of the accord in June, 1965.

Until 1965, the Nossa Senhora das Dores Hospital rendered assistance care exclusively to cancer patients, which naturally made the nursing service specialized, thus stimulating the implementation of a Nurse's Aide Course, of which the first class graduated the following year. In the same year, the transition from a Pthysiology Hospital to an establishment of general clinic was undertaken, which demanded intense infrastructure construction works well into the following decade. As a general hospital, Nossa Senhora das Dores renders services in various medical and surgical specialties, including plastic surgery; in addition to auxiliary specialized services.

\section{Register of Preservation:}

It is not listed.

\section{Sources:}

GOMES, J. Hospício de N. S. das Dores. In: CARVALHO, M. (org.). Notícia dos diversos estabelecimentos mantidos pela Santa Casa da Misericórdia da cidade de S. Sebastião do Rio de Janeiro. Rio de Janeiro: Typographia do "Jornal do Commercio" de Rodrigues \& C., 1908.

ZARUR, D. Hospital Nossa Senhora das Dores. 3ª ed. Rio de Janeiro: Binus Artes Gráficas LTDA., 2001.

Credits: Atiele Azevedo de Lima Lopes (research and text) 


\section{IMPERIAL TIMES}

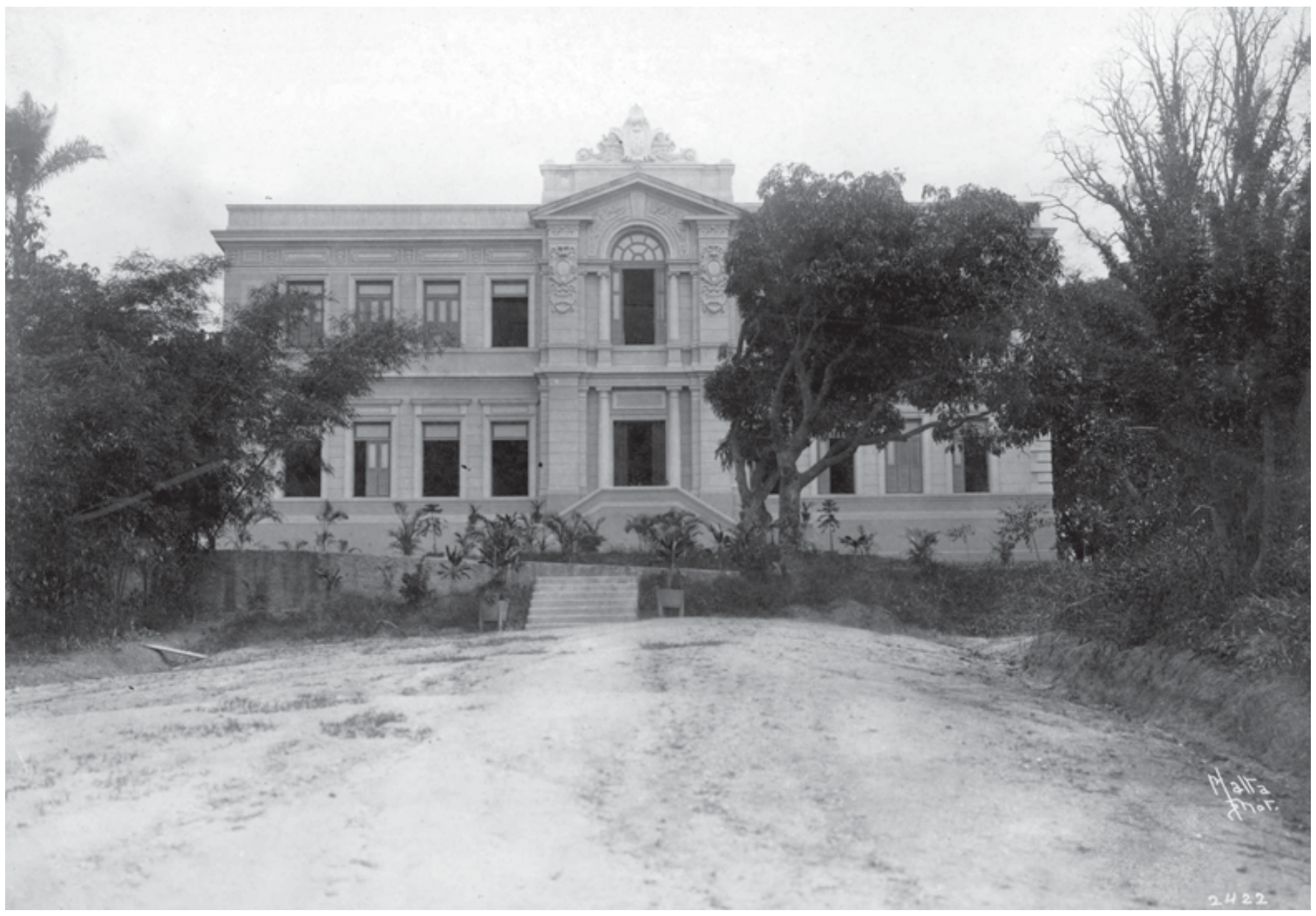

Nossa Senhora das Dores Hospital - façade, [s.d.]. Photo Augusto Malta. Museu da Imagem e do Som - RJ Archives

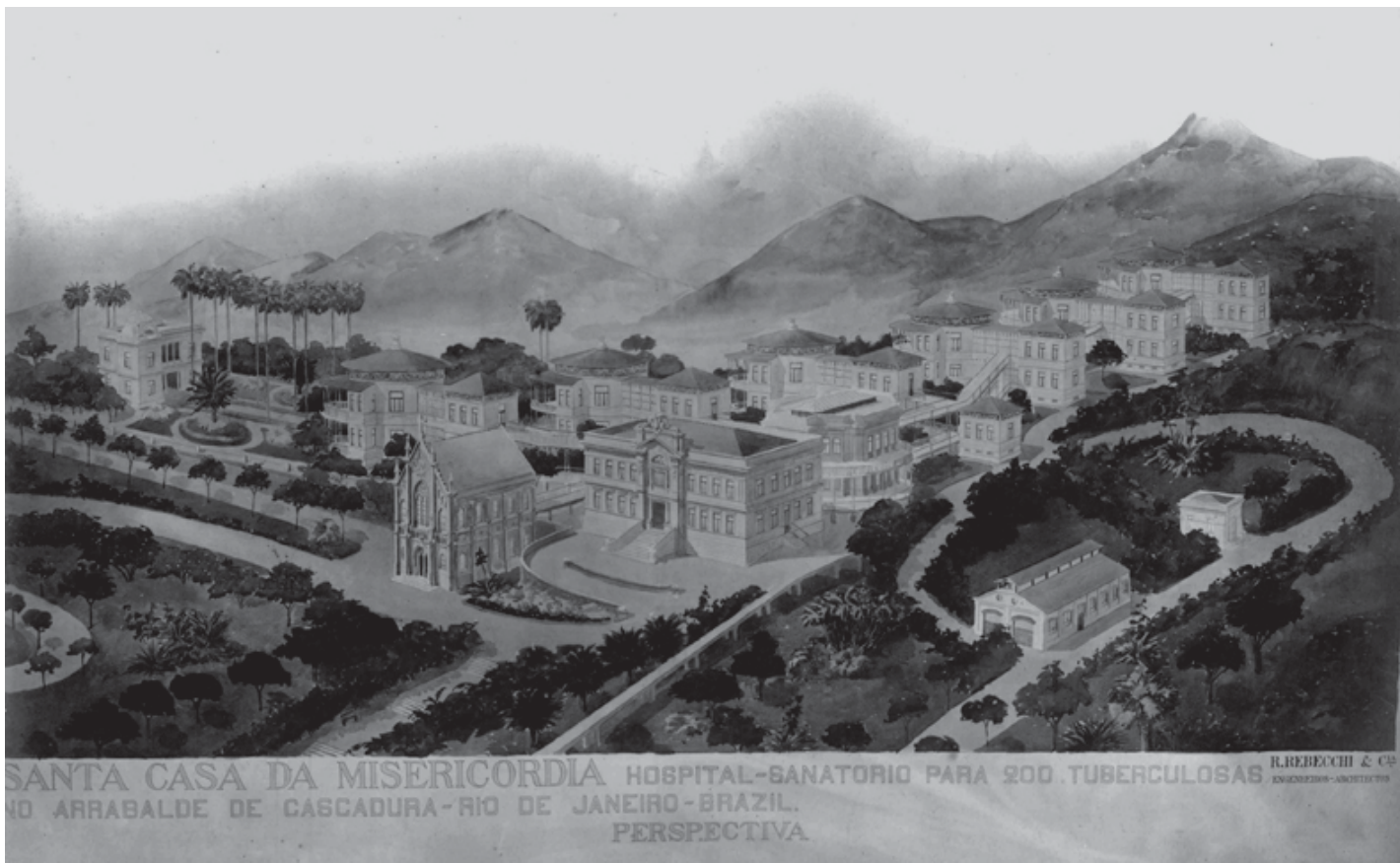

Cascadura Tuberculosis

Sanatorium Hospital perspective view, [s.d.]

Museu da Imagem e do Som - RJ Archives 


\section{Nossa Senhora do Socorro Hospital}

Other denominations: Nossa Senhora do Socorro Infirmary (1855-??); Nossa Senhora do Socorro Asylum (??-??); Nossa Senhora do Socorro Hospital (??-present day).

Location: Caju

Address: Rua Monsenhor Manoel Gomes no. 503

Category: Institution of assistance care

Period of construction: $1920-1929$

Proprietor: Santa Casa da Misericórdia of Rio de Janeiro

Author / Constructor: unknown

\section{History:}

The first yellow fever epidemic which occurred in the city of Rio de Janeiro, in the summer of 1849-1850, stimulated the promulgation of Act no. 583 (September 05 ${ }^{\text {th }}, 1850$ ), allowing the Imperial Government to expropriate properties for the installation of infirmaries and cemeteries. In virtue of the sanitation state of affairs of the monarchy, it was ordered the realization of a public bidding for the establishment of two cemeteries outside of the urban perimeter of the city of Rio de Janeiro. One of the clauses regulated the mandatory installation of three hospitals, by the winning entity, catered to the care of the victims of the epidemics that raged in the city.

The first infirmaries were created in 1852 (São João Baptista da Lagoa Infirmary) and in 1853 (Nossa Senhora da Saúde Infirmary). The third infirmary designated by the imperial regulation was dedicated to the care of the population of the community of São Francisco Xavier do Engenho Velho, which encompassed the districts of São Cristóvão and Caju.

On July $28^{\text {th }}, 1853$ the Nossa Senhora do Socorro Infirmary was installed, at first in a residence located in the Chácara do Morundú, whose extension ran from São Cristóvão beach to Rua dos Quartéis (currently Rua Bela). It was acquired by the Santa Casa da Misericórdia of Rio de Janeiro by purchase of the heirs of Balthazar Pinto dos Reis on October $6^{\text {th }}, 1851$. Later, other areas were expropriated and incorporated to the property located near the infirmary.

Its operations occurred in an incipient and improvised fashion at the former Chácara (small farm) until 1855, when the decree no. 1.576 (March, 10 ${ }^{\text {th }}$ ), released Santa Casa from the maintenance of the two infirmaries. It was decided at the time that the only infirmary to be maintained would be Nossa Senhora da Saúde, thus terminating activities on the other ones. However, a few months later, a cholera epidemic forced the reopening of the Nossa Senhora do Socorro Infirmary on August $01^{\text {st }}$, during the administration of Honório Hermeto Carneiro Leão (Marquis of Paraná) at Santa Casa da Misericórdia of Rio de Janeiro. Until its subsequent shutdown, on April $18^{\text {th }}$ of the following year, 170 patients had been cared for.

In 1857 , with the passing of the epidemic, it was concluded that the real estate had been mismanaged in relation to its maintenance; therefore it was sold to the Venerável Ordem Terceira da Penitência (Venerable Third Order of the Penitence) for the implantation of a cemetery. Nevertheless, amid indication of a new epidemic, the Nossa Senhora do Socorro Infirmary began operating again in the biannual of 1866-67, already in a building at Praia de São Cristóvão no. 95, which still did not meet the satisfactory conditions to receive the great number of infected individuals.

The institution underwent a series of shutdowns and reopenings until the administration of Zacharias de Góes e Vasconcellos, who executed long awaited reconstruction and equipped the building, thus paving the way for its definitive establishment in 1872. It maintained an annex, since January $10^{\text {th }}, 1867$, the São Cristóvão Consultation Clinic, which had already operated at the Recolhimento das Órfãs (Female Orphanage) as of 1859.

The Nossa Senhora do Socorro Hospital suffered a fire on November $30^{\text {th }}, 1920$ which destroyed its entire property. Since the fire, it embarked on its reconstruction, undertaken by the regent Miguel Joaquim Ribeiro de Carvalho and concluded on February $9^{\text {th }}, 1929$, under a solemn inaugural ceremony. 


\section{IMPERIAL TIMES}

Best known as Caju Hospital, the institution underwent innumerous reforms throughout the XX century, in order to fall in harmony with the prevailing technical and scientific development.

In the 1960's, the Surgery and Study Centers were inaugurated. In 1972, an agreement was signed between the Santa Casa da Misericórdia of Rio de Janeiro and the National Social Security Institute (INPS) for the medical-surgical assistance care of the beneficiaries of the latter. Trailing this consortium, in 1975, an agreement was established with the Federation of Independent Federal Schools of the State of Guanabara (FEFIEG) to make available hospital beds for the assistance care of patients by students of the School of Medicine and Surgery of Rio de Janeiro (currently the School of Medicine and Surgery of the University of Rio de Janeiro / UNI-RIO).

As of the 1970's, Nossa Senhora do Socorro Hospital gained recognition by the treatment of excellence administered to the elderly, becoming a reference in geriatric care, reason for which patients were referred to it by the Municipal Institute of Geriatrics and Gerontology. In 1976, such specialty was reaffirmed in virtue of the contract with City Hall of the city of Rio de Janeiro for the medical-hospital assistance care of the elderly referred by the Office of Municipal Health. As a result of the amplitude of this consortium, the beneficiaries of the Social Security System had their assistance care transferred to the Nossa Senhora da Saúde Hospital.

Currently, this hospital care unit renders clinical services in cardiology, ophthalmology, odontology, speech-language pathology, otorhinolaryngology and medical clinic, in addition to diagnostic and pharmacy services.

\section{Notes:}

There is no evidence of reliable dates in relation to changes in the denominations.

\section{Register of Preservation:}

It is not listed.

\section{Sources:}

LARA, J. Hospício de N. S. do Socorro. In: CARVALHO, M. (org.). Notícia dos diversos estabelecimentos mantidos pela Santa Casa da Misericórdia da cidade de S. Sebastião do Rio de Janeiro. Rio de Janeiro: Typographia do "Jornal do Commercio" de Rodrigues \& C., 1908.

ZARUR, D. Hospital N. S. do Socorro. 2ª ed. Rio de Janeiro: Binus Artes Gráficas LTDA., 1993.

Credits: Atiele Azevedo de Lima Lopes (research and text) 


\section{IMPERIAL TIMES}

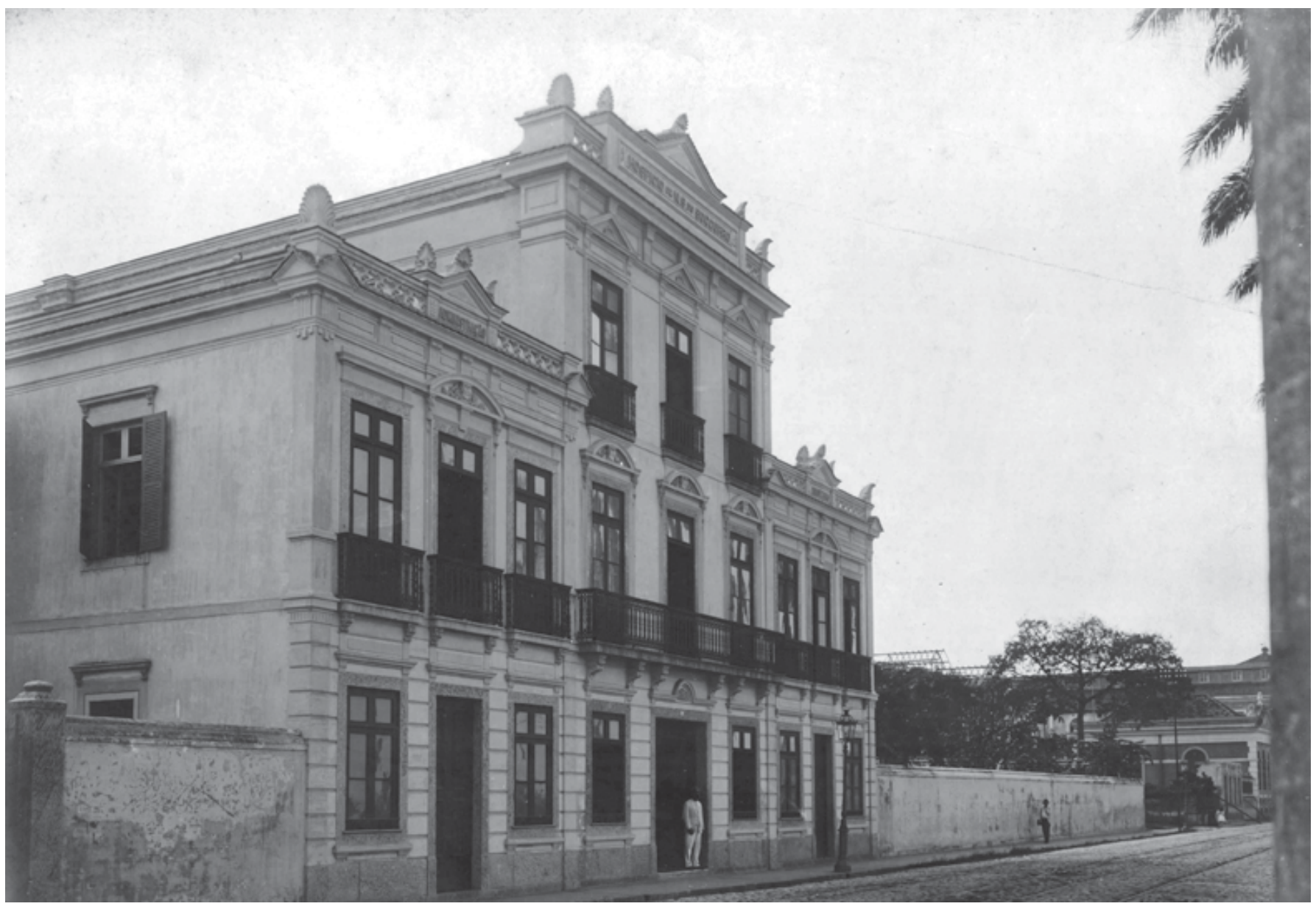

Nossa Senhora do Socorro Hospital, [s.d.]. Museu da Imagem e do Som, RJ Archives 


\title{
Pasteur Institute of Rio de Janeiro
}

\author{
Location: Downtown
}

Address: Rua das Marrecas, no. 25

Category: Research institute

Period of construction: XIX century

Proprietor: Santa Casa da Misericórdia of Rio de Janeiro

Author / Constructor: unknown

\section{History:}

In the last quarter of the XIX century, scientific knowledge in the international medical area underwent a period of rapid transformations, promoted principally by the revolution caused by Louis Pasteur and by microbiology. Under the strong influence of hygienist medical practice, this scientific leap owed a great deal to the research done on microorganisms performed by Pasteur, defender of the idea that microbes had their share of the responsibility in infectious actions. These studies made possible the development of new preventive techniques, such as sterilization and disinfection, and the appearance of biological prophylactics of an animal or human nature, such as those used in the preventive treatment of rabies.

Founded initially as the Anti-rabies Institute of Rio de Janeiro, a denomination that soon changed to Pasteur Institute of Rio de Janeiro, the idea behind it went goes back to 1886, when João Maurício Wanderley (Baron of Cotegipe), the then patron of the Santa Casa da Misericórdia of Rio de Janeiro, sent the professor of the Faculty of Medicine of Rio de Janeiro, Augusto Ferreira dos Santos, to Europe with the task of finding out about the discovery made by Louis Pasteur - the antirabies vaccine. Furthermore, it would be an opportunity to know and import specific equipment and materials for bacteriological research, promoting the desire of creating an institution in Brazil.

Connected to the Santa Casa da Misericórdia of Rio de Janeiro, the Pasteur Institute of Rio de Janeiro was officially inaugurated on February $25^{\text {th }}, 1888$, being the first Pasteur Institute in the world, founded nine months before the one in Paris. Under the direction of Augusto Ferreira dos Santos (author of the first notes about anti-rabies vaccine that are known about in Brazil), it was first established at Rua das Laranjeiras no. 84, in a rented building, owned by Luiza Leopoldina Guimarães de Araújo (Viscountess of Araújo). Although inaugurated on the referred to date, the Institute started its activities on the $09^{\text {th }}$ of the same month, the day on which the first anti-rabies inoculation was given in Brazil. According to a report of the Ministry of Affairs of the Empire, the Institute was already functioning before the inauguration in the same street, but at no. 62 .

The purpose of the implementation of the services of the Pasteur Institute of Rio de Janeiro was to produce and administer the anti-rabies immunizing agent as well as to relate the treatment of those sick with rabies with the development of the bacteriological studies done in its laboratories. However, according to Teixeira (1995), the institution limited itself to the first objective, functioning in practice as a production center of the immunizing agent and vaccination.

Between 1898 and 1903 similar institutes were created in Pernambuco, São Paulo, Rio Grande do Sul and Minas Gerais, with the objective of implementing the services inaugurated by Augusto Ferreira dos Santos in Rio de Janeiro - the manufacture of vaccines and the carrying out of preventive campaigns against the disease through the large scale vaccination of dogs.

With his death, in 1903, his first assistant, Dr. Samuel Pertence was nominated to substitute him as director of the Pasteur Institute of Rio de Janeiro. Under his direction, in 1910, the Institute was transferred to Rua das Marrecas no. 25, Centro.

After successive changes of use of the property, the building of the first headquarters, in Laranjeiras, is at present being used by a language course. 


\section{IMPERIAL TIMES}

\section{Architectural description:}

Eclectic building, typical of the Brazilian 1800’s.

\section{Register of Preservation:}

Temporary preservation order, by the INEPAC, on December 09 $9^{\text {th }}, 1998$, process no. E-18/001.553/98.

\section{Sources:}

ARAÚJO, A. A Assistência Médica Hospitalar no Rio de Janeiro no século XIX. Rio de Janeiro: Ministério da Educação e Cultura/ Conselho Federal de Cultura; 1982.

CASTRO-SANTOS FILHO, L. História Geral da Medicina Brasileira. São Paulo: Hucitec-EDUSP,1991. vol.2.

LIMA, A. As Sciencias Medico-Pharmaceuticas. In: Livro do Centenário. Rio de Janeiro: Imprensa Nacional; 1900, vol.2.

LIVRO de Visitas, no. 1.

RELATORIO apresentado à Assembléia Geral Legislativa na Segunda Sessão da Vigésima Legislatura pelo Ministro e Secretário do Estado dos Negocios do Imperio Barão de Mamoré. Rio de Janeiro: Imprensa Nacional, 1887. Relatórios Ministeriais (1821-1960). Obtido via base de dados PROJETO DE IMAGEM DE PUBLICAÇÕES OFICIAIS BRASILEIRAS DO CENTER FOR RESEARCH LIBRARIES E LATIN-AMERICAN MICROFILM PROJECT. Capturado em 13 mai. 2004. Online. Disponível na Internet: http://www.crl.edu/content/pindex.htm

SANTOS, A. Do tratamento preventivo da raiva pelo método Pasteur. Relatório. Rio de Janeiro, Imprensa Nacional, 1888.

TEIXEIRA, L. Ciência e Saúde na Terra dos Bandeirantes - A Trajetória do Instituto Pasteur de São Paulo no período de 1903-1916. Rio de Janeiro: Ed.Fiocruz, 1995.

Credits: Atiele Azevedo de Lima Lopes (research and text). 


\section{IMPERIAL TIMES}

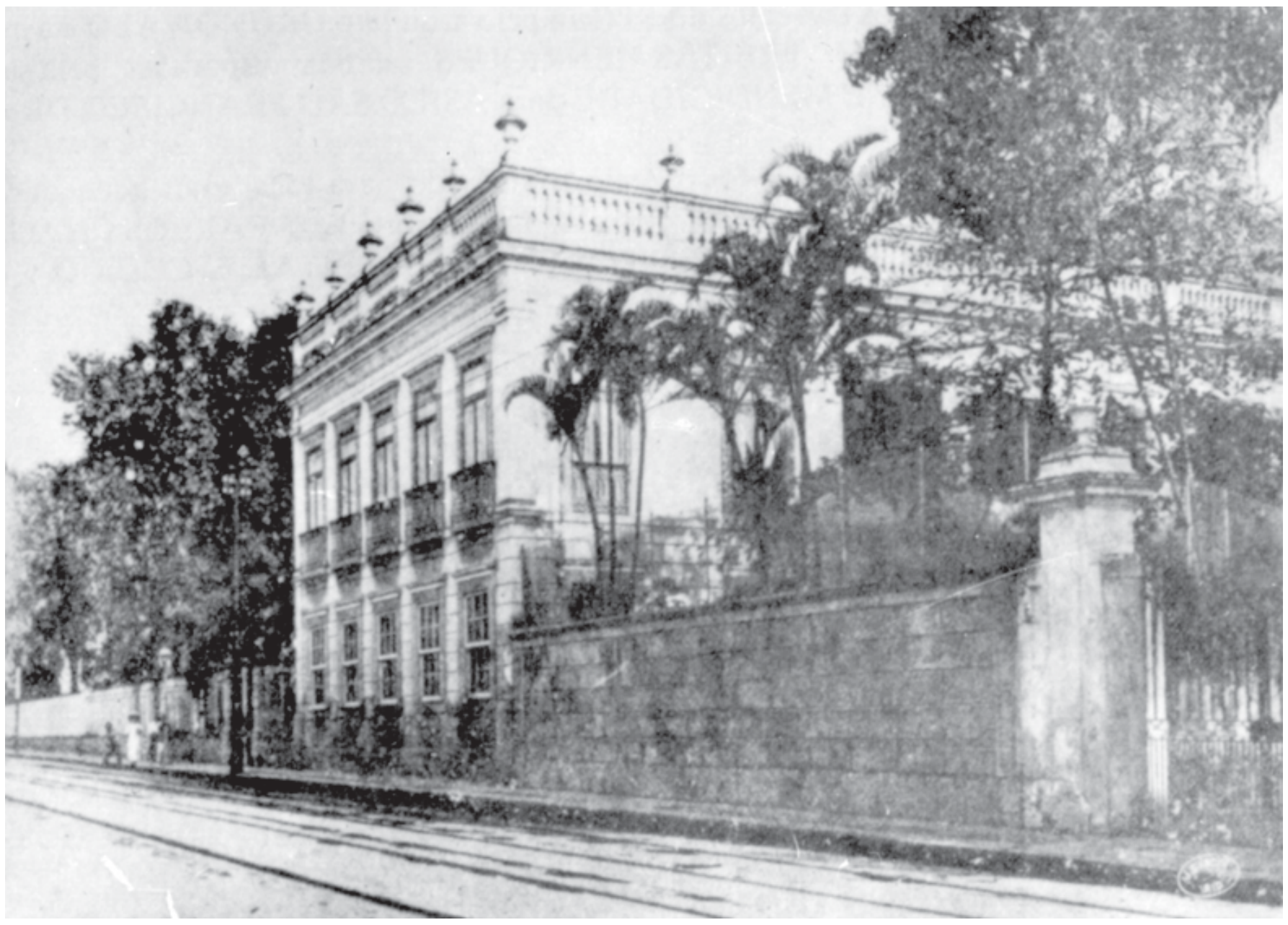

Pasteur Institute, Laranjeiras street, [s.d.]. Source: Assistência, 1922 


\section{Real e Benemérita Sociedade Portuguesa Caixa de Socorros D. Pedro V}

Other denominations: Caixa de Socorros D. Pedro V (1863-1897); Benemérita Sociedade Portuguesa Caixa de Socorros D. Pedro V (1897-1902); Real e Benemérita Sociedade Portuguesa Caixa de Socorros D. Pedro V (1902-present day).

\section{Location: Downtown}

Address: Avenida Marechal Floriano, no. 185/189

Category: Institution of assistance care

Period of construction: $19^{\text {th }}$ Century

Proprietor: Real e Benemérita Sociedade Portuguesa Caixa de Socorros D. Pedro V

Author/constructor: unknown; Antonio Jannuzi \& Brothers (adaptation)

\section{History:}

Since the middle of the XIX century there existed in Rio de Janeiro a movement of philanthropic associations articulating immigrant groups around societies dedicated to social and medical assistance care, such as, for instance, the Sociedade Portuguesa de Beneficência, created in 1840. On May 31 $31^{\text {st }}, 1863$, it was founded the Caixa de Socorros D. Pedro V, born with the goal to render medical, financial, social and legal assistance to the Portuguese and their descendents. Under the Presidency of Joaquim Manuel Monteiro (Visconde da Estrela), it initiated its service at Rua Municipal, no. 7.

Its denomination paid tribute to King D. Pedro V, who died on November $11^{\text {th }}, 1861$, date commemorated annually with an abundant distribution of handouts to indigents. Paid for by the institution, 100 needy orphans were dressed, preferably children of the Portuguese, to attend the commemorative mass.

Established under the initiative of Leonardo Caetano de Araújo, President from 1866 to 1868, the Caixa de Socorros had the objective to maintain a pharmacy and health care clinics destined for its associates as well as the non-associate needy Portuguese that sought help from the institution. In addition, the consultations rooms were open to needy people regardless of their background, whenever the institutional revenues allowed, and such cases were highest on the list of demand. Intent on adequately tending to its associates, the Caixa de Socorros offered residential clinical care, which was performed by volunteer doctors associated with the institution. It was one of the first establishments to install a homeopathic polyclinic with distribution of free medications.

It was not entirely dedicated to medical care, but also to educational endeavors, by articulating with private schools to obtain benefits for the associates and descendents. Yet it maintained the pledge to fund for its associates and nonassociates alike, a portion if necessary, the ticket back to Portugal.

In the first month of operations alone 875 Portuguese became associates of the entity, a great number of them linked to commercial activities. At the time, there was great concern with the mortality rate of the Portuguese in the city of Rio de Janeiro, mainly afflicted from yellow fever. This reason explains the high volume of adherents into the Sociedade soon after the initiation of operations, gradually increasing in the following years.

In respect to legal assistance, a commission of three associates and a lawyer was organized responsible for visiting the House of Detention and the House of Correction to render legal support to the Portuguese that had committed nonserious crimes.

Still, anticipated in its first statutes (in effect until 1871), was the founding of a sanatorium for the tuberculous associates or the economic provision of an institution willing to receive them. It was also anticipated the creation of an asylum to house the elderly associates that could no longer live on their own.

During the 1870's, already administered under new statutes (decree no. 4.817, 11/15/1871), the Caixa de Socorros performed jointly with the Agency of Colonization in the inspections of the immigrant ships that moored at the port of Rio de Janeiro, by carrying out health exams and medical consultations, taking in consideration the grave epidemics of yellow fever that propagated in the city. 


\section{IMPERIAL TIMES}

As of 1879, the Caixa de Socorros began to render services at Rua Sete de Setembro, no. 41. In 1881, it acquired the building at Rua Visconde do Rio Branco no. 27, which caught on fire on July $07^{\text {th }}$, 1910, destroying great part of the archives of the Sociedade and practically the entire building. As a result of the incident, it was momentarily transferred to a house with two floors at Rua São Bento, no. 10. Soon after the fire, the building on Rua Larga de São Januário, currently Avenida Marechal Floriano, no. 185, which belonged to the Evangélica Fluminense Church was put up for auction.

In the 1930's, the medical staff of Caixa de Socorros consisted of eight professionals, divided in the following clinics: allopathy (5), otorhinolaryngology (1), surgical (1) and homeopathy (1).

In 1966 with the approval of the new statutes, the mark of the Portuguese association was abolished and it began to accept Brazilian associates. However, it still sustained its philanthropic character offering medical and legal assistance, pensions and scholarships.

It inaugurated a home for the needy elderly, denominated Lar D. Pedro V in Copacabana on May $26^{\text {th }}, 1976$.

A Real e Benemérita Sociedade Portuguesa Caixa de Socorros D. Pedro V was considered an entity of public utility in the three branches of power: the state (08/09/1932), federal (decree no. 63.447, 10/18/1968) and municipal (Act no. $2.640,05 / 27 / 1998)$.

\section{Architectonic description:}

Neoclassical construction typical of the Imperial period strongly influenced by religious British temples was adapted by Antonio Jannuzi \& Brothers, who altered the frontispiece. The building, surrounded by ample windows, possesses a main hall that on the back can be found elegant balusters that involve the pulpit of the pastor, its bookstand and the chairs of the presbyteries.

\section{Register of Preservation:}

Endowed by the Municipality on March 07 1986.

\section{Sources:}

ASSISTÊNCIA Pública e Privada no Rio de Janeiro (Brasil) - História e Estatística. Comemoração do Centenário da Independência Nacional. Rio de Janeiro: Typographia do Annuario do Brasil; 1922.

HISTÓRIA Crítica das Administrações da Caixa de Socorros de D. Pedro V - o Asylo. Rio de Janeiro: Typographia Perseverança, 1867.

MENDES, J. Real e Benemérita Sociedade Portuguesa Caixa de Socorros D. Pedro V, Comemoração dos 125 anos de sua fundação. Rio de Janeiro: Guanapá Gráfica Editora e papéis Ltda, 1988.

SILVA, M. Filantropia e Imigração: a Caixa de Socorros de Pedro V. Rio de Janeiro: [s./n.], 1990.

Credits: Leonardo Rodrigues (research), Atiele Azevedo de Lima Lopes (research and text) and Gisele Sanglard (architectonic description). 


\section{IMPERIAL TIMES}

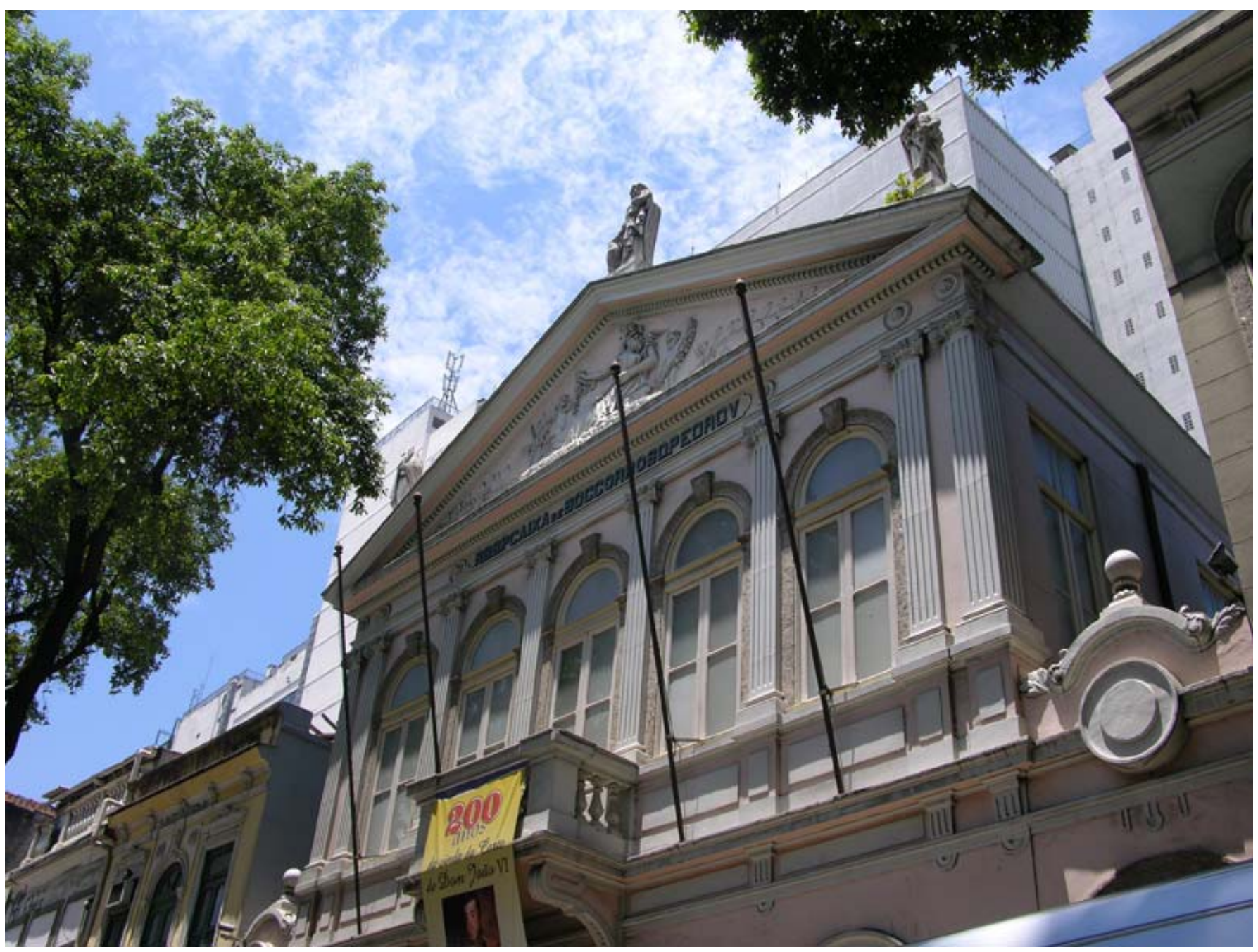

Real e Benemérita Sociedade Portuguesa Caixa de Socorros D. Pedro V. Photo Roberto Jesus Oscar \& Vinícius Pequeno de Souza, 2008. Casa de Oswaldo Cruz Archives 


\title{
Santa Casa da Misericórdia of Rio de Janeiro Hospital
}

\author{
Location: Downtown
}

Address: Rua Santo Amaro, 206.

Category: General Hospital

Period of construction: 1852

Proprietor: Santa Casa da Misericórdia of Rio de Janeiro

Author/constructor: José Domingos Monteiro, changed by José Maria Jacinto Rebelo.

\section{History:}

Santa Casa da Misericórdia of Rio de Janeiro has had an important role in the routine of the city, because, differently from the other sisterhoods, the medical care offered was not limited to its associates.

The first hospital of Santa Casa of Rio de Janeiro began to be constructed in 1582 as part of a complex of construction works that the Sisterhood of Misericórdia intended to develop. Such charity works were divided into seven spiritual attitudes - to teach the simple folk; to give good advice to the ones that requested it; to punish with generosity those who committed mistakes; to console the sad ones who grieved; to forgive the ones who offended us; to be patient with whom harmed us; to pray to God for the living and the dead - and seven corporal attitudes - to redeem the captives and visit the convicts; to heal the diseased; to cover the naked body; to feed the hungry; to quench the thirsty of who is thirsty; to shelter the pilgrims and the poor; to bury the dead. Such principles, to be followed by its associates, were part of the Commitment of the Santa Casa de Lisboa, published in 1516, the first sisterhood of the Nossa Senhora da Misericórdia, created in 1498.

Since then, many Health Centers in several parts of the Portuguese Empire were founded. Under royal protection and similar among themselves, they were a common reference and a factor of identification in the colonial territories for the individuals of Portuguese origin, in addition to facilitating the dialog between the local authority and the king, as the historiography has indicated.

With the settlement of the Portuguese Court, in 1808, in Rio de Janeiro, significant changes were identified. In this period many institutions were transferred or created in Rio de Janeiro, among them the Anatomic, Surgical and Medical School of Rio de Janeiro, headquartered at the Military Hospital. In 1813, the institution at the time referred to as the Medical-Surgical Academy, was transferred from the Military Hospital to the confines of the Santa Casa, occupying two halls of the hospital and it was determined that its course should be administered at Santa Casa. Since then until 1918, when the construction of the building was concluded to accommodate it in Praia Vermelha, the College of Medicine of Rio de Janeiro was installed at the halls of the Santa Casa. Therefore, the patients and corpses of the Santa Casa Hospital were used for the practical teaching of anatomy and other courses of the College curriculum. Due to the role the hospital used to have in the academic medical education more doctors, surgeons and students started to frequent it. The liaison with the college was fundamental so that the establishment of Misericórdia was a scenario of transformations in the practice of the arts of healing. The government would annually issue orders to transfer some patients or an infirmary, chosen by the professor, so they could be studied and treated by the students. Thus, the academy was offering an increasing number of available surgeons and doctors and with the intention to work in the hospital to attain more experience. Also, an increasing number of students were being admitted to work under the orientation of the doctors and surgeons. The hospital finally became a learning establishment.

The presence of the academic medicine in that environment pointed out problems in the physical structure of the building, considered inappropriate for the treatment of patients, according to medical concepts of the time. This issue also worried the administrators of the hospital, whose infirmaries began to have difficulties to house those who sought medical care due to the increase of the population of Rio de Janeiro, especially as of the arrival of the Portuguese Royal Court. Doctors and surgeons complained about the excess number of patients under their responsibility. This situation 
gave room to popular medicines, especially until the first decades of the XIX century, through, for example, bleeders and nurses who were more in contact with the hospitalized patients.

The number of employees without academic education - such as nurses, doorkeepers, servants, assistants - also had to increase a lot to meet the number of patients management wanted to serve. To better organize its working, Santa Casa tried, throughout the XIX century, to determine criteria for hiring and promotion of its employees, in addition to delimiting the roles and instruct the behavior of those who frequented that environment, by means of standards and regulations, which were faced with resistance and roused conflicts pervaded by the social positions of each one.

Other two important changes were instituted by the regulation of 1852. Firstly, the division of the infirmaries into the internal and external clinic, instead of infirmaries of medicine and surgery, reflecting the official joint between the professions of doctor and surgeon, which happened in the 1830s. Secondly, the introduction of the religious women of the São Vicente de Paula Order, coming from France, in the routine of the new hospital. The sisters were responsible for tasks ranging from supervision of monthly purchases, with the superior sister as co-administrator, up to the roles of nurse, feeding and providing medicine to patients, men and women. The male nurses took care of the male patients and the female nurses of the female patients and their work was inspected and aided by the sisters.

At the same time a new organization in the operation of the hospital was instituted, its purposes were adapted to the new period. The objective was to offer free treatment to poor patients and not only shelter them. The sisterhood practiced charity in many other areas - such as Recolhimento das Órfãs (Orphanage), Casa dos Expostos, feeding, treatment and legal support to convicts, burial of the poor and alms and clothes periodically given to some poor people -, this helped to confirm the tendency not to accept those who had contagious or incurable diseases in the hospital. The liaison of Misericórdia with the medical institutions, in the context of the fight for the monopoly in the arts of healing, changed the understanding about what would be curable and what would not, limiting the admission of patients to those who could be cured by academic medicine.

The patients received free treatment at the Misericórdia hospital upon proof that they were poor. For that, they should present certificate of their respective rector confirming they were poor; their poverty should be made evident through an acknowledged person; present certificate proving to be a sailor; or slave of a master who did not have more than two slaves, this was then limited to only one captive from the regulation of 1852. Throughout the XIX century, the number of poor people and consequently of patients increased, although the difficulties faced by the administration of Santa Casa were attenuated with the charity of the rich. Such individuals would make donations or leave estates concerned with the salvation of their own souls and, increasingly, with the preservation of their bodies which were under threat given the concentration of people living in conditions propitious for the development of diseases.

As of the 1850s, before the epidemics of yellow fever and cholera, the government tried to take over the medical care of the affected population, creating and administering hospitals specific for the diseases suspected of being contagious. Still, the State did not take the responsibility to directly promote medical care for the population in general - Santa Casa continued responsible to take care of the most common diseases. The liaison between the government and the sisterhood of Misericórdia changed with time, depending on the groups that had the authority in each area, the presence of the academic doctors at the infirmaries of Santa Casa, the need of hospital assistance to immigrants, sailors, free Africans and more concrete threats of epidemics, in such cases the public administration paid the medical treatment.

In addition to counting with financial aid from its benefactors and government, the hospital started housing more patients that could pay for their hospitalization attracted by the new structure of the hospital and by the disclosure of statistical data, produced in this context, which indicated improvement in the results of the hospital care. Although they did not constitute the majority of the services, they contributed to the financial balance of the institution.

Santa Casa administered and maintained several charity and health institutions in the city of Rio de Janeiro, in addition to the General Hospital, such as Pedro II Asylum, the Recolhimento de Órfãs (Orphanage), Roda dos Expostos, the infirmary of Nossa Senhora da Saúde, in the Morro da Gamboa, and free consultation rooms, in addition to burial services. It was also responsible for the maintenance of several leprous patients installed in the country. The healing of patients was only one of the seven "corporal attitudes" proposed by the Sisterhood of Misericórdia in its "Commitment". In fact, all pious benefits and charity works performed by the Catholics who helped Santa Casa were found in the gospels. 
During 1888, the number of patients cared for was 12,358, 6,325 nationals and 6,033 foreigners, with 2,194 dead due to various diseases. Augusto Ferreira dos Santos was the director of the Sanitarium Service of the Hospital back then, and his team of doctors and physicians was formed by the Drs. Julio Rodrigues de Moura, José Pereira Rego (Baron of Lavradio), Hilário Soares de Gouvêa, Pedro Affonso de Carvalho Franco (Baron of Pedro Affonso), José Cândido Barata Ribeiro, among others. The Hospital had a Homeopathic Infirmary, Children's Clinic, Maternity Ward and Gynecological Clinic, Ophthalmological Clinic, Clinic of Cutaneous and Syphilitic Diseases and a Medical-Surgical Statistic Cabinet.

In the beginning of the XXI, Santa Casa da Misericórdia of Rio de Janeiro administers five hospitals (General, Nossa Senhora das Dores, Nossa Senhora da Saúde, Nossa Senhora do Socorro, São Zacharias), which developed an important role in the medical care offered to the population of the city, through the National Health Program (SUS), maintaining itself as an area of medical education.

\section{Architectonic Description:}

The first hospital of 1582 was implemented at the sea shore on Praia de Santa Luzia (Santa Luzia Beach), surrounding the main access of the former Morro do Castelo, the Ladeira do Descanso (current Ladeira da Misericórdia). As for the current headquarters, it was constructed between 1840 and 1852 and implemented on the property of the old cemetery of the institution at the base of Morro do Castelo (Castelo Hill). Its neoclassical lines were designed by the architectengineer, José Domingos Monteiro, designated architect of the construction works of Santa Casa by the provider of the José Clemente Pereira Institution. The architect had already been a member of the Imperial Association of Engineers and an architect of the Chamber, according to Noronha Santos (1977:59).

According to the history, the first hospital would have been built without planning and expanded according to the needs. Two centuries later, the provider of Santa Casa, José Clemente Ferreira, described some of the defects of the facilities in the XVI century, which were in disagreement with the hygiene rules of the Oitocentos: the architecture was irregular; the infirmaries of the lower floor were almost underground, humid and had no air circulation; the female ones were very small; the tuberculosis patients were not separated, as well as the smallpox patients; and the accommodations of the mentally ill patients were like prisons. Such conditions were aggravated due to infiltrations, leaks and risk of collapsing in some parts of the building.

In 1838, the sisterhood invited the Imperial Academy of Medicine to create a project for a new hospital, which stated being constructed in 1840. The committee that elaborated the plan for the new building was constituted by the Doctors Thomaz Gomes dos Santos, Octaviano Maria da Rosa, José Martins da Cruz Jobim and Luiz Vicente De Simoni. Jobim was a doctor at Santa Casa, as De Simoni, and professor of college, as Gomes dos Santos, this would provide them full knowledge of the issues raised by the provider.

The basis for the construction of a hygienic hospital was planned, emphasizing the following general orientations: squared shape, with one of the angles pointed to the east and other to the west and absence of trees which would prevent the free circulation of air and maintain the walls humid. Among other recommendations, the infirmaries should be isolated one from another and there should be special rooms for contagious diseases and for those operated on.

With small changes in respect to the original project, the new hospital was inaugurated in 1840, indicating the acceptance of academic medical conceptions by the laymen administrators. Thus, more doctors were required and the environment was controlled by them. During the period, it was observed a progressive uniformity of language and procedures with the adoption of diets plans and maps for their application, monthly maps of the infirmaries, forms to regulate the prescription and a nosographic catalog. In "Memória descritiva da Planta do novo Hospital da Santa Casa da Misericórdia da Cidade do Rio de Janeiro" (Memorial Description of the Plant of the new Hospital of Santa Casa da Misericórdia of Rio de Janeiro), it was specified the size and number of doors and windows, that should be high, almost reaching the ceiling to facilitate the outlet of insalubrious emanations and bad gases. A small opening below each window was recommended for the exit of heavier gases that could also compromise the quality of the air. It was also determined that each one of the 20 infirmaries would have capacity for 32 beds, a total of 640 . And the beds of four inches of width 
would be separated by three inches on one side and six on the other. The change of big infirmaries where more than one hundred patients were settled for small separate spaces was justified by the need to preserve the patients in general from the miasmas produced by some patients with more serious diseases. The sections of the infirmaries were then settled along the corridors, ornamented by extensive bars of glazed tiles from the Netherlands, facing the gardens and internal yards, reflecting the principles of the hospital architecture of the XIX century.

On the occasion, the structure of the façade was revetted with beige gneisses highlighted by the interposition of a sequence of Tuscan columns in the two floors and by the frontage. The construction works of expansion, between 1840 and 1865, were of authorship of the architect and military engineer, José Maria Jacinto Rebelo (1821-1871), student of Grandjean de Montigny and also author of the Itamaraty Palace project, inaugurated in 1854 in the city of Rio de Janeiro. He designed the big portico with double sequence of columns of the Doric order and triangular frontage of the Santa Casa building. The ornamentation of the façade is austere and presents in its frontage, which was created by Luigi Giudice, allegorical figures that address mercy: a female figure aiding those in need - children, elderly, women, disabled people under the protection of her veil.

Its interior had a Chapel, the Nossa Senhora da Misericórdia Chapel, also known as Capela Dourada or Imperial (Golden or Imperial Chapel), whose works of ornamentation and painting of the Ceia do Senhor (Lord's Supper) were created by the painter and designer François René Moreaux (1807-1860), hired in 1851. The dome of the Chapel was constructed by Joaquim Cândido Guilhobel, and the stucco works were carried out by Francisco Alves de Nogueira.

\section{Notes:}

The furniture collection and the state of preservation of the pharmacy are highlighted, on the ground floor, where the Pharmacy Museum was installed. The wardrobes of hardwood, the bottles and measurement instruments permanently on exhibition show the pharmaceutical way of thinking and practice of the XIX century. The circular chapel stands out in the top floor of the hospital. It is dated from 1840, work of Joaquim Cândido Guilhobel.

\section{Register of Preservation:}

Federal Endowment no. 978/T/78, entry 490, Livro do Tombo Histórico (Book of Historical Endowment), sheets. 86, on 06/23/1983 and Livro do Tombo das Belas Artes (Book of Fine Arts Endowment), volume II sheets 5, on 06/23/1983. The endowment encompasses the old infirmaries.

\section{Sources:}

AZEVEDO, M. O Rio de Janeiro sua História, monumentos, homens notáveis, usos e curiosidades. Vol. 1. Rio de Janeiro, Ed. Brasiliana, 1969.

COSTA, N. Rio de ontem e hoje. Rio de Janeiro, Ed. Coleção Estácio de Sá, 1958.

CRULS, G. Aparências do Rio de Janeiro. Vol.1 e 2. Rio de Janeiro, Ed. José Olympio, 1949.

GERSON, B. Histórias das Ruas do Rio. Rio de Janeiro, Ed. Livraria Brasiliana, 1965.

INSTITUTO DO PATRIMÔNIO HISTÒRICO E ARTİsTICO NACIONAL. Arquivo Noronha Santos. Busca. Disponível: http:/ /www2.iphan.gov.br/ans/inicial.htm

José Maria Jacinto Rebelo. In: Wikipedia. A enciclopédia livre. Capturado em 13 dez.2007. Online. Disponível na Internet: http://pt.wikipedia.org/wiki/Jos\%C3\%A9_Maria_Jacinto_Rebelo

LEITE, A. História da Companhia de Jesus no Brasil. Vol. 1 ao 10. Rio de Janeiro, Imprensa Nacional, 1945.

MARTINS, A. Santa Casa de Misericórdia do Rio de Janeiro. Visitando a Casa da Memória da Medicina e da Farmácia no Brasil. Rio de Janeiro: LABLET/FAU/UFRJ, 2002.

MONTEIRO, M. Por que as obras dos hospitais nunca terminam?Capturado em 13 dez. 2007. Online. Disponível na 


\section{IMPERIAL TIMES}

Internet:http://www.vivercidades.org.br/publique222/cgi/cgilua.exe/sys/start.htm?from_info_index=49\&infoid =884\&sid= $5 \& t p l=p r i n t e r v i e w$

PIMENTA, T. O exercício das artes de curar no Rio de Janeiro (1828-1855). São Paulo: UNICAMP, 2003. (Tese de Doutorado) (mimeo)

Santa Casa da Misericórdia do Rio de Janeiro. Capturado em 13 dez. 2007. Online. Disponível na Internet: http:// www.almacarioca.com.br/hist09.htm

Santa Casa da Misericórdia do Rio de Janeiro. Dicionário Histórico-Biográfico das Ciências da Saúde no Brasil (1832-1930). Capturado em 14 dez. 2007. Online. Disponível na Internet http://www.dichistoriasaude.coc.fiocruz.br

SANTOS, P. Quatro Séculos de Arquitetura. Rio de Janeiro: Fundação Educacional Rosemar Pimentel, 1977.

ZARUR, D. Colônia, Império e República: 1582-1995. Rio de Janeiro, Santa Casa da Misericórdia/Binus Artes Gráficas, 1995.

Credits: Tânia Salgado Pimenta (research and text); Inês El-Jaick Andrade and Tânia Salgado Pimenta (architectonic description). 


\section{IMPERIAL TIMES}

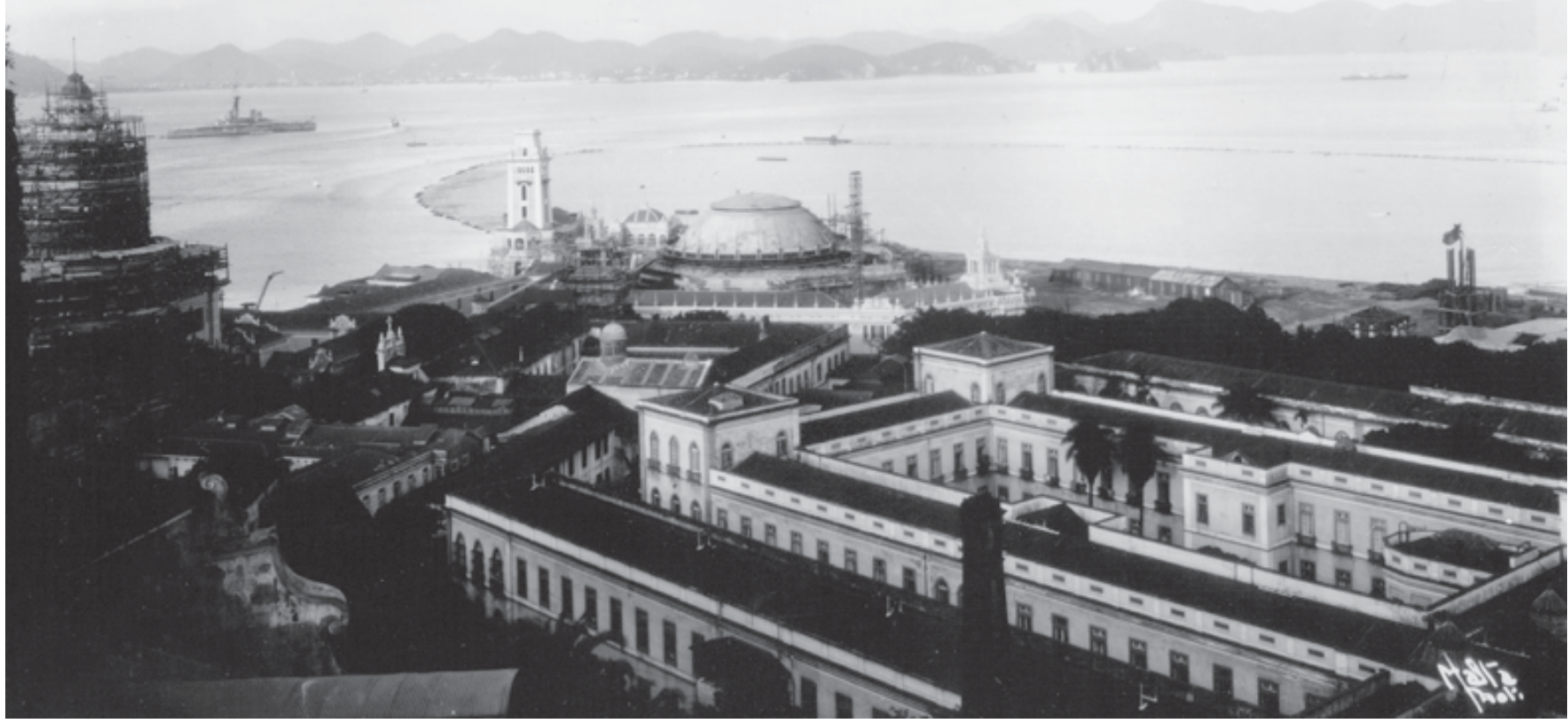

View of 1922 Rio de Janeiro International Exposition. Photo Augusto Malta, 1922. City of Rio de Janeiro General Archives

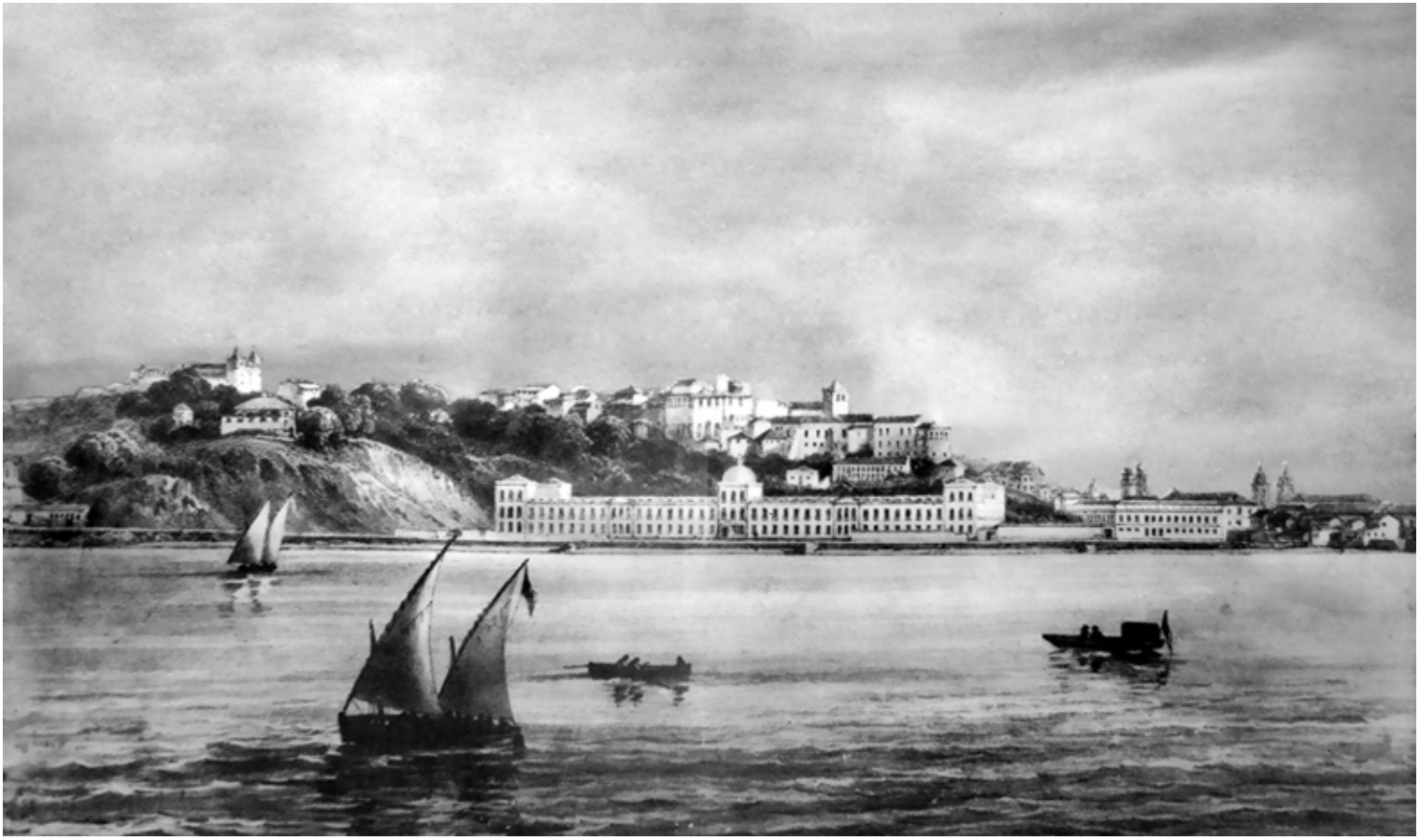

View of Misericordia Hospital, [s.d.].

Photo Victor Frond. Instituto Histórico e Geográfico Brasileiro Archives 


\section{IMPERIAL TIMES}

\section{São João Batista Asylum}

Other denominations: São João Baptista Infirmary of Lagoa; São João Baptista Asylum.

Location: Botafogo

Address: Rua da Passagem, no. 181.

Category: Institution of assistance care

Period of construction: XIX Century (Brazil Empire)

Proprietor: Santa Casa da Misericórdia of Rio de Janeiro

Author / Constructor: Cyrillo Eloy Pessoa de Barros

\section{History:}

The precarious salubrious state of the city of Rio de Janeiro, together with an epidemic of yellow fever in the middle of the XIX century stimulated the promulgation of act no. 583, 09/05/1850, which approved the expropriation of properties adequate to the establishment of infirmaries and cemeteries. Based upon such legislation, it was decreed the realization of a public bidding for the mentioned undertaking. One of the provisions regulated the mandatory installation of three infirmaries, by the winning entity, catered to the care of the epidemic victims of the Royal Court. Santa Casa da Misericórdia of Rio de Janeiro won the bidding along with Venerável Ordem Terceira dos Mínimos de São Francisco de Paula to manage the public cemeteries and infirmaries for 50 years. Complementary this act, decree no. 843 of 10/18/1851, established a six year time limit for the foundation, maintenance and conservation of the aforementioned infirmaries.

The first infirmary to be organized was São João Baptista Infirmary of Lagoa, inaugurated on January $01^{\text {st }}, 1852$, with the aim to render service care to the poor population of Botafogo and Copacabana. Besides medical service, it also provided services of elementary and religious education to children in surroundings areas.

For the undertaking of the project a property belonging to Santa Casa da Misericórdia of Rio de Janeiro, Chácara de Vigário Geral, was to be used. This property was inherited from priest Dr. Antônio Rodrigues de Miranda, who died in 1821. It was located at Rua da Copacabana, no. 15, 17 and 19, address which was maintained during a century of operations, S. João Baptista Infirmary of Lagoa had, as its first director, Manoel Antônio de Magalhães Calvet who had also been Santa Casa's deputy physician. Service care initiated on the date of its inauguration.

In 1855, decree no. 1,576 of March $10^{\text {th }}$ exempted Santa Casa from carrying out maintenance in two infirmaries, hence it was decided by the institution's Board and Union that the only infirmary to be maintained would be Nossa Senhora da Saúde, automatically terminating activities at Nossa Senhora do Socorro and São João Baptista. The latter functioned until August $10^{\text {th }}$ of the following year, until it was shutdown by Santa Casa due to financial hardships associated with maintenance expenses.

As the yellow fever and cholera morbus epidemics ravaged the city of Rio de Janeiro, the demand for rooms in the city's hospitals grew exponentially. In view of the great number of infected individuals, hospitalized patients and Santa Casa's employees that were being treated in its General Hospital, it was decided that patients would be transferred to N. S. da Saúde Asylum. However, soon the Asylum became overcrowded, stimulating the reopening of São João Baptista Infirmary, on April $26^{\text {th }}, 1867$. Yet, it was closed once again the following month because it had only treated one patient, citing difficulties in the rendering of services and inadequacy of the facilities.

On January $25^{\text {th }}, 1870$, the Imperial Government ordered Santa Casa de Misericórdia of Rio de Janeiro to reopen the infirmaries of N. S. do Socorro and S. João Baptista. The latter returned to operation once more on December $14^{\text {th }}, 1872$ to May $25^{\text {th }}, 1873$, and was reopened during subsequent periods of epidemics.

The old Infirmary was already known as São João Baptista Asylum when it terminated its activities on May $11^{\text {th }}, 1880$, at the old building which it occupied since its foundation. In the previous biannual a new headquarters had already been 


\section{IMPERIAL TIMES}

designed by engineer Cyrillo Ely Pessoa de Barros, however, he could not be in charge of the execution of the construction work. At the inaugural ceremony which took place on July $14^{\text {th }}, 1881$, José Vieira Fazenda was director of the Asylum, and remained in this position until 1886. The new building continued to be located on the same address, changing only its name and number, moving to Rua da Passagem no. 109.

In 1924, already with a new address number (no. 181), the S. J. Baptista Asylum inaugurated the sector of obstetrics and gynecology into its services, thus complementing the maternity service which had begun in 1920, being the only asylum to provide this service among the hospitals kept by Santa Casa. Since then, it embarked on a period of reformulation in the rendering of care and modernization of clinical services: Maternity ward was expanded (1926), São João Baptista chapel was reconstructed, contiguous the building and an area for employees and nurses were both constructed in 1929.

By the end of the 20s, the Asylum had 100 hospital beds for men and 20 for women. In view of this difference, the administration decided that the clinical service should be adapted to provide health care service to women only. This resolution transferred male hospitalized patients to $\mathrm{S}$. do Socorro Asylum, in the neighborhood of Caju.

In spite of any improvements, since the XIX century the hospital in Botafogo was considered the most modest hospital amongst all the ones kept by Santa Casa da Misericórdia of Rio de Janeiro. Since its foundation it underwent several closures and became an establishment maintained with scarce resources, but that inversely generated many expenses. This situation of permanent financial instability persisted during the entire next century in which it operated.

In the 1940s, it suffered a serious process of evasion by doctors and academicians, and, consequently, the capacity to provide service to hospitalized patients. However, its services had already been much expanded throughout the years, requiring ever more employees. Besides the Maternity ward, it also maintained three polyclinics (skin and syphilis, general surgery and pediatrics) along with three infirmaries. In the following decade it already totaled five infirmaries: two for medical clinic, one for malnutrition diseases, general surgery and maternity ward, in addition to a polyclinic.

In the 50s, due to several administrative and economic factors, Santa Casa da Misericórdia of Rio de Janeiro went through a period of intense budgetary deficit, culminating with the closure of São João Baptista Asylum. The high inflationary period, combined with the low profit of rents from properties belonging to the entity and payroll increases, City Hall of the Federal District still required that Santa Casa make more hospital beds available, which would be impossible given the financial onus resulting from the Asylum alone, which was already under a terrible state of conservation.

\section{Notes:}

There is no evidence of reliable dates in relation to changes in denominations, or specific shutdown date.

\section{Register of Preservation:}

It is not listed.

\section{Sources:}

MONTEIRO, A. Hospício de S. João Baptista. In: CARVALHO, M. (org.). Notícia dos diversos estabelecimentos mantidos pela Santa Casa da Misericórdia da cidade de S. Sebastião do Rio de Janeiro. Rio de Janeiro: Typographia do "Jornal do Commercio" de Rodrigues \& C., 1908.

ZARUR, D. Uma velha e nova história da Santa Casa. 2a ed. Rio de Janeiro: [s./n.], 1985.

Credits: Atiele Azevedo de Lima Lopes (research and text). 


\section{IMPERIAL TIMES}

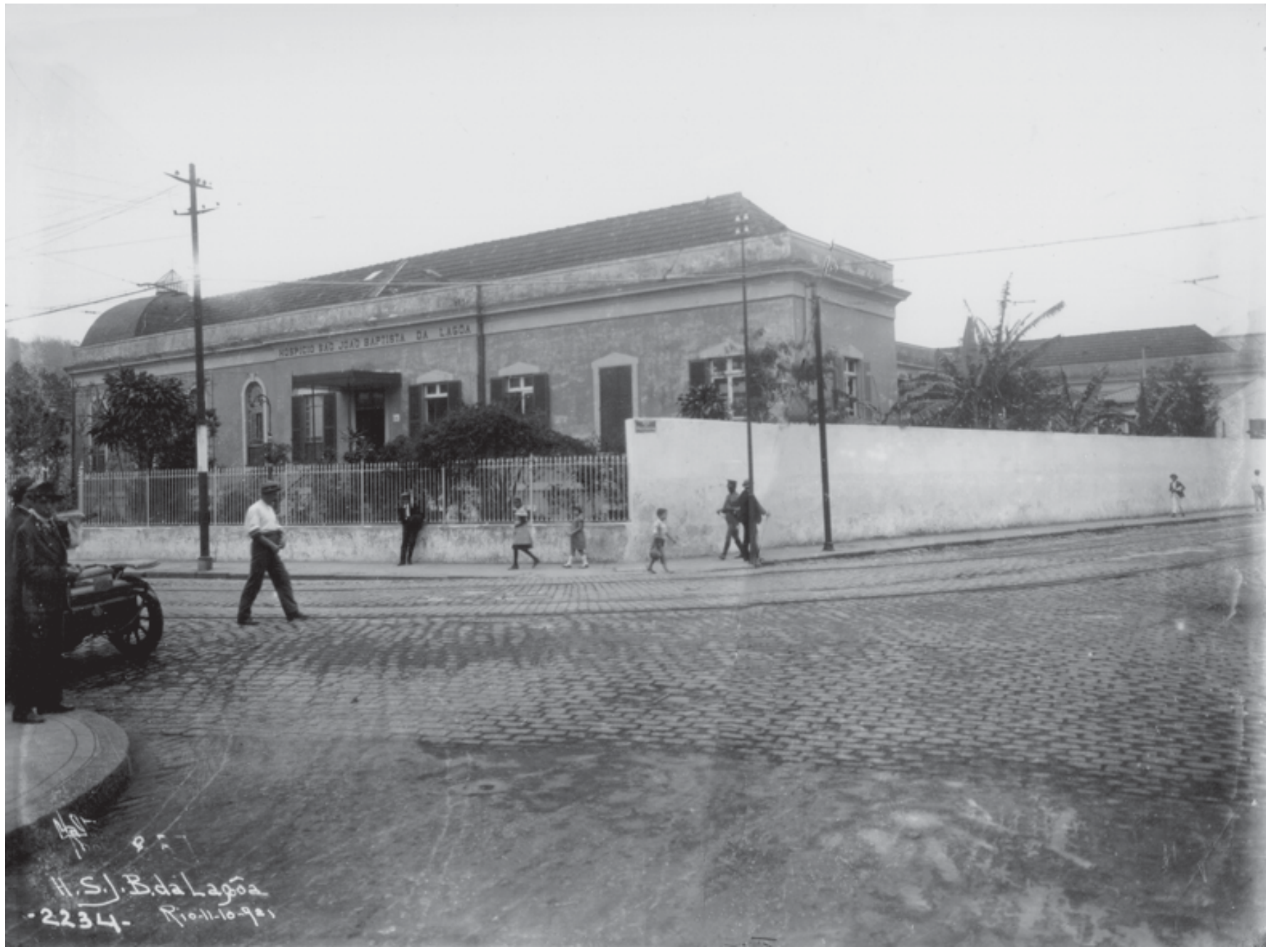

São João Batista da Lagoa Hospital. Photo Augusto Malta, 11/10/1901. Arquivo Geral da Cidade de Rio de Janeiro Archives 


\section{São Sebastião Health Center}

Location: Catete

Address: Rua Bento Lisboa, 160.

Category: Health Center

Period of Construction: XIX Century

Proprietor: The Simões Corrêa Family

Author/Constructor: unknown

\section{History:}

At a small farm acquired in 1873, formerly known as Rua da Pedreira da Candelária (currently Bento Lisboa), surrounding Largo do Machado, the São Sebastião Health Center was built in January, 1875. It is worth emphasizing that there was another São Sebastião Health Center in the city of Rio de Janeiro, founded in 1862, by Doctor João Ricardo Norberto Ferreira and it operated at the former residence of the Viscount of Aljezur, Morgado de Marapicu, at Largo do Rossio Pequeno, 10 - surrounding Praça Onze. In respect to this first Health Center, it is only known that João Ricardo was a member of the Public Health Central Committee, active in Freguesia de Sant'Ana, and that his undertaking certainly operated until the beginning of the 1870s; and that the Baron of Torres Homem had been a part of it.

The creation of the São Sebastião Health Center in Catete, which apparently has no connection with the one on Largo do Rossio Pequeno, occurred due to the initiative of an association of stockholding doctors of which doctors such as Felício dos Santos, Carneiro Leão and the chairman of the College of Medicine João Vicente Torres Homem were part of. The hospital complex, enclosed and away from the street, was part of a private hospital undertaking.

The first directors of the Health Center were Felício dos Santos and Carneiro Leão and, Torres-Homem, as head of the Medical Clinic. The São Sebastião Health Center has a renowned prominence in surgery because the first xiphopagus separation surgery was carried out on its confines by the Surgeon Eduardo Chapot-Prévost, in 1899.

In 1908, with the disaster at the Pedreira da Candelária (Stone pit of Candelária), which brought down the central pavilion that was still a wall of mud, the Center underwent several important substitutions and increments. As of 1912 all the current buildings that make up the complex were built of brick masonry. According to the sources researched, two wooden pavilions remained: the former bathhouse and laundry.

As of 1912 it becomes the property of Doctor Simões Correia, who administers it from this date until the end of 1930. This period is also marked by great modernization of the facilities.

As a result of the estate partition of the Simões Corrêa Family among ten heirs and the administrative problems stemming from it, the institution enters a period of decline.

The architectonic patrimony of São Sebastião was not endowed and the Health Center faces a process of bankruptcy since 1999 and is now closed.

\section{Architectonic Description:}

The hospital complex is composed by the main building, situated on the back of the property and by an interconnected annex. In front of rua Bento Lisboa there still remains two support constructions, with warehouses, dressing rooms, workshops and chapel. The tree-filled yard isolates the main building from the bustle of the street which includes the Health Center in the premises defended by the hygienists of its time. 


\section{IMPERIAL TIMES}

\section{Register of Preservation:}

It is not listed.

\section{Sources:}

Acervo família Simões Corrêa.

ARAÚJO, A. A Assistência Médica Hospitalar no Rio de Janeiro no século XIX. Rio de Janeiro: Ministério da Educação e Cultura/ Conselho Federal de Cultura; 1982.

Credits: Maria Elizabeth Bueno de Godoy (research and text) and Gisele Sanglard (research, text and architectonic description) 
IMPERIAL TIMES 


\section{São Sebastião State Institute of Infectology (IEISS)}

Other Denominations: Hospital São Sebastião (1889-19??); Instituto Estadual de Infectologia São Sebastião (19??present day)

Location: Rio de Janeiro

Address: Rua Carlos Seidl, 395, Caju.

Category: Specialized hospital

Period of construction: 1889

Proprietor: The Government of the State of Rio de Janeiro

Author/constructor: Eugênio de Andrade, engineer responsible for the adaptations and expansions of the first hospital (1889). Luiz Moraes Júnior performed the adaptations between 1903 and 1908.

History:

The construction of the isolation hospital inaugurated by D. Pedro II on November $9^{\text {th }}, 1889$, is related to the yellow fever epidemic in the imperial capital, in the summer of 1849/1850. Since then, the possibility to open another isolation hospital to join Santa Bárbara was discussed, on the island of the same name as Guanabara Bay, and Santa Isabel, dedicated to the mariners at Jurujuba beach in Niterói.

It was only in 1889 that the Imperial Academy of Medicine (currently the National Academy of Medicine) reached a consensus regarding the preventive measures required for the control of yellow fever, among them: to combat the epidemic propagation areas - including tenements, which are considered the main focuses of disease dissemination; and the construction of a hospital.

For such, a small farm was acquired at Praia do Retiro Saudoso, in Caju, and soon adaptation and expansion works got under way at the facilities, carried out by the engineer Eugênio de Andrade.

Considered a modern isolation hospital, its inauguration was attended by the Imperial family and authorities of the Empire, amongst them, D. Pedro II; the count d'Eu; Princess Isabel; and the general inspector of Hygiene, Benjamin Antônio da Rocha Faria.

The first director of the hospital was João da Silva Ramos, who, in the same year, was replaced by Luiz Manoel Pinto Neto. In 1891, Fernando de Paula Tavares took charge of the position remaining there until his death in 1892. However, the most memorable administration occurred under Carlos Seidl (1892-1912 and 1919-1929), who internationalized the work of the Hospital with the presence of the Mission from the Pasteur Institute in 1901, which had the attendance of Émile Marchoux and, three years later, in 1904, the German Mission.

At the beginning of the 1900's, the Hospital underwent its first changes, during the administration of Oswaldo Cruz as head of the General Office of Public Health - DGSP (1902-1906), reforms were made to canalize water; construction of a warehouse; adaptation of a building for the installation of a microscopy and clinical analysis laboratory; construction of three wooden pavilions to serve as the infirmary; construction of a pavilion for surgery and physiotherapy; replacement of hospital material; and acquisition of new technologies for electrotherapy and balneology. Afterwards, it would be reorganized to receive a maternity ward and other support facilities: new mortuary, incineration furnace, among others.

Names such as Miguel Couto, Lucas Antônio de Oliveira Catta Preta, Antônio Augusto Ferrari, João Pedro Leão de Aquino, Zeferino Justino da Silva Meirelles and João Lopes da Silva Júnior, Garfield de Almeida and Antonio Pires Salgado were part of its clinical staff.

Over its history, the hospital at times belonged to the Union, at times the municipality and at other times the state. Slowly, it ceased to be a hospital intended exclusively for patients with yellow fever, and began functioning as isolation for all those with infectious-contagious diseases. It played an important role during the smallpox epidemic (1905), and 


\section{IMPERIAL TIMES}

the Spanish flu pandemic (1919-1920), receiving around 300 lepers that were transferred, in 1927, to the newly inaugurated Colony-Hospital of Curupaity, in Jacarepaguá.

Over time, São Sebastião Hospital underwent several reforms, having many pavilions built, some of which became independent hospitals like Anchieta (1950), Francisco de Castro (1951) and Clemente Ferreira (1950).

In 1960, with the transfer of the federal capital to Brasília, the State of Guanabara was created encompassing the entire municipality of Rio de Janeiro. At this time, the hospitals belonging to City Hall of the Federal District came to have state jurisdiction. Fifteen years later, in 1975, with the merging of the states of Guanabara and Rio de Janeiro, some of these hospitals returned to the condition of municipal hospitals, while others remained state hospitals - among these the São Sebastião State Institute of Infectology.

From this reshuffling of the duties between the State and the Municipality of Rio de Janeiro, São Sebastião Hospital regained the Francisco de Castro Hospital - which had been constructed in 1928 as the Miguel Couto pavilion intended for victims of the yellow fever epidemic; becoming known as Francisco de Castro and dedicated entirely for phthisiology; and the Eduardo Rabello Hospital - created from one of the anti-venereal polyclinics maintained by the Gaffrée and Guinle Foundation at the beginning of the 1920s, installed in the old headquarters of the municipal Emergency Room, transformed to the Hospital of Venereal Diseases in 1948. Both institutions became responsible for the treatment of contagious diseases in general and dermatologic.

Nowadays, its facilities are underutilized showing signs of abandonment, although the hospital had always been a reference in the area of infectious-contagious diseases, offering care in medical clinic, pediatrics and phthisiology.

\section{Architectonic Description:}

The construction of the isolation hospital inaugurated by D. Pedro II on November $9^{\text {th }}, 1889$, is related to the yellow fever epidemic in the imperial capital, in the summer of 1849/1850. Since then, the possibility to open another isolation hospital to join Santa Bárbara was discussed, on the island of same name in Guanabara Bay, and Santa Isabel, dedicated to the mariners at Jurujuba beach in Niterói.

It was only in 1889 that the Imperial Academy of Medicine (currently the National Academy of Medicine) reached a consensus regarding the preventive measures required for the control of yellow fever, among them: to combat epidemic propagating areas - including tenements, which are considered the main focuses of disease dissemination; and the construction of a hospital.

For such, a small farm was acquired at Praia do Retiro Saudoso, in Caju, and soon adaptation and expansion works got under way on the facilities, carried out by the engineer Eugênio de Andrade.

Considered a modern isolation hospital, its inauguration was attended by the Imperial family and authorities of the Empire, amongst them, D. Pedro II; the count d'Eu; Princess Isabel; and the general inspector of Hygiene, Benjamin Antônio da Rocha Faria.

The first director of the hospital was João da Silva Ramos, who, in the same year, was replaced by Luiz Manoel Pinto Neto. In 1891, Fernando de Paula Tavares took charge of the position remaining there until his death in 1892. However, the most memorable administration occurred under Carlos Seidl (1892-1912 and 1919-1929), who internationalized the work of the Hospital with the presence of the Mission from the Pasteur Institute in 1901, which had the attendance of Émile Marchoux and, three years later, in 1904, the German Mission.

At the beginning of the 1900's, the Hospital underwent its first changes, during the administration of Oswaldo Cruz as head of the General Office of Public Health - DGSP (1902-1906), reforms were made to canalize water; construction of a warehouse; adaptation of a building for the installation of microscopy and clinical analysis laboratory; the construction of three wooden pavilions to serve as the infirmary; construction of a pavilion for surgery and physiotherapy; replacement of hospital material; and acquisition of new technologies for electrotherapy and balneology. Afterwards, it would be reorganized to receive a maternity ward and other support facilities: new mortuary, incineration furnace among others. 


\section{IMPERIAL TIMES}

Names such as Miguel Couto, Lucas Antônio de Oliveira Catta Preta, Antônio Augusto Ferrari, João Pedro Leão de Aquino, Zeferino Justino da Silva Meirelles and João Lopes da Silva Júnior, Garfield de Almeida and Antonio Pires Salgado were part of its clinical staff.

Over its history, the hospital at times belonged to the Union, at times the municipality and at other times the state. Slowly, it ceased to be a hospital designated solely to patients with yellow fever, and began functioning as isolation to all those with infectious-contagious diseases. It played an important role during the smallpox epidemic (1905), and the Spanish flu pandemic (1919-1920), receiving around 300 lepers that were transferred, in 1927, to the newly inaugurated Colony-Hospital of Curupaity in Jacarepaguá.

Over time, São Sebastião Hospital underwent several reforms, having many pavilions built, some of which became independent hospitals like Anchieta (1950), Francisco de Castro (1951) and Clemente Ferreira (1950).

In 1960, with the transfer of the federal capital to Brasília, the State of Guanabara was created encompassing the entire municipality of Rio de Janeiro. At this time, the hospitals belonging to City Hall of the Federal District came to have state jurisdiction. Fifteen years later, in 1975, with the merging of the states of Guanabara and Rio de Janeiro, some of these hospitals returned to the condition of municipal hospitals, while others remained state hospitals - among these the São Sebastião State Institute of Infectology.

From this reshuffling of the duties between the State and the Municipality of Rio de Janeiro, São Sebastião Hospital regained Francisco de Castro Hospital - which had been constructed in 1928 as the Miguel Couto pavilion destined for the victims of the yellow fever epidemic; becoming known as Francisco de Castro, solely dedicated for phthisiology; and Eduardo Rabello Hospital - created from one of the anti-venereal polyclinics maintained by the Gaffrée and Guinle Foundation at the beginning of the 1920s, installed in the old headquarters of the municipal Emergency Room, transformed to Hospital of Venereal Diseases in 1948. Both institutions became responsible for the treatment of contagious diseases in general and dermatologic.

Nowadays, its facilities are underutilized showing signs of abandonment, although the hospital had always been a reference in the area of infectious-contagious diseases, offering care in medical clinic, pediatrics and phthisiology.

\section{Register of Preservation:}

It is not listed.

\section{Sources:}

ASSISTÊNCIA Pública - Guanabara: 80 anos de história. Rio de Janeiro: Superintendência de Serviços Médicos (SUSEME); 1972. mimeo.

FALCÃO, E. Oswaldo Cruz Monumenta Histórica: campanhas e inquéritos sanitários. São Paulo: s.ed.; 1972. v.6. (Brasiliensia Documenta).

OLIVEIRA, P. Hospital São Sebastião (1889-1905): um lugar para a ciência e um lazareto contras as epidemias. Programa de PósGraduação em História as Ciências e da Saúde. Casa de Oswaldo Cruz. Rio de Janeiro: FIOCRUZ, 2005. (Dissertação de Mestrado)

SECRETARIA de Estado de Saúde do Rio de Janeiro. Indicadores e Informações em Saúde. In: http://www.saude.rj.gov.br/ informacoes/bancodad.shtml Acessado em 11/10/07.

Credits: Daniel Elian (research), Gisele Sanglard (text) and Renato da Gama-Rosa Costa (architectonic description). 


\section{IMPERIAL TIMES}

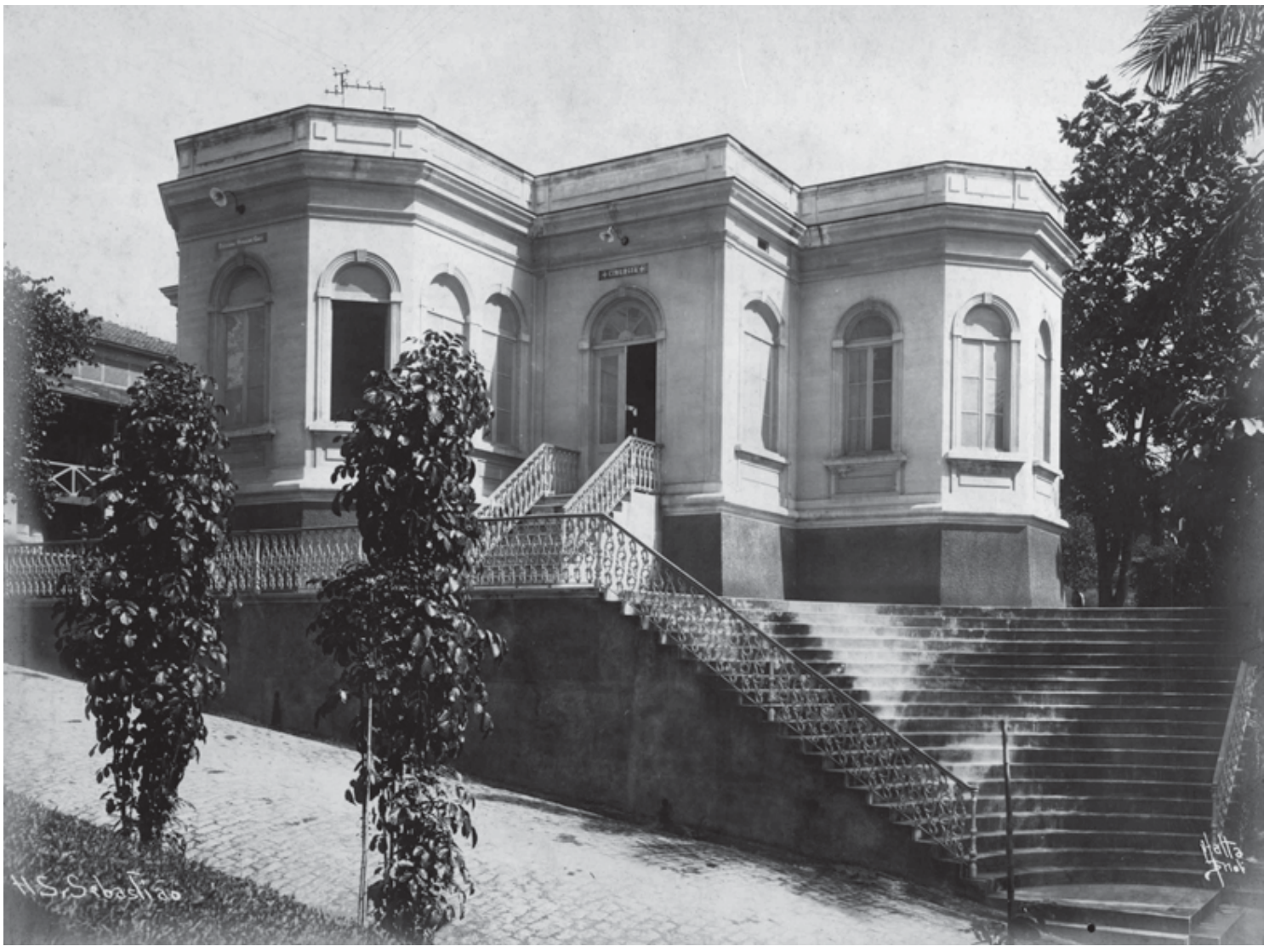

São Sebastião Hospital - façade, [s.d]. Photo Augusto Malta. Museu da Imagem e do Som RJ Archives

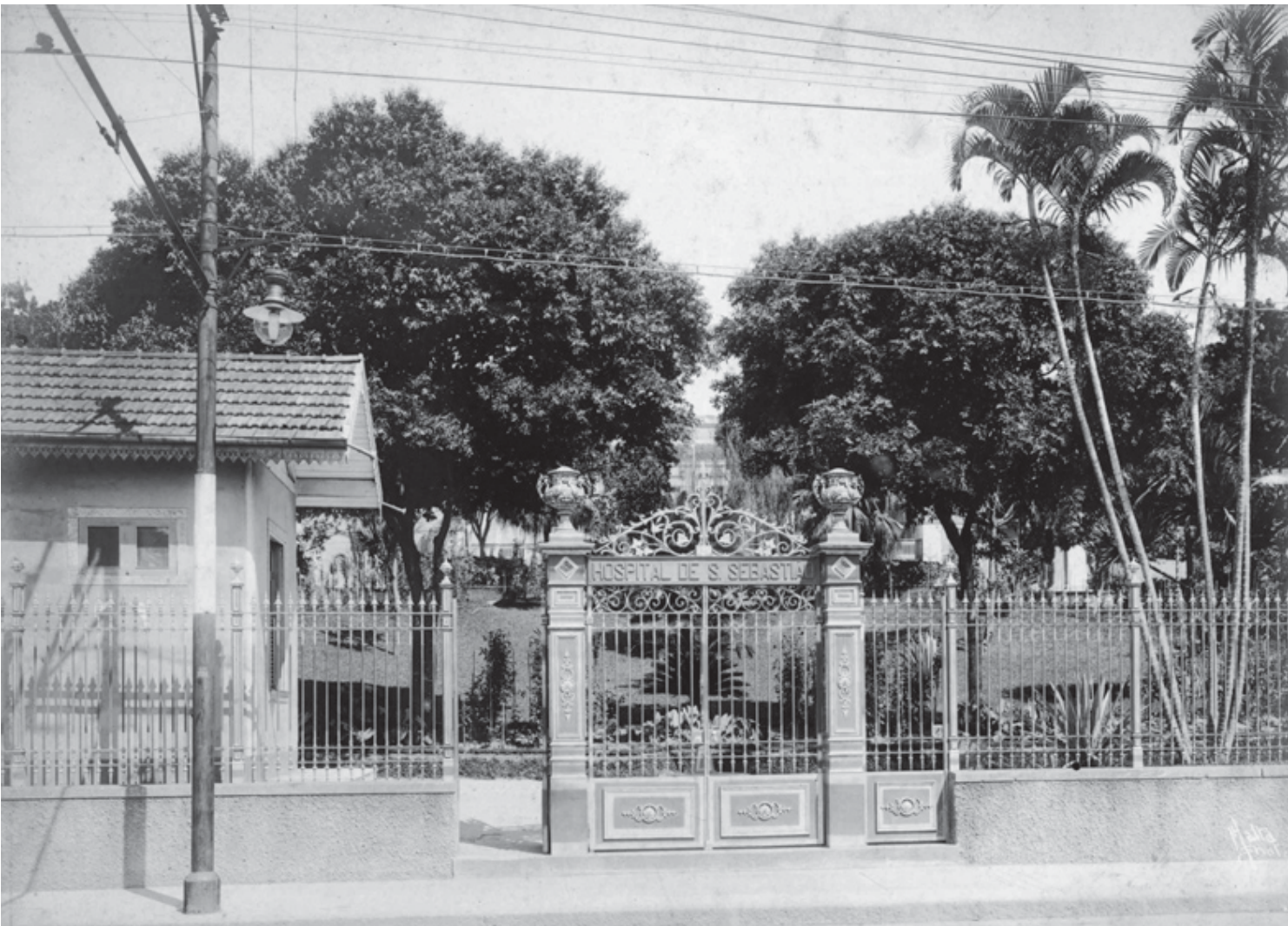

São Sebastião Hospital - entrance gate, [s.d]. Photo Augusto Malta. Museu da Imagem e do Som - RJ Archives 


\section{IMPERIAL TIMES}
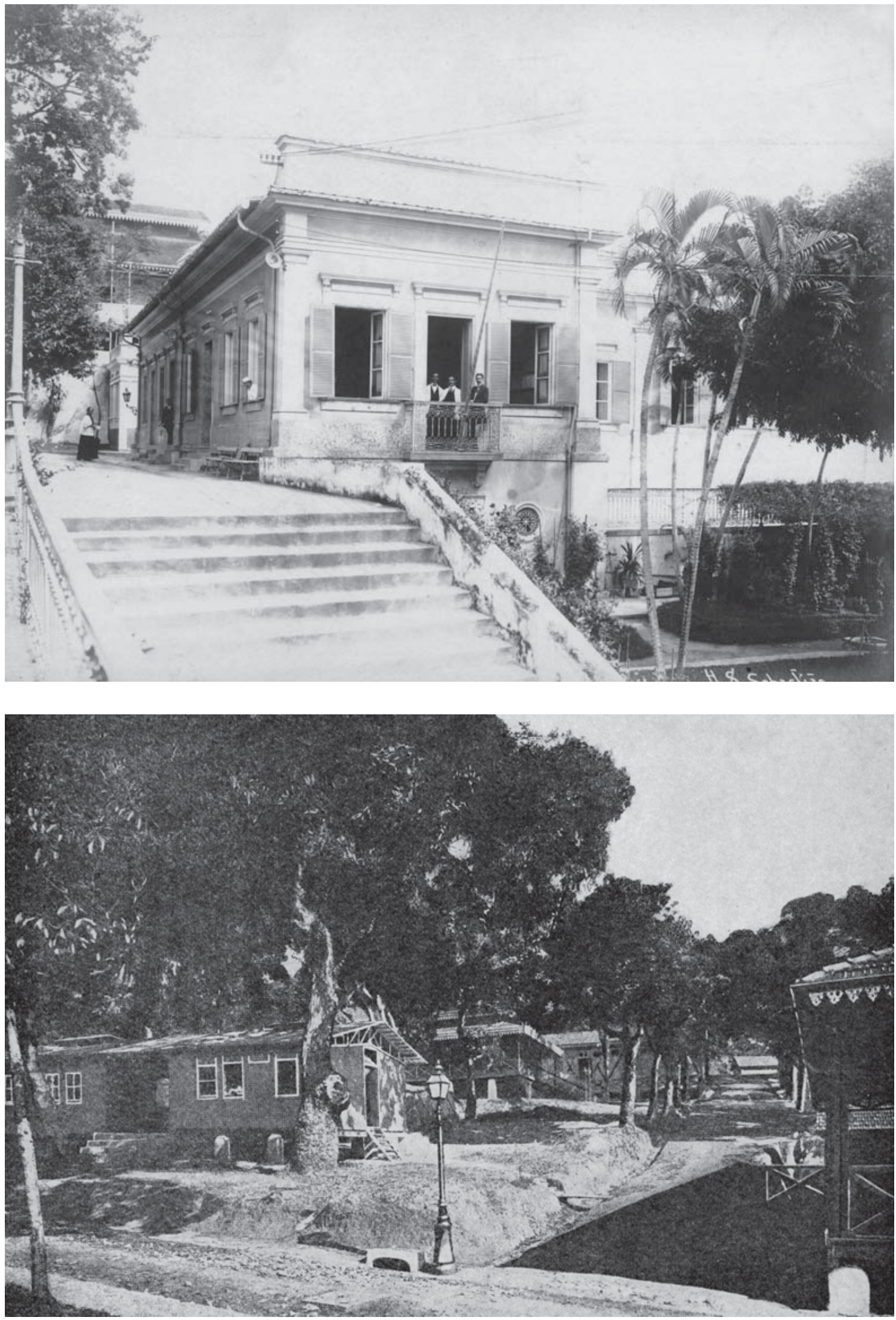

São Sebastião Hospital - facade, [s.d]. Photo Augusto Malta. Museu da Imagem e do Som, RJ Archives
São Sebastião

Hospital, [s.d.].

Source: Falcão, 1972 


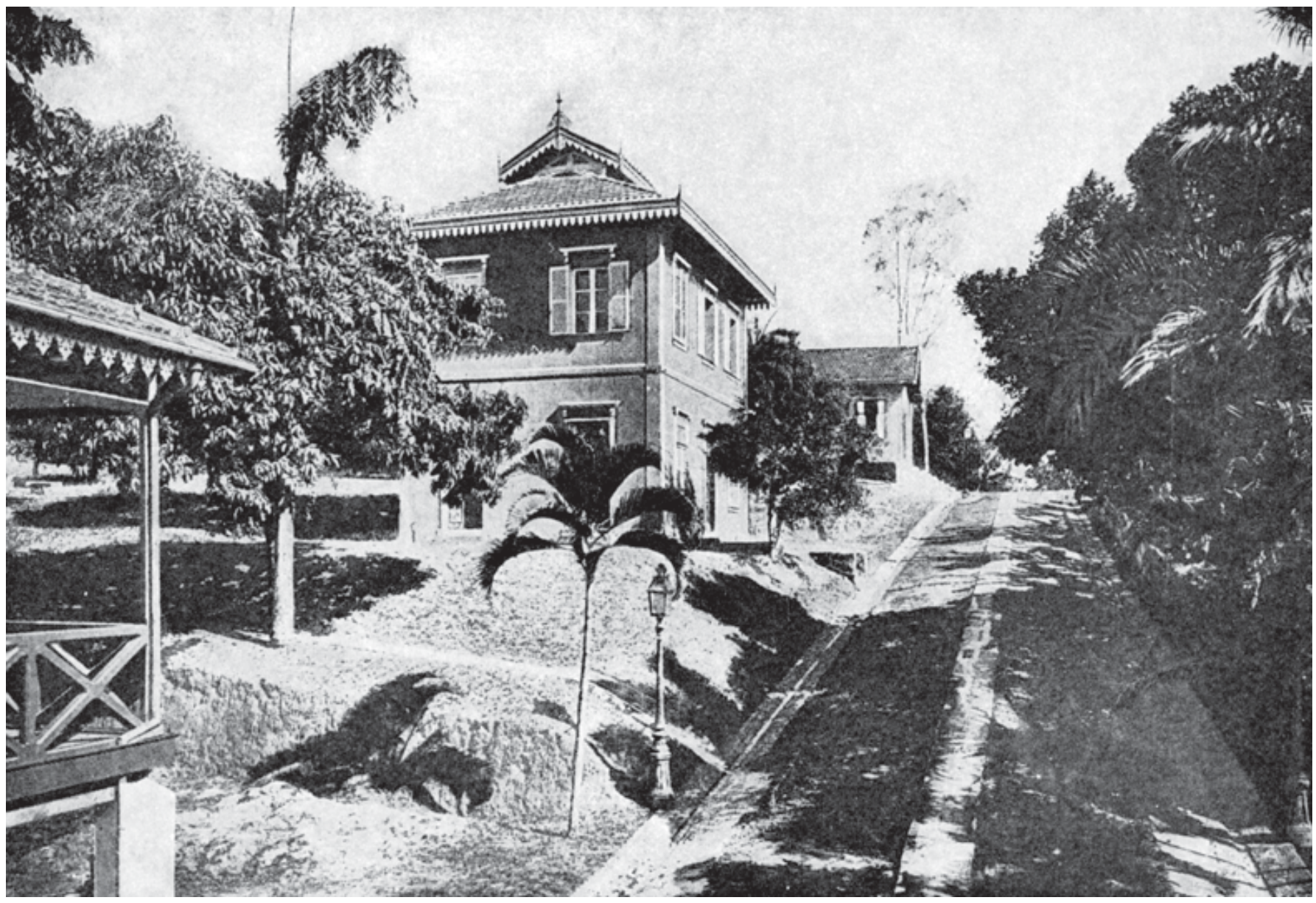

São Sebastião Hospital, [s.d.]. Source: Falcão, 1972 


\section{IMPERIAL TIMES}

\section{São Zacharias Hospital}

Other denominations: São Zacharias Hospital (1914-present day)

Location: Botafogo

Address: Avenida Carlos Peixoto, no. 124

Category: Healthcare Institution

Period of construction: $1922-1937$

Proprietor: Santa Casa da Misericórdia of Rio de Janeiro

Author / Constructor: unknown

\section{History:}

In 1904, after the transfer of the Army Central Hospital to the borough of Triagem (1902), the State granted a piece of land and the building that occupied it, on Ladeira da Misericórdia, on Morro do Castelo (Castelo Hill), at Santa Casa da Misericórdia of Rio de Janeiro. There was interest on the part of that entity to found a hospital near its General Hospital that could receive part of the growing volume of patients, particularly sufferers of tuberculosis, for its wards had already become incapable of adequately caring for them.

Responding to this demand, under the direction of engineer, João Barreto Costa Rodrigues, in March of 1913, works began to adapt the old building to the needs of a hospital that initially would care for male tuberculosis sufferers. However, the Director and Board of Santa Casa da Misericórdia of Rio de Janeiro decided not to dedicate it to this public, but to surgical and medical practice on children.

The reason behind this decision was the high rate of infant mortality. The city of Rio de Janeiro was still suffering the effects of the epidemics that had ravaged the capital throughout the previous twenty years and the health conditions of some dwellings and boroughs still didn't meet even the minimum conditions of hygiene. The Polyclinic of José Carlos Rodrigues Children's Hospital, located in São Cristóvão, another institution connected to Santa Casa, was unable to absorb the great number of children that were taken there, coming from all the parishes of the city.

It was due to this way then, that São Zacharias Hospital was founded, on June $28^{\text {th }}, 1914$, with the financial support of Miguel Joaquim Ribeiro de Carvalho, as a children's hospital, after a short period of large-scale reforms and re-equipping. At the inauguration ceremony, which occurred on the following day, the President of the Republic, Marechal Hermes da Fonseca and various public authorities were present. It was inaugurated with a structure of 6 wards, 190 beds, an operating theater and a temporary ward with 50 beds for women.

The invocation to Saint Zachariah (São Zacharias) fulfilled two tributes: first to Pope Zacharias, protector of children, and second to the financial benefactor Zacharias de Góes e Vasconcellos, who was at the head of Santa Casa da Misericórdia of Rio de Janeiro between 1866 and 1877.

During the Spanish flu epidemic, in 1918, the São Zacharias Hospital received more than 700 children, whose lack of nutrition prior to the infection was a major contributing factor to them not surviving the infirmity.

Although fundamental in the context of the public health services of the city of Rio de Janeiro, fulfilling its role of helping sick children, in 1922, São Zacharias Hospital was demolished during the clearance of Morro do Castelo. In its eight years of existence on the Ladeira da Misericórdia it had attended 5,978 children. The expropriation of the land rendered an indemnity payment for the Santa Casa from the Government, which was used to pay off debts and complement the amount destined to the transfer of the Hospital to a new address.

Having a plot of land in Botafogo, near to the entrance of the Túnel Novo (New Tunnel), acquired by Santa Casa in 1906, the entity then decided to set up São Zacharias Hospital at this location, with the objective of modernizing it and equipping it in order to render quality medical and surgical care for children, principally in critical periods of epidemics in the city. 


\section{IMPERIAL TIMES}

In the long interval between the closing of São Zacharias Hospital at Morro do Castelo, in 1922, and its re-opening in Botafogo, on April 30 ${ }^{\text {th }}, 1937$, the children of the city were sent to the José Carlos Rodrigues Children's Hospital, in São Cristóvão.

As a philanthropic entity, São Zacharias Hospital received the financial support of various illustrious families and personalities of the Capital of the Republic, such as the Paula Machado, Antonio Leite Garcia, José Carlos Rodrigues, Arnaldo Guinle families and others.

As from 1965, thanks to an agreement signed between the Municipal Department of Education and Culture and Santa Casa da Misericórdia of Rio de Janeiro, besides medical care, the children attended by São Zacharias Hospital received educational instruction. For this reason, since then the institution has been a part of the Municipal Teaching Network, receiving from the municipality, the same consideration conferred upon regular centers of learning. In exchange, the Hospital provides, without cost, the space for the pedagogic and recreational activities.

Although its speciality is children's healthcare, since its inauguration the São Zacharias Hospital has been willing to attend to the needs of people of any age. Its medical services of surgery, orthopedics, ophthalmology gynecology, neurology, psychology and physiotherapy are always open to the public in general.

At present it has agreements with the courses of medicine of the Universidade Gama Filho (UGF), Universidade Souza Marques and Pontifícia Universidade Católica of Rio de Janeiro (PUC-RJ).

\section{Register of Preservation:}

It is not listed.

\section{Sources:}

RELATÓRIO apresentado à Mesa da Santa Casa da Misericórdia da Cidade de São Sebastião do Rio de Janeiro na sessão de posse de 2 de agosto de 1914 pelo provedor Miguel Joaquim Ribeiro de Carvalho. Rio de Janeiro: Typ. Jornal do Commercio, de Rodrigues \& C.; 1914.

ZARUR, D. Hospital São Zacharias. 2a ed. Rio de Janeiro: Binus Artes Gráficas Ltda., 1993.

Credits: Atiele Azevedo de Lima Lopes (research and text). 


\section{IMPERIAL TIMES}

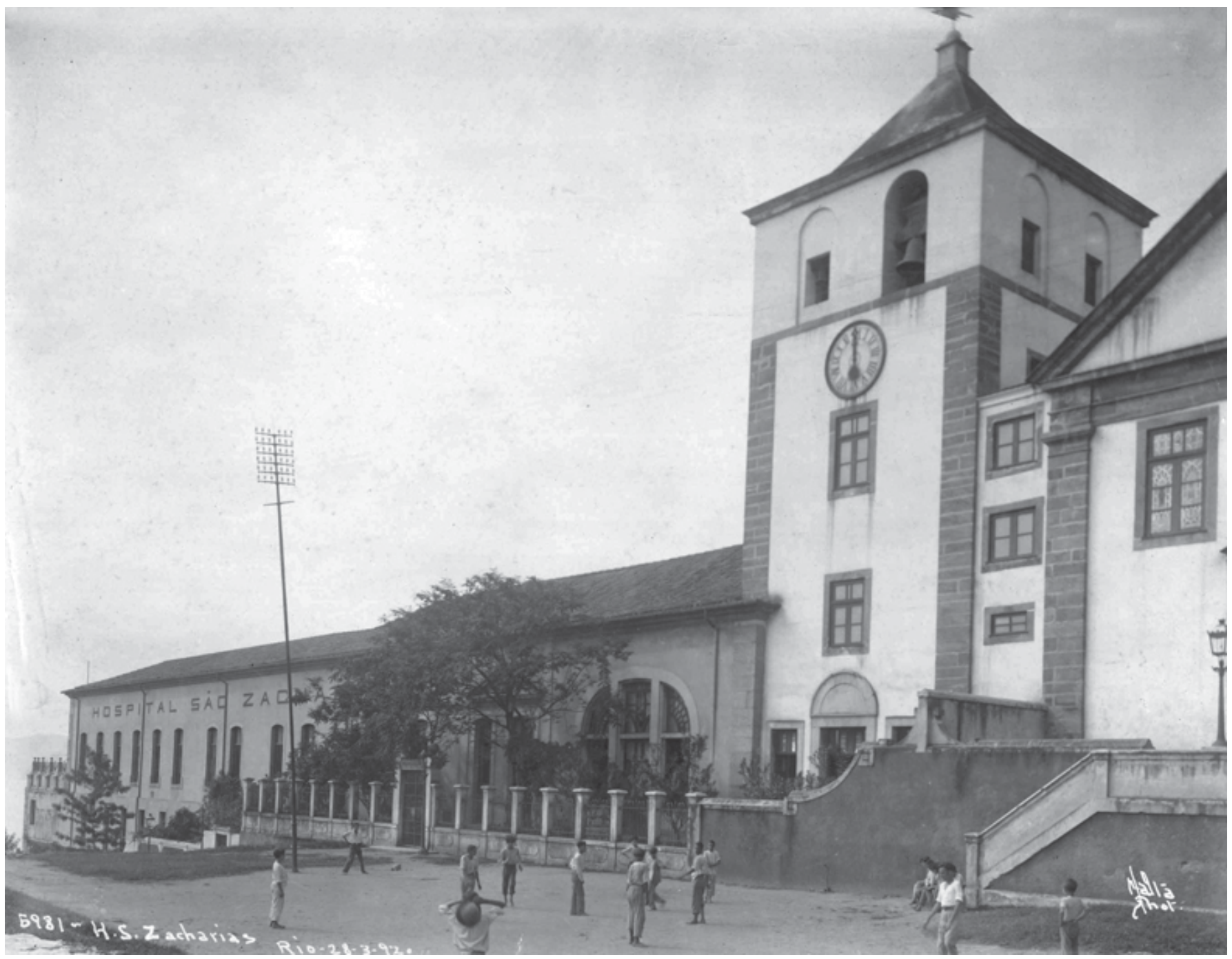

São Zacarias Hospital - in the Morro do Castelo. Photo Augusto Malta, 1920. Museu da Imagem e do Som - RJ Archives 


\section{IMPERIAL TIMES}

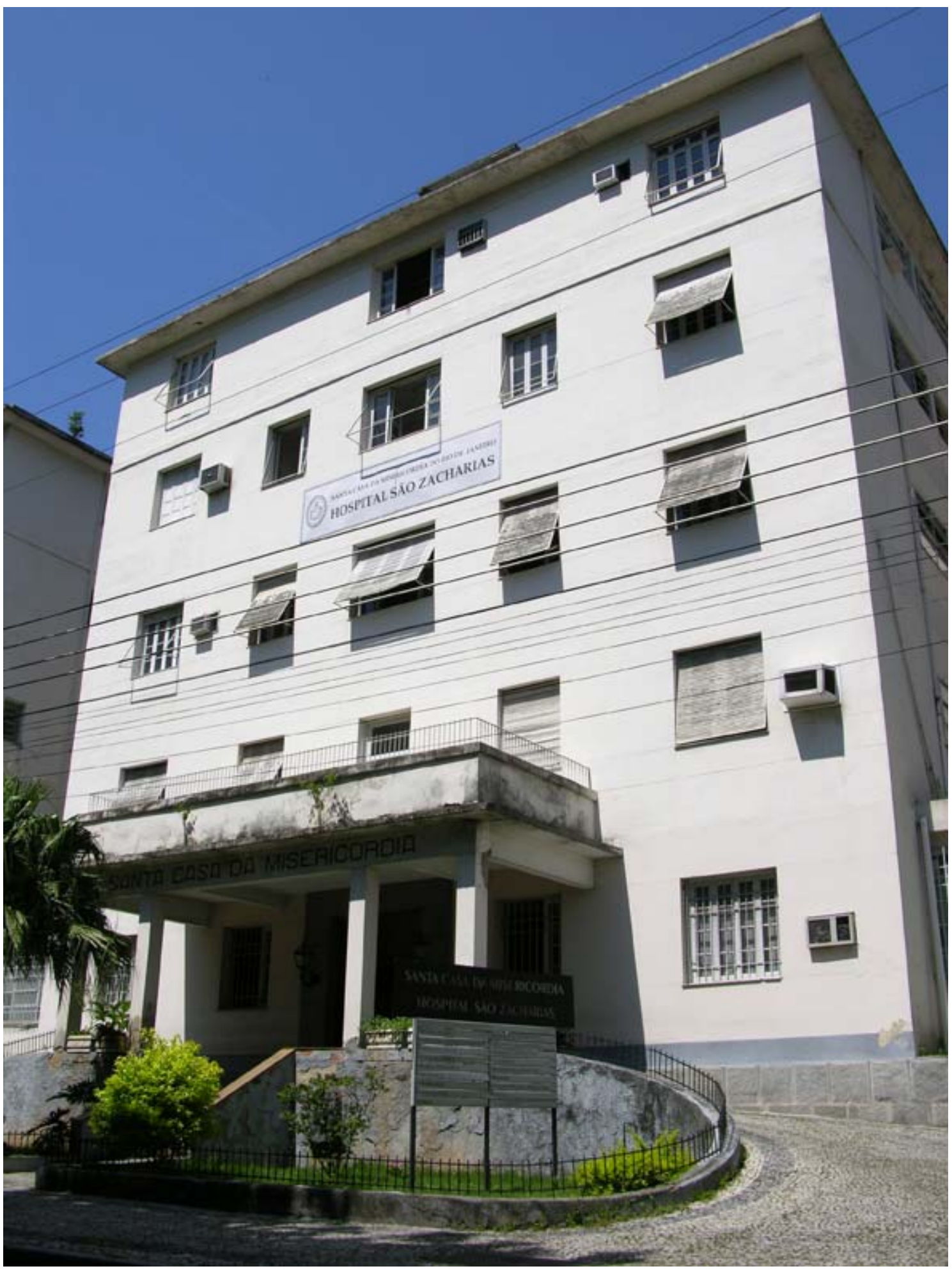

São Zacarias Hospital. Photo Roberto Jesus Oscar \& Vinícius Pequeno de Souza, 2008. Casa de Oswaldo Cruz Archives 


\section{Society of Medicine and Surgery of Rio de Janeiro}

Location: Downtown

Address: Avenida Mem de Sá, no. 197

Category: Professional and Scientific Association

Period of construction: 1918

Proprietor: Society of Medicine and Surgery of Rio de Janeiro

Author / Constructor: unknown

History:

At first installed in the Lyceum of Arts and Trades (Liceu de Artes e Ofícios) building (rua do Ouvidor no. 77), the Society of Medicine and Surgery of Rio de Janeiro was founded on February $14^{\text {th }}, 1886$, by initiative of Doctors Lucas Antônio de Oliveira Catta Preta, Hilário Soares de Gouvêa, Henrique Alexandre Monat and Marcos Bezerra Cavalcante.

At the time it was considered an institution proper of the Republic because it preached free medical association, in opposition to the elitism present in the adherence of doctors to the Imperial Academy of Medicine, created in 1829, the oldest association of such kind in Brazil. Although both entities were idealized under the same objective - congregate the medical class and institutionalize scientific debate on public health and similar areas - the Society of Medicine and Surgery of Rio de Janeiro, unlike the Academy, intended to gather the largest possible number of members without requiring public recognition and scientific notoriety for the entrance into the board of associates. As such, it intended to establish an effective interactive channel between public health matters and demands inherent in the clinical activities and social participation of doctors.

As of the 1860s, area professionals started to postulate in a systematic way a series of measures in favor of formalizing and making official the medical practice. As a result of such claims, some proposals of the category were discussed and inserted in medical education reform provisions (decree no. 7,247 of 04/19/1879 and decree no. 9,311 of 10/25/1884). The majority of the Society was formed by professors from the College of Medicine of Rio de Janeiro, which functioned to catalyze opinions and create environment for political and scientific discussion over the need to make changes in the legislation and in the role of the competent agencies.

In the year following its foundation in 1887, the Society of Medicine and Surgery received new statutes, organized by Doctors Oscar Adolpho de Bulhões Ribeiro, Antônio Augusto de Azevedo Sodré, Hilário Soares de Gouvêa, Henrique Guedes de Mello, Júlio Rodrigues de Moura and João Carlos Teixeira Brandão. One of the main points of this reform was the resolution which allowed for the promotion of congresses of medicine and surgery of national scope, determining the inauguration of the series for the following year. Thus, the $1^{\text {st }}$ Brazilian Congress of Medicine and Surgery (1888) was a pioneer in creating an official environment for debates concerning health in the country, representing a legitimate and institutional scientific discourse independent from the State.

With the advent of the Republic in 1889, the issue which mobilized the sessions of the Society was the yellow fever epidemic in the city of Rio de Janeiro and the possibility of a national epidemic, such matter dominated a great part of the discussions at the $2^{\text {nd }}$ Congress of Medicine and Surgery, which the entity held the same year.

In the 1920s, the conduct of the Society of Medicine and Surgery of Rio de Janeiro gained recognition in relation to the sanitation campaigns to combat the diseases which raged in the city. Between 1903 and 1907, it participated in the campaign against yellow fever, coordinated by Oswaldo Cruz and, in 1918, contributed with sanitary actions in the Spanish flu epidemic, promoting research projects relating its prophylaxis.

In the same year, the Society of Medicine and Surgery was beneficiary of the donation carried out by the Federal Government of a property located at Avenida Mem de Sá no. 197, where its first very own headquarters was constructed, remaining there until today. 


\section{IMPERIAL TIMES}

The content of the debates which emerged in the sessions of the Society were, at first, documented by medical area journals such as Brazil Médico; later, the association organized its own publications. The first ones were denominated Boletins da Sociedade de Medicina e Cirurgia do Rio de Janeiro (1889-1896), whose issues, as of 1890, became known as Boletins e Memórias da Sociedade de Medicina e Cirurgia do Rio de Janeiro. In 1896, it started to publish the Revista da Sociedade de Medicina e Cirurgia do Rio de Janeiro, which is believed to have circulated until 1910. However, it was only in 1915 that the institution found its longest lasting media outlet - Annaes da Sociedade de Medicina e Cirurgia do Rio de Janeiro. It was edited annually until 1930, when the title was changed to Annaes Brasileiros de Medicina e Cirurgia. It also attempts to reactivate the journal Edição Médica, media vehicle for its institutional accomplishments, whose last issue (no. 114) circulated in July and August of 2000.

Currently, it is an affiliate of the Medical Society of the State of Rio de Janeiro (SMERJ), the Society of Medicine and Surgery of Rio de Janeiro is considered an institution of public service, in virtue of decree-law no. 77 of August $29^{\text {th }}, 1969$.

\section{Register of Preservation:}

Listed by INEPAC in ambience category.

\section{Sources:}

FERREIRA, L.; MAIO, M.; AZEVEDO, N. A Sociedade de Medicina e Cirurgia do Rio de Janeiro: a gênese de uma rede institucional alternativa. História, Ciências, Saúde - Manguinhos, Rio de Janeiro, v.IV, n.3,p.475-491, nov. 1997/ fev.1998.

LIMA, A. As Sciencias Medico-Pharmaceuticas. In: Livro do Centenário. Rio de Janeiro: Imprensa Nacional; 1900, vol.2.

QUEIROZ, J. Memória da Sociedade de Medicina e Cirurgia do Rio de Janeiro num Século de Vida. Rio de Janeiro: RIOARTE/ MEC, 1986. 2v.

RIBEIRO, L. Congressos Médicos no $2^{\circ}$ Reinado. In: CONGRESSO de História do $2^{\circ}$ Reinado, nov., 1975, Rio de Janeiro. Anais do Congresso de História do $2^{\circ}$ Reinado. Comissão de História Científica, $2^{\circ}$ vol., Brasília/ Rio de Janeiro: Revista do Instituto Histórico e Geográfico, 1984, p. 307-315.

Credits: Atiele Azevedo de Lima Lopes (research and text). 


\section{IMPERIAL TIMES}

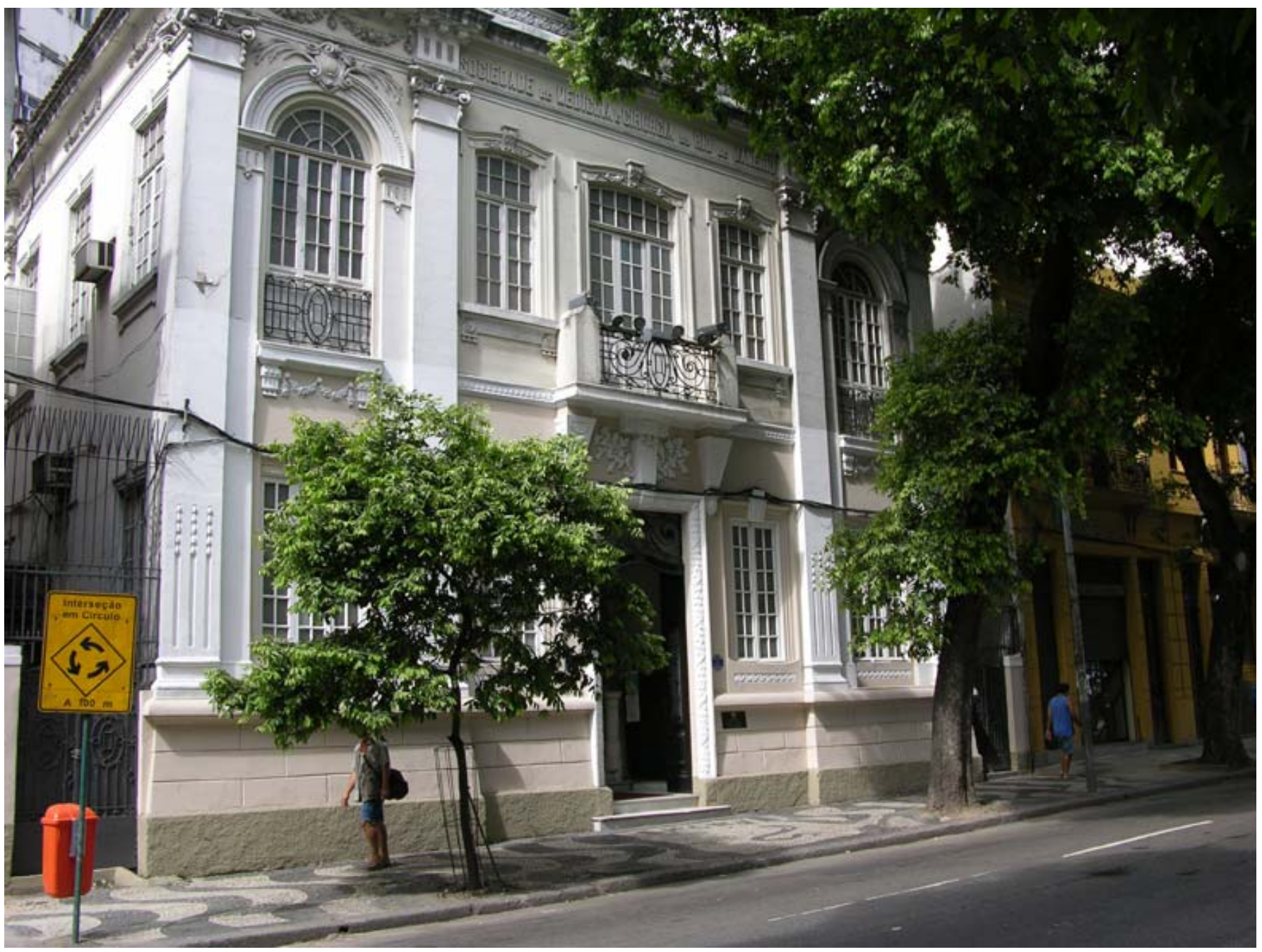

Rio de Janeiro Medicine and Surgery Society. Photo Roberto Jesus Oscar \& Vinícius Pequeno de Souza, 2008. Casa de Oswaldo Cruz Archives 


\section{University Palace}

Other denominations: Pedro II Asylum (1841-1890); National Psychiatric Asylum (1890-1911); National Psychiatric Hospital (1911- 1944)

Location: Urca

Address: Avenida Pasteur no. 250

Denomination: Institution of learning

Period of construction: $1842-1852$

Proprietor: Federal University of Rio de Janeiro.

Author / Constructor: Domingos Monteiro (original project); José Cândido Guillobel and José Maurício Jacinto Rebelo (project modifications)

\section{History:}

The former Pedro II Asylum, which was one of the charity works undertaken by the Sisterhood of Mercy (Irmandade da Misericórdia), has its creation linked to the transformations suffered by the Misericórdia Hospital in the middle of the XIX century. It was under the scope of the discussions at the Constitutional Assembly in 1823 that the areas of the Santa Casa of Rio de Janeiro began to be questioned and considered deleterious, and only in 1835 the commission which had been comprised in the 1820 's, with the mission to inspect the institution and report to the authorities about its servicerendering conditions, presented a report determining the need to provide distinct areas for the hospital, the Recolhimento das Órfãs (Orphanage) (since the 1743 building was considered inadequate) and the Casa da Roda (or Expostos). Partly as a result of this report, between 1838 and 1854 many improvements were introduced, among them the transfer of the cemetery to the vicinity of the district of Caju; the construction of a new hospital with 11 infirmaries; the creation of a special building for mentally ill patients in order to separate them from the other patients (hence the inauguration of Pedro II Asylum in 1852); and new accommodations for the vulnerable and orphaned.

On the other token, in 1832, Ordinances of the Municipal Council of Rio de Janeiro shifted the responsibility over the mentally ill to those families who could send them to adequate institutions of care. However, specific health facilities to treat such type of condition did not exist in the city and the more deprived mentally ill individuals were rounded up into the jails and infirmaries of the Santa Casa da Misericórdia of Rio de Janeiro, which were overcrowded and lacking any of the minimal standards to house such patients.

At the same time, emerged medical studies conducted by French Doctors Philippe Pinel (1745-1826) and Jean Etienne Dominique Esquirol (1772-1840) defending a more humane treatment for mentally ill patients. Such studies end up as an additional ingredient in the discourse favoring directed assistance care.

Finally, the creation of this institution was one of the acts which solemnized the crowing of D. Pedro II as Emperor. In virtue of decree no. 82 (07/18/1841), the foundation of Pedro II Asylum was authorized, a pioneering institution in Brazil exclusively dedicated to the treatment of the mentally ill.

It was installed at the former Chácara de Vigário Geral, in Praia Vermelha, in a property belonging to the Santa Casa da Misericórdia of Rio de Janeiro. In this location the laundresses of its General Hospital and an infirmary for mentally ill female patients had been installed.

At the time of the creation of Pedro II Asylum, the psychiatry area had not yet been formalized as a medical specialization, thus the work performed in this field occurred within the chair of medical clinic at the colleges of medicine of Rio de Janeiro and Bahia, the only ones in existence in the period. Such conformity was only modified by means of decree no. 7.247 of $04 / 19 / 1879$, which installed a chair of clinical psychiatry in the medical teaching curriculum. Therefore, in November 1842, a professor of forensic science (José Martins da Cruz Jobim) was nominated by the administrative 


\section{IMPERIAL TIMES}

council to be the first professional of the institution in charge of prescribing medications and treatments to the mentally ill asylum patients.

The original project for the Pedro II Asylum building was inspired by the architecture of the French hospital of Chareton (1641), under the responsibility of architect Domingos Monteiro. Nevertheless, it underwent alterations by the architects José Cândido Guillobel and José Maurício Jacinto Rebelo, since the façade was considered too simple for a public building. The construction works began on September $5^{\text {th }}, 1842$, extending until 1852 , period in which the mentally ill patients were temporarily cared for in two buildings contiguous to the construction works.

Attended by the Emperor as well as other public, ecclesiastic, civil and military authorities, Pedro II Asylum was inaugurated on December $5^{\text {th }}, 1852$, a day following the presentation of its bylaws, approved by decree no. 1.077. It is worth mentioning that its bylaws were inspired by French Legislation of 1838 concerning the mentally ill, which was responsible for instituting their legal protection, and had as one of its responsible members Doctor Jean Etienne Dominique Esquirol.

In accordance with those bylaws, the Asylum had the mission to promote the treatment of the mentally ill regardless of financial condition, origin or religion. However, classified as pensioners (those who could afford to pay expenses) and gratuitous (indigents, sailors and slaves of masters with few possessions), patients did receive varied treatment in function of the monthly payments that each was able to afford (ARAÚJO, 1982).

It began its activities in fact on December $8^{\text {th }}$ with 144 hospitalized patients coming from the makeshift infirmary of Praia Vermelha and the General Hospital of the Santa Casa da Misericórdia of Rio de Janeiro.

Under the administration of João Carlos Teixeira Brandão, assumed in 1887, a strong campaign was undertaken for the adoption of the rural colonies as a factor of treatment for the mentally ill, and was supported by many names of the national psychiatry establishment, which at the time unfolded as an autonomous area of study within medicine. In 1889, Antonio Ferreira Vianna, who was a Minister and Secretary of State of Justice Affairs, decreed the foundation of the rural colonies São Bento and Conde de Mesquita, in Ilha do Governador. The creation of such colonies was beneficial in the sense that they appeased overcrowded conditions in the Asylum and led to an assessment of new forms of treatment and recuperation for the mentally ill patients.

The instauration of the Republic Government in 1889 resulted in the sanctioning of decree no. 142-A (01/11/1890), which authorized the Federal Government to administer the Asylum under the jurisdiction of the Ministry of Justice and Internal Affairs. By means of the same decree, became known as the National Psychiatric Asylum, which, along with the colonies of Ilha do Governador, constituted the Medical-Forensic Psychiatric Assistance, created and regulated in the same year.

In 1890, decree no. 508 (June $21^{\text {st }}$ ), which was responsible for the regulation of the Medical-Forensic Psychiatric Assistance, determined the removal of the sisters of charity from the nursing services in the male ward of the National Psychiatric Asylum. As a show of protest, on August $11^{\text {th }}$, the sisters removed themselves from all and any type of service at the institution. In an attempt to ameliorate the lack of qualified personnel, on September $27^{\text {th }}, 1890$, decree no. 791 was approved establishing on the grounds of the Asylum the Professional School of Nurses, with the mission to train professionals in order to supply the Asylum's demand.

At the beginning of the XX century, the National Psychiatric Asylum underwent a process of intervention, tending to the verification of administrative and financial irregularities. On March $26^{\text {th }}, 1903$, aiming to circumvent such institutional problems, Juliano Moreira was designated to assume the direction of the sanitation service and the Medical-Forensic Psychiatric Assistance. Once in the post, he implemented many changes such as the enlargement of the pavilions and the acquisition of new equipments, targeting to conduct the work at the Asylum into the arena of psychiatric research. In addition, given his commitment to more humane treatment, he eradicated bars in the rooms, created reading and game rooms, recreation courtyards and workshops for the patients. He remained in the post of director until 1930, year upon which he was forced to retire.

As of the 1920's, the National Psychiatric Hospital, denomination received in 1911, began to receive an increasing volume of mentally ill patients, which exposed the inadequateness of the facilities and made satisfactory treatment 


\section{IMPERIAL TIMES}

unrealizable. Such situation persisted until 1944, year when all patients were transferred to the Juliano Moreira Colony, in Jacarepaguá, which had been established in 1924.

At the time, the centenary building at Avenida Pasteur was donated to the University of Brazil (currently the Federal University of Rio de Janeiro), who proposed renovating and adapting it according to its functions as future office of the dean of the college. In fact, such endeavor only began in 1949, under the technical support of the Department of Engineering of the referred University. Once construction works had been concluded in 1953, the former facilities of the Asylum began to configure the University Palace.

\section{Architectonic Description:}

Following the precepts to promote "peace, tranquility and accommodation" to the mentally ill patients, the edification of the asylum was implanted at a ranch far from town and with lots of fresh air (Praia Vermelha). The difficult access ensured the isolation of the patient, as well as the protection against eventual escapes.

The main façade on the neoclassical edification was positioned to a garden receded relative to the alignment of the street, which in former times had a view to Praia da Saudade (Praia Vermelha). The edification is accessible by means of a staircase which exhibits feminine allegories of charity and science (sciencia), symbolizing the pledge in the rendering of medical assistance to the unfortunate ones - objective of the actions of the Sisterhood of Mercy.

The symmetrical composition develops into two pavements (ground and upper) and is finished by ornamented external horizontal lines with pinecones and by a majestic façade in its central axis. The entrance portico, which is the main entrance, in ornamented gneiss with Ionic columns interrupts the volumetric rhythm of the windows and protruding doors in plain arch. This central structure also served the function of separating the female ward from the male one in the asylum. The long interlinking corridors (or galleries) of the infirmaries have walls finished with Portuguese tiles and the floor made of hardwood. Since circulation is positioned toward the internal tree-filled courtyards (and encircled by arches resembling the former covered galleries), the infirmaries are well ventilated (cross ventilation) and well lit.

The typology adopted for the edifice of the former Asylum is the hygienist, exhibiting six internal courtyards. Such composition follows the common style of the hospital establishments in Paris (such as Hôpital Lariboisière), being included in the hospital program in addition to the infirmaries, pharmacy and halls, a chapel.

The neoclassical chapel, denominated São Pedro de Alcântara is located in the upper pavement of the central body and is connected to the noble halls (or the "rooms of respect"). Its access is made possible by means of a staircase in jacaranda which emerges at the entrance-hall of the main entrance in the ground pavement and was frequented by D. Pedro II and presents a representative sacred art collection.

\section{Register of preservation:}

IPHAN, on July $11^{\text {th }}, 1972$.

\section{Sources:}

ARAÚJO, A. A Assistência Médica Hospitalar no Rio de Janeiro no século XIX. Rio de Janeiro: Ministério da Educação e Cultura/ Conselho Federal de Cultura; 1982.

BRANDÃO, João Carlos Teixiera. RELATORIO da Assistencia Medico-Legal de Alienados apresentado pelo Director Geral Dr. João Carlos Teixeira Brandão em janeiro de 1895. In: RELATORIO apresentado ao Presidente da Republica dos Estados Unidos do Brazil pelo Dr. Antonio Gonçalves Ferreira, Ministro de Estado da Justiça e Negocios Interiores em abril de 1895. Annexo-U-1. Rio de Janeiro: Imprensa Nacional, 1895. Relatórios Ministeriais (1821-1960). Obtido via base de dados PROJETO DE IMAGEM DE PUBLICAÇÕES OFICIAIS BRASILEIRAS DO CENTER FOR RESEARCH LIBRARIES E LATINAMERICAN MICROFILM PROJECT. Capturado em 14 de ago. 2007. Online. Disponível na Internet: http://www.crl.edu/ content/pindex.htm 


\section{IMPERIAL TIMES}

CALMON, Pedro. O Palácio da Praia Vermelha: 1852-1952. Rio de Janeiro, 1952.

CZAJKOWSKI, J. (org.). Guia da arquitetura colonial, neoclássica e romântica no Rio de Janeiro. Rio de Janeiro: Centro de Arquitetura e Urbanismo do Rio de Janeiro; Casa da Palavra; Prefeitura da Cidade do Rio de Janeiro, 2000.

DOYLE MAIA, G. Biografia de Uma Faculdade. 2aedição. São Paulo: Editora Atheneu, 1996.

ELIA, F. Doença mental e cidade: o Hospício de Pedro II. Rio de Janeiro: Fundação Casa de Rui Barbosa, 1996.

FALCÃO, E. Os serviços de saúde pública no Brasil (1808-1907). Brasiliensia Documenta, v. VI. Oswaldo Cruz Monumenta Histórica, tomo IV (I). Esboço Histórico. São Paulo: s.ed; 1978.

INSTITUTO do Patrimônio Histórico e Artístico Nacional. Arquivo Noronha Santos. Busca. Online. Disponível na Internet: http://www2.iphan.gov.br/ans/inicial.htm

MARTINS, A. Santa Casa de Misericórdia do Rio de Janeiro. Visitando a Casa da Memória da Medicina e da Farmácia no Brasil. Rio de Janeiro: LABLET/FAU/UFRJ, 2002.

MOREIRA, J. Noticia Historica sobre a Evolução da Assistencia a Alienados no Brazil pelo Dr. Juliano Moreira, Director do Hospicio Nacional de Alienados. In: RELATÓRIO apresentado ao Presidente da República dos Estados Unidos do Brasil pelo Dr. J. J. Seabra, Ministro de Estado da Justiça e Negocios Interiores em março de 1905. vol.II.- Directoria do Interior. Annexo A-E1-1. Rio de Janeiro: Imprensa Nacional, 1905. Relatórios Ministeriais (1821-1960). Obtido via base de dados PROJETO DE IMAGEM DE PUBLICAÇÕES OFICIAIS BRASILEIRAS DO CENTER FOR RESEARCH LIBRARIES E LATINAMERICAN MICROFILM PROJECT. Capturado em 12 de ago. 2007. Online. Disponível na Internet: http://www.crl.edu/ content/pindex.htm

SANTOS, P. Quatro Séculos de Arquitetura. Rio de Janeiro: Fundação Educacional Rosemar Pimentel; 1977.

TUNDIS, S.; COSTA, N. Cidadania e loucura: políticas de saúde mental no Brasil. Rio de Janeiro: Vozes, 1990.

Credits: Atiele Azevedo de Lima Lopes (research and text); and Inês El-Jaick Andrade (architectonic description). 


\section{IMPERIAL TIMES}
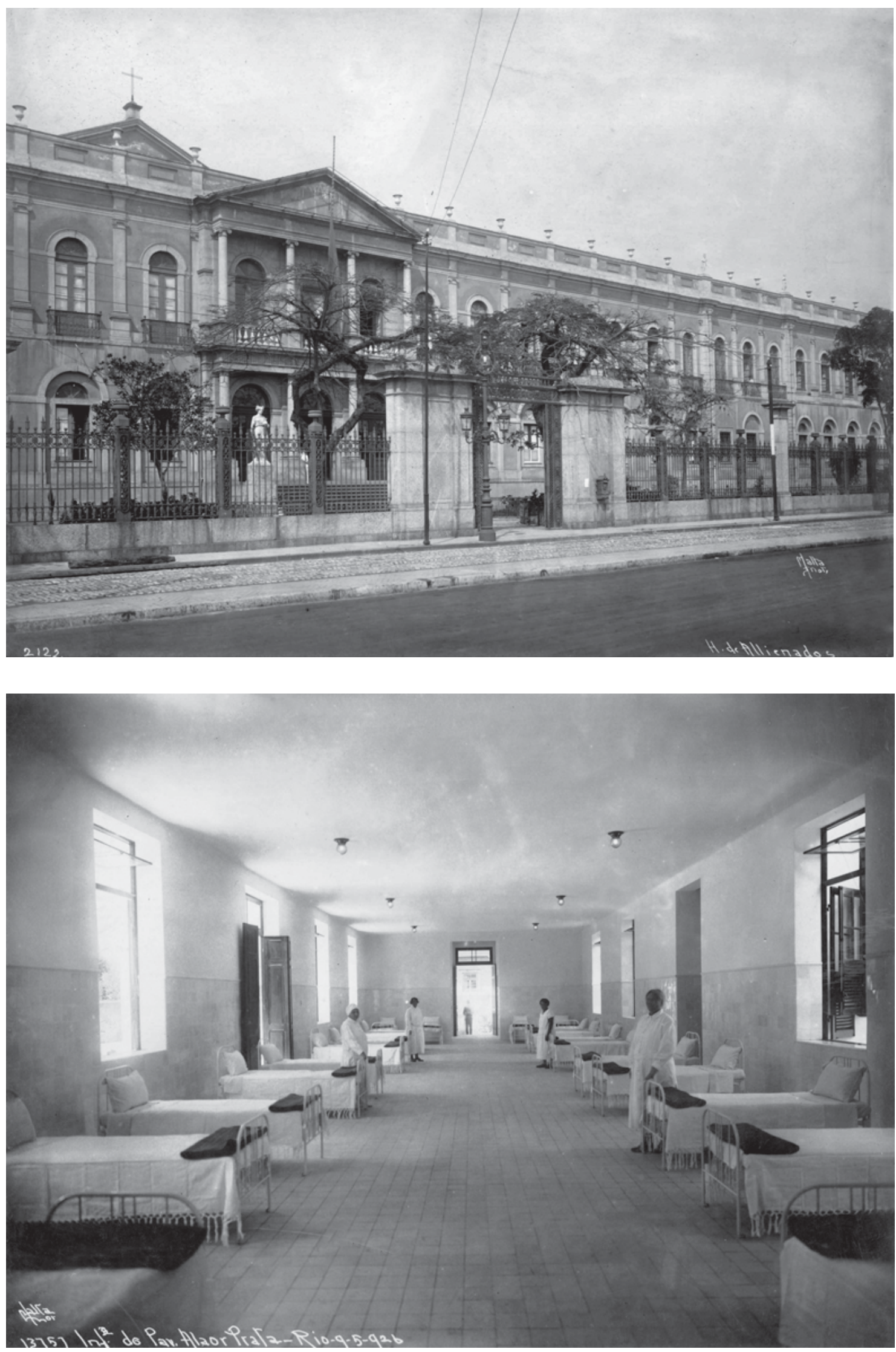

National Lunatic

Asylum. Photo

Augusto Malta, 1922

Museu da Imagem e do Som, RJ Archives

National Lunatic

Asylum. Photo

Augusto Malta, 1922

Museu da Imagem e do Som, RJ Archives 

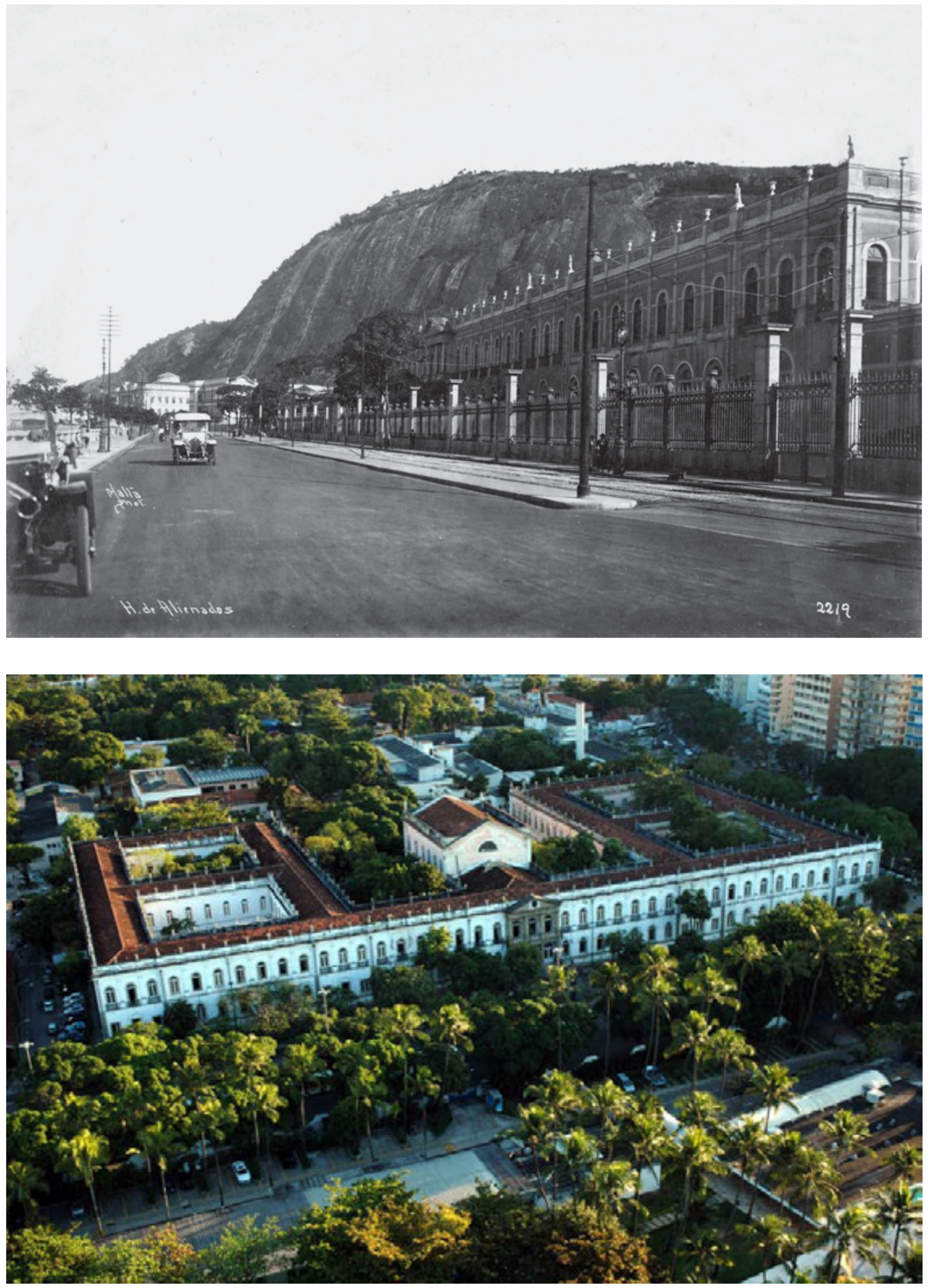

National Lunatic Asylum. Photo

Augusto Malta, 1922.

Museu da Imagem e do Som, RJ Archives

Generval View, [s.d.]. Universidade Federal do Rio de Janeiro Archives 


\section{Venerable and Archiepiscopal Third Order of Nossa Senhora do Monte do Carmo Hospital}

Location: Downtown

Address: Rua do Riachuelo, no. 43.

Category: General Hospital

Period of Construction: 1866-1870

Proprietor: Venerable and Archiepiscopal Third Order of Nossa Senhora do Monte do Carmo

Author / Constructor: unknown

History:

During the colonial period, daily services of education and health were fundamentally attributes of religious orders, confraternities and fraternities. Third Order of Nossa Senhora do Monte do Carmo was established in the city of Rio de Janeiro on July $19^{\text {th }}, 1648$, a few years after the foundation of other branches of the Order, in the cities of Lisbon and Salvador, and was first installed in a small chapel. In 1755 construction of its church began, beside the one which was conventual, facing Rua Direita (currently Primeiro de Março). The Church of the Third Order of Nossa Senhora do Monte do Carmo was built by Master Manuel Alves Setúbal and founded in 1770.

The Third Order is an association composed by laypeople from both genders, which, in secular life, and under the guidance of a Religious Order, follow the "rules" set forth by the Holy See. Since the moment of its installation in the city of Rio de Janeiro, the Venerable Third Order of Nossa Senhora do Monte do Carmo has provided medical assistance to the brothers of the confraternity and the idea of founding a hospital started becoming a pressing issue. The beginning of the fulfillment of such project occurred in 1733, during the priorate of João Gonçalves Preto, who chose the property in the rear of the Nossa Senhora do Monte do Carmo Church thus initiating construction work. The Hospital was inaugurated ten years later, on January $1^{\text {st }}, 1743$, with entrance through Rua de Atrás do Carmo, and its construction work only finished in 1745. According to Leoberto de Castro Ferreira, Procurator of this Hospital in 1978, the Prior chose, for its installation, the property in front of the primitive chapel of the Terceiros, "whose rear faced the alley which, like the present one of Barbeiros, opened communication between Rua do Carmo and Rua Direita" (1978, p.14). In the constructed building two ample infirmaries were installed in spacious rooms, facing Rua Atrás do Carmo or Detrás do Carmo (later rua do Carmo), denominated as such because it passes along the back of the Nossa Senhora do Monte do Carmo Church, currently located on Rua Primeiro de Março, in the historic district of the city of Rio de Janeiro.

According to the Statute of the Venerable Third Order of Nossa Senhora do Monte do Carmo, re-printed with changes and reforms by the Board on September 29 $9^{\text {th }}, 1848$ and approved on March $9^{\text {th }}, 1849$ by the Provincial Master Priest of the Order Father José da Conceição Meirelles, the Hospital was built in 1733 to help poor brothers, treating their diseases with love and decency. For the rendering of medical and administrative services in the Hospital, the Statute provided for the presence of head nurse, steward-brother, nurse- brothers and sisters, doctors, surgeons, service slaves, clerk, treasurer, patrimony administrator and others. Anyone could be treated in the hospital, with the exception of people suffering from contagious diseases, and brothers who could pay for the assistance care were expected to do so.

The Hospital provided free assistance care to innumerous poor patients of both genders. Its services were very important, since there were few hospital establishments in the city at the time, basically the Santa Casa da Misericórdia of Rio de Janeiro and the Royal Military and Ultramarine Hospital, the latter solely dedicate to serve military personnel.

In 1810, rooms of the Venerable Third Order of Nossa Senhora do Monte do Carmo Hospital, specially the ones on the top floor, were solicited for the installation of the Royal Library, "Library of the Kings" coming from Lisbon. The decree of June $27^{\text {th }}, 1810$ established that the Royal Library along with instruments of physics and mathematics, coming from Lisbon, should be installed in the Third Order of Carmo, thus transferring its hospital to another location. Still, in the 
same year, on October $29^{\text {th }}$, another decree determined that the Royal Library should be accommodated in place of the catacombs of the religious of Carmo close to the Royal Chapel. In 1814, the library practically occupied the entire building which had housed the hospital and contained about 60 thousand books or 70 thousand items (books, manuscripts, maps, etc.) according to accounts.

In 1812 the Hospital was transferred to the Retreat of Nossa Senhora do Parto, on Rua dos Ourives (later dismembered into two streets, rua Miguel Couto and rua Rodrigo Silva), at the corner of Rua de São José.

In the XIX century, the accomplishment of doctors such as Luis Francisco Ferreira (1800-1857), professor of external pathology at the College of Medicine of Rio de Janeiro and member of the Imperial Academy of Medicine, who rendered services from October $15^{\text {th }}, 1837$ to October $15^{\text {th }}, 1838$, becomes recognized. Still, in the XIX century, also recognized are the accomplishments of José Joaquim dos Santos, nominated hospital surgeon, José Ribeiro de Souza Fontes (1821-1893), deputy professor and later professor at the College of Medicine of Rio de Janeiro, Silva Lara, Cláudio Velho da Motta Maia (1845-1897), Carneiro da Rocha, Manoel Rodrigues Monteiro de Azevedo and the oculist Manoel da Gama Lobo (18321883).

Over time, the construction of its very own building for the installation of the Hospital became necessary; duly equipped for this purpose and with capacity to shelter the increasing number of brothers who, every year, sought the hospital for assistance care. The Board deliberation on February $15^{\text {th }}, 1864$, made possible the purchase of the property and houses at Rua Mata Cavalos no. 17 and 19 (currently rua Riachuelo); in front of Rua do Lavradio. In this location initiated, in 1866, the construction of a new building, inaugurated on June 24th, 1870, with the presence of Emperor D. Pedro II and the entire Imperial Family. In addition to the Emperor and members of the Imperial family, Viscount of Souza Fontes and José Ribeiro de Souza Fontes (1821-1893) also signed the Minutes of the inauguration, the latter was chairman of anatomy at the College of Medicine of Rio de Janeiro and João Baptista dos Santos (1828-1912), Viscount of Ibituruna, both doctors of the Imperial Chamber and renown surgeons, as representatives of the clinical Establishment.

According to the Rules of the Venerable Third Order of Nossa Senhora do Monte do Carmo Hospital, from 1894-1895, the sanitary body of the establishment would be formed by medicine doctors, pharmacists, and nurses, and all of them would be nominated by the administrative board, and by proposal of the Prior.

At the end of the XIX century, the medical clinic of the Hospital started being managed by Alfredo da Graça Couto (1864-1916), a renowned ophthalmologist, sanitarian, member of the National Academy of Medicine, and later Inspector of the Service of Quarantine and Disinfection in Rio de Janeiro.

The Hospital was dedicated mainly for the treatment of serious diseases or serious accidents stemming from chronic diseases. Medical assistance was also provided to the Brothers of the Order who suffered from incurable diseases and the disabled who had professed for ten years. Those who could not be treated there, such as the mentally ill, lepers and others suffering from other conditions, would be collected and the assistance care would be on account of the Order.

The building on Rua Riachuelo had, in its two pavements, in addition to waiting room and its general consultation room and cabinet dedicated to otorhinolaryngology clinic, nine infirmaries with a total of 154 beds, six private rooms and a pavilion for contagious diseases.

In the XX century the accomplishment of José Ribe Portugal (1901-1992) is registered in the management of the recently created Neurosurgery Service, in 1932, and of Roberto Chabo, who in 1994 assumed the management of the Medical Clinic Sector of the Venerable Third Order of Nossa Senhora do Monte do Carmo Hospital.

The Hospital received new additions and improvements, with the construction of new pavilions, rooms for polyclinic and operations, a new chapel and an access hall with artistic staircase. On May 24 ${ }^{\text {th }}, 1941$ still during the Priorate of Brother José Duarte Lopes Corrêa, a new block with seven pavements in armed cement was inaugurated, which became known as the most important and modern nucleus of the hospital complex. The undertaking of the new block also had the participations of Sub-Prior Francisco Cabral Peixoto and of the Procurator of the Hospital, Commendator José Pinto Duarte, and resources coming from a loan from Banco Mecantil of Rio de Janeiro.

Venerable Third Order of Monte do Carmo Hospital is still located at Rua do Riachuelo no. 43 and is managed by Prior Wilson Pereira das Neves and administered by General Secretary Armindo Fernandes Diniz. 


\section{Architectonic description:}

The chapel of Ordem Terceira de Nossa Senhora do Monte do Carmo Hospital is one of the most important works of the baroque and rococo styles situated in Rio de Janeiro, with a highlight for the Novices Chapel, work of Master Valentim; the façade in cut stone; the gateway of lioz limestone, "coming from Lisbon, with a notable locket with an image of the Virgin which, according to Lúcio Costa, would have influenced the risk of Antônio Francisco Lisboa, "Aleijadinho", for the doorways of the churches of the Third Order of St. Francis in Ouro Preto and São João del Rei. Internally, the carving was executed by Luís da Fonseca Rosa and Master Valentim, his disciple. The high-altar, of the XVIII ${ }^{\text {th }}$ century, has a silver front and back. The side altars are illuminated by silver candelabra, designed by Master Valentim. In the vestry, outstanding is the arch, the altar of São Miguel and a marble rest room, also the work of Master Valentim." (IPHAN, process 00-T-38).

The Hospital itself, whose construction is of the second half of the XIX ${ }^{\text {th }}$ century, is expressed in the neo-classic style, with a central triangular gable well marked by highlighted volume, statues and spaces with straight lintels of a classic design and protected by balconies in wrought iron, on the second floor, and gaps with arched lintels, on the ground floor, similar to Beneficência Portuguesa Hospital, of the same period. The difference between one project and another is the arched gable used in João de Deus Pavilion, of Beneficência Portuguesa.

\section{Register of Preservation:}

The church and the Third Order of Carmo Hospital, which belongs to the church, were listed by the Municipal Historic Patrimony, Historic Book, Enrolment 013, April 20 1938.

\section{Sources:}

ARAÚJO, A. A Assistência Médica Hospitalar no Rio de Janeiro no século XIX. Rio de Janeiro: Ministério da Educação e Cultura/ Conselho Federal de Cultura; 1982.

ASSISTÊNCIA Pública e Privada no Rio de Janeiro (Brasil) - História e Estatística. Comemoração do Centenário da Independência Nacional. Rio de Janeiro: Typographia do Annuario do Brasil; 1922.

CAPELA do Hospital do Carmo é reaberta. Restauração durou um ano. JB Online. Rio de Janeiro, 16 / 06 / 2004 . Online. Capturado em 23 out. 2007. Disponível na Internet: http://jbonline.terra.com.br/jb/papel/cidade/2004/06/16/ jorcid20040616007.html

ESTATUTO da venerável ordem terceira de Nossa Senhora do Monte do Carmo. (Novamente impresso com as reformas feitas pela meza conjuncta em 29 de setembro de 1848, sendo Prior da Ordem o irmão Prior Jubilado). 15 de outubro de 1849.

FERREIRA, L. Exposição feita pelo procurador do Hospital da V. e A. O. $3^{\text {a }}$ de N. S. do M. do Carmo, Leoberto de Castro Ferreira, a 30.9.1978, na sala do Consistório da mesma Venerável Ordem, por ocasião da $3^{\text {a }}$ reunião das organizações religiosas. Mimeogr. 1978.

FRIDMAN, F. \& MACEDO, V. A ordem urbana religiosa no Rio de Janeiro colonial. Online. Capturado em 22 out. 2007. Disponível na Internet: http://www.ifch.unicamp.br/ciec/revista/artigos/dossie2.pdf

GUSMÃO, S. História da Neurocirurgia no Rio de Janeiro. Arquivos de Neuro-Psiquiatria, São Paulo, v. 60, n. 2A, 2002. Online. Capturado em 23 out. 2007. Disponível na Internet: http://www.scielo.br/scielo.php?script=sci_arttext\&pid=S0004282X2002000200030

IGREJA da Ordem Terceira de Nossa Senhora do Carmo (Rio de Janeiro, RJ). Online. Capturado em 23 out. 2007. Disponível na Internet: http://www.iphan.gov.br/ans.net/tema_consulta.asp?Linha=tc_hist.gif\&Cod=1731

LEIS Históricas. Decreto - de 29 de Outubro de 1810. Capturado em 23 out. 2007. Online. Disponível na Internet: http:/ /www.planalto.gov.br/CCIVIL_03/revista/Rev_69/Decreto.htm

MARTINS, W. O Irmão José Batista Lisboa e a Ordem Terceira do Carmo do Rio de Janeiro. Online. Capturado em 23 out. 2007.Disponível na Internet: http://www.uff.br/ichf/anpuhrio/Anais/2004/Simposios\%20Tematicos/ William\%20de\%20Souza\%20Martins.doc.

ORDEM Terceira do Carmo Sodalício de Campos dos Goytacazes - RJ. Online. Capturado em 22 out. 2007. Disponível na Internet: http://www.otcampos.com.br/modules/wfsection/viewarticles.php?category=1/ 


\section{IMPERIAL TIMES}

REGIMENTO do Hospital da Venerável Ordem Terceira de Nossa Senhora de Monte do Carmo.(Aprovado pela meza administrativa de 1894 a 1895 sendo Prior o comendador Antônio Gomes De'Avillar). Rio e Janeiro: Typ. De Perreira Braga e C., Rua nova do ouvidor $\mathrm{n}^{\circ} 28,1895$.

SCHWARCZ, L.; AZEVEDO, P.; COSTA, A. A Longa Viagem da Biblioteca dos Reis - Do terremoto de Lisboa à Independência do Brasil. São Paulo: Companhia das Letras; 2002.

Credits: Maria Elizabeth Bueno de Godoy (research) and Maria Rachel Fróes da Fonseca (research and text) and Renato da Gama-Rosa Costa (Architectonic Description). 


\section{IMPERIAL TIMES}
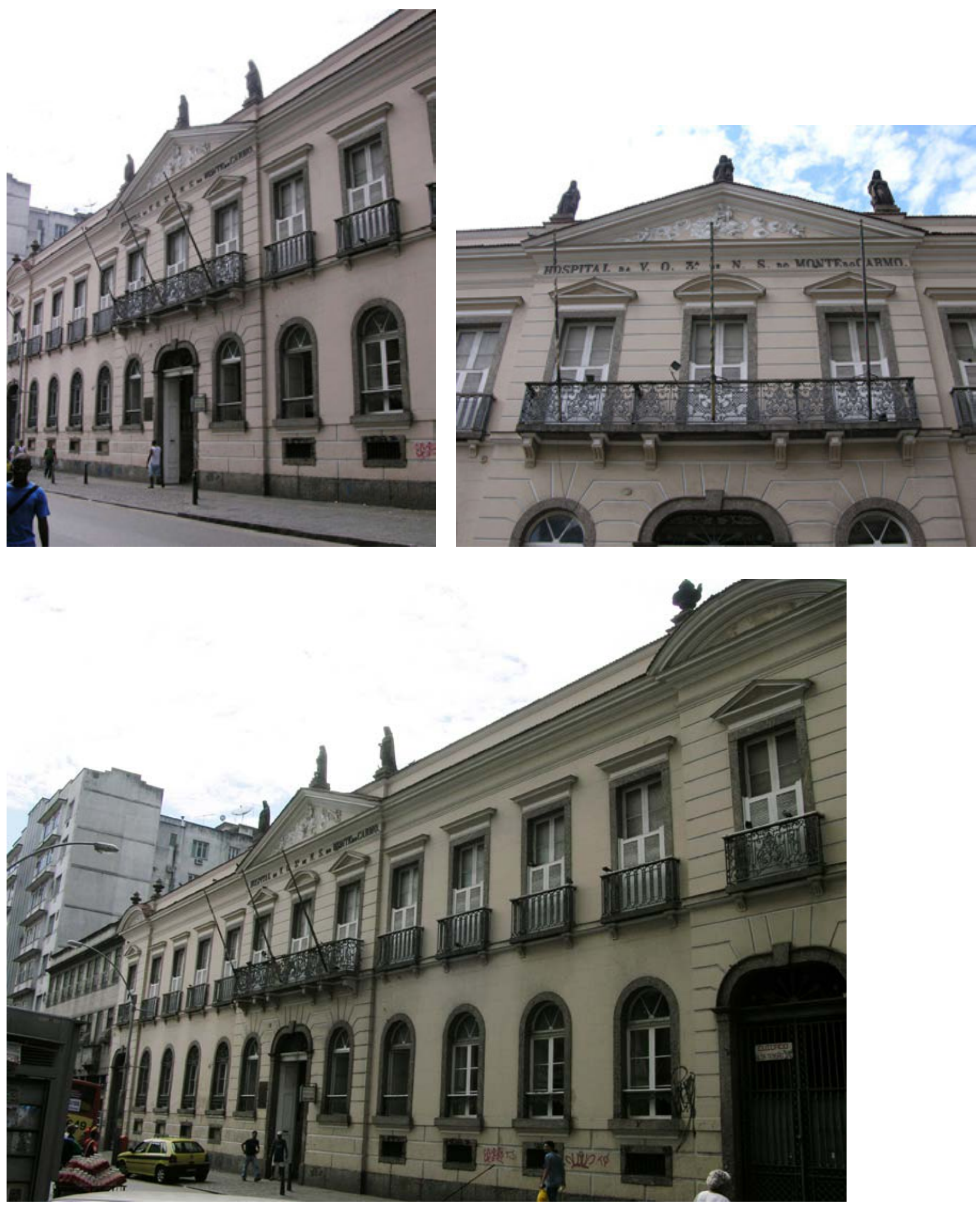

Ordem 3a do Monte Carmo Hospital. Photo Roberto Jesus Oscar \& Vinícius Pequeno de Souza, 2008. Casa de Oswaldo Cruz Archives 


\title{
Venerável Ordem Terceira de São Francisco da Penitência Hospital
}

\author{
Location: Tijuca
}

Address: Rua Conde de Bonfim no. 1033

Category: General Hospital.

Period of construction: 1917-1923.

Proprietor: Venerável Ordem Terceira de São Francisco da Penitência

Author / Constructor: Luiz Moraes Junior (director of the construction works, 1906); Pederneiras Construction Company (constructor, new hospital, 1933).

\section{History:}

The Venerável Ordem Terceira de São Francisco da Penitência was established in the city of Rio de Janeiro on March $20^{\text {th }}, 1619$ by Luis de Figueiredo and his wife Antonia who were novice members of the same charity organization and came from the city of Lisbon. Under authorization of the Franciscans of the Santo Antonio Convent, they were able to inaugurate, in 1622, the chapel of the Venerável Ordem Terceira de São Francisco da Penitência, in honor of the patron saint Nossa Senhora da Conceição, erected in a lot adjacent the Church of the Convent. The Venerável Ordem Terceira de São Francisco da Penitência Church began to be constructed in 1653, and was completed only in 1773 (or 1772), and is considered a prominent example of Brazilian baroque, where can be found panels by Caetano da Costa Coelho, woodcarvings by Manuel de Britto and works of sculpture by Francisco Xavier de Brito.

The Ordem Terceira is an association of laypeople, of both sexes, which in secular life, and under the orientation of a Religious Order, follow the 'rules' defined by the Holy See.

In March, 1748 the decision to purchase the lands belonging to the Ordem Terceira de Nossa Senhora do Monte do Carmo and incorporate them to the ones that the Ordem Terceira de S. Francisco da Penitência already possessed by means of a donation executed in 1741 by the religious of the Santo Antonio, represented the first step in the concretization of the objective of constructing a hospital. The cornerstone of this hospital was laid in May, 1748, on top of Morro de Santo Antonio (Largo da Carioca), in lands donated by the Santo Antonio Convent, and where initially a small chapel had been built. Present in the occasion were Governor Gomes Freire de Andrade and Bishop of Rio de Janeiro D.Antonio do Desterro. In virtue of financial difficulties the first part of the Venerável Ordem Terceira de São Francisco da Penitência Hospital was only inaugurated in 1763 , and although it only had two infirmaries for the rendering of services, it was able to house the asylum patients of the Recolhimento de Nossa Senhora do Parto, who had been saved from a fire in 1789. At hospital, still at Largo da Carioca, some of the conspirators of the Inconfidência Mineira (Failed independence movement which originated in the state of Minas Gerais) remained incarcerated until their transfer to the Island of Cobras, such as Thomaz Antonio Gonzaga (1744-1807) and the very own Joaquim José da Silva Xavier (1746-1792), a.k.a. Tiradentes.

With the arrival of the Portuguese Royal Family in 1808, one of its infirmaries was solicited by the government to serve as lodging for the servants of the Royal House, fact which caused the Ordem to evacuate and reestablish domicile service care.

After a long period in which construction work had been paralyzed, construction on the Hospital was reinitiated in 1852, with works of enlargement and improvement, which were concluded in 1858. In the subsequent years, the homeopathic infirmary, service of ophthalmology, library for the sick, section of hydrotherapy and a pavilion of isolation were inaugurated, in addition to other important enlargement construction works deliberated between 1870 and 1889.

On September $11^{\text {th }}, 1898$ a new pavilion of isolation was inaugurated, annexed the hospital. At the end of the XIX century, the hospital had three pavements, with 198 meters of front space, until August $24^{\text {th }}, 1905$, date in which it would be transferred to the buildings of the small farms at the time purchased at Rua Conde de Bonfim no. 171, 171 and 173.

At the beginning of the XX century the dental cabinet was created and the surgery service enlarged. During the administration of Mayor Francisco Pereira Passos (1902-1906), the Ordem Terceira de S. Francisco da Penitência Hospital 
was expropriated, by means of municipal decree no. 568 (December $\left.11^{\text {th }}, 1905\right)$, as a result of the project for the widening and extension of Rua Uruguaiana, in the center of the city. The imposition that such expropriation be met within three months and the foreseen compensation amount were not considered adequate by the Ordem Terceira de S. Francisco d Penitência, therefore it appealed to the courts. Later, an agreement was established and the amount of the compensation increased. In 1906, the former mansion of three pavements of Penitência Hospital, which for more than two centuries had dominated the landscape on the South side of Largo da Carioca (Carioca Public Square), between the street of the very same name and the Ladeira de Santo Antonio, was demolished by City Hall to provide "greater dimensions to the traditional Public Square, aligning it with Rua Uruguaiana, which prior to 1865 was called Rua da Vala" (ARAÚJO, p.54).

The Ordem then acquired the small farms at Rua Conde de Bonfim no. 171, 171-A and 173, in Tijuca, with 3 houses, where it would establish the temporary Hospital.

Two of the houses were ample and plausible to be adapted for the functioning of the infirmaries, and the adjacent lands allowed for the location of the future hospital.

On September $4^{\text {th }}$, 1906 the Portuguese engineer and architect Luiz Moraes Junior (1868-1955) was nominated director of the construction works of this new building, and on the $29^{\text {th }}$ of the same month the chapel of the hospital was blessed at Rua Conde de Bonfim no. 173 .

In 1909, the sick patients were transferred to a former house of barons, which was transformed into a small hospital, and all health services were discontinued in the last pavilion of the Venerável Ordem Terceira de São Francisco da Penitência Hospital at Largo da Carioca, and contiguous lands to the ones already existent were acquired on Rua Conde de Bonfim.

Between 1910-1911 the administration suspended the construction works on the new hospital, and were only reinitiated after a few years. Upon its financial consolidation, the Venerável Ordem Terceira de São Francisco da Penitência searched, between 1917 and 1923, for practical measures which would allow for the construction of the new hospital building. In such effort in favor of the Hospital the undertakings of the Chief of Surgery Fernando Ferreira Vaz (1877-1939) stood out.

The Hospital possessed, in 1922, 5 infirmaries with a total of 139 hospital beds, and a pavilion with 22 hospital beds. However the establishment did not possess private room. It had a pavilion for observations and six consultation rooms, 2 of them specialized (gynecology and odontology) and a cabinet-laboratory of microscopy.

In 1933, the main building of the Ordem Terceira da Penitência Hospital was inaugurated, whose configuration resembles its current form. As of this date, the Venerável Ordem Terceira de São Francisco da Penitência Hospital searched for ways to increase its activities and adjacent areas, seeking to offer a competent service to the population that sought it for care. Since then new buildings were built: in 1937 the "Pavilion Rebelo Lourenço" was inaugurated, currently known as Lar São Francisco, dedicated for the treatment of lung diseases, and in 1940 began the construction of the edifice "Ministro Manoel Pinto", currently Lar Santo Antonio, dedicated to the medical clinic of ladies, cardiology and hospitalization of incapacitated brother members.

In the 50's and 60's new infirmaries were created at the Hospital. In 1964, initiates construction of the edifice "Ministro Oswaldo da Rocha Pacheco", the EMORP, a 15-story building, which currently houses the dressing room and cafeteria of the employees of the institution, restaurants and other administrative sectors of the Venerável Ordem Terceira. As of the 90's, reforms were undertaken at the Lares São Francisco, Lar Santa Clara and Santa Izabel, and concluded the building which currently houses the Technical Nursing School, Unit of Cardiac Hospitalization, Unit of Medical Clinic and Physiotherapy.

The Ordem Terceira de S. Francisco da Penitência Hospital is currently under the administration of Frei Eckhart Hermann Höfling, and has become one of the main hospitals in the city of Rio de Janeiro, with more than 40 specializations and approximately 1000 doctors. The Hospital maintains a publication, the São Francisco da Penitência Hospital Magazine, which began in 1998.

The Venerável Ordem Terceira de São Francisco da Penitência Hospital is composed by a complex of eight buildings which occupy 42 thousand $\mathrm{m}^{2}$, in an area of 400 thousand $\mathrm{m}^{2}$ in the district of Tijuca. The VOT possesses, still, the São Francisco de Assis Community Center, in Vidigal, and the São José Community Center, in Duque de Caxias, where are offered gratuitous services in pediatrics, medical clinic, gynecology and dermatology. 


\section{IMPERIAL TIMES}

\section{Architectonic description:}

The present Venerável Ordem Terceira de São Francisco da Penitência Hospital is formed by a group of eight buildings that occupy 42 thousand $\mathrm{m}^{2}$, in an area of 400 thousand $\mathrm{m}^{2}$ in the borough of Tijuca. The first project for this land, in 1906, was signed by Luiz Moraes Jr., and it is not known how much of it remained, for the construction of its own headquarters, after the change of address from Largo da Carioca to Usina da Tijuca, suffered a great many problems and dragged on for three decades.

The main building was inaugurated in 1933 and presents a volume and formal aspects typical of the first decades of the XX century. Its language is very similar to projects of Porto d'Ave carried out in the 1920's, especially the first Hospital and Cancer Institute considered for the region of Cais do Porto: it has a ground plan in the form of an " $\mathrm{H}$ "; four floors with a basement and upper floor identified and differentiated from the two intermediary floors; neo-classic lines; and highlighted volumes at the main entrance and at the joining of the wings. The peculiarity of the Penitência Hospital is in its use of art déco elements of a European origin, which marks the passage of the thirties. The growth of the hospital complex accompanied the architectural evolution for the area of health and the building constructed in the 1960's is a typical mono-block, expressed in 15 floors.

\section{Register of Preservation:}

It is not listed.

\section{Sources:}

ARAÚJO, A. A Assistência Médica Hospitalar no Rio de Janeiro no século XIX. Rio de Janeiro: Ministério da Educação e Cultura/ Conselho Federal de Cultura; 1982.

ASSISTÊNCIA Pública e Privada no Rio de Janeiro (Brasil) - História e Estatística. Comemoração do Centenário da Independência Nacional. Rio de Janeiro: Typographia do Annuario do Brasil; 1922.

IGREJA da Venerável Ordem Terceira de São Francisco da Penitência. Rio de Janeiro. Pequeno Histórico. Capturado em 24 out. 2007. Online. Disponível na Internet: http://www.portaldoscondominios.com.br/turismoRioIgrejaSFPenitencia.asp

HOSPITAL da Venerável Ordem Terceira de São Francisco da Penitência. Portal VOT. Capturado em 24 out. 2007. Online. Disponível na Internet: http://www.vot.com.br/hospital/saude_historia.htm

MORAIS, A. Grandiosidade do complexo hospitalar é característica do VOT. Capturado em 24 out. 2007. Online. Disponível na Internet: http://www.hospitalgeral.com.br/2_port/atual/hosp_mes.htm

OliveirA, M. Ordem Terceira de São Francisco da Penitência: Questão Patrimonial. Capturado em 24 out. 2007. Online. Disponível na Internet: http://www.unirio.br/morpheusonline/N\%C3\%BAmero\%2003\%20-20especial\% 20mem\%C3\% B3ria/Maria\%20Fernanda.htm

Credits: Maria Elizabeth Bueno de Godoy (research); Maria Rachel Fróes da Fonseca (research and text) and Renato da Gama-Rosa Costa (Architectural description). 


\section{IMPERIAL TIMES}
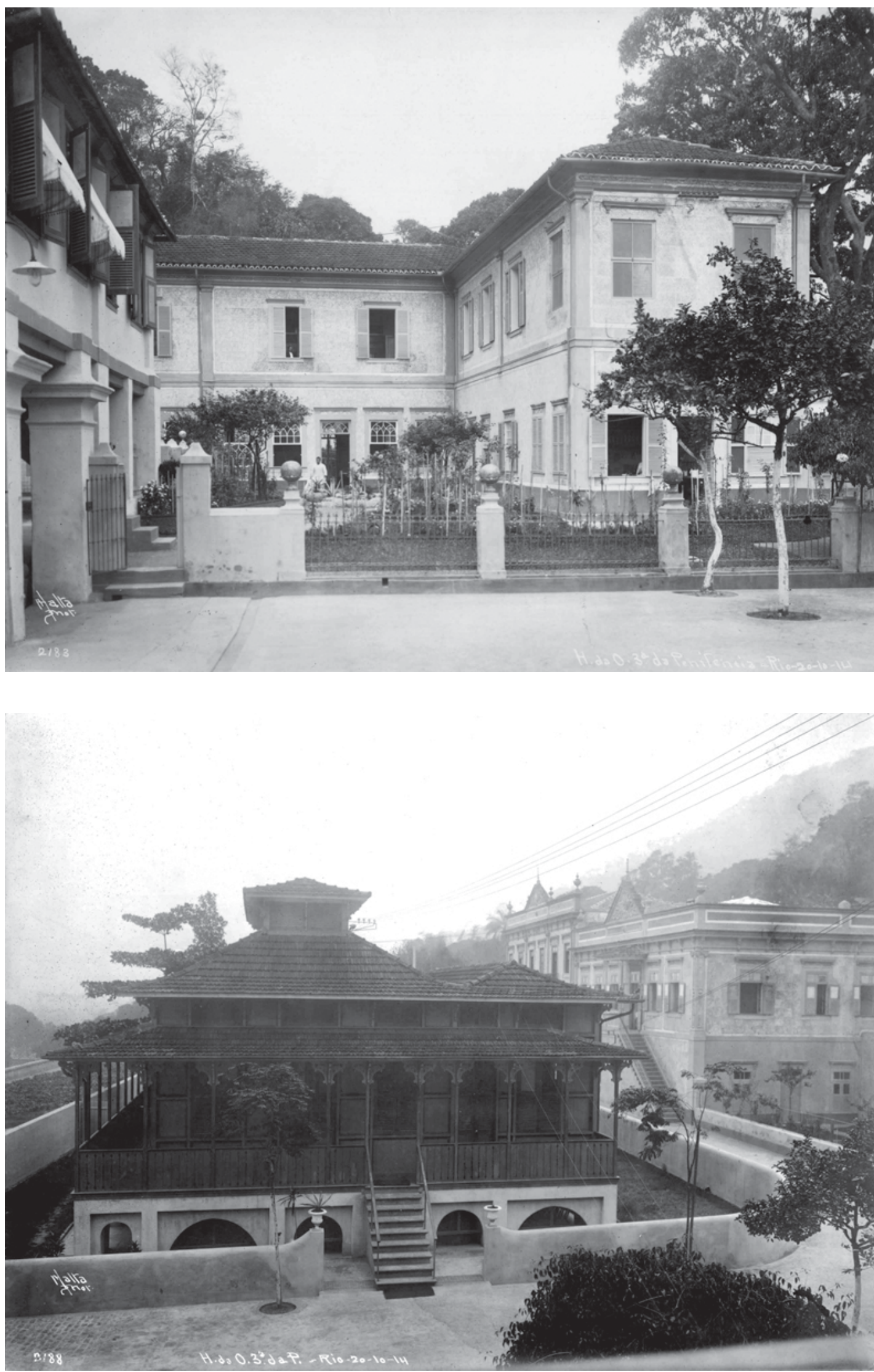

Ordem 3a de São Francisco da Penitência Hospital, 1914. Photo Augusto Malta. Museu da Imagem e do Som - RJ Archives
Ordem 3a de São Francisco da Penitência Hospital, 1914. Photo Augusto Malta. Museu da Imagem e do Som - RJ Archives 


\section{IMPERIAL TIMES}

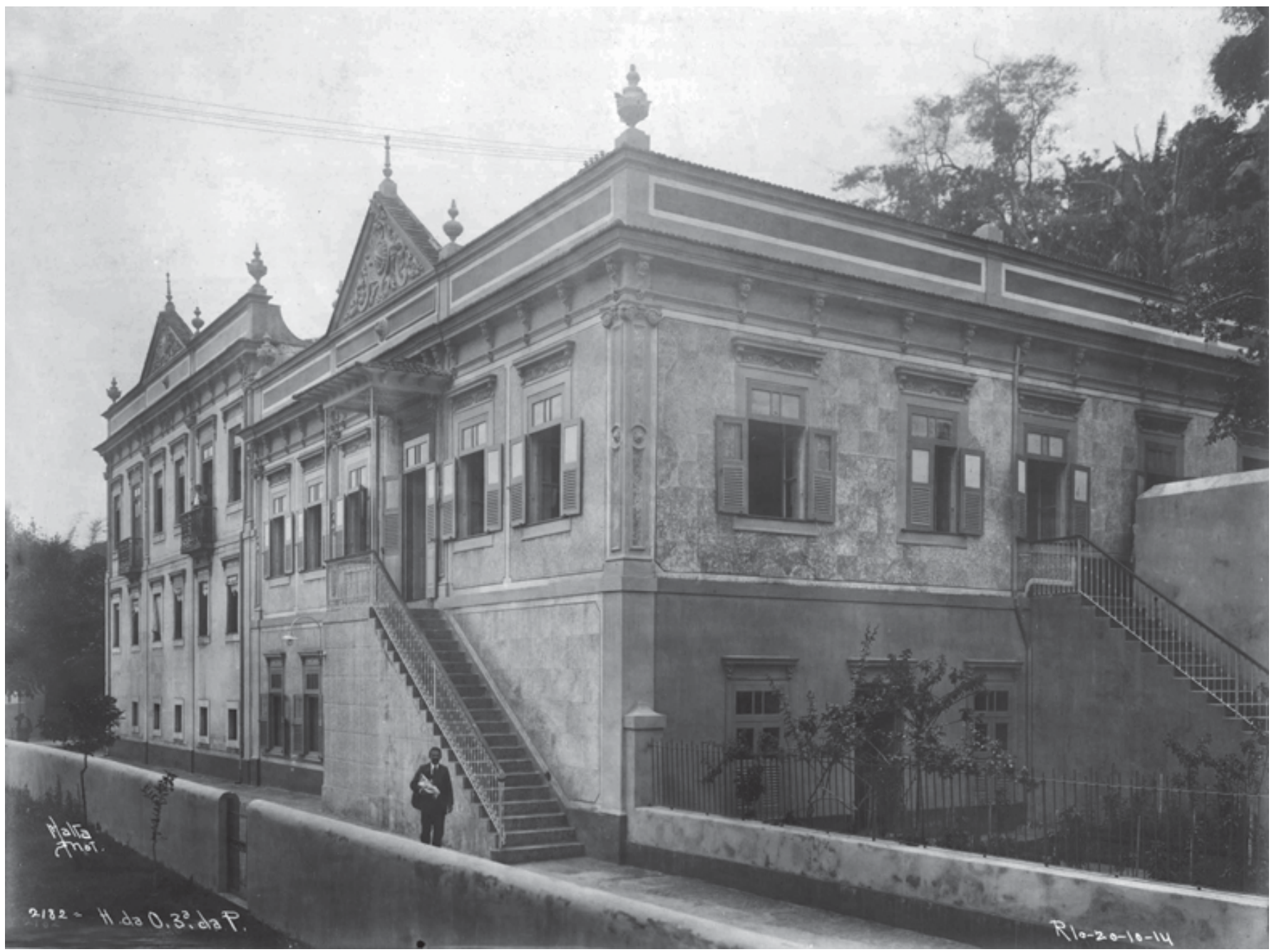

Ordem 3a de São Francisco da Penitência Hospital, 1914. Photo Augusto Malta. Museu da Imagem e do Som - RJ Archives 


\section{FIRST REPUBLIC}

\section{Albert Sabin Israelite Hospital}

Other denominations: Israelite Polyclinic (1937 - 196?), Israelite Hospital (196? - 1980) and Albert Sabin Israelite Hospital (1980 - present day)

Location: Tijuca

Address: Rua Lúcio Mendonça, 96

Category: General Hospital / Mutual Aid Society

Period of construction: [1962] and [1985 -?]

Proprietor: Israelite Charitable Society of Rio de Janeiro

Author / Constructor: unknown

History:

The history of the Albert Sabin Israelite Hospital goes back to the ambulatory that the Israelite Charitable Society decided to open, in 1937, to attend the city's Jewish community.

The Jewish immigration to Brazil has its peak in the beginning of the XX century and the creation of the Charitable Society of Support to the Immigrant (April 06 ${ }^{\text {th }}, 1920$ ) dates from this period - today the Israelite Charitable Society of Rio de Janeiro - which had the object of supporting the immigrant both in regard to the classical practice of assistance dressing, feeding and providing a roof - and in regard to making their communication easier, administering them Portuguese lessons, finding them a job, and helping them in the regularization of the immigration process. At the time of its creation, the Society worked in a large of the (street) Rua Marquês de Pombal, no. 39.

The increase of the offer of assistance by the Society, as well as the growth of the contingent of Jewish immigrants forced the search of a larger place. Thus, the real estate of the (street) Rua Joaquim Palhares No. 159 was rented, where the Society's first three ambulatories where installed.

At the time subsequent to World War Two, and with the increase in the number of medical specialities, the ambulatories were transformed into the Israelite Polyclinic. In 1951, upon receiving the donation of an X-ray device from a Jewish entity, the Society perceived the need expanding the facilities. With this intent, the house at the (street) Rua Lúcio Mendonça, No. 96 was acquired, where it remains to this day.

The house underwent adaptations to shelter the Polyclinic which counted, at the time, with 13 beds, divided into 5bed 2 infirmaries, and 2 private rooms. The care was gratuitous to the members of the community and the pharmacy distributed medicine to the needy. It is from this period that the entity begins to receive patients for internment, in spite that the beds were intended for the surgical cases. 18 doctors provided are in their premises.

At the end of the 1950's, a new expansion was needed, motivated, chiefly, by the increase in the search for of the Polyclinic's services. A campaign for collecting funds launched in 1959 permitted the house to be rebuilt.

Around 1962 the works of the Israelite Hospital were finished, and it began counting with 32 beds, from which 24 were intended for gratuity. At this time it maintained a room for large and small surgery, clinical internment, analyses laboratory, blood bank, among other facilities.

In the 1980's, it receives the name Albert Sabin Israelite Hospital in homage to the scientist's visit to its facilities.

Its expansion is not finished. In 1985, the construction of an eight-floor new building was started, interrupted in 1990 for lack of resources. The works were retaken recently and are being carried out in stages. The Society intends to achieve the number of one hundred beds as soon as the works are finished.

Today the Hospital counts with 44 beds and it is open to the Jewish community of Rio de Janeiro, but continues to maintain the gratuity of the members that are in need. 


\section{FIRST REPUBLIC}

\section{Register of Preservation:}

It is not listed.

\section{Sources:}

KEHILÁ, álbum histórico da comunidade judaica do Rio de Janeiro - Livro comemorativo dos 60 anos do Colégio A. Liessin. Rio de Janeiro: [s.n.]; 2005.

Credits: Gisele Sanglard (research and final text) 


\section{FIRST REPUBLIC}

\section{Alfredo Pinto School of Nursing of the Federal University of the State of Rio de Janeiro}

Other denominations: Professional School of Nurses (1890-1942); Alfredo Pinto School of Nursing (1942-1969); Alfredo Pinto School of Nursing of the Federation of Independent Federal Schools of the State of Guanabara (1969-1975); Alfredo Pinto School of Nursing of the Federation of Independent Federal Schools of the State of Rio de Janeiro (1975-1979); Alfredo Pinto Course of Nursing of the University of Rio de Janeiro (1979-1988); Alfredo Pinto School of Nursing of the Federal University of the State of Rio de Janeiro (1988-present day).

Location: Praia Vermelha - Urca

Address: Avenida Pasteur, no. 292

Category: Institution of learning

Period of construction: $\mathrm{XX}^{\text {th }}$ Century

Proprietor: Federal University of the State of Rio de Janeiro (UNIRIO)

Author / Constructor: unknown

History:

Until 1890 the assistance care provided to the sick was administered by the sisters of charity in all of the hospital establishments. In the same year, by means of decree no. 791, of September $27^{\text {th }}$, the first school in Brazil designated for the education of such professionals was founded, the Professional School of Nurses, located at Praia Vermelha. Established in the halls of the old Pedro II Hospice, it had the mission to educate nurses to perform in the hospices and civil and military hospitals.

On June $21^{\text {st }}$ of the same year, in accordance with the new regulation of the Hospice, the assistance care rendered by the sisters of charity was extinct in the male infirmaries, a fact which precipitated the removal of all of the religious care providers in the subsequent August. The demand for infirmaries, which was already felt in all of the health establishments, spurred the creation of the School annexed the Hospice, with the mission to graduate a workforce specialized in the treatment of mental illnesses to furnish for the lack of the institution itself. According to the decree which created it, the course being offered had a two-year duration period and, upon completion of the course, a diploma was awarded which granted the holder preferences when he/she came to be contracted by hospitals maintained by the State and the right to retire after 25 years of rendered services.

In virtue of decree no. 3.244, dated of 03/29/1899, the Medical-Legal Assistance of the Mentally Ill was transformed into the Assistance for the Mentally Ill. Due to the linkage of the School with a psychiatric institution, this decree also reorganized it. Nevertheless, despite all the institutional and professional perseverance, the School operated precariously in its first years, in part due to the incipient theory and practice of the nursing profession, still in the structuring phase, and due to the lack of human resources. Aiming to reverse this trend, it was re-inaugurated on February $16^{\text {th }}, 1905$, under the administration of the Directors Júlio Afrânio Peixoto (National Hospice of the Mentally Ill) and Antonio Fernandes Figueira (Professional School of Nurses). During this new stage, it was attempted to amplify the curriculum, in harmony with the teaching standards of nursing in general, not strictly confined to psychiatric care. In 1921, in accordance with the September $1^{\text {st }}$ regulation, the School was divided in three sections: mixed, male and female. The mixed section operated in the already denominated National Hospital of the Mentally Ill and the male ended up suspended. The female section began to operate in the Colony of Engenho de Dentro under the informal denomination of Alfredo Pinto School of Nursing, due to the referred regulation expedited by the Minister of Justice and Internal Affairs, Alfredo Pinto Vieira Melo.

As of 1923, the Professional School of Nurses began to educate mental hygiene monitors, in virtue of the creation of the polyclinic of Mental Hygiene by the Director of the Colony of Engenho de Dentro, Gustavo Riedel. 


\section{FIRST REPUBLIC}

Approved a new regulation for the services of Assistance Care to Psychopaths in the Federal District, in accordance with decree no. 17.805 , dated of $05 / 23 / 1927$, the School was also reorganized, which began to offer a third year in the educational curriculum of nurses, for the obtainment of the title "social visitor".

According to the regulation of the decree-act no. 4.725, dated of 09/22/1942, the School, already linked to the National Service of Mental Illnesses since the previous year, underwent new reorganization and officially received the name Alfredo Pinto School of Nursing. Until this year, the School had only been managed by doctors, a fact which was reversed in the administration of Nurse D. Maria de Castro Pamphiro, as head of the management until 1956.

Still, in 1942, the mixed and female sections were combined into a single headquarters, operating at Avenida Pasteur, no. 292, Praia Vermelha.

Under the University Reform (decree-act no. 773, 08/20/1969), the Alfredo Pinto School of Nursing was appointed as one of the integrated units of the Federation of Independent Federal Schools of the State of Guanabara (FEFIEG), and later the Federation of Independent Federal Schools of the State of Rio de Janeiro (FEFIERJ). In 1979, this Federation converted into the University of Rio de Janeiro (UNIRIO), federal institution of higher education under the legal norms of a Foundation, linked to the Ministry of Education. As such, the Alfredo Pinto School of Nursing became known as the Alfredo Pinto Course of Nursing of the University of Rio de Janeiro.

Since August $10^{\text {th }}, 1988$, the Course of Nursing at UNIRIO regained the denomination Alfredo Pinto School of Nursing.

\section{Register of Preservation:}

It is not listed.

\section{Sources:}

ARQUIVO Nacional. Base de Dados Mapa do Arquivo Nacional.

FEDERAÇÃO das Escolas Federais Isoladas do Estado do Rio de Janeiro. Catálogo. Brasília: MEC, Departamento de Divulgação, 1976.

GEOVANINI, T. et alli. História da Enfermagem: Versões e Interpretações. Rio de Janeiro: Revinter; c1995.

RELATORIO do director do Serviço Sanitario do Hospicio Nacional de Alienados. In: RELATORIO apresentado ao Presidente da República dos Estados Unidos do Brazil pelo Dr. Antonio Gonçalves Ferreira, Ministro de Estado da Justiça e Negocios Interiores em abril de 1895. Annexo A-U-11. Rio de Janeiro: Imprensa Nacional, 1895. Relatórios Ministeriais (1821-1960). Obtido via base de dados PROJETO DE IMAGEM DE PUBLICAÇÕES OFICIAIS BRASILEIRAS DO CENTER FOR RESEARCH LIBRARIES E LATIN-AMERICAN MICROFILM PROJECT. Capturado em 09 de ago. 2007. Online. Disponível na Internet: http://www.crl.edu/content/pindex.htm

Credits: Atiele Azevedo de Lima Lopes (research and text) 


\section{FIRST REPUBLIC}

\section{Amparo Feminino Hospital}

Other denominations: Itapagipe Association Hospital, Hospital do Amparo Feminino.

Location: Rio Comprido

Address: Rua Estrela, 27

Category: General Hospital

Period of construction: 1924

Proprietor: Associação Beneficente Amparo Feminino

Author / Constructor: unknown

\section{History:}

The Amparo Feminino Hospital has its history connected to the creation of a charitable society founded on August $22^{\text {nd }}$, 1912 by the preacher Friedrich Ludwig Hoepffner, fro the Lutheran Church of Rio de Janeiro, in conjunction with the Evangelic Ladies Association. The Society had the object of giving mother-child support to the needy women from the German colony of Rio de Janeiro. The first assistance work maintained by the group was a rest home for elderly women.

The work to collect funds for the hospital united the head of the Society and the deaconesses - women with a certain ecclesiastical degree which replaced the deacon, especially in acts of service for the feminine sex and in the hospitals maintained by the Lutheran Church - up to 1923 when they managed to commence the construction of the Itapagibe Hospital, inaugurated in the following year with maternity ward and nursery facilities.

In 1941, the Society started to be called Feminine Support of 1912 - Charitable Society (Amparo Feminino de 1912 Sociedade Beneficente), the name it maintains up to this day.

The first hospital expansion it underwent came in 1960, with the construction of the clinical-surgical pavilion inaugurated on August 22 $2^{\text {nd }}, 1965$.

The transformation of the clinical-surgical pavilion into a general hospital dates from 1992, with the extension of the number of beds available and the creation of an intensive care unit, allowing larger surgeries to be performed.

In 2005, the transfer of the operational sectors (storeroom, maintenance, clothes closet, medical file room, accounting and parking lot for workers) allowed the expansion and modernization of the Sterilization Station and the creation of the Hospital Waste Station, adapting itself to the new requirements of the Sanitary Inspection Authority.

Since 2004, it helps, in a gratuitous manner, the needy community of the Rio Comprido neighborhood, through the project "Support in the Community".

Today, the Feminine Support of 1912 maintains a shelter with a capacity for 45 elderly, and a general surgical hospital - with 08 operating rooms -; Neonatal ICU and adults' ICU, with a total availability of 108 beds. The Institution still provides ambulatory service to the needy community of Rio Comprido.

During the Vargas government, with the process of "nationalization" of the philanthropic entities, the Amparo Feminino Hospital, in May 22 ${ }^{\text {nd }}, 1945$, was acknowledged as an effectively Brazilian entity. In spite of the institution having adapted to the Brazilian legal requirements, it maintained some German traditions, such as the performance of ecumenical service, headed by the preacher Ivo Ristoff, every Thursdays.

\section{Architectonic Description:}

The Feminine Support Hospital, of 1924, received the chalet style architectural aesthetics, which was characterized by the romantic and picturesque assimilation of elements from the industrialization and the technical innovations introduced at the end of the XIX century, such as the iron and the hydraulic tile. This aesthetics is represented in the lambrequins 


\section{FIRST REPUBLIC}

and struts, in a similar manner of other hospitals from the first decades of the XX century, such as the campaign style pavilions of the São Sebastião Hospital.

The constructions that followed in the expansions carried out in the 1960's adopted more somber lines, close to a stylized déco.

\section{Register of Preservation:}

It is not listed.

\section{Sources:}

Hospital Estate.

Credits: Gisele Sanglard and Maria Renilda Nery Barreto (research and text); Renato da Gama-Rosa Costa (architectural description). 


\section{FIRST REPUBLIC}

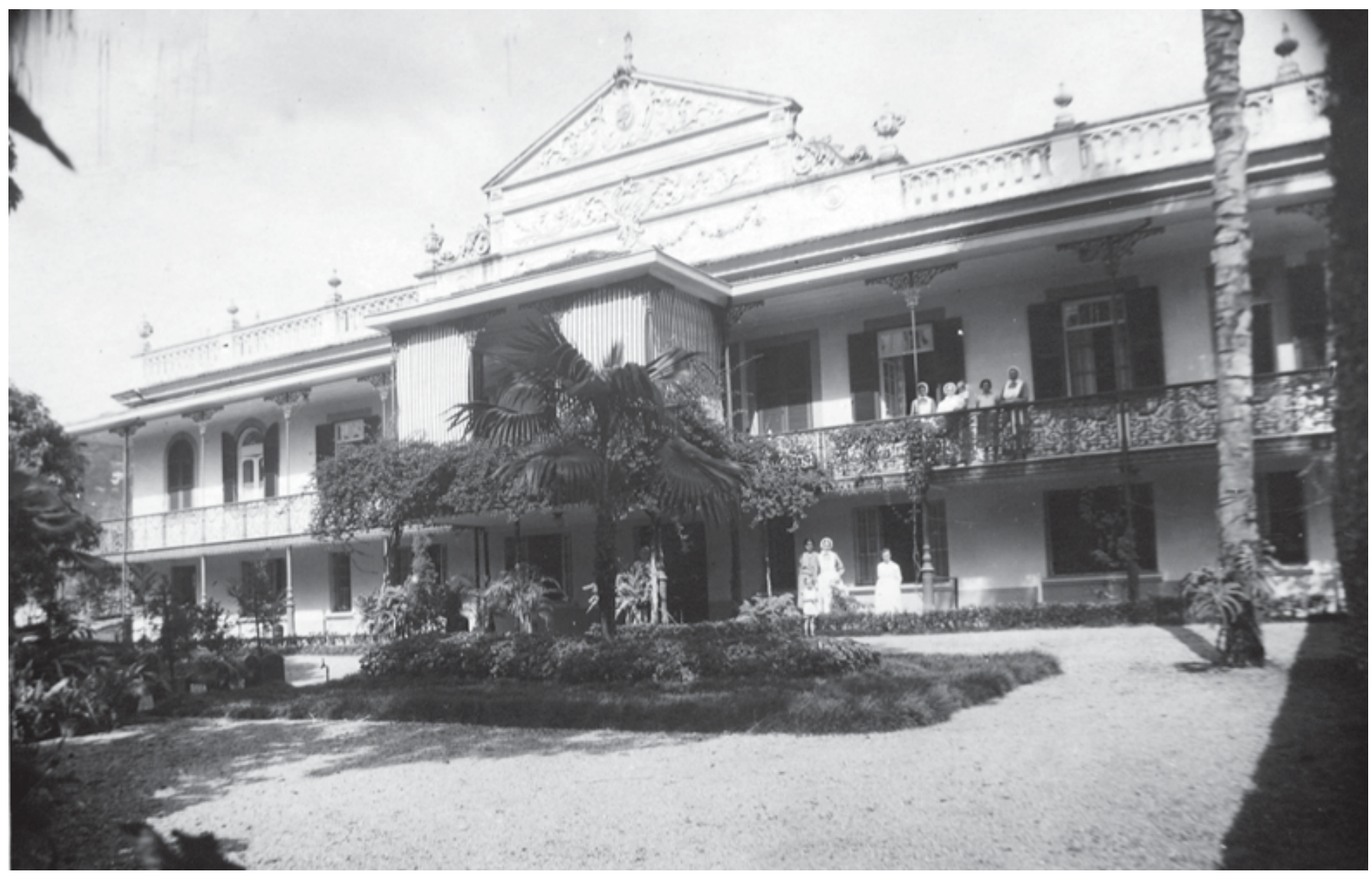

Amparo Feminino Hospital, [s.d]. Private Archives

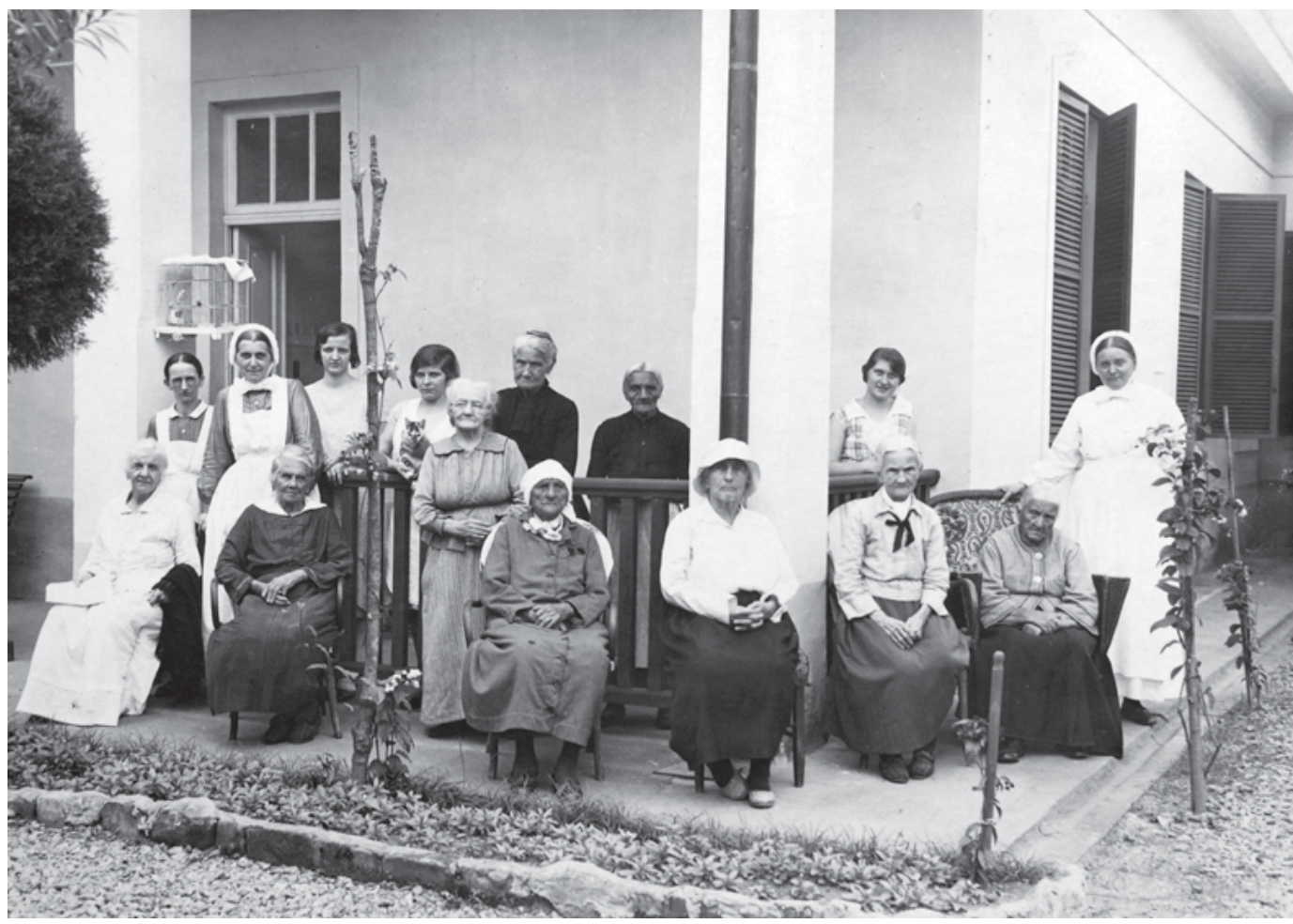

Amparo Feminino Hospital, [s.d]. Private Archives 


\section{FIRST REPUBLIC}

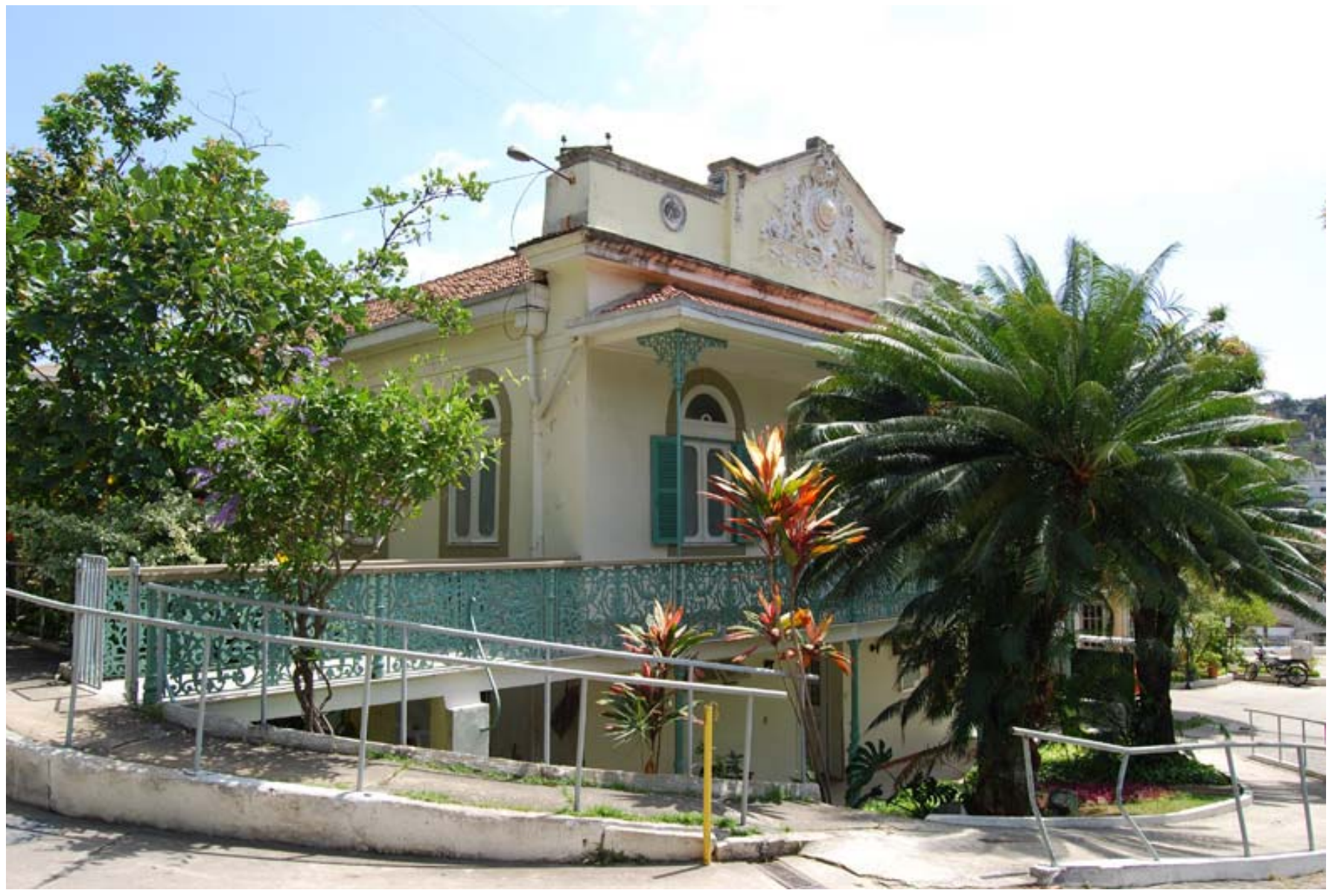

Amparo Feminino Hospital. Photo Roberto Jesus Oscar \& Vinícius Pequeno de Souza, 2007. Casa de Oswaldo Cruz Archives 


\section{FIRST REPUBLIC}

\section{Anna Nery Nursing School}

Location: Cidade Nova (Pavilion of Courses) / Flamengo (Residence Hall)

Address: Rua Afonso Cavalcante, no. 275 (Pavilion of Courses).

Denomination: Institution of Learning

Period of construction: 1926-27 (Pavilion of Courses) / 1922 (Residence Hall)

Proprietor: Federal University of Rio de Janeiro.

Author / Constructor: unknown (Pavilion of Courses) / Antônio Januzzi (Residence Hall)

\section{History:}

The 1920's marks the beginning of the implementation of the sanitary reforms proposed by Carlos Chagas when in the administration of the National Department of Public Health, occasion in which a nurse's service of public health, the General Assistance Hospital (currently São Francisco de Assis School Hospital of the Federal University of Rio de Janeiro) and a School of Nurses were created. In May, 1921, it requested pedagogic and financial aid from the International Health Board (IHB) of the Rockefeller Foundation in the United States for the establishment of a nursing service affiliated to that Department. In September of the same year, the referred to Foundation sent the nurse Ethel Parsons to Brazil in order to coordinate the Technical Cooperation Mission for the Development of Nursing, whose mission was to examine the possibilities of implementing a school or training courses for nurses, as to stimulate the development of a public nursing service in the country.

The founding of the School of Nurses of the National Department of Public Health was bound by article 7 of the decree no. 15.799, 11/10/1992, which approved the regulation of the General Assistance Hospital, allocating adjacent land for its establishment. In accordance with the regulation, the nursing service would come under the responsibility of the students of the School, substitutes of the practical nurses (without formal education) that up to then dominated the nursing services.

Throughout the works, still without its own headquarters and without room to perform the practical training of the students, at the end of 1923 a building next the Hospital (rua Visconde de Itaúna, no. 399) was rented, which later served as residence for the nurses. Given the physical and institutional development of the School, the transfer of part of the facilities to another building was arranged for at rua Valparaíso, no. 40-A, the first building remaining destined only for classes.

Thanks to the financial assistance furnished by the Rockefeller Foundation, the headquarters of the School of Nursing was inaugurated in 1926 with two sectors: one pavilion for classes and functioning of the management and another pavilion for the hospitalization of patients with infectious-contagious diseases, both located at rua Afonso Cavalcante, no. 275. The cornerstone was laid on the same date of the inauguration of the General Assistance Hospital (11/07/1922).

The fundamental model of the type of nursing practice to be adopted in the institution was called the "nightingale" system, of English extraction, inspired in the actions of Florence Nightingale (1820-1910) during the Crimean War, which gave rise to the first theoretical-practical school of nursing in 1860.

In 1925, the building of the old Hotel 7 de Setembro at Avenida Rui Barbosa no. 762, which was built by Mayor Carlos Sampaio for the commemorations of the 100-years of Independence, was donated from the Federal Government to the National Department of Public Health. As of April $7^{\text {th }}, 1926$, it began to operate as a residence hall for the students of the School of Nurses D. Anna Nery until 1973, when it became the House of the University Student. It remained as such until 1995, when the ownership of the building returned to the Federal University of Rio de Janeiro.

In virtue of decree no. 20.109, 06/15/1931, the regulation of the teaching of nursing in Brazil established the conditions to concede it the status of official institute, making the School of Nurses D. Anna Nery a standard school. After this deliberation, it was incorporated into the University of Brazil as a result of Act 452, 07/05/1937.

Currently, it integrates the Center of Health Sciences of the Federal University of Rio de Janeiro in accordance with the Plan of Restructuring approved by decree no. 60.455-A, of March $13^{\text {th }}, 1967$. It is distributed among the following university 


\section{FIRST REPUBLIC}

campuses: the campus of Cidade Nova (Pavilion of Classes and annexes) and the campus of the Cidade Universitária/Ilha do Fundão, in the Center of Health Sciences. The building of the Pavilion of Classes houses five departments: Department of Maternal-Infant Nursing (DEMI); Department of Fundamental Nursing (DEF); Department of Public Health Nursing (DESP); Department of Medical-Surgical Nursing (DEMC); Department of Nursing Methodology (DME). In addition, it possesses eight research core areas, which are: research in the history of Brazilian nursing, nursing and health of the worker and hospital nursing.

Performing as an institution of learning, research and extension, the Anna Nery School of Nursing of the Federal University of Rio de Janeiro (denomination acquired in 1965) sustains a tradition of vanguard in the country, responsible for the development of the nursing field when it turned into a standard school, which stimulated the emergence of new schools, in addition to stimulating the creation of the Brazilian Association of Graduate Nurses (1926), currently the Brazilian Association of Nursing - ABEn. It is in charge of the curricula of the Post-Graduate Programs in Nursing, implemented in the 1940's (lato sensu) and in 1972 (stricto sensu - Master's). The Doctorate program was instituted in 1989.

\section{Architectonic Description:}

The architectonic complex of the old Hotel Sete de Setembro is composed of a construction of three-floors with a rectangular design and two internal courtyards. The rectangular design offers the visitor a perspective of horizontal largeness, split by the central element which is elevated in one more floor.

The main façade prizes the main access differentiating it from the other floors, notably by the presence of a veranda supported by columns which leads access to seven empty spaces in abated arches and adorned in the arrival with the doorposts.

\section{Register of Preservation:}

Pavilion of Courses of the Anna Nery School of Nursing (listed by the INEPAC on August $14^{\text {th }}, 1987$ ); Residence Hall of the Anna Nery School of Nursing (listed by the INEPAC on June $09^{\text {th }}, 1989$ ).

\section{Sources:}

BREVE Histórico Institucional sobre a Escola de Enfermagem Anna Nery. Capturado em 26 de fev. 2007. Online. Disponível na Internet: http://www.eean.ufrj.br/sobre/sobre.htm

COELHO, C. A Escola de Enfermagem Anna Nery, suas histórias, nossas memórias. Rio de Janeiro: Cultura, 1997.

FRAENKEL, E. Histórico do Serviço de Enfermeiras do DNSP. Revista de Enfermagem, Rio de Janeiro, ano1, n.2, v.1, dez. 1997. O RIO de Janeiro e seus Prefeitos. Ed. Prefeitura da Cidade do Rio de Janeiro.

SAUTHIER, J; CARVALHO, V. A Missão Parsons: documentos históricos da EEAN/UFRJ 1922-1931. Rio de Janeiro, Ed. Escola Anna Nery, 1999.

UNIVERSIDADE Federal do Rio de Janeiro. Projeto de Restauração e uso do Hotel Sete de Setembro. Capturado em 04 de mar. 2007. Online. Disponível na Internet: http://www.ceu.ufrj.br/apresentacao.htm

Referências do arquivo da Escola de Enfermagem Anna Nery:

Ficha de Inventário do INEPAC.

Arquivo Geral da Cidade - fotos de Augusto Malta

SPU - Serviços de Patrimônio da União

Escola de Enfermagem Ana Nery da UFRJ

Credits: Leonardo Rodrigues (research), Atiele Lopes (reseach and text), Gisele Sanglard (architectonic description). 


\section{FIRST REPUBLIC}

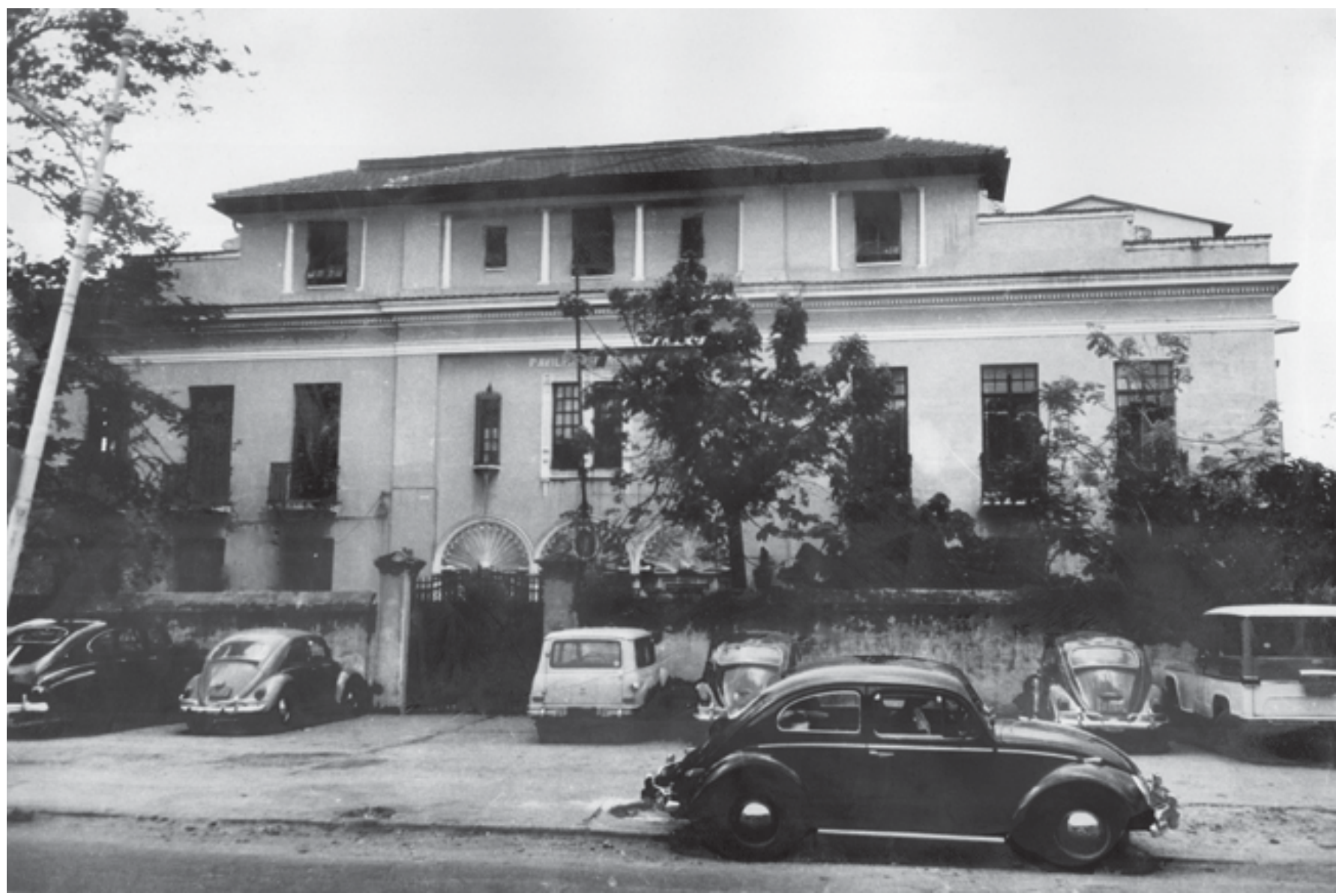

Anna Nery Infirmary School, [s.d]. Universidade Federal do Rio de Janeiro Archives 


\title{
FIRST REPUBLIC
}

\section{Aristarcho Pessoa Firefighters Central Hospital of the State of Rio de Janeiro}

\author{
Location: Rio Comprido
}

Address: Avenida Paulo de Frontin, 876.

Category: General Hospital.

Period of Construction: 1945

Proprietor: Corpo de Bombeiros Militar do Estado do Rio de Janeiro (Fire Department of the State of Rio de Janeiro).

Author / Constructor: unknown

\section{History:}

Imperial decree no. 1,775, signed by the Emperor D. Pedro II on July $2^{\text {nd }}, 1856$, created the Corpo Provisório de Bombeiros da Corte (Provisory Fire Department of the Royal Court), under the jurisdiction of the Ministry of Justice. In 1860, it was regulated and subjected to the jurisdiction of the Ministry of Agriculture created at the time. Corpo Provisório de Bombeiros (Provisory Fire Department) was militarized by means of decree no. 7,766 of July $21^{\text {st }}$, 1880, which granted military ranks to the officers of the Fire Department. In 1889, with the Republic, the corporation became known as Corpo de Bombeiros do Distrito Federal (Federal District Fire Department), as a result of the status change of the city of Rio de Janeiro from Neutral Municipality of the Royal Court into Federal District.

On January $1^{\text {st }}, 1894$, Colonel Eugenio Rodrigues Jardim, Provisional Commander of the Fire Department, established an infirmary considered to be the first medical unit of the corporation, in an area contiguous the Fire Department Central Headquarters of the Federal District, which had been occupied by the Public Deposit. Service care was rendered by two effective military doctors and four private ones. The first pharmacy was inaugurated on June $19^{\text {th }}, 1895$ and, in so manner, the Corporation offered treatment at the department and medicines to officers, soldiers and their families. The place was small and did not fully meet the requirements which it was intended for, thus a new hospital was designed and inaugurated on November $15^{\text {th }}, 1900$. The new hospital had cabinets of ophthalmology, hydrotherapy, electrotherapy, radiotherapy and odontology.

In 1912, the Hospital building consisted of three pavements and accommodated two consultation rooms (one special and another for ophthalmology), two infirmaries (allopathic medical clinic and surgical clinic), private rooms, three cabinets (electrotherapy and radiology, ophthalmology and hydrotherapy), an adjacent cabinet of dental clinic.

Colonel Aristarcho Pessoa Cavalcanti de Albuquerque, brother of the former Governor of Paraíba and candidate to the vice-presidency, João Pessoa Cavalcanti de Albuquerque (1878-1930), took Command of the Fire Department on December $15^{\text {th }}, 1930$. During his administration, he constructed many departments, reconditioned existing ones, acquired materials of more advanced technique and dedicated himself to the problem of education and social assistance. He had the initiative to acquire, through the Fire Department, Santa Alexandrina Hospital, an institution which rendered medical service care and social protection to military personnel and their dependents at the time.

On July $2^{\text {nd }}, 1941$, the chapel of the Fire Department was inaugurated in this city containing the name of the patron saint of all the firefighters, São João de Deus, and, on February $5^{\text {th }}, 1942$, the buildings at no 59 on Praça da República and nos. 158, 160 and 162 on Rua do Senado were expropriated to expand the Central Headquarters (currently headquarters of the Firefighters Museum).

In the fire of the commercial center known as "Park Royal", located in downtown, which occurred on July 9 $9^{\text {th }}, 1943$ and had great repercussion in the press of the time, a firefighter died and fifteen were wounded. The precariousness and insufficiency of the firefighters' contingent brought about the promulgation of decree-act no. 6381 of March 29 ${ }^{\text {th }}, 1944$, which established the increase of the Federal District Fire Department's contingent force.

Still under the administration of Aristarcho Pessoa Cavalcanti de Albuquerque, by means of decree 16,674 (September $28,1944)$, property at Rua Santa Alexandrina no. 254 was expropriated, where the former Rio Comprido Sanatorium used 


\section{FIRST REPUBLIC}

to be, in order to install the hospital of the Federal District firefighter corporation. At this time the Corporation already had almost 1500 firefighters, and the existing medical facilities of the Central Headquarters were insufficient for the rendering of medical service. In this place on October, 1945, Aristarcho Pessoa Central Hospital was inaugurated, in tribute to the General Commander of the corporation.

The Administrative Pavilion was remodeled in 1947 for the opening of Laboratory, sector of Radiology and Surgical Center. The Hospital also had 5 infirmaries and a Great Hall. Under the administration of Colonel Sadock de Sá, in 1955, the Female Pavilion was duplicated, dedicating the older part (with $\left.680 \mathrm{~m}^{2}\right)$ for the Maternity Ward, and the newer one $\left(1080 \mathrm{~m}^{2}\right)$ for the Hospital, itself. At this time, the Director's Office, lodging for the day Doctor, Ophthalmology, Otorhinolaryngology, Ladies' Clinic and the Clinic for Oral Health were installed on the $1^{\text {st }}$ floor of the Maternity Ward, and on the $2^{\circ}$ floor, 12 rooms. A Laundry room of 2 pavements where currently the Psychiatric Pavilion is located was constructed in this period.

Aristarcho Pessoa Hospital was interdicted in 1967 because it presented risk of collapsing due to cracks on the building, which appeared after intense rains in the city of Rio de Janeiro. Although Colonel Abel, General Commander of the Cooperation at the time, had solicited the Secretary of Public Safety a location for the construction of a new hospital unit, and had received a property located on rua São Francisco Xavier for that purpose, the Hospital still remained on that location, because containment work and crack restoration were concluded and considered satisfactory.

In the 1970s the cafeterias building was constructed in metallic structure and pre-molded. However, in 1871, Aristarcho Pessoa Central Hospital lost part of its property due to the construction of the Paulo de Frontin Highway. Since then its address changed to Avenida Paulo de Frontin no. 876.

Later, Aristarcho Pessoa Central Hospital also obtained other improvements, among them the construction of a studies center, a pharmacy, ICU, endoscopy sector and neonatal ICU. In the 90s, the Hospital received several improvements with the remodeling of the former Laundry to the present Psychiatric Pavilion, construction of a new Laundry room, as well as the Center of Studies with auditorium, Chapel, Guard Corps, Communications' Room, ICU, Pharmacy, Data Processing Center, Endoscopy and neonatal ICU, Health Unions (where Physical Medicine is located today), Odontology, Physical Medicine and Library adjacent the Studies Center.

Still operating at Avenida Paulo de Frontin, no. 876, Aristarcho Pessoa Central Hospital provides service care to firefighters, dependents and pensioners, and has 102 beds for hospitalization, seven beds for adult ICU, four for neonatal ICU, surgical center with three rooms, pediatrics infirmary with seven beds, psychiatric pavilion with 16 beds and maternity ward with six beds of shared rooms. Its service care includes several clinical medical specialties. It also has Emergency Service and Firefighter's Pharmacy.

\section{Architectonic description:}

The architecture of the Aristarcho Pessoa Hospital reveals its origins as a quarantine hospital: situated in a location far away from the urbanized areas of the city (the neighborhood of Rio Comprido, before the opening of the tunnel) and pavilions located on the hillside, with balconies along the whole façade and proto-modern lines. The main building, located more towards the front of the property, received revetment in marble which leaves only traces of its neoclassical lines.

\section{Register of Preservation:}

It is not listed 


\section{FIRST REPUBLIC}

\section{Notes:}

All documentation related to Aristarcho Pessoa Firefighters Central Hospital of the State of Rio de Janeiro is currently at the Firefighters Museum and their original plant in the National Archive.

\section{Sources:}

Aspectos Históricos. Histórico dos Bombeiros no Brasil. Capturado em 20 nov. 2007. Disponível na Internet: http:// www.brigadamilitar.rs.gov.br/bombeiros/hist-bra.html

ASSISTÊNCIA Pública e Privada no Rio de Janeiro (Brasil) - História e Estatística. Comemoração do Centenário da Independência Nacional. Rio de Janeiro: Typographia do Annuario do Brasil; 1922.

Avante Bombeiro. Publicação oficial do Corpo de Bombeiros Militar do Estado do Rio de Janeiro, Rio de Janeiro, ano II, n.2, jun. 1997.

CORPO de Bombeiros Militar do Estado do Rio de Janeiro. Dia da Saúde do Corpo de Bombeiros foi comemorado com entrega de medalhas. Online. Capturado em 20 nov.2007. Disponível na Internet: http://www.cbmerj.rj.gov.br/ modules.php?name=News\&file=print\&sid=232

HALFELD FILHO, J. Histórico do Corpo de Bombeiros. 1 $^{\text {a }}$ ed. Rio de Janeiro: [Museu do Corpo de Bombeiros],1991.

HOSPITAL Central Aristarcho Pessoa. Sobre o Hospital: Histórico. Online. Capturado em 18 nov. 2007. Disponível na Internet: http://www.hcap.ri.gov.br/

SOCIEDADE Médica do Estado do Rio de Janeiro. Hospital do Corpo de Bombeiros completa 59 anos. Associação Médica em revista, Rio de Janeiro, ago. 2004. Online. Capturado em 20 nov. 2007. Disponível na Internet: http://www.somerj.com.br/ revista/200410/2004_10_comemoracao.htm

Credits: Maria Elizabeth Bueno de Godoy and Maria Rachel Fróes da Fonseca (research and text); Renato da Gama-Rosa Costa (arqchitectonic description). 


\section{FIRST REPUBLIC}

\section{Ataulfo de Paiva Foundation}

Other denominations: Brazilian League Against Tuberculosis (1900-1924); Brazilian League Foundation Against Tuberculosis (1924-1936); Ataulpho de Paiva Foundation (1936-present day).

Location: Downtown

Address: Avenida Almirante Barroso, 54/15 andar

Category: Institution of research and production

Period of construction:

Proprietor: Ataulpho de Paiva Foundation.

Author / Constructor: unknown

\section{History:}

On August $4^{\text {th }}$, 1900, the Brazilian League Against Tuberculosis was founded in the city of Rio de Janeiro, a philanthropic institution whose objectives were to render medical-social assistance to people affected with tuberculoses and disseminate information about the disease, mainly, the notion that tuberculoses was curable.

In spite of the high incidence of tuberculosis at the end of the XIX and beginning of the XX centuries, the disease did not become a priority issue for the State, which was occupied with epidemic diseases that caused grave harm to the nation's economy. As a result, the medical elite took upon themselves the task of making tuberculoses a public issue and understood the severity of the problem, not only at medical assemblies but also in the outside press.

In 1899, the professor of pathological anatomy of the College of Medicine in Rio de Janeiro, Cypriano de Freitas, in a festive occasion, exclaimed to the medical society to create a specific agency to combat tuberculosis. It was the beginning of a grassroots movement which culminated with the foundation of the Brazilian League Against Tuberculosis, whose groundwork was established by a commission comprised of Cypriano de Freitas himself, Ismael da Rocha, Carlos Seidl, Guedes de Mello and Azevedo Lima (LBCT, 1901).

In attendance at the solemn inaugural ceremony of the League held at the National Academy of Medicine, in addition to the archbishop, who presided over the occasion, the President of the Republic, Campos Sales, a few ministers, the general director of Public Health, Nuno de Andrade, as well as other renowned personas of the political, social and artistic arenas were present.

During the occasion, Cypriano de Freitas called forth an alliance between church, science and the economic and social interests of the country that were united there. On the occasion, Alcindo Guanabara commented on the "duty and honor of western civilization" to combat tuberculosis (Guanabara, 1911).

Doctors were made in charge of the League's administration. They were, to the great extent, staunch supporters of the traditional clinic, and at the same time occupied posts at the National Academy of Medicine and the College of Medicine, and were influential figures in medical politics and politics in general, as well as, other non-medical professionals that also joined a privileged social and political position, worth noting Ataulpho de Paiva, whose recognition as a jurist was reinforced through his works on public and private assistance care (Nascimento, 2002). Ataulpho de Paiva presided over the League from 1912 to 1913 and 1919 to 1924, when he became its lifetime president. The first statute of the League (LBCT, 1900) defined its mission to create hospitals and sanatoriums, engage in a massive propaganda campaign about the curability of the disease and the enforcement of the compliance with municipal instructions. A year later, the League created a new statute (LBCT, 1901), which included the creation of dispensaries according to its prerogatives.

On January $26^{\text {th }}, 1902$, the League created its first dispensary, which, in 1907, was inaugurated in its own building and received the name Azevedo Lima Dispensary. This dispensary was the only entity in Rio de Janeiro specialized in the treatment and the prophylaxis of tuberculosis until 1911, year when the League inaugurated its second dispensary, 


\section{FIRST REPUBLIC}

Viscondessa de Moraes in São Cristóvão, which exercised a fundamental role in the education of phthisiologists and allowed for a few therapeutic tests. Pneumothorax was systematically administered to the patients of the dispensary by the phthisiologist Edgard Abranches.

In 1913, the League created the Domicile Assistance Care Service with the aim to render medical assistance care to the tuberculous who were unable to go to the dispensary. This service lasted until 1928.

As a propaganda strategy to mobilize popular public opinion to the problem of tuberculosis, the League executed popular meetings in factories, schools, army posts and professional clubs, news communication to newspapers, periodicals, and distribution of pamphlets. Various newspapers writers collaborated with the League, such as Antonio Pereira Leitão, Ernesto Senna, Eduardo Saboya, Alcindo Guanabara and Nuno de Andrade.

Also in 1913, the League edited the first edition of its magazine, which was published regularly until 1920 and substituted in 1921 by an Almanac whose objective was to disseminate information about tuberculosis. Its distribution was free at the dispensaries of the League, schools, factories, medical clinics, pharmacies and diverse associations.

Under the creation of the Tuberculosis Prophylaxis Enforcement Bureau in 1920, subordinate to the National Department of Public Health, the State inaugurated various dispensaries in the federal capital. In 1924, the League became a foundation. For its upkeep, the federal government began to provide it endowed funds which were destined for institutions whose statute was that of a foundation.

The League concerned with children's care began to articulate a project for a children's sanatorium which became a reality as a prevention center in 1927. Thus, in Ilha de Paquetá, the Rainha Dona Amélia Prevention Center was established with the mission to shelter weak children, however not with tuberculosis, children of tuberculous parents.

In 1921, the BCG vaccine, immunotherapeutic which protects against tuberculosis was discovered by Calmette and Guérin in France. This therapeutic treatment was introduced in Brazil in 1925 and Arlindo de Assis, an assistant at the Vital Brasil Institute was responsible for the first trials with the vaccine. In 1927, the League instituted the BCG Vaccination Service, forging an alliance with the Vital Brasil Institute where the Institute would produce the vaccine and develop biological research, and the League would administer and evaluate the results.

In 1930, with the accession of Getúlio Vargas into power, the State began to implement social policy intent on minimizing the conflicts between capital-labor and the League, on its behalf, entered into the production area by instituting its own BCG Preparation Laboratory, under the leadership of Arlindo de Assis who began to dedicate himself entirely to the work at the League, severing ties with the Vital Brasil Institute.

On January $22^{\text {nd }}$, 1936, the Brazilian League against Tuberculosis becomes known as the Ataulpho de Paiva Foundation. In 1937, a new Statute is published confirming this decision keeping the name Brazilian League against Tuberculosis as a complementary designation to be used when deemed opportune and necessary.

From then on, investments at the Ataulpho de Paiva Foundation shifted to its BCG Preparation Laboratory resulting in the transformation of the Viscondessa de Moraes Institute in 1940. In addition to producing BCG in an ever growing scale, the Institute developed laboratory research related to immunotherapy, as well as maintaining the field studies about the efficacy of the immunizing agent. This movement was in sync with the government policy to amplify the fight against tuberculosis with the creation of the National Tuberculosis Service in 1941, responsible for the prophylactic campaign nationally and, soon after, with the creation of the National Campaign against Tuberculosis in 1946, responsible for the construction of hospitals and sanatoriums around the country, enormously intensifying prevention with BCG.

On May $8^{\text {th }}, 1955$, Ataulpho de Paiva passed away, however his work as the driving figure of the institution was enough for the institution to remain alive. In the 1950's, the State had already magnified its attention to the tuberculosis issue a great deal plus anti-tuberculosis chemotherapy was being developed. Thus, the directorship of the FAP decided to shutdown the dispensaries Azevedo Lima and Viscondessa de Moraes and reaffirmed its commitment with the production of BCG as its number one priority.

The Viscondessa de Moraes Institute began to produce lyophilized vaccine in the 1970's which was defended by Milton Magarão, its technical-scientific director at the time. Still, under an initiative by Milton Magarão, the FAP created the Arlindo de Assis Research Center (CPAA) with the mission to study new techniques in the combat of tuberculosis. 


\section{FIRST REPUBLIC}

The legitimacy of the FAP, which was the only private laboratory in the production of immunobiologicals to participate of the National Self-Sufficiency Program of Immunobilogicals (PASNI), was awarded through the recognition as the largest producer of the BCG vaccine in Brazil and by demonstrating its potential for expansion with a new factory in Xerém. The FAP also began to invest in the development and commercialization of new products, without letting the BCG lose importance as its principal product with research leading in the direction of a recombinant vaccine.

In more than 100 years of existence, the Ataulpho de Paiva Foundation and the Brazilian League against Tuberculosis focused on three things care, production and research, having its professional development overlap in these three areas. Today, it maintains the Rainha Dona Amélia Prevention Center which legitimizes its status as a philanthropic institution, produces and develops research with BCG.

\section{Register of Preservation:}

It is not listed.

\section{Sources:}

GUANABARA, A. Discursos fora da Câmara

Fundação Ataulpho de Paiva: um século de luta

Credits: Dilene Raimundo Nascimento (research and text) 


\section{FIRST REPUBLIC}

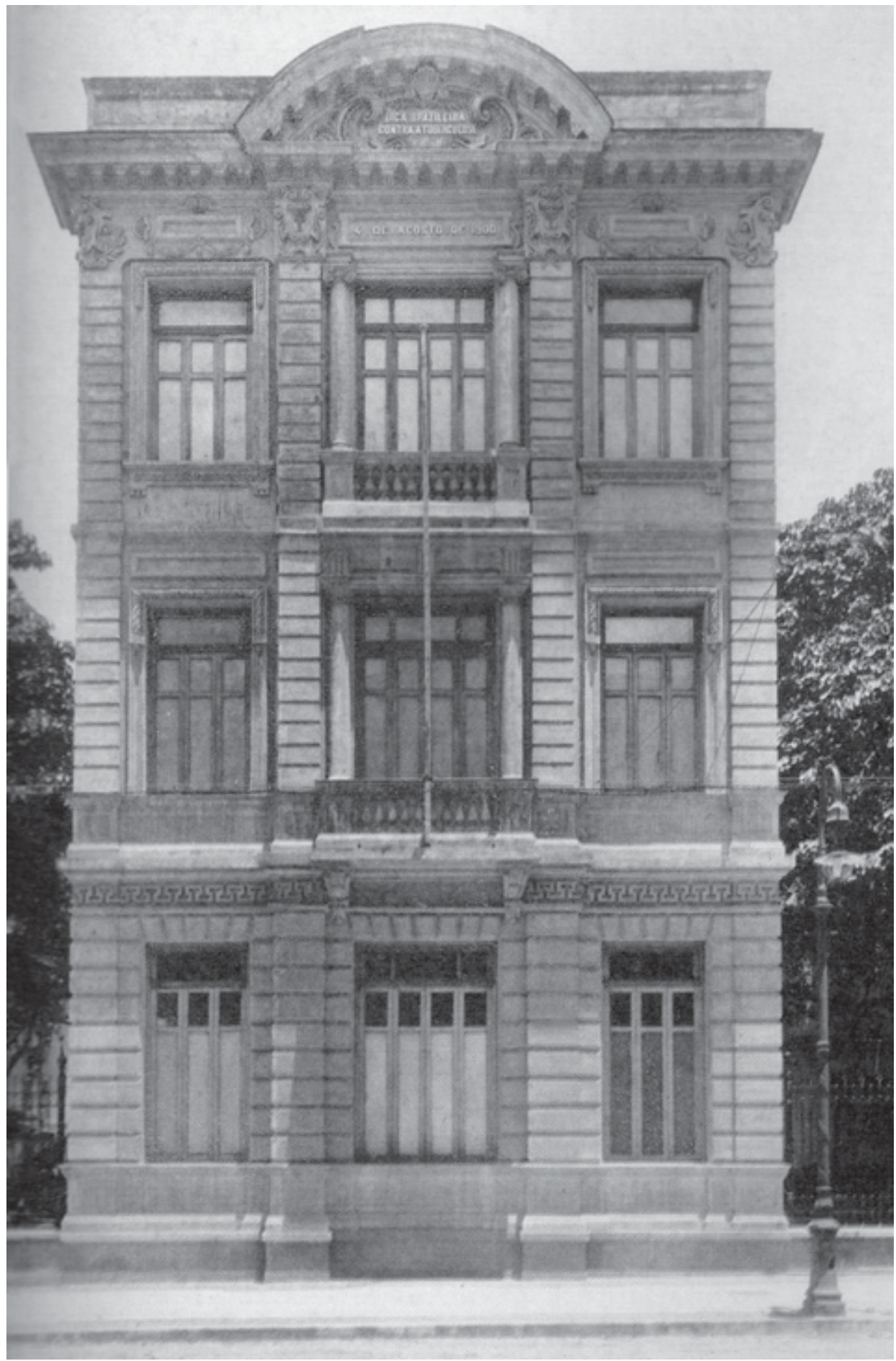

Dispensary Azevedo Lima and League Centre, 1901. Ataulfo de Paiva Foundation Archives 

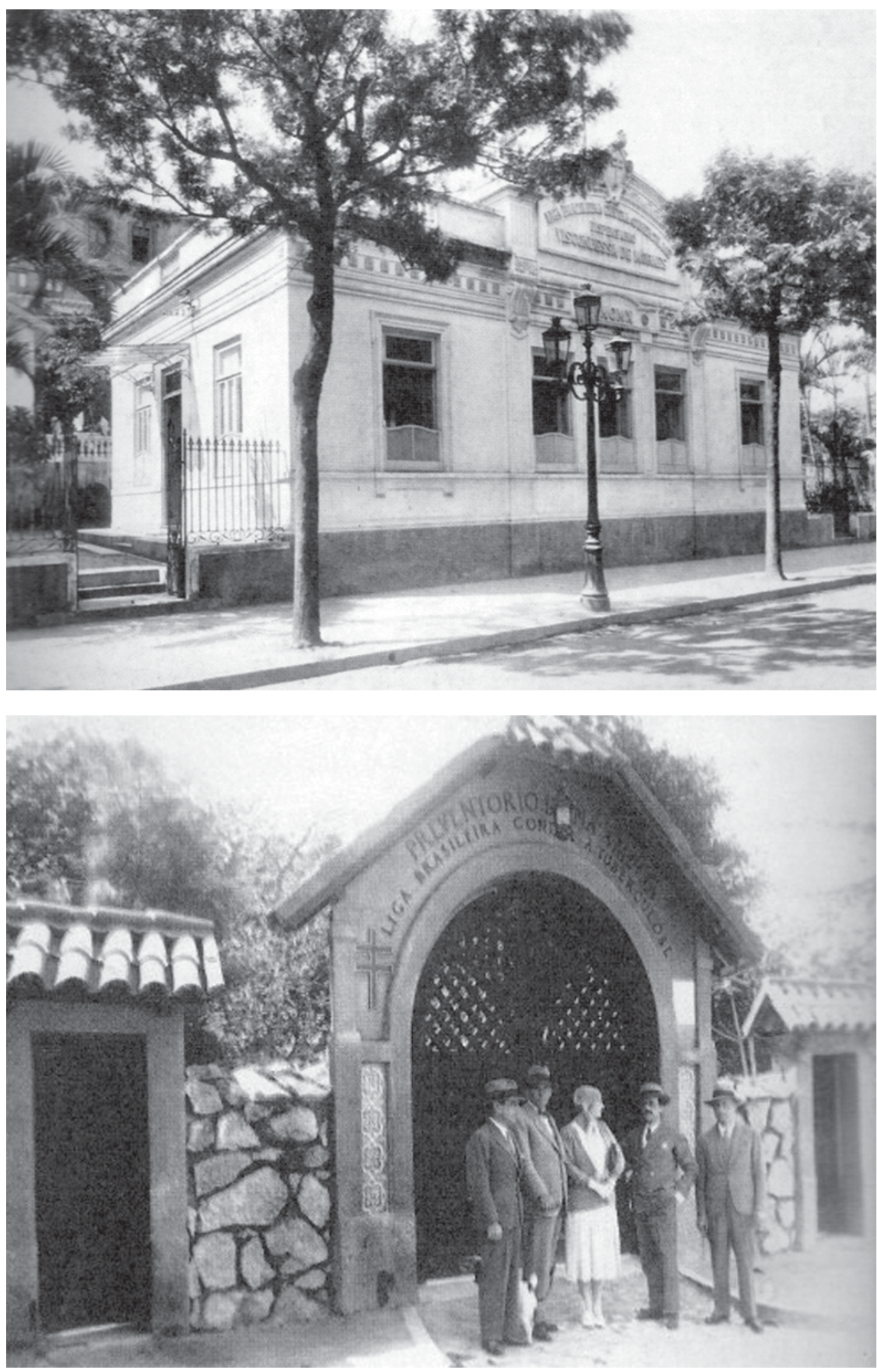

Dispensary Viscondessa de Moraes, 1911. Ataulfo de Paiva Foundation Archives
Preventive Service Queen D. Amélia, Paquetá Island, [s.d.] Ataulfo de Paiva Foundation Archives 


\section{FIRST REPUBLIC}

\section{Barata Ribeiro Municipal Hospital}

Location: Mangueira

Address: R. Visconde de Niterói, 1450

Category: General Hospital

Period of construction: 1926-1948

Proprietor: City Hall of Rio de Janeiro

Author / Constructor: Adelstano Porto d'Ave (architect, $1^{\text {st }}$ project)

History:

The construction of this hospital is connected to the various manifestations that took place after the death of Oswaldo Cruz, in February 1917. One of these resulted in the creation of the Oswaldo Cruz Foundation, at August 25 ${ }^{\text {th }}, 1922$, by initiative of a few doctors, some of them belonging to the staff of Manguinhos, in addition to other personalities. The Foundation had the object of cultivating the memory of Oswaldo Cruz; and in the first session of its board it established as a goal the construction of a hospital dedicated to the study and treatment of cancer, by initiative of the carioca (Rio de Janeiro-born) industrialist Guilherme Guinle (1882-1960) - its president of honor. The expenses with the works and the outfitting ran on account of the Guinle family. A commission - formed by the doctors Carlos Chagas, Eduardo Rabello and João Marinho- was charged with preparing the plans for the construction of the Cancer Institute and the Hospital for cancer patients, which should act according with the donator - Guilherme Guinle. The blueprints, graphs and drawings were presented in the first meeting of the Decision-Making Council of the Oswaldo Cruz Foundation of the year 1925 and the performance of the project was up to the architect Adelstano Porto d'Ave (1890-1952).

The proposal of a hospital for fighting and controlling cancer is directly connected to the public health policy put into practice at that time: the works of the DNSP, directed by Carlos Chagas, and the Inspectorship of Prophylaxis of Syphilis and Veneral Diseases, under the responsibility of Eduardo Rabello, who was also in charge of the control of cancer.

The construction of the building which would house the Hospital was slow and involved several uncertainties and disputes. The first was the choice of the grounds: the Oswaldo Cruz Foundation had gained a terrain in the Port Docks, where a project of the architect Porto d'Ave was performed, under the direction of the Eduardo Rabello. On November 1926 the cornerstone of the hospital was launched on the Mangueira grounds, with a project by the same architect and technical direction of Salles Guerra and João Pedroso.

From the drawings and the blueprint of the Hospital we perceive that the change from the Port Docks to the Mangueira brought an increase in the facilities: if on one hand the project for the Institute of Research seems strictly the same, the Hospital was considerably changed. The grounds gained in size, in buildings and in socialization spaces. In this reformulation, the vivarium, the chapel and the space intended for the storeroom, the boilers and the trash burner were considerably extended. Ganhou também em jardins, que deram um ar aprazível ao local. The Hospital also underwent additions: its new " $\mathrm{H}$ " plant increased the number of wings and, consequently, of beds and services. Lastly, the Mangueira project is very close to the one that was performed in the Gaffrée \& Guinle Hospital, of authorship of the same architect. The Hospital would be provided with a large ambulatory and infirmaries for internment and applying the existing therapies. It would accept a paying public and the needy.

In spite of the great expectation for the inauguration of the Hospital, the training of personnel in Paris, the works of the Hospital dragged on until 1935; Guilherme Guinle notifies Salles Guerra that he will no longer finance the project.

The lack of a clear policy on the part of the DNSP for fighting cancer in Rio de Janeiro and, above all, the absence of a group of cancerologists in the city prevented a greater development of this project. It must be considered that the same group that fought for the creation of the Cancer Hospital and Institute was considerably involved in the application of the anti-venereal legislation in all its multiple facets, whether in anti-venereal education and advertising, in the opening 


\section{FIRST REPUBLIC}

of ambulatories, in the signing of covenants with the states, or even in the mounting of its medical-relief complex of the Gaffrée \& Guinle Foundation - with its Hospital, its Research Institute and its ambulatories. It is worthwhile to stress, however, the efforts of the Brazilian doctors in the sense of opening hospitals intended for treating this disease, which shows an affinity on their part with the matters discussed in an international scope, despite the inexistence of formally institutionalized cancerologists.

On June $28^{\text {th }}, 1936$, the General Meeting of the Oswaldo Cruz Foundation decided for its extinction, seen that without the aid of Guilherme Guinle and with no support from the Federal Government, the conclusion of the works became unfeasible. Soon after, the hospital's building was donated to the City Hall of the Federal District, in the administration of Henrique Dodsworth (1937-1945), who installed the Barata Ribeiro Municipal Hospital therein.

In the early 1940's, works were commenced on the face of Rua Visconde de Niterói - where the building of the Cancer Hospital would be located - for the construction of an Orthopedics Pavilion, which would be hospital's reference. The new facilities are inaugurated on January $28^{\text {th }}, 1948$, which first director is Luthero Vargas who performs, on this same day, the first orthopedic surgery in the new facilities. Two institutions facilities began to coexist on the grounds of the old Cancer Hospital, the Barata Ribeiro Orthopedics Pavilion and the Oswaldo Cruz Medical-Pedagogical Center which interned children that came from the public and private teaching network who needed orthopedic surgeries.

On 1946, the cornerstone of the Oswaldo Cruz Medical-Pedagogical Center was launched, following the precepts defended by Professor Oscar Clark of the College of Medicine. According to him, the new school of Medicine would be founded in the maternity wards, in the nurseries, the primary schools, the kindergartens and the Schools-hospitals considered by him as efficient instruments in fighting child mortality, thus exerting what the author considers as a humanitarian function, in addition of ensuring the nation's future, by means of a healthy race. The pedagogy of these schools is based on philosophy and psychology, reaching the children's mind and body. Its object is achieved by means of classes of physical education, intellectual instruction and moral education. The target public of these institutions is children who are at a risk, notably, the malnutrition and tuberculosis. For in addition to the Oswaldo Cruz Medical Center, there were the Oscar Clark School Hospital, at Maracanã (today the Oscar Clark Municipal Institution of Physical Medicine and Rehabilitation) and the José de Mendonça School Hospital, at Araruama (RJ) - both originally maintained by the method's defender and discloser himself.

In 1960, with the transfer of the federal capital to Brasilia, the state of Guanabara is created, which comprised the entire municipality of Rio de Janeiro. At this time, the hospitals belonging to the City Hall of the Federal District were transferred to the state jurisdiction. Fifteen years later , in 1975, with the merger of the states of Guanabara and Rio de Janeiro, some of these hospitals returned to the condition of municipal hospitals - among these, the Barata Ribeiro Municipal Hospital; while others remained as state hospitals.

During the government of Negrão de Lima (1965-1971) the Service of Plastic and Reparatory Surgery was installed on the Hospital.

Currently, the Hospital is intended for teenagers and adults bearers of special needs. To that purpose, it maintains the services of Orthopedics, Traumatology, Reparatory Plastic Surgery and Dental, both for ambulatory and surgery, and auxiliary services of Laboratory, X-Ray, Physical Medicine, Pharmacy, Transfusional Unit, Occupational Therapy, Social Assistance, Mental Health, Medical Clinic, Nutrition and Physiotherapy.

\section{Architectural Description:}

In the project, the architect Porto d'Ave followed a hygienist model, improving the option for larger wings in the second project, developed for the grounds of Mangueira. In the adopted architectural style, a traditional language stood out, close to the neoclassicism. 


\section{FIRST REPUBLIC}

\section{Register of Preservation:}

It is not listed.

\section{Sources:}

ASSISTÊNCIA Pública - Guanabara: 80 anos de história. Rio de Janeiro: Superintendência de Serviços Médicos (SUSEME); 1972. mimeo.

CLARK, O. As políticas dos campos de saúde (escolas-hospitais silvestres). Rio de Janeiro: Gráfico Canton \& Raile; 1936.

SANGLARD, G. \& COSTA, R. Porto d'Ave - projetos para a saúde, 1920-1940 (catálogo da exposição). Rio de Janeiro: Casa de Oswaldo Cruz/FIOCRUZ; 2007.

SANGLARD, G. Entre os salões e o laboratório: filantropia, mecenato e práticas científicas no Rio de Janeiro - 1920-1940. Rio de Janeiro: Casa de Oswaldo Cruz/Fiocruz; 2005 (Tese de doutorado).

Credits: Gisele Sanglard (research, text and architectural description) 


\section{FIRST REPUBLIC}

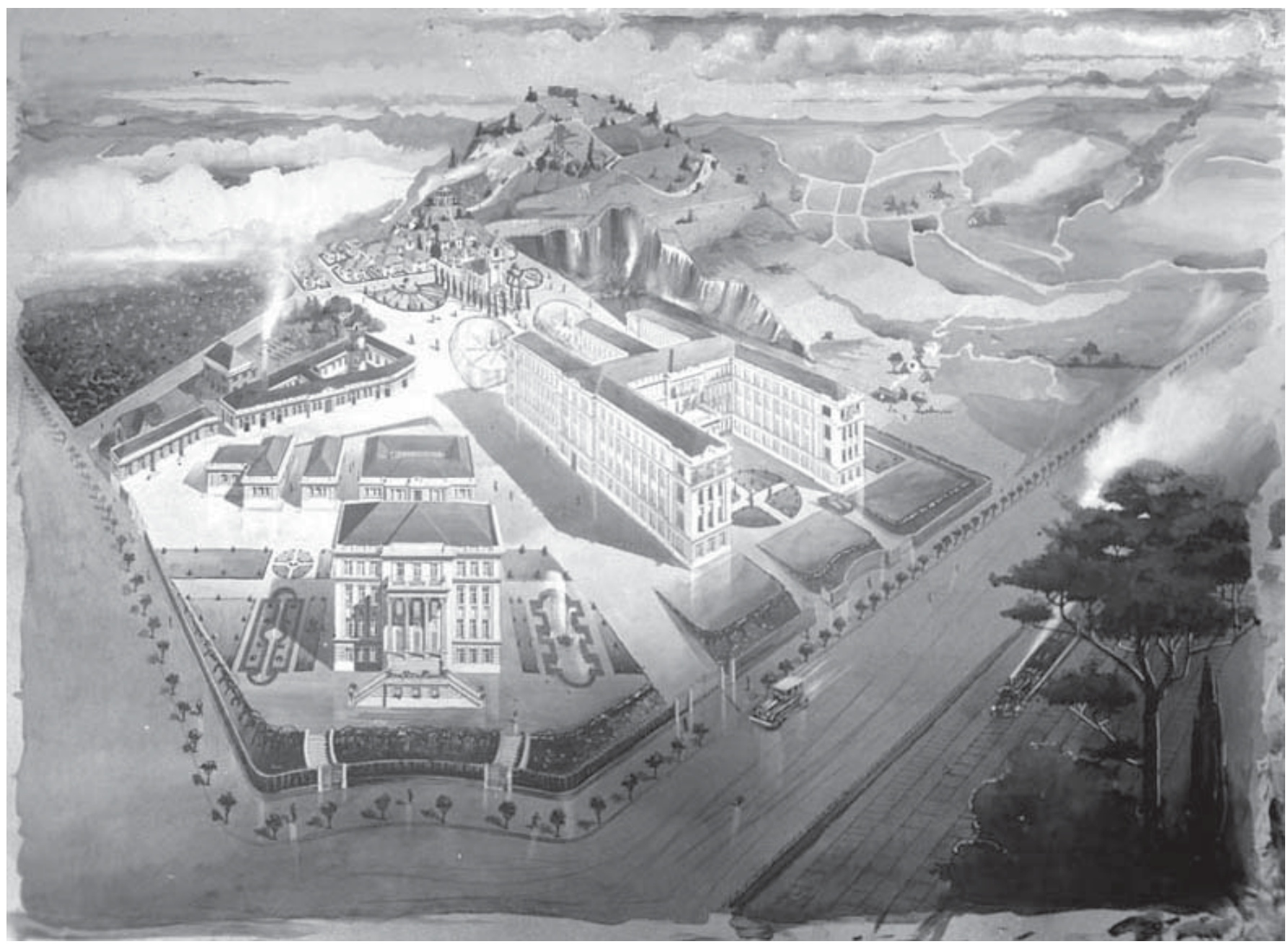

Hospital and Institute of Cancer, Mangueira, [1927]. Porto d'Ave Fund, Casa de Oswaldo Cruz Archives 


\section{FIRST REPUBLIC}

\section{Botafogo Polyclinic}

Location: Botafogo

Address: Avenida Pasteur no. 72

Category: Institution of assistance care

Period of construction: 1922

Proprietor: Botafogo Polyclinic

Author / Constructor: unknown

\section{History:}

The pioneering visionary of the Polyclinic of Botafogo was Doctor Luiz Pedro Barbosa who, in 1898, assembled a group of doctors around the common theme of establishing an institution which would operate as an area of clinical practice for students in their last semesters of medical school and also as an area of development for courses of open instruction under the discretion of those professionals. Among the ones involved in the project were: Alfredo Porto, Oswaldo Cruz, Aureliano Werneck Machado, Francisco Cláudio de Sá Ferreira, Carlos Fernandes Eiras, Candido de Andrade, Francisco Eiras, José Parga Nina, Oscar Frederico de Souza, Henrique Guedes de Mello, Francisco Furquim Werneck de Almeida and Lucas Antônio de Oliveira Catta Preta.

Depending solely upon the support of such doctors, the Polyclinic of Botafogo began operating on June $10^{\text {th }}, 1900$, at 45 Rua Bambina, Rio de Janeiro, location of the Society for the Propagation of the Instruction of the Working Classes of the Community of Lagoa, which ceded a pavement to it. In this location, gratuitous consultations were performed to the poverty-stricken population of the district of Botafogo and surrounding areas.

Established as a non profitable organization, its operations were guaranteed by means of the revenue acquired through the donations of guardian associate members, the majority of which were residents of the district of Botafogo. Selectively, separated from this group were the benefactor associate members - in other words, those who contributed the most to the development of the entity, among them: Lucas Antônio de Oliveira Catta Preta, Eugenio José de Almeida e Silva, Eduardo Palassin Guinle, Cândido Gaffrée, Antonio Azeredo and John Gregory.

In a partnership with City Hall of the Federal District, in 1901, the Polyclinic ceded a section of its accommodations for the implantation of a municipal clinic for the vaccination against pests, which became an important experimental field for the sanitation doctor Oswaldo Cruz, who developed initial research on yellow fever there.

Operations procedures of the Polyclinic of Botafogo were performed in the facilities of the Pavilion "Cândido de Andrade", which required great construction works for its organization, in order to allow the execution of surgeries until then redirected to other hospital establishments. Under such reforms, various sectors were created and others redistributed, which resulted in a significant increase in the volume of services rendered, thus revealing the physical incapacity to allocate so many services. On account of such fact, in 1922, it was decided to begin construction work on its own headquarters in adjacent properties located at Avenida Pasteur no. 72, inaugurated on April $12^{\text {th }}$, 1928. Proportionally related to the size of the new building, many services were implemented, such as maternity, radiology, clinical pathology, neurology and psychiatry, medical clinic and general surgery.

The imminent participation of Brazil in the First World War (1914-1918) instigated discussions related the creation of a nurses training course with the mission to prepare a qualified professional body able to render assistance to the sick under adverse situations. In fact, such a course was implanted in 1917, and the first class was composed entirely of women, many of which were already working as nurses of the very same Polyclinic. In the following year, with the end of the war, the course content was restructured, contemplating themes about home economics, clinical aspects and hospital administration.

Although it was a private, philanthropic institution, the Polyclinic of Botafogo always worked side by side with public health establishments. Still in 1917, in function of the Spanish flu outbreak, it forged an agreement with the Brazilian 


\section{FIRST REPUBLIC}

League against Tuberculosis aiming to guarantee treatment for the residents of the district by the institution. In 1920, as a result of the dimensions which the epidemic achieved, management decided to create a Tuberculosis Service, in addition to ceding accommodations of its headquarters for the implantation of an emergency mobile unit of Public Assistance, in order to render assistance care to the ones affected by the flu. In June of the following year, as by-product of an alliance with the National Department of Public Health, a Prophylactic Polyclinic against Leper and Venereal Diseases was organized.

Since its inauguration, the Polyclinic of Botafogo has been aligned to the diffusion of the well-child care ideals, whose diffusion was in climax at the time. It is not surprising that the institution functioned as catalyst for distinguished names of such specialty around the professional recognition of Luiz Pedro Barbosa, who, since 1908, administered courses of pediatric medical clinic and infantile hygiene. In 1910, the Service of Childhood Diseases was established at the entity, where such doctors as Azarias de Andrade Carvalho, Luiz Torres Barbosa, Jacob Renato Woiski, Álvaro Aguiar and Rinaldo de Lamare had a practice and became renowned professionals in the field of pediatrics. It was exactly in this service that the cathedra of pediatrics of the College of Medicine of Rio de Janeiro had functioned, bond maintained until 1940, year when it exited the premises of the Polyclinic.

As a beneficent, non profitable organization, it currently possesses many clinical, surgical and auxiliary diagnostic services, encompassing various specialties, among which are: rheumatology, trauma-orthopedics, physiotherapy and neurosurgery. Its departments function under administrative autonomy, with the goal of making the rendering of services more efficient. According to data of the Ministry of Health, it does not possess educational activities and its management is under municipal administration.

\section{Architectonic Description:}

Exemplary of the proto-modern, fairly uncharacteristic (additions in volume and form). The edification, of austere architecture, occupies the extremity of the block on the edge of the rocky wall of the imposing Morro do Pasmado. It is an edifice of discrete decoration, with the predominance of striking vertical, rhythmic and protruding lines on the structure of the façade. The edification has a crowning (horizontal outlines) partially covered by posterior annexes. Contrasts with the adjacent space which is inserted, surrounded by glazed towers of great height which conceal the view of the hillside.

\section{Register of Preservation:}

It is not listed.

\section{Sources:}

1922.

. Rio de Janeiro: Prefeitura do Distrito Federal,

CURSO de Enfermeiras da Policlínica de Botafogo.

, Rio de Janeiro, ano IX, 1919. pp. 683-684.

POLICLÍNICA de Botafogo. Nossa História. Capturado em 13 de dez. 2006. Online. Disponível na Internet: http:// www.policlinicadebotafogo.com.br/historia.html

POLICLÍNICA de Botafogo. ， Rio de Janeiro, 1901. p. 727.

POLICLÍNICA de Botafogo - lançamento da pedra fundamental do novo edifício.

, Rio de Janeiro, 15 de julho de 1922, p. 5.

POLICLÍNICA DE BOTAFOGO. www.policlinicadebotafogo.com.br/historia.html

Capturado em 21 de out. 2007. Online. Disponível na Internet: http://

Credits: Atiele Lopes (research and text); Inês el Jaick Andrade (architectonic description). 


\section{FIRST REPUBLIC}

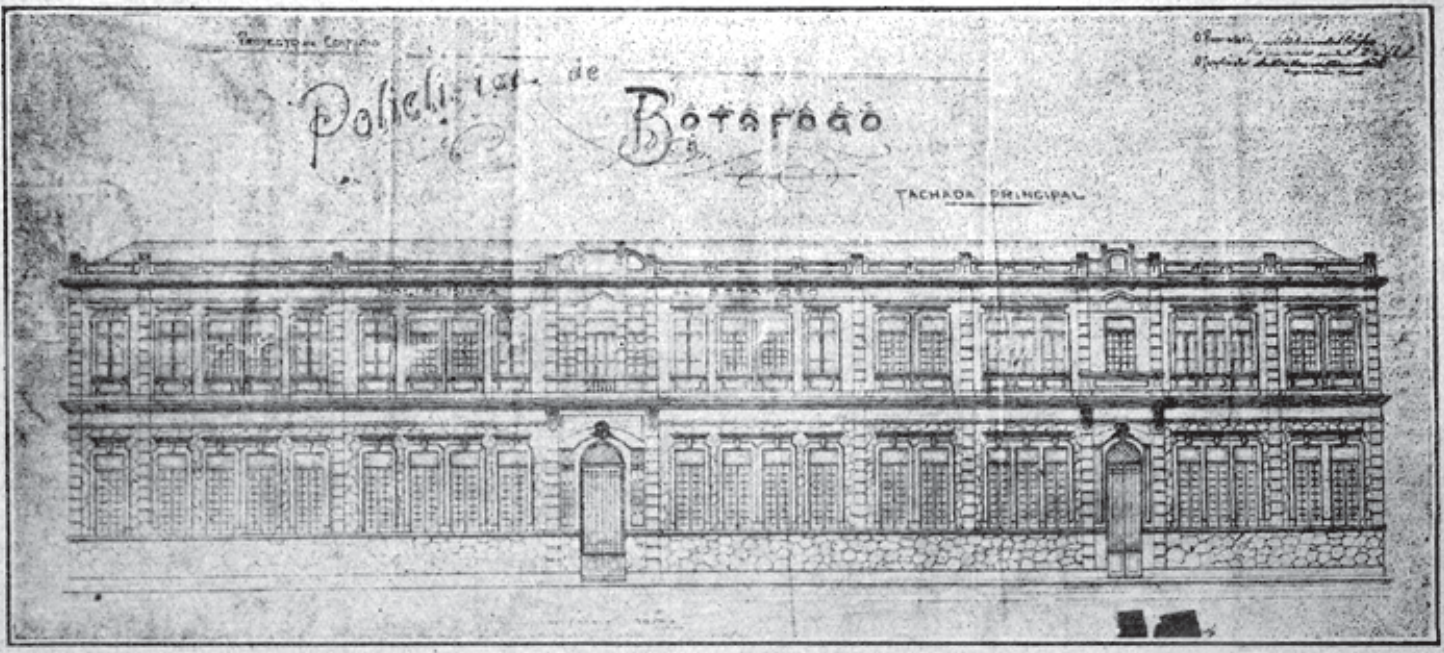

POLICLINICA DE BOTAFOGO - Novo edificio em construcçäo (Fachada)

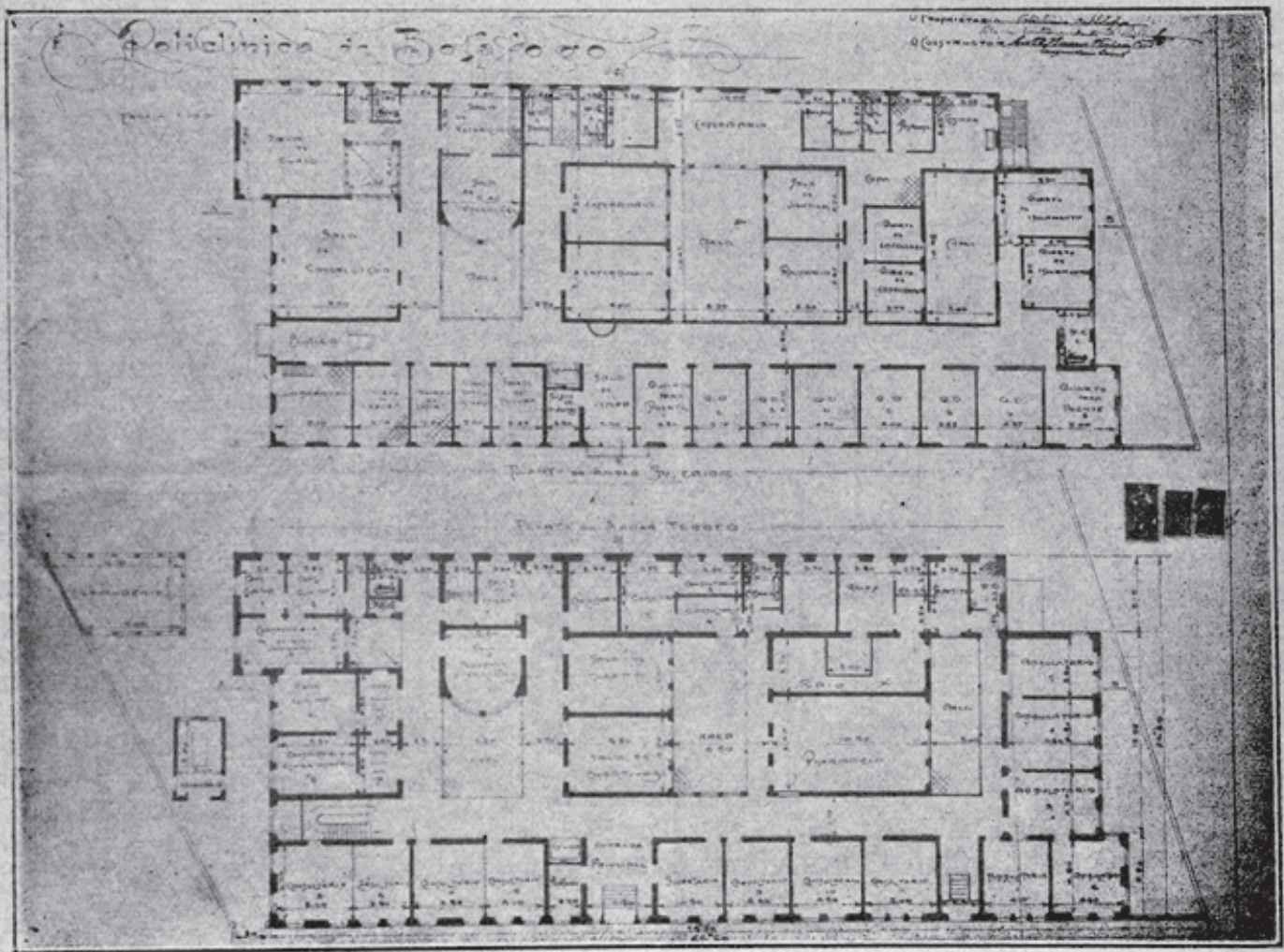

POLICLINICA DE BOTAFOGO - Novo edificio em construção (Planta baixa)

Plan of Botafogo Policlinic, [s.d.]. Fuente: ASSISTÊNCIA 1922 


\section{FIRST REPUBLIC}

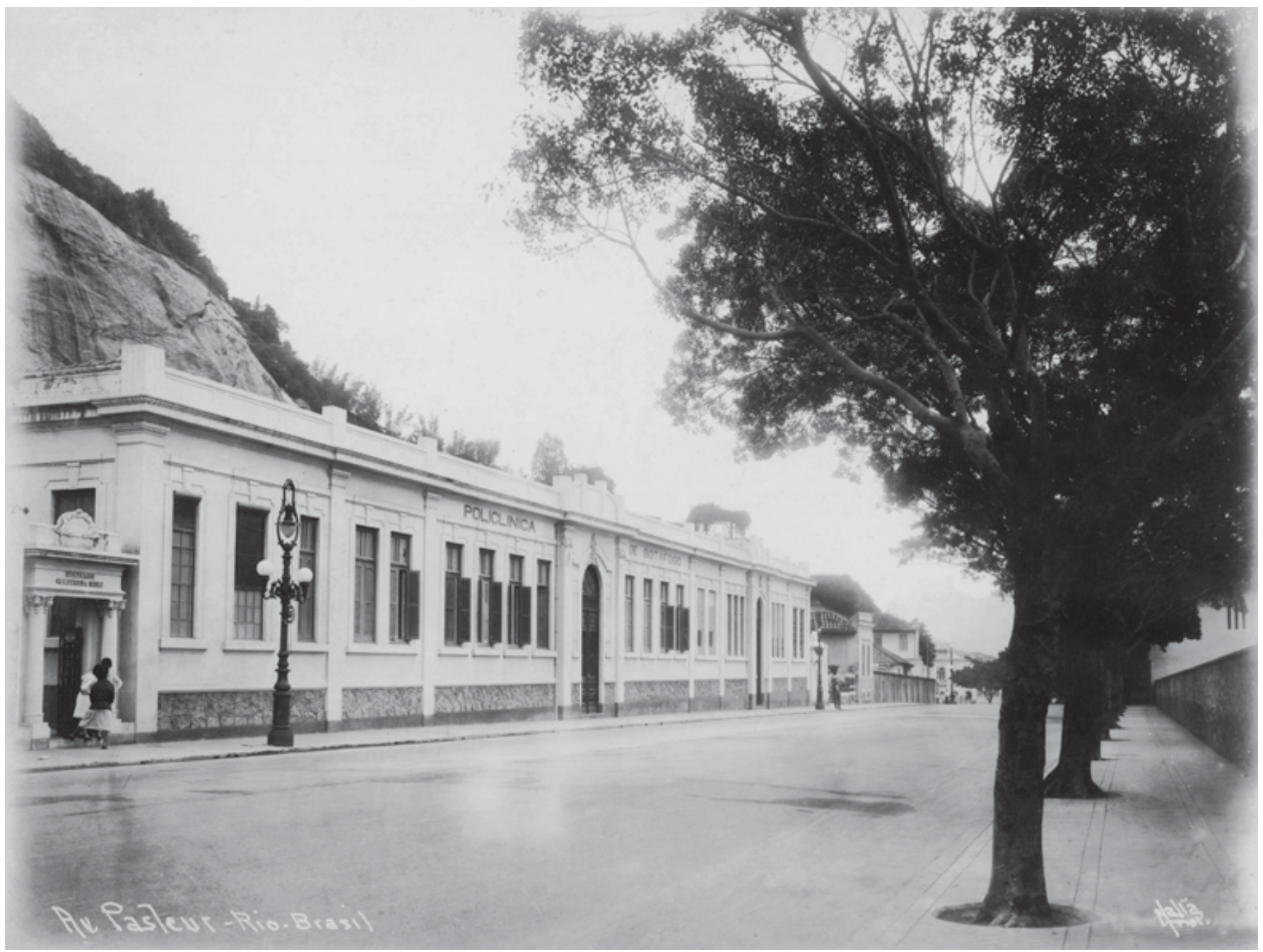

Botafogo Policlinic, [1922]. Augusto Malta Photo. Museu da Imagem e do Som - RJ Archives 


\section{Casa de Portugal Hospital and Maternity}

Location: Rio Comprido.

Address: Rua do Bispo, no. 72.

Category: Hospital and maternity.

Period of construction: 1951.

Proprietor: Rede Filantrópica e Beneficente Casa de Portugal

Author / Constructor: unknown

\section{History:}

The Commendator José Gomes Lopes Hospital is a part of the philanthropic and beneficent network of Casa de Portugal. This cultural, philanthropic and beneficent society was founded in 1928 with the mission to offer an assistance and support network to the Portuguese colony situated in Rio de Janeiro.

The Casa de Portugal project was conceived with the objective to integrate diverse Portuguese associations present in Rio de Janeiro. However, such endeavor was not successfully implemented, since the referred to centers did not reach an agreement, becoming bogged down in regional interests and legal disputes. On September $10^{\text {th }}, 1928$ the Centers Beirão, Douro, Algarve, Alentejo and Extremadura were incorporated, leaving out the Centers Minho and Transmontano.

In 1928, a medical center was created under the direction of Doctor Ernesto de Souza who was also a part of the management of Casa de Portugal. The medical center tended to various specializations, such as skin diseases and syphilis; throat, nose and ear diseases; eye disease; urinary and respiratory tract diseases; general surgery; and diseases of mistresses. In the same period the library was created. This center can be considered the embryo of the hospital that would be constructed decades later.

In 1930, the project for the construction of the Hospital began to circulate in the sessions of the Board of Directors. In 1934, fund-raising campaigns destined for the construction of the Hospital began.

In 1936, Casa de Portugal acquired the real estate at Rua do Bispo, no. 72 and transferred its headquarters to the newlyacquired manor that had belonged to the family of Caio Tavares.

As of 1943 the movement for the construction of the hospital began, among its collaborators participated the Commendator José Gomes Lopes, financier of a significant part of the project. Gomes Lopes had been a member of the Portuguese Beneficence and, after leaving the institution, turned his attention and resources to the projects developed at Casa de Portugal, among these was the founding of the hospital that would carry his name.

On June $10^{\text {th }}, 1951$ the Hospital was inaugurated. A year later, the exchange program with the IAPI (Institute of Retirement Pensions and Pensions of Industrial Workers) began. In the 50's and 60's the hospital was expanded to cater to the ever growing demand.

In the years subsequent its founding, gynecological and obstetrics care were responsible for a great percentage of the consultations performed at hospital. Currently, the maternity performs a small number of births and the hospital became a general hospital, open to the general public not just like the philanthropic formats but affiliated to the SUS (National Health Program).

\section{Architectonic description:}

The facilities that Casa de Portugal occupies since 1936 were adapted from two old, very large houses located on Rua do Bispo, dating presumably from the 1910's. The adaptation is inspired in the tradition of Lusitanian architecture, expressed in the panels and tile friezes, bringing attention to typically Portuguese drawings and colors; in the molding arrangement of the elements on the façade, specially the ones used in the frames of the ironwork in the windows and 


\section{FIRST REPUBLIC}

doors; in the statuesque that reproduces figures of the medieval Knights Templar with the Coat of Arms of Portugal, and finally, in the very adoption of the denomination solariums for the referred to two-story houses. In the interior of the main Pavilion, the employment of wood in the staircase access to the top floor and in the tribune of the meeting hall stand out, with furniture made of jacarandá in neo-Manuelino design, theme which expresses the Portuguese National Style.

The numerous additions that were made throughout the life of the institute sought to follow this inspiration, including in the hospital constructed in 1951, however without major architectonic qualities.

\section{Register of preservation:}

It is not listed

\section{Source:}

CASA de Portugal: 40 anos de história. Rio de Janeiro: Nobre Gráfica Editora LTDA, 1968. Depoimento do Sr. Alexandre Estelito Mourão e Melo. Livro de Atas da Casa de Portugal.

Credits: Maria Renilda Nery Barreto (research and text); Renato da Gama-Rosa Costa (architectonic description). 
FIRST REPUBLIC

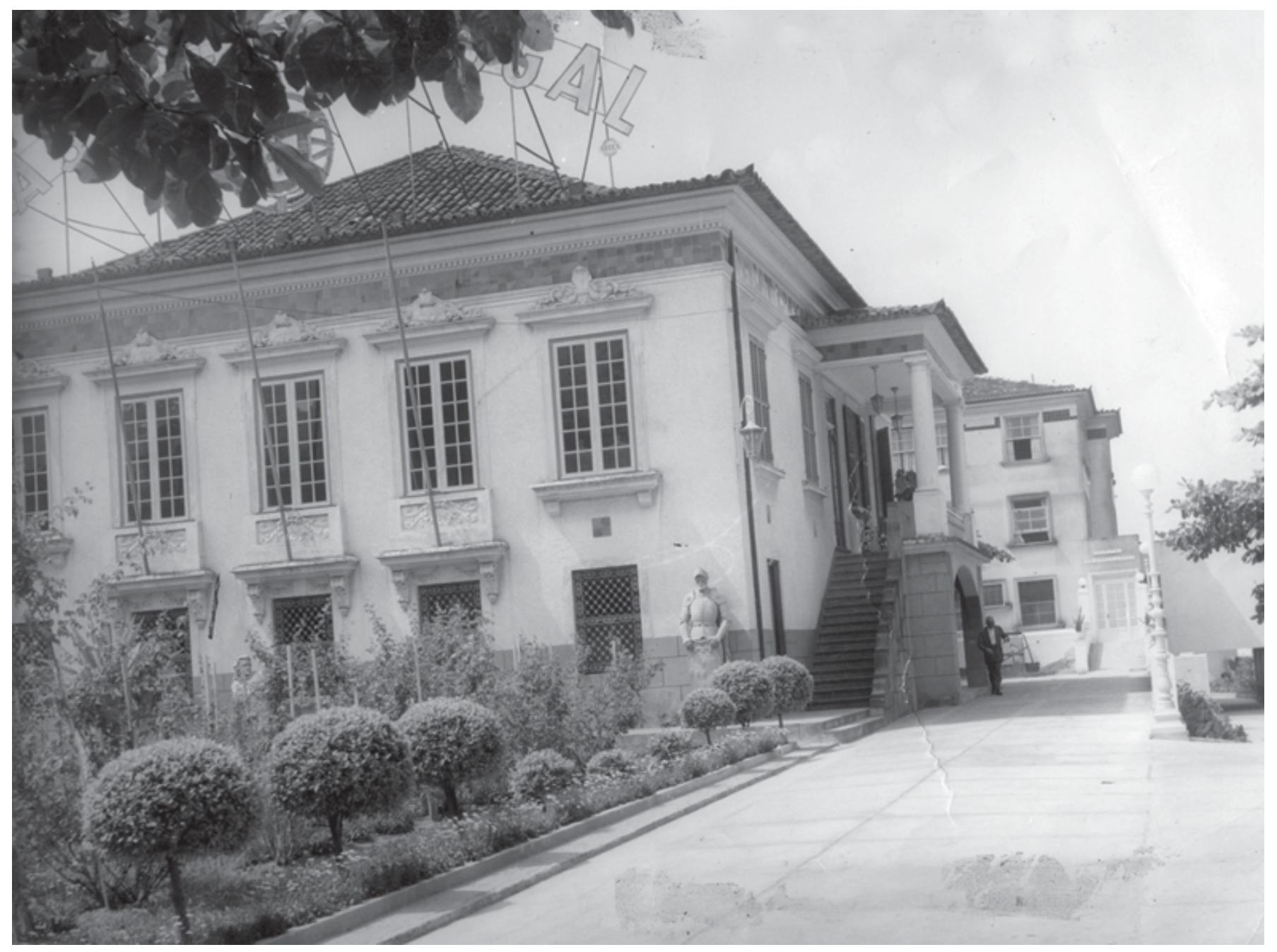

Casa de Portugal Hospital and Maternity, [s.d.]. Private archives 


\section{FIRST REPUBLIC}

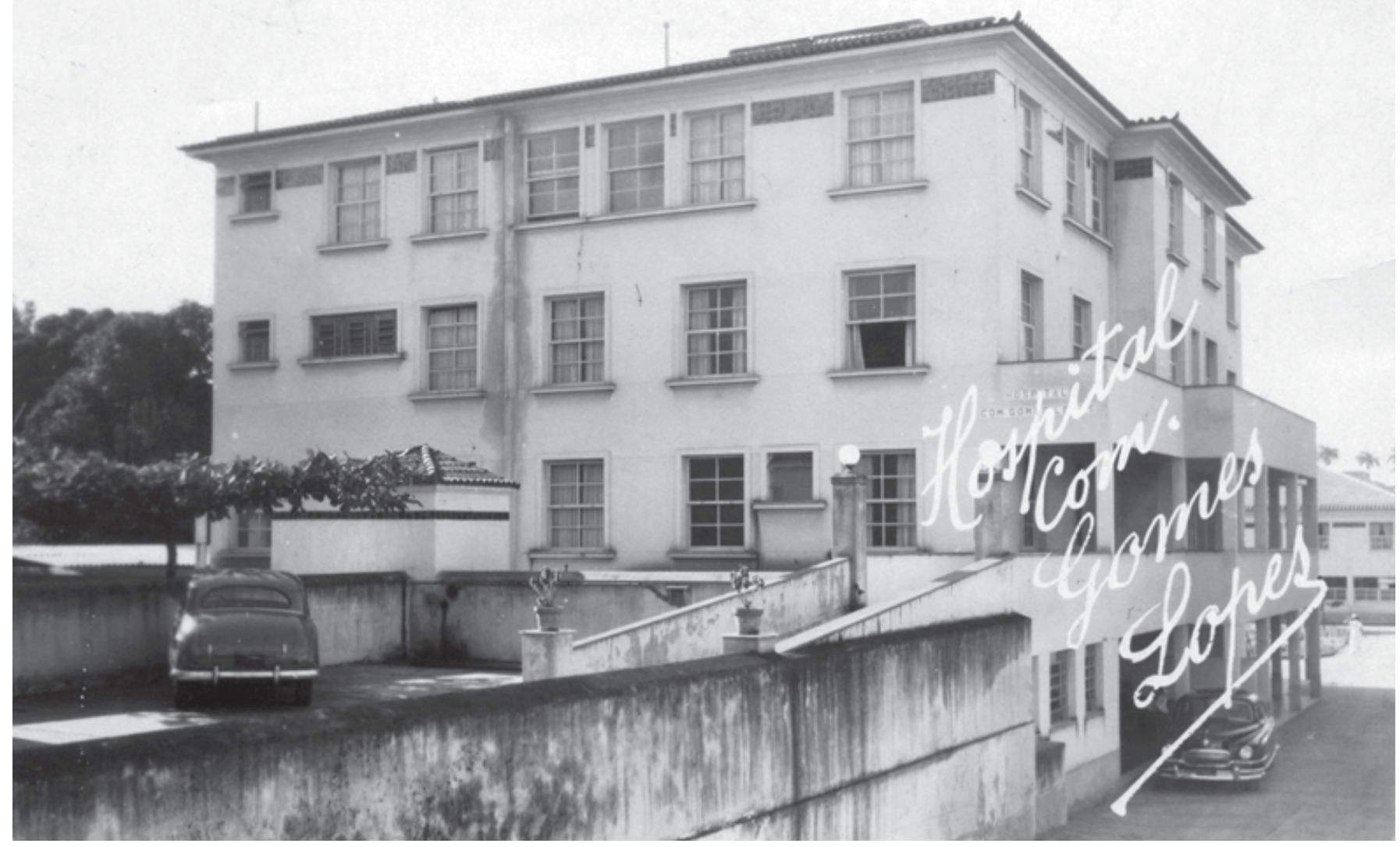

Casa de Portugal Hospital and Maternity - Comemdador Gomes Lopes Hospital, [s.d.]. Private Archives

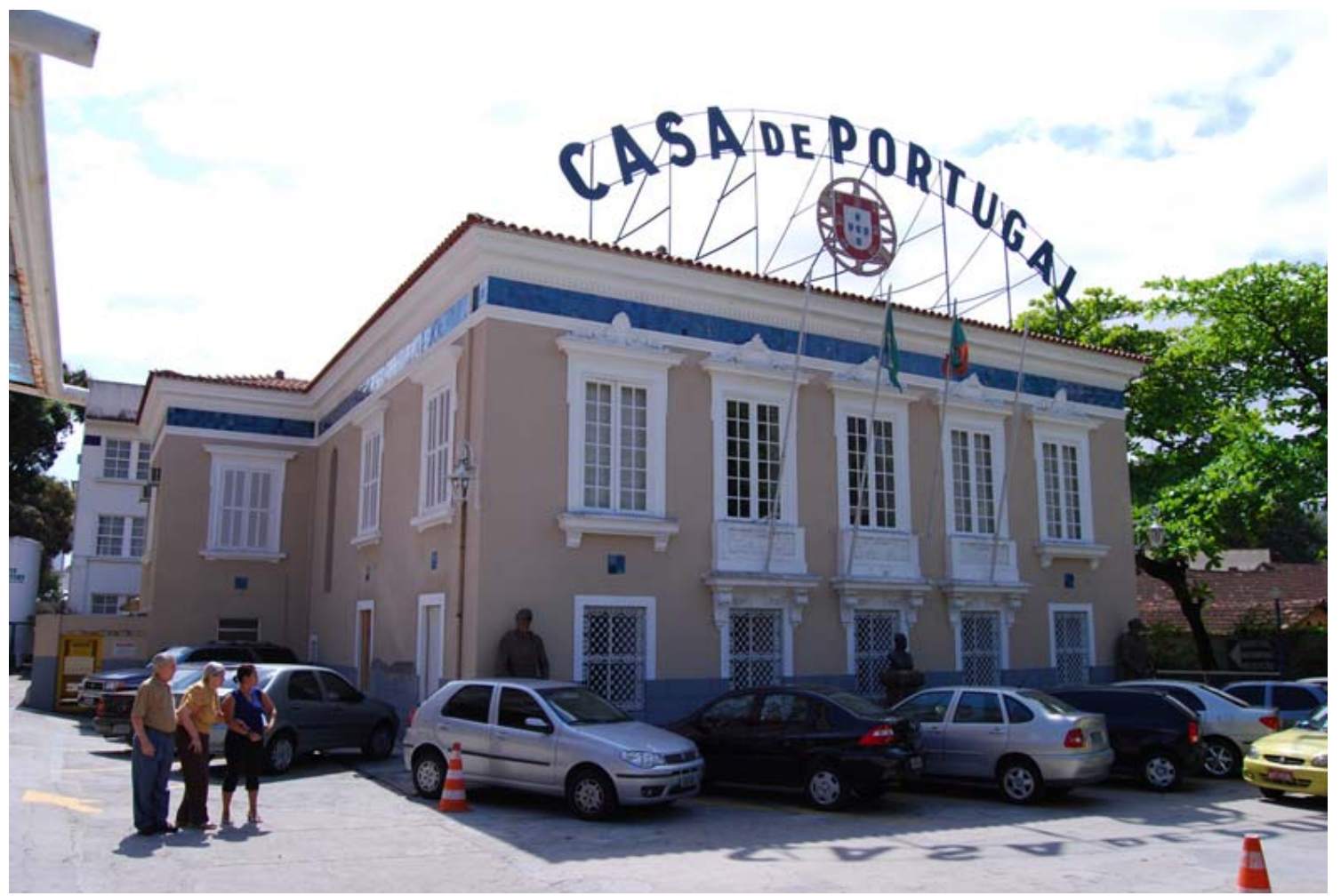

Casa de Portugal

Hospital and

Maternity. Photo

Roberto Jesus Oscar \&

Vinícius Pequeno de

Souza, 2008. Casa de

Oswaldo Cruz Archives 
FIRST REPUBLIC 


\section{FIRST REPUBLIC}

\section{Oswaldo Cruz Foundation}

\section{Evandro Chagas Hospital}

Other denominations: Pavilion Hospital for Human Diseases / Manguinhos Hospital (1912-1918); Oswaldo Cruz Hospital (1918-1941); Evandro Chagas Hospital (1941-1959); Gaspar Vianna Pavilion (1959-1978); Evandro Chagas Hospital (1978-1999); Evandro Chagas Hospital Research Center (1999-2002); Evandro Chagas Institute of Clinical Research (2002present day).

Location: Manguinhos.

Address: Av. Brasil, 4365.

Category: Institute of clinical research.

Period of construction: 1912-1918.

Proprietor: Federal Government.

Author / Constructor: Luiz Moraes Jr.

\section{History:}

The Oswaldo Cruz Foundation originated from the Federal Serum Therapy Institute, created in 1900 by the Baron of Pedro Affonso with the task of manufacturing serums and vaccines to combat epidemics which threatened the Federal Capital, at the beginning of the $\mathrm{XX}^{\text {th }}$ century - especially bubonic plague and yellow fever. During an outbreak of the plague, the institute had to be installed in the old Manguinhos Farm, belonging in the distant past to the Jesuits, on the shores of Baía de Guanabara (Guanabara Bay), between Ponta do Caju (Caju Point) and Cais de Inhaúma (Inhaúma Pier). In 1892, the farm was expropriated for the installation of garbage crematory ovens. Medical-sanitary needs adapted it then to its new functions.

As from 1903, under the direction of Oswaldo Cruz, the institute was transformed into a clinical research institution. The sanitary engineer, through the research carried out by the Experimental Pathology Institute, was able to develop the base of action of the health authorities in the control of the great epidemics of the beginning of the $\mathrm{XX}^{\text {th }}$ century. As from 1908, he expanded the activities of the institute to become a center of production, research and biomedical teaching in the field of microbiology.

Since 1904 the construction of an isolation hospital was planned for the study of endemic/epidemic diseases, to be installed in Manguinhos, near to the facilities of the institute headed by Oswaldo Cruz. A project for this hospital was presented at the Berlin International Hygiene Exposition, in 1907. But, only between 1908 and 1909, with the discovery of the biological cycle of Chagas Disease, by Carlos Chagas, was it that the idea of the construction of the isolation hospital began to develop, this time directed toward the treatment and studies about the disease coming from the countryside, principally, from the most affected areas. The works for the construction of the hospital, initiated only in 1912, were paid for, in part, by the institute itself. This second project included the construction of six pavilions. The death of Oswaldo Cruz, in 1917, accelerated the conclusion of the works, and only one pavilion was constructed.

The hospital, however, would only fully enter service in 1921, with the name Oswaldo Cruz Hospital, functioning as a center of clinical research, and also as a medical service provider to the population in general. Besides Chagas disease, yellow fever, visceral and cutaneous leishmaniasis, Lutz disease and pemphigus foliaceus were studied.

In 1926, Evandro, the oldest son of Carlos Chagas - at this time, director of the institute (1917-1934) -, was beginning his career as an employee of the hospital for the service of Radiology and Electrocardiology. In the 1930's, Evandro Chagas would be responsible for the continuity and renewal of the studies about the research carried out by his father, in large measure, using the facilities of the hospital. In it, in 1935, Evandro would create the Study of Great Endemics Service (SEGE). In 1940, an air accident over Baía de Guanabara would claim the doctor/sanitary engineer as its victim, which lead to the hospital being baptized with his name, in his honor. 


\section{FIRST REPUBLIC}

During this period, the Oswaldo Cruz Institute would be transferred to the jurisdiction of the Ministry of Justice and Internal Affairs to the jurisdiction of the Ministry of Education and Health, lasting until 1953, when the health portfolio was separated from that of education. At this time it had eight divisions (no longer sections), including that of Endemics, which remained subordinate to the Hospital Evandro Chagas.

In the 1950's, there arose a proposal to expand the hospital facilities, which were recognized as being too small for the research activities being developed, since the 1930's. So the construction of various annexes was begun, among them being a laundry. The largest of these annexes, the Leônidas Deane Pavilion, a six floor building, with more modern facilities and more ample spaces, was initiated in 1956. With the project of Ramiro Pereira, of the Division of Works of the Ministry of Health, this new building, implanted with the intention of demolishing the original hospital, would have a temporary inauguration in 1970, with the use of only the ground floor, as part of the recuperation plan of the old Oswaldo Cruz Institute. This annex would undergo various works of adaptation, being delivered as complete only in the year 2000, but without ever serving the original proposal.

In the year 1999, re-organized as from a multi-professional clinical research project, the old hospital became a TechnicalScientific Unit of FIOCRUZ, with the denomination Evandro Chagas Hospital Research Center. In 2002, it was constituted as Evandro Chagas Cinical Research Institute - IPEC/FIOCRUZ, whose mission is to study infectious diseases by means of research and inter-professional teaching projects, integrated with programs of attendance, directed toward the recovery, promotion and protection of health and prevention of injury.

\section{Architectural description:}

To develop the project and the construction of the historic architectural group of Manguinhos, Oswaldo Cruz invited the Portuguese architect Luiz Moraes Jr., who had recently arrived in Brazil, summoned to work on the reform of the Penha Church. The pavilions designed by the engineer-architect, which substituted the old facilities of the Serum Therapy Institute created by the Baron of Pedro Affonso, are included in the language of architectural eclecticism, where two or more tendencies of style and decoration are mixed.

The Evandro Chagas Hospital is a construction of one floor with a usable basement, whose spacial organization distributes, at the center, the areas of basic services and, at the extremities, the areas of support, such as the kitchen, laundry, etc. Interconnecting these areas, the rooms of the wards are located. Externally, the building got a sober, symmetrical solution, where the ornamental elements are restricted to the varandas that surround the wards, providing a good ventilation of the internal environments. The functioning of the Evandro Chagas Hospital lead to the construction of small support buildings, that already appeared around about it at the end of the decade of 1910, and that were later used as a canteen, a residence, outpatients, a biotherium and a deposit.

\section{Register of Preservation:}

January of 1981. Process no. 1.037-T of the National Institute of Historical and Artistic Heritage (IPHAN).

\section{Sources:}

BENCHIMOL, J. (Coord.). Manguinhos do sonho à vida. A ciência na Belle Époque. Rio de Janeiro: Casa de Oswaldo Cruz; 1990.

GUIA Casa de Oswaldo Cruz. Departamento de Arquivo e Documentação. Rio de Janeiro: COC/FIOCRUZ; 1995.

GUIMARÃES, M; PAULA, R. Hospital de Manguinhos: 1904-1940. Rio de Janeiro: FIOCRUZ, IPEC, 2004.

http://www.ipec.fiocruz.br/ipec/hist_ipec.html, acessado em 21 de setembro de 2007.

OLIVEIRA, B.; COSTA, R.; PESSOA, A. Um Lugar para a Ciência: a formação do campus de Manguinhos. Rio de Janeiro: Editora Fiocruz; 2003.

Credits: Renato da Gama-Rosa Costa (research, text and architectural description). 


\section{FIRST REPUBLIC}

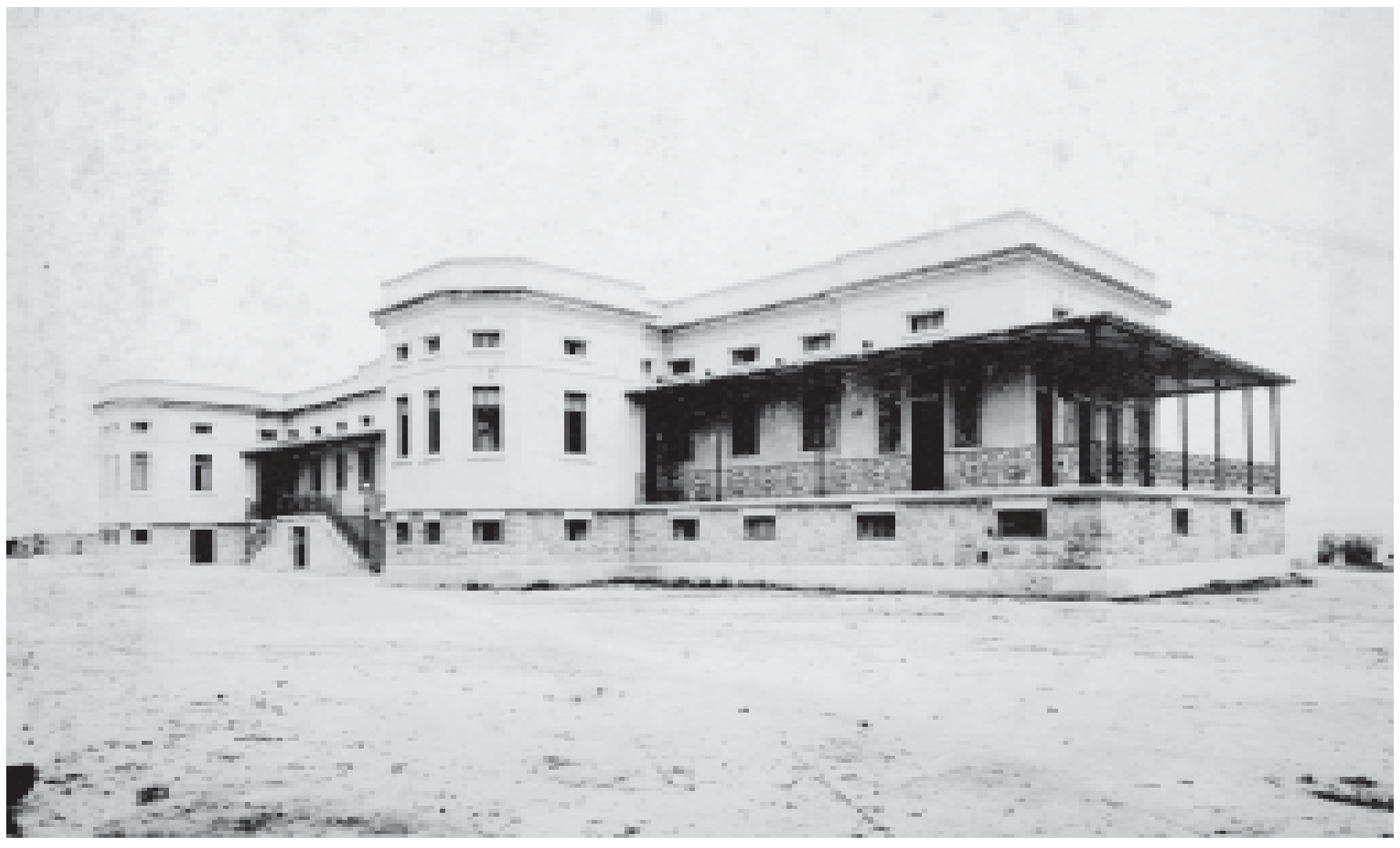

Oswaldo Cruz Hospital. [s.d.]. Casa de Oswaldo Cruz Archives 


\title{
FIRST REPUBLIC
}

\section{Evangelical Hospital of Rio de Janeiro}

\author{
Location: Tijuca
}

Address: Bom Pastor, no. 86

Category: General Hospital

Period of construction: 1896-1912

Proprietor: Foundation and Conservation Association of the Evangelical Hospital

Author / Constructor: Antônio Jannuzzi

History:

The construction of the Evangelical Hospital is related to the presence of the German colony in Rio de Janeiro. Since 1883, its members discussed the possibility to install a hospital to serve, above all, the Germans who preach the Lutheran faith. The major motivation was the religious issues, both regarding the discrimination in the infirmaries of the Santa Casa and the requirements to participate in religious services in the rooms of the Fraternity - considered unacceptable by them.

Even with the union of the Evangelical Churches, the Young Men's Christian Association and the Evangelical Hospital Association its construction was postponed because it was considered very expensive. It is only in 1887 that this wish gets closer to becoming a reality, with the initiation of meetings dedicated for this cause. On October $12^{\text {th }}, 1887$, the first bylaws "Foundation and Conservation Association of the Evangelical Hospital" were discussed and approved, with the purpose to construct, maintain and develop the Evangelical Hospital of Rio de Janeiro. In October 1891, it became known as the "Evangelical Hospital Association of Rio de Janeiro". Finally, in April 1892, it was able to acquire the property at Rua Bom Pastor no. 83, where the hospital is located today. The property has an area of $80 \mathrm{~m} 50$ in the front by $105 \mathrm{~m}$ in the back.

The cornerstone of the Hospital was laid on July $14^{\text {th }}, 1896$, with construction work starting soon after. The project and execution were the responsibility of the architect-engineer Antônio Jannuzzi, who himself was the first director of the hospital, which would be inaugurated on October $12^{\text {th }}, 1912$, after 25 years of construction. The inauguration ceremony was attended by Rodrigues Alves, who represented the Municipal Council; and by the Mayor of the Federal District, General Bento Ribeiro. At this moment, it was a hospital destined for the German colony, for people who preached evangelism and designated two hospital beds for indigents - which were permanently occupied.

At the year of its inauguration, the hospital had the capacity to accommodate 100 patients. It had two ample general infirmaries, private rooms, a maternity ward, surgical operating room, room for application of medical electricity, medical laboratory, cabinet of dental surgery, consultation rooms for associates and public, pharmaceutical laboratory, medical residence, isolation pavilion and mortuary. On December $23^{\text {rd }}, 1923$ new rooms were inaugurated. a new infirmary with the capacity for thirty beds, a maternity ward with the capacity for ten beds and a bungalow-styled residence with five rooms, three living rooms and more rooms. In 1958, it was equipped with X-Ray equipment for deep and superficial radiotherapy, diathermy of short and long waves, ultraviolet, tents and masks for oxygen- therapy, modern parturition rooms and operating rooms.

In the 70's, a three-story building was constructed in order to install a new surgical center with five rooms, infirmaries and 14 ICUs.

Currently, the hospital is expanding its facilities, with the construction of a new three-story building which will enable it to offer 100 more beds; in addition to the remodeling of the surgical center in preparation for the creation of five Day-Clinic beds. 


\section{FIRST REPUBLIC}

\section{Architectonic Description:}

The project for the Evangelical Hospital, elaborated between 1892 and 1896 by Antonio Jannuzzi, who was an architect engineer of Italian extract, and constructor and author of several buildings in Rio de Janeiro, adopts the neoclassic aesthetics, within the reinterpretation provided by the eclecticism in architecture. It is a symmetric building of elevated basement, with the main entrance highlighted by stairs and three access doors situated above by neoclassical frontage. The program is developed in a great square with an inner gardened courtyard, which used to lead to the rooms and where the chalet-typed balconies stand out with iron structure and hydraulic floor. There is a chapel separated from the main body, with gothic lines and discrete decoration.

\section{Register of Preservation:}

It is not listed.

\section{Sources:}

ASSISTÊNCIA Pública e Privada no Rio de Janeiro (Brasil) - História e Estatística. Comemoração do Centenário da Independência Nacional. Rio de Janeiro: Typographia do Annuario do Brasil; 1922.

BOLETIM da Associação do Hospital Evangélico do Rio de Janeiro, dezembro de 1958, nº 32.

HOSPITAL Evangélico Fluminense. Reprodução dos artigos publicados no Expositor, do dia 2 de Fevereiro de 1899, graciosamente oferecido por sua ilustrada Diretoria em favor das obras do mesmo Hospital. Casa Publicadora Metodista, Rio de Janeiro, 1899; RELATÓRIO da Associação do Hospital Evangélico, 1923-1925, Rio de Janeiro, Tipografia Leuzinger, 1925.

Credits: Nathalia Morais (research); Gisele Sanglard (text) and Renato da Gama-Rosa Costa (architectonic description) 


\section{FIRST REPUBLIC}

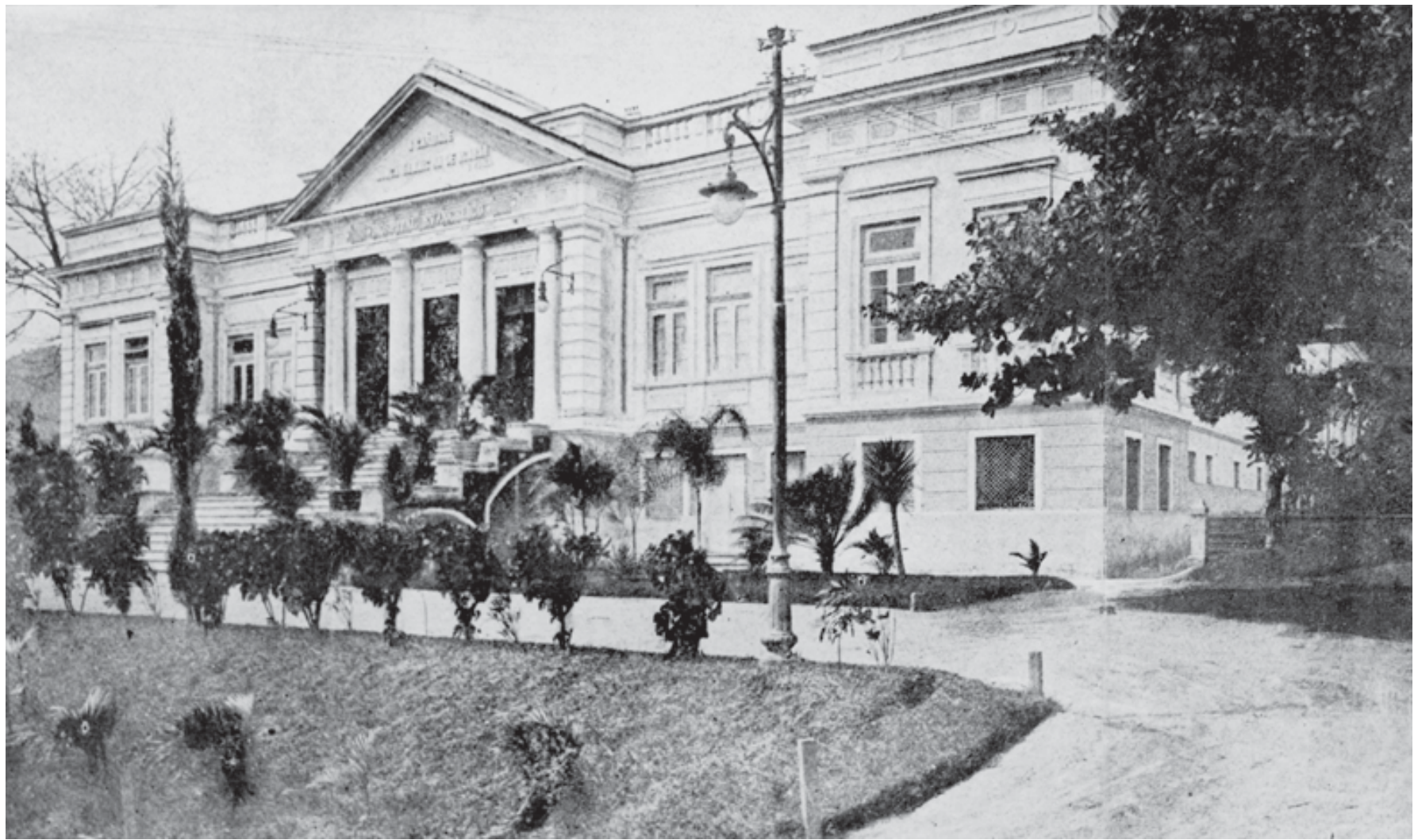

Evangelical Hospital, [s.d.]. Private Archives
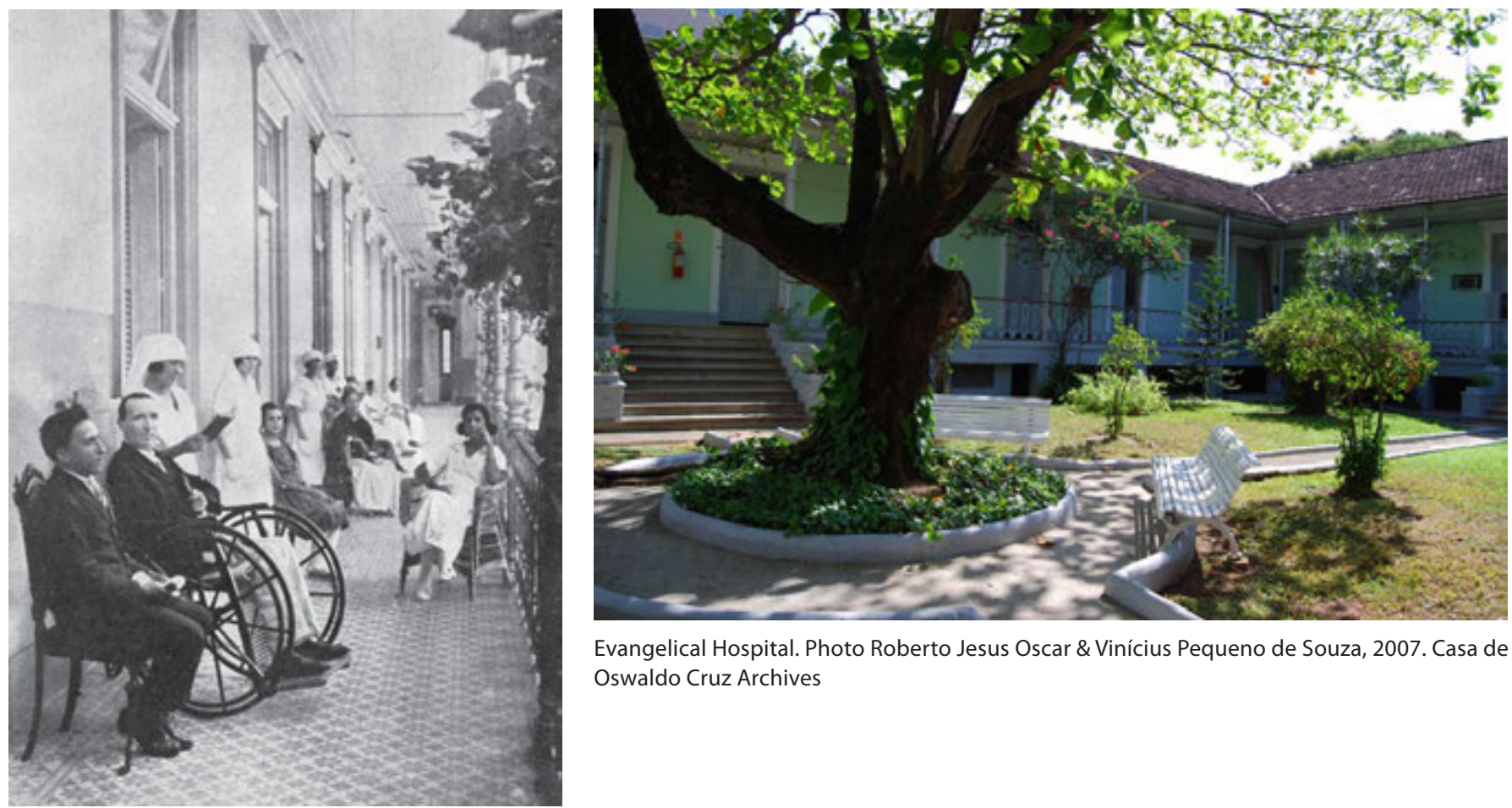

Evangelical Hospital. Photo Roberto Jesus Oscar \& Vinícius Pequeno de Souza, 2007. Casa de Oswaldo Cruz Archives

Evangelical Hospital, [s.d.]. Private Archives 


\section{FIRST REPUBLIC}

\section{Oswaldo Cruz Foundation}

\section{Fernandes Figueira Institute}

Other denominations: Arthur Bernardes Shelter Hospital (1924-1946); Fernandes Figueira Institute (1946-present day).

Location: Flamengo.

Address: Av. Rui Barbosa, no. 716.

Category: Maternal-infantile Hospital.

Period of construction: 1922, Hotel Sete Setembro; 1957, IFF main building.

Proprietor: Oswaldo Cruz Foundation / Ministry of Health

Author / constructor: Antônio Jannuzzi, Irmão \& Cia. (architect) and Eduardo V. Pederneiras (constructor) (1922); Ramiro Pereira (1957).

\section{History:}

The Fernandes Figueira Institute (IFF), currently a technical-scientific unit of Oswaldo Cruz Foundation (FIOCRUZ), was created in 1924, when the then President Arthur Bernardes (1922-1926), by means of Decree 4,793 of January $7^{\text {th }}$, 1924, authorized the utilization of the rear wing of the old Hotel Sete de Setembro, located at Av. Rui Barbosa, no. 762, in the neighborhood of Flamengo, to install a children's hospital.

The 1920's was marked by the creation of new hospitals to meet the demand of the Public Health Reform during the administration of Carlos Chagas before the National Department of Public Health (DNSP) and the creation of a hospital dedicated to children's health became a reality in a public action through the direct association of Carlos Chagas, director of DNSP at the time, and of Antonio Fernandes Figueira, Head of Superintendence of Infantile Health at the time.

Fernandes Figueira was part of the first generation of sanitarian doctors linked to the Manguinhos tradition, lead by Oswaldo Cruz, having been appointed to run the infirmary of children's infectious diseases for São Sebastião Hospital, where he introduced the practice of maintaining mothers next to hospitalized children. In 1909, he took over the administration of the Children's Polyclinic at the Santa Casa da Misericórdia of Rio de Janeiro, in São Cristóvão and it was in this space that Fernandes Figueira developed many of his premises on maternal-infantile health care and "studied", influencing a generation of pediatricians, such as for example, Ademaro de Lamare, Adamastor Barbosa, Aida de Assis, Mário Olinto, among others.

The hospital was created in 1924 and when it was administered by Fernandes Figueira, it became known as Arthur Bernardes Shelter Hospital, guided by a hygienist conception where the hospital area besides providing treatment for diseased children should also have a pedagogic role, and during the period of convalescence of children, the mothers would learn hygienic and nursing principles in order to spread it in their social environment. Thus, the hospital was not conceived to be limited to the activities of health care, but it should also become a "maternal school" to enable study, planning and execution of actions capable of promoting new habits and attitudes related to maternal-infantile health.

In 1946 there was a renovation and Arthur Bernardes Shelter Hospital had its name changed to the Fernandes Figueira Institute, to pay homage to Antônio Fernandes Figueira its idealizer and first director. It had a structure that consolidated the spirit of combining assistance, clinical service, research and instruction. The IFF was constituted of: A Children's Medicine Section (nursery, pupillary, maternal school, a shelter for mothers-to-be, a maternal shelter, cafeteria, doctor's office for infantile hygiene, gota de leite (breastfeeding), lactation center and dietetic cuisine); A Pediatrics Section (polyclinics, medical and surgical infirmaries); A Maternity Section (obstetrics infirmaries, pre-natal hygiene consultation room); Otorhinolaryngology Department, Ophthalmology, Dermato-Sifilography, Odontology, Electrodiagnostics, Physiotherapy and Radiology; a Blood Bank; Pharmacy; Social Services Agency; Administrative Offices. 


\section{FIRST REPUBLIC}

In 1970, the IFF was incorporated into the Oswaldo Cruz Foundation. Following the tradition of research associated with the practice of medicine, established by Olinto de Oliveira through the Studies Center created in 1940, the program of Medical Residence was structured in four areas: pediatrics, obstetrics and gynecology and pediatrics surgery. The Medical Residence in pediatrics was subdivided into four sub areas of concentration - neonatology, pediatric pneumology, and pediatric intensive care. Another innovation was the creation of courses for qualification in services for egress from Medical Residence through courses of post-graduation in allergy and immunology, pediatric anesthesiology, fetal pathology, clinic genetics and pediatric infectology, pediatric neurosurgery, pediatric neurology, breast pathology and cervical pathology. Another important innovation was the creation of Nursing Residence, including neonatal nursing, pediatric nursing, Human Milk Banks, and Coordination of Actions to Control Hospital Infection. Finally, in 1988, the stricto sensu Post-Graduation program was created as a Masters degree in Children's Health, indicated for doctors and pediatricians. In 1996 the doctorship course was initiated and the area encompassed was modified to Children's and Women's Health.

The IFF has been contributing to consolidate the domestic policies of Science and Technology in health and of SUS programs (Unified Health System), with concentration in the areas of clinical research, biomedicine, laboratorial services and in Social Sciences. The incorporation of the IFF into FIOCRUZ has stimulated the consolidation of its traditional role of elaborating and administrating domestic guidelines in maternal-infantile health, without however deviating from its main undertaking that was and still is health care. Currently the IFF encompasses health care for women, children and adolescents, based on the intensive use of new technologies, without however losing the dimension of subjective and social aspects of the patient.

During its history, the Fernandes Figueira Institute (IFF) became a national reference in women's and children's health care, in the qualification of health professionals and in the development of biomedical research on maternity, childhood, adolescence and correlated social problems.

\section{Architectonic Description:}

Installed in one of the wings of the old Hotel Sete de Setembro, at Avenida Rui Barbosa, the building was constructed as a health-resort hotel in 1922 to accomodate special guests for the celebrations of the Centenary of Independence.

According to Maria Helena da Fonseca Hermes, the reference for this, is in the French health-resort hotels of Côte $D^{\prime} A z u r$, specially in Cannes, presenting aspects of its ornamentation and of its repertory of elements and representations. These constructions are predominantly presented in the horizontal, facing the landscape whose ground plan distribution privileges the spaces to promote intimacy and well being of the guests, as well as the interconnection of the interior with the exterior. The highlights include miradors, terraces and balconies, loggias and porches, internal yards and open porches, giving emphasis to the social theatricalism of the game of seeing and being seen.

The division into two wings allowed it to be separated in 1924 for the installation of the Shelter Hospital, associating its privileged situation facing the Guanabara Bay with the therapeutic treatment. The frontal wing destined to reception and to the spaces of social gathering, and today belonging to the Federal University of Rio de Janeiro, has three floors with a rectangular planning solution, broken by the central body that includes one more floor. The rear wing destined to the rooms of the hotel and occupied by the Fernandes Figueira Institute, has gone through several renovations that were out of character, including an over elevation executed in the 1970's, by Carlos Nadalutti.

In 1957, a five-floor building was constructed specifically for the IFF, facing Avenida Rui Barbosa, with severe modernist traces by Ramiro Pereira, architect of the Department of Construction Works of the Ministry of Health.

\section{Register of Preservation:}

June $15^{\text {th }}, 1989$, by the State Institute of the Artistic and Cultural Endowments of Rio de Janeiro (INEPAC), case number E-03/11.357/83.. 


\section{FIRST REPUBLIC}

\section{Sources:}

CARNEIRO, G. Um compromisso com a esperança: história da Sociedade Brasileira de Pediatria (1910-2000). Rio de Janeiro: Expressão e Cultura, 2000.

Decreto 4.793 de 07 de janeiro de 1924.

HERMES, M. O antigo Hotel Balneário Sete de Setembro: Arquitetura eclética de tendência clássica. Online. Disponível na Internet: http://www.dezenovevinte.net.

O HOSPITAL, Janeiro de 1970, vol 77, $\mathrm{n}^{\circ}$ 1, p. 374-378.

OLIVEIRA, B.; COSTA, R.; PESSOA, A. Um Lugar para a Ciência: a formação do campus de Manguinhos. Rio de Janeiro: Editora Fiocruz; 2003.

REVISTA da Academia Nacional de Medicina. Jan/mar 1965, n 1, p. 47-48.

SETA, M. Instituto Fernandes Figueira: delineamento de 50 anos de história institucional. Rio de Janeiro. Rio de Janeiro: Instituto de Medicina Social, UERJ, 1997 (Dissertação de mestrado).

Credits: Maria Renilda Nery Barreto (research and text), Luiz Otávio Ferreira (text), Renato da Gama-Rosa Costa (architectonic description). 


\section{FIRST REPUBLIC}

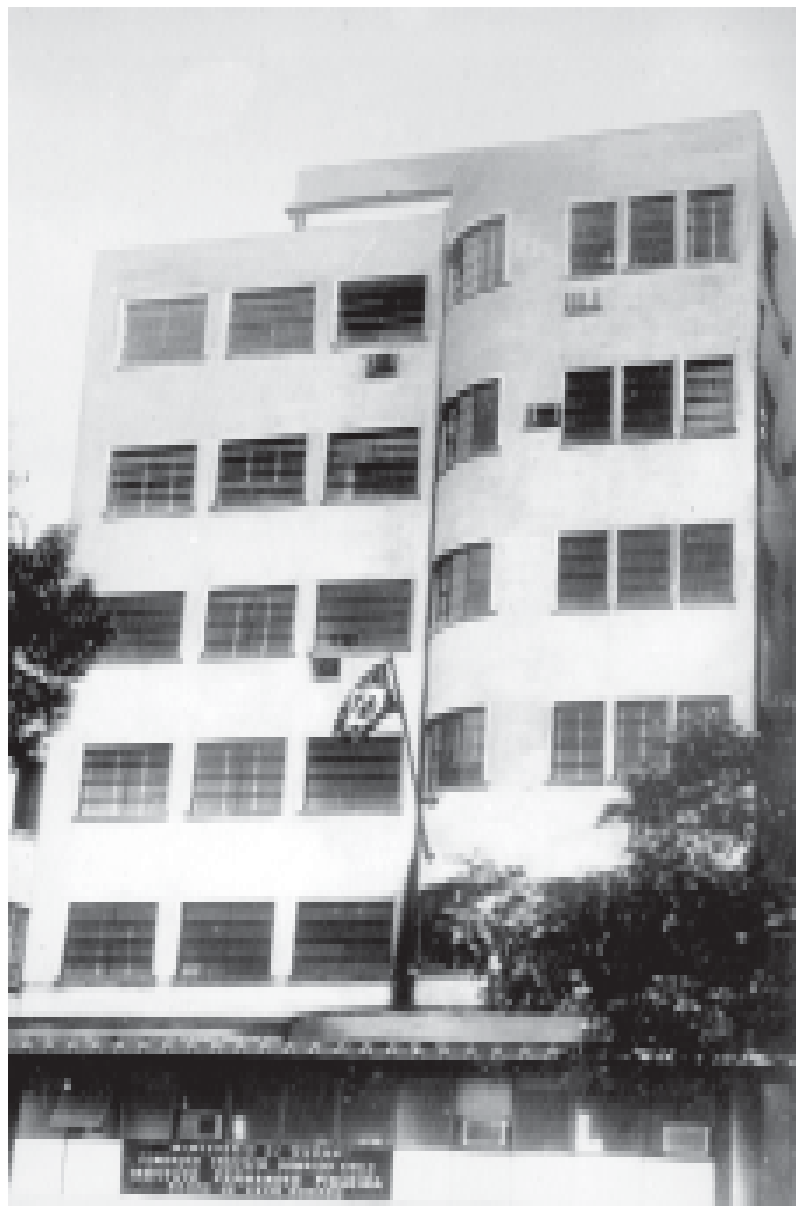

Fernandes Figueira Institute, [1970]. Casa de Oswaldo Cruz Archives

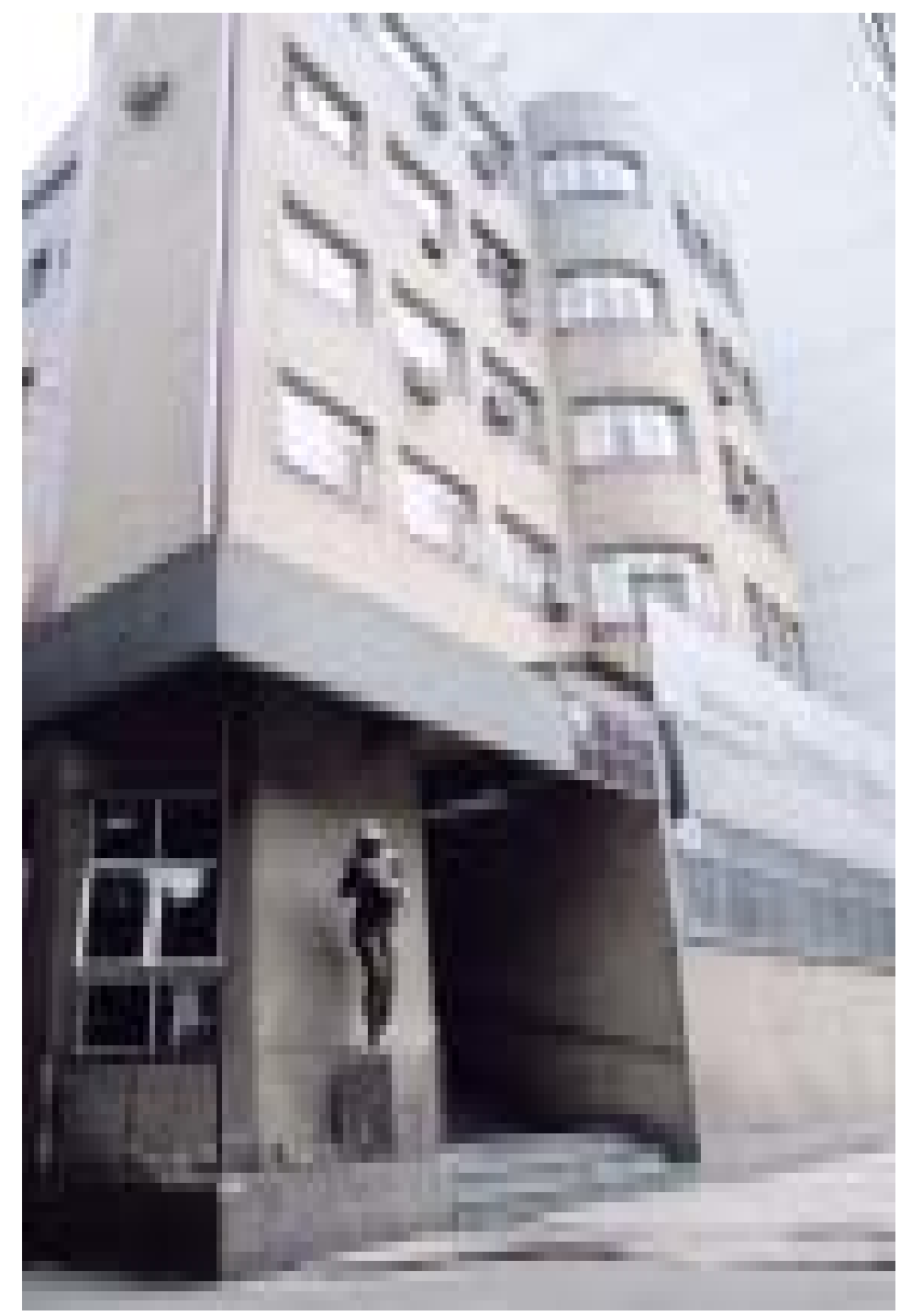

Fernandes Figueira Institute, [s.d.]. Photo Roberto Jesus Oscar \& Vinícius Pequeno de Souza. Casa de Oswaldo Cruz Archives 


\section{FIRST REPUBLIC}

\section{Oswaldo Cruz Foundation}

\section{Fiocruz's Advanced Center in Jacarepaguá}

Other Denominations: Guanabara Research Nucleus of the National Institute of Rural Endemic Diseases (INERu) (1956-1976)

Location: Jacarepaguá.

Address: Estrada da Covanca, 56

Period of construction: 1956.

Proprietor: Oswaldo Cruz Foundation (Fiocruz).

Author / Constructor: unknown.

History:

The necessity for a scientific research and investigatory agency led to the creation, in 1946, of the Malaria Institute, associated to the National Malaria Service (SNM). It was foreseen under Decree no. 21.712 dated of 08/21/1946 which approved SNM's regiment, that the Malaria Institute should be constituted as a school and specialized center of studies and research in the area of malaria, destined for the training of technicians and the improvement of work methods within a scientific basis, which could serve as reference to conduct the national experiment. The Institute was inaugurated in May, 1949 in the municipality of Duque de Caxias, Rio de Janeiro, in a place known as "Cidade das Meninas" (City of Girls) (Santos, 2003).

Toward the end of 1955, as a result of a policy of research regionalization on endemic diseases, the Institute was transferred to Belo Horizonte. Nevertheless, the choice of regionalization certainly was accompanied by other factors which determined the move.

The difficulty in the maintenance of the Malaria Institute under conditions of isolation on the base of the Baixada Fluminense mountain range associated to the dispersion of works, above all as of the moment upon which it assumed the task of endeavoring studies and investigations, the plans to fight other diseases, took part of the research team to Belo Horizonte. Once in the capital of Minas Gerais, the research group from the Institute, already under the direction of René Rachou, occupied the building formerly destined to house the future "research center" for schistosomiasis and other endemic diseases, project implemented by the Ministry of Health under the orientation of the researcher Amílcar Vianna Martins.

In the following year, the nucleus was transformed into the Research Center of Belo Horizonte, associated to the newly created National Institute of Rural Endemic Diseases (INERu), a research agency of the National Department of Rural Endemic Diseases (DNERU), created on March 6, 1956 by Act no. 2.743.

The DNERU consolidated the national services of Malaria, Pest and Yellow Fever, and instituted the National Institute of Rural Endemic Diseases (INERu) to perform studies and research on 13 endemic diseases whose combat had been attributed to the Department, mainly malaria, leishmaniasis, Chagas' disease and schistosomiasis. Mário Pinotti, its first director, utilized the experience acquired at the National Service of Malaria to structure it, unifying the dispersed efforts and transferring the activities of research and production to the new agency. It even had the participation of the Sanitary Organization Division (DOS) of the former National Department of Health (DNS), strategic area in charge of performing studies on public health problems which were not reached by specialized services (Fonseca, 2001).

The National Institute of Rural Endemic Diseases (INERu) represented an expansion in the boundary of the Malaria Institute, through the research centers located in Belo Horizonte, Salvador and Recife and still maintained, in the Federal 


\section{FIRST REPUBLIC}

District, the Central Research Nucleus, later denominated Guanabara Research Nucleus, in function of the transfer of the capital to Brasilia. In 1966, the Research Center of Belo Horizonte would become known as the René Rachou Research Center, in tribute to the sanitation doctor who ran it from 1955 to 1957. The research nucleus of Salvador and Recife, created by the governments of Bahia and Pernambuco in 1950 were later incorporated into INERu.

INERu was the research institute in charge of developing the scientific technology and methodology which would give substance to the work at DNREu, that is, it should develop applied scientific research in the control of great endemic diseases, performed by means of the department's campaigns. During the 1960s, under another political context, prisoner of the dispersion of investigative objects and of the seepage of resources, INERu institutes certain programs and work actions aiming to intensify the control and combat of rural endemic diseases, among which the following gained recognition: Pilot Plan for the Experimentation and Assessment of the Methodology in the Control of Schistosomiasis; Investigations and Studies on Chagas' disease; Research on Leishmaniasis; Pilot Project for Applied Research in the Control of Pest in Brazil.

In 1970, the Public Health Campaigns Superintendence (SUCAM) was created, as a result of the merger between DNERu and the Variola and Malaria Eradication Campaigns. In the same year, by means of Decree no. 66.624the Human Resources Foundation of Health (FRHS) was transformed into the Oswaldo Cruz Foundation (Fiocruz), which began to house the Oswaldo Cruz Institute (IOC) and other institutions of the Ministry of Health: the National School of Public Health (ENSP) - under the denomination of President Castelo Branco Institute -, the Fernandes Figueira Institute (IFF), the National Institute of Rural Endemic Diseases (INERu), the Evandro Chagas Institute, the Leprology Institute and the Medicine Production Institute (Ipromed). By Decree no. 67.049 of August 13 ${ }^{\text {th }}, 1970$, under the denomination of Rural Endemic Diseases Institute it stayed under the coordination of Oswaldo Cruz Institute (IOC), as an autonomous organization.

In 1976, during the administration of Vinícius da Fonseca (1975-1979), Fiocruz's Programmatic Reorientation Plan approved by the minister of Health, upon integrating the activities and defining the objectives in the areas of research, incorporated INERu, the functional structure of IOC, being its centers and regional nucleuses transformed into the following special units: René Rachou Research Center (CPqRR), Aggeu Magalhães Research Center (CPqAM) and Gonçalo Muniz Research Center (CPqGM).

\section{Architectonic description:}

The edifice constructed to be the headquarters of the INERu's Guanabara Research Nucleus does not possess architectonic qualities and the authorship of the project is ignored. However, its modernistic and candidly functional appeal presents an interesting contrast to the eclectic construction which occupies part of the property which for sometime also served INERu, most likely built in the first decades of the XX century.

\section{Register of Preservation:}

It is not listed.

\section{Sources:}

FONSECA, C. (2001). As campanhas sanitárias e o Ministério da Saúde, 1953-1990. In: BENCHIMOL, J. (Coord.). Febre Amarela: a doença e a vacina, uma história inacabada. Rio de Janeiro: Editora Fiocruz; 2001, p. 299-305.

GUIA Casa de Oswaldo Cruz. Fundo Centro de Pesquisas René Rachou. Resumo Histórico. Departamento de Arquivo e Documentação. Rio de Janeiro: COC/FIOCRUZ; 1995.

KLEIN, L. \& THIELEN, E. A ciência das doenças nas gerais. Da filial de Manguinhos ao Centro de Pesquisas René Rachou. Produção Científica Centro de Pesquisas René Rachou (1980-1999). Belo Horizonte: Centro de Pesquisas René Rachou; s.d. 


\section{FIRST REPUBLIC}

OLIVEIRA, B.; COSTA, R.; PESSOA, A. Um Lugar para a Ciência: a formação do campus de Manguinhos. Rio de Janeiro: Editora Fiocruz; 2003.

SANTOS, P. Inovação em saúde e desenvolvimento nacional: origens, criação e atuação do Instituto de Malariologia (19461956). Revista Rio de Janeiro, Rio de Janeiro, n.11, set-dez 2003, p. 97-115.

Credits: Daniel Elian and Renato da Gama-Rosa Costa (research and text); Renato da Gama-Rosa Costa (architectonic description). 


\section{FIRST REPUBLIC}

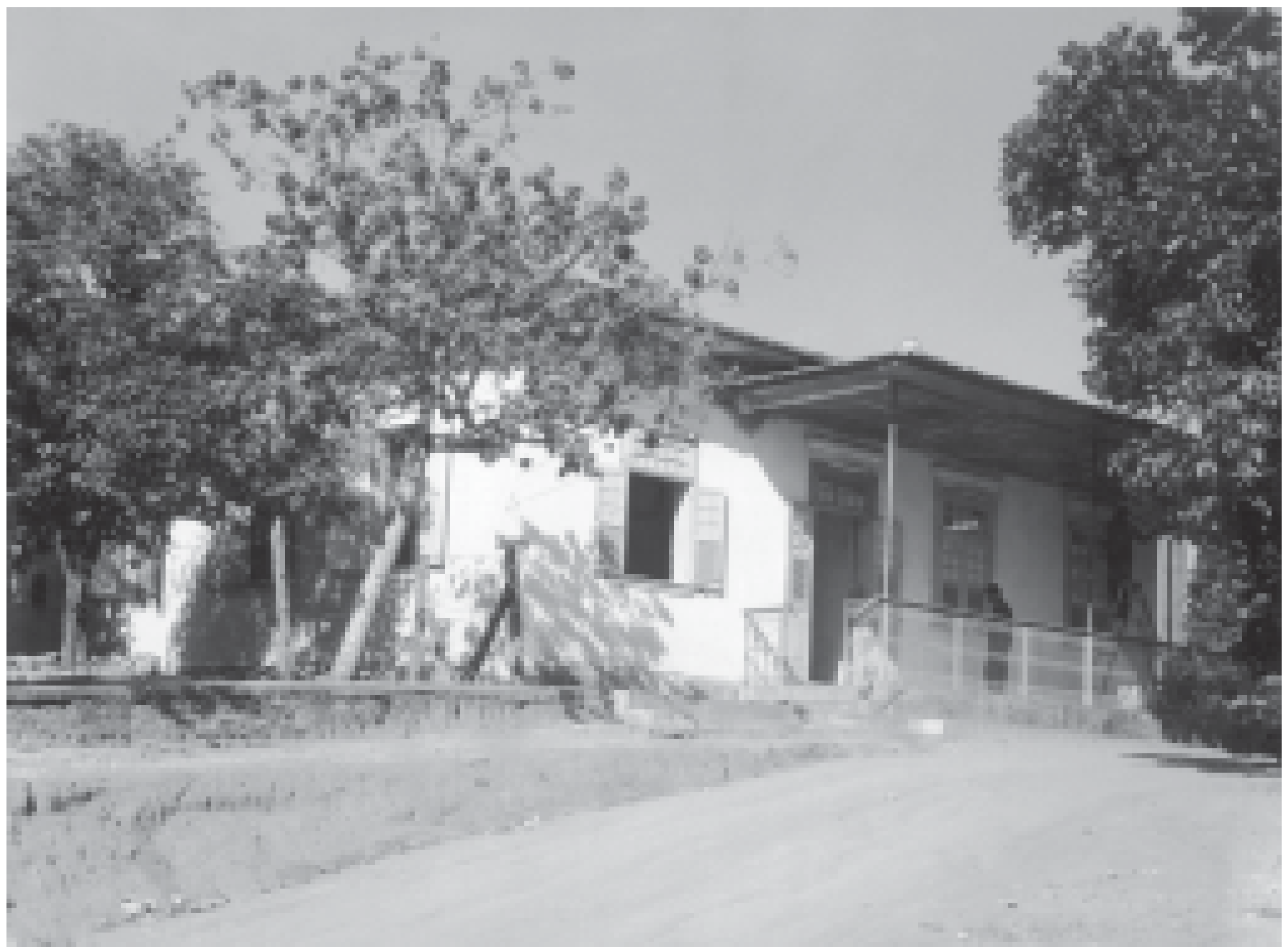

House used by INERu, in Jacarepaguá, [s.d.]. Casa de Oswaldo Cruz Archives 


\section{FIRST REPUBLIC}

\section{Gaffrée \& Guinle University Hospital}

Other denominations: Gaffrée \& Guinle Hospital (1924 - 1966), Gaffrée \& Guinle University Hospital (1966 present day)

Location: Tijuca

Address: Rua Mariz e Barros, 775

Denomination: University Hospital

Period of construction: $1924-1929$

Proprietor: Federal University of Rio de Janeiro State (UNIRIO).

Author / Constructor: Porto d'Ave \& Haering (architects and builders)

\section{History:}

The construction of the Gaffrée \& Guinle Hospital, intended for the control and prophylaxis of syphilis and venereal diseases, had its creation linked directly to the philanthropic action of the carioca industrialist Guilherme Guinle (1882 1960). The latter was strongly connected to Carlos Chagas and to his national construction program, which sought the salvation of the Brazilian race by way of health - at the time in which the eugenic speech reached its peak, and syphilis allow both a social and moral analysis.

Guilherme Guinle did not build a hospital, but rather, invested in the project of a center of reference for the control, treatment and research about syphilis and the venereal diseases in general, which resulted in the creation of the Gaffrée \& Guinle Hospital (1924 - 1929) and its anti-venereal ambulatories, represented by the Gaffree \& Guinle Foundation. This proposal is directly related to the actions of the Inspectorship of Leprosy and Venereal Diseases, created in 1920 in the core of the Sanitary Reform and headed by the doctor Eduardo Rabello - university professor in Dermatology and Syphilography of the medical School of Rio de Janeiro. In this sense, it is not possible to think about the creation of this hospital is removed from the reforms put into practice by the Carlos Chagas management at the head of the National Public Health Department (DNSP), between 1919 and 1926.

The Gaffrée \& Guinle Foundation was created in August $20^{\text {th }}, 1923$, by initiative of Guilherme Guinle - in the object of perpetuating the memory of his father, Eduardo Palassin Guinle - together with this partner, Candido Gaffrée. It would be up to the Guinle family to acquire the grounds and the construction of a hospital for syphilis and venereal diseases, in addition to ambulatories for diagnostics and prophylaxis of syphilis. This entire asset should be transferred, later, to the institution. The hospital's outfitting and maintenance, as well as the installation of the ambulatories would run at the cost of the federal government. There would be a Board of Directors, formed by the director of the DNSP (Carlos Chagas, at the time), by a specialist from the Medical School (Eduardo Rabello), and by a representative of the Guinle family (Guilherme Guinle); in a to an Advisory Board formed by 17 members, chosen among the people of standing in the society, among which Ataulpho de Paiva, Clementino Fraga, Fernando Terra, Fernandes Figueira, Linneo de Paula Machado and Miguel Couto.

The composition of the Board of Directors of the Gaffrée \& Guinle Foundation, at the time of its regulation, reaffirmed the proximity of the institution with the direction of the public health, entrusted to Carlos Chagas, and with the Inspectorship which should direct its works, given to Eduardo Rabello - the latter, in spite of appearing as a representative of the Medical School, as the on responsible for the anti-venereal legislation implemented at that time. There was a close relationship between the Medical School, the Inspectorship of Prophylaxis of Leprosy and the Venereal Diseases and the Gaffrée \& Guinle Hospital. Such a relationship was noticed not only the presence of teachers and former students (Oscar da Silva Araújo and Joaquim Mota, disciples of Eduardo Rabello and connected to the three institutions), as well as in the operational part, since one of the ambulatories was installed in the old College building, in the premises of the Santa Casa da Misericórdia; and the other in the Maternity Ward of Laranjeiras. 


\section{FIRST REPUBLIC}

The project of the Gaffrée \& Guinle Foundation also took into consideration the dynamics of the city expansion in the direction of the suburbs of Gávea, Cascadura, Andaraí, in addition to other neighborhoods that grew around the factories established therein, installing anti-venereal ambulatories in these sites. These complied with a model plant and contained a surgical center, clinical analyses laboratories, specialized medical staff, as well as pharmacists and nurses.

At the time, its ambulatories were already working and its Research Institute, which works were directed by José Gomes de Faria - researcher for the Oswaldo Cruz Institute, reinforcing the Hospital's filiation to the tradition of Manguinhos - it was also already working since 1927 - same year of publication of the first number of the Archives of the Gaffrée and Guinle Foundation - organized from the technical works performed in the ambulatories and laboratories. The Archives were published uninterruptedly until 1931. In the next four years only two numbers were edited, the first one relative to the year of 1932 and 1933, and the other to the period of 1934 and 1935. From then on it stopped circulating The Technical Commission was formed by the doctors Carlos Chagas (director of the DNSP), Eduardo Rabello (Chief-Inspector) and Gilberto de Moura Costa (director of the Gaffrée \& Guinle Hospital).

The hospital, inaugurated on the $01^{\text {st }}$ day of November of 1929, and projected by office of Porto d'Ave e Haering, was built to offer 320 beds in the main building of four floors - the fourth floor was intended for the solarium -, where the various services and an ambulatory were located. On it where located the services of first-aid ward, urinary tracts, gynecology and obstetrics, as well as the auxiliary services to the hospital ambulatory (laboratory, physiotherapy and X-rays), of visceral syphilis, otorhinolaryngology and ophthalmology, the surgery rooms and the contagious women service.

In the same building were installed the superintendencies of the administrative, statistics and nursing services, the institution's revenues and the sanitary services. There was still the amphitheater, the clothes closet, the honor hall, the library and the museum. Special pavilions were projected in the campus to shelter the research institute, the vivarium, the chapel consecrated to Our Lady of Conception of Brazil, the director's residence, the conservation workshops, the dormitory and the laundry.

The good results collected by prophylaxis of syphilis campaigns, as well as the success of its control allowed that, in time, the Gaffrée \& Guinle Hospital diversified its services. In 1946, an agreement between the Gaffrée \& Guinle Foundation and the DNSP made that a part of the Hospital was loaned to the National Cancer Service, this agreement being in force for around 11 years, and another part to the Child Welfare Institute of the University of Brazil, which remained there until 1953.

With the death of Guilherme Guinle in 1960, the relations of the Gaffrée \& Guinle Hospital with the family that founded and maintained it did not last long. In 1966 an agreement between Gaffrée \& Guinle Foundation and the federal government, transferred Hospital to the federal jurisdiction, which became the university hospital of the Medicine and Surgery College of Rio de Janeiro, today the University of Rio de Janeiro (UNIRIO), having its name to the Gaffrée \& Guinle University Hospital.

Since 1987, the hospital is a center of reference in the research and treatment of AIDS.

\section{Architectural Description:}

The option for the neocolonial as an architectural language, where the national traces were valorized, sums up the nationalist ideals defended by both the architect and the doctors and Guilherme Guinle: the nationalism. Therefore, the valuation of the Brazilian style at the same time it ensures the salvation of the race and the future generations by mean of controlling and fighting syphilis and venereal diseases.

In relation to the architectural project, it can be considered a hygienist hospital, for having infirmaries interconnected by corridors and by the concern with airing, perceived in the amount of large windows in each infirmary - one for each bed. Its project sums up the transformations which the hospital architecture went through at the moment, chiefly in what concerns the verticality and the technological innovations. 


\section{FIRST REPUBLIC}

\section{Register of Preservation:}

Listed as historical site by the City Hall of Rio de Janeiro in August 2003.

\section{Sources:}

SANGLARD, G. \& COSTA, R. Hospital Gaffrée e Guinle. In: Porto d'Ave - projetos para a saúde, 1920-1940 (catálogo da exposição). Rio de Janeiro: Casa de Oswaldo Cruz/FIOCRUZ; 2007.

SANGLARD, G. Entre os salões e o laboratório: filantropia, mecenato e práticas científicas no Rio de Janeiro - 1920-1940. Rio de Janeiro: Casa de Oswaldo Cruz/Fiocruz; 2005 (Tese de doutorado).

Credits: Gisele Sanglard (research, text and architectural description) 


\section{FIRST REPUBLIC}

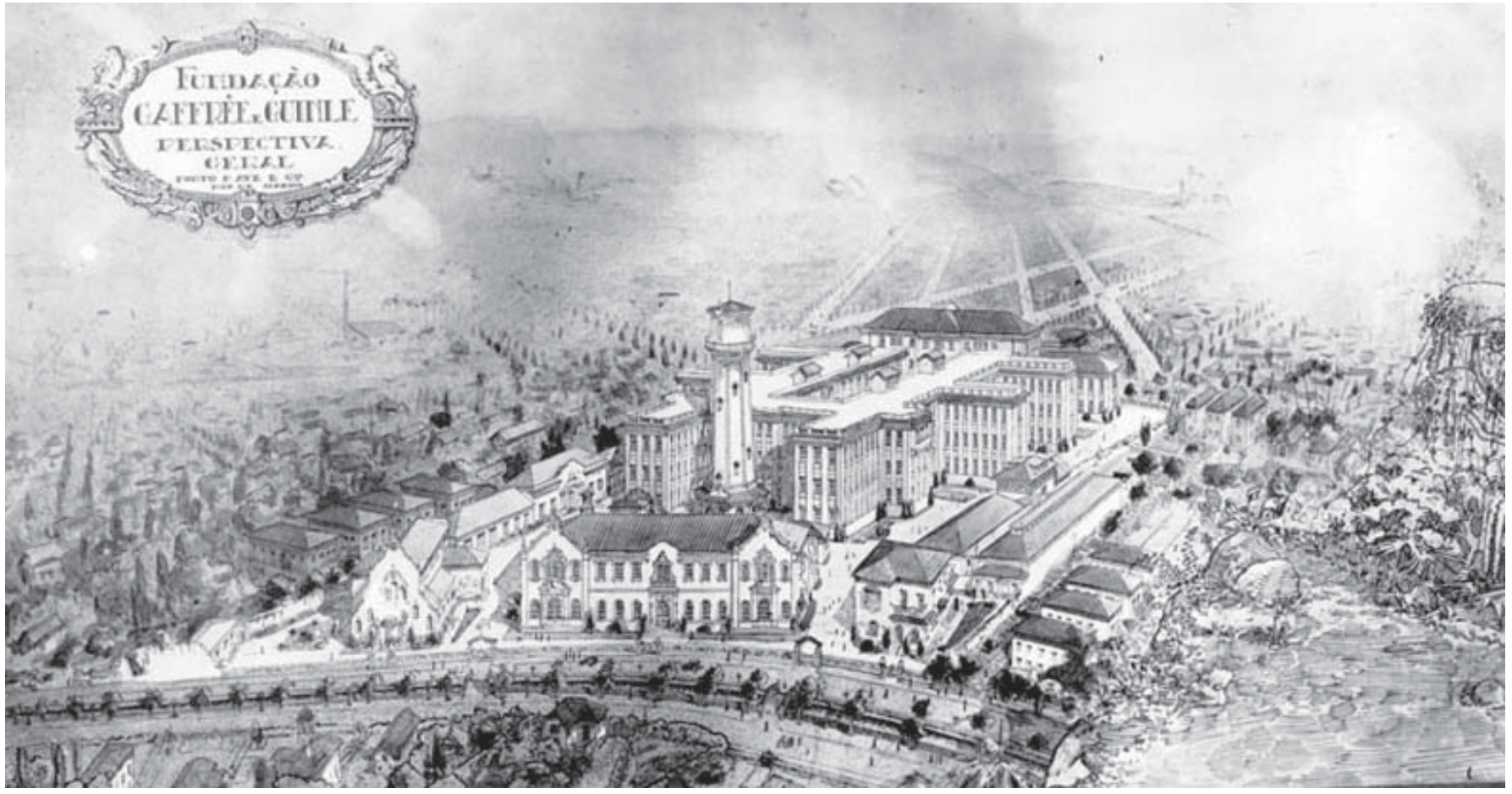

View of the Gaffrée \& Guinle Hospital, [1924-1929]. Porto d'Ave Fund, Casa de Oswaldo Cruz Archives

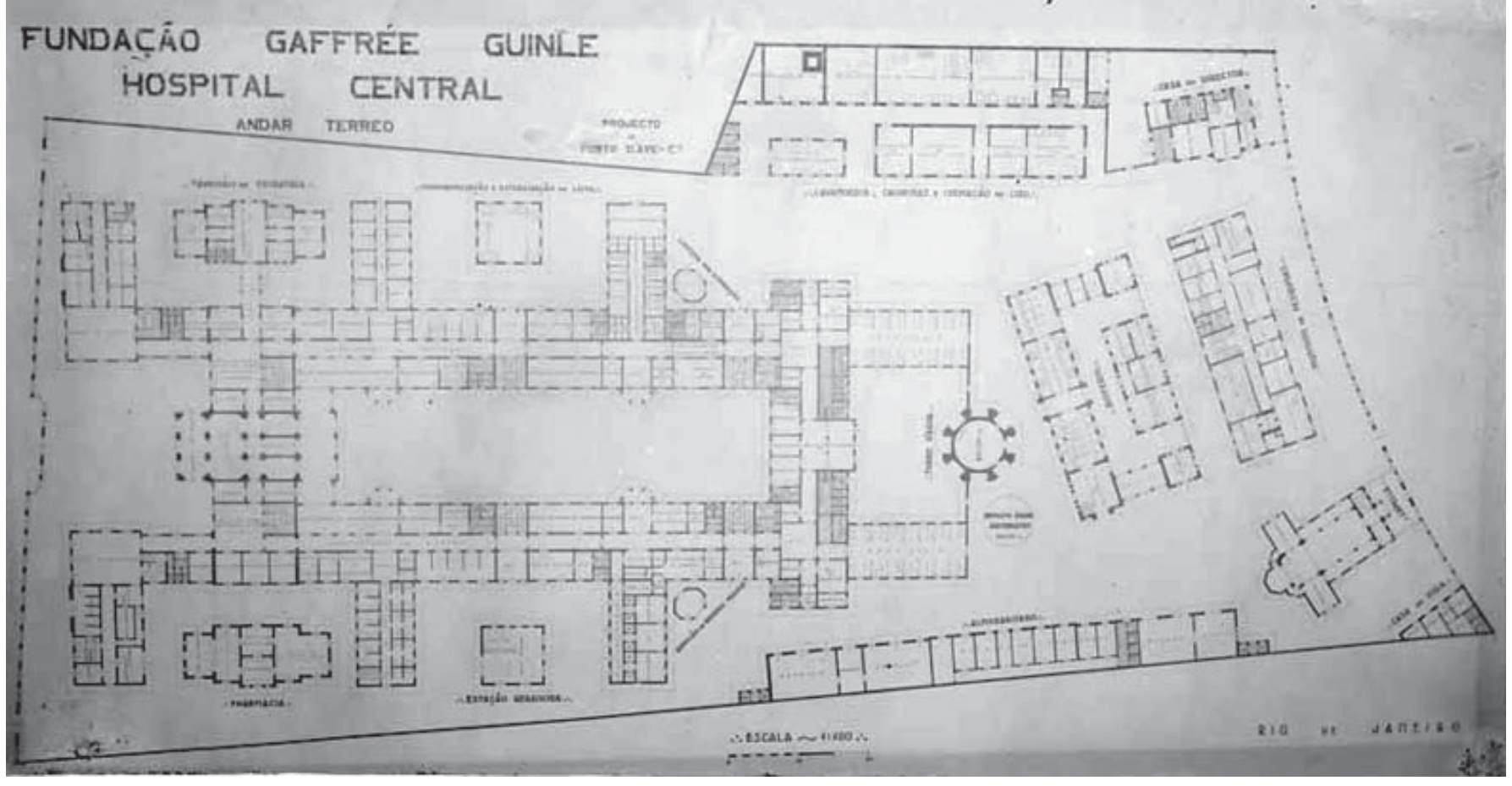

Plan of the Gaffrée \& Guinle Hospital, [1924-1929]. Porto d'Ave Fund, Casa de Oswaldo Cruz Archives 


\section{FIRST REPUBLIC}

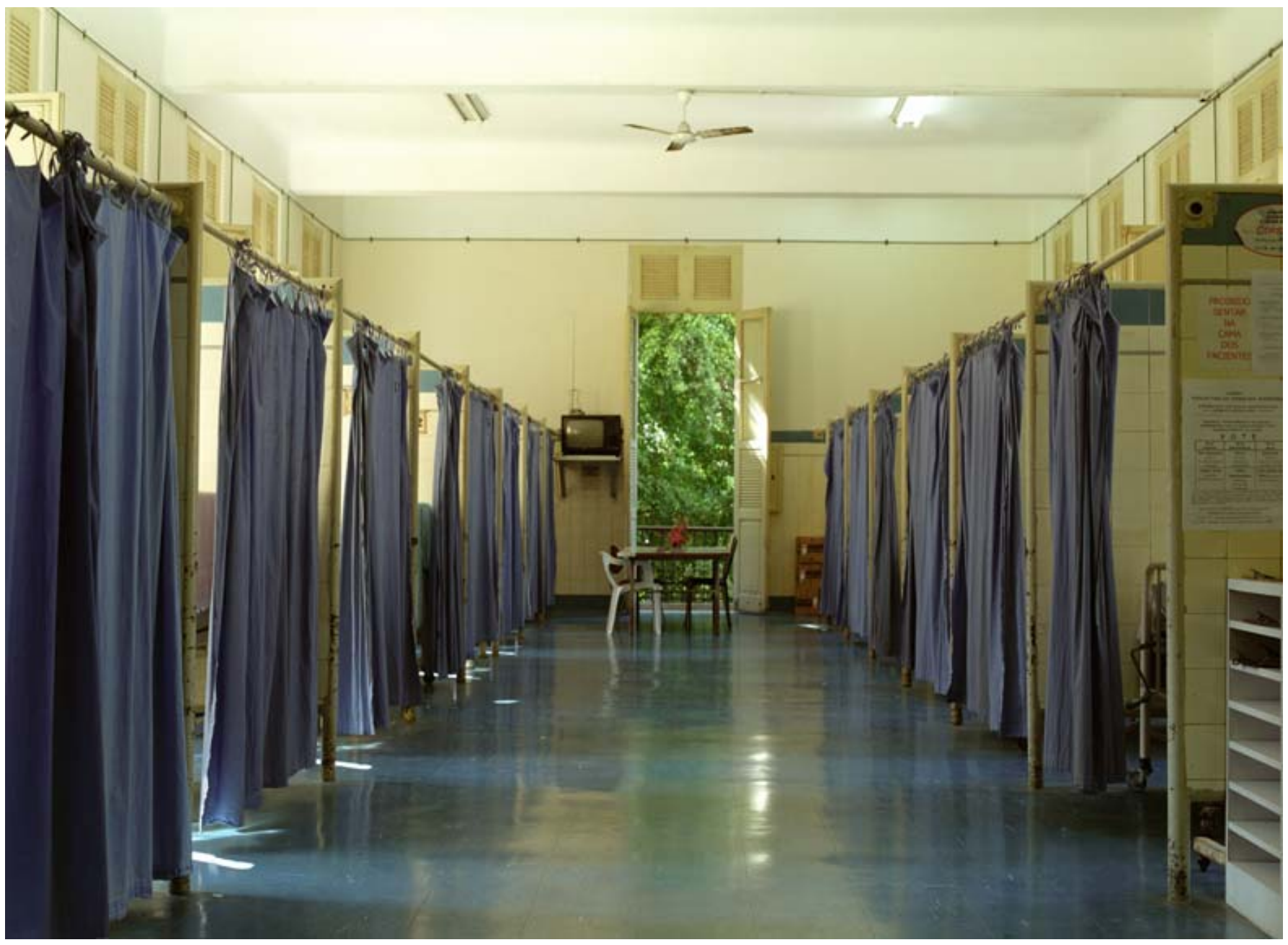

Gaffrée \& Guinle Hospital, 3rd Infirmary. Photo Roberto Jesus Oscar \& Vinícius Pequeno de Souza, 2003. Casa de Oswaldo Cruz Archives 


\section{FIRST REPUBLIC}

\section{Herculano Pinheiro Maternity Hospital}

Other Denominations: Maternity Hospital of Cascadura or Suburban (1926-1934); Dispensary of Cascadura (19341945); Fernando Magalhães Maternity Hospital (1945-1958); Infantile-Maternal Emergency Center of Cascadura (19581959); Herculano Pinheiro Maternity Hospital (1959-1960); Herculano Pinheiro State Maternity Hospital (1960-1975); Herculano Pinheiro Municipal Maternity Hospital (1975-1992); Herculano Pinheiro Integrated Health Unit (1992-2007); Herculano Pinheiro Maternity Hospital (09/20/2007-present day).

Location: Madureira

Address: Rua Ministro Edgard Romero, 276

Category: Maternity Hospital.

Period of construction: 1930

Proprietor: Government of the State of Rio de Janeiro.

Author / Constructor: unknown

\section{History:}

The history of the foundation of several maternities in the first decades of the XX century is related to the benefactor actions of women groups, who, in partnerships with doctors, organized associations, founded and managed maternities, nurseries, orphanages and schools among other institutions of mother-infantile assistance care. It was not any different with the Maternity Hospital of Cascadura, also known as Suburban Maternity Hospital, in function of its geographic location, dedicated to provide assistance care to poor women of the suburban and rural zones.

In 1926, an Association of Ladies started the construction of a maternity at Avenida Suburbana no. 3,097, in the Cascadura district. The property was donated by José Francisco da Silva and the hospital project had the direct support of Doctor Herculano Pinheiro and the indirect support of Doctors Fernando Magalhães - whose name is attributed to the benefactors of the Pro Matre Maternity -, and Rodrigues Lima - founder of the Laranjeiras Maternity - as well as the local traders.

Herculano Pinheiro, dentist and doctor, graduate of the College of Medicine in Bahia came to Rio de Janeiro as a doctor of the Companhia Lloyd Brasileiro, and settled in the suburbs of Madureira in 1908, being one of the few health professionals to provide assistance care to the population in the districts of Madureira and Cascadura. He practiced medicine in the dependencies of the Suburban pharmacy until the foundation of the maternity, which was envisioned and managed by him.

The administrative management of the Maternity was constituted by Rosa Pinheiro (presidency), Judith Cabral Pereira (vice-presidency), Professor Joaquina Horta ( $1^{\mathrm{a}}$ secretary), Odete Nunes da Costa ( $1^{\mathrm{a}}$ treasurer), Alaíde Cardoso ( $2^{\mathrm{a}}$ treasurer), Célia Cardoso Ururahi ( $2^{\mathrm{a}}$ secretary), Guilhermina Santos, Hercília Peixoto and Alice Araújo (members of the Fiscal Council). Herculano Pinheiro was the clinical director of the Institution until his death in 1946.

In 1930, the maternity was inaugurated, however, only the polyclinics of obstetrics, gynecology and pediatrics were under working conditions. In 1933, the Association of Ladies donated the patrimony to City Hall of the Federal District, under the condition that the Municipality concluded the construction of the maternity. This agreement was signed by Mayor Pedro Ernesto (1931-1934) and Gastão de Oliveira Guimarães, General-Director of Municipal Assistance of the Federal District. A committee comprised of doctors, representatives of public government and the Companhia Industrial Construtora of Rio de Janeiro was constituted to accompany the conclusion of the construction.

Throughout the 30s, the Maternity of Cascadura continued to receive public investment. In 1932, Belizário Penna, director of Public Health, gave continuity to the construction of infirmaries. In 1938, during the administration of Clementino Fraga, as head of the General Office of Health and Assistance, Maternity services are expanded to 28 beds for obstetrics assistance care. 


\section{FIRST REPUBLIC}

As of 1934, the Maternity of Cascadura undergoes continuous change in denominations and functions, although it maintained its original identity of providing maternal-infantile assistance care. In 1934, the maternity becomes the Dispensary of Cascadura, affiliated to the Children's Medical Centers and subordinate to the Department of Hospital Assistance, with the purpose to provide assistance care to pregnant women and women in labor, under the direction of Herculano Pinheiro.

In 1945, the maternity became known as Fernando Magalhães Maternity, in tribute to Doctor Fernando Magalhães, deceased on January $10^{\text {th }}, 1944$. In 1958, the denomination changed again from Fernando Magalhães Maternity to São Cristóvão Maternity and the Maternity of Cascadura became known as Infantile-Maternal Emergency Center. On December $26^{\text {th }}, 1959$, the Infantile-Maternal Emergency Center was transferred to the $10^{\text {th }}$ District, in Piedade, and the institution received the named of its idealizer - Herculano Pinheiro Maternity.

In 1960, with the transfer of the federal capital to Brasília, the state of Guanabara is created encompassing the entire municipality of Rio de Janeiro. At this moment, the hospitals belonging to city hall of the Federal District were transferred to state jurisdiction. Fifteen years later, in 1975, with the fusion of the States of Guanabara and Rio de Janeiro, some of these hospitals returned to the condition of municipals - among them Herculano Pinheiro Maternity Hospital; while others remained state hospitals.

In 1965, Herculano Pinheiro State Maternity was transferred from Cascadura to Madureira, on Rua Andrade Figueira, s/no., located in the same building as the Alberto Borgerth Medical-Sanitation Center. This transfer caused controversy because many doctors found it improper to gather pregnant women along with patients with infectious-contagious diseases under the same roof.

In 1992, the Maternity merged with the Alberto Borgeth Municipal Health Center and received the denomination Herculano Pinheiro Integrated Health Unit. In 1997, after undergoing reform, the Maternity was re-inaugurated with 64 beds distributed among shared room, pregnant, abortions, pre-births, Kangaroo mother care, among others; 02 delivery rooms; 01 surgery room; 01 curettage room; 01 relaxing room; neonatal ICU; Milk Bank and Lactation Station; laboratories; radiology; cardiotocography and ultrasonography. Municipal Decree of 09/20/2007 altered once again the name of the Institution to Herculano Pinheiro Maternity Hospital.

\section{Architectonic Description:}

The 3-story building is located on a lot with accentuated decline between Rua Andrade Figueira and Rua Edgard Romero in the Madureira district. The Maternity occupies the entire $3^{\text {rd }}$ pavement and part of the second one.

The building with $4.357 \mathrm{~m}^{2}$ of total developed area, allocates only $2.500 \mathrm{~m}^{2}$ for the Maternity, and the rest is occupied by the Alberto Borgerth Municipal Health Center which operates in the other areas of the building. The administration, obstetrics center, reception and infirmaries are located via the access on Rua Andrade Figueira, where there is also access to the women in labor.

In 1997, when the most recent reform was carried out, there was an important expansion with the construction of a small house for the functioning of administrative and management activities which is interconnected to the main building by means of a covered flat roof.

\section{Register of Preservation:}

It is not listed.

\section{Sources:}

ASSISTÊNCIA Pública - Guanabara: 80 anos de história. Rio de Janeiro: Superintendência de Serviços Médicos (SUSEME); 1972. mimeo. 


\section{FIRST REPUBLIC}

Brazil-Médico, Rio de Janeiro, 26/01/1938.

MATERNIDADE Suburbana. Revista da Semana, Rio de Janeiro, ano 33, n. 22.14 de maio de 1932, p. 25.

TEIXEIRA, C. A Reforma Pedro Ernesto (1933): perdas e ganhos para os médicos do Distrito Federal. Rio de janeiro: COC/ FIOCRUZ; 2004 (Dissertação de mestrado).

Credits: Lidiane Monteiro and Renato Pereira da Silva (research); Maria Renilda Barreto (research and text) and Fábio Bitencourt (architectonic description). 


\section{FIRST REPUBLIC}

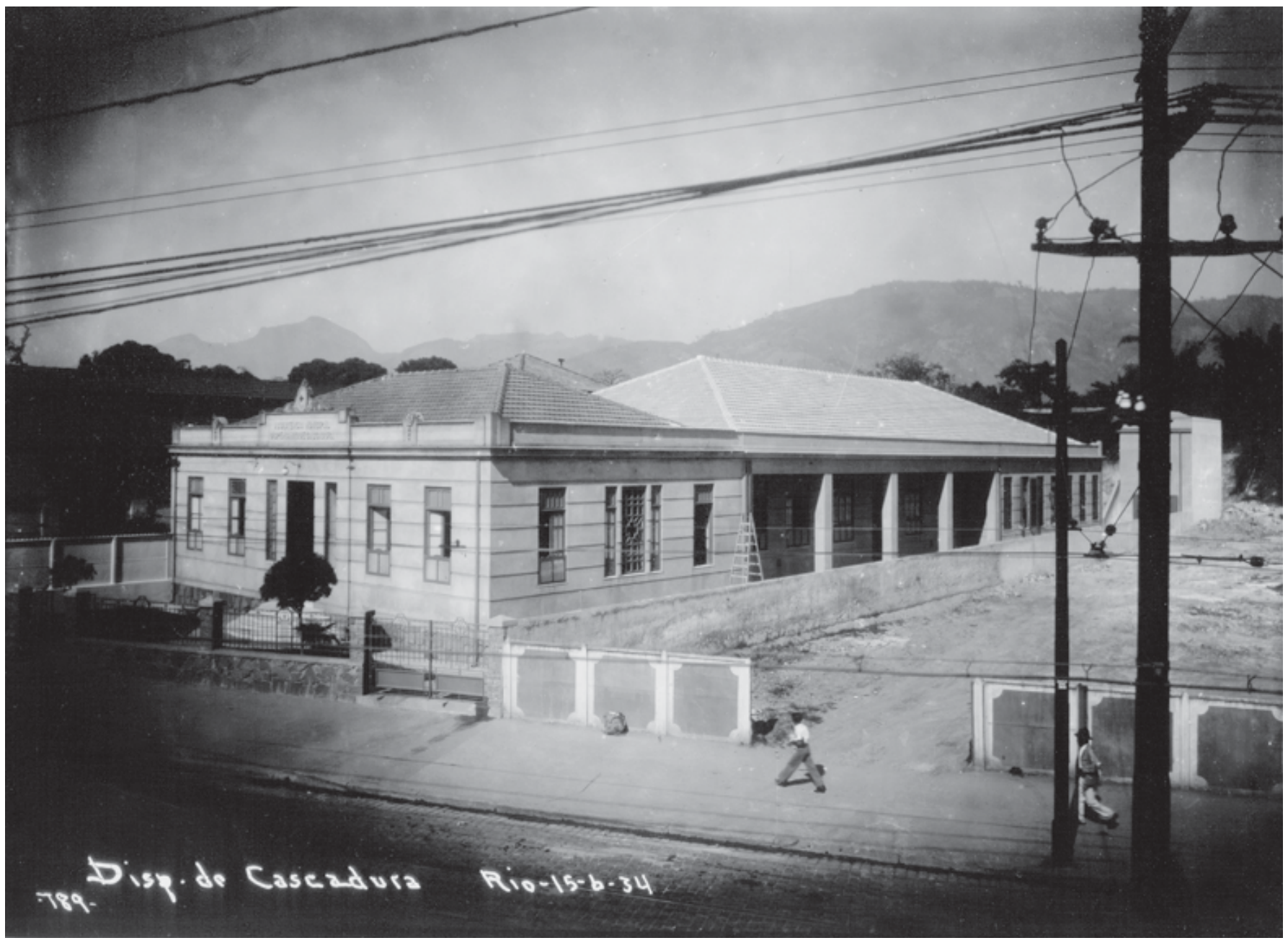

Dispensary in Cascadura. Photo Augusto Malta, 15/06/1934. City of Rio de Janeiro General Archives

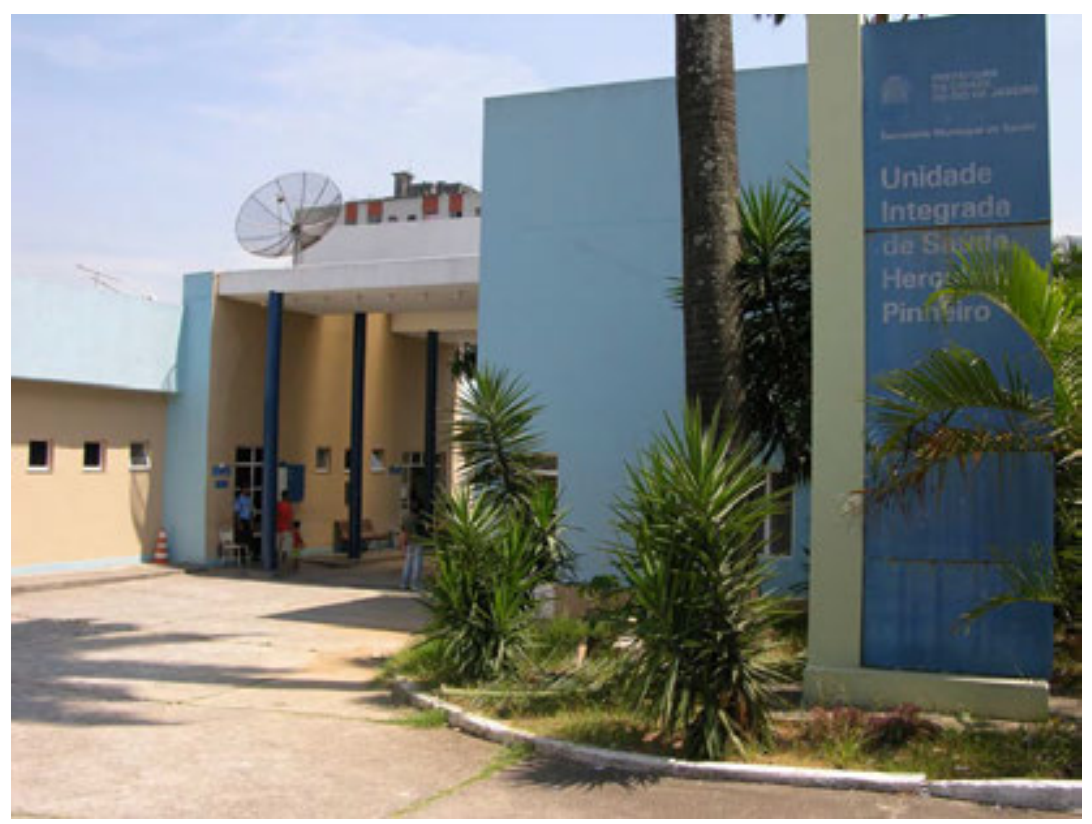

Herculano Pinheiro Hospital and Maternity. Photo Roberto Jesus Oscar \& Vinícius Pequeno de Souza, 2007. Casa de Oswaldo Cruz Archives 


\section{FIRST REPUBLIC}

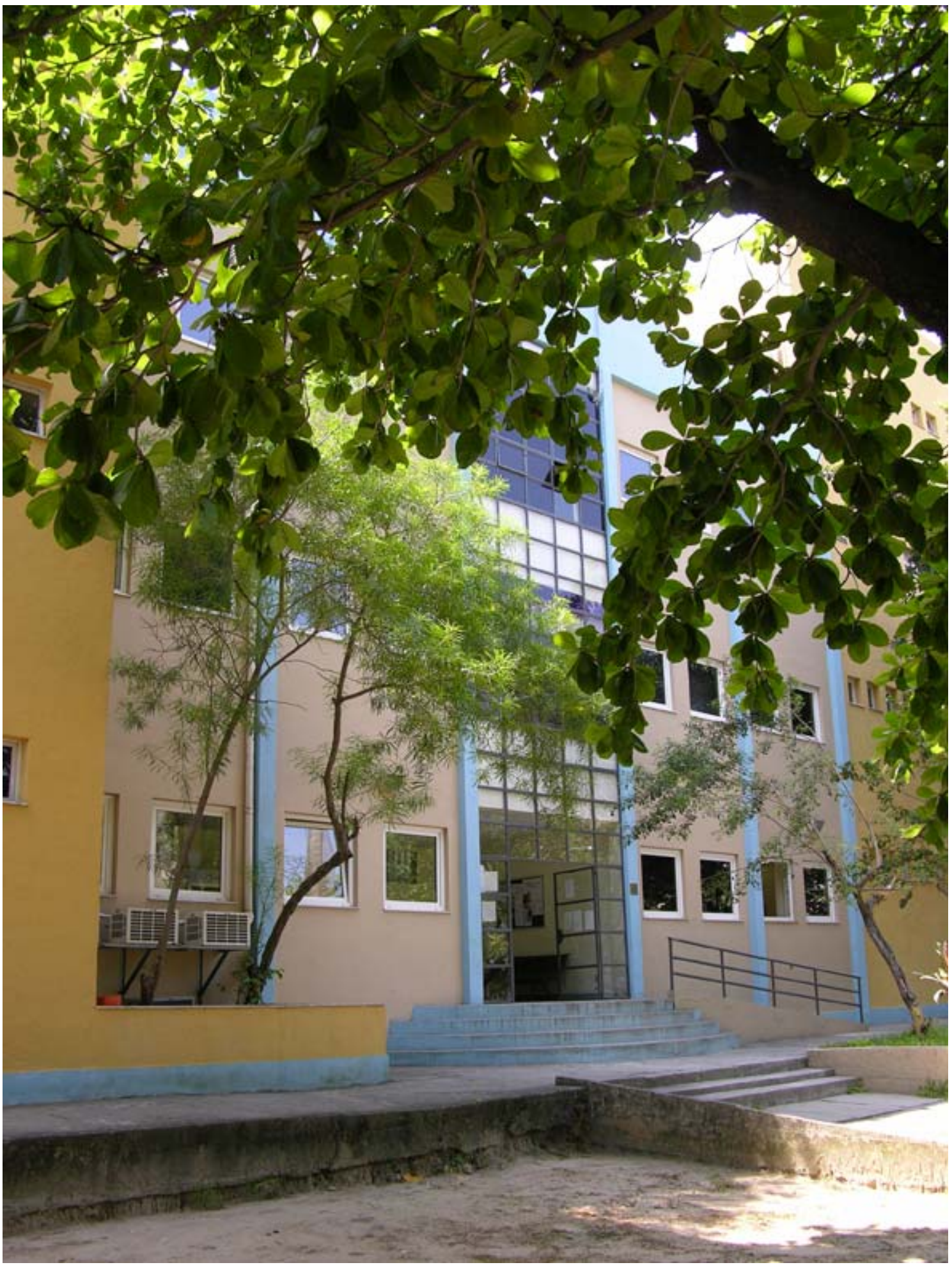

Herculano Pinheiro Hospital and Maternity, 2007. Roberto Jesus Oscar \& Vinícius Pequeno de Souza Photo. Casa de Oswaldo Cruz Archives 


\section{FIRST REPUBLIC}




\section{FIRST REPUBLIC}

\section{Brazilian Red Cross}

Location: Downtown/Lapa

Address: Praça da Cruz Vermelha, no. 10/12.

Category: Welfare Institution; Teaching Institution.

Period of construction: 1919

Proprietor: Brazilian Red Cross Society

Author / constructor: Pedro Campofiorito (architect); Leonídio Gomes (constructor).

\section{History:}

The innumerous episodes of conflicts in the XIX century stimulated the foundation, in 1863, of the International Committee to help injured military personnel - an organization later denominated the International Red Cross Committee. At the end of the XIX century, various branches of the Red Cross were opened throughout the world due to the need to offer voluntary help to the victims, in accordance with the provision contained in the Geneva Convention (1894-1906), which regulated the their operation.

In Brazil, under the inspiration of Joaquim de Oliveira Botelho, the project of implanting the Brazilian Red Cross came to light in 1907, backed by a group of doctors and various professional people who, on October $17^{\text {th }}$ of this year, in a meeting of the Society of Medicine and Surgery of Rio de Janeiro, presented the fundamentals of the Brazilian Red Cross Society. On December 31 ${ }^{\text {st }}, 1907$, there occurred a meeting where the members of the provisional board of directors were elected, who would be responsible for the elaboration of the first articles of incorporation, having Oswaldo Gonçalves Cruz as chairman. On December $05^{\text {th }}, 1908$, these by-laws were discussed and approved, this date being considered as that of the founding of the Brazilian Red Cross, as an entity of public and private assistance in Rio de Janeiro and with objective of establishing in the country a hospital assistance corps similar to those created in other cities of the world.

In 1914, the Female Members of this Society requested the board to elaborate a course for the helpers, with the objective of giving practical training on how to give support to the sick and injured. Following this proposal, the Volunteer Nurses Course was then prepared, to be held initially, at the Army Central Hospital. In the following year, the theoretical classes were transferred to the provisional headquarters of the Society, at Praça XV de Novembro, and the practical classes began to be offered at Santa Casa da Misericórdia of Rio de Janeiro, which opened up its infirmaries to the students of the referred to course. Due to the satisfactory performance of the Volunteer Nurses Course, on March $20^{\text {th }}$ of 1916, the then president of the Society, Thaumaturgo de Azevedo, inaugurated the Professional Nursing Course, which, in parallel with the former, formed the Red Cross Practical Nursing School. The theoretical part of the course was first of all given in the hall belonging to the Geography Society of Rio de Janeiro, in Avenida Rio Branco, due to the lack of an appropriate place for it.

Starting in 1911, an appeal was made to the Federal Government for the donation of land capable of holding the various annexes and services offered by the Brazilian Red Cross, which was only granted in 1916, with the donation of land at Esplanada do Senado. A temporary pavilion was quickly constructed and inaugurated in May, of 1917, providing a location for the School of Nursing and the Brazilian Red Cross Society .

The Volunteer Nurses Course, a fruit of the climate of expectation created by the First World War (1914-1918), influenced the opening of various similar courses throughout the national territory. As its initial objective was to train a body of helpers for times of conflict, it lost its function when the war ended and was declared extinct in 1919. In the post-war period the Brazilian Red Cross played an important role in combating and helping the victims of the Spanish flu epidemic by means of services rendered by the Practical Nursing School, which provided specially trained labor and functioned as a place of isolation for the sick. In the meantime, works were begun on the Red Cross Hospital, a building designed by the architect, Pedro Campofiorito, which was constructed between 1919 and 1923. 


\section{FIRST REPUBLIC}

Similar to that which occurred in 1914, as soon as the Second World War was declared (1939-1945), a First Aid Course was set up to train as quickly as possible support personnel to give emergency hospital assistance. In 1942, approximately 90\% of the nursing staff who accompanied the Brazilian Expeditionary Force (FEB) was composed of professionals trained by the Red Cross Nursing School.

In the first three years of the 1940`s, the Red Cross Nursing School, besides giving the Nursing Course, also administered the Social Assistant Course, which because it only operated in this period, saw just one class of graduates. In 1947, an Auxiliary Nursing Course was offered, having less rigorous pre-requisites and, for this reason, it was procured by a large number of candidates with a low level of schooling.

By decree no. 24.768, of April $06^{\text {th }}, 1948$, the Brazilian Red Cross School of Nursing was declared equivalent to the Anna Nery School of Nursing of the University of Brazil, considered to be a standard school.

From 1969 to 1971, the entity underwent a process of federal intervention related to the elaboration of new by-laws and the election of a new administering body. Having fulfilled all the requirements, it continued to operate normally, maintaining all the medical practices offered by the Hospital, which, however, terminated its activities in 1977, after a procedure for its closure in the previous year. The Brazilian Red Cross Society continued to operate at the same location, maintaining its educational functions (courses, lectures, and conferences), humanitarian programs (technical support for campaigns) and social activities (welfare programs). However, in the 1990`s, it went through a period of institutional crisis, with the paralyzation of its services and the closure of its units of attendance. This crisis was only resolved in 2001 with the election of a new administrative board and the renewal of the national board of directors.

At present it offers courses for the professional training of nursery staff and baby sitters, environmental education and health, care of the elderly and basic first aid training.

The Brazilian Red Cross presently functions as a maintaining entity, according to criteria of the Ministry of Health, and only maintains the Red Cross Hospital of the branch in the State of Paraná.

\section{Architectonic description:}

The building of the Red Cross Hospital stands out due to its establishment in the square, baptized with the same name as the institution and that followed the urban planning proposed by Pereira Passos (1903-1906) for intersections of principal roadway routes. The architectural design, in three floors with an inhabitable basement and penthouse, follows this establishment: the main façade accompanies the curvature of the square and the shape of the corners, which makes it unique and imposing. The architectural program was developed in blocks which form two internal patios, which help with the internal ventilation of the rooms.

The main façade obeys a rigorous modulation, with eight bays divided by the central module of the façade, where the entrance is to be found, of large dimensions, composed of a semi-circular drum frontispiece made of iron and glass framework and statues in high relief, finished off with a dome in the shape of a clergyman's cap in slate and a four-sided gazebo, highlighting the emblem of the Red Cross. On the first floor the modules are decorated with full arch lintels and wood frames and glass. The second and third floors have the same decoration as the previous floor however the bays are delimited by columns with grooves on the shafts and capitals of the composite order. In the original design of 1919, the crowning was constituted of openings that stylized alcoves influenced by the French renaissance. In 1920, this particularity was abandoned at the request of the Mayor, Carlos Sampaio, for the installation of the residence for the nurses.

\section{Register of preservation:}

Listed by the municipality on September $08^{\text {th }}, 1987$. 


\section{FIRST REPUBLIC}

\section{Sources:}

ASSISTÊNCIA Pública e Privada no Rio de Janeiro (Brasil) - História e Estatística. Comemoração do Centenário da Independência Nacional. Rio de Janeiro: Typographia do Annuario do Brasil; 1922.

BRASIL. Decreto $n^{\circ} 4.377$, de 26 de novembro de 1921. Colleção das Leis da República dos Estados Unidos do Brasil de 1921. v. I. Actos do Poder Legislativo (janeiro a dezembro). Rio de Janeiro: Imp. Nacional, 1922.

CASTRO-SANTOS FILHO, L. História geral da medicina brasileira.. São Paulo: Hucitec/ Edusp, 1991. v. 2.

COSTA, N. Rio de Ontem e Hoje.

Archivos Brasileiros de Medicina

Archivos Brasileiros de Medicina

Voluntárias

Estatutos da Escola de Enfermeiras. Programmas dos Cursos Profissional e das Enfermeiras

$$
\text { Apresentação - Histórico }
$$

Guia da Arquitetura Eclética no Rio de Janeiro

Ficha de Inventário Arquitetônico do Município do Rio de Janeiro

História das Ruas do Rio

Revista Paulista de Enfermagem,

O Brasil e a Segunda Guerra Mundial.

Revista da Cruz Vermelha Brasileira

Revista Brasileira de Enfermagem

Credits: Leonardo Rodrigues (research), Atiele Lopes (research and text) and Renato da Gama-Rosa Costa (architectural description). 


\section{FIRST REPUBLIC}

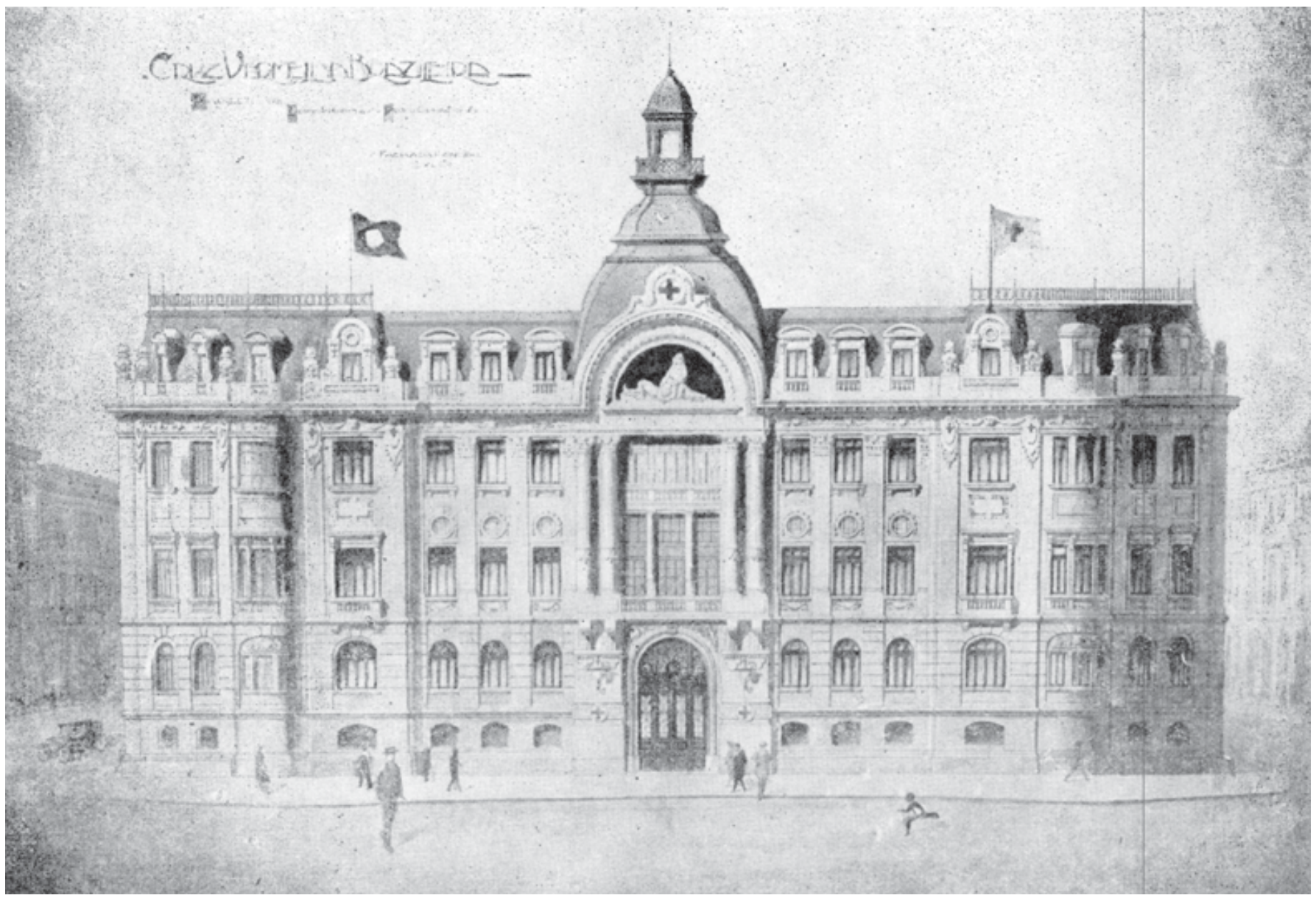

Cruz Vermelha building, [s.d.]. Assistência (1922) 


\section{FIRST REPUBLIC}

\section{Juliano Moreira Municipal Institute of Health Care}

Other denominations: Hospital Colony of Jacarepaguá (1924-1930); Juliano Moreira Colony (1930-1996); Juliano Moreira Municipal Institute of Health Care.

Location: Jacarepaguá

Address: Estrada Rodrigues Caldas, no. 3.400.

Category: Institution of specialized care in mental health

Period of construction: $\mathrm{XX}^{\text {th }}$

Proprietor: Ministry of Health.

Author/constructor: Various

\section{History:}

The Juliano Moreira Colony of the Mentally Insane was established on lands of the old Engenho Novo Farm, originated from Engenho de Nossa Senhora dos Remédios, whose name was taken from a small chapel constructed in the XVII ${ }^{\text {th }}$ century by the slaves in homage to this saint. As from 1715, under the control of the Teles Barreto de Meneses family, it consolidated itself as one of the most prosperous farms of the old parish of Jacarepaguá. Dedicated to the cultivation of sugar cane, these lands came into being in 1653, as a result of the fragmentation of the old Camorim Farm.

Still in the XIX ${ }^{\text {th }}$ century, the lands received the denomination of Engenho Novo Farm of Curicica or of Pavuna, substituting the cultivation of sugar cane for coffee and indigo. Up to the first decade of the $\mathrm{XX}^{\text {th }}$ century, it continued with small scale cultivation and stock-raising until it was expropriated by the Government on August 31 $1^{\text {st }}, 1912$, the legal procedure related to this lasting until 1918.

At the time, the director of the Ilha do Governador colonies, the Count of Mesquita e São Bento, João Augusto Rodrigues Caldas, heeding the claims for the transfer of the interns because of the unsuitability of the buildings, decided to encourage the Government to acquire these lands and use them to house a new asylum for the insanes. In 1919, works began on adapting the old farm to the needs of a hospital establishment, under the perspective of an agricultural colony asylum.

Since the second decade of the $\mathrm{XX}^{\text {th }}$ century, the focus on treating the mentally disturbed in rural colonies was in fashion in the field of psychiatric medicine. In 1911, the director of the Juliano Moreira National Asylum for the Insane obtained authorization to implant, at the site of Engenho de Dentro, a colony destined to mentally disturbed women. The new colonies were, in his opinion, indispensable in substitution of the Ilha do Governador colonies, on lands where today the Galeão Air Base is to be found. These places were in every way in a precarious state and did not allow for an appropriate treatment for their interns, besides the requirement of the monks of the São Bento Monastery, owners of the land where they were located, and the Navy, which desired to install at the location its recently created Air Division.

Finally, in 1923 the Ilha do Governador colonies were de-activated and the patients transferred to the psychiatric complex of the Jacarepaguá Colony of the Mentally Disturbed, officially inaugurated on March $29^{\text {th }}, 1924$ at Estrada Rodrigues Caldas, no. 3,400, in the district of Jacarepaguá. The road received this name in 1932, in honor of the director of the colony, between 1909 and 1926, João Augusto Rodrigues Caldas. In 1930, it became known as the Juliano Moreira Colony, in honor of the psychiatrist responsible for the law on care for the mentally ill, of 1904.

The Juliano Moreira Colony was for many years a reference in the treatment of mental infirmities, functioning as a receiver of patients who were thought to be incurable. In the 1960's it housed up to 5,000 patients.

At the beginning of the 1980's, already falling into decay, it adhered to the new psychiatric tendencies in the treatment of the patients, in vogue in various countries. New measures were adopted towards long internments (the responsibility of the Jurandyr Manfredini hospital), electroshock treatment, lobotomies and the excess of neuroleptics.

The handing over of the health care services of the Juliano Moreira Colony, an ex-federal psychiatric hospital, to the municipality, was ventilated in 1990, in fulfillment of Federal Law no. 8,080, of September 19th. This process was only 


\section{FIRST REPUBLIC}

put into practice in 1996, with the implantation of the Single Health System (SUS), changing the name of the institution to Juliano Moreira Health Care Institute. With the handover to the municipality, the old asylum was sub-divided into three units: the institute itself, responsible for the interned residents; the Jurandyr Manfredini Hospital, caring for chronic patients and the Álvaro Ramos Municipal Hospital, destined to the clinical attendance of the patients.

At present it has approximately 950 interns, whose average time of internment is 40 years. With the objective of changing this situation, the institution adopted a program of de-institutionalization, supported by the Ministry of Health, aiming at transferring the patients with some progress to therapeutic care, outside of the Hospital. In the buildings of the complex, there can also be found the Bispo do Rosário Museum, concentrating the artistic reserve of Arthur Bispo do Rosário, an intern of the institution for 50 years.

\section{Architectural Description:}

The institution was conceived under the inspiration of the model of the agricultural colonies which established as a basic element of the cure, the so-called traditional therapy, or in other words, therapy through work. It was also based on the health care model called hetero-familiar through which, employees living at the Colony received patients in their houses in exchange for the rendering small services to the latter. It is to be pointed out that this was one of the very characteristics of the colony hospitals, in which the treatment of the disease would acquire an urban dimension with houses for residents and circulation of persons, including some patients.

Among the buildings existing in the Colony today, outstanding are the Rodrigues Caldas Center, which houses the headquarters of the old Engenho Novo Farm, the aqueduct and the church, Nossa Senhora dos Remédios which has a great historical cultural value. In its turn the Heitor Peres Headquarters Building - which today houses the administration of the Juliano Moreira Municipal Institute of Health Care - is outstanding because it is a good example of modern architecture. Some other pavilions express the time of their construction and represent the type of policy that was given to the issue of mental illness, such as the Franco da Rocha Center, Jurandyr Manfredini Hospital and tuberculosis pavillion $\mathrm{N}^{\mathrm{a}} S^{\mathrm{a}}$ dos Remédios, projected by Noel Ramos de Azevedo: the first was in agreement with psychiatric current of the 1930 's, the second inserts itself into the context of the concept of general hospital and the third one shows hibrid caracteristics fot both tuberculosis and mental illness treatment for women pacients. The architectural languages adopted vary from stylized colonial to the modern, expressed both in the pavilions as well as in the hospital buildings, counting with the participation of several architects, including the ones from the Ministry of Education and Health.

\section{Register of Preservation:}

IPHAN, May 11 $1^{\text {th }}, 1938 ;$ INEPAC, 1972.

The aqueduct is preserved by IPHAN since May $11^{\text {th }}, 1938$. The Church, Nossa Senhora dos Remédios was preserved by the old State of Guanabara, as from 1972 and today both are protected by the State Institute of Cultural Heritage, which granted an extension to the preservation order, in 1990, including the Rodrigues Caldas Center and its "area of ambiance": the gateway of the old Mill, the old headquarters, the wall that passes behind the latter, pavilions 1, 2, 3, 4, 5, 6 and 7, the fountain, the group of listed houses of the employees and the Church, Nossa Senhora dos Remédios. This was designed by Theodoro Marx and inaugurated in 1892, on the same site as the ancient chapel founded in the XVII ${ }^{\text {th }}$ century.

\section{Sources:}

BARBOSA, D. Da Fazenda de Engenho à Instituição e Assistência à Saúde. Capturado em 20 de jul. 2007. Online. Disponível na internet: http://www.cdsm.ufes.br/files\%5CTextosdaMostra.pdf. 


\section{FIRST REPUBLIC}

COSTA, W. História de Jacarepaguá. Capturado em 24 de jul. 2007. Online. Disponível na Internet: http://www.acija.org.br/ cap08. html

DIVISÃO de Apoio Didático e Tecnologia Educacional. Instituto Municipal de Assistência à Saúde Juliano Moreira. Servidor / Saúde-Rio. Capturado em 17 de jul. 2007. Online. Disponível na Internet:

http://www.saude.rio.rj.gov.br/servidor/cgi/public/cgilua.exe/sys/reader/htm/preindexview.htm? editionsectionid= 165\&user=reader

GONÇALVES, A. Colônia Juliano Moreira: um estudo sobre as relações do sujeito estigmatizado como "louco" e o espaço urbano. Niterói: Universidade Federal Fluminense, 2006. (Dissertação de mestrado)

MADERA, L. Diagnóstico Urbanístico da Colônia Juliano Moreira. Rio de Janeiro: Fiocruz, 2005. Capturado em 16 de ago. 2005. Online. Disponível na Internet: http://www2.fiocruz.br/cj1

MINISTÉRIO da Saúde. Colônia Juliano Moreira. Ações conclusivas do processo de Municipalização - Relatório Final. Brasília [DF]: Ministério da Saúde, 2001.

Credits: Atiele Azevedo de Lima Lopes (research and writing), Ana Paula Casassola Gonçalves (Archtectural description) and Leonardo Rodrigues Pereira (research). 


\section{FIRST REPUBLIC}
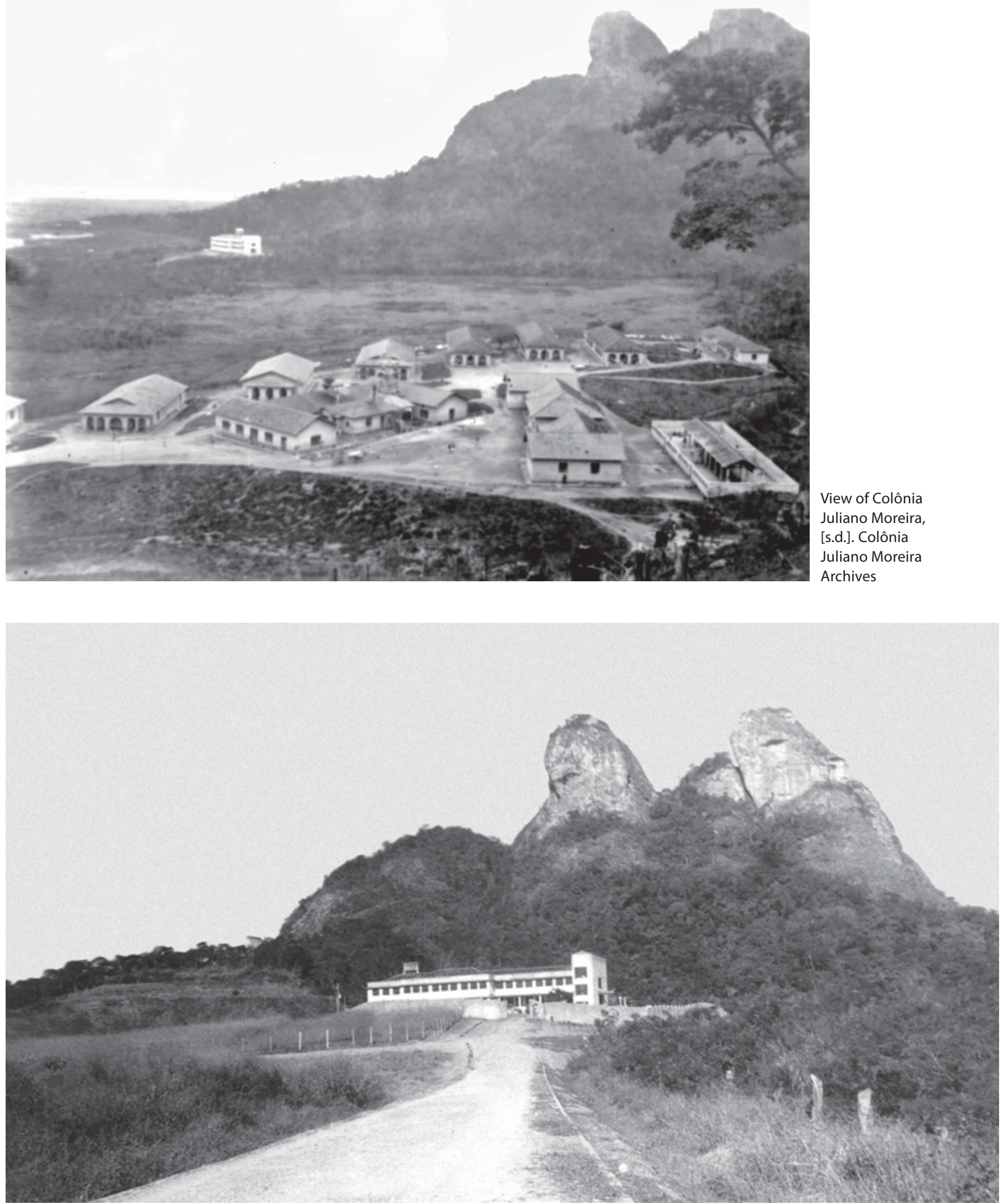

Nossa Senhora dos Remédios Hospital, [s.d.]. Colônia Juliano Moreira Archives 


\section{FIRST REPUBLIC}

\section{Maternity School of the Federal University of Rio de Janeiro}

Other denominations: Maternity of Laranjeiras or Maternity of Rio de Janeiro (1904-1918); Maternity School of Rio de Janeiro (1918-1937); Maternity School of the University of Brazil (1937-1965); Maternity School of the Federal University of Rio de Janeiro (1965-present day).

Location: Laranjeiras, Rio de Janeiro - RJ

Address: Rua das Laranjeiras, no. 180

Category: Maternity School

Period of construction: [XIX ${ }^{\text {th }}$ century]

Proprietor: Federal University of Rio de Janeiro

Author / Constructor: unknown

\section{History:}

The Maternity of Laranjeiras, as is popularly known the present Maternity School of the Federal University of Rio de Janeiro, was created by Decree no. 5117, of January $18^{\text {th }}$, 1904, during the administration of Francisco de Paula Rodrigues Alves, as President of the Republic, and José Joaquim Seabra, in the post of Ministry of Justice and Internal Affairs. In March 03 ${ }^{\text {rd }}, 1904$ the By-laws of the Maternity Clinic of Rio de Janeiro were published, by means of decree no. 5154.

The discussion around the creation of a placed reserved for mothers-to-be, childbirth, parturients, as well as care of the new-born accompanied the turn of the XIX ${ }^{\text {th }}$ to the $\mathrm{XX}^{\text {th }}$ century. The doctors were the main defenders of this hospital ideal, published in the pages of popular and specialized periodicals, in the sessions of the National Academy of Medicine and of the Municipal Chamber. In the 1870's, the public authorities had tried to create a municipal maternity hospital the Santa Isabel Maternity - which was to render aid to poor and "needy" women, as well as providing the Faculty of Medicine of Rio de Janeiro with a suitable environment for classes on Childbirth Practices. However, during the republican period, a divergence of interests between the central executive authority and the Federal District lead to the abandonment of the Santa Isabel Maternity project and the city of Rio de Janeiro had to wait until 1904 to have its maternity unit, in Laranjeiras.

In the process of founding the Maternity Clinic of Laranjeiras one can perceive the interaction between medical know-how and political discourse, initiated by a native of Bahia, then residing in Rio de Janeiro, Antônio Rodrigues Lima - a doctor, teacher, member of the National Academy of Medicine, a practitioner with many clients and congressman for Rio de Janeiro; among the ladies of the Rio high society and the press.

Rodrigues Lima, in the editorial of the newspaper, O Paiz (09/26/1903) called upon "the Brazilian ladies" to support the project of protection for women and children. He was betting on the "sentiment of altruism of the Brazilian ladies" and mentioned other countries that had put into practice the combined action of the public authorities and private charities on behalf of maternal protection. In a speech to the Chamber of Deputies, Rodrigues Lima defended the juxtaposition of the public merit and science. The campaign was well orchestrated and produced the desired result. The project was supported by the public authorities and by the feminine wing of Rio society, which founded the "Maternity Assistance Association", on November $26^{\text {th }}, 1903$, with its headquarters in the maternity clinic itself, with the function of aiding the medical board of directors in the maintenance of the establishment and in the foundation of the assets.

The realization of the maternal assistance project by means of a maternity school cannot be separated from the project of sanitation and embellishment of the capital of the Republic at the beginning of XX ${ }^{\text {th }}$ century. The Maternity Clinic of Laranjeiras was founded in 1904, in parallel with the hygiene reform of Rio de Janeiro, since "civilizing" the capital of the Republic also meant combating mortality, whether that caused by mosquitos and rats, or that caused by the deficient medical-hospital assistance to expectant mothers and to children, particularly those of a low income. 


\section{FIRST REPUBLIC}

The Maternity Clinic/School of Laranjeiras was born with two well-defined functions: maternal assistance for the less favored populations and the training of specialized labor. The facilities of the maternity clinic should be prepared to do examinations of the mothers-to-be; admit pregnant women or parturients that needed help; perform gynecological operations; shelter orphaned children; distribute milk to the new-born whose mothers cannot breast feed; and finally, be the locus of training of nurses, mid-wives and doctors. This role is carried out up to the present day, and it has been the responsibility of the Maternity School de Laranjeiras to educate various generations of doctors who have consecrated themselves in the field of gynecology and obstetrics.

The creation of this exclusive space for pregnant women and women in labor, independent of the custody of the Santa Casa da Misericórdia brought about the search for a space of its own, independent of the sheltering wing of the Sisterhood and of the restrictions imposed upon the presence of the students in the feminine wards.

On December $11^{\text {th }}, 1918$ the Maternity Unit was attached to the Faculty of Medicine of Rio de Janeiro, reinforcing the link between the spaces of being born and learning. The administration of the institution has been undertaken by Antonio Rodrigues Lima (1904-1914), José Thomaz Nabuco de Gouvêa (1914-1915), Fernando Augusto Ribeiro de Magalhães (1915-1918; 1922-1944), Érico Marinho da Gama Coelho (1918-1922), Octávio Rodrigues Lima (1944-1971), Jorge Fonte de Rezende (1972-1981); Carlos Antônio Barbosa Montenegro (1981-1994), José Leonídio Pereira (1994-1998), Joffre Amin Júnior (1998-2006) and, at present, Rita Bernadete Ribeiro Guerios Bornia (as from 2006).

The Maternity School of the Federal University of Rio de Janeiro expanded its area of operation over these 100 years by means of the incorporation of the new technologies in medicine and the appearance of new specialities. Clinical medicine, perinatology, care of the newborn, accompaniment of women with a risky pregnancies, pre-natal genetics, complete care of the woman's health, graduation courses in medicine, nursing, nutrition, social assistance, psychology, phono-audiology, and post-graduations, are actions that make up the double function of this institution: maternal health care and professional training.

\section{Register of Preservation:}

It is not listed.

\section{Sources:}

ANNAES da Academia de Medicina, Acta de 29 de agosto de 1901, p. 128-129.

ASSISTÊNCIA Pública e Privada no Rio de Janeiro (Brasil) - História e Estatística. Comemoração do Centenário da Independência Nacional. Rio de Janeiro: Typographia do Annuario do Brasil; 1922.

Decreto $n^{\circ}$ 5117, de 18 de janeiro de 1904.

Decreto $\mathrm{n}^{\circ}$ 5154, de 03 de março de 1904.

EXTRA, 14 de março de 2004.

FIALHO, A. A Maternidade do Rio de Janeiro. Renascença, Rio de Janeiro, mar. 1904, Ano I, n. 1., p 24-28.

http://portal.mec.gov.br/sesu/arquivos/pdf/humat.pdf, capturado em 06/08/2007.

INSTITUIÇÕES médicas no Brasil. Archivos Brasileiros de Medicina, Rio de Janeiro, 1º sem. , ano III, 1913, p. 255-260.

LIMA, R. A maternidade. Rio de Janeiro: Tipografia Besnard Frères, 1904.

MAGALHÃES, F. A obstetrícia no Brasil. Rio de Janeiro: Grande Livraria Editora Leite Ribeiro, 1922.

MATERNIADE do Rio de Janeiro. Revista da Semana, Rio de Janeiro, ano. 18, n. 6, 17 de março de 1917, p. 10.

O GLOBO, 18 de janeiro de 1994.

O PAIZ, Rio de Janeiro: [s/n], 23 de setembro de 1903, n. 6924, ano XIX.

Credits: Maria Renilda Nery Barreto (research and text). 


\section{FIRST REPUBLIC}

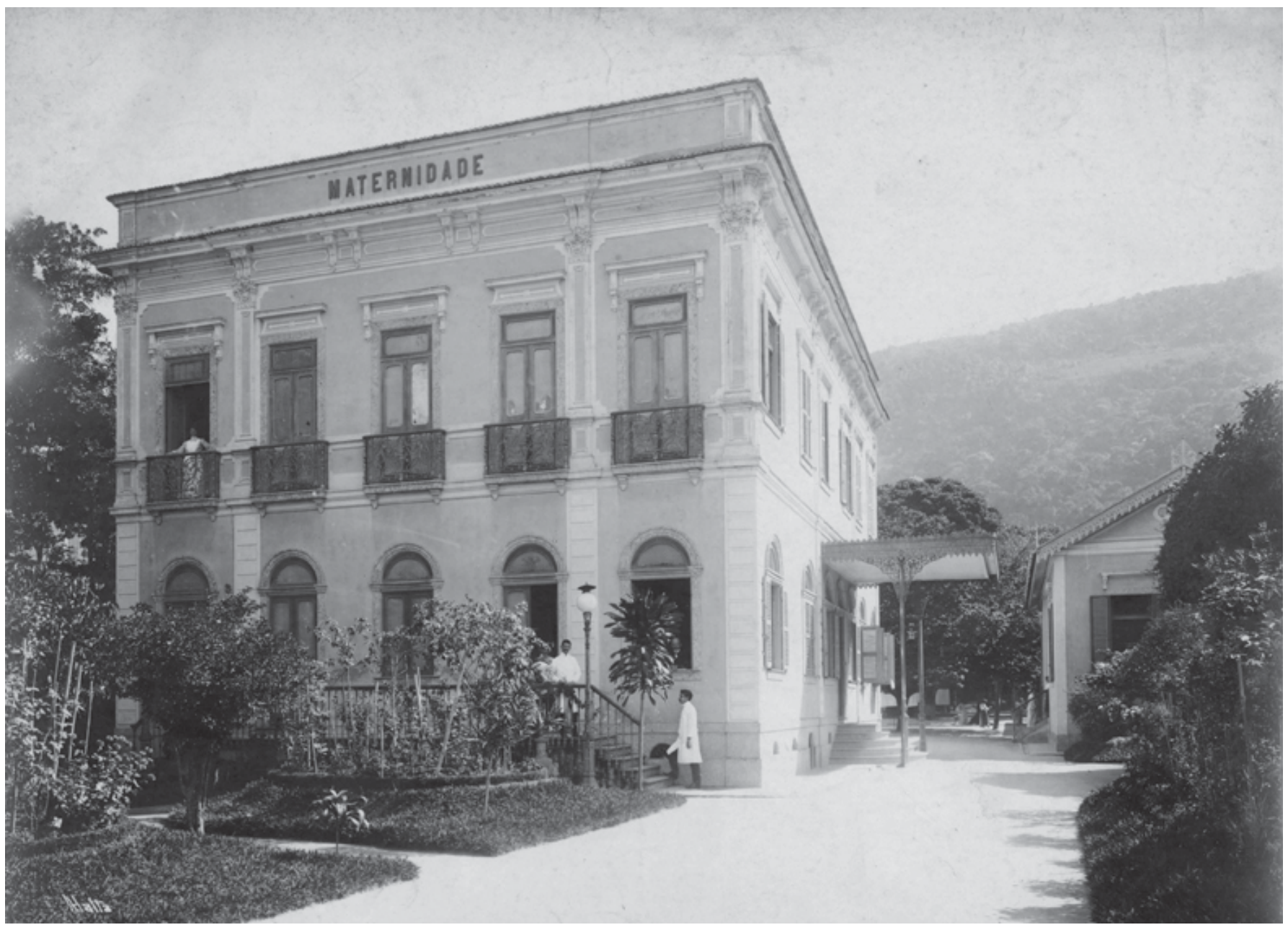

Laranjeiras Maternity, [s.d.]. Museu da Imagem e do Som - RJ Archives

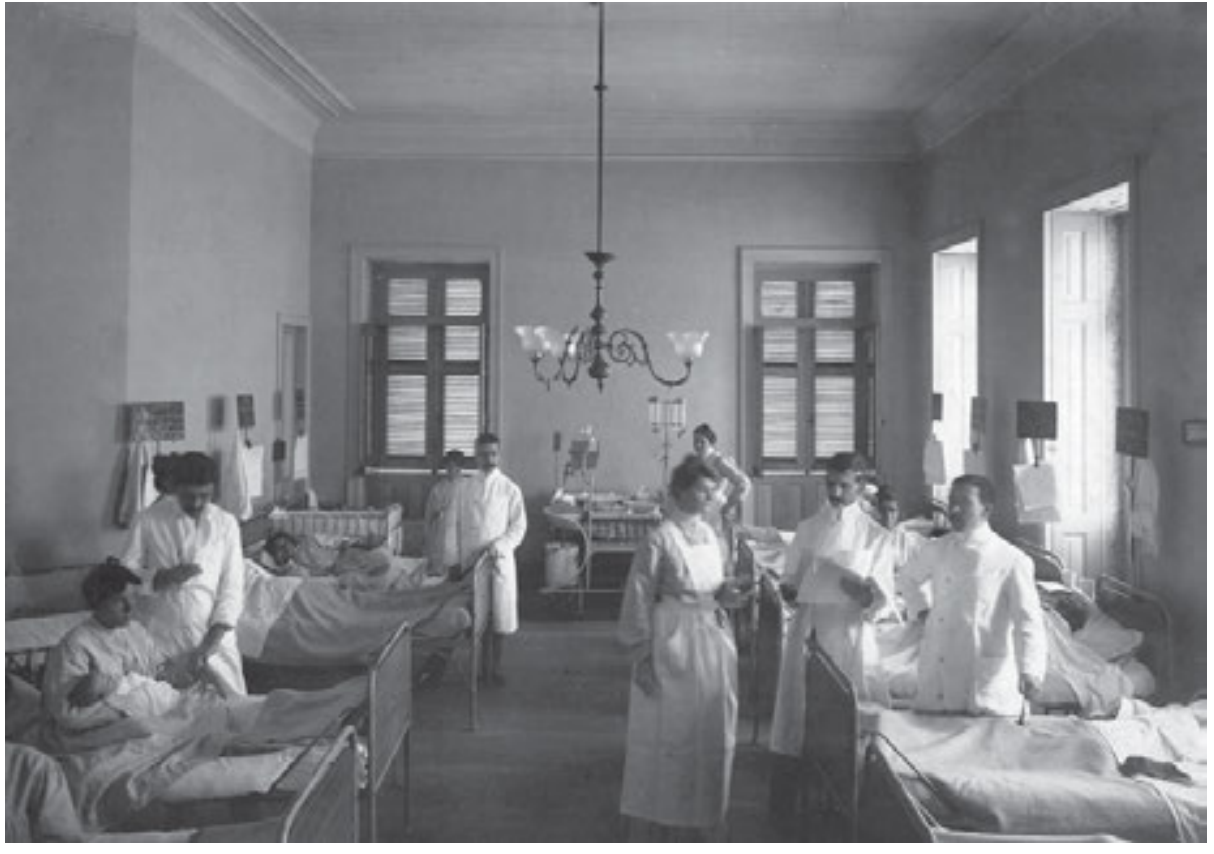




\section{FIRST REPUBLIC}

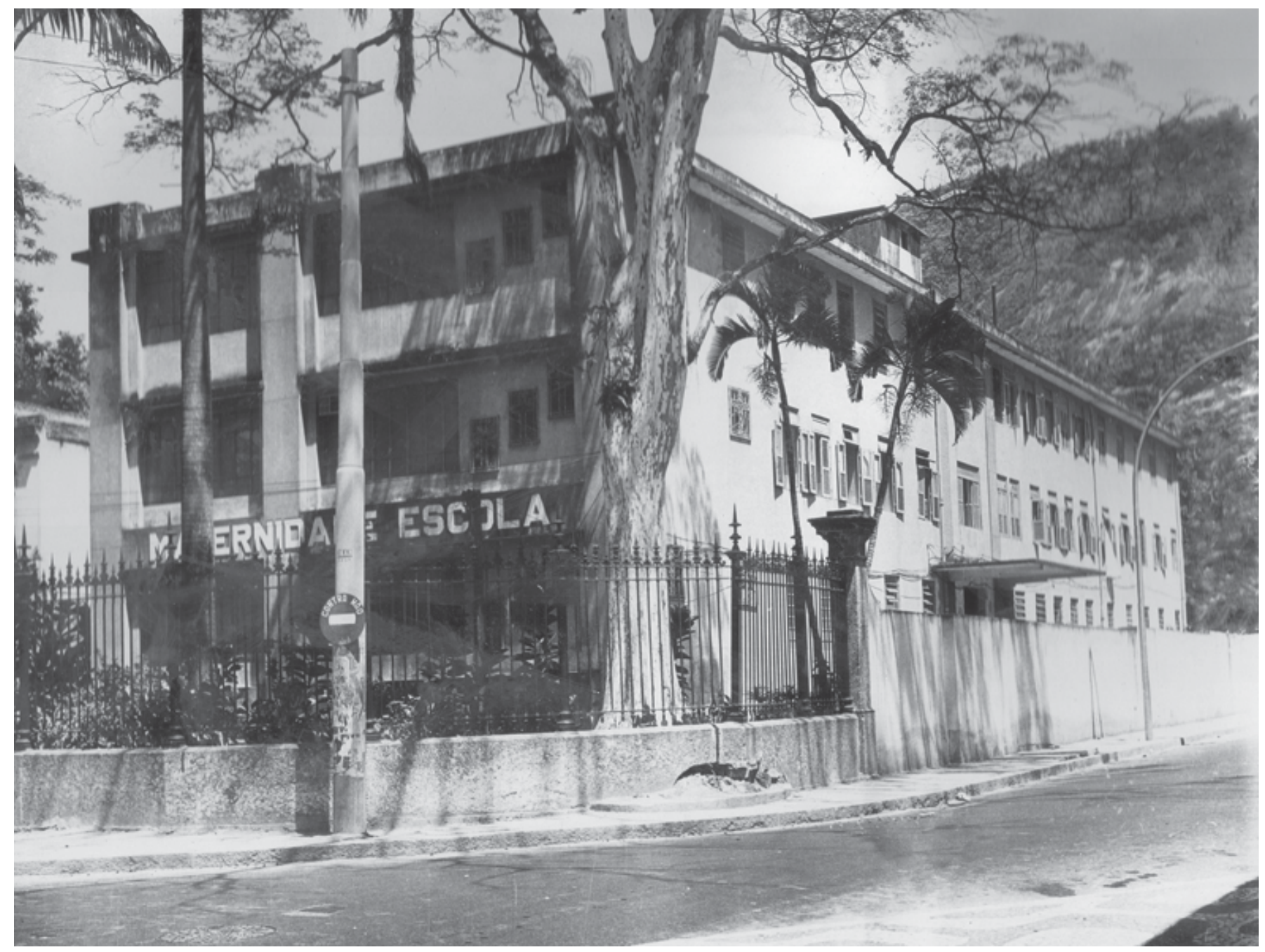

Maernity Scholl, [s.d.]. Universidade Federal do Rio de Janeiro Archives 


\section{FIRST REPUBLIC}

\section{Moncorvo Filho Hospital and Luiz Capriglione State Institute of Endocrinology (IEDE)}

Other denominations: Institute of Child Care and Protection (IPAI, 1889-1941); Moncorvo Filho Hospital (1941present day)

Location: City Center

Address: Rua Moncorvo Filho, 90

Category: Endocrinology and Diabetes Hospital; Gynecology

Period of construction: end of XX ${ }^{\text {th }}$ century, renovated in 1914.

Proprietor: Government of the State of Rio de Janeiro and Federal University of Rio de Janeiro (UFRJ)

Author / Constructor: unknown

\section{History}

Son of pediatrician, Carlos Arthur Moncorvo de Figueiredo, Carlos Arthur Moncorvo Filho (1871-1944) followed the vocation of his father toward medicine, becoming known for his untiring fight for social and medical care for children, which brought to him recognition as the precursor of the policies of child protection in Brazil. For up to the beginning of the $\mathrm{XX}^{\text {th }}$ century, child care was restricted to those orphans or abandoned children in the "rounds" of the Homes for Abandoned Children. Only from the middle of the XIX ${ }^{\text {th }}$ century was care extended to poor children in the country, which began to include medical, hygienic and pedagogic aspects.

Inspired, among other things, by French organizations such as Goûttes de Lait, the ideological and institutional model proposed by Moncorvo Filho in his crusade on behalf of children was in harmony with the republican debate on the construction of nationality - where the children represented the future of the nation -, and the reform project based on hygiene. And although he did not achieve the desired governmental backing, it became the embryo of the child care actions that would be developed in Brazil, especially from the decade of the 1930's.

The Institute of Child Care and Protection (IPAI) was the administrative center of the project created by Moncorvo Filho directed toward educational campaigns and mother/child care, and rapidly transformed itself into a reference for a network of institutions created throughout Brazilian territory. Founded on March $24^{\text {th }}, 1889$, in Rio de Janeiro, IPAI functioned for the first two years in the doctor's own residence, at Rua da Lapa, 93, being later transferred to a rented building at number 22, of Rua Visconde do Rio Branco, until its own headquarters were constructed, in 1914, on land donated by the then president, Marechal Hermes da Fonseca at Rua do Areal - later denominated Rua Moncorvo Filho.

The Institute's building, of two floors, followed an eclectic model, with balustrades, columns, arches, and alcoves which gave to it the imposing appearance of a palace. As for its objectives, IPAI proved itself to be equally ambitious: to study the living conditions of poor children, control the wet nurses, supervise child labor, inspect schools, promote vaccination campaigns, and disseminate knowledge about child rearing, among other things, with the desire to work in strict cooperation with the public authorities in the protection of Brazilian children.

To Moncorvo Filho, IPAI constituted only the foundation of a greater undertaking. Thus, in 1919 the Department of the Brazilian Child was founded, with the objective of producing information about the situation of children in the country, installing itself in the same building. But despite the praise and encouragement for his work and the Institute having been recognized as a public utility by decree 139 , of 09/17/1909, the movement for the protection of children remained as if it were a personal crusade of the doctor, who maintained both IPAI as well as the Department of the Child at his own expense until 1938; only two years later, the Federal Government would create the National Department of the Child, under the authority of the Ministry of Education and Health. 


\section{FIRST REPUBLIC}

The weight of his 70 years, the presumption of the proximity of his death and the desire to preserve his work inspired Moncorvo Filho to offer the installations of IPAI to the city hall of the Federal District. By decree-law 3472, of July $26^{\text {th }}$, 1941, the President of the Republic authorized the donation of all the assets of IPAI and of the Department of the Child, estimated at nine million Cruzeiros. The building - which occupied from number 90 to 100 of Rua Moncorvo Filho came to be denominated, as from September of that same year, the Moncorvo Filho Hospital, being installed there, the clinics of the city hall and of the National Faculty of Medicine. At the inauguration ceremony of the Hospital, on July $25^{\text {th }}, 1942$, the Minister of Education and Health, Gustavo Capanema, the Mayor, Henrique Dodsworth, the Rector of the University of Brazil, Raul Leitão da Cunha, the Director of the Faculty of Medicine, professor Fróes da Fonseca, and innumerous authorities were present and Dr. Celso de Sá Brito assumed the position of director of the Hospital. In January of 1951, a contract signed between the city hall of the Federal District and the University of Brazil would transfer the useful dominion of the Moncorvo Filho Hospital to the Faculty of Medicine, which promised to continue caring for patients who up to then were attended jointly by the municipality.

Until the construction of the Clinical Hospital of the University was concluded, it was therefore the Moncorvo Filho Hospital - as well as the Santa Casa de Misericórdia and in the São Francisco de Assis Hospital - that the clinical disciplines of the course of medicine were administered. From the five branches of clinical medicine, installed in the 250 beds of its infirmaries, originated, among others, the Gynecology Service, under the direction of professor Arnaldo de Moraes, the Kidney Pathology Section, created by professor José Augusto Aguiar, and the Cardiology Service, which had as its titleholder, Dr. Luiz Capriglione - embryos of the future specialized Institutes.

At present, the Institute of Gynecology of UFRJ - created at the beginning of the 1940's in the Estácio de Sá Hospital, by doctor Arnaldo de Moraes and transferred in 1942 to the Moncorvo Filho Hospital - continues to be installed in the annexes of the Moncorvo Filho Hospital, as one of the hospital units of the Faculty of Medicine of the Federal University of Rio de Janeiro (UFRJ), being specialized both in the academic part, as well as in the services offered.

At the location the Luiz Capriglione State Institute of Diabetes and Endocrinology (IEDE) still functions, an independent institution that succeeded, as from 1967, the Luiz Capriglione Center for Diabetes and Endocrinology, created six years previously in substitution of the old Diabetes Center of the Moncorvo Filho Hospital.

The IEDE occupies the building constructed during the government of Carlos Lacerda (1960-1965) to house it and the services of Diabetes, Endocrinology and Radiology of the Hospital. Its first director was the endocrinologist, Francisco Arduíno. It offers clinical medicine, surgery and pediatric services directly related to its area of work.

\section{Architectural Description:}

The palace style construction of the end of the XIX ${ }^{\text {th }}$ century, was re-modelled in 1914 to house the Institute of Child Care and Protection. On this occasion it received eclectic, classic-looking ornamentation.

The architectural construction, of two floors, is preceded by a front garden. Its volume raises itself some steps (raised cellar) in relation to the land, being accessible by a stairway set in the central body. Its internal layout does not differ from other examples of hospitals, of a pavilion style architecture, with a ground plan in the form of a $U$, with a central administrative body and wards distributed along the attached wings.

The group presents a central body highlighted by a triangular gable supported on four columns and crowned with a domed cover in metallic scales. The ornamental crown work of the windows of the ground floor is a full arch, while on the upper floor it is alternated between a full arch and a straight beam. The lateral bulwarks, highlighted in relation to the central body repeat the ornamentation of the wings, being crowned with low wall with an interrupted ballustrade.

\section{Register of Preservation:}

INEPAC, provisional preservation on January 25 ${ }^{\text {th }}, 1990$ (process E-18/000.112/90). 


\section{FIRST REPUBLIC}

\section{Sources:}

ASSISTÊNCIA Pública - Guanabara: 80 anos de história. Rio de Janeiro: Superintendência de Serviços Médicos (SUSEME); 1972. mimeo.

CARNEIRO, G. Um compromisso com a esperança: História da Sociedade Brasileira de Pediatria, 1910 - 2000. Rio de Janeiro: Expressão e Cultura; 2000.

FERREIRA, L.; FREIRE, M. Higienismo, Feminismo e Maternalismo: ideologias e práticas de proteção à infância no Brasil, 1899 -1940. Estudos do século XX, Coimbra, n. 5, 2005, pp. 301-315.

INSTITUTO ESTADUAL DO PATRIMÔNIO CULTURAL. Bens Tombados. Consulta Hospital Moncorvo Filho. Estado do Rio de Janeiro. Capturado em 02 de out. 2007. Online. Disponível na Internet: http://www.inepac.rj.gov.br/ modules.php?name=Guia\&file=consulta_detalhe_bem\&idbem $=274$.

MONCORVO FILHO, A. Histórico da proteção à infância no Brasil 1500-1922. Rio de Janeiro: Empreza Graphica Editora, 1926.

ROCHA, G. A Faculdade de Medicina da UFRJ: os sentidos da mudança físico-espacial da escola da Praia Vermelha para a Ilha do Fundão. Cadernos de Saúde Coletiva, 13(2), Rio de Janeiro, 2005, pp. 359-386.

ROCHA, J. Introdução à História da Puericultura e Pediatria no Brasil 1500-1882. Rio de Janeiro: s/ed, 1947.

SECRETARIA de Saúde do Estado do Rio de Janeiro. Indicadores e Informações em Saúde. In: http://www.saude.rj.gov.br/ informacoes/bancodad.shtml Acessado em 11/10/07

Sociedade Brasileira de Pediatria. CADEIRA 2 - Carlos Arthur Moncorvo Filho (1871-1944). Capturado em 05 de nov. 2007. Online. Disponível na Internet: http://www.sbp.com.br/show_item.cfm?id_categoria=74\&id_detalhe=1274\&tipo=D.

WADSWORTH, J. Moncorvo Filho e o problema da infância: modelos institucionais e ideológicos de assistência à infância no Brasil. Revista Brasileira de História. São Paulo, v. 19, n. 37, 1999, pp. 103-124.

www.inepac.rj.gov.br. Acessado em 06/08/2007.

Credits: Martha Freire (research and text); Inês el Jaick Andrade (architectural description). 


\section{FIRST REPUBLIC}
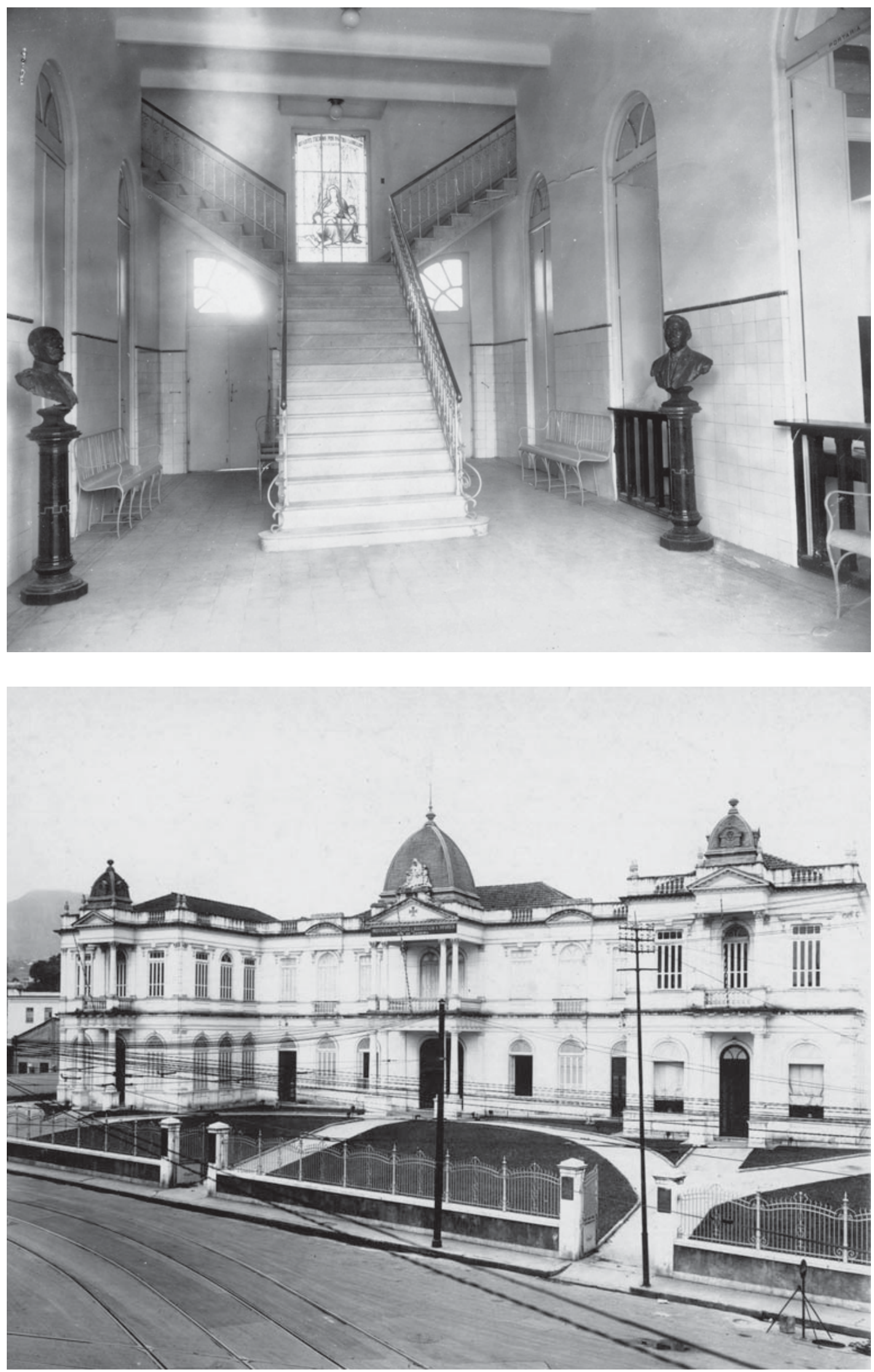

Entrance of Moncorvo

Filho Hospital, [s.d.]. Museu da Imagem e do Som, RJ Archives

Institute of Child Care and Protection - façade, [s.d.]. Museu da Imagem e do Som RJ Archives 


\section{FIRST REPUBLIC}

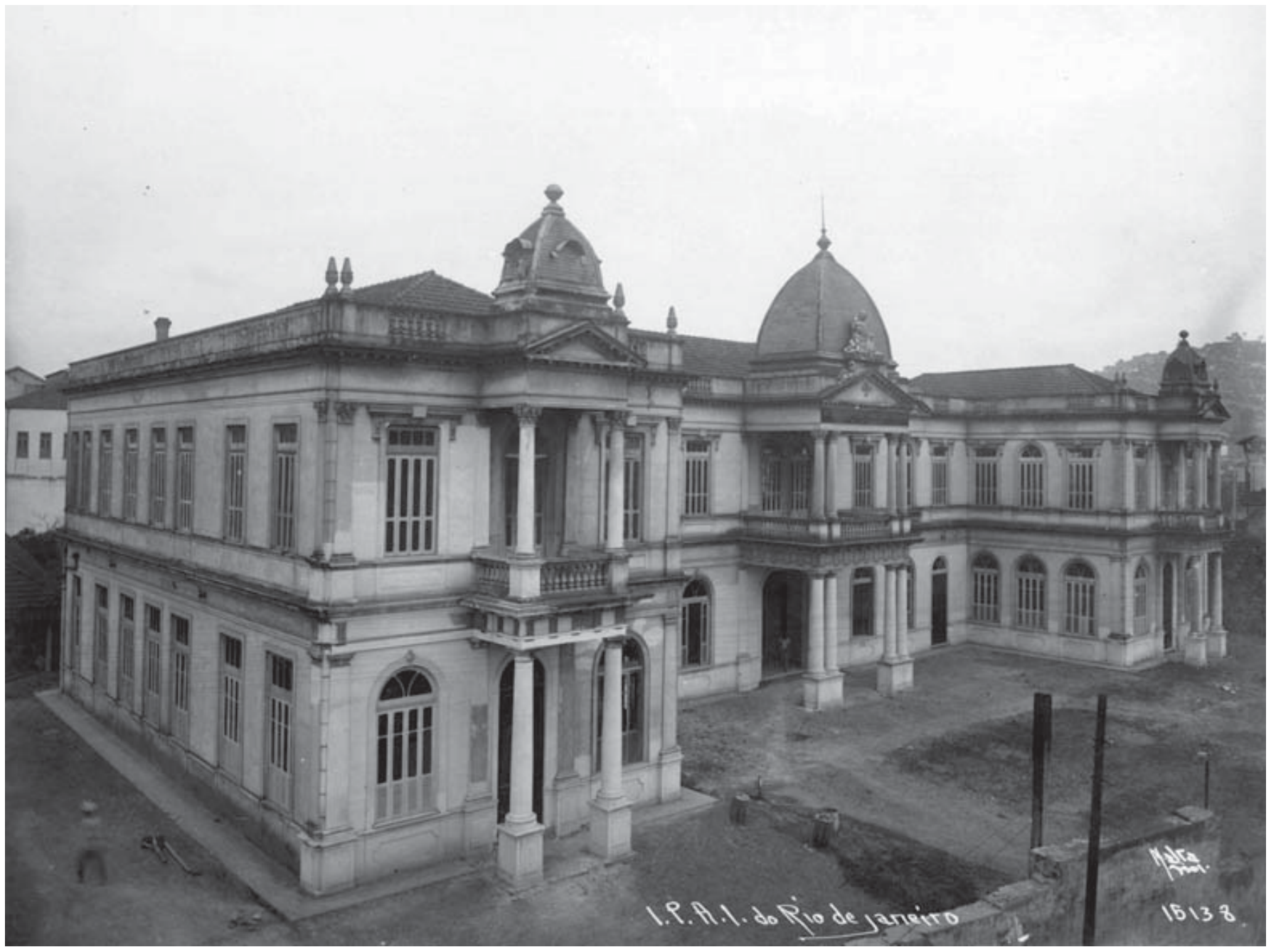

[Construction of the IPAI], [s.d.]. Augusto Malta Photo. Museu da Imagem e do Som - RJ Archives 


\section{FIRST REPUBLIC}

\section{National Analysis Laboratory}

Other denominations: Laboratory of the State (1889-1890); National Analysis Laboratory (1890-present day).

Location: Saúde.

Address: Avenida Rodrigues Alves, 81

Category: Laboratory.

Period of construction: 1944.

Proprietor: Federal Inspectorate Revenue Service of Rio de Janeiro Port (Inspetoria da Receita Federal do Porto do Rio de Janeiro).

Author / Constructor: José Afonso Soares, Aristides Figueiredo and Edson Nicol (project).

\section{History:}

Decree no. 10.230, of April 13 ${ }^{\text {th }}$, 1889, established that the service of analyses and examinations of drinks and foodstuffs would no longer be an attribution of the Hygiene Laboratory of the Faculty of Medicine of Rio de Janeiro, and that for this purpose the State Laboratory was being created, in the city of Rio de Janeiro. The institution was inaugurated on October $14^{\text {th }}, 1889$, and set up at Rua Visconde de Itaboraí, in front of Rua Teófilo Otoni. The building (present Casa França-Brasil (France-Brazil House)), that would house all the apparatus of the laboratory, had been designed by the French architect Grandjean de Montigny, in 1819, with the objective of being Praça do Comércio (Commercial Block). However, it had its function modified over time, being the headquarters of the Customs of Rio de Janeiro up until the year 1944.

Decree no. 277-G, of March 22nd, 1890, altered the name of the institution to the National Analysis Laboratory, and connected it to the Ministry of the Interior. However, this connection was modified by law no 26, of December $30^{\text {th }}, 1891$, that determined that the National Analysis Laboratory should come to be under the administration of the Ministry of Finance, which was ratified in 1892 (decree no. 1.166, 12/17/1890).

The functioning of the National Analysis Laboratory was defined, initially, by decree no. 10.231, of April 13 ${ }^{\text {th }}, 1889$, according to which the Laboratory would be responsible for the analyses and examinations determined by the Imperial Government, requested by the General Hygiene Inspectorate and Customs Inspectorate, or requested by private individuals. The staff would include a Director, sub-director, six chemists, a book-keeper-pharmacist, a secretary and a caretaker/ maintenance man.

Law no. 813, of December 23rd, 1901, defined as obligatory the sending of all food and drink products to the National Analysis Laboratory, bringing it closer to the Customs Laboratory.

The year 1920 was marked by the expansion of establishments along the lines of the National Analysis Laboratory. The customs offices of Santos, Porto Alegre, Corumbá, Bahia, Recife, Paraíba, Fortaleza, Maranhão, Belém and Manaus would have in the laboratories, created at their locations, partners to guarantee that no product harmful to public health would enter into the country and also to classify the products in a correct manner, with the objective of charging fees in accordance with the regulations in force.

As from 1939 a discussion was started about new customs facilities which also included a new space for the National Analysis Laboratory. The headquarters was transferred to a new address, located at Avenida Rodrigues Alves, no. 81. Later, it came to be denominated Analysis Laboratory, its present name. Today the Analysis Laboratory, connected to the Inspectorate of the Federal Revenue Service of the Port of Rio de Janeiro, still operates at Avenida Rodrigues Alves, no. 81.

\section{Architectural description:}

The building of the Analysis Laboratory, located at Av. Rodrigues Alves, no. 81, was designed by José Afonso Soares, Aristides Figueiredo and Edson Nicol. Inaugurated in 1944, it was set aside for the installation of the customs office next 


\section{FIRST REPUBLIC}

to the Quay of the Port, near Warehouse no. 1, for up to that date the customs office used to be located near to the quay at Praça Quinze, on the site of the present Casa França-Brasil.

The building has three inter-connected blocks: the central building, of four floors and a tower, 35 meters high and $7,778 \mathrm{~m}^{2}$, constructed to house the Administrative Office of Customs Revenues and the Inspectorate of the Customs of Rio de Janeiro; a guard-house with 1,530 $\mathrm{m}^{2}$ is at the right, and to the left, the Analysis Laboratory, with $1,334 \mathrm{~m}^{2}$.

\section{Register of Preservation:}

INEPAC. Process n. E-18/001.539/98; Temporary Preservation Order: 12.09.1998.

\section{Sources:}

BRASIL. Decreto n ${ }^{\circ}$ 1.166, de 17 de dezembro de 1892. In: Collecção das Leis do Brasil da República dos Estados Unidos do Brasil de 1892, Partes I e II. Rio de Janeiro: Imprensa Nacional, 1893.

BRASIL. Decreto n 277 G, de 22 de março de 1890. In: Decretos do Governo Provisório da República dos Estados Unidos do Brasil, $3^{\circ}$ fascículo. Rio de Janeiro: Imprensa Nacional, 1890.

BRASIL. Decreto n ${ }^{\circ}$ 7.751, de 16 de dezembro de 1909. In: Collecção das Leis do Brasil da República dos Estados Unidos do Brasil de 1909, Partes I e II. Rio de Janeiro: Imprensa Nacional, 1913.

BRASIL. Decretos no 10.231 e 10.232 de 13/4/1889. In: Colleção de Leis do Império do Brazil de 1889. Rio de Janeiro: Imprensa Nacional, 1889.

CENTER FOR RESEARCH LIBRARIES E LATIN AMERICAN MICROFORM PROJECT . Projeto de Imagens de Publicações Oficiais Brasileiras. Capturado em 05 de jul. 2006. Online. Disponível em: http://www.crl.edu/content/pindex.htm

FARIA, L. Reminiscências do Laboratório Nacional de Análises. Revista da Sociedade Brasileira de Química, Rio de Janeiro, v. XIX, nº 3-4, jul.-dez., 1950.

GONÇALVES, A. Difusão da química no Brasil, 1808-1934. Rio de Janeiro: Sobrerodas, 1993.

INEPAC. Instituto Estadual do Patrimônio Cultural. Guia de Bens Tombados - Consulta de Bem. Capturado em 18 nov. 2007. Online. Disponível na Internet: http://www.inepac.rj.gov.br/modules.php?name=Guia\&file =consulta detalhe_bem\&idbem=239

LABORATÓRIO Nacional de Análises. Annuario Medico Brasileiro, Rio de Janeiro, ano V, 1890.

MEMÓRIA Receita Federal. Capturado em 18 nov. 2007. Online. Disponível na Internet: http://www.receita.fazenda.gov.br/ Memoria/administracao/reparticoes/1822a1970/1822a1970L.asp

Credits: Carlos Frederico da Silva Reis (research, text and architectural description). 


\section{FIRST REPUBLIC}

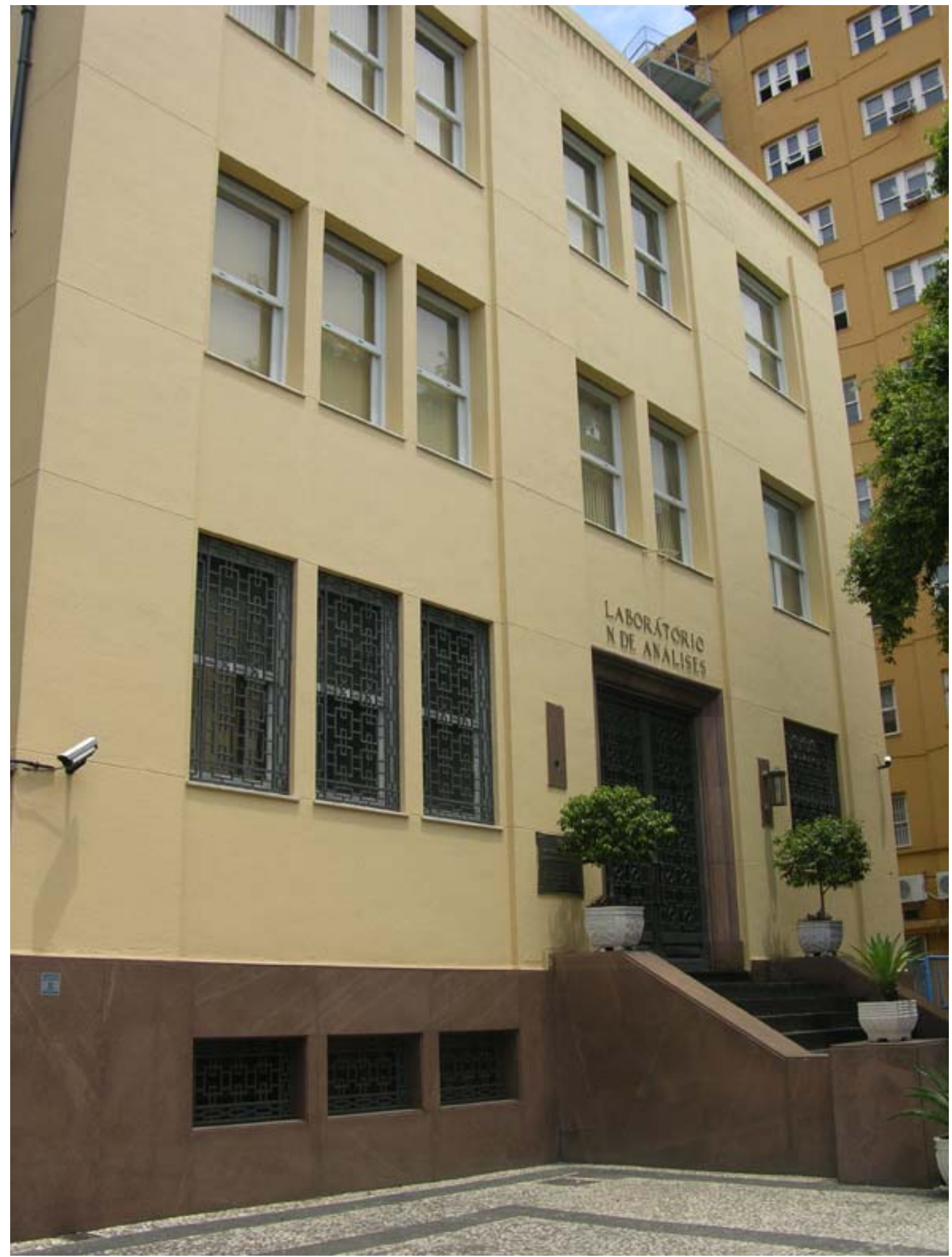

National Analysis Laboratory. Photo Roberto Jesus Oscar \& Vinícius Pequeno de Souza, 2008. Casa de Oswaldo Cruz Archives 


\section{FIRST REPUBLIC}

\section{Nise da Silveira Health Assistance Municipal Institute}

Other denominations: Women's Psychopath Colony of Engenho de Dentro (1911-1938); National Psychiatric Center (1938-1965); Pedro II Psychiatric Center (1965-2000); Nise da Silveira Health Assistance Municipal Institute (2000present day)

Location: Engenho de Dentro

Address: Rua Ramiro Magalhães, 521

Category: Specialized Hospital - Psychiatry

Period of construction: Old Republic - XX Century

Proprietor: City Hall of the City of Rio de Janeiro

Author / Constructor: unknown

History:

The origins of the Nise da Silveira Institute date back to the demands stemming from the National Asylum, created in 1841, in Praia Vermelha, Rio de Janeiro. In an era in which psychiatry still had not developed its theoretical scientific base, the Asylum was destined to treat people who suffered from mental illnesses despite of their social class; it even encompassed alcoholics as being mad. As such, it was not long until the institution showed an alarming sign of overcrowdedness, which, naturally, was not conducive for any type of therapy.

Such condition persisted until the beginning of the XX century, when Juliano Moreira became its director in 1903. Seeking to implant a more efficient asylum treatment, he began to defend, along with the Legislative Branch of government, the release of resources for the construction of new agricultural colonies, since São Bento and Conde de Mesquita, both in Governor's Island (Ilha do Governador), no longer accommodated the increase in the number of patients, mainly women. Since the cited colonies were destined for male patients, there sprung the need to found an establishment which could house the female excess of the Asylum. With this in mind, by means of decree no. 8.834of 06/11/1911, the Women's Psychiatric Colony of Engenho de Dentro was founded, nominating doctor Simplício de Lemos Braule Pinto as its director, a psychiatrist of the National Asylum. It was only inaugurated under its official name - Women's Psychopath Colony of Engenho de Dentro - in August, occupying a property on the hillside of the Morro dos Pretos Forros, in a location which today corresponds to Rua Dias da Cruz, in the district of Méier. The building where the Colony was installed had originally been a glass factory, which during a smallpox epidemic in 1908, was destined by Oswaldo Cruz, General Director of Public Health on the occasion, to house the Smallpox Hospital.

Given the high number of women, the Colony of Engenho de Dentro's mission was not agricultural, like had been the ones in Ilha do Governador, and there prevailed manual tasks (sewing, weaving, handcrafting, manufacturing) as instruments of occupational treatment, which, later, would prove to be the basis for the establishment of the Museum of the Unconscious (1952).

Although in the forefront of the therapeutic treatment of mental illness, the Women's Psychiatric Colony of Engenho de Dentro, throughout the administration of Braule Pinto, exercised a function complementary to the National Asylum Hospital. Upon his passing, on September $18^{\text {th }}, 1918$, Doctor Gustavo Riedel assumed the directorship of the Women's Psychiatric Colony of Engenho de Dentro, which began to develop a series of modifications at the institution, measures which influenced the country's ideology concerning psychiatric assistance at the time. It was his the initiative to create the first psychiatric polyclinic in Latin America, in February, 1921, called Rivadávia Correa Polyclinic, under the administration of Doctor Plínio Olinto. The polyclinic had consultations rooms of medical clinic, surgery, pediatrics, gynecology, in addition to services for nervous and mental illnesses, laboratories for the necessary research to obtain a good diagnosis, with the intention to combine the knowledge of etiology and mental prophylaxis. 


\section{FIRST REPUBLIC}

Also created by Gustavo Riedel was the Mental Hygiene Monitoring Service, integrated to the Rividávia Correia Polyclinic, with the function to accompany the mental patients even once outside the colony, allowing for psychiatric services to go beyond the boundaries of the hospital. The director even developed other projects so called "open services", which had the objective to receive patients who did not need hospitalization or simply needed short term ones. A pavilion was destined for the treatment of patients with curable acute mental illnesses or drug addictions, denominated Presidente Epitácio Pavilion, consisting of infirmaries, rooms, cafeteria and internal garden.

Still, in 1921, the Alfredo Pinto School was founded, a "nursing school" annexed to the Colony. His creation sought to improve the professional qualification of the nurses in the field of psychiatry. Two years later, Riedel founded the Experimental Psychology Laboratory of the Women's Psychopath Colony of Engenho de Dentro, which was transformed into the Psychology Institute in 1932, an extension of the Psychology and Psychiatry chair of the University of Brazil.

Since the onset of his administration as head of the National Psychiatric Hospital, Juliano Moreira, had begun to formulate the idea of family colonies as a new modality of treatment. Denominated hetero-familial assistance, it sought to create for the patient a surrogate family, thus producing the "illusion of the family". This new treatment had been proposed in the second article of the same decree which established the Women's Psychiatric Colony of Engenho de Dentro, however it was only introduced in 1921, when Riedel implanted the Family Assistance Service, by building 11 houses which would be leased to the families of the nurses willing to care for two or more patients. The family assistance services inside the Colony were interrupted in 1927.

In 1937, the National Psychiatric Hospital started to admit all of the indigent mental patients, and once again generated a new overcrowding crisis among hospitalized patients. The building inaugurated as D. Pedro II was in a state of decadence, badly preserved, and no longer apt to house patients. Without the necessary budgetary provisions for the renovations of the installations, in January, 1944, the National Psychiatric Hospital was deactivated. As a result, the process of incorporating the archives and transfer of the patients to Pedro II Hospital, an extension of the Women's Psychiatric Colony, which since 1938 was called the National Psychiatric Center, began to occur.

In the same year in 1944, Nise da Silveira assumes the directorship of the Occupational Therapy Section of the National Psychiatric Center. She introduces a new method of treatment and understanding of schizophrenia through activities of open expression. This new understanding was based upon the idea that the unconscious could be revealed by means of the images configured in the plastic expression expressed by the patients. As a natural evolution of the works performed at the painting and modeling studios of the Occupational Therapeutic Section, the Museum of the Images of the Unconscious was founded on May $20^{\text {th }}, 1952$, in Engenho de Dentro.

In virtue of the decree-law no. 55.474of 1965, in tribute to the Emperor D. Pedro II, who had inaugurated the first psychiatric hospital in the country in 1852, the National Psychiatric Center received the name of Pedro II Psychiatric Center (CPP-II).

The CPP-II received the new denomination following the death of Nisa da Silveira in 1999. In the same year, the hospital was municipalized, together with other federal hospital institutions. In tribute to the psychiatrist, it was instituted by means of decree no. 18.917of 09/05/2000, the change of the former Pedro II Psychiatric Center to Nise da Silveira Health Assistance Municipal Institute.

\section{Register of Preservation:}

It is not listed.

\section{Sources:}

DIAS, P. Arte, Loucura e Ciência no Brasil: as origens do Museu de Imagens do Inconsciente. Rio de Janeiro: Programa de PósGraduação em História as Ciências e da Saúde. Casa de Oswaldo Cruz, 2003. (Dissertação de mestrado)

ENGEL, M. Os delírios da razão: médicos, loucos e hospícios (Rio de Janeiro, 1830-1930). Rio de Janeiro: Ed. Fiocruz; 2001. 


\section{FIRST REPUBLIC}

OLIVEIRA, E. Engenho de Dentro do lado de fora: o território como um Engenho Novo. Rio de Janeiro: Fundação João Goulart, 2004.

RAMOS, F. ; GEREMIAS, L. Instituto Philippe Pinel: origens históricas. Capturado em 02 de mar. 2007. Online. Disponível na Internet: http://www.sms.rio.rj.gov.br/pinel/media/pinel_origens.pdf

RELATÓRIO do Diretor da Colônia de Alienadas do Engenho de Dentro ao Diretor do Hospício Nacional dos Alienados relativo ao ano de 1911.

Credits: Natália Morais and Atiele Azevedo de Lima Lopes (research and text) 


\section{FIRST REPUBLIC}

\section{Oswaldo Cruz Foundation}

Other denominations: Federal Serotherapy Institute (1900-1907); Institute of Experimental Pathology (1907-1908); Oswaldo Cruz Institute (1908-1969); Health Human Resources Foundation (1969-1970); Oswaldo Cruz Institute Foundation (Fiocruz) (1970-1974); Oswaldo Cruz Foundation (1974-currently).

Location: Manguinhos.

Address: Av. Brasil, 4365.

Category: Research Institution.

Period of construction: as of 1904.

Proprietor: Federal Government.

Author/constructor: Luiz Moraes Junior (eclectic buildings of the Manguinhos Historical Nucleus); Department of Construction Works of the Ministry of Education and Health (1934-1977).

\section{History:}

The Oswaldo Cruz Foundation originated from the Federal Serotherapy Institute, created on May $25^{\text {th }}, 1900$ by Pedro Affonso Franco, Baron of Pedro Affonso, with the task of producing serum and vaccines to fight the epidemics that threatened the Federal Capital, in the beginning of XX century - especially the bubonic plague and yellow fever. During an epidemic, the institute was installed at the former Fazenda de Manguinhos (Manguinhos Farm), which belonged to City Hall of the city of Rio de Janeiro and, a long time ago, had been property of the Jesuits, located on the margin of Guanabara Bay, between Ponta do Caju and Cais de Inhaúma. In 1892, the farm was expropriated for the installation of garbage incinerating furnaces and the medical-sanitarian needs adapted it to their new functions.

On May $26^{\text {th }}$, 1900, Baron of Pedro Affonso, who was responsible for the organization and administrative direction of the Institute, informed the General Director of Public Health, Nuno Ferreira de Andrade, the names and categories of the personnel employed in the laboratory and their corresponding remunerations. Among the "technical personnel" were the following names: Oswaldo Gonçalves Cruz, Ismael da Rocha, Henrique Figueiredo de Vasconcellos and Ezequiel Caetano Dias (student). José Muniz de Medeiros, Artur Leite, Manoel Dias Cordeiro and Miguel Ferreira dos Santos also integrated the team. Furthermore, the Baron requested a guard and travelling passes for the Estrada de Ferro do Norte (North Railway) and the continuation of vaporized ferry services to take the personnel to the laboratory. On July $23^{\text {rd }}$, 1900, the Federal Serotherapy Institute was inaugurated, with the presence of several authorities and famous persons, according to the media coverage at the time.

The Baron resigned on December $9^{\text {th }}, 1902$ and Oswaldo Cruz took over the general management of the Institute. Oswaldo Cruz introduced a new orientation in the activities of the Institute, resulting in his nomination for the General Management of Public Health in the following year.

As of 1903, the institute was transformed into an institution of clinical research, and, in the same year, started the construction of the ambitious architectonic complex, which replaced the modest facilities of the Serotherapy Institute. The project was handed over to the Portuguese engineer, Luiz Moraes Júnior, who, in 1905, started the excavations for the main building, the Mourisco Pavilion, finished only in 1918.

In 1907, the Federal Serotherapy Institute changed its name to Experimental Pathology Institute, expressing the orientation of the activities which came to prevail under the administration of Oswaldo Cruz and, in 1908, when Oswaldo Cruz received an important award at the Demography and Hygiene Exhibition in Berlin, the Institute was officially named after its director who returned to Brazil as a national hero.

As of 1908, the Experimental Pathology Institute expanded the activities of the institute to become a center of production, research and biomedical learning in the field of microbiology. In 1909, the discovery of the biological cycle of Chagas' 


\section{FIRST REPUBLIC}

Disease, by Carlos Chagas - who would succeed the administration of the institute after Oswaldo Cruz (1917-1934) -, occasioned the construction of a hospital for the treatment and studies of diseases coming from the countryside, especially from the most affected areas.

In addition to being active in the urban centers and, in particular, in the Federal Capital, as of the end of the first decade of its operations, the Institute began to shift its attention to the countryside, promoting scientific expeditions. Most of the time these expeditions were hired by companies such as the one that constructed the Madeira-Mamoré Railway in the north, which ended up revealing data of critical relevance about living conditions of the countryside populations, influencing the mentality and political policies not only of the doctors and sanitarians, but also of intellectuals and public authorities regarding the priorities when confronting the social issue in Brazil.

In 1926, the Oswaldo Cruz Institute, which at the time was linked to the Ministry of Justice and Internal Affairs, underwent new reorganization by decree no. 17,512 of November $5^{\text {th }}$, which consolidated as objectives of the Institute, the studies of experimental pathology, medical zoology, veterinary medicine, mycology, phytopathology, pathological anatomy, hygiene, public health, physiology and applied chemistry; the preparation of biological and chemical products for the treatment and prophylaxis of human and animal diseases; the preparation of anti-smallpox vaccine; the execution of official medicine services; analysis of vaccine serums and biological products introduced in the market and the realization of practical courses in microbiology, medical zoology and pathologic anatomy.

Among the scientific sections defined under this regulation, which reflected their end results, were Bacteriology and Immunity, Medical Zoology, Mycology and Phytopathology, Pathological Anatomy, Hospitals and Applied Chemistry. As of 1930, the Institute was transferred to the jurisdiction of the Ministry of Education and Public Health, remaining there until 1953, when the field of health was disassociated from education. At this time, it had eight departments (no longer sections), including Endemic Diseases, which was subordinate the Evandro Chagas Hospital, new denomination of the former Oswaldo Cruz Hospital, which had been established in 1919.

As of 1962, the Institute started to have a new regulation that maintained the existing departments and created the new Department of Learning and Documentation, organized to perform applied research and production, thus reaffirming its initial attributions of research, production and learning.

In 1970, the Oswaldo Cruz Institute was integrated into the other institutions linked to the Ministry of Health - the National School of Public Health (ENSP), Figueira Fernandes Institute (IFF), Rural Endemic Diseases Institute (INERU), Evandro Chagas Institute, Leprology Institute and Medicine Production Institute (Ipromed) - receiving the title, Oswaldo Cruz Institute Foundation. The objectives of the new institution included the realization of scientific research in the field of experimental medicine, biology and pathology; the promotion of educational activities and improvement of researchers in biomedical sciences, sanitarians and other health professionals, as well as the preparation and manufacture of biological and prophylactic products and medicines. Four years later, the Oswaldo Cruz Foundation began to include among its objectives, the participation in the formulation, coordination and execution of the Basic Research Health Plan, in agreement with the National Policy of Scientific and Technological Development.

In the mid 1980s, Fiocruz took over the administrative structure which it maintains until today, with assistance agencies linked to the Presidency and their substitutes, Technical-administrative Units, Technical-scientific Units and a Technical Support Unit.

\section{Architectonic description:}

In order to develop the design and the construction of the historic architectonic complex of Manguinhos, Oswaldo Cruz invited the Portuguese architect, Luiz Moraes Júnior (1868-1955), who had just arrived in Brazil to work in the restoration of the Igreja da Penha (Penha Church). During this period, a long-lasting relationship between the scientist and the architect was begun. Moraes was responsible for the design of more than a dozen buildings in Manguinhos, in addition to the disinfection center of Botafogo, currently Rocha Maia Hospital; the head office building of the Public Health Office and the building of the College of Medicine in Rio de Janeiro, in Praia Vermelha. 


\section{FIRST REPUBLIC}

The pavilions, designed by Luiz Moraes, replaced the former facilities of the Federal Serotherapy Institute, created by the Baron of Pedro Affonso. His first projects in Manguinhos were the shipping dock and the small vivarium, installed next to the primitive facilities of the farm in 1903. The first big pavilion to be constructed was the Pest Pavilion, in 1904. Later, in the same year, the Cavalariça building was constructed, and the Mourisco Pavilion, which started being constructed in 1905 when the first ones had already been built. The Aquário building was concluded around 1915 (and demolished in the 1960s), and the Quinino building, or Figueiredo Vasconcellos Pavilion was constructed in 1919 to house the Official Medicines Service. Outside this complex, Moraes also built the Vivarium for small animals, Pombal in 1904, and Oswaldo Cruz Hospital between 1912 and 1917, on another hill of the property, and the Vacínico or Vacinogênico (Vaccinal or Vaccinogenic) Pavilion in 1922 located in the road between the two hills.

The buildings designed by Luiz Moraes Junior are included in the architectonic eclecticism language, where two or more trends of style and decoration mix. The English language is very present in the architecture of the Cavalariça building, for example, and also in the iron elements of its stairs, stalls, rails, grates, luminaries, roof structure, edges, etc.; in equipment, such as scales and vertical elevators; in the use of the composition and revetment material, such as granite and solid brick. On the other side, the Portuguese and Arabic languages mix especially in the main building of this complex, the Mourisco Pavilion or Castle. The decorative reference to the neo-Moorish language was inspired by the Alhambra Palace from de city of Granada, Spain. As a matter of fact, the Arabic language used by Moraes in Manguinhos can be noticed in several constructive and decorative details used in the Castle.

But the rich formal collection is not limited to buildings constructed in the first decades of the XX century. A complex of the same importance was built between 1947 and 1960 and refers to the modern period. The participation of the architects, engineers and constructors at Fiocruz fundamentally encompasses three different periods: from 1903 to 1922; 1937 to 1977; and 1977 until today.

The first period in the chronology includes the participation of the architect-engineer Luiz Moraes Jr., responsible for the design and construction of the first buildings, as already mentioned. His last contribution was in 1922 in the project for the Vacínico or Vacinogênico Pavilion, built after the death of Pedro Affonso. Moraes would supervise the over elevation of the Official Medicines Pavilion, the Quinino, in 1943, at the same time that the building of the College of Medicine in Praia Vermelha also received increments.

The projects developed in Manguinhos, as of the ministerial reform of January 1937, originated from the Department of Construction Works of the Ministry of Education and Health. Created in the first administration of Getúlio Vargas, this department would change, in the five decades that followed, the relationship among the architects and the institution. That is, projects would no longer be developed by a single professional but by a team, and through a management agency of the ministry and not directly by the Institute.

During its lifetime, the Department of Construction Works, from 1934 to 1977, developed about 20 new projects at the Oswaldo Cruz Institute with effective building and several services of restoration and increments, including the over elevation of the Official Medicines Pavilion (Quinino).

During this period, it is worth noting the construction of buildings whose style tried to absorb the formal language of the modern carioca school of architecture. The two most representative projects of this collection - the Cursos Pavilion and the Refeitório Central Pavilion - were created by Jorge Ferreira, and were endowed by the State of Rio de Janeiro. The list is completed by the Entrance on Avenida Brasil (1954-1955), of Nabor Foster; and by the Febre Amarela Pavilion (1954-1960), of Roberto Nadalutti. This last project was developed by the architecture team of the Special Service of Public Health (SESP), which Nadalutti was part of. In all these examples the five essential points of this language are present in whole or in part: ground floor with pillars; independent structure; horizontal openings; terrace-garden and free façade.

After the construction of Brasília, in 1960, started the dismembering and reduction of funds for the Department of Construction Works of the Ministry of Education and Health, formerly divided into two ministries, Health and Education. In this context the architects of the Department were gradually transferred to several units throughout Brazil. 


\section{FIRST REPUBLIC}

After the definitive extinction of the Department of Construction Works, the projects for the Institute, already transformed into the Oswaldo Cruz Foundation, began to be publicly bid on. Thus, Fiocruz itself would regulate and carry out the works of restoration and construction, as well as the maintenance services of the buildings, facilities and equipment.

\section{Register of Preservation:}

January, 1981. Proceeding no. 1,037-T of the National Institute of Patrimonial History and Art (IPHAN) the buildings of the eclectic period - Mourisco Pavilion, Cavalariça, Relógio Pavilion, Quinino, Pombal and Evandro Chagas Hospital. October, 2001, proceeding E-18/001-538/98 of the State Institute of Artistic and Cultural Endowments of Rio de Janeiro (INEPAC) - the buildings of the modernist period.

\section{Sources:}

BENCHIMOL, J. (Coord.). Manguinhos do sonho à vida. A ciência na Belle Époque. Rio de Janeiro: Casa de Oswaldo Cruz; 1990.

GUIA Casa de Oswaldo Cruz. Departamento de Arquivo e Documentação. Rio de Janeiro: COC/FIOCRUZ; 1995.

OLIVEIRA, B.; COSTA, R.; PESSOA, A. Um Lugar para a Ciência: a formação do campus de Manguinhos. Rio de Janeiro: Editora Fiocruz; 2003.

Credits: Renato da Gama-Rosa Costa and Maria Rachel Fróes da Fonseca (research and text); Renato da Gama-Rosa Costa (architectonic description). 


\section{FIRST REPUBLIC}

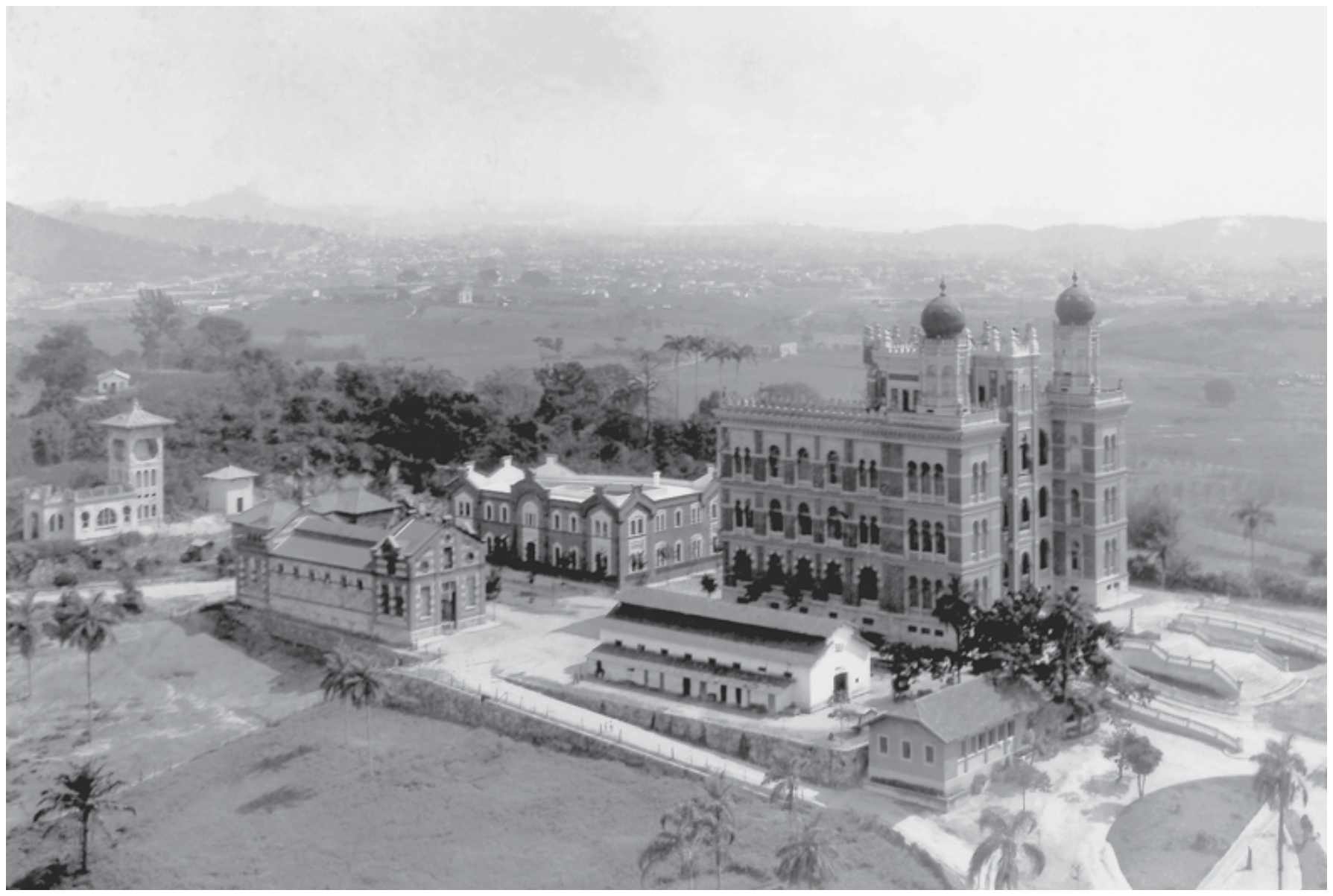

Air view of Oswaldo Cruz Institute, [1920]. Casa de Oswaldo Cruz Archives 


\section{FIRST REPUBLIC}

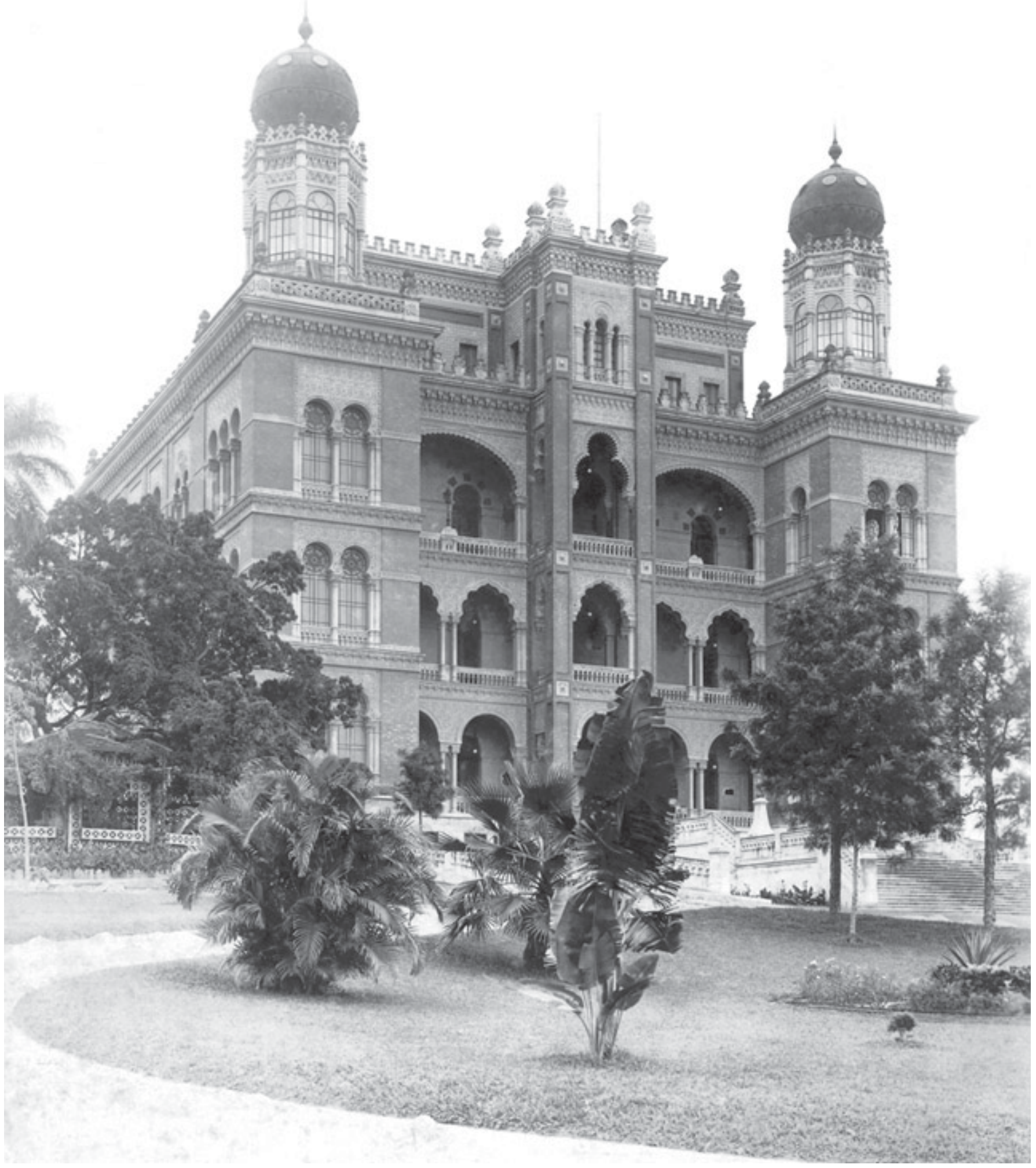




\section{FIRST REPUBLIC}

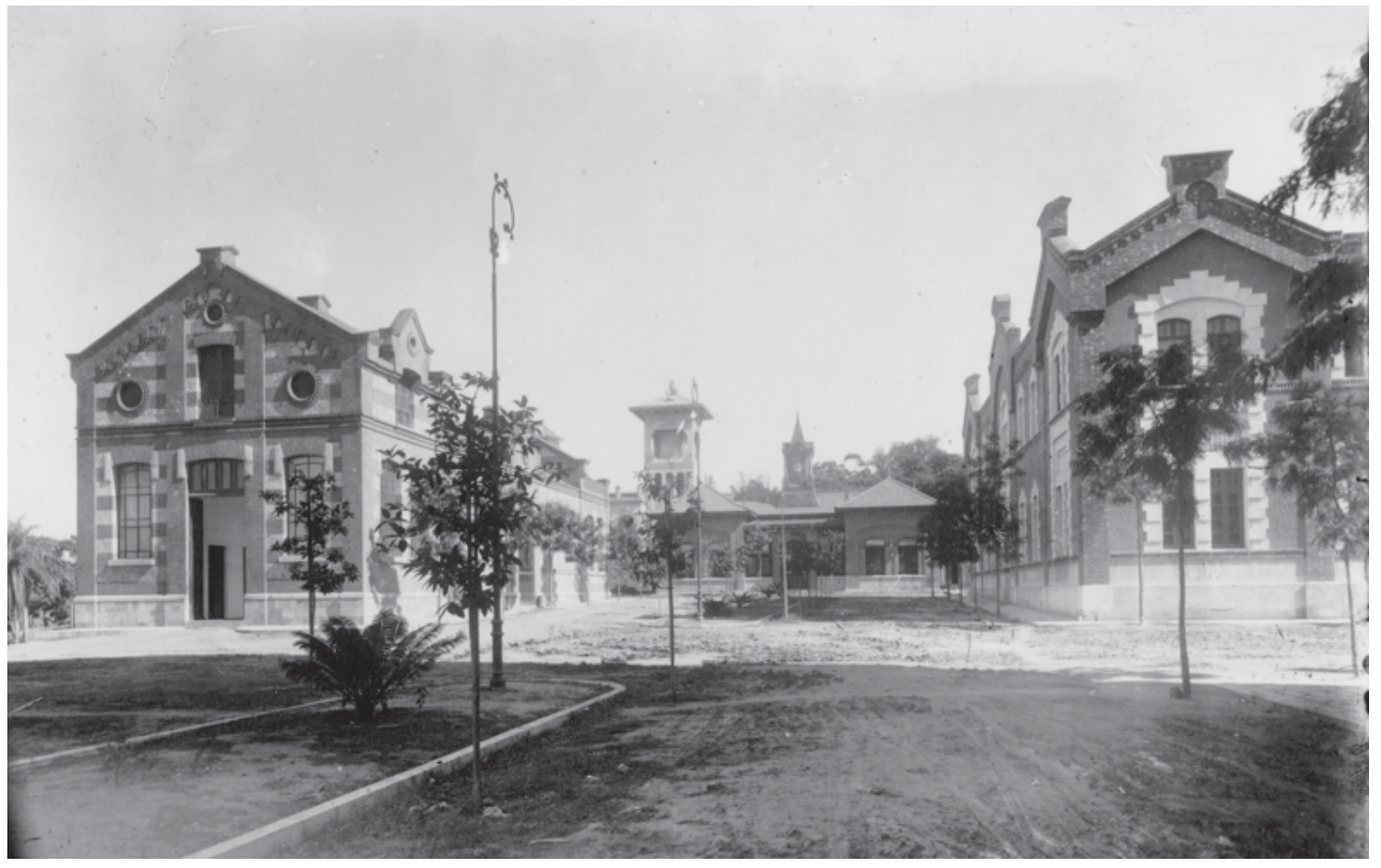

View of Pasteur Square [s.d.]. Casa de Oswaldo Cruz Archives

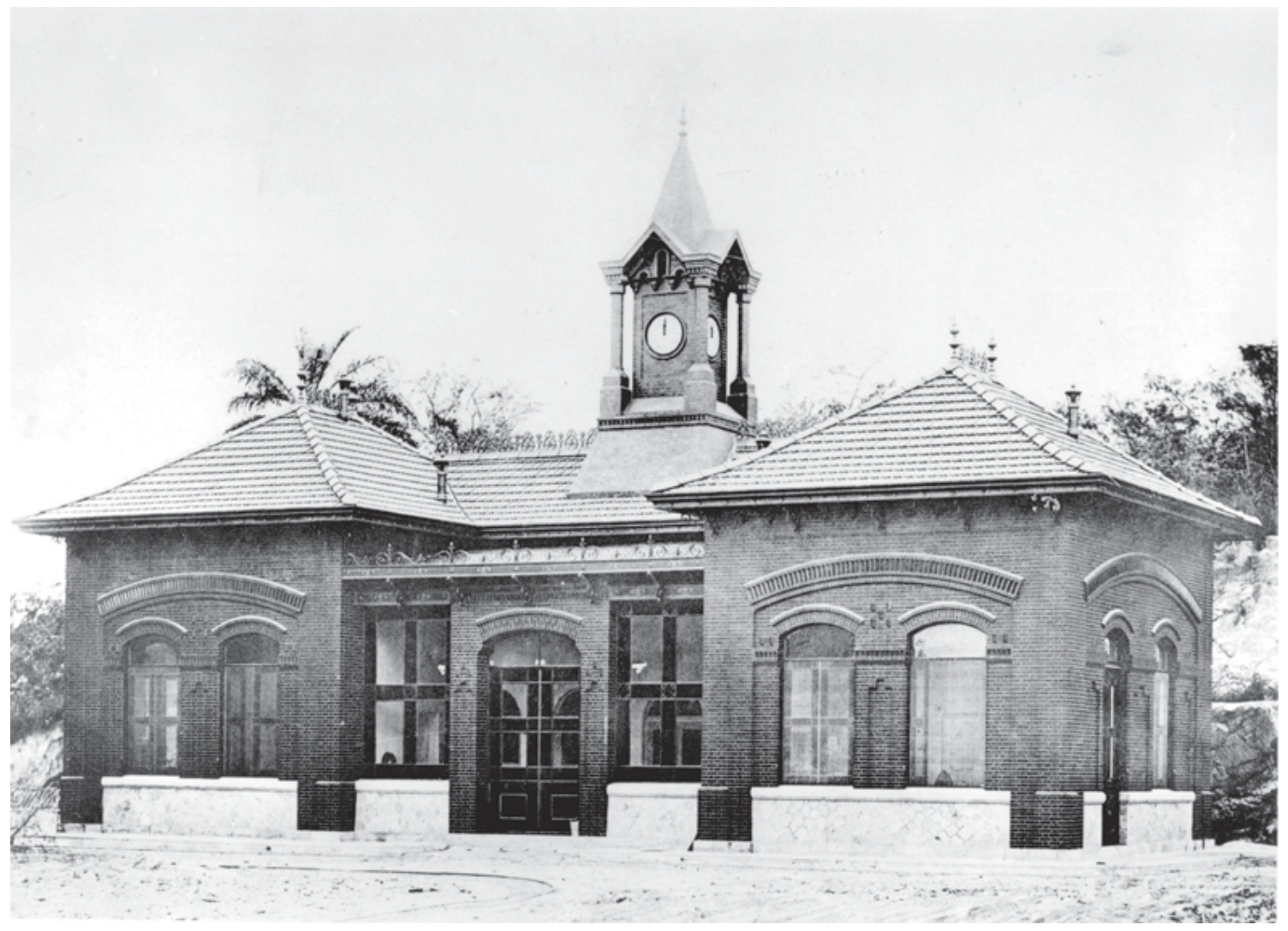

View of Pavillon Clock (or Pavillon Plague), [s.d.]. Casa de Oswaldo Cruz Archives 


\section{FIRST REPUBLIC}

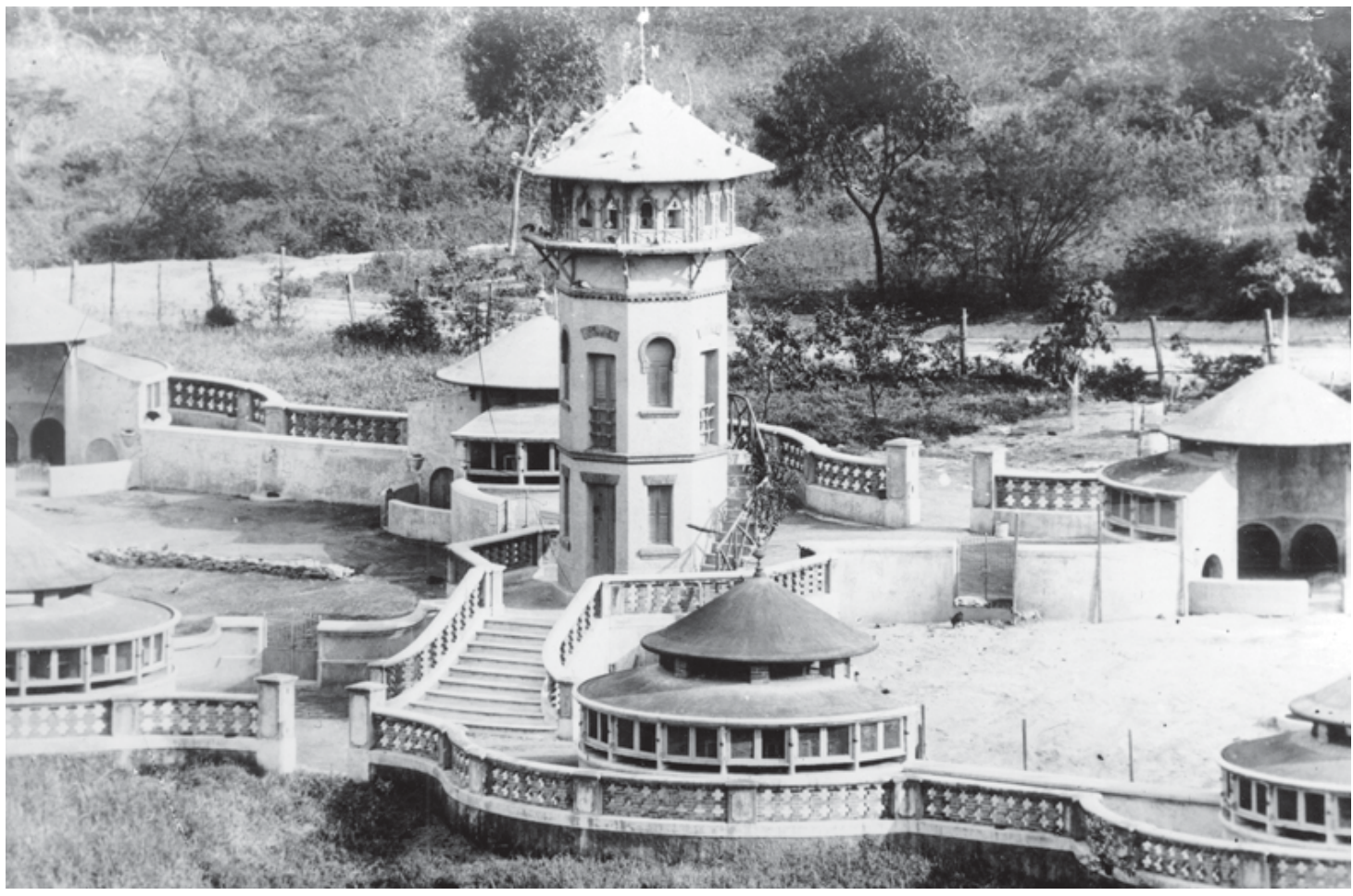

View of Pombal, [s.d.] Casa de Oswaldo Cruz Archives

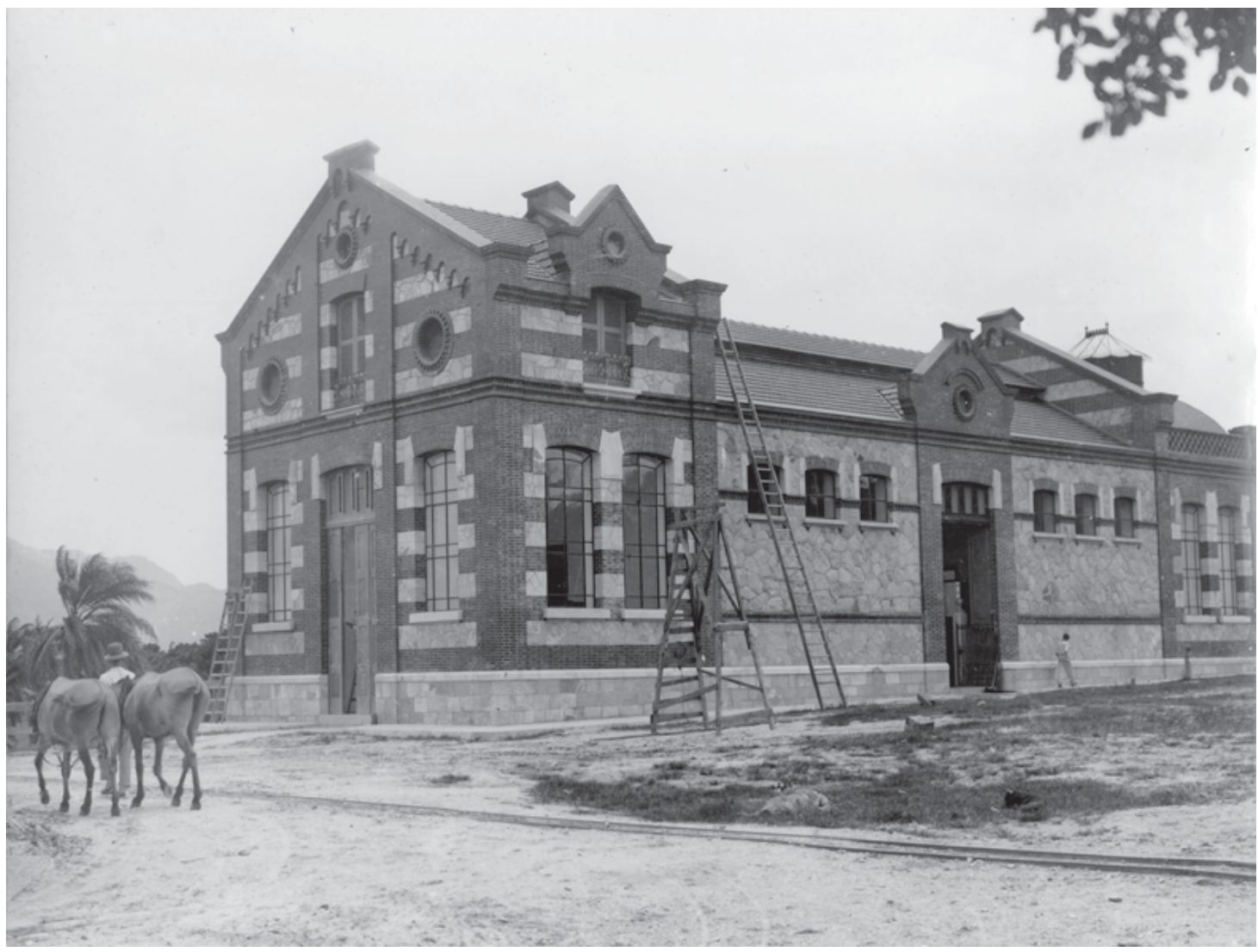

View of Stable, [s.d.]. Casa de Oswaldo Cruz Archives 


\section{FIRST REPUBLIC}

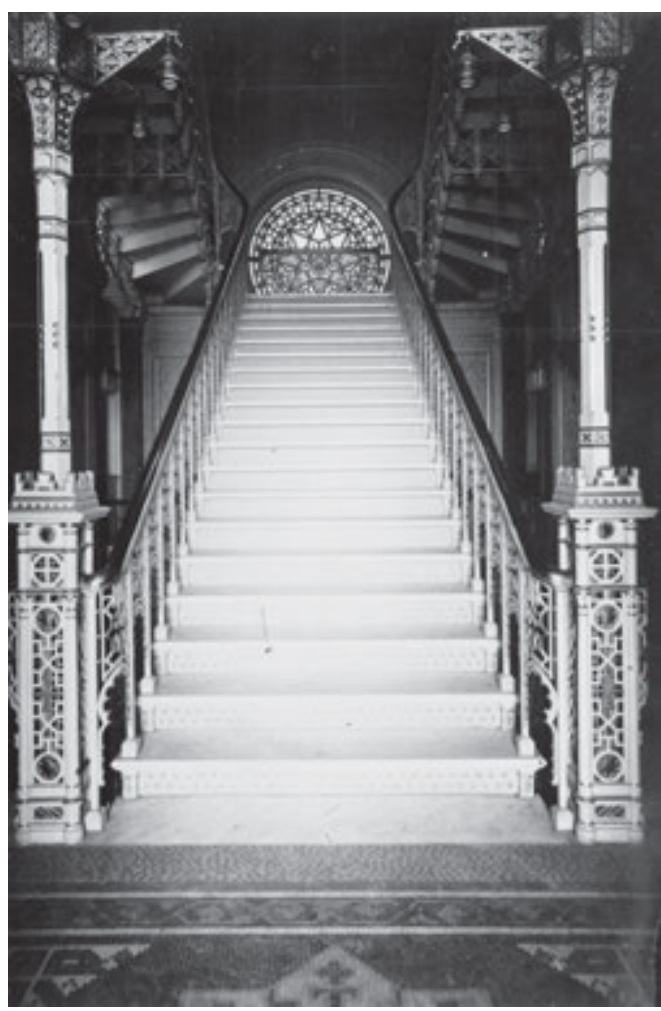

View of the staircase at Mourish Pavillion, [s.d.]. Casa de Oswaldo Cruz Archives

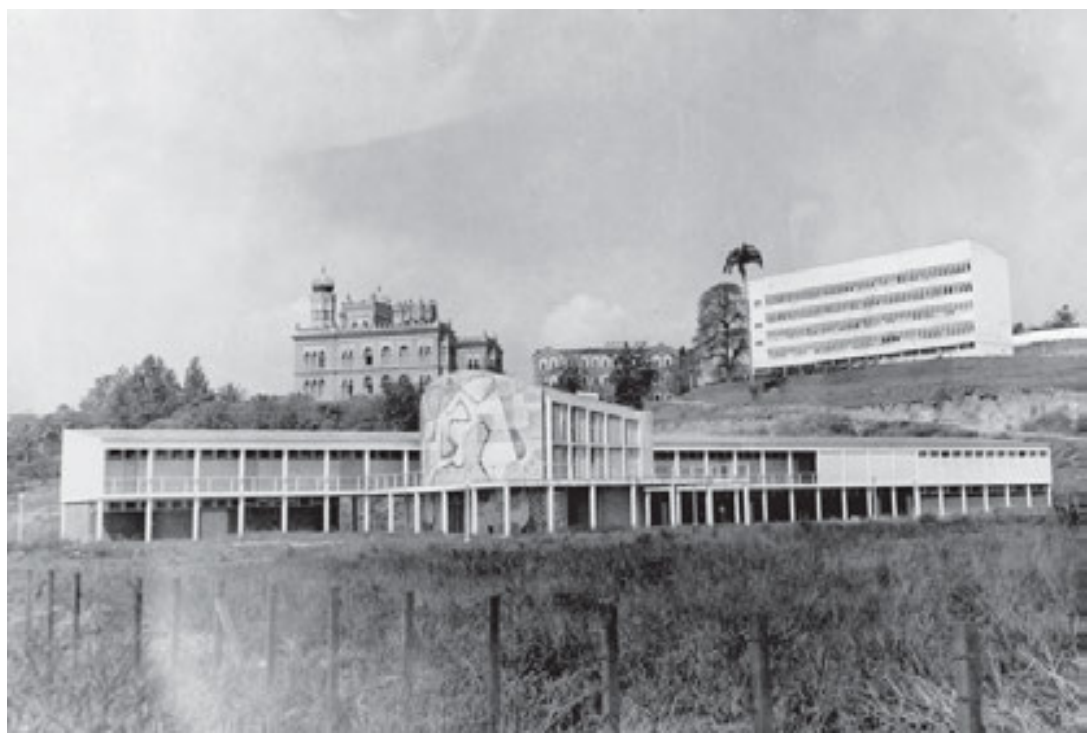

View of Courses Pavillon, [s.d.]. Casa de Oswaldo Cruz Archives

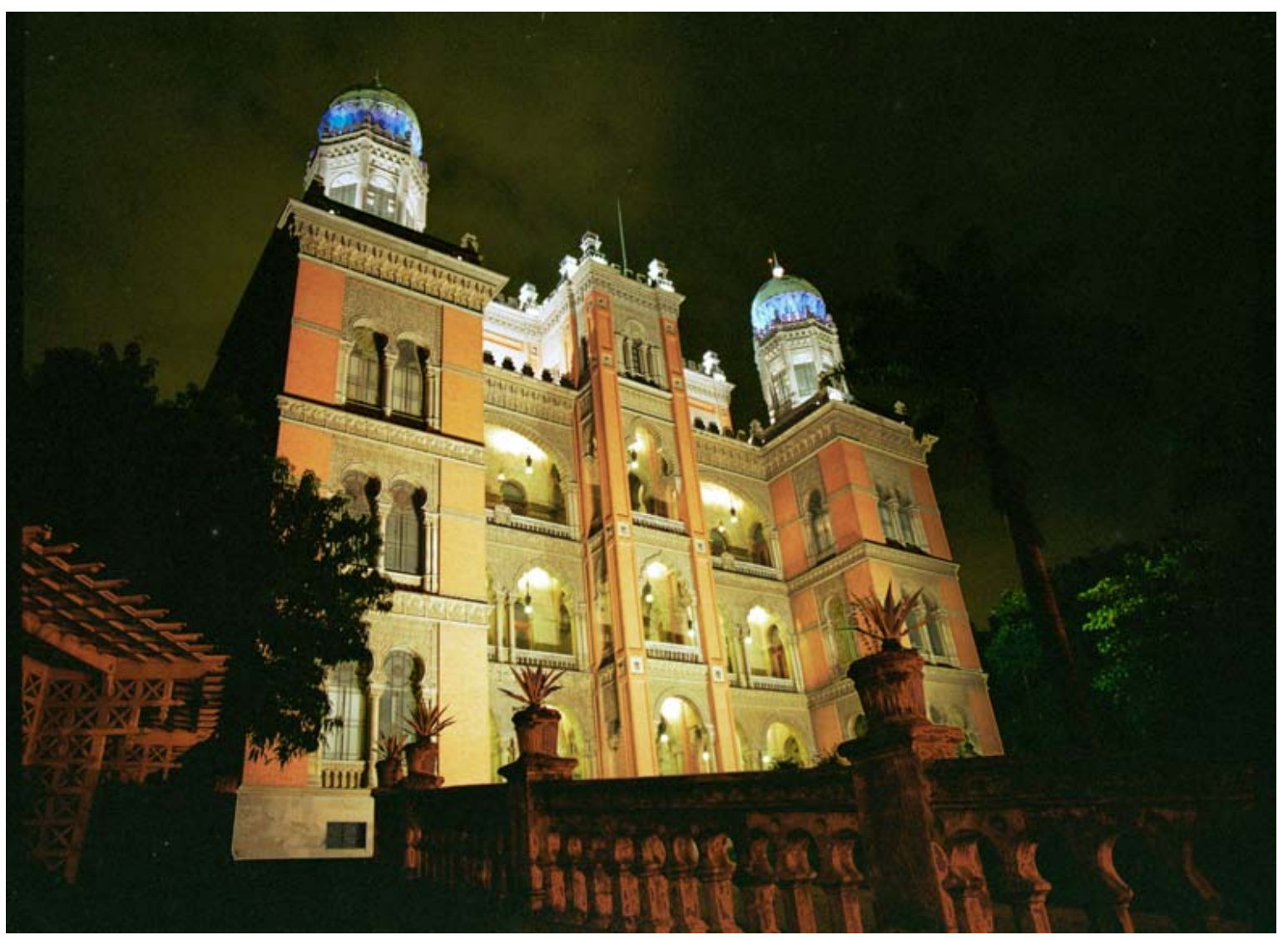

Fiocruz by night, [s.d.]. Photo Roberto Jesus Oscar \& Vinícius Pequeno de Souza. Casa de Oswaldo Cruz Archives 


\section{FIRST REPUBLIC}

\section{Pedro II State Hospital}

Location: Santa Cruz.

Address: Rua Padre, 325.

Denomination: General Hospital.

Period of construction: 1970's.

Proprietor: State Government of Rio de Janeiro.

Author / constructor: unknown

\section{History:}

Its origin is linked to a malaria outbreak that afflicted the town of Santa Cruz in 1920. At that time, the government of the Federal District setup an emergency center for the ones affected by the disease in an old school of the Imperial era. After the outbreak had been subdued, Carlos Chagas, then Director of the National Department of Public Health, decided to maintain the hospital services, thus initiating the actions of the Department in matters related to Rural Prophylaxis and Hospital Care - two indispensable themes for the doctor.

Its first director, Doctor Eurico Villela, had his life-course linked to Carlos Chagas and the Oswaldo Cruz Institute, as one of those responsible for the organization of the Oswaldo Cruz Hospital, inaugurated in 1918 at the Oswaldo Cruz Institute; in addition to having been the first director of the São Francisco de Assis Hospital - one of the projects realized during the Carlos Chagas administration - as head of the National Department of Public Health; and he succeeded Chagas in the chair of Tropical Diseases at the College of Medicine, when he died in 1934.

Slowly, the hospital grew, expanding its services and gaining new pavilions. In 1928, the buildings that would house the polyclinic, pharmacy, emergency and the operating theaters were built. In 1932, the Azevedo Sodré Pavilion was built for the campaign against tuberculoses.

In 1940, under the new Public Health reform, Pedro II Hospital was transferred to the City Hall of the Federal District. In 1945, the maternity ward was readapted and received the name of Altamiro de Oliveira, who had been the director of the hospital for many years.

The great modification in the hospital took place in the 1960's when discussions began about the construction of a new building for Pedro II. The old hospital was in ruins and threatening to collapse, therefore it was completely demolished. In 1968, construction work was initiated only to be concluded in the middle of the following decade.

In 1960, with the transfer of the federal capital to Brasilia, the state of Guanabara was created encompassing the entire municipality of Rio de Janeiro. At this time, the hospitals belonging to city hall of the Federal District came to have state jurisdiction. Fifteen years later, in 1975, with the merging of the states of Guanabara and Rio de Janeiro, some of these hospitals returned to the municipality, while others remained as state hospitals - among them Pedro II.

Even today the hospital is considered a reference for emergency treatment in its areas of practice. It is one of the few hospitals in the State to offer obstetrics - together with Alberto Scweitzer and Rocha Faria - and the only one in psychiatry; in addition to the specialties in medical clinic and surgery; and pediatrics - common to all of the hospitals of the state health system.

\section{Architectonic Description:}

As of the 1960's, many hospitals would undergo renovations and expansions. A huge number of institutions had their old facilities demolished, to make way for the blocks of five, seven or ten floors, as in the case of Pedro II. Others received annexes, maintaining the original facilities, but with adaptations. The change in medicine would bring to architecture a formal impoverishment, revealed in rectilinear lines, without ornament and standardizations. 


\section{FIRST REPUBLIC}

Note:

It is worth mentioning that on the property where the current Pedro II Hospital building was built, there used to operate, during the Colonial and Imperial eras, the Hospital of the Slaves of the old Royal Estate of Santa Cruz. Few vestiges have survived of this old building.

\section{Register of Preservation:}

It is not listed.

\section{Sources:}

ASSISTÊNCIA Pública e Privada no Rio de Janeiro (Brasil) - História e Estatística. Comemoração do Centenário da Independência Nacional. Rio de Janeiro: Typographia do Annuario do Brasil, 1922.

ASSISTÊNCIA Pública - Guanabara: 80 anos de história. Rio de Janeiro: Superintendência de Serviços Médicos (SUSEME); 1972. mimeo.

SECRETARIA de Saúde do Estado do Rio de Janeiro. Indicadores e Informações em Saúde. In: http://www.saude.rj.gov.br/ informacoes/bancodad.shtml Acessado em 11/10/07

Credits: Daniel Elian dos Santos (research); Gisele Sanglard (text) and Renato da Gama-Rosa Costa (architectonic description). 


\section{FIRST REPUBLIC}

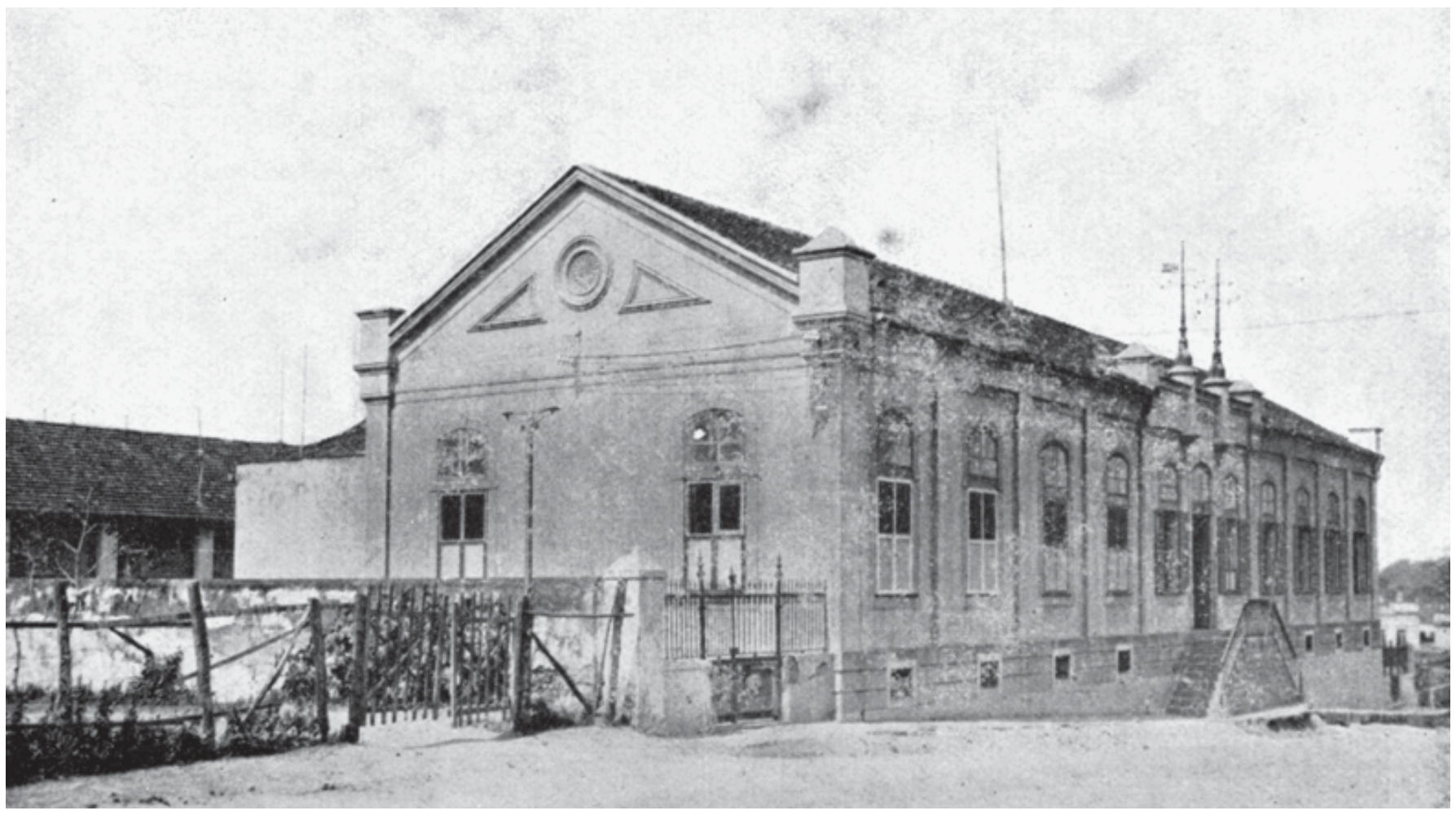

Pedro II Hospital, [1910]. Fonte: ASSISTÊNCIA, 1922

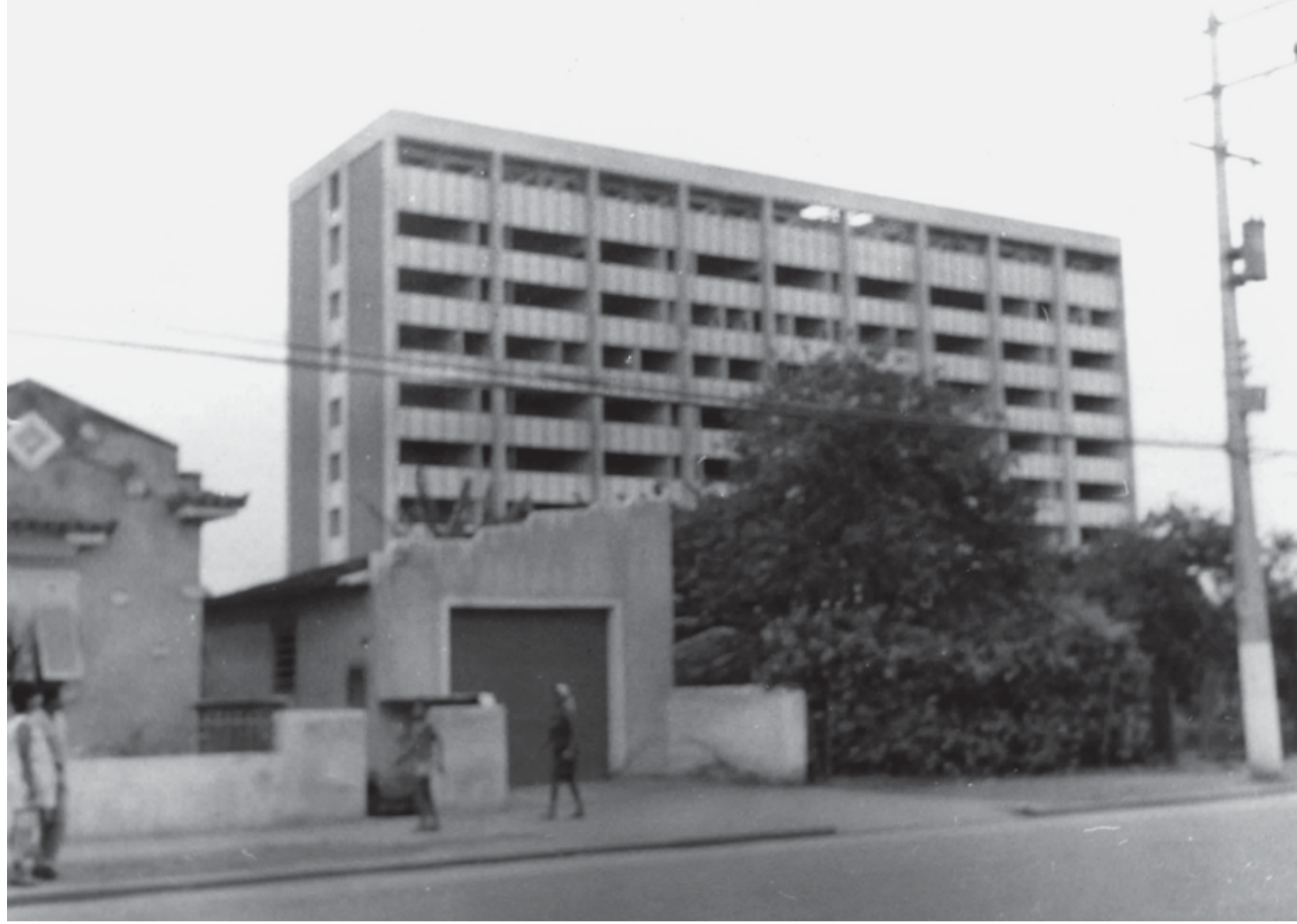

Construction of Pedro II Hospital, [1960]. Correio da Manhã Fund, Arquivo Nacional Archives 


\section{FIRST REPUBLIC}

\section{Pro Matre}

Location: Downtown

Address: Avenida Venezuela, No. 153.

Category: Maternity

Period of construction: 1919; 1937 e 1945

Proprietor: Pro Matre Association.

Author / Constructor: unknown

\section{History:}

In 1917, in the city of Rio de Janeiro, a charitable and mutual help association - designated Pro Matre - was created, for the purpose of "providing protection to the disgraced woman with no distinction of religious creeds or social standing" exercising the mutuality, founding maternity wards, day care centers, canteens, shelters, workshops and maternal havens (By-Laws of Pro Matre, 1918, p.3-4). As the social project became a reality, the Pro Matre Association extended its benefits to the children considered "disgraced", as it can be perceived in the Institution's by-laws.

This movement in the defense of the woman and the child enrolled in the context public assistance organization and redefinition of the private actions in Brazil in the turn of the XIX to the XX century, especially in the federal capital: Rio de Janeiro. The State defended the need to "save the child support the mother, them shape the citizen" (Public and Private Assistance in Rio de Janeiro, 1922). In this manner, the maternal assistance was turned towards the support and collecting. The mediatization of this project would come about from the maternity wards, understood as spaces to be organized in the hygienic and antiseptic molds, capable of disseminating preventive measures among the mothers, whether in the hospital space or assistance at home. In addition, nursing was another worrisome factor of the public and the aid workers, as well as the foundation of day care centers, capable of sheltering the child during the mothers' work journey, especially the factory workers.

Pro Matre appears in the core of the reaffirming between the public and private assistance action, where members of the society became partners of the State and undertake actions in tune with the official demands. Thus, the first philanthropic action of the Pro Matre Association was the creation of a maternity ward on April $1^{\text {st }}, 1918$, spearheaded by the feminist Stella de Carvalho Guerra Duval (1879-1971), and the doctor and the professor Clinical Obstetrics of the College of Medicine of Rio de Janeiro, Fernando Magalhães (1878-1944), in addition to the Ladies of the Green Cross. This group of fourteen ladies of the carioca society played an important role in the making the project feasible, by means seeking resources for the construction and outfitting the maternity ward, as well as its administration.

It is worthwhile to stress that the Ladies of the Green Cross counted with the support of prominent masculine figures, for example the doctor Fernando Magalhães and other benefactors, such as Wenceslau Braz, Epitácio Pessoa, Washington Luiz Pereira de Souza, Paulo de Frontin, Getulio Dornelles Vargas, among others signed the Book of Benefactors, when it was founded. Thus, the private assistance corroborated with the public health policies from aid actions, many of them taken over by women.

According to its first by-laws, the Association would chose twenty-four associates, which would comprise the Board of Directors and the Boards of Auditors (Pro Matre By-Laws, 1918, p.4-5). Up to this day, Pro Matre continues to be a charitable association, chaired by women, although the feminine condition is not imperative for composing the administrative staff.

The building where the PRO MATRE was installed was an old Customs warehouse, donated by the President of the Republic Wenceslau Braz where, provisionally, "the first infirmaries for protecting the desolate women and the disfavored childhood" (PRO MATRE, 1998). The reformation works were financed by charitable events, organized by founders (PRO MATRE, 1968, p. 1). 


\section{FIRST REPUBLIC}

Soon after the commencement of the maternity functions in 1918, the building was transformed into an emergency hospital as a function of the Spanish Flu (PRO MATRE, 1968, p. 1). The Maternity ward assigned its 50 beds and suspended its activities for a month, reinitiating them in February 1919. After a fire in June 1919, propagated from a nearby building, the Pro Matre facilities were soon recovered and re-inaugurated on September of the same year. The hospital space was enlarged to 70 beds, 22 appointment posts, obstetric and gynecologic ambulatory and a day care center (BRAGA, 2004, p. 47).

In the beginning of the XX century, the institution was maintained by contribution of the associates, the donations, the legacies and the federal and municipal grants (Pro Matre Articles of Association, 1918, p. 3). Currently, the Pro Matre is a part of the SUS (Sole Health System) network; it has a covenant with the Municipal City Hall of Rio de Janeiro, in addition to contributions from partners and legacies.

In spite of countless changes in the public health policies which took place in Brazil on the course of the XX century, Pro Matre maintained its focus in the aid to the health of the woman, especially to birth.

\section{Architectural Description:}

The PRO MATRE Maternity Ward would come to occupy an old pavilion with only one pavement at Avenida Venezuela, at the heart of the port zone, where it remains up to the current days. Along the years, the maternity ward underwent successive reforms.

Some buildings, such as the Dr. Luiz Rocha Miranda Pavilion were added to the original building, which allow the expanding of the aid activities, as well as the functional characteristics for providing the services.

A chapel dedicate to Our Lady of Graces it is a part of the cultural asset of Pro Matre, located at the left wing of the hospital complex, currently named Surgical Clinic R. M. Mass is said at the chapel in festive occasions, graduation of resident, Mother's Day.

Likewise, a zenithal ventilation of the original warehouse was preserved, which, at the time, served to provide an improvement to the conditions of thermal comfort inside the building. In this atrium, under the skylight, festivities of the Maternity Ward are currently held, and, on account of having been reformed in 2007, it still provides natural lighting and ventilation to the environment.

Another important aspect in the conservation of the skylight refers to the perception that such a wooden structure still offers as a referential of the original building conditions.

\section{Register of Preservation:}

It is not listed.

\section{Sources:}

ASSISTÊNCIA Pública - Guanabara: 80 anos de história. Rio de Janeiro: Superintendência de Serviços Médicos (SUSEME); 1972. mimeo.

ASSISTÊNCIA Pública e Privada no Rio de Janeiro (Brasil) - História e Estatística. Comemoração do Centenário da Independência Nacional. Rio de Janeiro: Typographia do Annuario do Brasil; 1922.

BRAGA, Antonio et al. PRO MATRE. 75 anos de ensino e assistência obstétrica no Rio de Janeiro. Resumo. IX Congresso Brasileiro de História da Medicina. Jornal Brasileiro de História da Medicina. Suplemento 1, vol 7, novembro, 2004 , p. 47.

BOLETIM da Pro Matre - Sociedade Civil de Amparo as Gestantes Necessitadas. Pro Matre: Rio de Janeiro, 1937, Ano I, nº 1. BOLETIM da Pro Matre - Sociedade Civil de Amparo as Gestantes Necessitadas. Pro Matre: Rio de Janeiro, 1937, Ano I, n ${ }^{\text {os }} 2$ e 3 .

BOLETIM da Pro Matre - Sociedade Civil de Amparo as Gestantes Necessitadas. Pro Matre: Rio de Janeiro, 1937, Ano I, nº 4. 


\section{FIRST REPUBLIC}

BOLETIM da Pro Matre - Sociedade Civil de Amparo as Gestantes Necessitadas. Pro Matre: Rio de Janeiro, 1937, Ano I, n 9. BOLETIM da Pro Matre - Sociedade Civil de Amparo as Gestantes Necessitadas. Pro Matre: Rio de Janeiro, 1937, Ano I, $^{\circ} 11$. BOLETIM da Pro Matre - Sociedade Civil de Amparo as Gestantes Necessitadas. Pro Matre: Rio de Janeiro, fevereiro de 1937, Ano II.

ESTATUTOS da Associação Pro Matre. Rio de Janeiro: Oficinas Gráficas da A NOITE, 1918.

FOLHA da Pro Matre, Rio de Janeiro, ano V, número 1, Órgão da Associação Pro Matre / Rio de Janeiro, janeiro de 2003,8 p. JUSTA Homenagem. O $2^{\circ}$ Aniversário da Fundação da "Pró-Matre". Rio de Janeiro: Jornal do Comércio / Rodrigues \& Cia, 1939.

LIVRO de Beneméritos. Acervo Pro Matre.

PRO MATRE. Histórico da Pro Matre. Em Benefício da Pro Matre - 80 anos. Rio de Janeiro, 1998.13 p.; il.

O que você deve saber sobre a PRO MATRE. Folheto. Dizer - Relações Públicas e Comunicação Social Ltda. Bloch Editores. Jubileu de Ouro, Rio de Janeiro, 1918/1968, 14 p.: il.

. Amou, sofreu, realizou: Homenagem a Stella Guerra Duval. Folheto, [s.n.], Rio de Janeiro, 1971, 16 p.

SMS/RIO - Secretaria Municipal de Saúde. Rio de Janeiro, 2007. Disponível em: http://www.saude.rio.rj.gov.br/media/ mes_2005.pdf . Acesso em: 26 jun 2007.

Credits: Fábio Bitencourt (research, text and architectural description); e Maria Renilda Nery Barreto (research and text). 


\section{FIRST REPUBLIC}

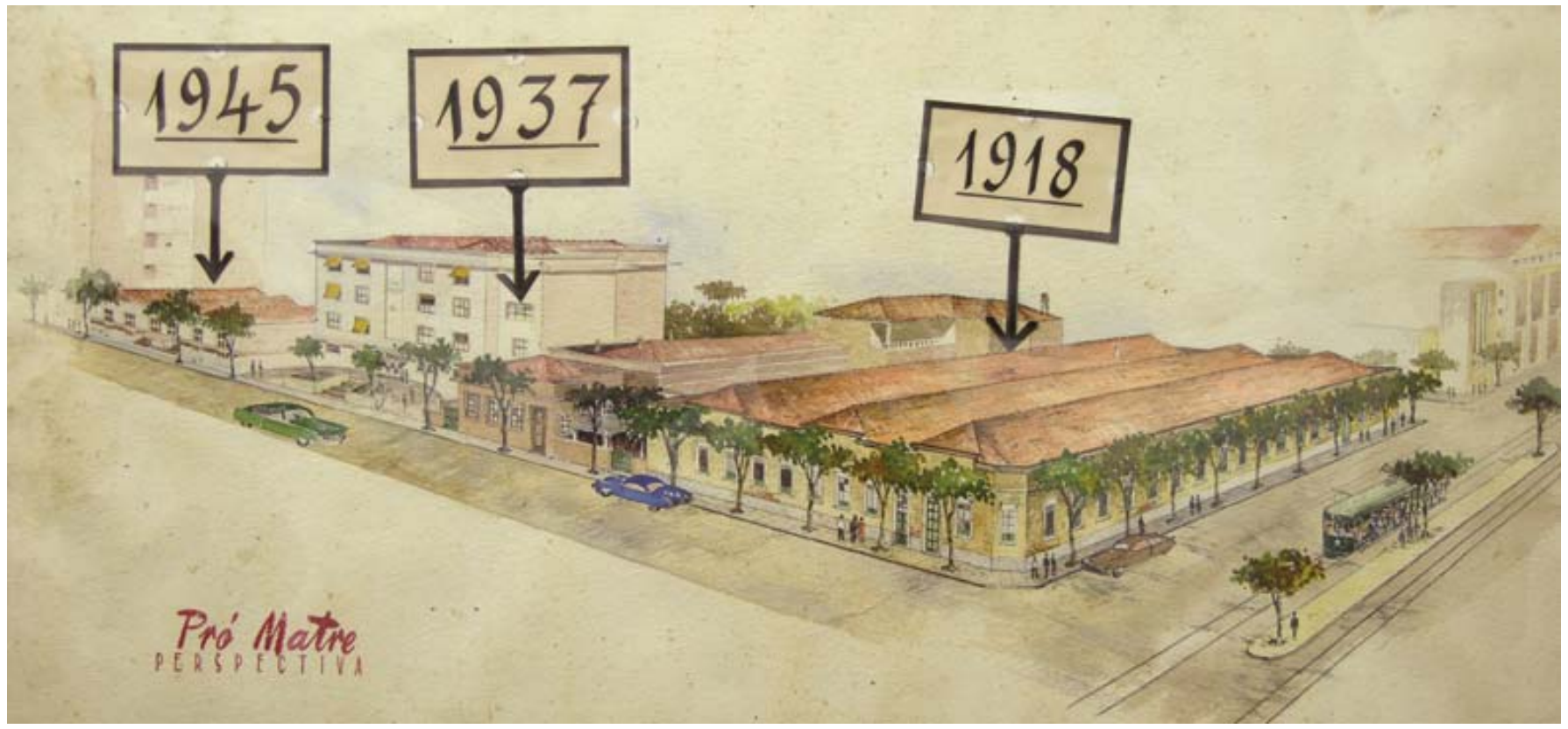

Pro Matre perspective, [s.d.]. Private Archives

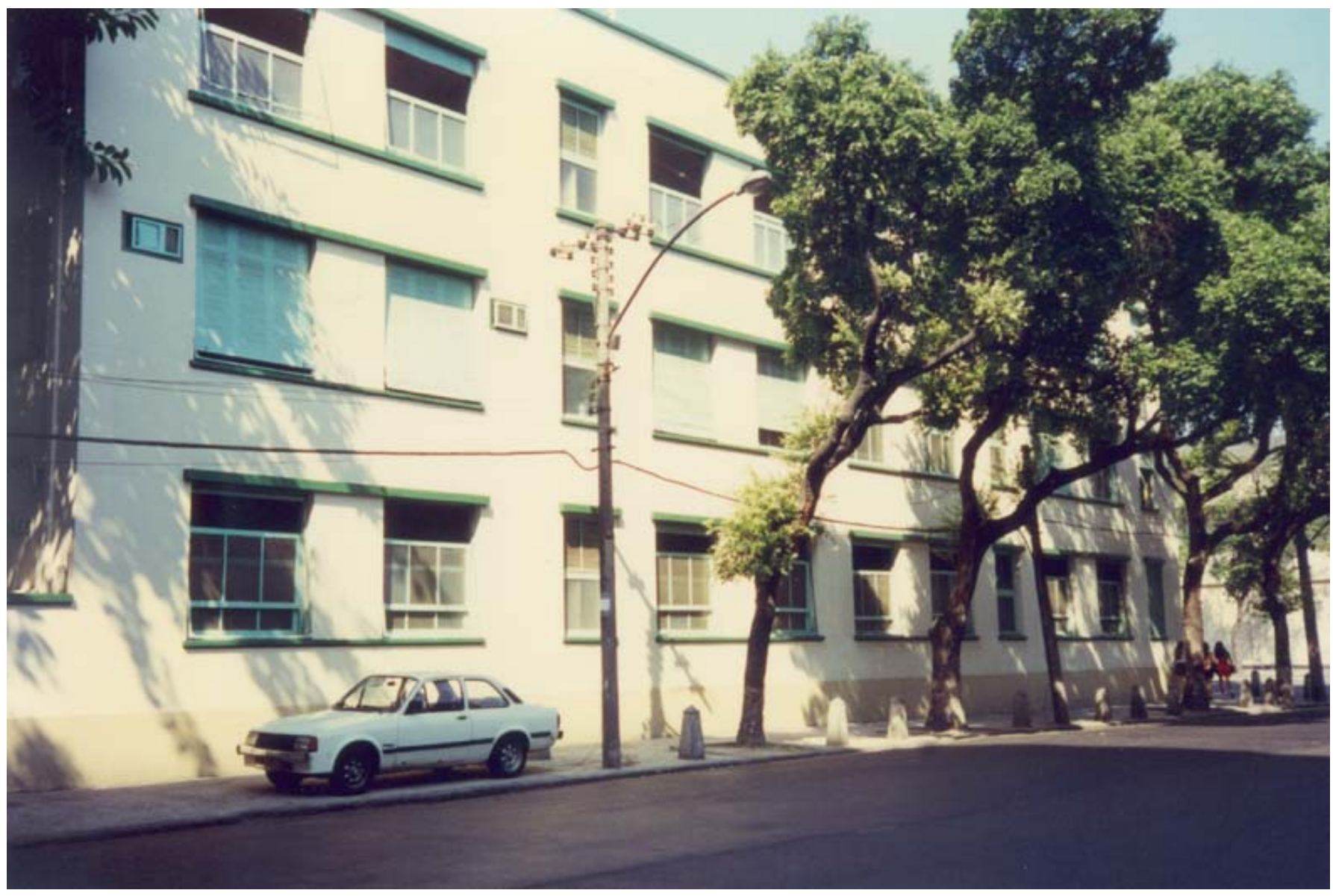




\section{FIRST REPUBLIC}

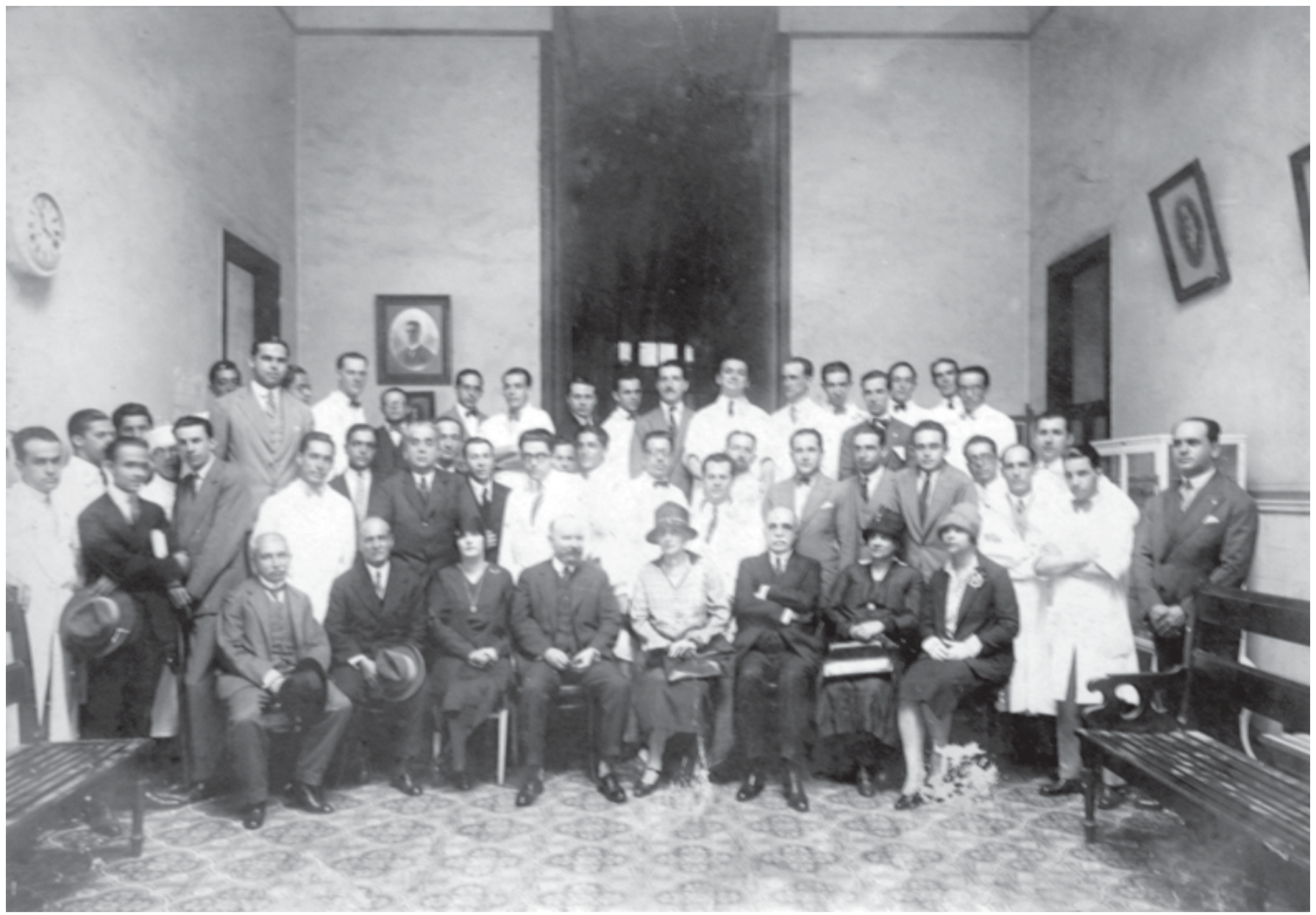

PRO MATRE, [s.d.]. Private Archives 


\section{FIRST REPUBLIC}

\section{São Francisco de Assis Hospital}

Other denominations: Mendacity Asylum (1876 - 1895); São Francisco de Assis Asylum (1895 - 1922); São Francisco de Assis General Hospital (1922 - 1977); School Hospital São Francisco de Assis (1988 - present day).

Location: Cidade Nova.

Address: Avenida Presidente Vargas, 2863.

Category: University Hospital

Period of construction: 1876.

Proprietor: Federal University of Rio de Janeiro.

Author / Constructor: Heitor Rademacker Grünewald.

History:

The School Hospital São Francisco de Assis has its origins in the Mendacity Asylum, inaugurated in 1879, to fulfill the "public need to build an Asylum for beggars" (Law 2670/1876), in replacement of the old lodging-house of the Santa Luzia beach, insufficient and inadequate to the purpose of sheltering the elderly, the invalid and the poor with no family protection, both men and women.

The regulation of 1884 allowed the admission of four classes of beggars from both sexes: the ones less than fourteen years old, abandoned and idlers; the indigents, the elderly and the incapable which appealed to the charity of passers-by; the ones who presented themselves spontaneously, proving indigence and the insane who could not be received at the Pedro II Mental Institution, overcrowded and with grave financial difficulties. The asylum received the undesired from other institutions. The great agglomeration of people and the bad conditions of life led to serious criticisms from names such as Dr. Teixeira Brandão, psychiatrist from the Medicine College, upon finding a large number of insane in the Asylum. The attempt to discipline and sooth the problem led Counselor Ferreira Vianna, Minister of the Justice of the Empire in 1888, to create the São José House, to shelter the minors and the Insane Colony of Galeão.

For understanding that the denomination of Mendacity Asylum was humiliating to the interns, the name of he São Francisco de Assis Asylum was adopted. A reform in the regulation limited the capacity in two hundred and fifty interns, of both sexes, indigents and fit for work.

The second moment of the institution is marked by the deactivation of the Asylum with the transfer of the inters to the new building in the neighborhood of Vila Isabel and the transformation of the building into the General Hospital of Assistance, or, as spelled in some documents, São Francisco de Assis General Hospital. This was inaugurated after large reformation and adaptation works, on September seventh of 1922, member of the recently created National Public Health Department (DNSP), instruments of the so-called Carlos Chagas reform, during the conjuncture of the first republic. The hospital's regulation, of the same year, determines its destination of "providing medical-surgical assistance to the indigents, composed of six infirmaries of the medical clinic and respective doctors' office; seven infirmaries of surgical clinic and respective doctors' office; anatomical-pathological institute; clinical research laboratory and radiology unit."

The Carlos Chagas reform (1919) also created the Superintendence of the Nurses Service, the Public Health Visitant Service and the Nurses School, currently the Anna Nery Nursing School, fruits of the Technical Cooperation Mission for the Development of Nursing in Brazil, sponsored by the Rockefeller Foundation and headed by the North-American nurse Ethel Parsons (1921-1931), introducer of the Anglo-American graduating model in Brazil. The hospital's growth and prestige led the National Medicine College to install in its therapeutic and otorhinolaryngology clinics on it, followed by the subjects of medical propaedeutics, medical and surgical pediatrics, orthopedics and tropical and infectious diseases. The Hospital's medical Magazine became "The hospital", the institution's official communication vehicle. 


\section{FIRST REPUBLIC}

In the 30's, as a consequence of a new political and institutional conjuncture, the public health model of the Minister of Education and Health was in decline and the social security medicine captained by the Retirement and Pensions Institutes (IAP’s) expands. The São Francisco de Assis General Hospital, implemented in 1922, was in 1945, one of the great hospitals of Rio de Janeiro, already involved with the production and he reproduction of the medical knowledge. Upon assisting the indigent, "the ones with no formal work agreement" as per its regulation, it turned towards the contingent not included in the social security system. The lack of budget and the overcrowding, heritages from the old Asylum, and the Franciscan myth, summed up elements for coinage of the popular title of "hospital for the poor".

At the end of the New State, with the re-democratization promoted by the Constitution of 1946, the hospital was acquired by the City Hall Union of the Federal District and delivered to the University of Brazil (U.B.), currently the Federal University of Rio de Janeiro, under the denomination of the São Francisco de Assis School Hospital, maintaining itself as a field of teaching for the Anna Nery Nursing School, incorporated to it in 1937, and to the other university units, especially the National College of Medicine, which established therein several of its cathedra, previously dispersed in hospitals such as the Santa Casa de Misericórdia, State's Servants Hospital and the Gaffreè \& Guinle Clinics Hospital. In this process, the Pavilion of Infectious-Contagious Diseases Miguel Couto, of 1926, later renamed Carlos Chagas, and the Thompson Motta Maternity Ward, were also incorporated to the U.B., expansions of the hospital that, together with the Classes Pavilion of the Nursing School, comprised the Mangue complex. It is worthwhile to point out that in this period, the urban surroundings of the hospital underwent profound changes with the opening of the (avenue) Avenida Presidente Vargas (1942) and the later installation of the modern buildings in the Cidade Nova.

The changes in the upper-level teaching and the need of expanding the university units, strongly determined by the university reform of 1968, reinforced the old claim of building the modern university hospital for the UFRJ, with the overcoming of the lost opportunity with the "skeleton" initiated in the region of Mangueira, and the retaking of the university city project at Isle of Fundão, initiated in the 30's. Its actual inauguration, with the facilities still unfinished in 1978, determined the deactivation of the São Francisco de Assis School Hospital. Threats of sale of the complex, demolition and losses to the structure by the subway works unleashed a campaign for the registration and preservation of the Hospital for the Poor as a historical site, disclosed by the (newspaper) Jornal Última Hora since 1977, which determined its registration as a historical site by the National Historical and Artistic Asset Institute, homologated by the Minister of Education and Culture in 1978. New threats of alienation of the asset by the UFRJ were denounced in the press in 1984. Organization foreign to the university occupied the building on an irregular manner, which gave rise to an action for reinstatement to the university, which it won around 1987, when it got back a complex considerably deteriorated by years of use and bad conservation.

In February 1988, by reason of the state of public calamity in the city determined by strong rains, the Anna Nery Nursing School, a member of the SOS Rio campaign, offered the Hospital as shelter to a group of sick elders displaced by the collapse of the Santa Genoveva Clinic in Santa Tereza, having its teachers and students as voluntaries. This fact bailed out in the proposal for reactivating the Hospital by the Nursing School, under the direction of one of its teachers. Since then, the São Francisco de Assis School Hospital comprised the eighth hospital unit of the UFRJ, directed by the teachers of the Anna Nery Nursing School, integrated to the Single Health System, with teaching, research and extension activities mainly from the Center of Health Sciences and other academic units.

\section{Architectural Description:}

The lots of the grounds for the construction of the primitive Correction Facility were assigned by the Municipal Chamber and, by donation on the part of the Baron of Piraçununga, in 1876. The construction was carried out in stages (1876 to 1895) due to the difficulty to obtain financing. One of the largest difficulties encountered was the construction in a mangrove ground, which increased the cost of the foundations. The author of the architectural project was Heitor Grünewald who elaborated it after a trip to Europe to study similar establishments, in 1875. 


\section{FIRST REPUBLIC}

The main building of the complex has a volumetric composition composed of a central body with 5 rods in juxtaposition, developed in two floors. It is an eclectic edification, from the classic ruling, implemented in the forepart of the old (street) Rua Visconde de Inhaúma, currently the (avenue) Avenida Presidente Vargas, and an important arterial route of the city of Rio de Janeiro.

The architectural project presents similarities with a building built in Saburn (USA) and later copied in Alkmar (Holland). The architectural party followed the principles of the prison institutions of Europe, the "Bentham Panoptical". Although applied to incarceration institutions, this radial party, which induced to the confinement and the control, is also an object of project for hospitals. In its reform to general hospital, the original structure of the wings was exploited as "pavilion-style hospital"- adaptation for halls-infirmaries, creation of an isolated doctor's office, rationalization of the hygiene and the circulation system.

A chapel located at the central body of the building was part of the original project and two of its three projected rods, finished in 1885. From 1921 expansions are carried out, authorized by the doctor Carlos Chagas and directed by Carlos Penna.

\section{Notes:}

Along the years, several other annexed buildings were built, since in 1978 they were the object of recommendations for its demolition by the $81^{\text {st }}$ Ordinary Meeting of the Advisory Board of IPHAN. However, this did not prevent the construction of a mess hall ad two bathrooms dated from 1993.

\section{Register of Preservation:}

Federal registration as a historical site (IPHAN): 1978, Book of Historical Site Registration; and 1983, Book of Historical Site of Fine Arts. The registration as a historical site comprises only the original pavilions.

\section{Sources:}

AGUINAGA, H. Hospital São Francisco de Assis. Rio de Janeiro: Ed. Companhia Brasileira de Artes Gráficas; 1977.

CZAJKOWSKI, J. (Org.). Guia da arquitetura eclética no Rio de Janeiro. Rio de Janeiro: Centro de Arquitetura e Urbanismo do Rio de Janeiro; Casa da Palavra/Prefeitura da Cidade do Rio de Janeiro; 2000.

FRAMPTON, K. História crítica da Arquitetura moderna. São Paulo: Martins Fontes; 2000.

INSTITUTO DO PATRIMÔNIO HISTÓRICO E ARTİSTICO NACIONAL. Arquivo Noronha Santos. Busca. Disponível na Internet: http://www2.iphan.gov.br/ans/inicial.htm

SILVA JUNIOR, O. Do Asylo da Mendicidade ao Hospital Escola São Francisco de Assis: a Mansão dos pobres. Rio de Janeiro: Papel \& Virtual; 2000.

SOUZA, Mariana Vaz de. Sistematização para projetos de restauro no Brasil estudo de caso - Hospital São Francisco de Assis. Rio de Janeiro: Faculdade de Arquitetura e Urbanismo, UFRJ, 2004. (Dissertação de mestrado)

Credits: Osnir Claudiano da Silva Junior - Laboratory of Research of the Nursing History - Alfredo Pinto Nursing School. Federal University of the State of Rio de Janeiro (research); Inês El-Jaick Andrade (architectural description). 


\section{FIRST REPUBLIC}

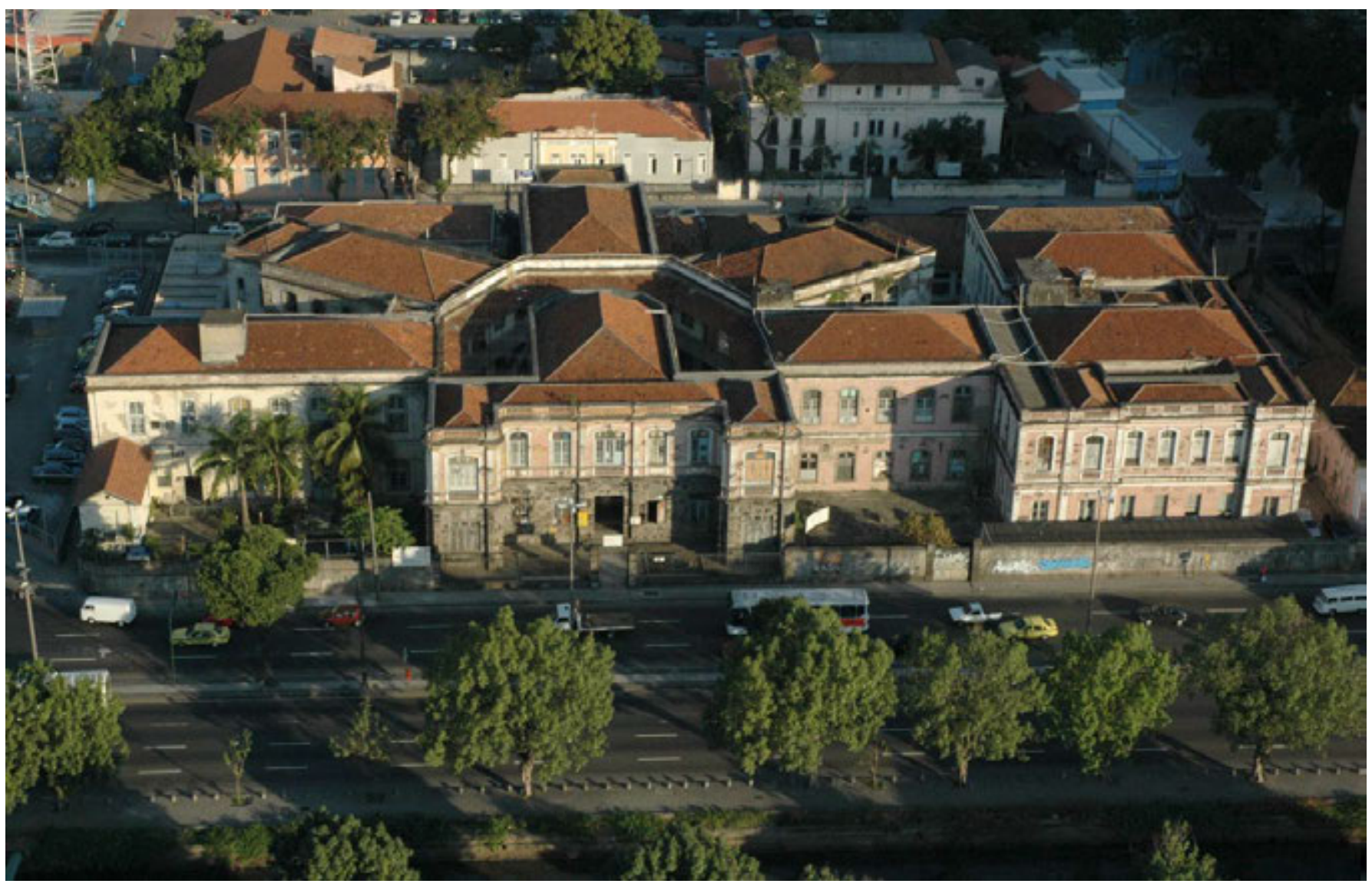

São Francisco de Assis Hospital, [s.d.]. Universidade Federal do Rio de Janeiro Archives 


\section{FIRST REPUBLIC}

\section{São José Hospital}

Location: Humaitá

Address: Rua Macedo Sobrinho no. 21

Denomination: São José Hospital.

Period of Construction: 1983

Proprietor: Santa Catarina Congregation

Author / Constructor: unknown

\section{History:}

The creation of the São José Hospital is tied to the history of the Santa Catarina Congregation founded in the XVI century (1571) in Germany, by Mother Superior Regina Portman, and dedicated to the residential care of the sick - which in the XIX century established itself as a "hospital congregation". On June $16^{\text {th }}, 1897$, the first four sisters of this order arrive in the city of Petrópolis, Brazil, where they founded the Santa Catarina School. In 1915, the sisters came to the city of Rio de Janeiro to work for a six-year period at the São Francisco de Paula Hospital, of the Venerável Ordem Terceira dos Mínimos de São Francisco de Paula, which, at the time, was established on Rua General Canabarro, in Tijuca.

After renting a house on Rua Dona Carlota for the care of the needy, they decided, in 1922 - by means of a loan - , to purchase a lot on Rua Macedo Sobrinho, in the district of Humaitá, for the set up of their very own Hospital. Today, the Santa Catarina Association Congregation is the proprietor of various hospitals, educational establishments and asylums located in the states of Rio de Janeiro, São Paulo, Espírito Santo and Mato Grosso.

The history of the Hospital is directly associated to Doctor Leônidas Côrtes. Upon invitation of Vital Brasil Filho, Dr. Côrtes entered the hospital as an internal doctor, in 1929, still, therefore, in the incipient years of operations of the Hospital. He became Hospital Director in 1932, position which he occupied for more than seventy five yeas, Dr. Leônidas Côrtes turned 100 years old in June, 2007, still at the head of management. Throughout his long administration, the hospital underwent innumerous works. In 1983, enlargement works of the São José Hospital were inaugurated thus ensuring modern facilities and completely remodeling its aspect. A coronary unit was incorporated to the hospital complex, in 1999. There are no indications of the Guilhobel Manor, where the Hospital had been installed in the 20's of the XX century. The last trace of the past which still remains is the São José Chapel, at the entrance of the Hospital, whose cornerstone was laid by Cardinal D. Jaime Câmara, at the end of the 40's.

Today, São José Hospital has available more than $10.000 \mathrm{~m}^{2}$ of developed area with complete infrastructure for the attending of the most diverse specialties.

\section{Register of Preservation:}

It is not listed.

\section{Sources:}

Associação Congregação de Santa Catarina. Disponível na Internet: htp://twww.acsc.org.br

CASA de Saúde São José. Dr. Leônidas Côrtes: um médico, um século. Rio de Janeiro, Tapioca Comunicações, 2007.

Credits: Maria Elizabeth Bueno de Godoy and Ângela Porto (research and text). 


\section{FIRST REPUBLIC}

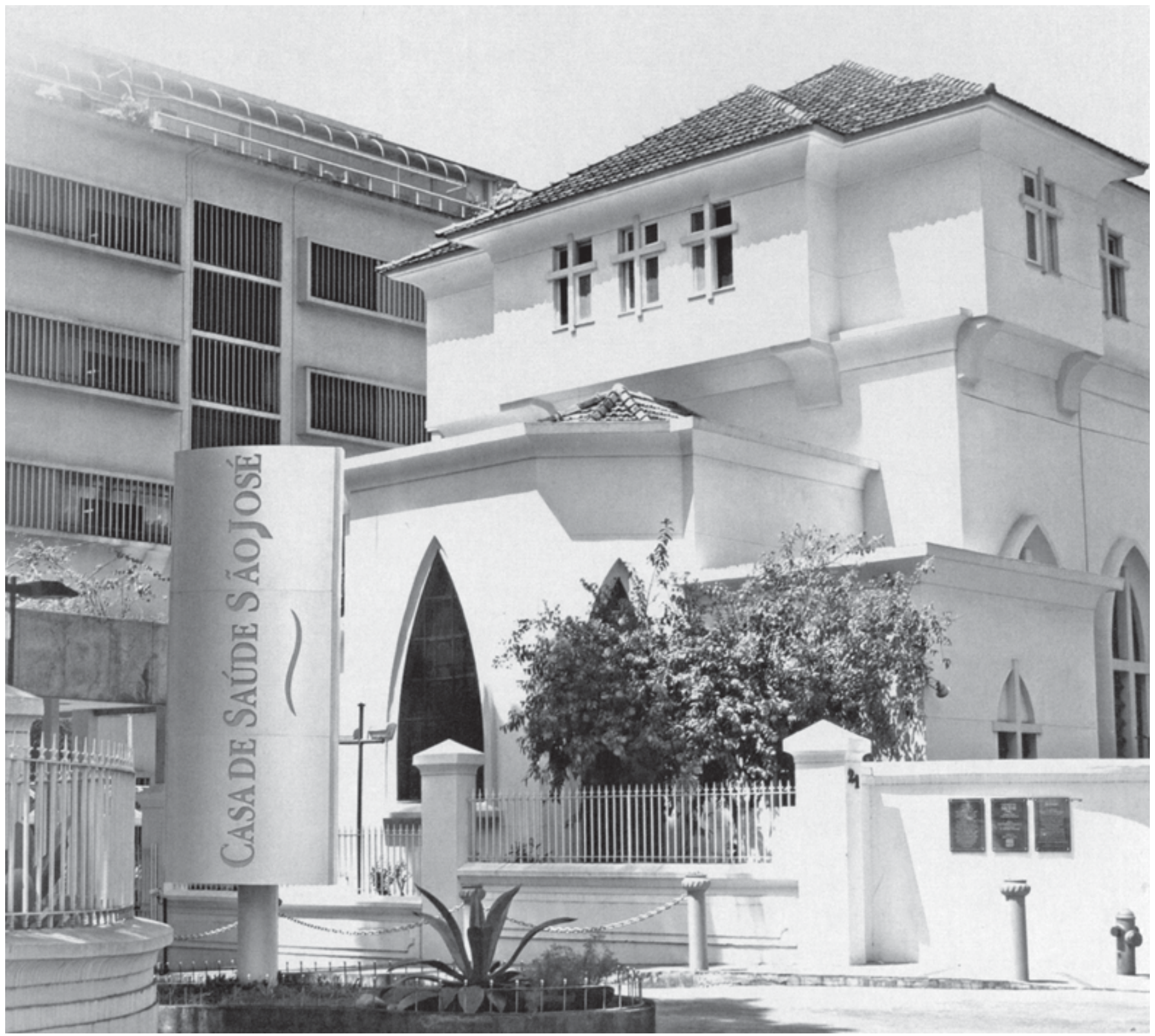

São José Medical Center, [s.d.]. Casa de Saúde São José Archives 


\section{FIRST REPUBLIC}




\section{FIRST REPUBLIC}

\section{School of Medicine and Surgery of the University of State of Rio de Janeiro}

Other Denominations: College of Homeopathic Medicine of Rio de Janeiro (1912); Hahnemann College (1912); School of Medicine and Surgery of the Hahnemann Institute (1924-1948); School of Medicine and Surgery of Rio de Janeiro (1948-1969); School of Medicine and Surgery of Rio de Janeiro of the Federation of Isolated Federal Schools of Guanabara State (1969-1975); School of Medicine and Surgery of the Federation of Isolated Federal Schools of the State of Rio de Janeiro (1975-1979); School of Medicine and Surgery of the University of State of Rio de Janeiro (1979-currently).

Location: Downtown

Address: Frei Caneca, 94094

Category: Institution of learning

Period of construction: 1971 - XX Century

Proprietor: University of Rio de Janeiro

Author/constructor: unknown

\section{History:}

In 1881, the Hahnemann Institute of Brazil pleaded to the Imperial Government the organization of two cathedra of homeopathy in the College of Medicine of Rio de Janeiro. After analyzing the case, the requirement was denied under the justification that homeopathy did not constitute the field of scientific medical knowledge. In 1900 there was another similar attempt, intermediated by the homeopathic doctor and Minister of Finance, Joaquim Duarte Murtinho, which, however was refused under the same allegation.

After exhausting the possibilities of institutionalizing the learning of homeopathy in Rio de Janeiro, the Hahnemann Institute founded in April 10 $10^{\text {th }}$ 1912, the College of Homeopathic Medicine of Rio de Janeiro, located in the beginning of Rua do Hospício (currently Buenos Aires) and soon transferred to Avenida Rio Branco, no. 133. Among the founders were Domingos Marques de Oliveira, Saturnino Nicolau Cardoso, Licínio Athanásio Cardoso - members of the Hahnemann Institute of Brazil -, Marco Evangelista de Negreiros Sayão Lobato, Francisco Pacheco de Oliveira and Antônio Guilherme Cordeiro.

According to its bylaws, the College had the objective to graduate homeopathic pharmacists and doctors through two programs offered - annex (one year) and graduate (four years). Completed with the approval of the cathedras included in the annex program, the student received a diploma in pharmacy. Having completed the $4^{\text {th }}$ year of the graduate program, the student was qualified to defend his/her thesis which, upon approval, a Doctor's degree in homeopathic medicine was granted.

In 1912, due to the dissidence of Antônio Guilherme Cordeiro and the subsequent legal action filed by him against Hahnemann Institute, some of the members decided on the organization of another institution, denominated Hahnemann College - this proposal was presented by Licínio Athanásio Cardoso, who was elected director with the approval of the bylaws the following December $2^{\text {nd }}$. The institutional collection of the former College of Homeopathic Medicine was delivered to the dissident member, who extinguished it.

The new establishment, situated at Praça Tiradentes no. 52, offered two courses: graduate, including the teaching of medicine and pharmacy, and annex, constituted by disciplines of secondary instruction required for the ingress into the graduate program. In total, the medical program lasted six years and the pharmaceutical two.

As soon as educational activities began, the Hahnemann Institute worked in the project of a homeopathic hospital to provide assistance care to the needy, also serving as a base for practical studies in the cathedras of the Hahnemann College and the association of its laboratories to the clinical services of the hospital. In 1914, Licínio Athanásio Cardoso, president of the Institute and director of the College, requested to the Legislative Branch the free cession of a property 


\section{FIRST REPUBLIC}

located at Rua Frei Caneca, no. 94, for this purpose. The request was attended by means of decree no. 1,473, of 02/03/ 1915, which permitted the construction of the Hahnemann Hospital inaugurated the following year.

As of the validity of the Carlos Maximiliano teaching reform (decree no. 11,530, of 03/18/1915) the Hahnemann College changed its bylaws in 1916, extinguishing the annex program of secondary instruction. In this scenario, the Congregation began before the public authorities the plea of equalization to the standards established and turn homeopathy official.

Through decree no. 3,540 of 09/25/1918, the Federal Government legally acknowledged homeopathy as a field of medical knowledge and conferred the habilitation of its practice and manipulation, at clinics and pharmacies, to the graduated not only by the Hahnemann College but also to doctors and pharmaceutics graduated by the official institutes. This measure still did not equalize the referred to College to official congeners, this only became reality with the Ministerial Act of December $05^{\text {th }}, 1921$, fulfilled the opinion of the Superior Council of Learning. Since then, the students graduated by Hahnemann College had the same rights granted to the ones graduated by official colleges.

Based on requirement provided for in a Notice of September $18^{\text {th }}, 1924$, the denomination of the College was changed to School of Medicine and Surgery of Hahnemann Institute.

The 1930s marked a period of intensification of the attacks towards homeopathy as medical science and to the legitimacy of the institutions that taught it, especially by the National Council of Learning. In 1933, the doctor and member of the Miguel Couto Council suggested the cancellation of the equalization granted in 1918 to the former College. At the end of the decade, the learning of homeopathy courses was optional in this institution, maintaining the learning of allopathy courses mandatory.

The School of Medicine and Surgery obtained autonomy from the Hahnemann Institute in December, 1948, being denominated School of Medicine and Surgery of Rio de Janeiro. Instituted as civil entity, it had its new bylaws ratified in 1950, obtaining in the following year the right to incorporate part of the property of the Hahnemann Institute.

Transformed in an unit of allopathic medicine learning, offering courses of homeopathy as optional, the School was federalized (decree no. 3,271, of 09/30/1957), being directly subordinate to the Ministry of Education and Culture. In 1966, it obtained from the Federal Government the annexation of the Gaffrée e Guinle Hospital to be used as a field of application of theoretical studies.

The buildings of the School and of the Hahnemann Hospital on Rua Frei Caneca were demolished. At the same address the Biomedical Institute was constructed, inaugurated in 1971 where the basic cycle of the Medicine program works. Denominated, since 1979, School of Medicine and Surgery of the University of Rio de Janeiro, it counts with the Gaffrée e Guinle Hospital for the activities of its professional cycle.

\section{Register of Preservation:}

It is not endowed.

\section{Sources:}

CASTRO-SANTOS FILHO, L. História Geral da Medicina Brasileira. São Paulo: Hucitec/EDUSP; 1991, v. 2.

GALHARDO, J. História da homeopatia no Brasil. In: Livro do $1^{\circ}$ Congresso Brasileiro de Homeopatia. Rio de Janeiro: 1928. LOBO, F. O ensino da medicina no Rio de Janeiro: homeopatia. Rio de Janeiro: Oficina Gráfica da Universidade Federal do Rio de Janeiro; 1968, v. 3.

REGIMENTO Interno da Faculdade Hahnemanniana (Escola de Medicina e Cirurgia). Rio de Janeiro: Typ. Metropole, 1922.

Credits: Atiele Azevedo de Lima Lopes (research and text) 


\section{FIRST REPUBLIC}

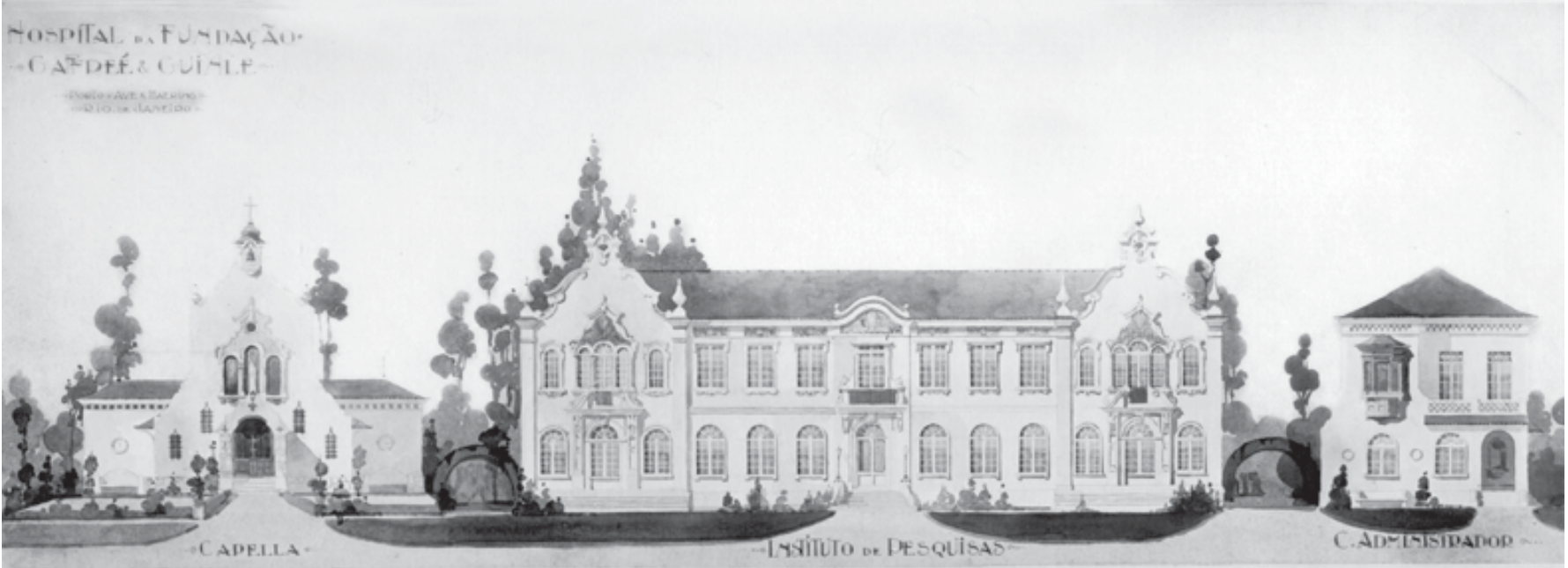

Gaffrée \& Guinle Hospital Façade, with the Director House in detail, [1924-1929]. Paula Machado family's Archives

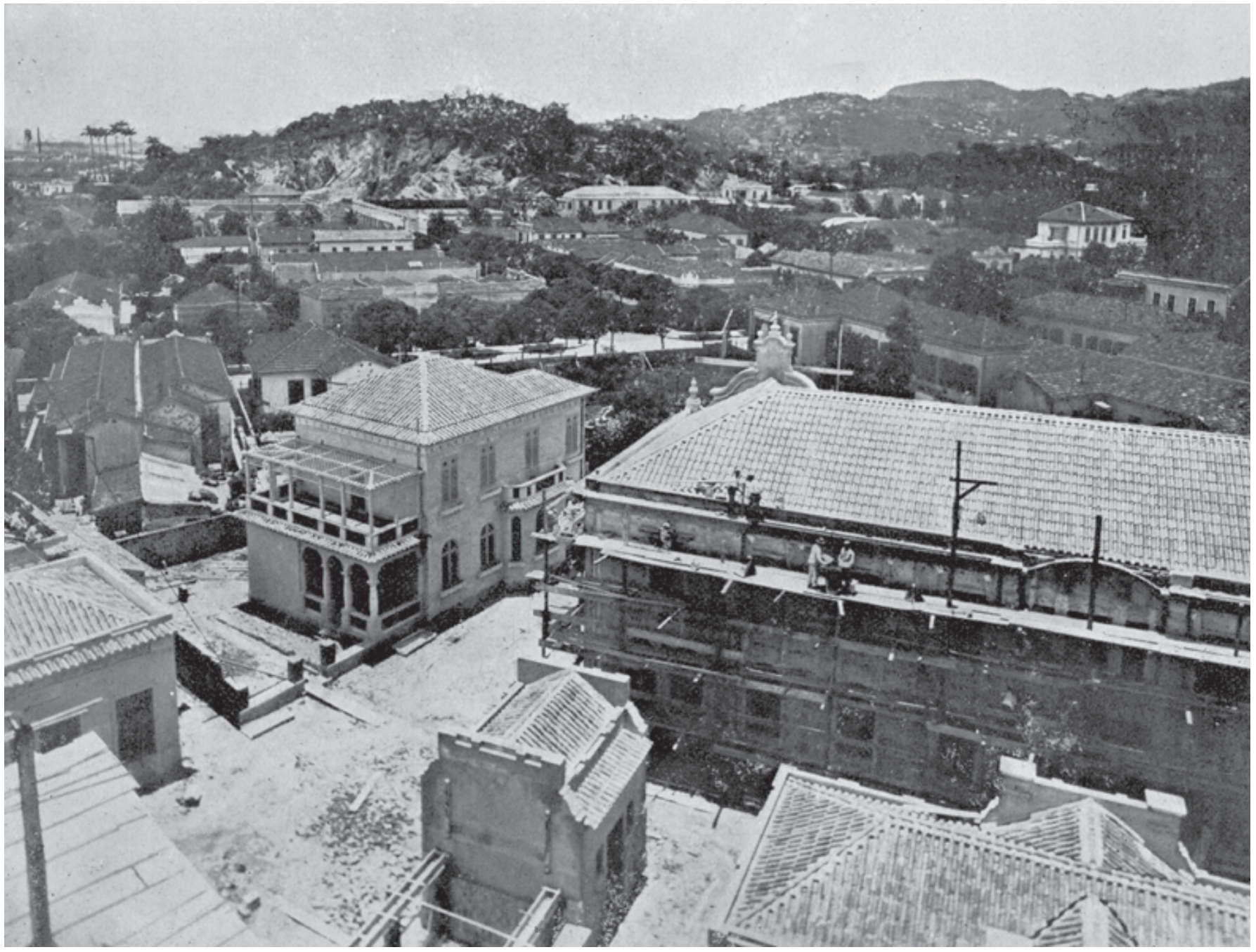

Construction of Gaffrée \& Guinle Hospital, [1924-1929]. Paula Machado family's Archives 


\section{FIRST REPUBLIC}

\section{Souza Aguiar Municipal Hospital}

Other denominations: Health Center (1907-1925); Emergency Hospital (1925-1955); Souza Aguiar General Hospital (1955-1963); Souza Aguiar State Hospital (1963-1975); Souza Aguiar Municipal Hospital (1975-present day).

Location: Centro.

Address: Praça da República, 111.

Category: General Hospital

Period of construction: 1965-1968 (current building).

Proprietor: City Hall of the City of Rio de Janeiro.

Author / Constructor: Ary Garcia Roza (1965-1968)

\section{History:}

The history of this hospital dates back to the old Health Center, inaugurated on November $1^{\text {st }}, 1907$, at Rua Camerino, during the administration of the Mayor of the Federal District, General Francisco Marcelino de Souza Aguiar. A construction of two floors, which contained a first aid dressing room, operating room, consultation room, accommodations for the doctors, assistants and subordinates and garage for an ambulance.

The Health Center would soon be insufficient, forcing the transfer and the construction of a new center at Praça da República, nos. 87 and 89, still in the administration of Souza Aguiar. This was inaugurated on October 17 ${ }^{\text {th }}, 1910$, by his successor, General Serzedelo Correia, however, the name of its idealizer would always remain associated to this hospital. Comprised of a central structure of three floors and two side structures of two floors, the hospital was serviced by an elevator. On the ground floor was located the radiology services, otorhinolaryngology, pharmacy, clinical research laboratory, sterilization, carpentry and storage; the $1^{\text {st }}$ floor had private rooms with piped water, infirmaries with six rooms, two beds, operating room with scialitic lamp, Schaerer operating table, autoclave, green house; on the second floor, there was a bathroom for burn victims, the only in the city at the time, bathrooms for adults and children, clothes closet and a room for casting equipment.

Ten years later, there was yet another need to construct more modern spaces, which began as of 1920 . The cornerstone was laid on October $12^{\text {th }}$, of the same year. The new facilities, separated in two blocks, would house the Emergency Hospital and the Department of Municipal Health Care. The architectonic complex, whose hospital had 130 beds, was inaugurated on September $20^{\text {th }}, 1925$ by Mayor Alaor Prata Soares, and the old Health Center was demolished. The Hospital and the Department of Assistance were unified under the health reform undertakings by Mayor Pedro Ernesto, in 1933.

In 1940, the Emergency Hospital was considered "the most important emergency hospitals in the Municipal Assistance" (Ribeiro, L. 1940: 172-173), answering cases through the telephone and ambulance service and hospitalization, with increased capacity for 200 beds. The beds were distributed between the Medical Clinic and the Surgical Clinic for Women and for Men. Otorhinolaryngology, ophthalmology clinic, dentistry, clinical research, pathological anatomy, roentgenology and pharmacy services were maintained.

In the very same year, 1940, there were rumors of the construction a "very modern" building, with ten floors, whose construction would only begin 25 years later.

On June $2^{\text {nd }}, 1955$, celebrating the centenary of Souza Aguiar, the Emergency Hospital became known as Souza Aguiar General Hospital, by means of decree no. 12865, under Mayor Alim Pedro and Secretary of Health, Eitel Pinheiro de Oliveira Lima. Under Act 279 of December $28^{\text {th }}, 1962$ and decree no. 1612 of March $2^{\text {th }}, 1963$, the General Hospital Souza Aguiar was linked to the Medical Services Superintendence (SUSEME) and received the name Souza Aguiar State Hospital. 


\section{FIRST REPUBLIC}

The modernization project of the hospital, which had been planned and approved since 1940, underwent modifications and the proposal for a building constituted by one single strip of 10 floors was changed to a construction of three blocks. One with three floors, for the emergency sector and the Surgical Center and Radiology; one with seven floors, consisting of the infirmaries, polyclinics and the new entrance to the hospital; and, finally, one with two floors, consisting of the administration, the main auditorium and the dependencies of the Center of Studies, Training and Improvement. The latter was inaugurated on November $4^{\text {th }}, 1968$. Under this expansion, the number of beds doubled, and the hospital remained a reference for emergency services. During this period, Souza Aguiar was considered "the most modern in Latin America", able to tend to 700 people daily, as published by the Jornal do Brasil on October $29^{\text {th }}, 1965$.

In 1960, with the transfer of the federal capital to Brasília, the State of Guanabara was created encompassing the entire municipality of Rio de Janeiro. During this period, the hospitals belonging to City Hall of the Federal District begin to have state jurisdiction. Fifteen years later, in 1975, with the merging of the states of Guanabara and Rio de Janeiro, some of these hospitals returned to the condition of municipal hospitals - among these Souza Aguiar Municipal Hospital, while others remained state hospitals.

Currently, it is still considered one of the biggest emergency hospitals in Latin America, tending, on average, a thousand people a day, in more than 25 medical specialties, including the Burns Treatment Center.

\section{Architectonic description:}

As of the 1960's, many hospitals would undergo reforms and expansions. The old facilities of these hospitals were becoming obsolete and needed to undergo adaptations given the imposed and consolidated typology coming from the North-American single-block structures. A great number of institutions had their old facilities demolished to make way for blocks of five, seven or ten floors. Others, received annexes, maintaining and reforming the original facilities. The changes in medicine would bring to architecture rectilinear lines, without ornaments and following the standard type. Accord to Garcia Roza description, the arquitectonic conception foresaw a construtive system made by a concrete structure free of any inlaid facilyties, helping the maintenance and repairs, without interfer the. The work was planned in stages to avoid stopping the hospital services as well. The material choice aimed, beyond the assemble harmony, the maintenance and durability easiness.

\section{Register of Preservation:}

It is not listed.

\section{Sources:}

A CRIAÇÃO de mais um serviço de Assistência Pública. Correio da Manhã, Rio de Janeiro, 22 de setembro de 1925. ASSISTÊNCIA Pública e Privada no Rio de Janeiro (Brasil) - História e Estatística. Comemoração do Centenário da Independência Nacional. Rio de Janeiro: Typographia do Annuario do Brasil, 1922.

ASSISTÊNCIA Pública - Guanabara: 80 anos de história. Rio de Janeiro: Superintendência de Serviços Médicos (SUSEME); 1972. mimeo.

ASSISTÊNCIA Pública. Jornal do Brasil, Rio de Janeiro, 02 de novembro de 1907.

DEPARTAMENTO de Assistência Pública. Jornal do Commercio, Rio de Janeiro, 08 de setembro de 1921.

HOSPITAL Souza Aguiar. Conjunto Hospitalar. Revista Arquitetura, Rio de Janeiro, n. 35, p. 10-12.

O SERVIÇO de Pronto Socorro será inaugurado hoje. Correio da Manhã, Rio de Janeiro, 04 de agosto de 1920.

POSTO Central de Assistência Municipal. Jornal do Commercio, Rio de Janeiro, 18 de outubro de 1910.

POSTO central de Assistência. Jornal do Commercio, Rio de Janeiro, 02 de novembro de 1907. 


\section{FIRST REPUBLIC}

PROGRAMA de hoje começa com a inauguração do Porto. Jornal do Brasil, Rio de Janeiro, 29 de outubro de 1965. RIBEIRO, L.. Medicina no Brasil. Rio de Janeiro: Imprensa Nacional; 1940.

SOUZA Aguiar festeja seu aniversário. Correio da Manhã, Rio de Janeiro, 05 de novembro de 1968.

Credits: Daniel Elian (research) and Renato da Gama-Rosa Costa (text and architectonic description). 


\section{FIRST REPUBLIC}

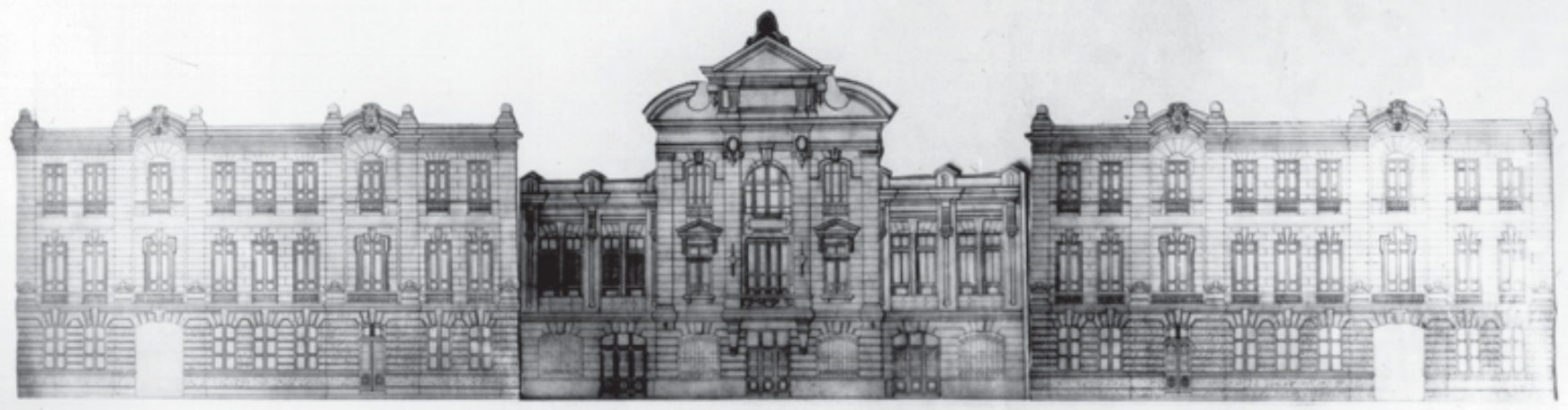

View of Pronto Socorro Hospital, [1907]. Photo Augusto Malta. Museu da Imagem e do Som - RJ Archives

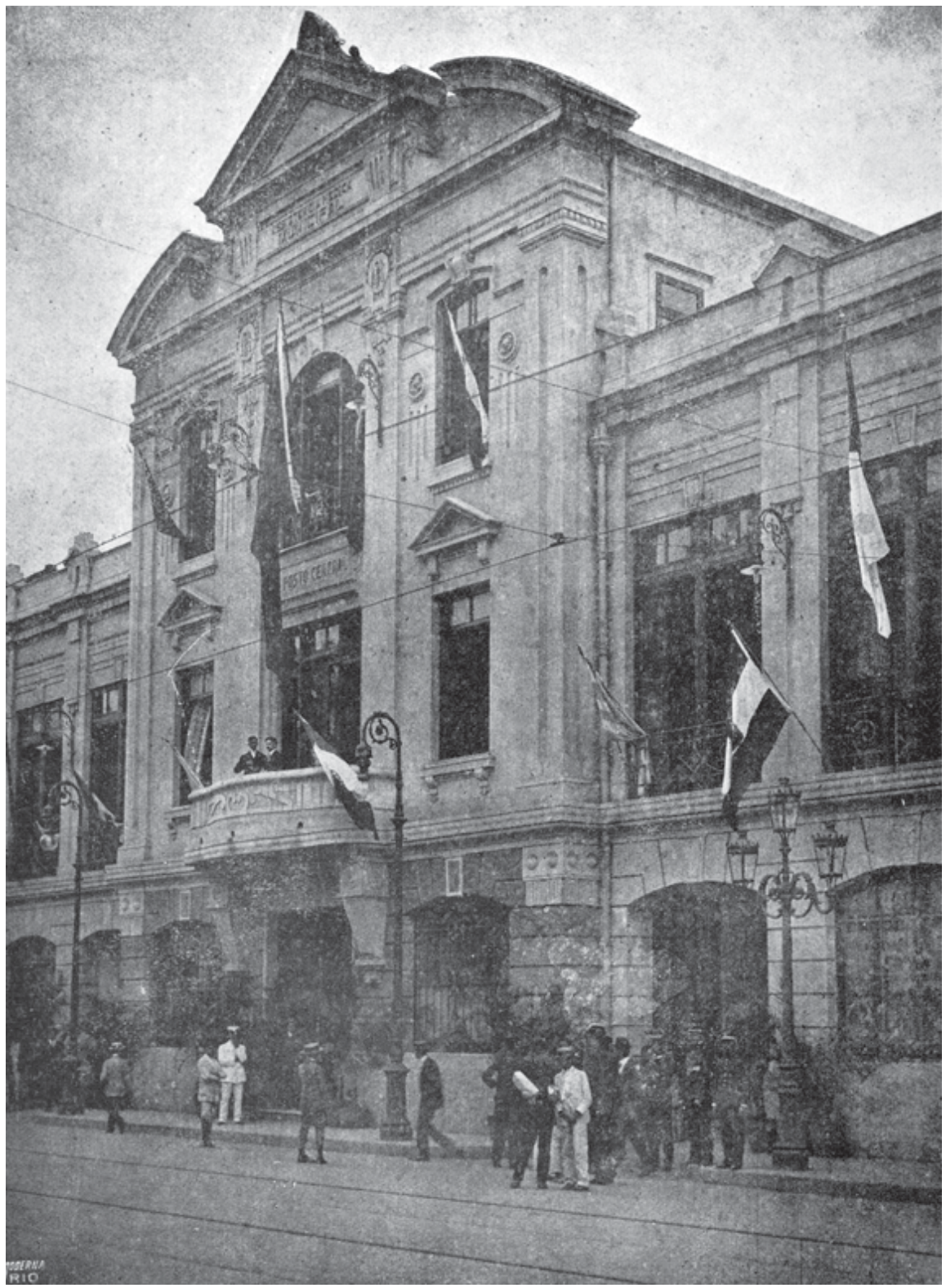

Pronto Socorro Hospital, [s.d.]. Source: ASSISTÊNCIA, 1922 


\section{FIRST REPUBLIC}

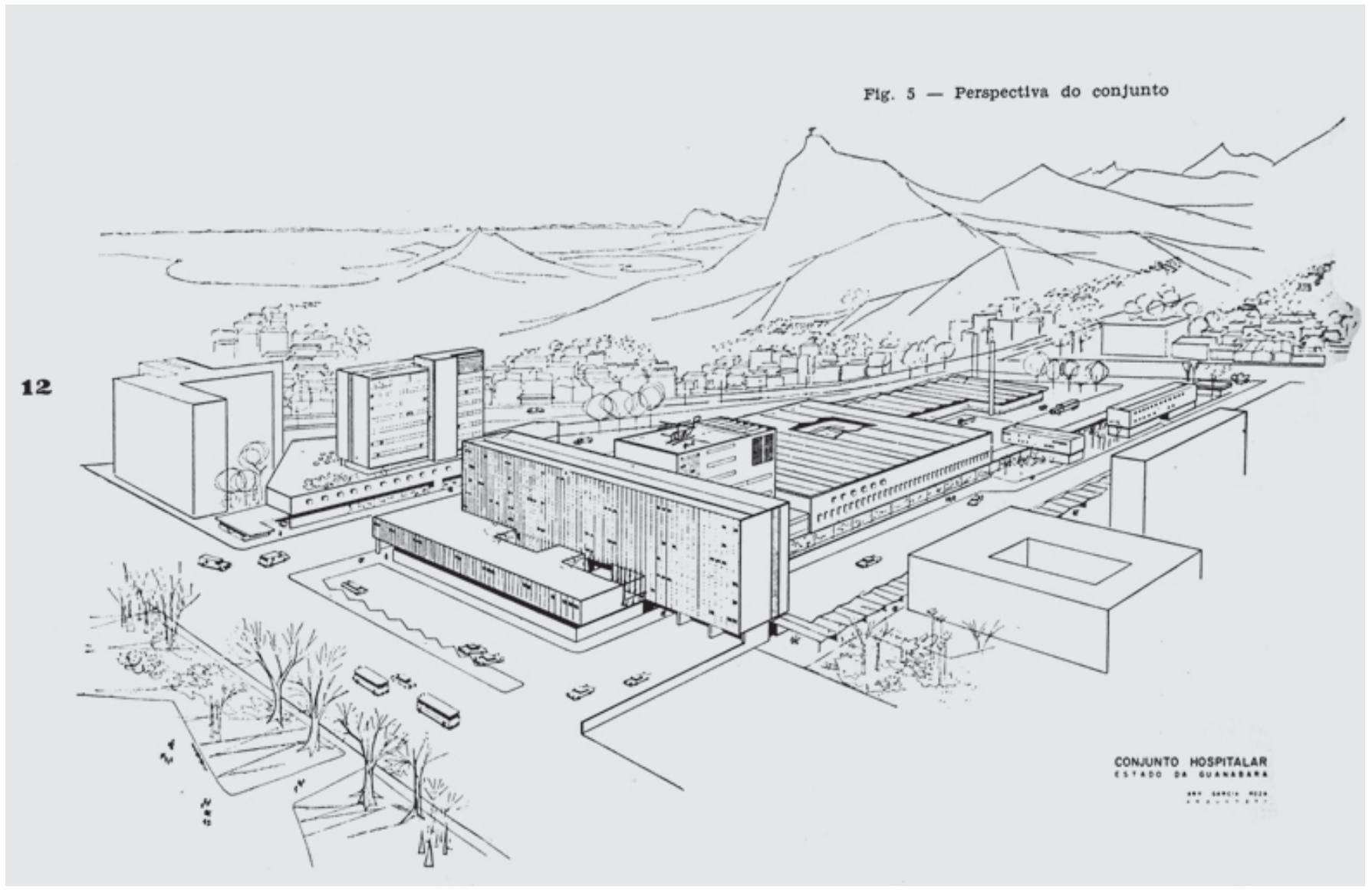

Perspective of Souza Aguiar Hospital, [1965]. Arquitetura, n. 35, 1965 


\section{FIRST REPUBLIC}

\section{Spanish Hospital}

Location: Lapa

Address: Rua do Riachuelo, 302

Category: General Hospital

Period of Construction: $19^{\text {th }}$ century

Proprietor: Sociedade Espanhola de Beneficência

Author / Constructor: unknown

\section{History:}

The Sociedade Espanhola de Beneficência (Spanish Beneficence Society) was created in Rio de Janeiro on September $13^{\text {th }}, 1859$, seeking to give assistance to the Spanish community at the Court. In the following year, it obtained recognition for its philanthropic action by the emperor, Pedro II. This period is marked by the existence of various mutual aid societies, many of them linked to the colonies of foreigners: the Portuguese, Spanish, Italians, English, French, Germans and Swiss maintained cultural and philanthropic entities to help their fellow countrymen in periods of necessity. Very often, such actions were brought to fruition in the maintenance of a hospital.

The idea of the creation of a hospital was raised over many years until, in the second decade of the century people began to talk more often about the creation of funds for the construction of the Spanish Hospital, especially, from the beginning of the decade of 1910. But it was only in 1918, with the constitution of the Comision de Fiestas y Propaganda (Commission of Parties and Advertising), that had as its objective, making work on the hospital viable, is that its realization got closer.

In 1917, the Sociedade Espanhola de Beneficência bought some land at Rua Fonseca Telles, in the district of São Cristóvão, with the purpose of establishing there the future hospital and where there would start to operate, as from 1919, medical consultation rooms of the Society in houses constructed with the purpose of raising funds for the realization of the hospital project.

With the donation of the land, by a Spanish tradesperson, at Rua Fonseca Telles, near to the clinics of the Society, at the beginning of the 1920's, the desire for the construction of a hospital became closer to reality. In 1922 the foundation stone of the hospital was laid and preparation for the building of the first pavilion began. The project was delivered to the architect Adelstano Soares de Mattos Porto d'Ave.

In 1926 the final plans were not ready and the Society was still discussing the definitive authorization, as well as the payment of the architect for the inspection of the work. In the same year, the proposal of the acquisition of the Criciúma Health Care Center, situated in Rua do Riachuelo no. 302, was forwarded to the Society, which ended up being purchased in 1927. The hospital was then inaugurated on October $12^{\text {th }}, 1928$, the $2^{\text {nd }}$ floor having been dedicated to the King of Spain, don Affonso XIII and the $3^{\text {rd }}$ floor, the maternity wing, dedicated to the Queen, dona Vitória Eugênia.

Porto d'Ave's project was forgotten and the land at Rua Fonseca Telles came to be rented by the Society.

The hospital offered free service to the members of the Spanish community in the region and maintained agreements with some entities of professional categories - such as drivers - for attending to the family members of their associates in the buildings of the hospital; besides private patients. Its clinical staff was formed by doctors of all nationalities, even though in the beginning there was a movement so that it was formed only by Spanish doctors.

In 1929 the first great modification in the structure of the hospital happened with the restructuring of the consultation rooms, the construction of the pharmacy and the clinical analysis laboratory. In this same year the first ambulance was purchased - thanks to the contribution of Spanish agencies, through the Spanish Embassy in Rio de Janeiro.

The last transformation of the hospital was in 1940, with the installation of the headquarters building of the Society on the hospital grounds in 1943. In this same year the physiotherapy service was inaugurated; new laboratories; three apartments; rooms for the employees and a meeting room were added. 


\section{FIRST REPUBLIC}

Recently, it underwent a reformulation seeking to adapt itself to the new paradigms that guide the operation of a hospital: its emergency service was inaugurated in 2002, offering modern technology and installations; it adhered to the concept of a hospital-hotel for internments; and its surgical center is equipped for major surgeries. It serves both associates as well as the convention members.

\section{Register of Preservation:}

It is not listed.

\section{Sources:}

SANGLARD, G. \& COSTA, R. Hospital Espanhol. In: Porto d'Ave - projetos para a saúde, 1920-1940 (catálogo da exposição). SOCIEDADE Espanhola de Beneficência - 146 anos de história.

Credits: Renato Pereira da Silva (research) and Gisele Sanglard (research and text) 


\section{FIRST REPUBLIC}

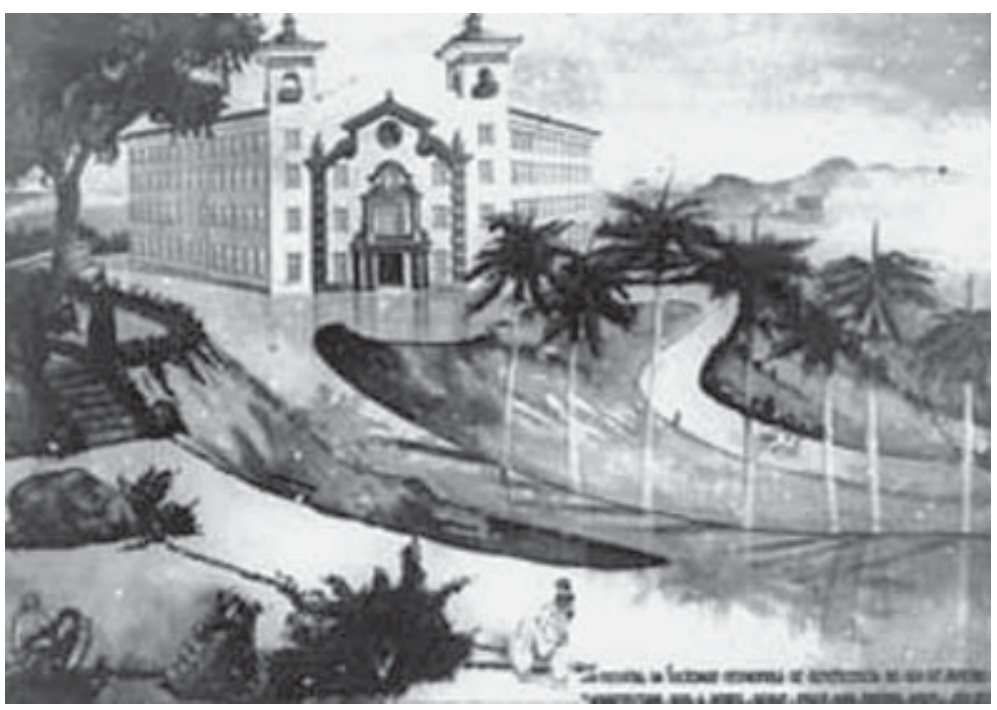

Spanish Hospital, [s.d.]. Porto d'Ave Fund. Casa de Oswaldo Cruz Archives

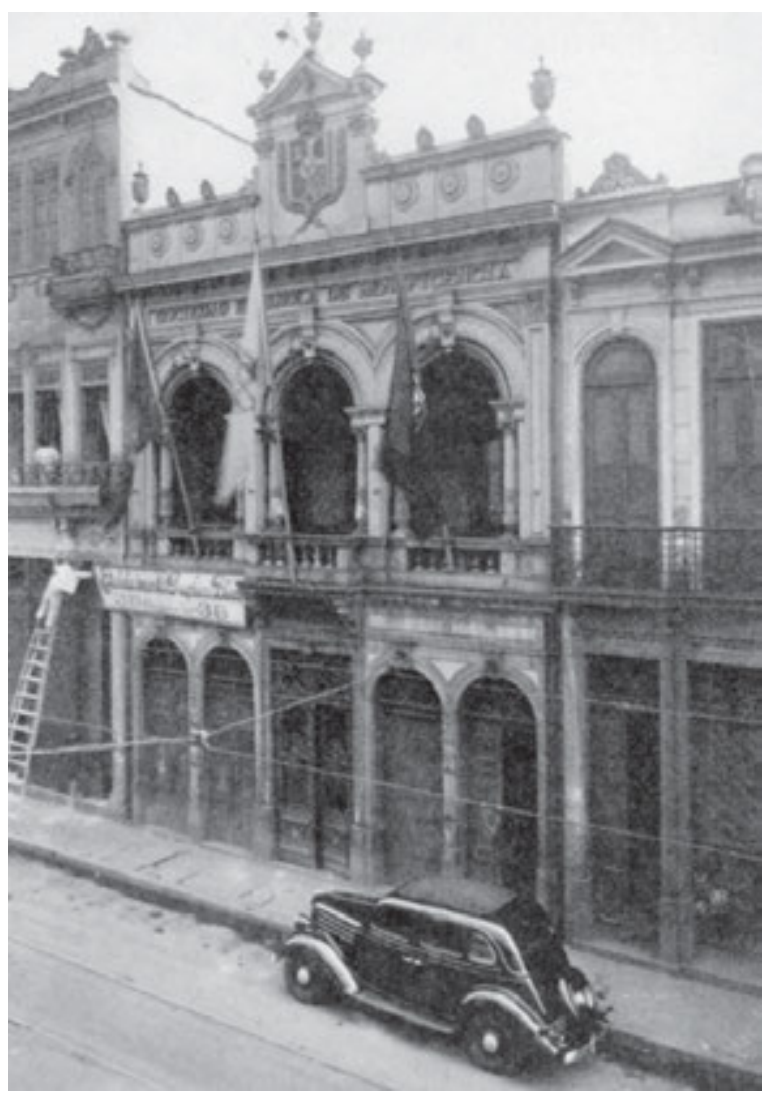

Spanish Beneficence Society old façade, [1930]. Sociedade Espanhola de Beneficência Archives

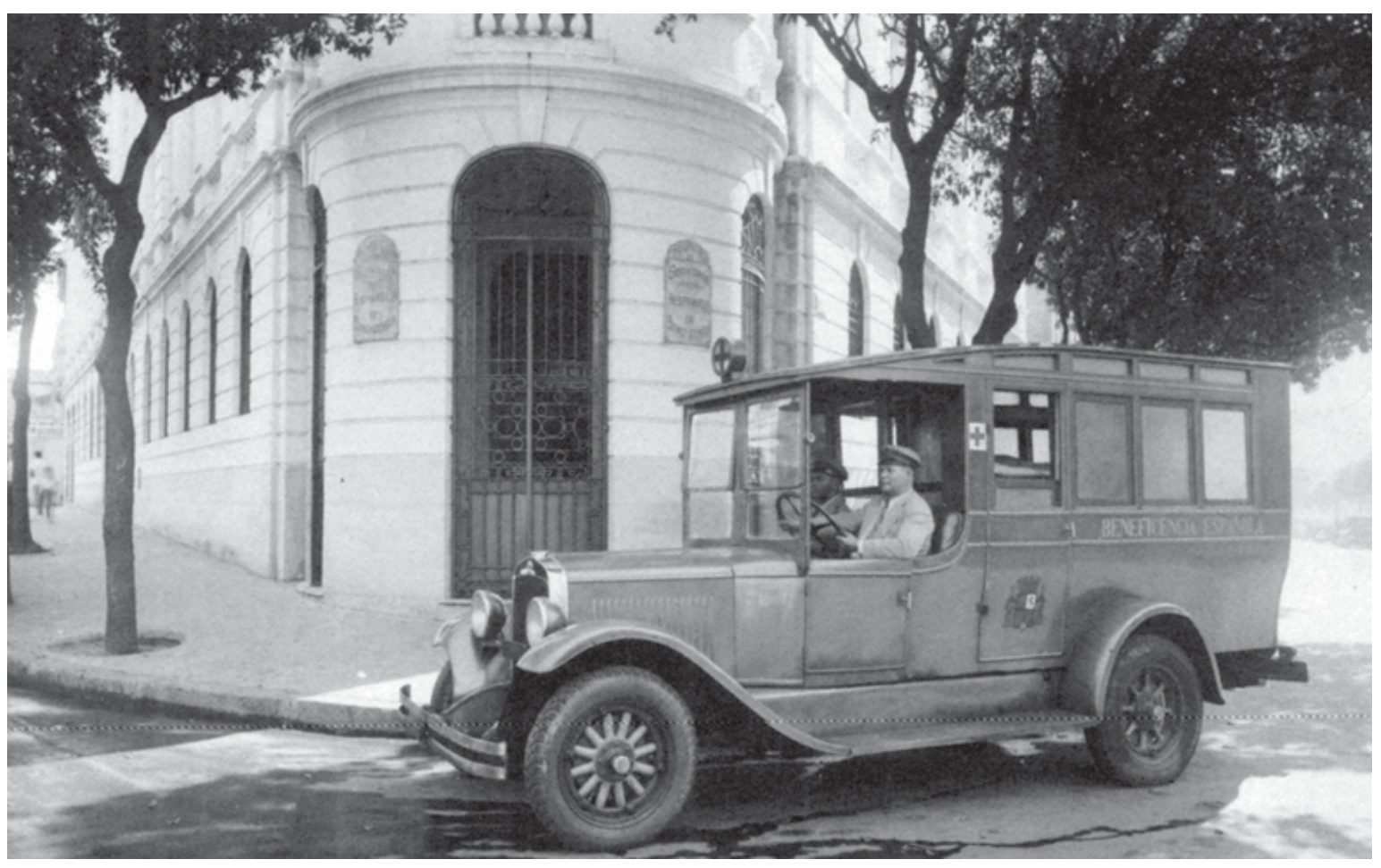

Spanish Hospital old entrance,

[1930]. Sociedade Espanhola de Beneficência Archives 


\section{FIRST REPUBLIC}

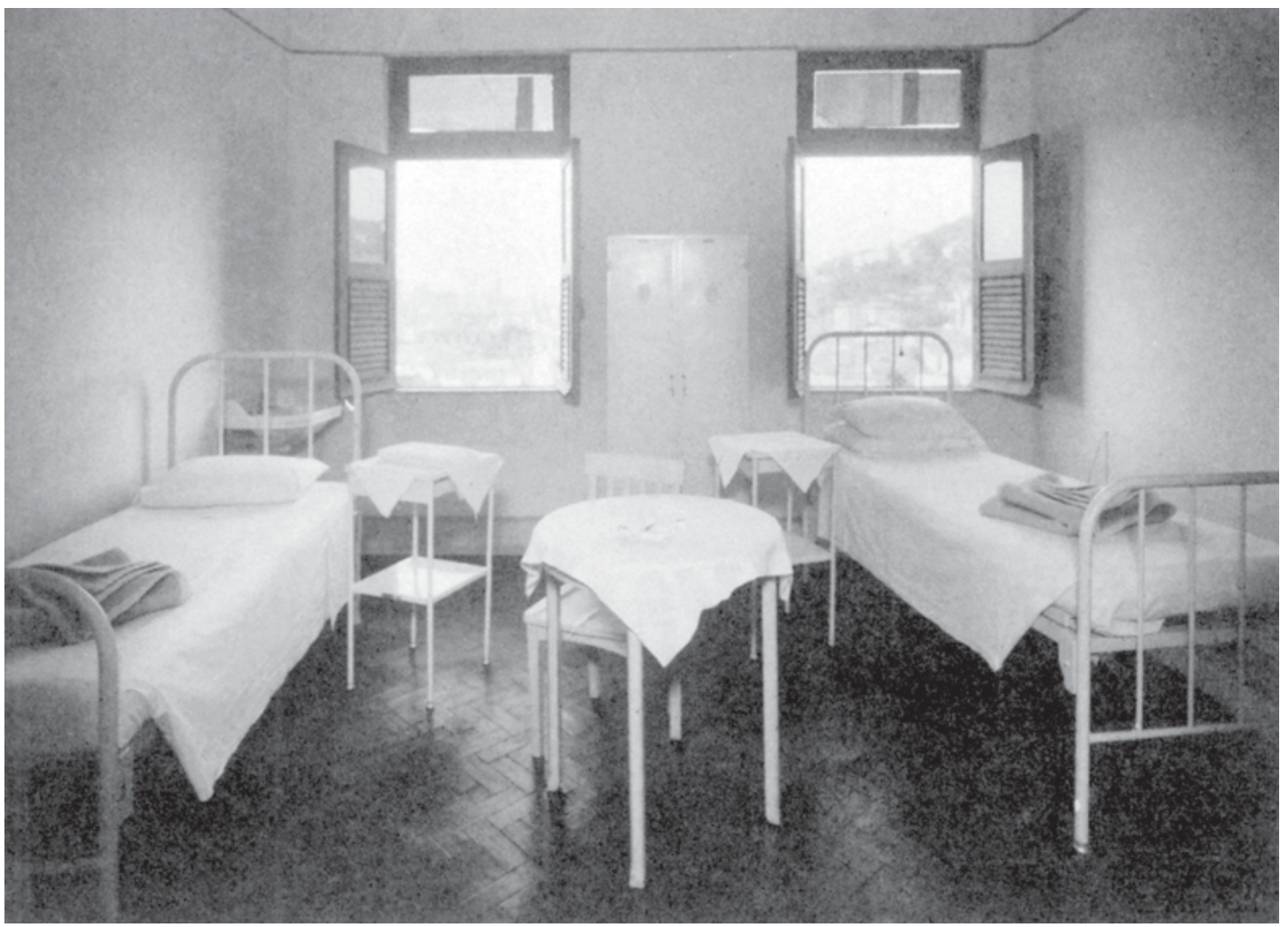

Campaign Room -

Spanish Hospital, [1930].

Sociedade Espanhola de Beneficência Archives

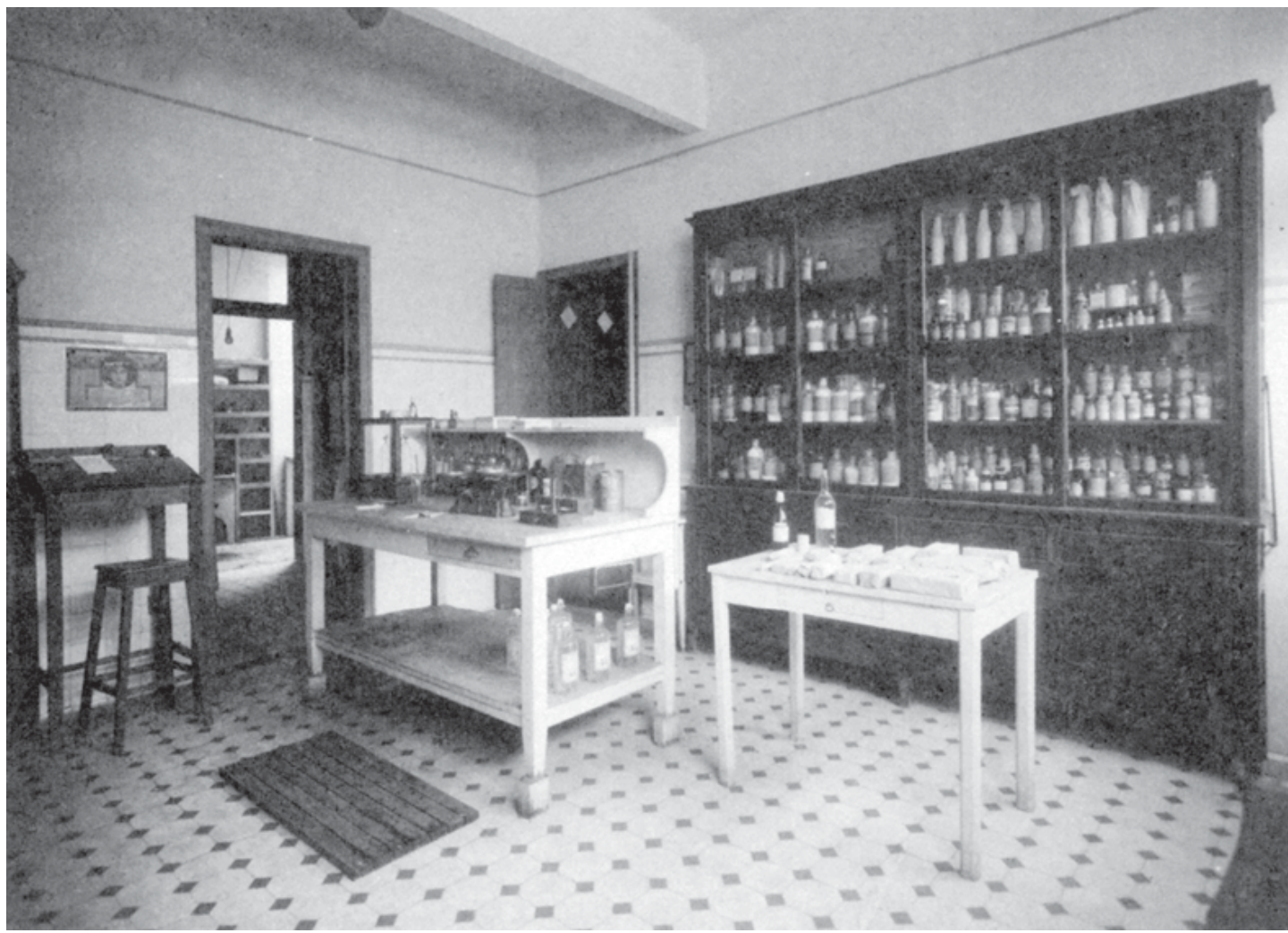

The Spanish Hospital

Pharmacy, [1930].

Sociedade Espanhola de

Beneficência Archives 


\section{FIRST REPUBLIC}

\section{State Institute of Sanitary Dermatology}

Location: Jacarepaguá

Address: Rua Godofredo Viana, 69

Category: Specialized Hospital

Period of construction: 1922-1929

Proprietor: Government of the State of Rio de Janeiro

Author/constructor: unknown

\section{History:}

The State Institute of Sanitary Dermatology, the old Curupaity Hospital, is located in Jacarepaguá, Rio de Janeiro. The 'Curupaití Site', with 130 thousand $\mathrm{m}^{2}$, was acquired by the Government in April of 1922, and in October of the same year, the foundation stone was laid. According to Souza Araújo (1956: p. 533), a short time later, the first patients arrived who were interned in the São Sebastião Hospital. However, only six years later, in October of 1928, a larger number of patients were registered (53 women and one boy). At that time, the works were well advanced and it already had the feminine and masculine tuberculosis wards and the so-called "neutral or healthy zone", where normally the administration of the hospital was located.

The official inauguration of the Hospital-Colony of Curupaity occurred on January $01^{\text {st }}, 1929$, and its first director was Theophilo de Almeida, a leprologist designated by Joaquim P. Motta, director of the Inspectorate of the Prophylaxis of Leprosy and Venereal Diseases, the highest authority for the definition of health policies with regard to these diseases, which was subordinated to the Hospital. In March of 1929, another 70 patients were interned and this group of 120 persons consolidated the image of the federal leprosy hospital as a model institution in the federal capital for the treatment of leprosy sufferers

Anxiously awaited by the leprologists, the inauguration and operation of this Hospital helped to consolidate a health policy based on the isolation of the sick in institutions specially created for this purpose and that reflected both the health policy as well as the scientific knowledge that had been accumulated about the sickness up to that time. This policy suggested that the leprosy hospitals should be constructed in an area away from city centers where a higher demographic density is found. This measure was used to make contact with society difficult, and in some cases make impossible, for, by this, it was thought, the infection and the appearance of new cases could be avoided.

It should be recalled that at this time the Sanitary Regulation of 1923 was already in force, where it was defined that the prophylaxis used for the disease would be by means of isolation, at home or in hospital, and it would be the responsibility of the State to provide the conditions making it possible for the internment of the number of known sufferers. This standardization of isolation as the ideal treatment for lepers and the increasing construction of isolation hospitals in Brazil represented, in a certain manner, the cleansing of the social environment and of the individual and that, due to this, it would be possible to have a healthier city.

As it was one of the first isolation hospitals constructed in the country and being very close to the leprologists connected to the Inspectorate for the Prophylaxis of Leprosy and Veneral Diseases, Curupaity became a model hospital, a center of national reference for the treatment of the disease, contributing to its high number of internments during the decade of the 1950's, when it came to have around 2 thousand patients. The International Leprology Center also functioned there, from 1934 to 1939, which was linked to the League of Nations, and that represented a model in experimental research about the disease.

Life behind the walls of the institution involved the total isolation of the patients and the lack of contact with family members led many of them to establish new "family" relationships and to constitute another life. There were marriages and a social life among the sufferers, who associated together in the games room, the cinema, the musical band and the 


\section{FIRST REPUBLIC}

schools; all these activities took place within the confines of the Hospital. Visits were permitted only for a very few family members and, in time, these became less frequent until they stopped, in the majority of the cases.

The treatment of the lepers up until the 1960's was based on the existence of three institutions that complemented each other: isolation hospitals, outpatient centers and preventive centers, that so constituted the "tripod model" which communicated between themselves and complemented each other epidemiologically and socially, in the control of leprosy. The most serious cases and those with more severe physical mutilations were interned in the isolation hospital; the children of these patients and those that were born in the "new" life inside the hospital, would be sent to the prevention centers with the objective of minimizing the contact of the child with the sick parents; the dispensaries were created to prevent future cases of leprosy and prevent indications of the disease in those who had daily contact with the lepers, above all family members and friends.

At the end of the 1940's and beginning of the 1950's, there were modifications in the treatment of the sick with the advance of the pharmaceutical industry and medicines, for the use of sulfone and specific antibiotics such as Promin began, with the interns in the isolation hospitals and with those in contact with them cared for by the dispensaries. At this time, isolation in hospitals for lepers came under severe attack as a form of control due to the growth in the number of cases. At the beginning of the 1960's, the basic research about the peculiarities of the bacillus that causes the disease and the existing medicines had already given sufficient confidence to think about abolishing the isolation hospital and this became official by means of decree no. 968, of May 07 th, 1962 , but it is known that in states such as São Paulo, for example, the isolation hospital existed until 1967, when doctor Abraão Rotberg assumed the direction of the Department of Prophylaxis of Leprosy and definitively terminated their use in the State. In the 1970's, the World Health Organization recommended the use of poly-chemotherapy in Brazil and in parallel with this, initiatives were taken with the objective of minimizing prejudice and the stigma surrounding the term "leprosy" and its derivatives, and the disease began to be designated as 'hansenosis'.

In the 1980's, in the context of the end of the dictatorship and the quest for democracy, the $8^{\text {th }}$ National Health Conference was held in 1986, fully recovering citizen's rights. At this time the isolation hospitals had their role redefined and some were transformed into general hospitals, dermatology hospitals, as is the case of Curupaiti, and others into research centers, as is the case of the Aymorés Sanatorium, which was transformed into the Lauro de Souza Lima Institute, in Bauru, São Paulo. As a form of assuring the rights of the patients, seeing that many of them were confined for decades and giving attention to their role as citizens, guaranteeing their social re-inclusion, the Movement for the Reintegration of Persons Suffering from Hansenosis (MORHAN) was created, which is one of the most successful social movements in Brazil, with representation on the National Board of Health.

In 2009, Curupaity will complete 80 years of existence, a date marked by its official opening, in January of 1929 . Even today, it has around 500 patients who reside within the limits of the hospital and its surroundings, besides offering medical and surgical services related to its speciality.

\section{Architectural description:}

The proposal of the construction of a hospital for lepers isolated from the populated centers led to thinking of its establishment by reproducing the planning, the elements and the equipment of a small urban community, placing the main buildings for treatment, recreation, workship and administration around a central square. The residences were positioned along the roads leading to the square and on the other side of the hill, respecting the typology of the isolation.

The architectural languages are in accordance with the purposes of the buildings: the ones specifically destined to the treatment of the patients; to the outpatients and the preventive centers; to the administrative areas; to the areas of recreation (cinema, games room and the Elite club) and for the patients residences. The buildings - especially the residences of the patients - follow a more traditional architectural tendency, with reference to a more simple type of the Brazilian eclectic, much used in health institutions created throughout the 1920's. The highlight is the art déco architecture used 


\section{FIRST REPUBLIC}

for the administrative buildings and especially for the cinema. This was provide with a more cubist line of the déco language, which reached its peak in the 1930's in the United States, confirming the adoption of this style in this type of use and culture.

\section{Register of Preservation:}

It is not listed.

\section{Source:}

MANUAL de leprologia. Rio de Janeiro: SNL, 1960, pp. 24-9.

SECRETARIA de Estado de Saúde do Rio de Janeiro. Indicadores e Informações em Saúde. In: http://www.saude.rj.gov.br/informacoes /bancodad.shtml Acessado em 11/10/07.

SOUZA-ARAUJO, H. História da lepra no Brasil - Período Republicano (1890-1952). vol. III. Rio de Janeiro: Departamento de Imprensa Nacional; 1956.

Credits: Laurinda Rosa Maciel (research and text) and Renato da Gama-Rosa Costa (architectural description). 


\section{FIRST REPUBLIC}

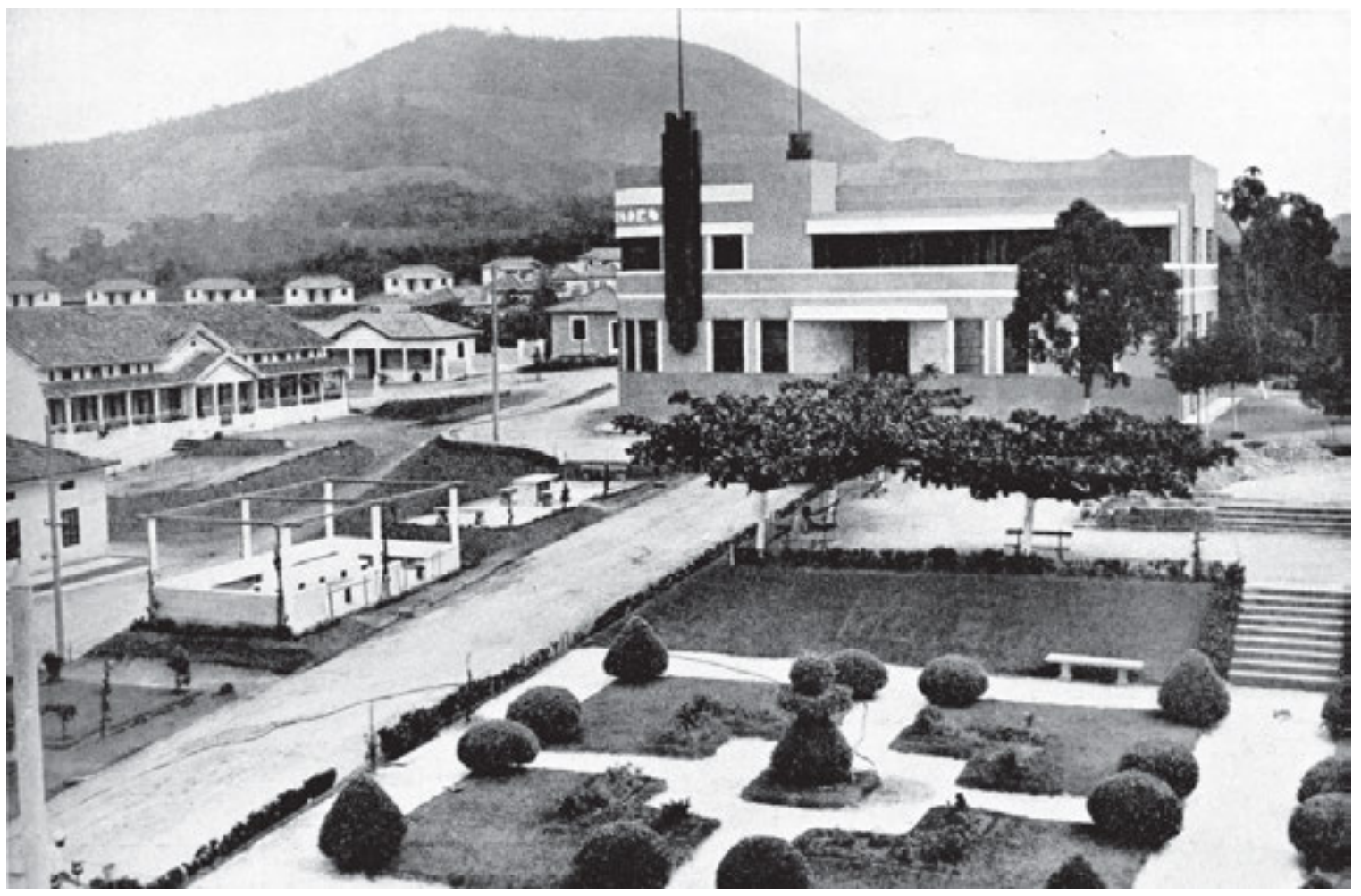

Curupaity Hospital,

[s.d.]. Source: SOUZAARAÚJO (1958)

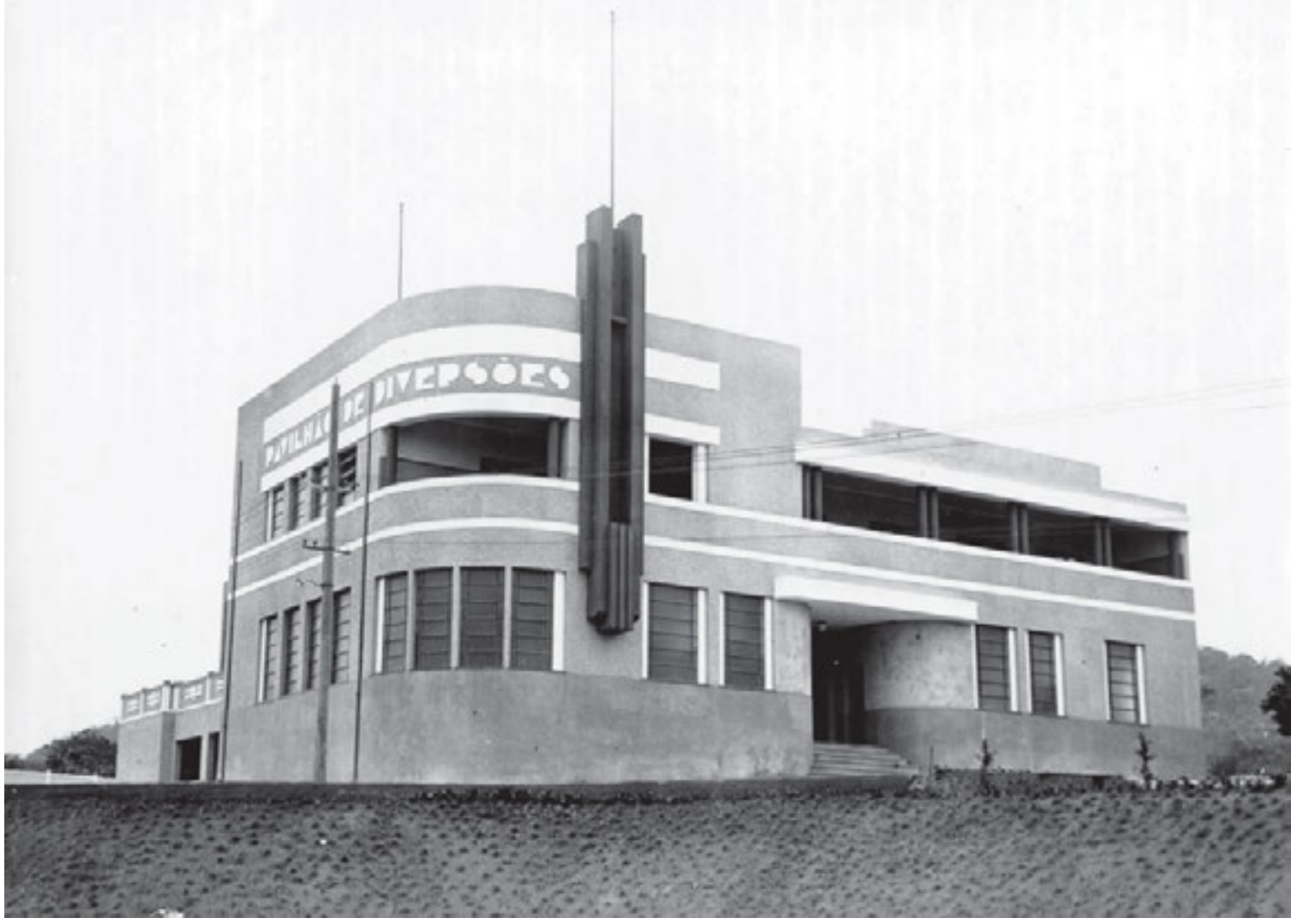

Curupaity Hospital [s.d.].CPDOC/FGV

Archives 


\section{Alexander Fleming Maternity Hospital}

Other denominations: Alexander Fleming Polyclinic (1956-1979); Alexander Fleming Maternity Hospital (1979-present day).

Location: Marechal Hermes

Address: Rua Jorge Schmidt, 331

Category: Maternity

Period of construction: 1953-1955.

Proprietor: City Hall of Rio de Janeiro

Author / Constructor: Project of Oscar Valdetaro and Roberto Nadalutti; constructor D. T. Engenharia (Paulo Gentil de Carvalho Mello e Abelardo de Araújo Jurma, engeneers).

\section{History:}

On January $26^{\text {th }}, 1956$, the Alexander Fleming Polyclinic, situated in Marechal Hermes, was inaugurated. Construction was initiated on September $24^{\text {th }}, 1953$. For 23 years the Polyclinic was an annex of the State Civil Servants Hospital and its maternity unit was assigned to care for the federal public servants that contributed to the State Civil Servant's Welfare Institute (IPASE).

At the time of the inauguration, the Polyclinic had 50 beds and 04 cots, including a Section for Premature Babies. Healthcare for women and children appeared on the national public health scenario as an immediate necessity for women of all social segments. The state and private initiative were responsible for the founding of various maternity units in the city of Rio de Janeiro, over the first half of the last century, with the objective of meeting this need.

In 1979 it became an independent unit of the State Civil Servants Hospital becoming a part of the network of those insured by the National Institute of Social Welfare - INAMPS, and coming to be called the Alexander Fleming Maternity Hospital.

With the implementation of the Unified Health System (SUS) in 1990, eleven of the sixteen hospitals belonging to the Ministry of Health in the city of Rio de Janeiro, came to be under municipal authority, among them being, the Alexander Fleming Maternity Hospital. Of the remaining five, three were elevated to the category of Institutes, with the attribution of proposing health policies for their areas of interest (National Trauma-orthopedics Institute, National Cancer Institute and Institution of Cardiology of Laranjeiras); while the two remaining ones - the State Civil Servants Hospital and the Bonsucesso General Hospital - due to their being a reference to the municipal and state health network, were maintained by the Ministry of Health.

At present, a large proportion of the population served at the Alexander Fleming Maternity Hospital comes from Baixada Fluminense; from the regions of the West Side of the City (Campo Grande, Santa Cruz, Guaratiba), Bangu, Realengo, Deodoro and surrounding areas. The women that use the services of the referred to institution find a pre-natal service, interdisciplinary care of the newborn at risk, nutritional accompaniment, care for family members and patients who are victims of sexual violence, medical practice, an oral health program, family planning, vaccination and examination room, radiology, ultrasound, and cardiotocography services, among others.

\section{Register of Preservation:}

It is not listed. 


\section{Sources:}

BITENCOURT, F. Hospital dos Servidores do Estado: um patrimônio de saúde, Arquitetura e história. Rio de Janeiro, 2007. Informações da Diretoria.

http://www.sms.rio.rj.gov.br

Credits: Maria Renilda Nery Barreto and Isaura Faria - Director of the Administrative Division of tha AFMH - (research and text). 


\section{AFTER 1930}

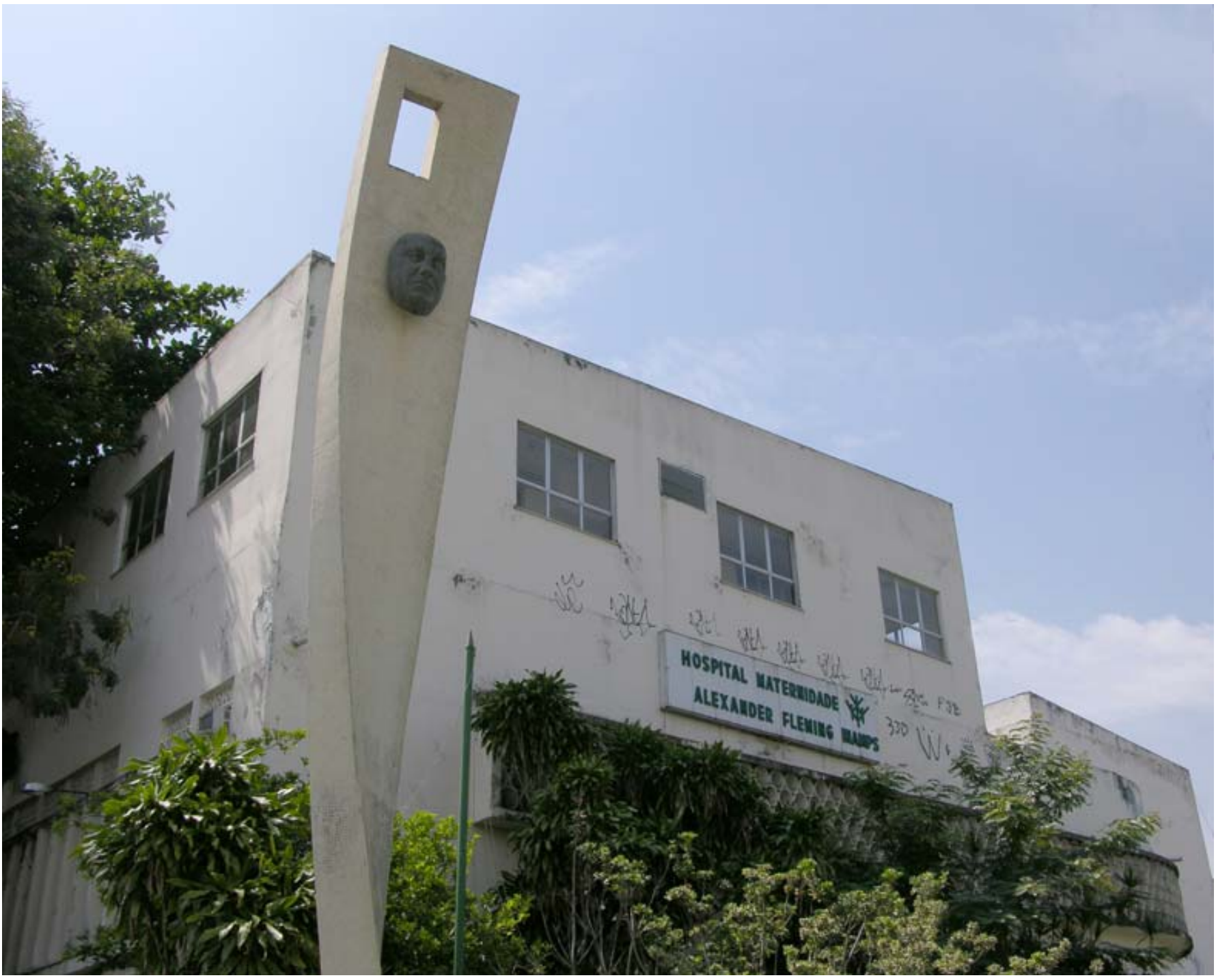

Alexandre Fleming Maternity. Photo Roberto Jesus Oscar \& Vinícius Pequeno de Souza, 2008. Casa de Oswaldo Cruz Archives 


\section{Aloysio de Castro State Institute of Cardiology}

Previous denomination: Assistance Service for Cardiovascular Diseases (1941-1944); Institute of Cardiology (19441962); Aloysio de Castro State Institute of Cardiology (1962-present day)

Location: Humaitá

Address: Rua Davi Campista, no. 326

Category: Cardiological Hospital

Period of construction: [195?]

Proprietor: Government of the State of Rio de Janeiro

Author / Constructor: Estanislau V. Zaremba and Helmut Braunschweiger (architects)

\section{History:}

The history of the Aloysio de Castro Institute of Cardiology is directly related to the action of a group of doctors among them being, Genival Londres - which culminated in the creation of the Assistance Service for Cardiovascular Diseases, subordinate to the Department of Hospital Assistance, of the General Health and Assistance Department, by President Getúlio Vargas, on January $27^{\text {th }}, 1941$.

The Service had as its purpose to promote, direct and coordinate the treatment of cardiovascular diseases in the federal capital. Its first address was the Municipal Emergency Hospital, today Souza Aguiar; and its first director was doctor Genival Londres, one of its founders.

In 1944, Decree-Law no. 6769, of August $7^{\text {th }}$, signed by Getúlio Vargas, transformed the Service into an Institute of Cardiology and it received a space of its own in a two floor building, next to the Hospital. At that time it had 5 outpatient departments - with a total of 20 beds, and X-ray, electrocardiography and phonocardiography services. It had a medical team of about 10 professionals.

In March of 1950, General Mendes de Moraes, Mayor of the Federal District, transferred the Institute of Cardiology to the Pedro Ernesto Hospital, where it had a hundred beds available. Some time later, the Institute became a part of the Heart, Arteries and Kidney Diseases Service of the Hospital. If, on the one hand, this change meant a greater capacity to attend to patients, on the other, it brought with it a loss of the autonomy that the institution had possessed.

In the year of 1956 new changes took place and the Institute became independent of the Pedro Ernesto Hospital when it was temporarily installed at Rua Silveira Martins, no. 161, where only the outpatients operated.

In 1958, a new change, going on to function on one floor of the Bromatologic Laboratory building, at Rua Washington Luiz no. 17. In the following year, it began to occupy another floor, thus, expanding the number of beds, outpatients and doctors.

In 1962 the Hospital became linked to the Medical Services Department (SUSEME) of the then State of Guanabara, receiving the name of Aloysio de Castro State Institute of Cardiology, in honor of one of the great men of Brazilian medicine.

With the growth that was experienced, the need was seen for a new change, to a place that could meet the requirements of the Institute. The solution found by the Department of Health, during the administration of Raymundo de Moura Brito - government of Carlos Lacerda (1960-1965) - was the purchase of the old Hospital do Radialista, in the borough of Humaitá, which had closed down in 1962. Two years later, in August of 1964, the Institute was transferred to the old building of the Hospital dos Radialistas, where it is to be found up to the present time. It was only in December of that year that the official inauguration of the Institute occurred at its definitive address (12/06/64), having at its disposal a total of 130 beds and outpatients and the services of cardiovascular surgery, a clinical pathology laboratory, radiology and pathological anatomy. 
In the following decade, the building underwent a re-modelling and recuperation of various annexes, notedly its surgical center, having at this time the capacity for the internment of 95 patients.

At the beginning of the 1960's, the history of the Institute runs parallel with that of the Hospital do Radialista. The principal character behind this hospital was Eron Domingos, popularly known as Esso reporter - a program that made him well known. Since the end of the 1940's, campaigns were carried out to raise funds for its construction by the Brazilian Association of the Radio, with the competition Queen of the Radio of 1953 - won by Emilinha Borba - with 1 million votes and the amount raised by means of the program César de Alencar of National Radio was entirely directed to the work on the hospital. Later, in the years of 1954 and 1956, and with the support of deputy Aaron Steinbruck (PTB/RJ), funds from the Ministry of Health were obtained for the conclusion of the 10 floor building.

The project was delivered to two young architects, Estanislau V. Zaremba and Helmut Braunschweiger, who had developed a modern program, optimizing spaces. The 10 floor block was prepared to receive, in addition to the administrative part (clothing store, maintenance, cleaning, mortuary, among other areas); the surgical clinics (orthopedics, urology and otorrhinolaryngology), obstetrics and medical; besides the isolation beds and the dietetical services for employees and patients. Neither the outpatients part nor the social service were planned for because both were being supplied at the headquarters of the Brazilian Association of the Radio, in the center of the city.

It is worth pointing out that it was in its premises, that on 11/9/1959, Pró-Cardíaco began to function. The idea of a cardiological emergency service had already been proposed by doctor Onaldo Pereira, however it was only put into effect with the invitation to Carvalho Azevedo to head the cardiology service of the Hospital dos Radialistas. An agreement with the administration of the Hospital allowed for the setting up of Pró-Cardíaco - the cardiological emergency service inside the hospital, which, in exchange for some rooms, promised to offer free treatment to the journalists who were members of the catergory's union. The eight doctors who made up the initial team had at their disposal, in principle, an ambulance, and an electrocardiogram machine for use in the outpatients and at the homes of the patients. With the closure, in 1962, of the Hospital dos Radialistas, Pró-Cardíaco moved to the Santa Lúcia Clinic, in Botafogo, coming to have its own headquarters in 1967 at Rua D. Mariana, where today it still maintains its examinations center; in the meantime, the hospital was transferred to Rua General Polidoro, 192.

\section{Architectural Description:}

Set on the side of the Morro dos Guararapes, it is surrounded by greenery and accessed by streets of local traffic in a residential area. It should be pointed out that the access roads, immediately around it, are narrow, one-way streets partially occupied by parked cars on both sides of the sidewalk - for the number of vehicles in circulation, hampering the flow of traffic necessary for a hospital project of the size proposed by its creators. The formal characteristics of the surrounding area, constructed moderately homogeneously - continuity of the form, uses and setting back of the buildings - and the configuration of the road network ("in blocks") generate perspectives (de-limited perspective as well as deflection) and interesting views, that highlight and emphasize the modernist building.

The model of the modernist hospital architecture, of the mono-block style, is, at present, very much without character. The formal solution used by the architects was a block of ten floors parallel to the front edge of the land. The volumetric impact of the hospital is intensified by its setting (on the hillside and surrounded by compact vegetation) and by its surroundings (multi-family buildings of an eclectic taste: classic standards, norman, art déco, among others).

Of the original volumetric composition there is still perceived the formal set amongst the outstanding body $\left(5^{\text {th }}\right.$ and $6^{\text {th }}$ floor) highlighted from the façade (access) and a des-aligned canopy that projects out over the sidewalk, while the main entrance in glass is set back toward the main body. There also remain, in the composition of the access façade, the original marks of horizontal lines (covered by green and blue tiles below the windows). However this treatment is not continued on the other façades (possible de-characterization, since this resource is part of the project).

The main part of the construction is finished off by a terrace with a crowning similar to the formal solution of the design of the Consulate of the United States of America (1952-1953) signed by the Harrison Abramovitz Office. At present 
the crowning of the building (pergolated structure in ornamented reinforced concrete with hollowed out rectangular elements), which gave a lightness to the original part, has been covered by fiber-cement tiles.

The program proposed by the hospital building, of a rational type - functional rationality and economy -, was designed based on four basic services of the new hospital: the administration, emergency, diagnosis and therapeutic departments. The hospital building was conceived to house a limited number of persons, with a modest provision for growth (50 beds) and with a flexibility of the spaces due to the use of a modulated network $(1,70 \mathrm{~m})$ in the construction.

The application of the formal and functional model, of the internal layout of the hospital follows the principal of the pavilion like division applied vertically, so as to reduce costs with maintenance and distances and to maintain the quality of the isolation of the areas. The design studies also took into consideration the environmental factors (heat from the sun), determining the direction of the wards and of the rooms toward the southeast façade (direction of the front of the building), and the infirmary services, due to their characteristic of not being permanent, were placed in the northwest direction, facing the wall of rock.

\section{Register of Preservation:}

It is not listed.

\section{Sources:}

50 ANOS de história da cardiologia do estado do Rio de Janeiro. Rio de Janeiro: SOCIERJ, 2005.

ASSISTÊNCIA Pública - Guanabara: 80 anos de história. Rio de Janeiro: Superintendência de Serviços Médicos (SUSEME); 1972. mimeo.

BRASIL. Decreto no 36.462, de 10 de novembro de 1954. In: Leis do Brasil. Rio de Janeiro: Imprensa Nacional, 1954.

Correio da Manhã, Rio de Janeiro, 06/12/1964, página 19.

HOSPITAL do Radialista, Rio de Janeiro - arquitetura funcional nas organizações hospitalares. Revista Paulista de Hospitais, São Paulo, ano 1, vol. 1, no. 10, outubro de 1953.

http://www.arcadovelho.com.br/Anos_50/Radio_Nacional.htm, Acessado em 03/09/2007.

http://www.camara.gov.br/internet/sileg/Prop_Detalhe.asp?id=195400, Acessado em 17/08/2007.

http://www.procardiaco.com.br/h_text.asp?it=1039, Acessado em 17/08/2007.

http://www.tribuna.inf.br/anteriores/2005/abril/19/coluna.asp?coluna=helio, Acessado em 17/08/2007.

Jornal do Commercio, Rio de Janeiro, 06/12/1964, página 7.

SECRETARIA de Saúde do Estado do Rio de Janeiro. Indicadores e Informações em Saúde. In: http://www.saude.rj.gov.br/ informacoes/bancodad.shtml Acessado em 11/10/07.

Credits: Daniel Elian (research), Gisele Sanglard (text) and Inês El-Jaick Andrade (architectural description) 


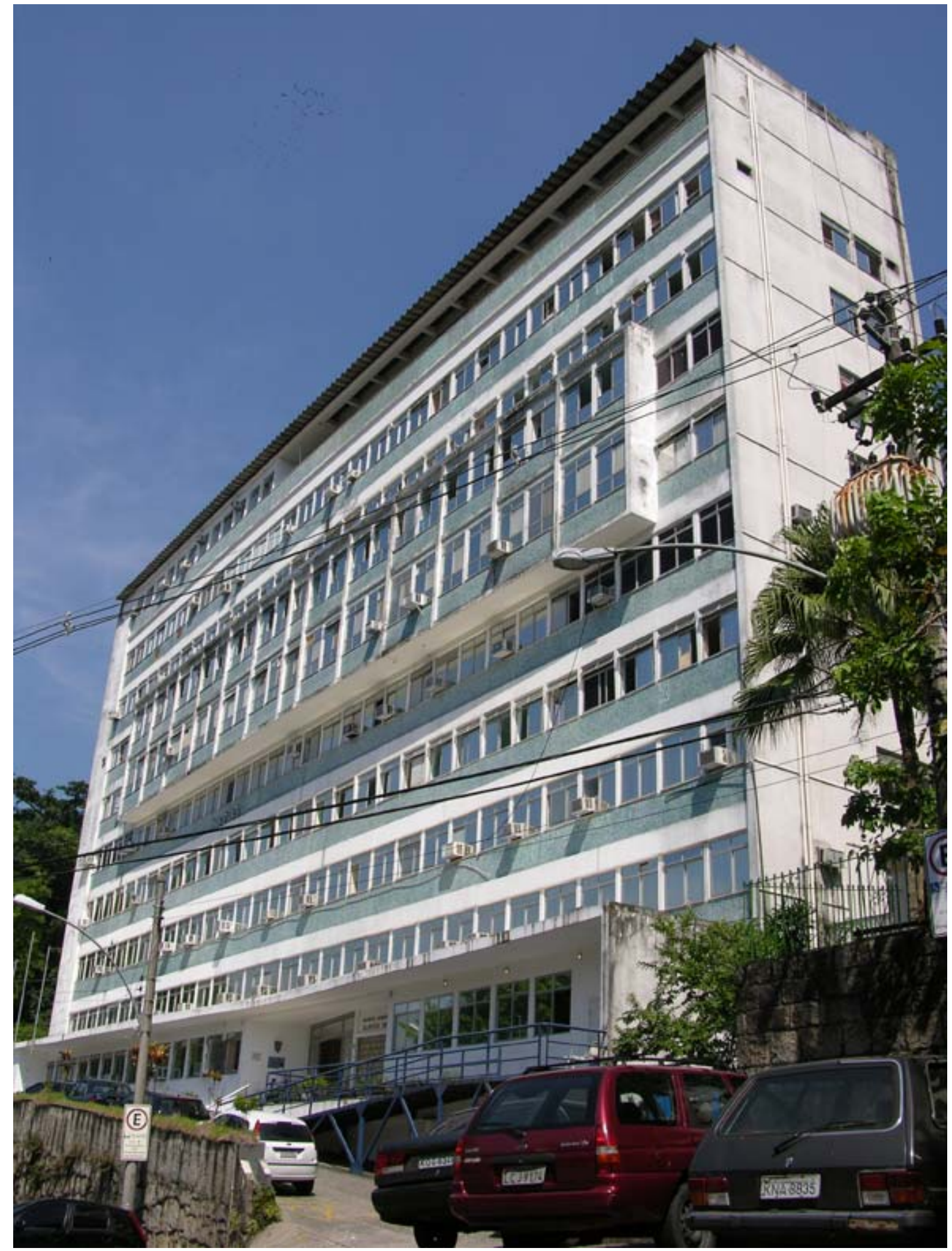

Aloysio de Castro State Institute of Cardiology. Photo Roberto Jesus Oscar \& Vinícius Pequeno de Souza, 2008. Casa de Oswaldo Cruz Archives 


\section{Anchieta State Hospital}

Other Denominations: Henrique Dodsworth Pavilion (1945-1950); Anchieta Shelter Hospital (1950-1952); Anchieta Hospital-Dispensary(1952-1956); Anchieta School Hospital (1956-?); Anchieta State Hospital (current).

Location: Caju

Address: Rua Carlos Seidl, nº 785.

Category: Orthopedic Hospital

Period of Construction: 1945

Proprietor: Government of the State of Rio de Janeiro

Author / Constructor: unknown

\section{History:}

The history of the Anchieta State Hospital is directly linked to the mystique that involved the campaign against tuberculosis in Brazil, since the creation of the Brazilian League against Tuberculosis in 1900, which united various personalities from the political, industrial and intellectual world of the city of Rio de Janeiro, led by the jurist Ataulfo de Paiva. Its construction, in 1945, as the Henrique Dodsworth Pavilion destined to the treatment of infantile osteoarticular tuberculosis, occurred thanks to the benefaction of the Rio industrialist, Mario Rebello de Oliveira, who donated it to the jurisdiction of the Federal District. Its inauguration occurred on January $19^{\text {th }}, 1946$, and included the presence of various authorities, including that of Ataulfo de Paiva.

At the time of its inauguration, it had 50 beds and modern equipment for the treatment of tuberculosis. The administration of the services was delivered to the orthopedist Dagmar Chaves, professor of the Faculty of Medicine of Rio de Janeiro. His actions were subordinate to the National Tuberculosis Department.

In 1949 a project was carried out so that the Pavilion could be autonomous from the São Sebastião Hospital and could also begin to attend adults suffering from the same infirmity. On October 21 $1^{\text {st }}, 1950$, Law no. 490 transformed the Henrique Dodsworth Pavilion into a hospital establishment, destined to the treatment of adult and infantile osteoarticular tuberculosis, and to teaching. In December of the same year, by means of Decree no. 10698, the pavilions "Arlindo de Assis" and "Fernandes Figueira" were annexed, giving rise to the Anchieta Shelter Hospital.

In April of 1952, the Anchieta Shelter Hospital was re-graded to the category of Hospital-Dispensary. And, in 1956, a new alteration raised it to the category of Hospital-School of the Faculty of Medical Sciences of the University of Rio de Janeiro, destined to classes on orthopedic medicine.

At the end of the 1950's, still under the administration of the mayor, Negrão de Lima (1956-1958), the hospital underwent renovations due to the increase of the services - considered reference services and to where patients from all the regions were sent; and for the needs of medical teaching. With this renovation, there was a substantial increase in the number of beds available; the construction of new surgical centers, with amphitheaters; support services (plaster casting room, sterilization, physiotherapy, dressings); accommodations for doctors, nurses and students; and an amphitheater for classes and conferences.

In 1960, with the transfer of the federal capital to Brasília, the state of Guanabara that covered the whole of the municipality of Rio de Janeiro was created. At this time, the hospitals belonging to the jurisdiction of the Federal District were handed over to state jurisdiction. Fifteen years later, in 1975, with the fusion of the states of Guanabara and Rio de Janeiro, some of these hospitals returned to being municipal hospitals, while others remained state hospitals, among these being the Anchieta State Hospital .

The three pavilions that originally made up the Anchieta Hospital were sub-divided into: the Henrique Dodsworth Pavilion, the surgical pavilion, with X-ray facilities, an amphitheater for classes, and the director's office; the Arlindo de 


\section{AFTER 1930}

Assis Pavilion, was destined to clinical service; the Fernandes Figueira Pavilion, to administrative services, mess hall and kitchen. In the campus a special pavilion was installed for the deposit and laundry.

In the 1980's, the Hospital administered courses for the students of the Faculty of Medical Sciences (present University of the State of Rio de Janeiro), of the Fluminense Faculty of Medicine (present Fluminense Federal University), of the Faculty of Medicine of Vassouras and of the University of Brazil (present Federal University of Rio de Janeiro); to the doctors of the National Campaign against Tuberculosis and to the students of the Rachel Haddock Lobo School of Nursing.

Until today the Anchieta Hospital remains dedicated to orthopedic surgery.

\section{Architectural Description:}

The Henrique Dodsworth Pavilion, when it was built in the 1940's, followed the line of sanatoriums for tuberculosis patients: the adoption of a pavilion style, with rooms ventilated by large windows and a bucolic air - an ingredient necessary for the cure of tuberculosis. The main entrance was adorned with two tiled panels picturing scenes from the life of father José de Anchieta, a donation made by the son and the wife of Dr. Dagmar Chaves, its first director.

\section{Register of Preservation:}

It is not listed.

\section{Sources:}

ASSISTÊNCIA Pública - Guanabara: 80 anos de história. Rio de Janeiro: Superintendência de Serviços Médicos (SUSEME); 1972. mimeo.

CHAVES, D. O bem-aventurado José de Anchieta, SJ - vida e obra. Rio de Janeiro: [s.n.]; 1992.

SECRETARIA de Estado de Saúde do Rio de Janeiro. Indicadores e Informações em Saúde. In: http://www.saude.rj.gov.br/ informacoes/bancodad.shtml Acessado em 11/10/07.

Credits: Daniel Elian (research) and Gisele Sanglard (text and architectural description) 


\section{AFTER 1930}

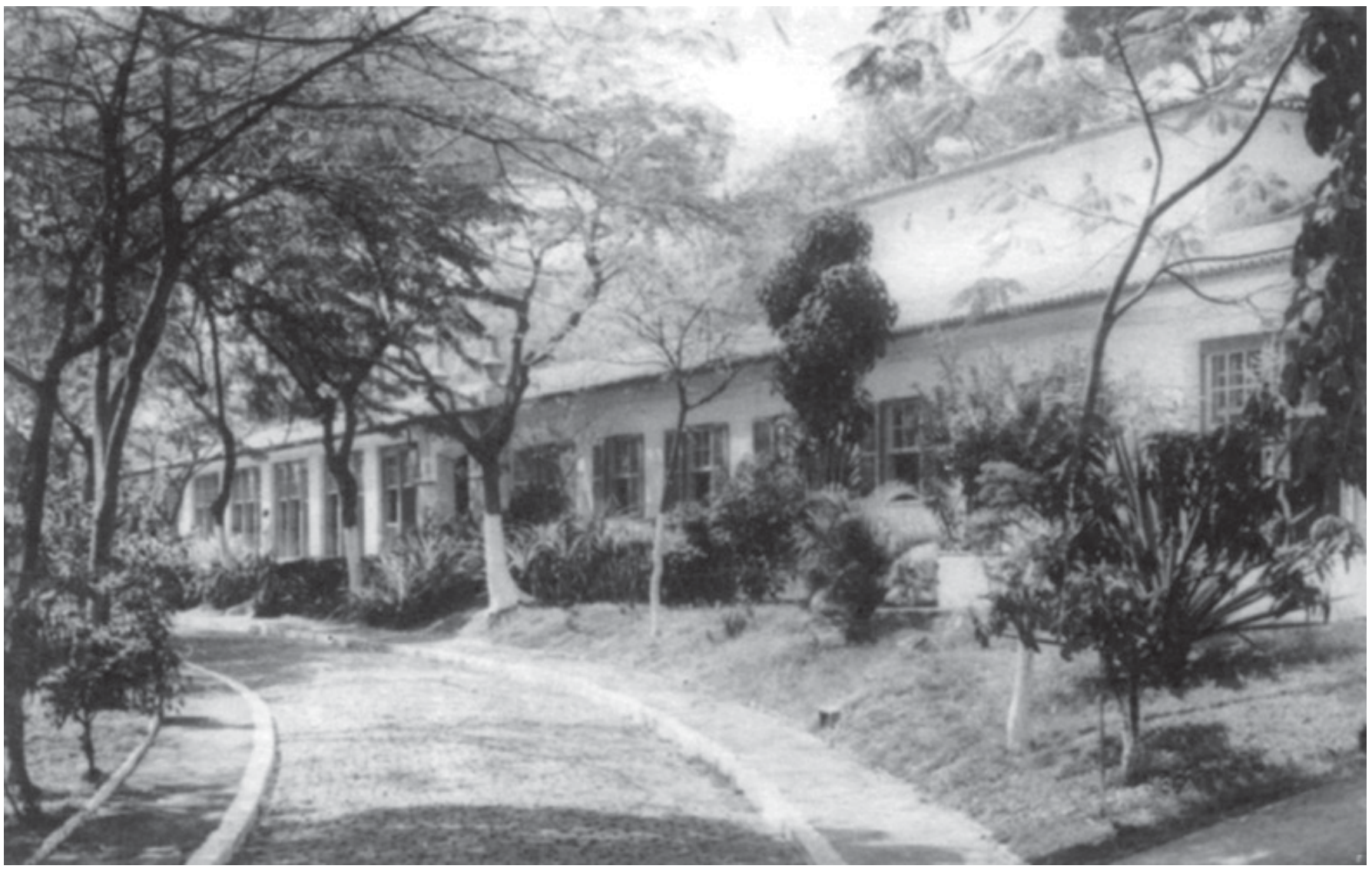

Anchieta Hospital, [s.f.]. Source: Chaves (1992)

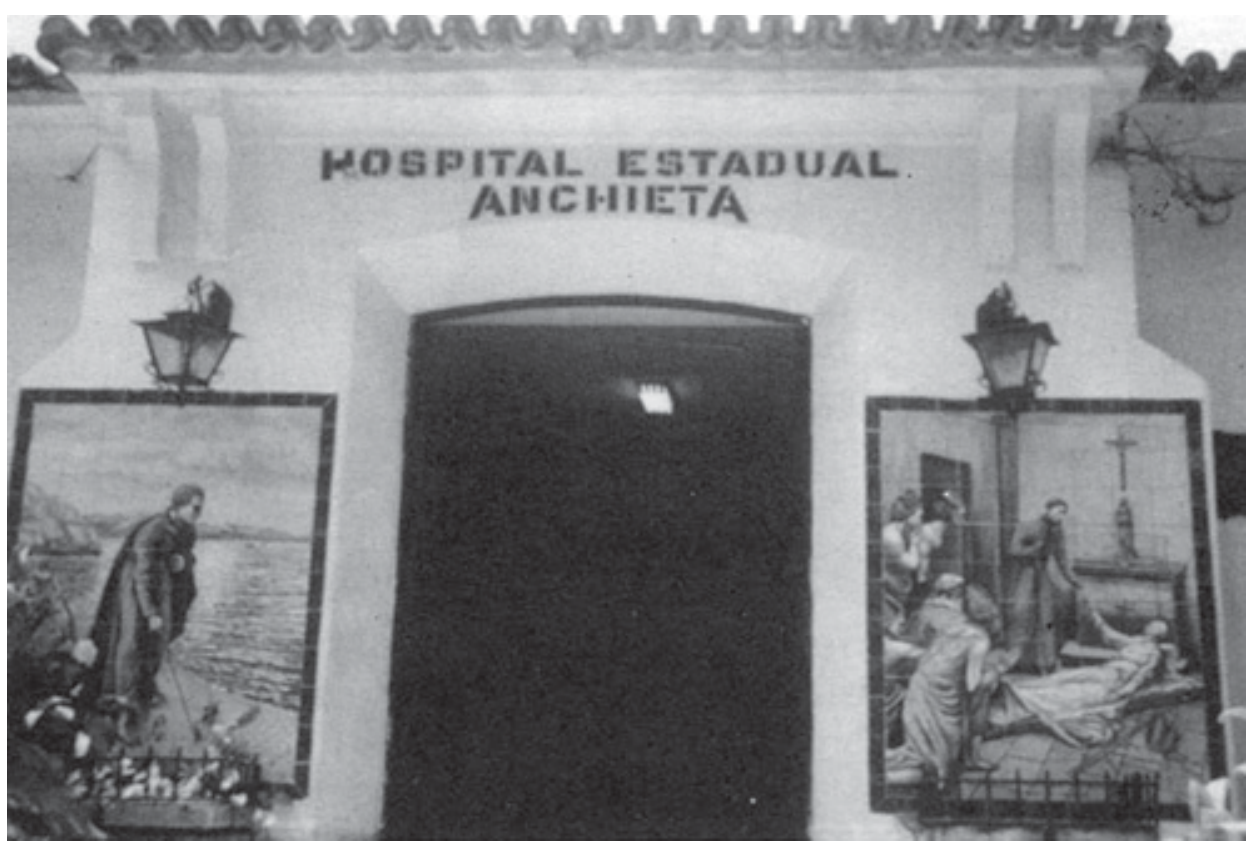

Anchieta Hospital, [s.f.]. Source: Chaves (1992) 


\section{Andaraí Hospital}

Other Denominations: São Jorge Health Center; Central Mariners' Hospital (1955-1968); Andaraí Hospital (1968present day)

Location: Andaraí

Address: Rua Leopoldo, 280

Category: General Hospital

Period of construction: 1955

Proprietor: Ministry of Health.

Author / Constructor: Firmino F. Saldanha (architect)

\section{History:}

In the 1920s emerged the embryo of the Brazilian social security system - with the creation of the Retirement and Pension Credit Unions (CAPs) - as of the promulgation of the Eloy Chaves Act in 1923. The arrival of Getúlio Vargas into power in 1930 alters labor relations then in effect and, in relation to the social security issue, the standard of the CAPs was undone for the establishment of the Retirement and Pension Institutes (IAPs), tied to the professional categories and linked to the newly created Ministry of Labor, Industry and Commerce. The objective of the IAPs was to guarantee access to health care for the particular professional category. The first occupations to organize their institutes were: mariners (IAPM), in 1933; bankers (IAPB) and merchants (IAPC), in 1934; industrial workers (IAPI), in 1936; stowage (IAPE) and cargo transport employees (IAPETC), in 1938 (Hochman e Fonseca, 1999; 77-78). Many of these IAPs sought to build hospitals for the health care of its associates.

The IAPM was destined for the officers and employees of the navigation companies, whether Brazilian or foreign - as long as dully registered; fishermen; employees of the Brazilian Lloyd Company; among other companies associated with maritime transport. In 1945, the IAPM acquired the São Jorge Health Center, on 280 rua Leopoldo, in Andaraí, in order to offer health care for its associates. In the following year, the federal government initiates studies for the expansion of the Mariners' Hospital, aiming to build new infirmaries. In the place of the former Health Center, a twelve story edifice was constructed to house the Central Mariners' Hospital, inaugurated on June $29^{\text {th }}, 1955$.

In 1967, all of the institutes which served the workers were consolidated under the National Social Security Institute (INPS), and the Central Mariners' Hospital became known as Andaraí Hospital, shifting over to federal administration and serving all users of the INPS.

With the implementation of the SUS (National Health Program) in 1990, eleven of the seventeen hospitals belonging to the Ministry of Health in the city of Rio de Janeiro were municipalized, among them Andaraí Hospital - whose municipalization process was only accomplished in 2000; and only one - the Cardiology of Laranjeiras - was briefly under state administration. The five remaining ones were elevated into Institutes under the condition to propose health policies in their areas of expertise:

National Trauma-orthopedic Institute, National Cancer Institute and the Cardiology Institute of Laranjeiras; while the State Employees' Hospital and the Bonsucesso Hospital , considered references in the municipal and state health systems, were kept under the Ministry of Health.

Currently, Andaraí Hospital occupies an entire block, having expanded its facilities thanks to the annexation of a property belonging to the Catholic Church, and is composed of five buildings: main, polyclinic, laboratories; and the residents' quarters.

Andaraí Hospital is noted for its Burn Treatment Center, created 35 years ago, due to the expertise developed in the care of extensive and complex burns. Nevertheless, it is a general hospital, a reference in emergencies of medium and low complexity; and recognized as a care unit of high complexity in oncology (UNACOM). Throughout the years, it has 
demonstrated the tendency to specialize in the health care of high complexity ailments, whether under optional hospitalization or emergency related.

With the declaration of a public calamity in the hospital network of the National Health Program (SUS) in the municipality of Rio de Janeiro in 2005, Andaraí Hospital was reintegrated into the Ministry of Health.

\section{Architectonic description:}

Andaraí Hospital is located on a slight slope toward the end of the street, standing out from the urban mesh which is formed by houses and small residential buildings in the district which carries the same name. It is a legitimate single block hospital of the 1950s, with areas destined for vertical circulation and ample access corridors to the rooms which overlook the surrounding landscape. Its volume is composed of a ground floor foundation and entresol, a ten story strip and penthouse. The modern lines of the façade are expressed in the closing of the windows in guillotine type persian blinds and the pillars. A new elevator hall was inaugurated in 1982, given the high number of patients.

\section{Register of Preservation:}

It is not listed.

\section{Source:}

Decreto $\mathrm{n}^{\circ}$ 21.042, de 1 de maio de 1946. Dispõe sobre os estudos para ampliação do Hospital dos Marítimos. Capturado em 13 de dez. 2007. Online. Disponível na Internet: http://www6.senado.gov.br/sicon/ExecutaPesquisaBasica.action

HOCHMAN, Gilberto et FONSECA, C. O que há de novo? Políticas de saúde pública e previdência, 1937-45. In: PANDOFI, D. (org.). Repensando o Estado Novo. Rio de Janeiro: Editora FGV; 1999, p. 73-93.

Informações prestadas pelo Dr. Dásio Lopes Simões, diretor geral substituto e coordenador de assistência do Hospital do Andaraí, em 13/12/2007.

MERLINO, A. A reconfiguração do Serviço de Enfermagem do Hospital dos Marítimos: 1966-1968. Rio de Janeiro: UERJ; 2006 (dissertação de mestrado).

MINDLIN, H. Arquitetura Moderna no Brasil. Rio de Janeiro: Aeroplano Editora, 1999.

Credits: Renato da Gama-Rosa Costa (research, text and architectonic description). 


\section{AFTER 1930}

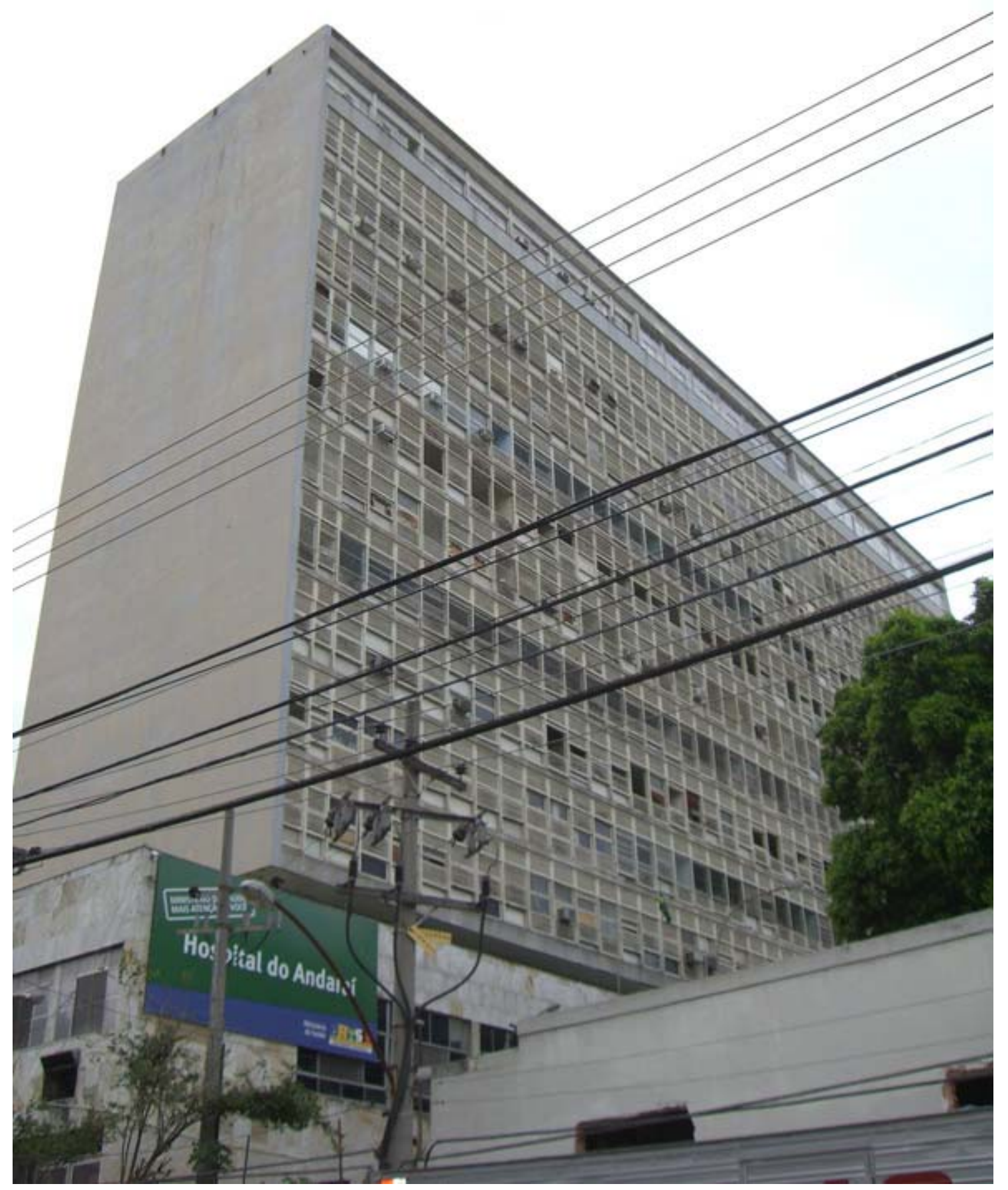

Andaraí Hospital. Photo Renato Gama-Rosa Costa, 2007 


\title{
Bonsucesso General Hospital - HGB
}

\author{
Other denominations: IAPETEC Hospital (1948)
}

\section{Location: Bonsucesso}

Address: Av. Londres, 616

Category: General Hospital.

Period of construction: 1948

Name of the proprietor: Ministry of Health

Author / constructor: Moacir Fraga (attributed to him)

\section{History:}

The Bonsucesso General Hospital, the old Hospital of the IAPETEC - Retirement and Pensions Institute of the Transport and Cargo Workers, as it is known even today by the local population, was inaugurated in 1948, and was part of a group of IAPs. The architectural group, with five buildings, has its design attributed to Moacir Fraga.

Located in the borough of Bonsucesso, at Av. Londres, 616, it was constructed at the edge of Av. Brasil, the principal access route into the city of Rio de Janeiro, with a low population density at the time. Its main entrance was located in Av. Londres, a street crossing Av. Brasil.

It had at that time five of the present six buildings, composing a hospital complex, inter-connected underground. The sixth building, that today houses the out-patients wing, was constructed in the 1970's, with direct access by means of another public roadway, Av. Roma, and without a connection with the others.

In 1967, with the creation of the National Institute of Social Welfare (INPS) - which absorbed the functions of the various IAP's in existence, the BGH came under the jurisdiction of the federal government. In 1970, the system of Medical Residence was established in the hospital. On May 24 ${ }^{\text {th }}, 1973$, the External Patients Unit was inaugurated - the Emergency and the Pre- and Post-Operative units, as well as the Pavilion of the Pathological Anatomy Service. In 1975, new outpatient units and an Intensive Care Center were inaugurated.

With the implementation of the Unified Health System (SUS) in 1990, eleven of the seventeen hospitals belonging to the Ministry of Health in the city of Rio de Janeiro, were passed over to the municipality. Of the remaining five, three were elevated to the category of Institutes, with the attribution of proposing health policies for their areas of operation: the National Institute of Orthopedic Trauma, the National Cancer Institute and the Institute of Cardiology of Laranjeiras; while the other two - the State Civil Servants Hospital and the Bonsucesso General Hospital - because of being a reference to the municipal and state health network, were maintained by the Ministry of Health.

At the end of the 1980's the Renal Transplant service and the Cardiac Surgery Clinic were established and, at the beginning of the year 2000 onwards, the services of Hepatic Transplants, Oncology, High Risk Maternity and Hemotherapy became available.

It is located in the programmed area designated AP3.1, where the higher concentration of slums and the lowest index of human development is to be found, its care profile being that of a tertiary hospital, being today the largest healthcare unit in the Federal Public Network of the State of Rio de Janeiro. Linked to the Ministry of Health, and co-administered by the State and Municipality, it has its own budget. In the year 2000, the Board of Administration of the Bonsucesso General Hospital was formed, with representatives of the Ministry of Health and the State and Municipal Health Departments, representatives from the community, the AP3.1 and Fiocruz.

The Bonsucesso General Hospital renders services in 25 medical specialities and has reinforced its high complexity profile. It is a reference for the Metropolitan region and throughout the state for services of Nephrology, Hepatology, Ophthalmology and Head and Neck Surgery. 


\section{Architectural description:}

The services offered by the BGH are distributed throughout six buildings. Its campus also includes a church; a smaller building where the "Projeto Acolhida" (Reception Project) functions; a sub-station; boiler, and medicine deposit. The buildings are set out around a central courtyard that makes possible internal access and inter-connection on the ground floor. Buildings 1, 2, 3, 4 and 5 are also interconnected underground, which besides serving as a means of access, provides space for a series of services, such as a refectory and kitchen, which are at present de-activated; a clothing store; building maintenance workshops; a central store, dressing rooms and deposit for cleaning material.

Its architectural language is undefined, being between the traditional and the formal modern clean lines, somewhat similar to the most recent projects of A. Porto d'Ave. The layout and disposition of a ground plan in an "H" and "I" formation, with an interconnection underground, on the ground floor and over the columns of support, suggests an inspiration in the typology of the hygienic hospital set out in pavilions, although the number of floors sets it apart from this model, without, however, approaching the mono-block model, which gives to it a peculiar interest for the history of the health system in Rio de Janeiro.

\section{Register of Preservation:}

It is not listed.

\section{Sources:}

GESTHOS, gestão hospitalar, capacitação a distancia em administração hospitalar para pequenos e médios estabelecimentos de saúde. Módulos I e II. Brasília: Ministério da Saúde; 2002.

Credits: Thereza Motta Gould (research, text and architectural description). Renato da Gama-Rosa Costa (architectural description). 


\title{
Associação Brasileira Beneficente de Reabilitação (Brazilian Beneficent Association of Rehabilitation)
}

\author{
Location: Jardim Botânico \\ Address: Rua Jardim Botânico, 660. \\ Category: Rehabilitation Hospital \\ Period of Construction: 1954. \\ Proprietor: Associação Brasileira Beneficente de Reabilitação \\ Author/Constructor: Fernando Lemos (project);
}

\section{History:}

The occurrence of poliomyelitis in Brazil during the 1950's was quite expressive, with a great number of people bearing the aftereffects of the disease which needed special treatment. The ABBR (Associação Brasileira Beneficente de Reabilitação) was created on August $05^{\text {th }}, 1954$, at the initiative of architect Fernando Lemos, and of a group of business people led by industrialist Percy Charles Murray (1910-1961), bearer of a serious lesion that had left him paraplegic. The resources of his father, Charles Murray, had made it possible for him to receive treatment abroad, in a specialized clinic. On returning to Brazil, he became a successful company director.

The main force behind the ABBR, the architect Fernando Lemos, also had an experience in this sense, as a result of the rehabilitation of his son, suffering from infantile paralysis. His dedication to the health of his son had lead him to organize, in his own home, a genuine physiotherapy center, where he created mechanisms and devices to facilitate the treatment and the activities of the daily lives of the patients suffering from poliomyelitis.

The proposal of creating ABBR had as its objective the establishment and development, in the country, of a program of rehabilitation, along the lines set out by the World Health Organization, in an integrated manner, including the adoption of medical, social, educational and professional measures for the preparation, re-adaptation and integration of the individual into society. The ABBR should, initially, have the conditions to care for patients from all over the country, in view of the inexistence of institutions of this size in the other regions. In the city of Rio de Janeiro, up to that time, only the Jesus Hospital, established in the borough of Vila Isabel, was rendering care to children with infantile paralysis.

The group of founders of the ABBR included members of the Armed Forces, business people, industrialists and doctors of prestige at the time. Percy Charles Murray was its first president, and Celso Rocha Miranda, a businessman in the area of insurance, was a member of the Board of the institution and one of its most important supporters.

The doctors, Oswaldo Pinheiro Campos, Jorge Faria, Antônio Caio do Amaral and Hilton Baptista were invited to be members of the team of doctors and Technical Board of the institution.

Bearing in mind the complexity that the creation of a center represented, the board of directors of ABBR decided that, initially, there would be created a school for teaching physiotherapists and occupational therapists. On September $23^{\text {rd }}$, 1955 plans were laid out for the creation of the school, which were based on the model of the School of Rehabilitation of the Columbia University. To teach the first classes two foreign teachers were hired - the Scot, Edith MacConnel and the Canadian, Ann Winter.

Among the founding teachers of the school were Pedro Nava, Antonio Rodrigues de Mello, Zeny Miranda, Alcino Affonseca Jr, Edmundo Haas, Pedro Baptista de Oliveira Neto, Gualter Doyler Ferreira, Evangelina Leivas, Edith Mc Connel, Mary Ellis, Dora Schlochauer and the representatives of the board of directors of ABBR, Fernando Lemos and José Maria de Almeida.

On September $17^{\text {th }}, 1957$, the Rehabilitation Center of the ABBR was inaugurated in the presence of President Juscelino Kubitschek, on land donated by the city hall of the Federal District, at Rua Jardim Botânico, where it is to be found up to the present day. At that time, on this same land, a convalescence service destined to the children interned for poliomyelitis 
was offered at the Jesus Hospital. The pavilions of the recently installed Center were made of wood, donated in large part by the wife of the President of the Republic, Sara Kubitschek.

The elaboration of the architectural project for the Rehabilitation Center was the responsibility of Fernando Lemos himself, who also could count on the donation of materials (cement, tiles, flooring, etc.) on the part of Rio businesses. The Center was organized into six departments, Administrative, Social Services, Medical, Therapy, Vocational and Professional, Works and Planning.

Over the years other doctors also joined the project, such as Donatello Sparvoli, Pedro Bloch, Ary Borges Fortes, Sivaldo Bruno, Murilo Campelo, Ernani Lucas, Mário Gonçalves da Fonseca, Ludovina Siqueira, Vitor Cohen, Maurício Sathler and Joaquim Meyer.

In the 1950's and 60's, ABBR was maintained by agreements with institutes, organizations, associations, hospitals, industries and commerce, and likewise, thanks to the support of persons who patronized the treatment of some children.

At the end of the 1990's, ABBR underwent a re-organization and modernization of its facilities, offering new resources to the patients. At the present time the following medical services are offered: Treatments and Consultations, Orthopedic Workshop, Orthopedic Shop and Rehabilitation Center.

The Hospital of the ABBR is organized in two distinct sectors, the Sector of Clinical Internment, directed exclusively for the rehabilitation of patients bearing serious physical disabilities, and the Sector of Surgical Internment, set aside for the performance of highly complex surgical procedures in the areas of Orthopedics, Traumatology and Reconstructive Plastic Surgery.

The Surgical Center is composed of 4 large theaters, a materials supply center and equipment for the performing of the surgical procedures that are necessary, and the Sector has at its disposition a Semi-Intensive Care Unit for patients immediately after coming out of surgery.

The ABBR performs, at present, around 3,500 procedures per day and cares for and offers service to children, young people, adults and the elderly - approximately 2,500 patients, principally from the State of Rio de Janeiro, due to the multi-disciplinary and integral nature of the rehabilitation treatments.

The ABBR is an entity of private law, and is non-profit making. It was considered a Municipal, State and Federal Public Utility by Law no. 892, of November $14^{\text {th }}, 1957$ and Decree-Law no. 43.890 , of June $10^{\text {th }}, 1958$, and recognized as a Center of National Reference and Institution of Renowned Experience.

\section{Register of Preservation:}

It is not listed.

\section{Sources:}

BARROS, F. Autonomia profissional do Fisioterapeuta ao longo da história. Revista FisioBrasil, 59, 2003:20-31.

BATISTA, H. A História da Medicina de Reabilitação. Capturado em 06 nov. 2007. Online. Disponível na Internet: http:// www.abbr.org.br/historico.php

História das Ruas de São Paulo. Capturado em 6 nov. 2007. Online. Disponível na Internet: http://www. dicionarioderuas.com.br/LOGRA.PHP?TxtNome=RUA\%20CHARLES\%20MURRAY\&dist= 15\&txtusuario =\&\%20TxtQuery=1

Histórico da ABBR. Capturado em 5 nov. 2007. Online. Disponível na Internet: http://www.abbr.org.br/historico.php

Credits: Maria Rachel Fróes da Fonseca (research and text) 


\section{Cardoso Fontes Hospital}

Other Denominations: Tuberculosis Hospital (???-1968), Cardoso Fontes Sanatorium (1968-1973), Jacarepaguá General Hospital (1973-1999), Cardoso Fontes Municipal Hospital (1999-2005), Cardoso Fontes Hospital (2005-present day)

Location: Jacarepaguá

Address: Avenida Menezes Cortes, $\mathrm{n}^{\circ} 3.245$

Category: General Hospital

Period of construction: 1940's

Proprietor: Federal Government

Author / Constructor: unknown

\section{History:}

The low-lying area of Jacarepaguá came to be considered, as from the 1920`s, an ideal place for the construction of isolation hospitals, both because it was a rural region and sufficiently far away from the city center, and also because of it's bucolic climate, perfect for long term hospitalization. Thus it was, that the Juliano Moreira Colony (1924), for the mentally disturbed; the Hospital Colony of Curupaity (1927), for sufferers of leprosy; the Santa Maria Hospital-Sanatorium (1938) and the Curicica Sanatorium (1952), both for tuberculosis, came to be built. It is for this reason that the Tuberculosis Hospital was created from the old Bank Workers Retirement and Pension Institute (Instituto de Aposentadoria e Pensão dos Bancários - IAPB).

The place chosen for setting up the hospital, at the foot of the Grajaú hills, was part of the old Cantagalo farmstead one of the properties of Engenho Novo -, belonging to the descendents of Mateus José Nunes (1781-1854).

The 1920's saw the embryonic Brazilian pension system arise - with the creation of Retirement and Pension Savings Accounts (Caixas de Aposentadorias e Pensões - CAPs) - as from the enactment of the Eloy Chaves Law, in 1923. The coming of Getúlio Vargas to power in 1930 altered the labor relations that were up to that time in force and, with respect to the pension issue, the CAP system was changed with the setting up of the Retirement and Pensions Institutes (Institutos de Aposentadorias e Pensões - IAPs), linked to the professional categories and to the policies of the recently created Ministry of Labor, Industry and Trade. The objective of the IAPs was to guarantee to that a group of professionals had access to benefits and services - especially medical services. The first categories to organize their institutes were: seamen (IAPM), in 1933; bank workers (IAPB) and tradesmen (IAPC), in 1934; industrial workers (IAPI), in 1936; dock workers (IAPE) and the employees of transport companies (IAPETC), in 1938 (Hochman and Fonseca, 1999; 77-78). Many of these IAPs wanted to construct hospitals for the benefit of their members.

The IAPB maintained two hospitals for its associates: the Tuberculosis Hospital and the Bank Worker's Hospital (Hospital dos Bancários), acquired in 1962 (today Lagoa Hospital). The opening of this hospital destined to the treatment of tuberculosis was in line with the public health policy put into practice by the Minister of Education and Health, Gustavo Capanema, and the administration of Barros Barreto, in charge of the National Health Department (DNS) and the implementation of the Public Health Reform of 1941, which created the national services, among which, that of Tuberculosis, during the New State period (1937-1945).

In 1967, The National Social Welfare Institute (Instituto Nacional de Previdência Social - INPS) was created which absorbed the functions of several existing IAPs, the hospital passing over to the administration of the new agency, now linked to the Ministry of Social Welfare. In this change-over period, the then Cardoso Fontes Sanatorium was closed and remained so until 1973, when it was re-opened as a pediatric service.

The growth in the population of Jacarepaguá made it necessary to build a General Hospital in the region and the old sanatorium was slowly transformed into a hospital to meet the needs of the population of the region, coming to be called 
the Jacarepaguá General Hospital. Thus, in October of 1975, the services of General Surgery, General Medicine, Gynecology, Proctology, Urology, Nephrology, Pediatrics, Children's Surgery, Cardiology, Oncology, Dermatology, Hematology, Gastroenterology, Pneumology, Thoracic Surgery, Anesthesiology, Intensive Care, Pathological Anatomy, Image Center, Laboratory of Medical Analyses and the country's first Odontology Service for children with special needs, were created.

With the implementation of the Unified Health System (Sistema Único de Saúde - SUS) in 1990, eleven of the sixteen hospitals belonging to the Ministry of Health in the city of Rio de Janeiro came under municipal administration, among them being the Jacarepaguá General Hospital which came to be denominated the Cardoso Fontes Municipal Hospital. Of the five remaining ones, three were elevated to the category of Institutes, being able to propose health policies for their own specialized areas (the National Institute of Orthopaedic Traumas, the National Cancer Institute and the Laranjeiras Cardiology Institute); while the other two - the State Civil Servants Hospital (Hospital dos Servidores do Estado) and the Bonsucesso General Hospital - due to their being references to the municipal and state health networks, were kept under the Ministry of Health.

With the declaration of a state of public calamity of the Unified Health System hospital network in the municipality of Rio de Janeiro, in 2005, Cardoso Fontes Hospital was re-integrated into the Ministry of Health.

\section{Register of Preservation:}

It is not listed.

\section{Sources:}

Acervo do Hospital.

http://www.cirurgiageralcardosofontes.com.br/Historico.htm, acessado em 02/07/07.

http://www.wsc.jor.br/romances/imagens/7.htm, acessado em 02/07/07.

HOCHMAN, G. et FONSECA, C. O que há de novo? Políticas de saúde pública e previdência, 1937-45. In: PANDOFI, D. (org.). Repensando o Estado Novo. Rio de Janeiro: Editora FGV; 1999, p. 73-93.

Jornal Prisma, Rio de Janeiro, ano VI n 87, 08 de novembro de 2000, pg. 07.

Credits: Nathalia Morais (research); Gisele Sanglard (text) 


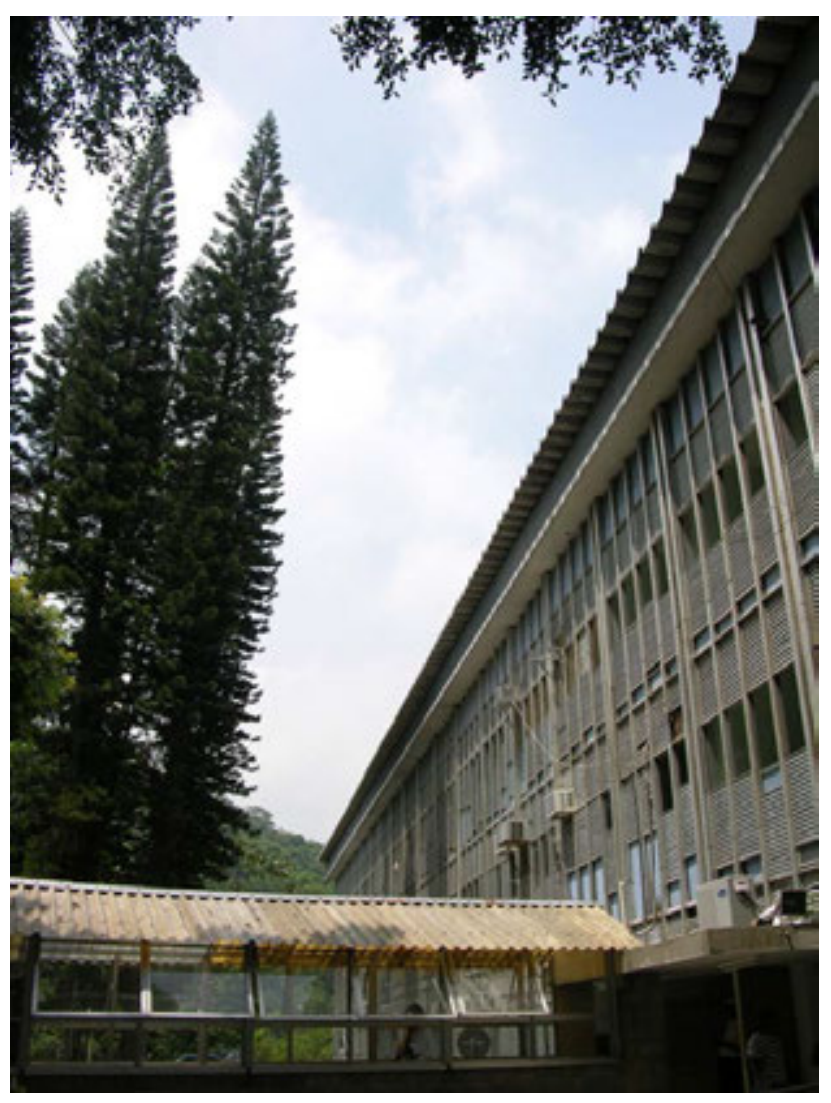

Cardoso Fontes Hospital.

Photo Roberto Jesus Oscar \& Vinícius Pequeno de

Souza, 2008. Casa de Oswaldo Cruz Archives

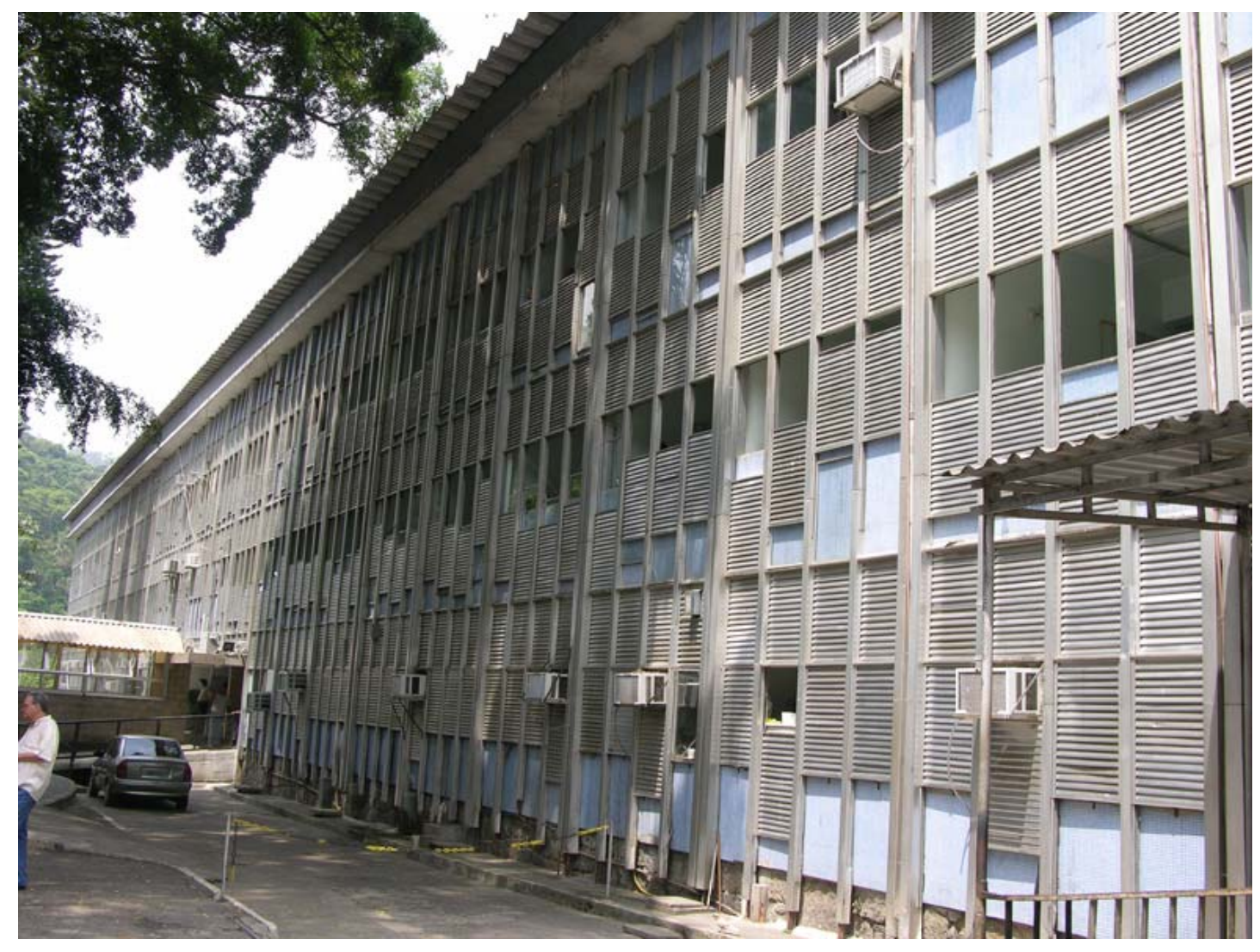

Cardoso Fontes Hospital. Photo Roberto Jesus Oscar \& Vinícius Pequeno de Souza, 2008. Casa de Oswaldo Cruz Archives 


\section{Carlos Chagas State Hospital}

Other denominations: Regional Polyclinic Hospital of Marechal Hermes (1933-1937); Carlos Chagas Hospital (1937present day).

Location: Marechal Hermes

Address: Av. General Osvaldo Cordeiro de Faria, no. 466

Category: General Hospital

Period of construction: 1937.

Proprietor: State Government of Rio de Janeiro

Author / Constructor: Companhia Industrial Construtora of Rio de Janeiro

\section{History:}

The construction of the Hospital of Marechal Hermes followed the plan for the opening of regional polyclinic hospitals and dispensaries developed by Mayor Pedro Ernesto Batista, during his first term in office of the then Capital Federal, between the years 1931 and 1934. Construction began in 1933 and ended four years later. In the same plan, elaborated at the General Department of Municipal Assistance, were included the General Hospital of the plan (the present Pedro Ernesto Hospital), the Méier Health Center (the present Salgado Filho Hospital), the Jesus, Getulio Vargas, Miguel Couto and Rocha Faria hospitals and the dispensaries of Ilha do Governador (the present Paulino Werneck Municipal Hospital), Ilha de Paquetá (the present Paquetá Hospital), and Rocha Miranda (the present Carmela Dutra Hospital) and Campo Grande. Construction work on these new units of medical-hospital assistance was accompanied by a commission designed specially for this purpose, in which doctors Rodolpho de Abreu Fialho, Alcides Pinheiro Marques Carneiro, Alberto Borgerth and Amadeu de Barros Saraiva participated. It was the responsibility of the Companhia Industrial Construtora of Rio de Janeiro, owned by the architect Luiz Moraes Jr and Archimedes d'Arthagnam Saldanha, to perform the construction work.

In June, 1937, by decree no. 5974, of the then Mayor Olympio de Mello (1936-1937), the Hospital of Marechal Hermes became known as the Carlos Chagas Hospital, in homage to the Brazilian doctor. The hospital was inaugurated on June $26^{\text {th }}, 1937$, by Getúlio Vargas.

The hospital complex also had emergency and polyclinic services. At the time of its inauguration, distributed throughout its two wings were the consultation rooms; the maternity ward; the surgery services, in rooms equipped with airconditioning; and the medical clinic. In a separate building were the mortuary, gas plant, garage and the lodgings for the employees.

In 1967, the administration of Negrão Lima took advantage of the abandoned construction on the side of the hospital to install the Maternity Ward and the Nursery, in addition to the polyclinics, expected to be built 25 years earlier. This annex was inaugurated on December 22 $2^{\text {nd }}, 1968$.

In 1960, with the transfer of the federal capital to Brasilia, the state of Guanabara was created encompassing the entire municipality of Rio de Janeiro. At that time, the hospitals belonging to city hall of the Federal District came to have state jurisdiction. Fifteen years later, in 1975, with the merging of the states of Guanabara and Rio de Janeiro, some of these hospitals returned to the municipality, while others remained as state hospitals - among them being Carlos Chagas State Hospital.

Even today the hospital is considered a reference in the emergency services it renders, tending in the medical clinic and surgical specialties; and pediatrics. 


\section{Architectonic Description:}

Composed of two wings and with two floors, its original architecture follows that of other hospitals constructed by Pedro Ernesto, that is, it presents a strong North American art deco influence, the prevailing fashion back then.

As of the 1960's, many hospitals would undergo renovations and expansions, and such was the case of Carlos Chagas. The old facilities became obsolete and needed to undergo adaptations to the imposed and consolidated typology coming from the North American single-block structures. The change in medicine would bring to architecture a formal impoverishment, revealed in rectilinear lines, without ornament and standardizations.

\section{Register of Preservation:}

It is not listed.

\section{Sources:}

Correio da Manhã, Rio de Janeiro, 27/06/1937, página 3.

, Rio de Janeiro 27/06/1937, página 11.

RIBEIRO, L.

Rio de Janeiro: Imprensa Nacional; 1956.

SECRETARIA de Estado de Saúde do Rio de Janeiro. informacoes/bancodad.shtml Acessado em 11/10/07.

Credits: Daniel Elian (research) and Renato da Gama-Rosa Costa (text and architectonic description). 


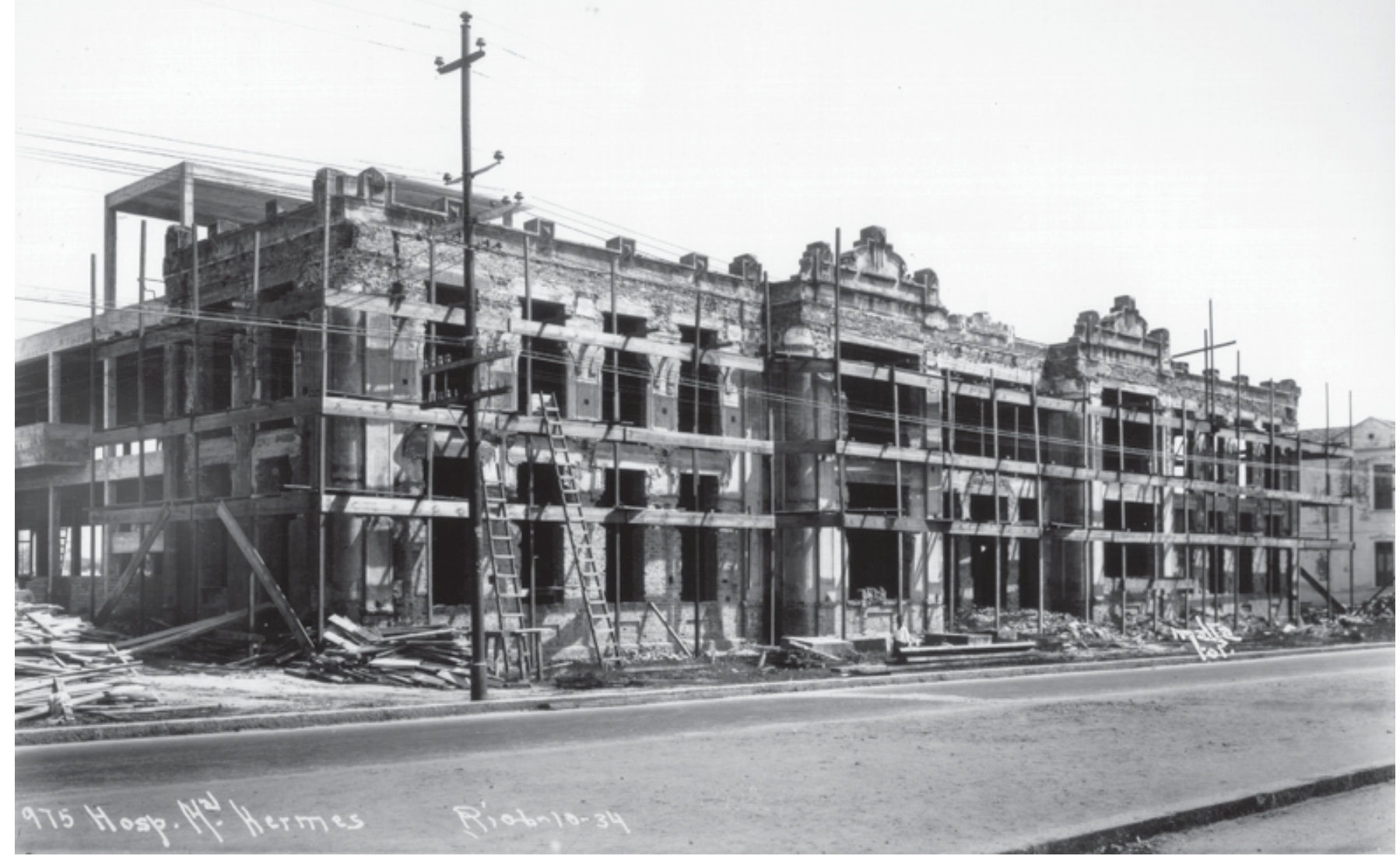

Marechal Hermes Hospital. Photo Augusto Malta, 1934. City of Rio de Janeiro General Archives

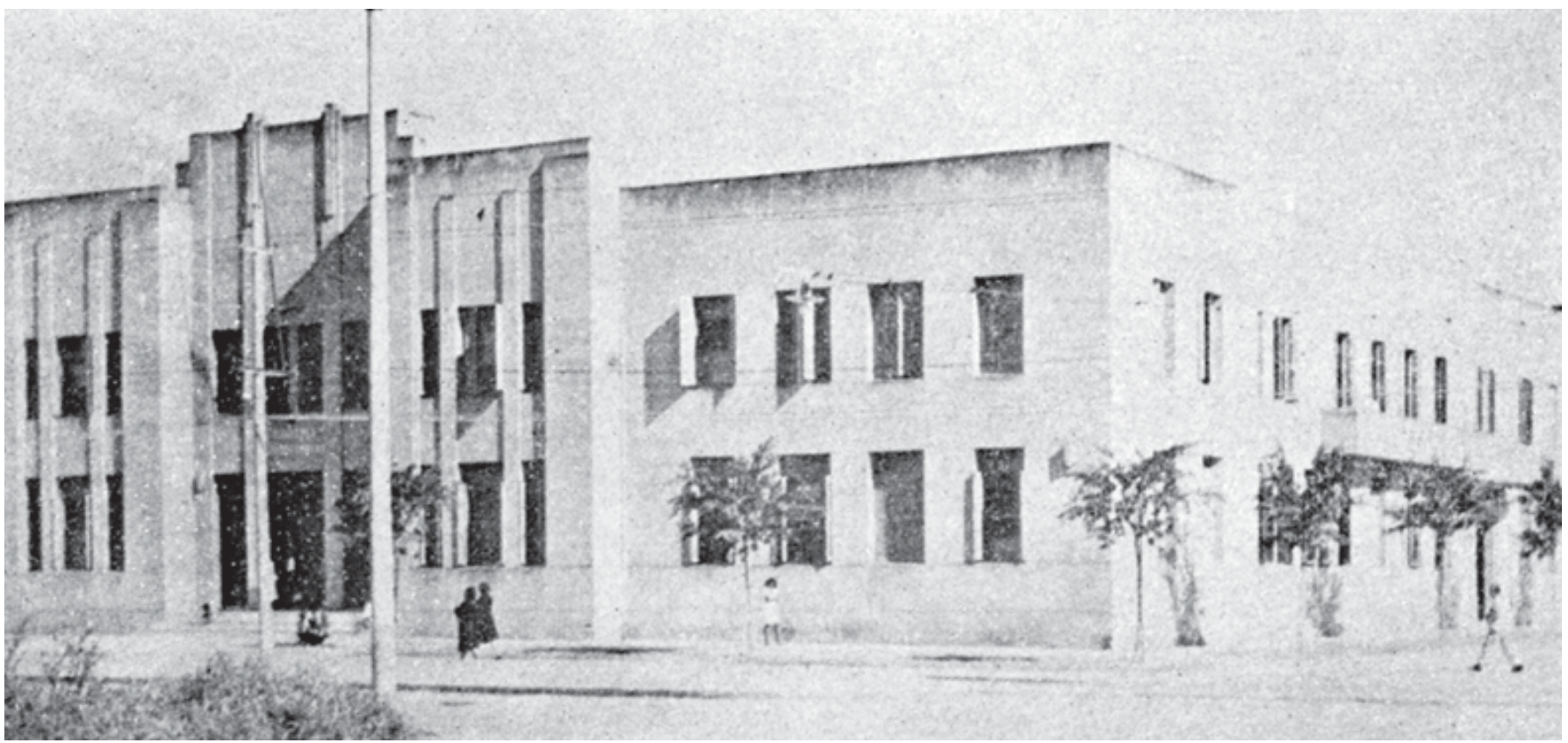

Carlos Chagas Hospital, [s.d.]. Ribeiro (1956) 


\section{Carmela Dutra Maternity Hospital}

Other denominations: Carmela Dutra Maternity (1946-1961); Carmela Dutra Maternity Hospital (1961-present day).

Location: Lins de Vasconcelos

Address: Rua Aquidabã, 1037

Category: Maternity.

Period of construction: 1949

Proprietor: City Hall of Rio de Janeiro

Author / Constructor: unknown

\section{History:}

The Carmela Dutra Maternity Hospital was inaugurated in June of 1949, as one of the welfare services of the Commerce Social Services of the Federal District (SESC-DF). Together with nine pre-natal healthcare posts distributed throughout the city, it was a part of the maternity healthcare service offered by the SESC-DF.

In the 1940`s, the National Department of the Child, an entity subordinate to the Ministry of Education and Health, did research with the purpose of providing information to the State so that it could propose measures directed toward maternal care, expanding or improving the institutions that rendered services in this field. The result of the work revealed that the healthcare situation for pregnant women and nursing mothers in the federal capital was, to say the least, precarious.

In the 1940's, the city of Rio de Janeiro possessed thirty-eight maternity units of which nineteen were especially constructed for this purpose, and the others were adaptations made to constructions destined for other purposes. In the light of the situation described by the National Department of the Child, the public authorities began to stimulate the creation of maternity hospitals, to be paid for by private capital, philanthropy, or by workers associations, such as the Carmela Dutra Maternity.

In 1954, the Carmela Dutra Maternity Hospital had 70 beds, 1 nursery for new-borns, another one for premature babies and a further one for isolation purposes. The professional team was composed of thirty-six obstetricians including a medical director; two pediatricians, an ophthalmologist, two practitioners, an anatomopathologist, a laboratory technician, a social assistant and a dentist. The nursing service was performed by nurses trained in the Ana Nery Nursing School.

The following decade was marked by reforms in the social welfare system and in medical care, initiated in the 1950's. In 1967, with the creation of the Nation Social Welfare Institute (INPS), this began to absorb the institutions created and maintained by the Retirement and Pension Institutes - the IAPs -, and other workers organizations. Thus, in 1973 the Carmela Dutra Maternity was absorbed by the Nation Social Welfare Institute.

In the 1990's the area of public health underwent a further re-organization and the Unified Health System (SUS) was created, initiating the process of attributing the role of administration and executor of the needs of the citizen to the municipality. In this project, various public health institutions were transferred over to the municipal public authorities, among them being the Carmela Dutra Maternity Hospital, in 1996.

Among the various services available to the population are obstetric procedures, odontology, family planning, care for the newborn at risk up to four years of age, phono-audiology, neo-natal physiotherapy, social services, care of women who have been victims of sexual violence, nutrition, occupational therapy and laboratory of clinical analyses. It also has a neonatal Intensive Care Unit and a human milk bank. 


\section{Register of Preservation:}

It is not listed.

\section{Sources:}

Acervo do Centro de Estudos da Unidade hospitalar. Capturado em 10 de mai. 2007. Online. Disponível na internet: http://www.saude.rio.rj.gov.br/servidor/cgi/private/cgilua.exe/sys/reader/htm/preindexview.htm?editionsectionid= $156 \&$ user=reader

ASSISTÊNCIA Pública - Guanabara: 80 anos de história. Rio de Janeiro: Superintendência de Serviços Médicos (SUSEME); 1972. mimeo.

O Povo

Credits: Lidiane Monteiro (research), Maria Renilda Nery Barreto (research and text) 


\section{Carmela Dutra Municipal Hospital}

Other Denominations: Sapê Clinical Dispensary (1934-1938); Rocha Miranda Dispensary (1938-1946); Carmela Dutra Hospital-Dispensary (1946-1966); Carmela Dutra Hospital (1966-present day).

Location: Rocha Miranda

Address: Avenida dos Italianos, 480

Category: General Hospital

Period of Construction: 1938

Proprietor: Rio de Janeiro City Hall

Author / Constructor: Companhia Industrial Construtora do Rio de Janeiro

\section{History:}

The construction of the Carmela Dutra Hospital followed the construction plan of regional polyclinic hospitals and dispensaries, developed by the Mayor, Pedro Ernesto Batista, in his first administration of the then Federal Capital, between the years 1931 and 1934. This same plan, elaborated in the General Office of Municipal Assistance, included a General Hospital (present Pedro Ernesto Hospital), the Méier Medical Assistance Center (present Salgado Filho Hospital), the Jesus, Miguel Couto, Carlos Chagas and Getúlio Vargas hospitals and the dispensaries of Ilha do Governador (present Paulino Werneck Municipal Hospital), of Ilha de Paquetá (present Paquetá Hospital), Rocha Miranda (present Carmela Dutra Hospital) and Campo Grande. The works on these new units of medical-hospital assistance were accompanied by a commission formed especially for this purpose and headed by the doctors, Rodolpho de Abreu Fialho, Alcides Pinheiro Marques Carneiro, Alberto Borgerth and Amadeu de Barros Saraiva. The Companhia Industrial Construtora of Rio de Janeiro, owned by the architect Luiz Moraes Jr and de Archimedes d'Arthagnan Saldanha, was responsible for carrying out the works.

Its foundation stone was laid on September $16^{\text {th }}, 1934$ and, at this time it received the name of the Sapê Clinical Dispensary. The land set aside for the construction of the Dispensary was donated by Ignácio Brígido de Novaes Machado and his wife. Despite the work being delivered in June of 1937, the Dispensary was only inaugurated on September $10^{\text {th }}$, 1938, then with the name Rocha Miranda Dispensary.

In 1946, the inhabitants of Rocha Miranda, paid homage to the First Lady Carmela Dutra, Who had recently died, and requested the change of the name of the Rocha Miranda Dispensary, and it passed to the category of a Hospital-Dispensary, receiving the name of Carmela Dutra.

In 1960, with the transfer of the federal capital to Brasília, the State of Guanabara was created which covered the whole of the municipality of Rio de Janeiro. At this time, the hospitals belonging to the jurisdiction of the Federal District were handed over to state jurisdiction. Fifteen years later, in 1975, with the fusion of the states of Guanabara and Rio de Janeiro, some of these hospitals returned to being municipal hospitals, among these being the Carmela Dutra Municipal Hospital, while others remained as state hospitals.

Despite being destined primarily to an out-patients service, it operated during a short period (from 1958 to 1963) as a General First-Aid Center. The expansion of its functions only took place in the 1980's, in the administration of the mayor, Saturnino Braga (1986-1988), going on to maintain a 24 hour First-Aid and basic out-patients service in two shifts.

In the following decade, the Hospital underwent a physical expansion, doubling its capacity to attend the public. With this the Carmela Dutra Hospital was re-inaugurated in September of 1997, having 12 consultation rooms and equipments for examinations, with an echocardiogram machine and ergometric treadmill; the provision of the DayHospital for attending to bearers of the HIV virus; the odontology service had three new equipped consultation rooms; Xray services; mental health; nutrition and a pharmacy. It was then able to attend to about 960 persons per month. 
The Hospital was characterized, then as a Health Unit for secondary level attendance and of average complexity. Thus, in addition to being a Basic Clinic and offering Emergency Services, the hospital became a Cardiology Center, receiving specialists and echocardiography, electrocardiography and ergometry equipment.

At present, the unit attends in the areas of Clinical Medicine, Pediatrics, Medical Treatment for Adolescents, Homeopathy, Children's Medicine, Gynecology and Pre-Natal Services, DST/AIDS, Cardiology, Endocrinology, Nursing Consultations, Psychology, Odontology and Nutrition.

\section{Architectural Description:}

As from the 1960's, many hospitals underwent renovations and expansions. The old facilities of these hospitals, in their great majority constructed in the 1930's, by Pedro Ernesto, proved to be obsolete and needed adaptations to the typology imposed and consolidated by the North American mono-blocks. A great number of institutions had there old facilities demolished, to make way for blocks with Five, seven or tem floors. Other, received annexes, maintaining the original facilities after renovation. The change in medicine would bring to architecture a formal impoverishment, revealed in straight lines, without ornamentation and standardized.

\section{Register of Preservation:}

It is not listed.

\section{Sources:}

Acervo do Centro de Estudos da Unidade hospitalar. Capturado em 10 de mai. 2007. Online. Disponível na internet: http://www.saude.rio.rj.gov.br/servidor/cgi/private/cgilua.exe/sys/reader/htm/preindexview.htm?editionsectionid= 156\&user=reader

ASSISTÊNCIA Pública - Guanabara: 80 anos de história. Rio de Janeiro: Superintendência de Serviços Médicos (SUSEME); 1972. mimeo.

O Povo, Rio de Janeiro, 21 de setembro de 1997.

Credits: Nathalia Morais (research), Gisele Sanglard (text) and Renato da Gama-Rosa Costa (architectural description) 


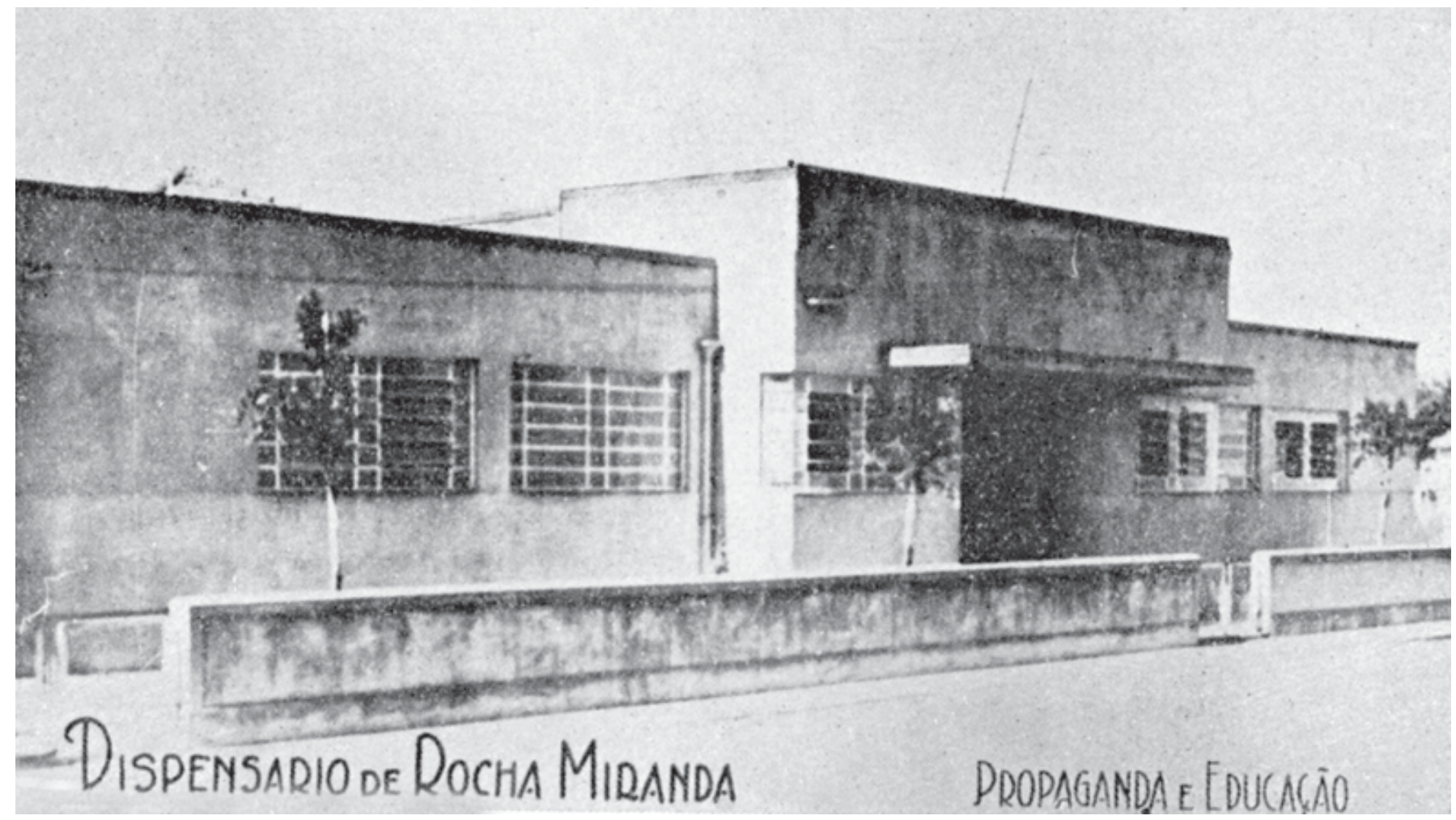

Dispensário de Rocha Miranda, [s.d.]. Apud Ribeiro (1956) 


\section{Hospital Central do Instituto de Assistência dos Servidores do Estado do Rio de Janeiro (Central Hospital of the Institute for Assistance of Civil Servants of the State of Rio de Janeiro) - IASERJ}

Other Denominations: Sociedade de Beneficência do Servidor Municipal (Beneficence Society of the Municipal Civil Servants) (1932-1944); Serviço Médico-Cirúrgico dos Funcionários da Prefeitura do Distrito Federal (Hospital and Center of Medical Investigations of the Federal District City Hall Civil Servants) (1944-19??); Hospital dos Funcionários da Prefeitura do Distrito Federal (Civil Servant Hospital of Federal District City Hall) (19??-1960); Hospital Central do Instituto de Assistência dos Servidores do Estado da Guanabara (Central Hospital of the Institute for Assistance of Civil Servants of the State of Guanabara) (1960-1975); Hospital Central do Instituto de Assistência dos Servidores do Estado do Rio de Janeiro (Central Hospital of the Institute for Assistance of Civil Servants of the State of Rio de Janeiro) (1975-present day).

\section{Location: Centro}

Address: Henrique Valadares, 107

Category: General Hospital

Period of construction: [1950]

Proprietor: Government of the State of Rio de Janeiro

Author / Constructor: unknown

\section{History:}

The history of the Institute for Assistance of Civil Servants of the State of Rio de Janeiro (IASERJ) began with the founding, in 1932, of the Sociedade Beneficiente of the Municipal Civil Servant, entity of mutual support catered to the civil servants of city hall of the Federal District. Just as other Sociedades Beneficentes (Beneficent Societies) in the city, the Municipal Civil Servant aimed at offering medical care to its associates. Its revenue came from the voluntary contribution of its members.

For the rendering of medical care, it had some polyclinics spread in the neighborhoods of Centro, Tijuca and Méier. Around 1938-1939, the Sociedade acquires the building on rua Henrique Valadares, in Centro, where the Casa de Saúde (Hospital) belonging to Pedro Ernesto used to operate.

In 1944, in the administration of Mayor Henrique Dodsworth (1937-1945), the Sociedade was revoked by City Hall and transformed into the Department of Assistance for Civil Servants of City Hall, thus becoming known as Civil Servant Hospital and Center of Medical Instigations, offering surgical-medical services to municipal civil servants, which was an obvious inspiration to the services offered by IPASE - Institute of Retirement and Pension of Federal Civil Servants.

In the 1950s, the Surgical-Medical Service was transformed into a Hospital, still operating in the rooms of the former Casa de Saúde. The physical expansion of the hospital started at the end of the 1950's with the construction of a new polyclinic and emergency room - the latter facing rua Washington Luiz.

In 1960, with the transfer of the federal capital to Brasília, the state of Guanabara is created encompassing the whole municipality of Rio de Janeiro. In such occasion, the Institute for Assistance of Civil Servants of the State of Guanabara (IASEG) is instituted, subordinates the Administration office and not the Superintendence of Medical Services (SUSEME), as was the case with other hospitals in the State. The Institute was entitled to provide medical care and make available daily supplementary services through its own entities - its hospital - and indirectly through agreements with hospitals, health centers, clinics, laboratories and other services. Fifteen years later, in 1975, with the fusion of the states of Guanabara and Rio de Janeiro, it became denominated Assistance for Civil Servant of the State of Rio de Janeiro (IASERJ). At such moment, the hospital becomes sustained by payroll deduction of the civil servants from the municipality and state - first from Guanabara and later the state of Rio de Janeiro - allowing them, and their relatives, vast access to first class hospitalmedical assistance. 
During the administration of Carlos Lacerda (1960-1965), the Hospital went through its golden period, with huge investments in equipment, personnel and physical space. For such, the whole block was acquired: starting with an 11story building where a Casa de Saúde used to operate and was destined to be the pavilion of hospitalizations; a cafeteria, pavilion for the management of IASEG, new polyclinic - installed in a building of five floors and a pavilion dedicated for pathological anatomy service were built..

Its services became famous during this period - maternity ward, surgery and medical clinic, which are the foundation of a hospital, were of excellent quality. In the words of cardiologist Raphael Leite Luna, who, during 47 years, dedicated himself to the hospital, it was a hospital which was concerned about clinical research and for such, offered experimental surgery room for its doctors and weekly debates about the most complex clinical cases; in addition to well equipped laboratories - the Emergency Room service had its own laboratory, 24h a day.

In the 1960s, the Cardiology service was equipped with Hemodynamics Laboratory, Ergonomics Laboratory and an Acoustic Laboratory of Phonocardiography and a Polyclinic with eight examination rooms. In 1969, the creation of a model Intensive Care Unit attracted patients from other states of the federation, such as patients from the state of Pará and doctors from the Clinics Hospital of Paraná, to observe the procedures that were being adopted.

In 1970, the Intensive Care Unit is inaugurated. During such decade, the Cardiology Course of the Graduate Medical School at PUC-RJ was initiated in the rooms of the hospital; the implantation of the nuclear medicine service, considered pioneer in Rio de Janeiro; and the Laboratory of Echocardiogram, in 1975.

In the 1970s, the Hospital had Services of Anesthesia, Obstetrics, Medical Clinic, Pediatrics, Pneumology, Infantile Surgery and Pathological Anatomy. The Hospital was expanded to 600 beds transforming itself into a large scale hospital, possessing two automated clinical laboratories.

The heads of service of the hospital were all university professors, which aggregated more prestige to the hospital. Given the increased demand for its services, it necessary to expand by opening polyclinics spread throughout the city and metropolitan region: Niterói, Tijuca, Penha, Madureira, Gávea and Campo Grande - Eduardo Rabello Hospital, inaugurated in 1973 and dedicated to geriatrics.

The 1980s marks the initial downfall of the Hospital. In 1985, an administrative measure adopted under the government of Leonel Brizola (1982-1986), created a "consolidated fund" for the budget of the state, which caused a reduction of funds for the Hospital. The final blow happened in 1999 with the termination of the civil servants' payroll deduction contribution to IASERJ, as a result, it had no means to sustain itself.

In the same year, Act no. 3189 of February $22^{\text {nd }}$ created RioProvidência - a.k.a., Social Security Fund of the State of Rio de Janeiro - which has the objective to guarantee retirement and pension payments for the State's civil servants.

In between these two events, the State as well as the Municipality - in the administration of Mayor César Maia (19931996) - stopped transferring to IASERJ their share in the financing of the institution. In the administration of Marcello Alencar (1995-1999), Raphael Leite Luna took over the management at IASERJ and tried to transform the hospital into a foundation, in order to gather external funds, without formalizing the proposal. There was hope for the finances of the hospital during this period, nevertheless, a surplus turned into deficit; until the allocated budget was altogether removed with the creation of RioPrevidência, in the administration of Anthony Garotinho (1999-2002).

The last twenty years have been marked by a process of decadence, deterioration and even ruin of equipment, physical space and furniture. Not to mention the disorganization, among other agreements, of the maintenance, food and janitorial services.

The signing of the covenant between the governor of the state of Rio de Janeiro and the Ministry of Health on June $6^{\text {th }}$, 2007, has the purpose to revert the scenario of despair at the institution, as IASERJ becomes integrated in the REDE SUS (National Health Program System) therefore, it may be able to provide assistance to patients that are not strictly civil servants of the state, with financing guaranteed by transfers of SUS. 


\section{Register of Preservation:}

It is not listed.

\section{Sources:}

ALBANESI FILHO, F. 50 anos de História da Cardiologia no Estado do Rio de Janeiro. Rio de Janeiro: SOCERJ; 2005. Entrevista com o dr. Raphael Leite Luna, 26/10/2007.

http://www.arquivosonline.com.br/entrevistas/drluna/entrevistaimpressa03.asp, Acessado em 17/08/2007. http://www.iaserj.rj.gov.br/quem_somos.asp, Acessado em 17/08/2007.

http://www.imprensa.rj.gov.br/scssiteimprensa/detalhe_noticia.asp?ident=38217, Acessado em 17/08/2007. Roberto Stern, http://www.crprj.org.br/2007030101.asp, Acessado em 17/08/2007.

Credits: Nathalia Morais (research) and Gisele Sanglard (text) 


\section{AFTER 1930}

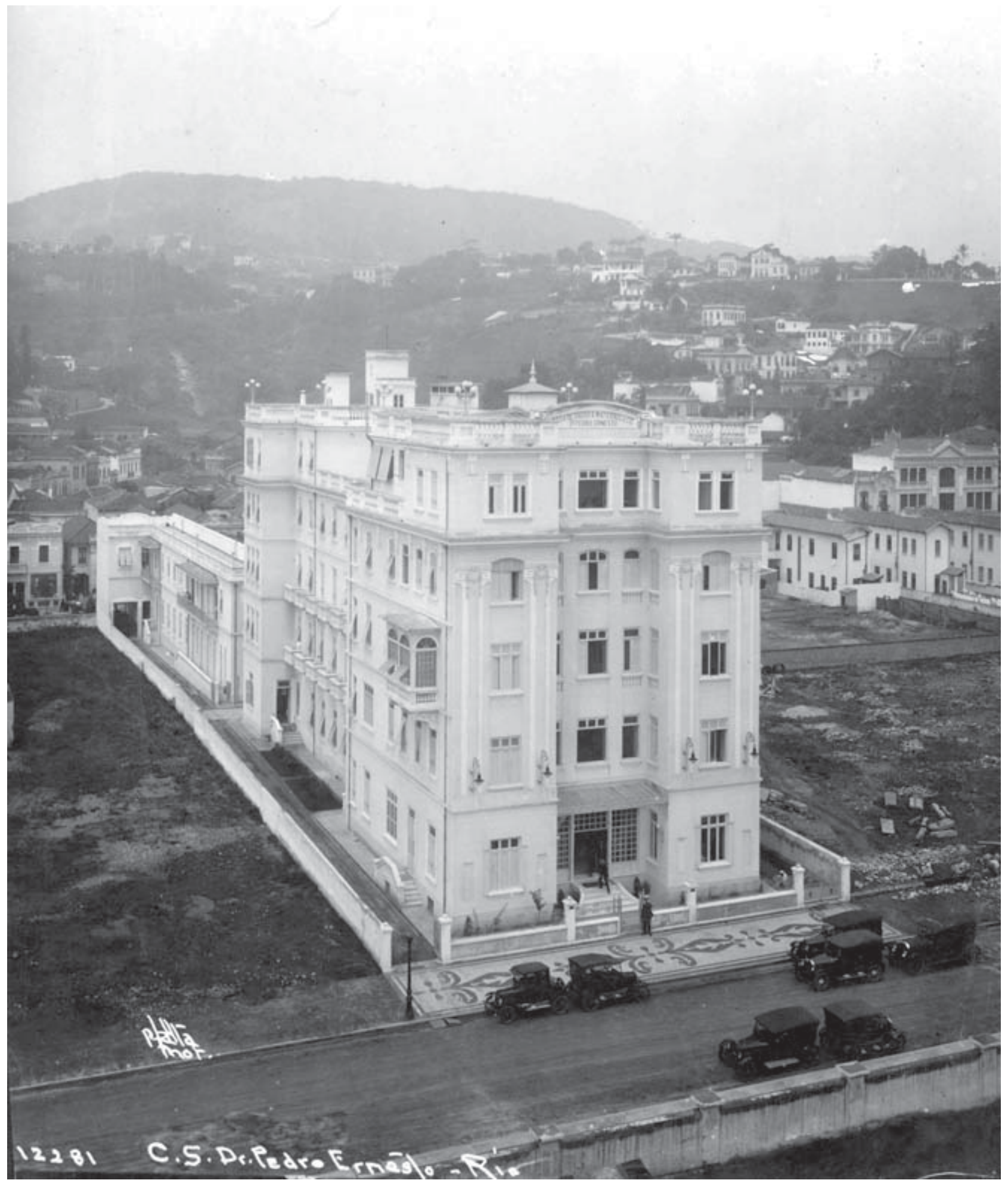

Dr. Pedro Ernesto Medical Center, [s.d.]. Photo Augusto Malta. Museu da Imagem e do Som - RJ Archives 


\section{AFTER 1930}

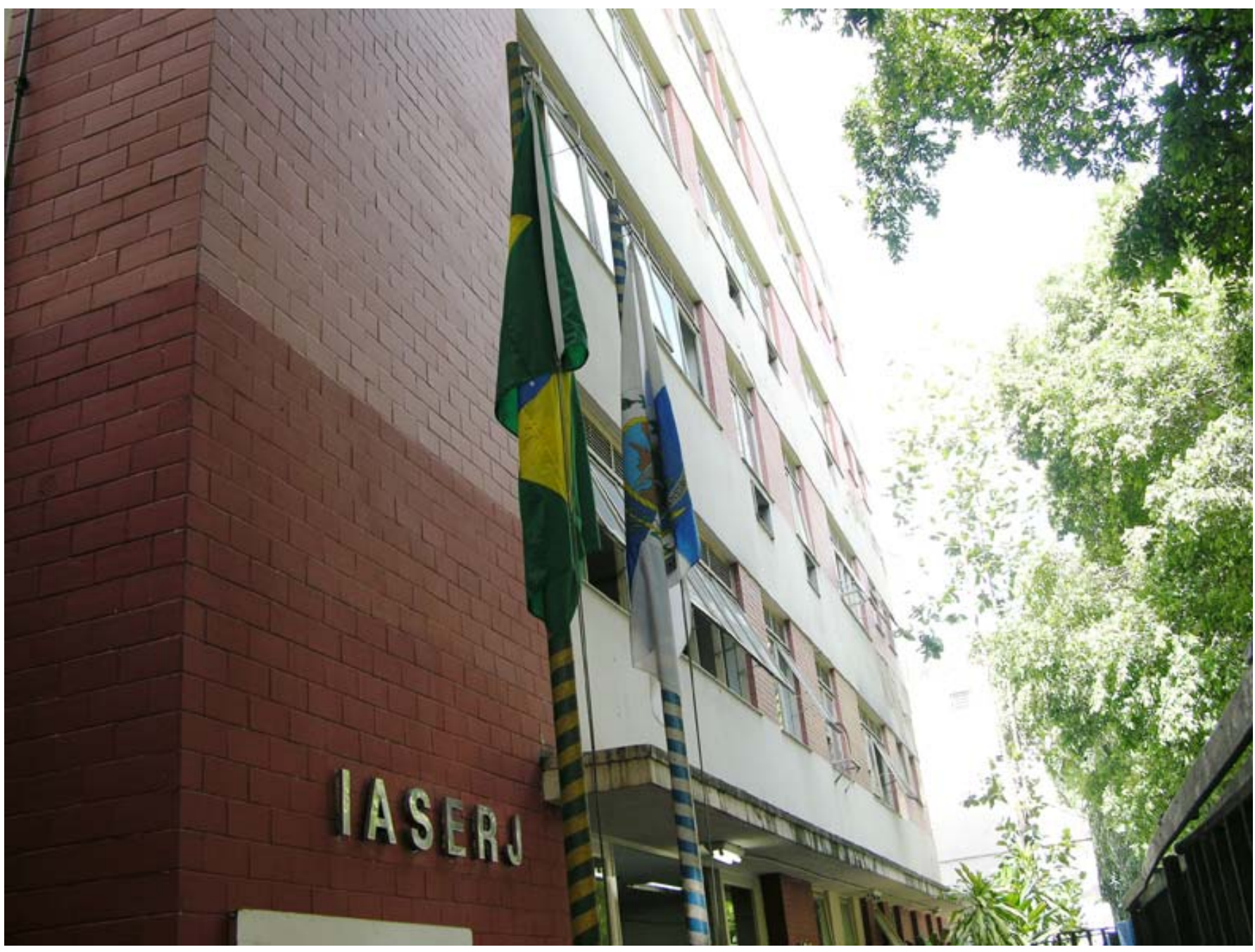

Façade of Institute for Civil Servants Assistance of Rio de Janeiro State Central Hospital. Photo Roberto Jesus Oscar \& Vinícius Pequeno de Souza, 2008. Casa de Oswaldo Cruz Archives 


\section{Dr. Phillippe Pinel Municipal Institute}

Other denominations: Neurosyphilis Institute (1937-1944); Neurosyphilis Hospital (1944-1965); Pinel Hospital (19651985); Dr. Phillippe Pinel Hospital (1985-1994); Philippe Pinel Institute (1994-2000); Dr. Phillippe Pinel Municipal Institute (2000-present day).

Location:Botafogo

Address: Avenida Wenceslau Brás, 65

Category: Institution of assistance care

Period of construction: XX Century

Proprietor: City Hall of the City of Rio de Janeiro

Author / Constructor: unknown

\section{History:}

The origins of the Phillippe Pinel Institute date back to the former Pedro II Asylum, the first psychiatric hospital in Latin America, founded by decree 82, of 07/18/1841, in Praia Vermelha. Adhering to the scientific concepts of French psychiatrists Phillippe Pinel (1745-1826) and Jean Etienne Dominique Esquirol (1772-1840), it proposed a more humane approach to the care of mental patients.

In 1903, upon assuming the directorship of the Asylum, Dr. Juliano Moreira, instituted a series of modifications to the services available, in addition to developing the sections already in existence. Since he had interned at the Dermatology and Syphilography Clinic in the College of Medicine in Bahia, where he concluded his medical training in 1891 with a thesis on syphilis, soon after becoming director, he installed a laboratory of clinical analyses and the practice of lumbar punctures, a method to diagnose neurosyphilis.

Under such conditions, the evolution of the services needed for the establishment of a specialized institute was only a matter of time. In fact, institutional autonomy came in January $13^{\text {th }}, 1937$, with the inauguration of the Neurosyphilis Institute, an organ of the Psychopaths' Assistance Service of the Ministry of Education and Health, making up the psychiatric complex in Praia Vermelha along with the Psychiatric Institute of the University of Brazil (IPUB). This Institute absorbed the Pinel Section of the already renowned National Psychiatric Hospital, denomination acquired in 1911.

Following the deactivation of the cited Hospital, in 1944, only the Neurosyphilis Institute and the IPUB continued to occupy the properties in Praia Vermelha. In 1946, already renamed the Neurosyphilis Hospital, its staff, under the direction of Humberto Matias Costa, was composed of the psychiatric doctors Antônio Xavier de Oliveira, Januário Jobim Bittencourt, José Carneiro Ayrosa and Deusdédit Araújo.

In tribute to the "father of psychiatry", in 1965, it received the name of Pinel Hospital, conferred by former President of the Republic Castelo Branco, assuming the role of a psychiatric emergency center. The removal of the term "neurosyphilis", in addition to paying tribute to Phillippe Pinel, also reflected the decline of the syphilis epidemic and, consequently, neurosyphilis. Moreover, since it functioned as an emergency center, the assistance rendered fulfills the role of avoiding hospitalization, adopting procedures adequate for emergency care.

On August 13 ${ }^{\text {th }}, 1966$, in the confines of the Pinel Hospital (inaugurated in November), the record of the foundation of the Brazilian Psychiatric Association was signed. The selection of the place to mark this event was not random, it was important to be established inside a prestigious institution in the field of psychiatry, a center of affluence of Brazilian psychiatric scholars.

It was in the 1960s, with the establishment of the Pinel Hospital, that the psychosocial therapies were introduced, such as praxis therapy, music therapy, crisis care, group psychotherapy and the therapeutic community.

The Hospital underwent complete architectonic reformulation in 1968, in order to meet the growing influx of patients. The original Pavilion was demolished and three edifices were constructed, constituting the new Hospital complex. 
Adhering to decree 481, of 07/15/1985, the entity became known as Dr. Phillippe Pinel Hospital, following a request by the descendents of the French psychiatrist, who wished to bestow more respect to his scientific legacy incorporating the qualitative name of doctor.

Yet, in 1994, in virtue of Ministerial Decree 1.805 of October $24^{\text {th }}$, it received the name of Phillipe Pinel Institute, also receiving a new Internal Regiment. The shift from Hospital into an Institute meant a change in the orientation of the institution, which began to invest in scientific research and specialized teaching.

As of this date the institute implanted a Medical Residency Program in Psychiatry, which along the Residency Program in Mental Health (partnership with the National School of Public Health/FIOCRUZ), compose the Integrated Residency Program in Psychiatry and Mental Health, which seeks to specialize the qualification of the mental health professional based on the demands of medical residence.

Following an agreement signed on December $28^{\text {th }}, 1999$, in effect on January $01^{\text {st }}, 2000$, the Institute ceased to be a federal unit and became part of the Municipality, as an organ of the Municipal Office of Health of Rio de Janeiro.

Without ever having abandoned psychiatric hospital-related assistance, the Institute also offers rehabilitation and cultural intervention programs, and, implanted more recently, Pinel TV and the Pinel Newsletter. It even has a Studies Center that is responsible for the production of technical-scientific material related to mental health, with a special focus in the updating of studies and professional qualification of its staff. All these actions in favor of psychiatric assistance, research and specialized teaching configure a state of reference for all similar entities in the country.

\section{Register of preservation:}

It is not listed.

\section{Sources:}

RAMOS, F.; GEREMIAS, L. Instituto Phillippe Pinel: origens históricas.

Revista do Centro Psiquiátrico Nacional

Credits: Atiele Azevedo de Lima Lopes (research and text) 

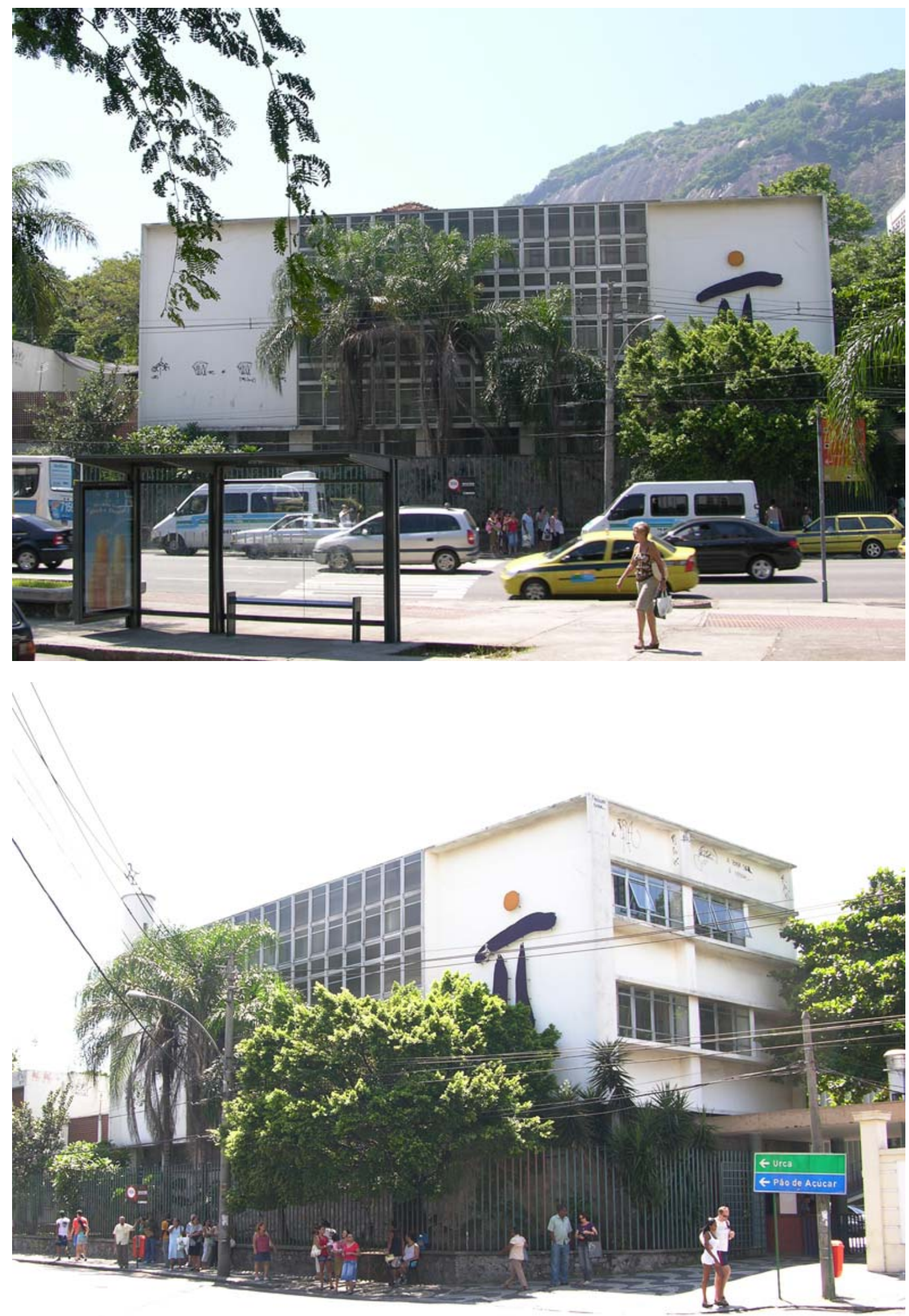

Pinel Institute. Photo Roberto Jesus Oscar \& Vinícius Pequeno de Souza, 2008. Casa de Oswaldo Cruz Archives
Pinel Institute. Photo Roberto Jesus Oscar \& Vinícius Pequeno de Souza, 2008. Casa de Oswaldo Cruz Archives 


\section{Fernando Magalhães Municipal Institute of The Woman}

Other denominations: São Cristóvão Maternity (1955-1958); Fernando Magalhães Maternity (1958); Fernando Magalhães State Maternity (1958-1975); Fernando Magalhães Municipal Maternity (1975-1987); Fernando Magalhães Municipal Institute of the Woman (1987-present day).

Location: São Cristóvão

Address: Rua General José Cristino, 87.

Category: Institute of the Woman.

Period of construction: 1955

Proprietor: City Hall of Rio de Janeiro.

Author / Constructor: unknown

\section{History:}

In the first half of the $\mathrm{XX}^{\text {th }}$ century, various maternity clinics were founded in the city of Rio de Janeiro. The initiative of these places destined to the care of women and children was almost always connected to the philanthropic action of women and doctors, sometimes that of private initiative and at others, that of the public authorities.

In the 1940's, the authorities linked to health and health care took up the discussion again about the founding of a municipal public maternity clinic, a subject already ventilated at the turn of XIX th to the XX ${ }^{\text {th }}$ century and that resulted in the creation of the Santa Isabel Municipal Maternity Clinic. The central argument for the creation of an institution for the care of pregnant women was the same: the establishment of a space that would provide good services to the population and that served the needs for the obstetric training of doctors and nurses.

In 1944, Ari de Oliveira Lima, then Secretary of Health and Health Care of the Federal District, concluded the São Paulo-Rio Obstetrics and Gynecology Week defending the creation of a large-sized municipal maternity clinic. The project was taken seriously and in the following year the city hall of the Federal District expropriated the property at Rua General José Cristino for this purpose. On July 06 ${ }^{\text {th }}, 1955$, the São Cristóvão Maternity Clinic was inaugurated with 54 beds and having a technical-administrative team originating from the extinct Henrique Batista Maternity Clinic.

In 1960, with the transfer of the federal capital to Brasília, the Estado da Guanabara (State of Guanabara) was created which covered the whole municipality of Rio de Janeiro. At that time, the hospitals belong to the city hall of the Federal District came to be under state jurisdiction. Fifteen years later, in 1975, with the fusion of the states of Guanabara and of Rio de Janeiro, some of these hospitals returned to the condition of municipal hospitals - among these being the Fernando de Magalhães Maternity; while others remained as state hospitals.

In 1987, the institution changed its care profile and also its name, coming to be called the Fernando Magalhães Municipal Institute of Care for Women. Besides caring for pregnant women, new mothers and the new-born at risk, it expanded its offer of services, including, for example, women who are victims of sexual violence.

\section{Sources:}

ASSISTÊNCIA Pública - Guanabara: 80 anos de história. Rio de Janeiro: Superintendência de Serviços Médicos (SUSEME); 1972. mimeo.

http://www.sms.rio.rj.gov.br/, Acessado em 20/08/2007.

Credits: Lidiane Monteiro Ribeiro (research) and Maria Renilda Nery Barreto (research and text) 


\section{Getúlio Vargas State Hospital}

Other denominations: Municipal Hospital of Penha and Dispensary of Penha (1933-1934); Getúlio Vargas Hospital (1934-1969); Getúlio Vargas State Hospital (1975-present day).

Location: Penha.

Address: Rua Lobo Júnior, 2293.

Category: General Hospital.

Period of construction: 1937.

Proprietor: State Government of Rio de Janeiro.

Author / constructor: Companhia Industrial Construtora of Rio de Janeiro

\section{History:}

The construction of the Getulio Vargas Hospital followed the plan for the construction of polyclinic regional hospitals and dispensaries, or central and peripheral ones, developed by Mayor Pedro Ernesto Batista, during his first term in office of the then Federal Capital, between the years 1931 and 1934. In the same plan, elaborated at the General Department of Municipal Assistance, were included the General Hospital of the plan (the present Pedro Ernesto Hospital), the Méier Health Center (the present Salgado Filho Hospital), the Jesus, Miguel Couto, Chagas and Rocha Faria hospitals and the dispensaries of Ilha de Governador (the present Paulino Werneck Municipal Hospital), of Ilha de Paquetá (the present Paquetá Hospital) and Rocha Miranda (the present Carmela Dutra Hospital). Construction work on these new units of medical-hospital assistance was accompanied by a commission designed specially for this purpose, in which doctors Rodolpho de Abreu Fialho, Alcides Pinheiro Marques Carneiro, Alberto Borgerth and Amadeu de Barros Saraiva participated. It was the responsibility of the Companhia Industrial Construtora of Rio de Janeiro, owned by the architect Luiz Moraes Jr and Archimedes d'Arthagnam Saldanha, to perform the construction work.

By Decree no. 5096 of September 1 ${ }^{\text {st }}$, 1934, the Mayor of the Federal District, Pedro Ernesto named the old Municipal Hospital of Penha, Getúlio Vargas Hospital, which also encompassed the services of the Dispensary of Penha, inaugurated on October $30^{\text {th }}$, 1933 with the entrance at Rua Albertino de Araújo.

The termination of the construction of the new hospital was on September 30 $0^{\text {th }}, 1937$; however its inauguration only occurred on December $3^{\text {rd }}, 1938$, in the presence of Mayor Henrique Dodsworth (1937-45). The new facilities began to operate at Rua Lobo Júnior, the current address of the institution. During construction, the patients of the new hospital were cared for in the old dispensary.

During the term of General Ângelo Mendes de Moraes (1947-51), the property located at Rua Dr. Weischenk, next to the hospital, was confiscated for public utility, so that the hospital could be expanded. However, the expansion project was only initiated during the term of Carlos Lacerda (1960-65), by the State of Guanabara. In this property would be built the Polyclinics, Emergency Center, Medical Documentation, Radiology Service, Pharmacy, Clinical Pathology Laboratories, Infirmaries, Rooms, Surgical Center, Sterilization Center and the Intensive Care Unit and Post-Anesthesia Care Unit, in addition to rooms for the convenience of the doctors and the nursing staff. Construction work began after almost ten years of waiting, however they were once again paralyzed, and it was up to Negrão Lima (1965-70) and his Secretary of Health, Hildebrando Monteiro Marinho, to reinitiate the construction work. The inauguration of the annex was on December $3^{\text {rd }}, 1969$.

In 1960, with the transfer of the federal capital to Brasília, the state of Guanabara was created encompassing the entire municipality of Rio de Janeiro. At that time, the hospitals belonging to city hall of the Federal District came to have state jurisdiction. Fifteen years later, in 1975, with the merging of the states of Guanabara and Rio de Janeiro, some of these hospitals returned to the municipality, while others remained as state hospitals - among them being Getúlio Vargas State Hospital. 


\section{AFTER 1930}

Even today it is considered to be the largest public hospital in the State, tending in the areas of medical clinic and surgery; and pediatrics.

\section{Architectonic Description:}

Its original architecture follows that of other hospitals constructed by Pedro Ernesto, that is, it presents a strong North American art deco influence, the prevailing fashion back then. This hospital, however, stands out from the rest because it has four floors and three blocks in a horseshoe shape. Its surgery theaters also enjoyed the same comfort as the other facilities, with air conditioning.

As of the 1960's, many hospitals would undergo renovations and expansions, and such was the case of Getulio Vargas. The old facilities became obsolete and needed to undergo adaptations to the imposed and consolidated typology coming from the North American single-block structures. The change in medicine would bring to architecture a formal impoverishment, revealed in rectilinear lines, without ornament and standardizations.

\section{Register of Preservation:}

It is not listed.

\section{Sources:}

Jornal do Commercio, Rio de Janeiro, 04/12/1938, página 9. RIBEIRO, L.

Rio de Janeiro: Editorial Sul-Americana; 1956.

SECRETARIA de Estado de Saúde do Rio de Janeiro. informacoes/bancodad.shtml Acessado em 11/10/07.

Credits: Daniel Elian (research) and Renato da Gama-Rosa Costa (text and architectonic description). 


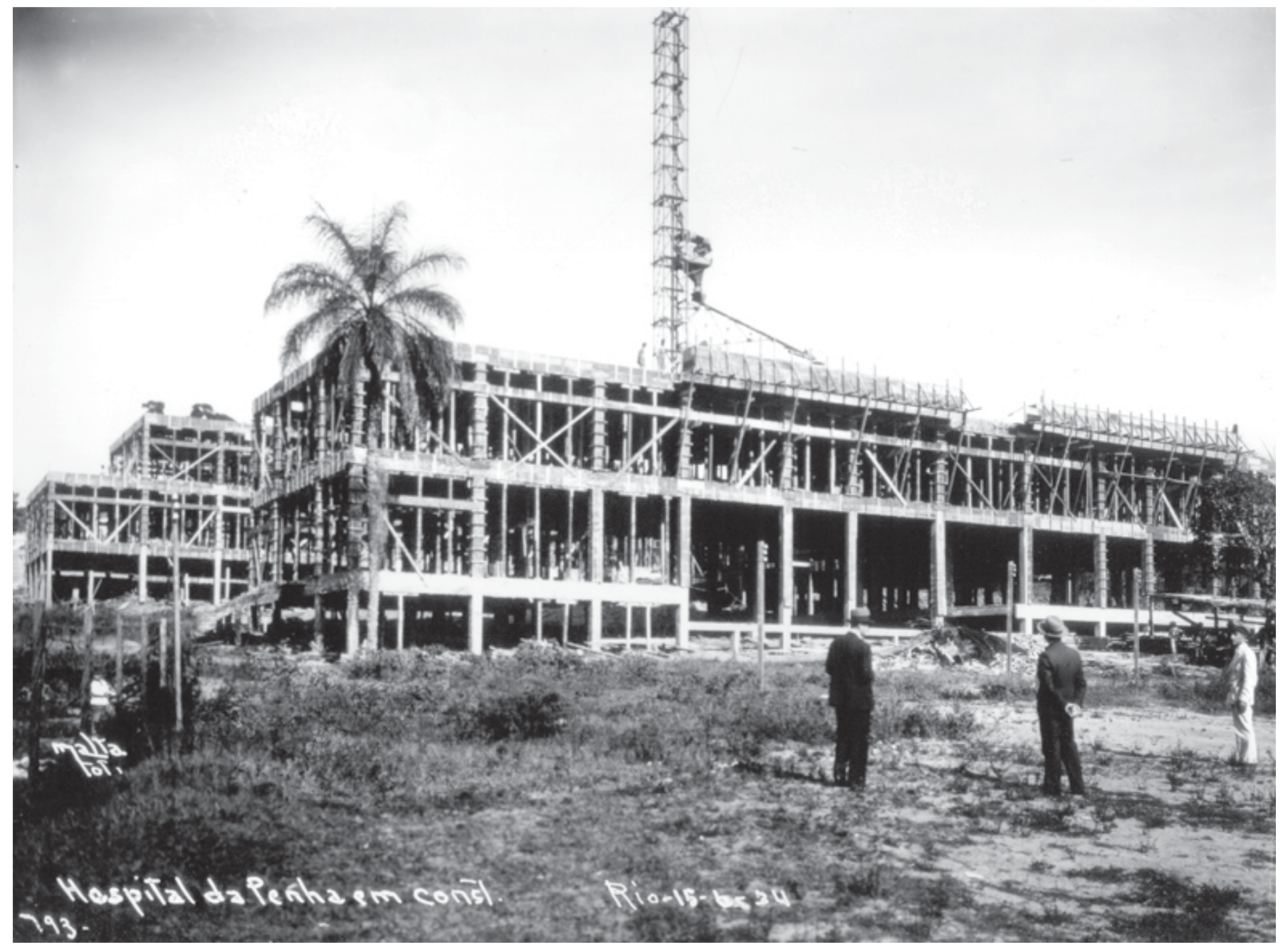

View of Penha Hospital Construction works. Photo Augusto Malta, 1934. City of Rio de Janeiro General Archives 

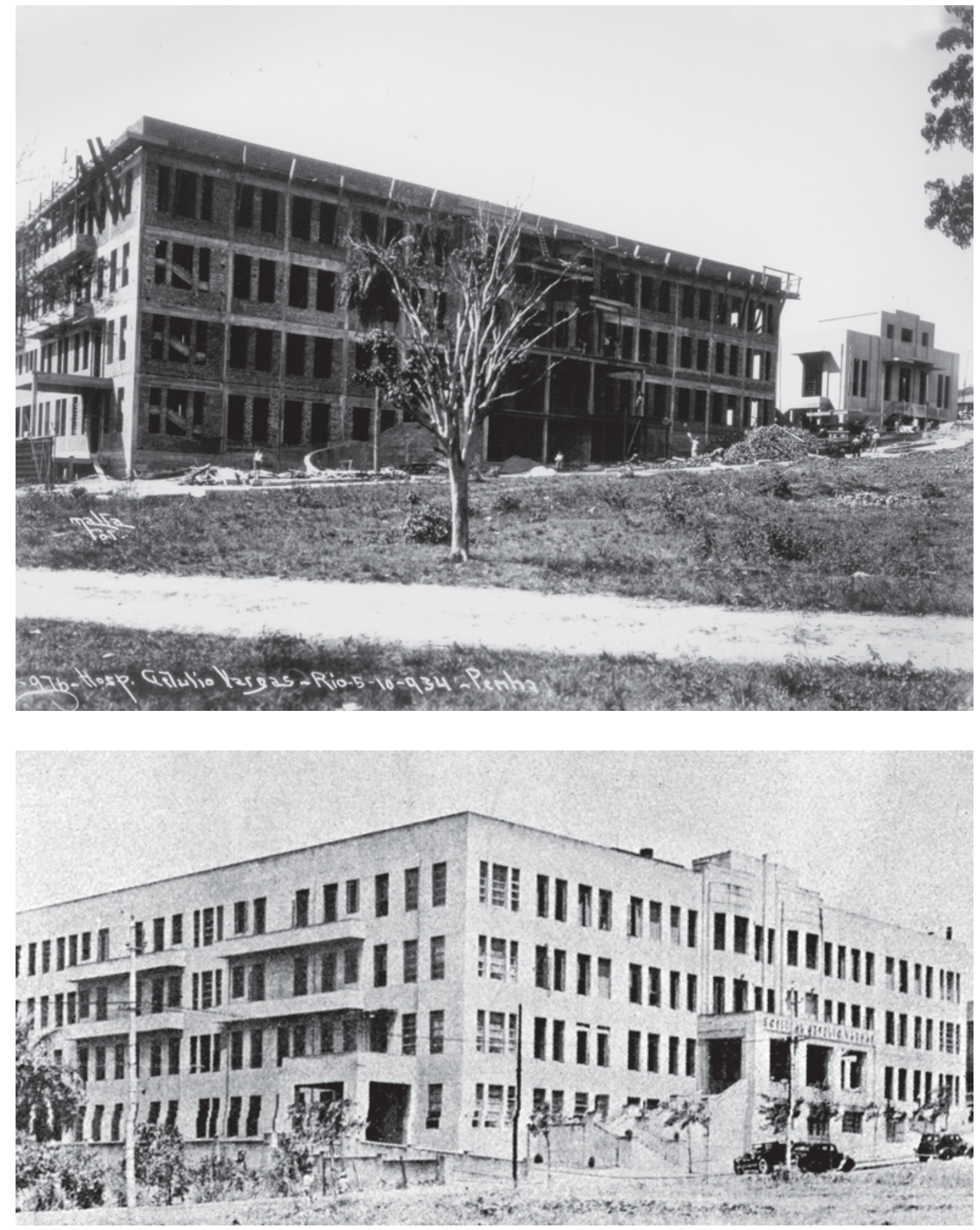

Getúlio Vargas Hospital, Penha. Photo Augusto Malta, 1934. City of Rio de Janeiro General Archives

Hospital Getúlio Vargas, [s.f.]. Source: Ribeiro (1956) 


\section{Hospital Central da Aeronáutica}

Other denominations: Hospital Alemão (1932- 1934); Hospital Itapagibe (1934-1942); Hospital Central da Aeronáutica (1942 - to present day)

Location: Rio Comprido.

Address: 109-129 Rua Barão de Itapagibe

Category: General Hospital.

Period of Construction: 1932-1934.

Proprietor: Ministry of Aeronautics.

Author/Constructor: F. Munk and Ernst Kupp (Engineers/architects); National Construction Company (constructor).

\section{History:}

The history of the creation of the Hospital Central da Aeronáutica dates back to a period of great political changes in the Americas and in Europe. Following the end of World War I, in 1918, there was an increase in the number of European immigrants to Brazil, part of a migratory process which had already been initiated decades earlier. German immigration to Brazil began in 1824 and reached its climax between 1918 and 1933, period in which around 80,000 Germans arrived in the country. It is important to remember that during the unification process of Germany - concluded in 1871, following the victory of the Prussian Army over the French - and with the creation of the II Reich (empire) in Germany, many small land-owners of the Northern German regions not only migrated to large European centers, but also received incentives to come to America. During the 1930s there was a great expansion in the number of German companies installed in Brazil.

And it was in this context that a German Association was created in 1897 by a small German colony at no. 109-129 Rua Itapagibe in the city of Rio de Janeiro. Since 1883 the German Association, as a Deutscher Hospital-Verein, had the aspiration to create a Hospital. Worth noting that, since the $19^{\text {th }}$ century there was a society of mutual assistance which, as of 1883, discusses the construction of a hospital to serve the needs of the colony, notably those of the Lutheran faith. This project gave rise to the Hospital Evangélico, constructed between 1896 and 1912. In the year of the hospital's inauguration a beneficent society is created by the Lutheran Church and the Associação de Senhoras Evangélicas (Association of Evangelical Ladies) whose aim is to open a hospital to render maternal-infant assistance care to needy women of the German colony in Rio de Janeiro - Hospital do Amparo Feminino was inaugurated in 1924.

Thus, the Hospital Alemão proposed by the German Association of 1897 would be the third hospital oriented to the assistance care of the German colony in the city of Rio de Janeiro.

The German Association collected the resources for the realization of its project and on December $8^{\text {th }}, 1932$ it laid the cornerstone of the Hospital Alemão, fruit of the work of Consul Otto Mattheis. Following the outline of the construction, the project was sent to Professor F. Munk who had already oriented the construction of the model hospital Martin Luther in Berlin, considered to be the most modern German hospital of the period. Later, the project was also sent to Ernst Kupp, a specialist in the construction of hospitals in hot climate countries whose curriculum included the construction of a hospital in the city of Alexandria, Egypt. In Brazil, the National Construction Company was left in charge of the construction, a company of proven experience in large construction work, of which the new ideas on the construction of hospitals were incorporated, according to which a single construction was defined, only a single block capable of accommodating, without the risk of contagion, patients of various infectious diseases, instead of erecting various blocks and pavements which until then characterized that type of construction. These characteristics can be observed until today in the central building of the Hospital Central da Aeronáutica, whose façade was preserved in the original model, despite of the new, more modern buildings surrounding it. 
In attendance at the cornerstone laying ceremony of the Hospital Alemão were the German Minister Hubert Knipping, ecclesiastic authorities, Brazilian journalists, such as Herbert Moses (Brazilian Press Association), and Doctor João Marinho de Azevedo - professor of ophthalmology at the College of Medicine of the University of Rio de Janeiro, currently UFRJ.

The Hospital Alemão was constructed to accommodate 100 beds and admit the sick in general without regard to creed or nationality. Its main building had five floors, four of which were dedicated to the sick. The $5^{\text {th }}$ floor was especially constructed for surgery service and was equipped with circular shaped operating rooms facing south, which afforded direct contact with the sunlight. On the $4^{\text {th }}$ floor was placed the maternity with delivery rooms, a service room and a room for newborns. The ground floor housed the polyclinic, to where first-time patients would go when in need of hospitalization or continuation of outpatient treatment.

During this period in Europe, especially in Germany, the scenario of new political trends was being delineated which, in 1933, culminated in the victory and election of Adolph Hitler as the German chancellor for the Nazi Party. In order to avoid possible complications of the political order for Brazil and already having been constituted the Hospital Association "Beneficent Society Itapagibe", the original name of the Hospital Alemão was altered to Hospital Itapagibe, whose inauguration was on August $18^{\text {th }}, 1934$.

Some important names of Brazil's aviation history, and, especially of the medicine of aviation, had their trajectories linked to the history of the hospital some years later, in 1942, when Brazil and Germany became belligerent nations. Brazil aligned itself to the countries spearheaded by the U.S. and England against the axis powers represented by Germany, Italy and Japan. Under the context of the "good neighbor" policy with the U.S., under the Government of Getúlio Vargas, since 1929 there was intense contact among military personnel, above all the Navy, with the North-American military schools specialized in aviation medicine, such as the Naval Medical School, in Pensacola. In 1931, Captain Lieutenant Doctors Edgard Barroso Tostes and Manoel Ferreira Mendes, both with specialization from North-American schools, along with Pontes de Miranda, constituted the first Health Inspection Board for the aviators of Brazil. Barroso Tostes, in 1937, organized the Medical Service of the airline company Panair do Brasil, dedicated to the assistance of the personnel and control of those who flew, under the medical aeronautical point of view.

The Ministry of Aeronautics was created on January $20^{\text {th }}, 1941$, by decree no. 2,961, which established the fusion of all of the country's aviation elements and on December $2^{\text {nd }}, 1941$ the Aeronautical Health Unit was created. Under this context, the Ministry needed a hospital and the Brigadier Generals Heitor Varady and Ajalmar Vieira Mascarenhas, and Lieutenant Coronel Doctor Ângelo Godinho dos Santos, sent to the Minister of Aeronautics, Joaquim Pedro Salgado Filho, the requisition proposal of Hospital Itapagipe for such end use. On August 17 th, 1942 , Hospital Itapagipe was arrested by the Brazilian Government to house the Aeronautical Health Unit, becoming known as Hospital Central da Aeronáutica, by means of Ministerial Directive no. 100.

The hospital's first director was Coronel Ângelo Godinho dos Santos, a graduate in Aviation Medicine of the $1^{\text {st }}$ class of Army Doctors in 1935, who became the father of the Aeronautical Health Service, by decree no. 63,152 of August 29th, 1968. It was the responsibility of the hospital's first administration to transform that health center into a military hospital and with this in mind promoted the replacement of all specialized technical personnel and incorporated medical professionals from the military and naval aviation. On September $12^{\text {th }}, 1942$ the hospitalization of $1^{\text {st }}$ Lieutenant Aviator

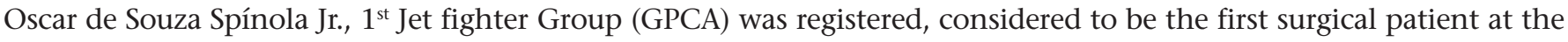
Hospital Central da Aeronáutica, who was submitted to an appendectomy.

Major Doctor Edgard Barroso Tostes was nominated director on November $26^{\text {th }}, 1942$, and implemented, with the support of the Minister of Aeronautics, Salgado Filho, the guidance necessary for the direction of a model hospital, such as the recruitment of nurses from the Anna Nery Nursing School of the University of Brazil, which remained at the Hospital Central da Aeronáutica until 1953. On December $15^{\text {th }}, 1944$ the clinics of ophthalmology, otorhinolaryngology, surgery and a cabinet of odontology were inaugurated. Still during this year the "American" infirmary was inaugurated.

He managed the institution until 1945, having left a fully equipped Hospital to fulfill its mission, outfitted with outpatient services, dental consultation rooms, infirmary and a vast library. On May 21 ${ }^{\text {st }}, 1945$ the Center of Studies of the Hospital Central da Aeronáutica was inaugurated. Decree-act no. 18,730 of May 30 ${ }^{\text {th }}, 1945$ established, conclusively, the expropriation and incorporation of the Hospital into the property of the Union. 
On December $17^{\text {th }}, 1945$ Coronel Doctor Edgard Correia de Mello assumed the management of the Hospital. In the following year, the technical section became constituted by: medical clinic, surgical clinic, forensic medicine and pathological anatomy, radiological service, physical therapy, analysis service and clinical research, pharmacy service, orthopedic service and nursing service. In February, 1947 proceeded the operation of the clinics of otorhinolaryngology, ophthalmology, obstetrics and gynecology, siligraphic dermatology, orthopedic and the clinics of neuropsychiatry and urology; and the clinics of proctology, dermatology and allergic diseases began operating.

On July 16 $6^{\text {th }}, 1951$ professors Garnett and Portmann of the Faculte de Medicine of Bordeaux, France, visited the Hospital. In 1960 the facilities of the laboratories of analyses and clinical research, of the mortuary chapel and of the pathological anatomy section were constructed and renovated. On August $6^{\text {th }}, 1984$ the xeromammography equipment was inaugurated, considered the first to be installed in Rio de Janeiro and the second in Brazil.

In 2001 the Edificio Garagem was inaugurated with 8 floors, including a helipad and the facilities of the emergency of the Hospital Central da Aeronáutica were inaugurated. In September, 2003 construction works were performed, such as renovations on the frontal wall, renovation of the main gate, with electronic turnstiles, construction of a gate for cargo vehicles and renovation of the Radiology Section.

The Hospital Central da Aeronáutica offers service of medical clinic and surgery, odontology and specialized services to the military personnel of the Brazilian Air Force and their dependents.

\section{Architectonic Description:}

In order to satisfy the program of the German hospital, at first, two properties were considered, one located on Rua Barão de Petrópolis and the other on Rua Barão de Itapagipe. The choice of the latter took advantage of the "wholesome air", protection against "the insalubrious winds" and its great dimensions, which enabled the main block to be located far from the thoroughfare.

The Hospital Alemão was equipped with innovated details such as the use of a single cement slab where five isolating layers were placed over, aimed at avoiding problems resulting from noise, easily transmitted in the solid and continuous structure of reinforced concrete. These isolating layers were constituted by sand or slag, on top of this there was another of bituminous felt and another on top of the asphalt, concrete, cast in the shape of a "swallow's tail". Over the concrete, smooth cement, and over the cement, linoleum made of a mixture which included cork. Concerned with avoiding noise double walls were constructed, $41 \mathrm{~cm}$ in thickness and free space in between them and inner doors of 14 centimeters.

The architectonic program used the monobloc typology, in earnest development at the time in countries such as the United States and in Germany itself. This architectonic typology sought to unite under the same construction, different diseases, separated by pavements and wings. The infirmaries were grouped in "stations", following German orientation. In turn, aesthetic lines follow a severe composition, without decorations, except for the ogival arches of Gothic origin used in the chapel and in the wings which form the " $U$ " of the ground pavement. These characteristics can be observed until today in the central building of the Hospital Central da Aeronáutica, whose façade of its main building was preserved, despite of the new, more contemporary buildings surrounding it.

\section{Notes:}

All the documentation on the founding of the Hospital Central da Aeronáutica, former Hospital Alemão, is available in a room at the ground floor of the main building of the hospital.

\section{Endowment registration:}

It is not endowed. 


\section{Sources:}

Arquitetura e Urbanismo, maio-junho, 1936.

HOSPITAL Central da Aeronáutica - Histórico do HCA. Capturado em 11 out. 2007. Online. Disponível na Internet: http:/ /www.hca.aer.mil.br/externo/index.php?pag=externo/oqueehca.htm

PATRONOS NA AERONÁUTICA. O Patrono da Aeronáutica. Capturado em 11 out. 2007. Online. Disponível na Internet: http://www.resenet.com.br/ahimtb/patfab.htm

SOLIZ, N. As diferentes fases da imigração alemã no Brasil. Capturado em 11 out. 2007. Online. Disponível na Internet: http://www.dw-world.de/popups/popup_printcontent/0,,1195367,00.html

Credits: Maria Elizabeth Bueno de Godoy and Maria Rachel Fróes da Fonseca (research and text) and Renato da GamaRosa Costa (architectonic description). 

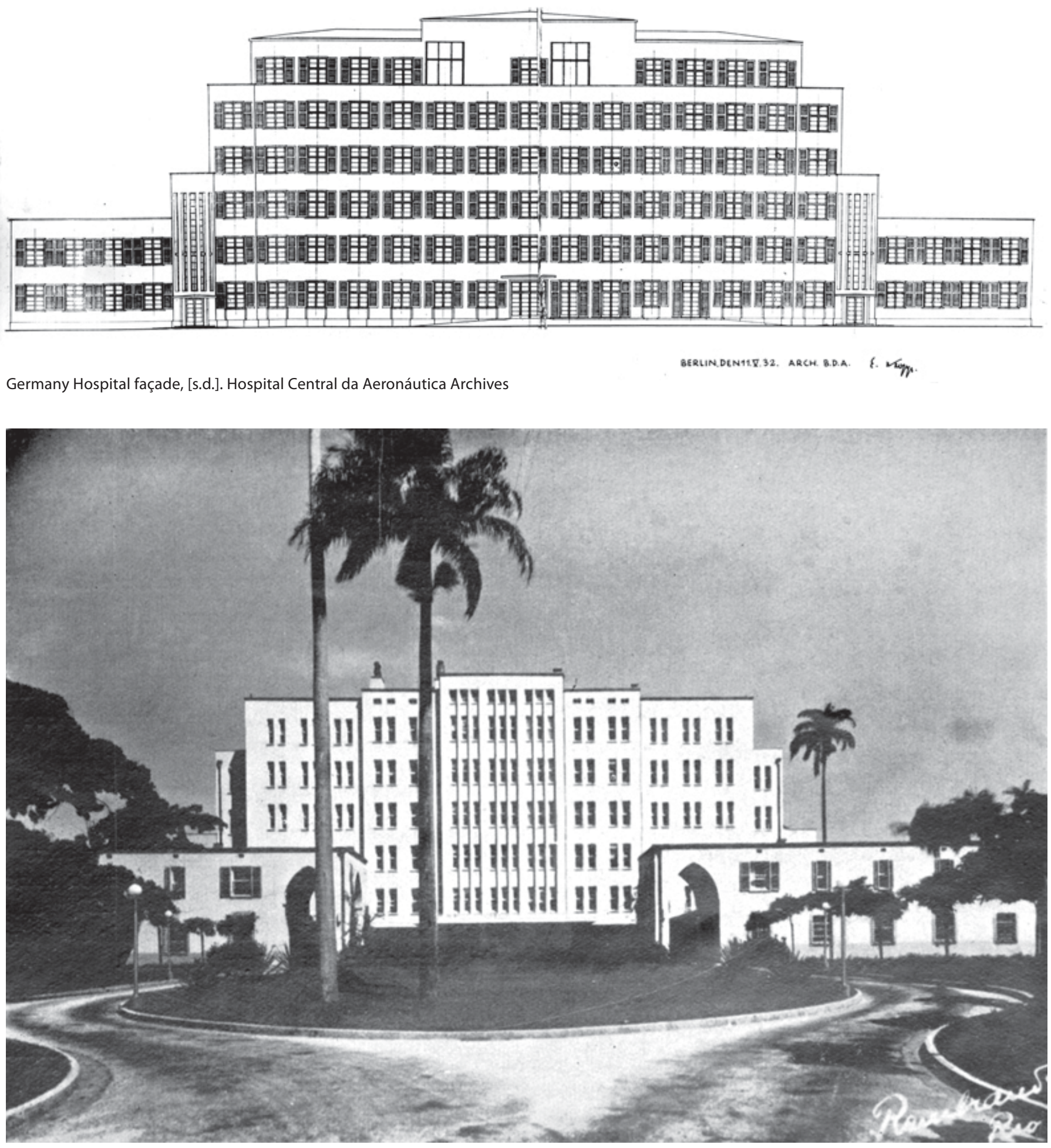


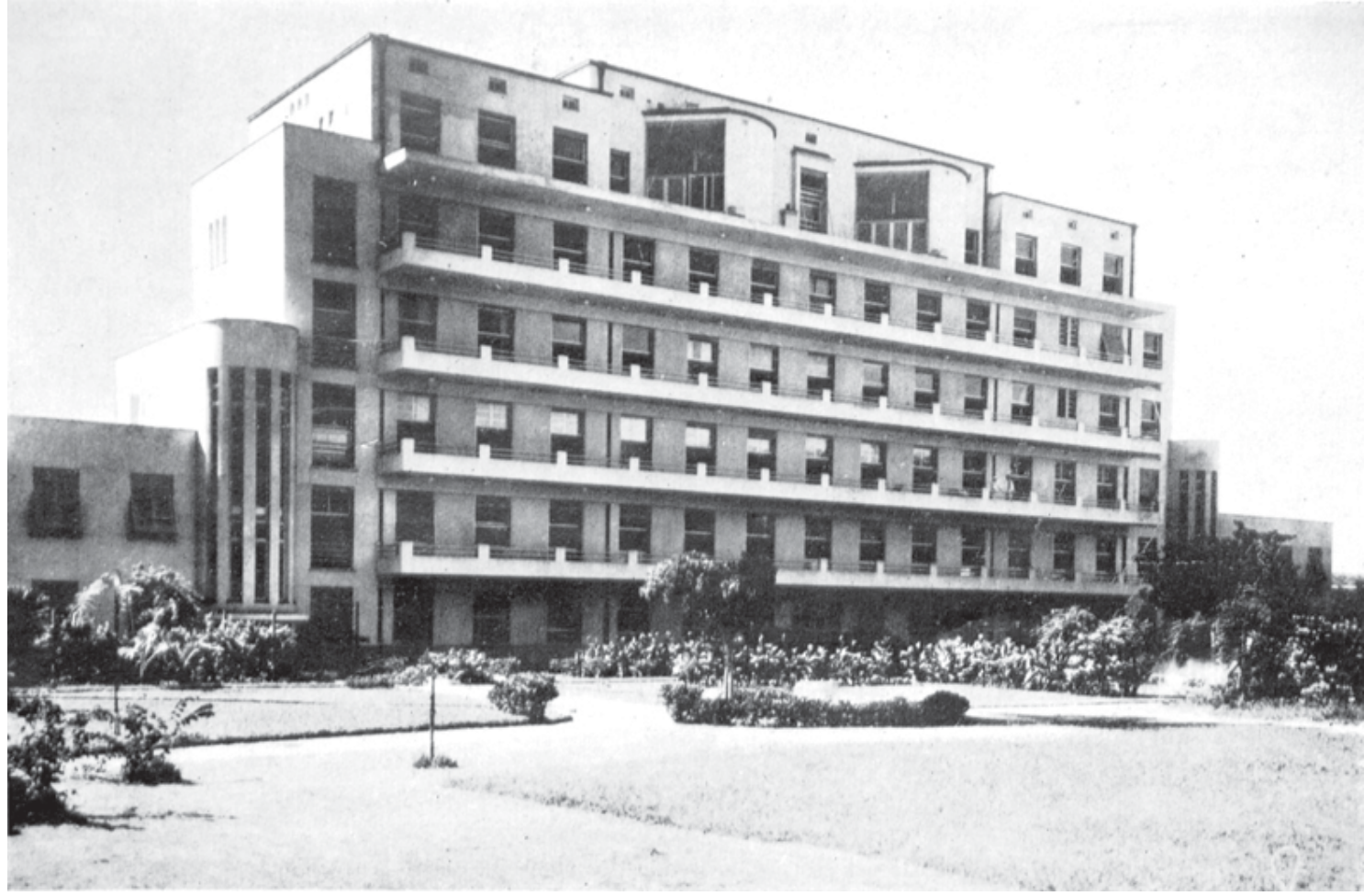

Germany Hospital detail, 1936. Source: Arquitetura e Urbanismo, 1936

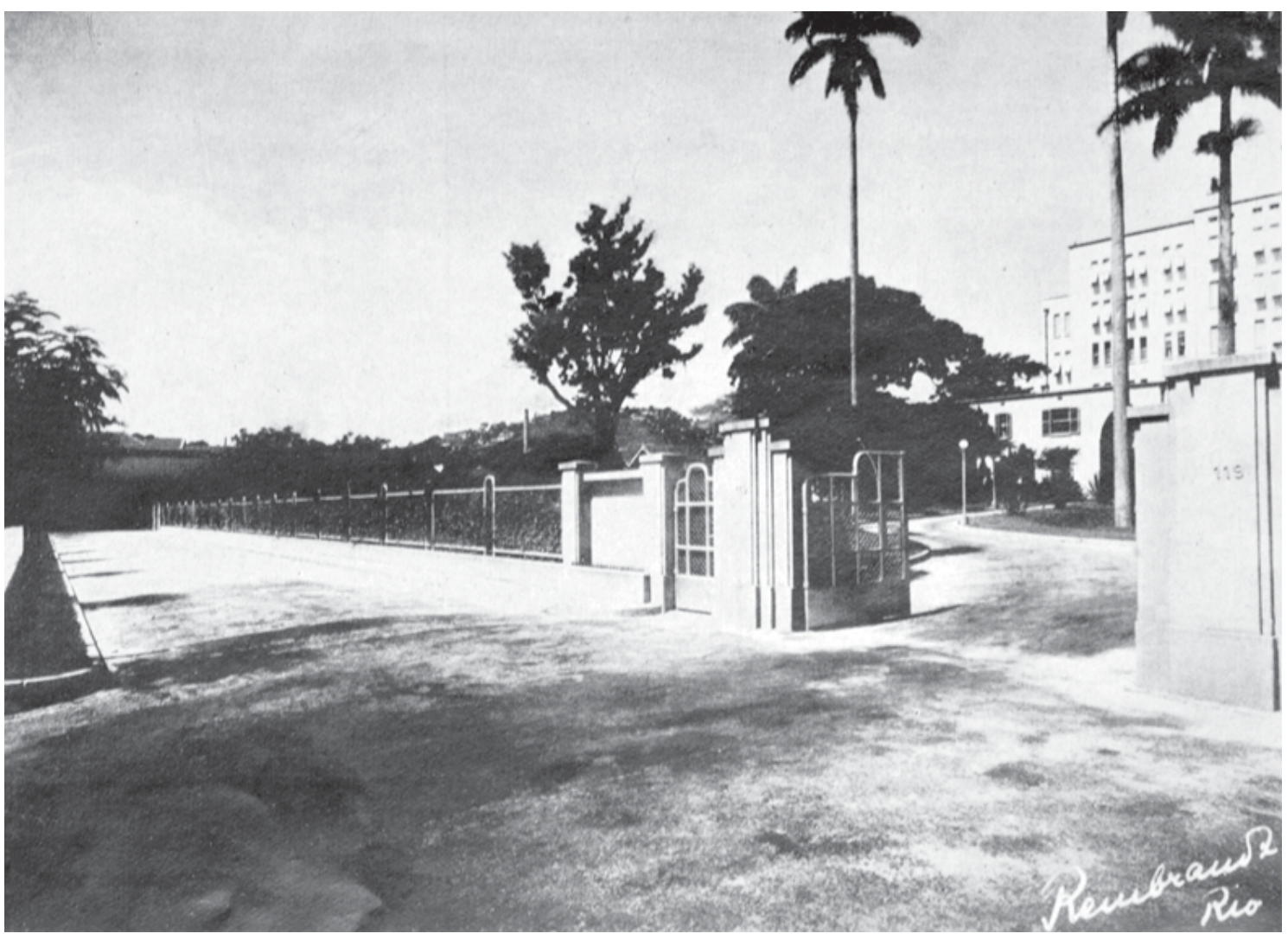

Germany Hospital plan of the construction, 1936. Source: Arquitetura e Urbanismo, 1936 


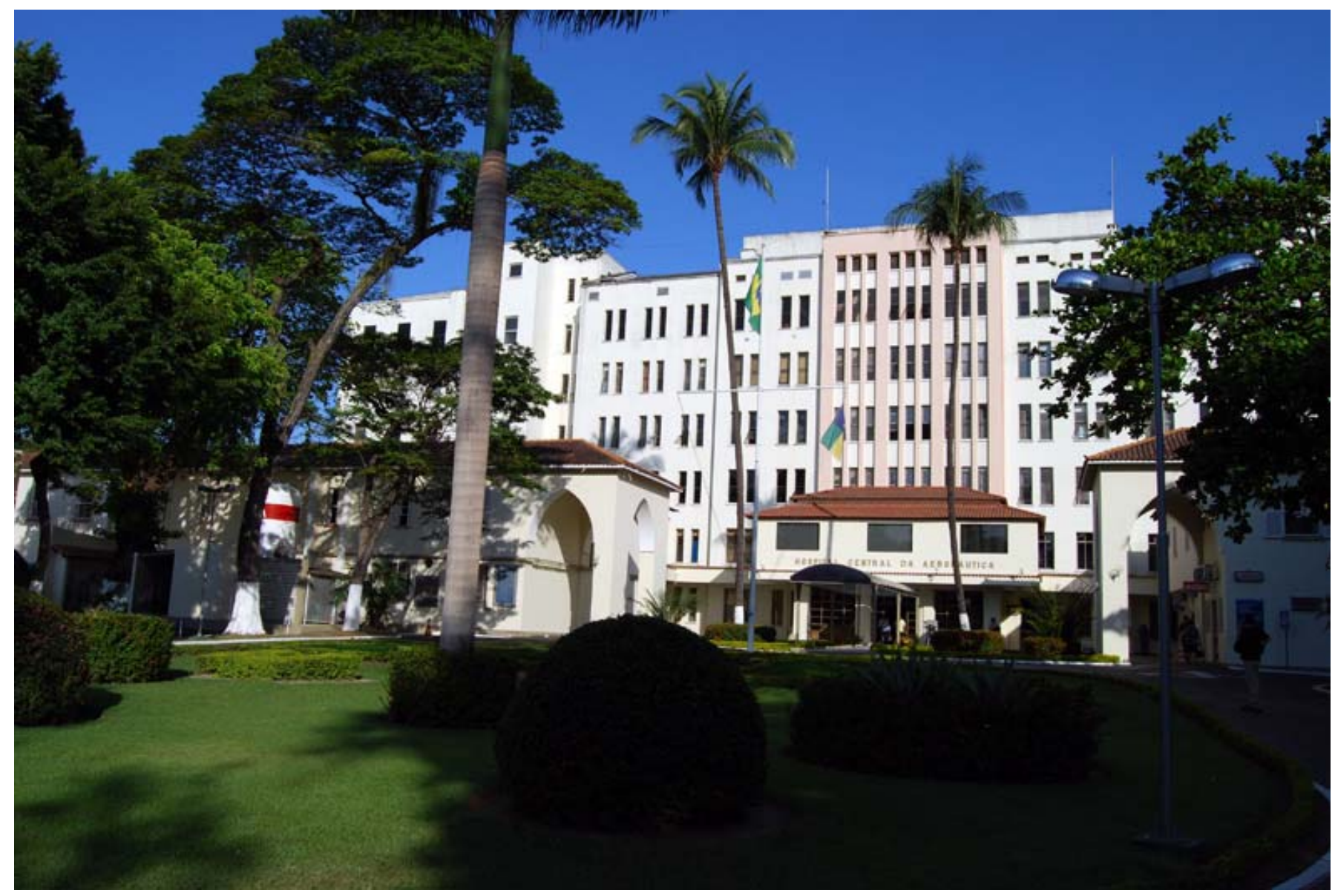

Aeronáutica Central Hospital. Photo Roberto Jesus Oscar \& Vinícius Pequeno de Souza, 2008. Casa de Oswaldo Cruz Archives 


\section{Ipanema Hospital}

Other Denominations: Merchant's Hospital of the Federal District (1955-1967); Ipanema Hospital (1967-present day).

\section{Location: Ipanema}

Address: Rua Antônio Parreiras, 67.

Period of construction: 1951-55.

Name of proprietor: Ministry of Health.

Author / Constructor: Ramos de Azevedo, Severo e Villares of Rio de Janeiro Technical Office.

\section{History:}

Ipanema Hospital has its origins in the Nossa Senhora das Vitórias Hospital (HNSV), located on Rua Voluntários da Pátria, in Botafogo, which belonged to the Merchant's Retirement and Pension Institute (IAPC), an agency which was created in the 1930s to benefit certain professional occupations, and, which after 1945, expanded its area of activity by including health services.

In the 1920s emerged the embryo of the Brazilian social security system - with the creation of the Retirement and Pension Credit Unions (CAPs) - as of the promulgation of the Eloy Chaves Act in 1923. When Getúlio Vargas came into power in 1930, he modified labor relations in force and, in respect to the social security issue, the CAPs standard was broken for the formation of the Retirement and Pensions Institutes (IAPs), tied to the professional occupations and linked to the policies of the newly created Ministry of Labor, Industry and Commerce. The purpose of the IAPs was to guarantee that particular group of professionals had access to benefits and services - mainly medical services. The first occupations to organize their institutes were: the mariners (IAPM), in 1933; bankers (IAPB) and merchants (IAPC), in 1934; industrial workers (IAPI), in 1936; stowage (IAPE) and cargo transport employees (IAPETC), in 1938 (Hochman e Fonseca, 1999 ; 77 78). Many of these IAPs sought to construct hospitals to provide assistance care for their members.

In 1951, the IAPC acquired a hotel in Ipanema, which after undergoing adaptations, was inaugurated in 1955 with the name Merchant's Hospital of the Federal District. The IAPC had initiated surgical treatment while still at the Nossa Senhora das Vitórias Hospital, and concentrated its areas of general surgery, urology, proctology and gynecology in Ipanema, at the new facilities of the former hotel. During the construction work, surgeries were offered at the Accident Victim's Hospital (currently the Trauma-orthopedic Institute - INTO).

In 1967, all of the institutes that served the workers were grouped under the National Social Security Institute (INPS), and Ipanema Hospital shift to the federal sphere, serving all of the users of the INPS.

Under the implementation of the National Health Program (SUS) in 1990, eleven of the seventeen hospitals belonging to the Ministry of Health in the city of Rio de Janeiro, were municipalized, among them Ipanema Hospital; and another - the Cardiology Hospital of Laranjeiras - were, for a brief period of time, made state hospitals. Of the five remaining, three were promoted to the category of Institutes, under the condition to propose health policies according to its areas of expertise: National Trauma-orthopedic Institute, National Cancer Institute and Cardiology Institute of Laranjeiras; whereas the State Employees' Hospital and General Hospital of Bonsucesso - considered references in the municipal and state health systems - remained under the auspices of the Ministry of Health.

In the 1980s, a nine story annex building was constructed, where the polyclinic service, studies center and library were placed. In 1997, Ipanema Hospital was the only non-university institution to perform bariatric surgery in Rio de Janeiro. Currently, the hospital is a reference in its areas of activity, predominantly geriatric endoscopy. 


\section{AFTER 1930}

\section{Architectonic description:}

No one knows whether the hotel operated as such and who was the author of its architectonic project. The scarce information that is available indicate that the adaptation for the use of the hospital carried the signature of the Ramos de Azevedo, Severo e Villares of Rio de Janeiro Technical Office. This office was formed following the death of Francisco de Paula Ramos de Azevedo (1851-1928), with the union of its last members, Ricardo Severo and Arnaldo Dumont Villares.

Ramos de Azevedo was most active in the State of São Paulo and in the area of health, he is the author of the projects for the Psychiatric Hospital of Juquery (1985) and the Military Hospital, among others. The buildings designed by Ramos de Azevedo present coherence and unity in the entirety of the work, with spaces organized in accordance to its practical utilization, taking into account functionality and articulation. The projects of Ramos de Azevedo, among them hospitals, asylums, quarters, public buildings and schools, sought to explore the materials, programs and models of the industrial world of the XX century to the max, conforming to the modern necessities of the era, with technical-scientific rigor and rationality in service of utility and functionality. These same principles were applied by his successors at Ipanema Hospital, this time conforming to the challenges imposed by XX century modernity, both the modern architecture perspective as well as the organization of the roles and uses.

The main façade is an example of the single block hospital type: foundation and penthouse stand out from the intermediary floors destined for the patients' rooms. On such floors, the alternation of the opening of the void spaces creates a rhythm which opposes the formal rigor more common for this type of construction. Another element which stands out from the façade is the arched overhang which marks the entrance of the building. Also typical of the era is the use of mosaic and stone materials of masonry.

\section{Register of Preservation:}

It is not listed.

\section{Sources:}

Entrevista Dr. Armando de Oliveira. DVD 51 anos de tradição. Acervo Hospital de Ipanema.

HOCHMAN, G. et FONSECA, C. O que há de novo? Políticas de saúde pública e previdência, 1937-45. In: PANDOFI, D. (org.). Repensando o Estado Novo. Rio de Janeiro: Editora FGV; 1999, p. 73-93.

http://www.poli.usp.br/Organizacao/Historia/ramosazevedo/obras/hJuquery.html. Acessado em 10 de dezembro de 2007. http://www.sampa.art.br/biografias/ramosdeazevedo. Acessado em 07 de outubro de 2007.

Credits: Renato da Gama-Rosa Costa (research, text and architectonic description). 


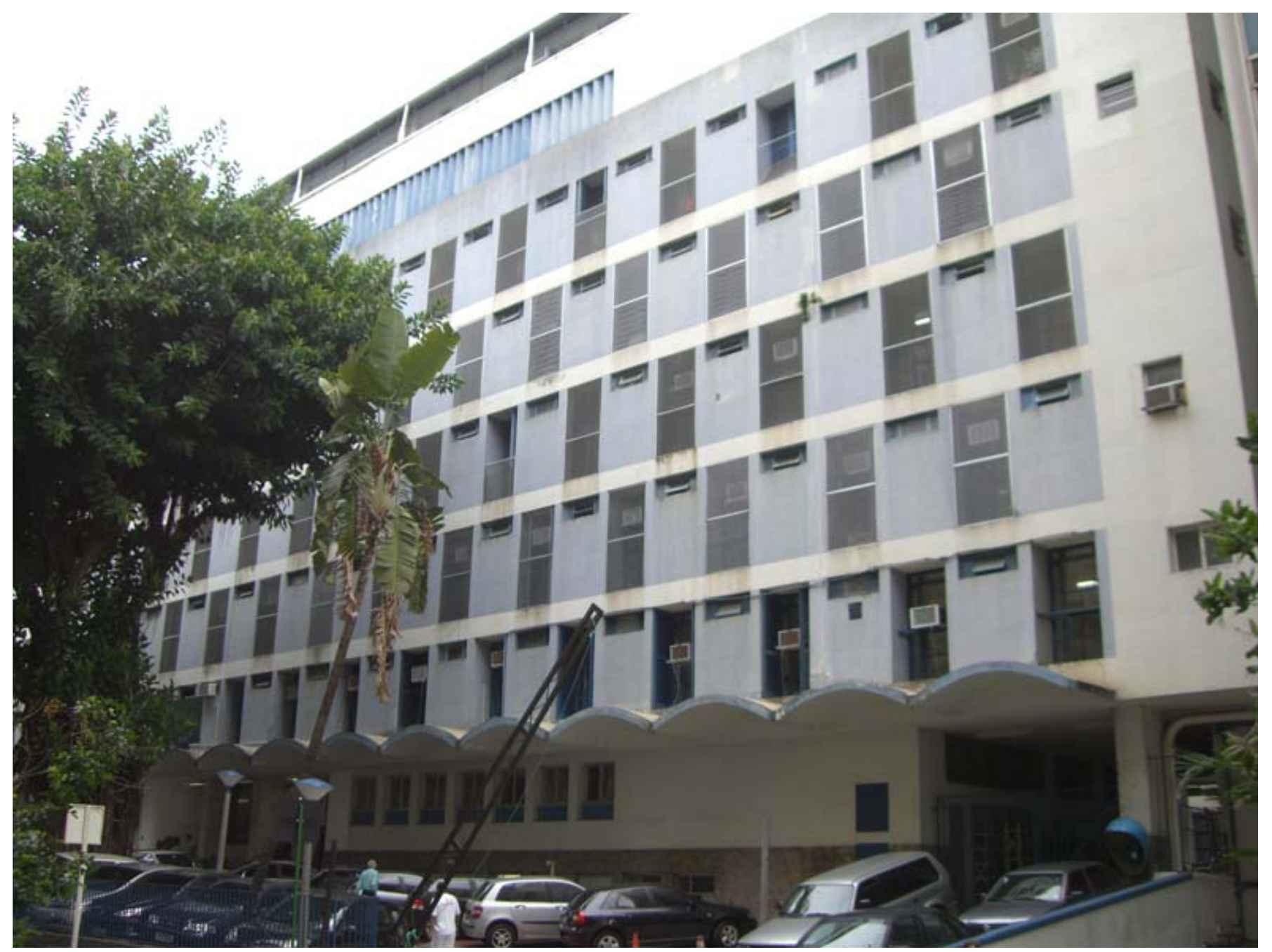

Ipanema Hospital. Photo Renato Gama-Rosa Costa, 2007 


\section{Jesus Municipal Hospital}

Other denominations: Jesus Hospital (1035-1954); Jesus General Hospital (1054-1962); Jesus State Hospital (19621975); Jesus Municipal Hospital (1975- present day).

Location: Vila Isabel.

Address: Rua 08 de Dezembro, 717.

Category: Pediatric Hospital.

Period of construction: 1934-1935.

Proprietor: City Hall of the City of Rio de Janeiro

Author/constructor: Companhia Industrial Construtora of Rio de Janeiro

\section{History:}

The construction of the Jesus Hospital is linked to the demolition of the São Zacarias Hospital, belonging to the Santa Casa de Misericórdia, located on Castelo Hill. As a way to compensate for the demolition, the Civil Society of Jesus Hospital was created on December $25^{\text {th }}, 1924$, by José Cardoso Lopes, which bought the land from the Companhia A Propriedade S.A.. As the society did not have resources for the construction of the hospital as planned, the land was given to City Hall under the condition that Jesus Hospital be constructed on the site, with at least 150 beds, with the objective of serving Mangueira and the suburbs all the way to Central, Vila Isabel, Andaraí and surrounding areas.

Pedro Ernesto Batista, Mayor of the Federal District, considered the construction of Jesus Hospital an extreme necessity, paving the way for Decree no. 4721 of April 12 $2^{\text {th }}, 1943$, under the Presidency of Getúlio Vargas. The construction of Jesus Hospital became a part of the plan to open regional polyclinic hospitals and dispensaries developed by Mayor Pedro Ernesto Batista, during his first administration of the then Federal Capital, between 1931 and 1934. Out of this same plan, administered by the General Council of Municipal Assistance, included the General Hospital of the Plan (currently Pedro Ernesto Hospital), and the Méier Health Center (currently Salgado Filho Hospital), and the hospitals, Getúlio Vargas, Miguel Couto and Rocha Faria and the dispensaries of Ilha do Governador (currently Paulino Werneck Municipal Hospital), of Ilha de Paquetá (currently Paquetá Hospital), Rocha Miranda (currently Carmela Dutra Hospital) and Campo Grande. Work on these new units of medical-hospital assistance was accompanied by a commission formed especially for this purpose, in which the doctors, Rodolpho de Abreu Filho, Alcides Pinheiro Marques Carneiro, Alberto Borgeth and Amadeu de Barrol Saraiva participated. The Companhia Industrial Construtora of Rio de Janeiro, whose owners were architect Luiz Moraes Jr and Archimedes d'Arthagnam Saldanha, were responsible for the realization of the construction work.

It was inaugurated on July $30^{\text {th }}, 1935$, with capacity for 190 beds, and began to operate effectively on August $13^{\text {th }}$ of the same year. The Hospital was destined mainly for children up to 13 years of age, and was equipped with eight infirmaries, distributed in pediatric surgical clinics ( 84 beds) and pediatric medical clinics ( 76 beds).

Out-patient services were distributed in physiotherapy, otorhinolaryngology, pediatric surgery and pediatrics. The dependencies of the hospital included surgery rooms, odontology, a pediatric consultation room, pharmacy, office and administration, otorhinolaryngology sessions, X-ray room, sterilization room, infirmaries, doctors' room and nurses' room. It even had consultations and services in infant hygiene, a lactation station with a laboratory for milk analysis, clinic and surgery services, infirmaries and terrace for sunbathing. Since then, the lactation station was installed in another building, its service directed towards educating mothers about nutrition.

The Federal Chamber promulgated Law no. 802 of November 19 ${ }^{\text {th }}, 1954$, transferring Jesus Hospital from the Department of Hospital Assistance to the Municipal Department for Children and Adolescents. Under the directorship of the Secretary of Health, Mourão Filho and under the administration of Mayor Francisco de Sá Lessa (1955/1956), hospital expansion projects were carried out, with the construction of a new Surgical Center and an Annex in an area equivalent to that of 
the Hospital. Other works were done on the hospital Annex during the administration of Carlos Lacerda (1960-1965), however these were only concluded in 1970.

In 1960, with the transfer of the federal capital to Brasília, the State of Guanabara was created encompassing the entire municipality of Rio de Janeiro. During this period, the hospitals belonging to City Hall of the Federal District came to be under state jurisdiction. Fifteen years later, in 1975, with the merging of the states of Guanabara and Rio de Janeiro, some of these hospitals returned to the condition of municipal hospitals - among these being Jesus Municipal Hospital, while others remained state hospitals.

During the administration of Negrão Lima (1965-1970), the Secretary of Health Hildebrando Monteiro Marinho undertook to renovate the Hospital, such as the construction of the Jonas Salt Acute Poliomyelitis Treatment Center and the Albert Sabin Respiratory Center which were inaugurated on August $1^{\text {st }}, 1966$. During this period, an emphasis was placed on new respiratory equipment, defibrillators and electrocardiograms and the availability of other materials.

The newly inaugurated installations allowed for the utilization of three new steel lungs, the installation of a new X-ray and the tending of patients in two shifts. On the same occasion, the new X-ray service installations and the Jesus Hospital History Museum were inaugurated. With the new installations, Jesus State Hospital came to have 260 beds, distributed among pediatrics, orthopedics, infant surgery, isolation of poliomyelitis and emergency.

On July $30^{\text {th }}, 1970$, the Anatomical Pathology sector was concluded and inaugurated, in the old building destined to documentation. On the same date, the total renovation work of the Annex was inaugurated, where the Polyclinic, the Center of Studies with a Library and Auditorium, the Medical-Surgical Experimentation Service, Museum of Anatomical Parts, Laboratory and Pharmacy are located.

Currently, it is a reference for the specialized treatment of the majority of pediatric pathologies: clinical, surgical, neurosurgical, orthopedic, plastic surgery, in addition to a reference for the treatment of children with AIDS.

\section{Architectonic Description:}

The publication Medicina no Brasil, of 1940, praised its architecture of modern and elegant lines. Jesus Hospital is one more example of the hospital construction inaugurated in the 1930s to utilize the proto-modern language, characterized by the adoption of the influences of North American art déco.

\section{Sources:}

A Inauguração do Hospital Jesus. Jornal do Commercio, Rio de Janeiro, 05 de julho de 1935.

As crianças enfermas da cidade já têm seu hospital. Correio da Manhã, Rio de Janeiro, 31 de julho de 1935.

ASSISTÊNCIA Pública - Guanabara: 80 anos de história. Rio de Janeiro: Superintendência de Serviços Médicos (SUSEME); 1972. mimeo.

Centro Sabin salva criança minutos após ser inaugurado. Correio da Manhã, Rio de Janeiro, 02 de agosto de 1966.

Hildebrando inaugurou o Serviço de Documentação Médica no Hospital Jesus. Jornal do Brasil, Rio de Janeiro, 02 de setembro de 1967.

Hospitais Infantis. Correio da Manhã, Rio de Janeiro, 9 de maio de 1934.

Hospital Jesus. Jornal do Commercio, Rio de Janeiro, 31 de julho de 1935.

Médicos do Jesus ganham nova ala. Jornal do Brasil, Rio de Janeiro, 16 de janeiro de 1968.

RIBEIRO, L. Medicina no Brasil. Imprensa Nacional. Rio de Janeiro, 1940.

Credits: Nathalia Morais (research) and Renato da Gama-Rosa Costa (text). 


\section{AFTER 1930}

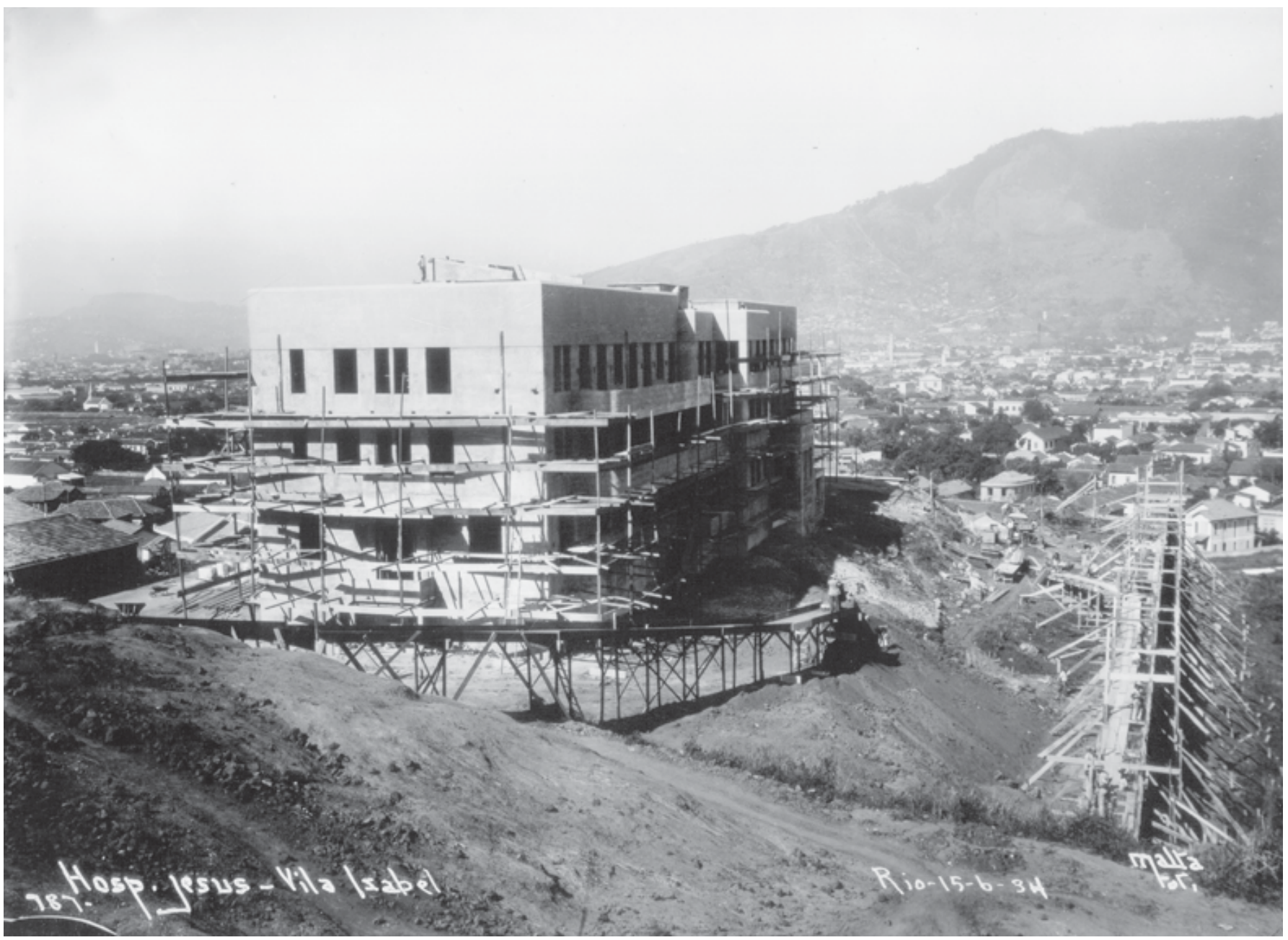

Jesus Hospital, Vila Isabel. Photo Augusto Malta, 15/06/1934. City of Rio de Janeiro General Archives 


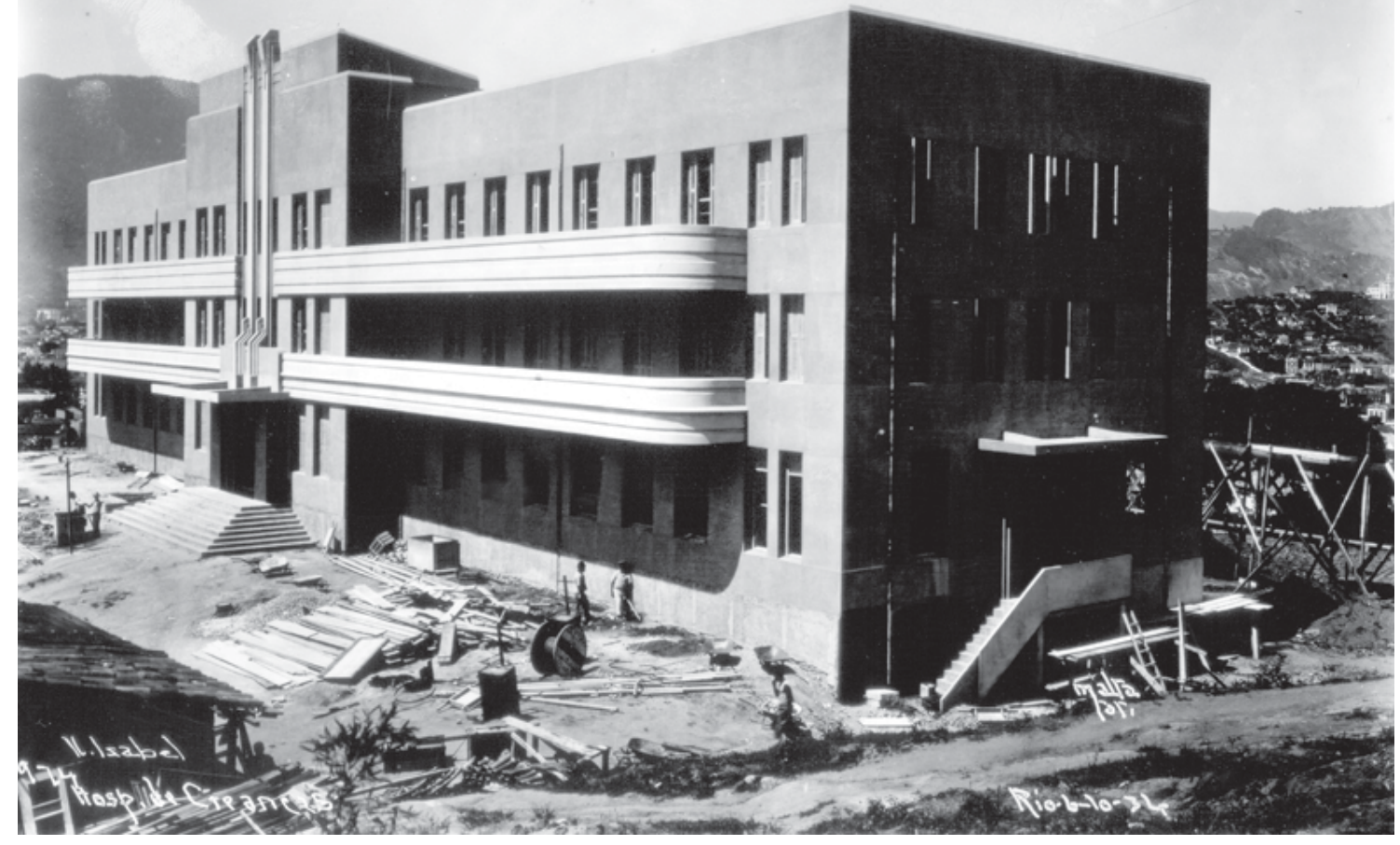

Children Hospital, 6/ 10/1934. Augusto Malta photo. City of Rio de Janeiro General Archives
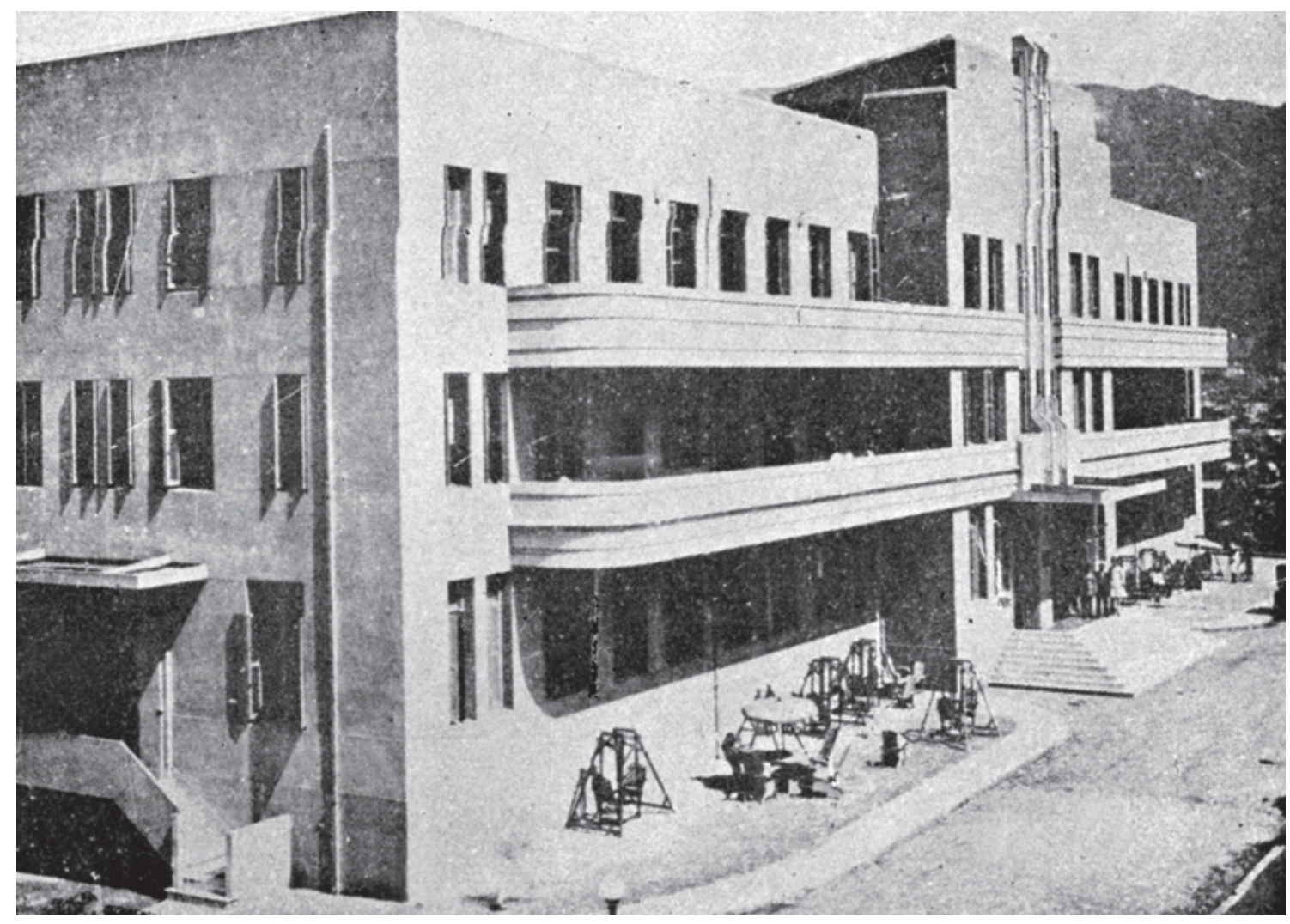


\section{Lagoa General Hospital}

Other denominations: Larragoitti Hospital (1951); Sul América Hospital (1958-1962); Hospital dos Bancários (19621967); Lagoa Hospital (1967-present day).

Location: Jardim Botânico

Address: Rua Jardim Botânico, 501.

Category: General Hospital

Period of construction: 1951-1959.

Proprietor: Federal Government.

Author / constructor: Oscar Niemeyer and Hélio Uchoa (architect); João Batista Bidart (structure); Morales Ribeiro Technical Office (facilities); Roberto Burle Marx (landscaping and urbanization); Cia. Construtora Pederneiras (construction).

\section{History:}

Lagoa Hospital was constructed for the employees of the Lar Brasileiro Bank and for the South America National Life Insurance Company, founded in 1895 by Joaquim Sanchez Larragoitti, responsible for the first denomination of the hospital. The architectonic project of the Larragoitti Hospital was entrusted to Oscar Niemeyer and Hélio Uchoa. The project received orientations from Doctor Leonídio Ribeiro as well as hospital consultancy of Félix Lamela, who was also a doctor, acting on behalf of UNESCO at the time, of the Morales Ribeiro Technical Office and SORTEC (Organization Technology Service).

Work initiated in 1951 with the removal of about one thousand residents of the Hípica slum, and dragged on until 1958-1959, when the Larragoitti Foundation gave up on the "social medical assistance" project and began to search for a new owner for the hospital. The entity offered the hospital to other institutions such as IPASE (Social Security and State Government Employees Assistance Institute) and the Armed Forces, among various entities interested in its purchase. The hospital was then acquired by the Bankers Retirement and Pension Institute (IAPB) in 1962, supported by the bankers' class and authorized by the President João Goulart. The IAPB had joined the fight against tuberculosis, and already possessed, four sanatoriums spread throughout the country, acquired between 1945 and 1948: Messejana Sanatorium, in Fortaleza, Ceará; Santo Antonio Sanatorium, in São Paulo, capital; Alberto Cavalcanti Sanatorium, in Belo Horizonte, Minas Gerais and the Cardoso Fontes Sanatorium, located in the city of Rio de Janeiro.

After five years of being closed, the building was re-inaugurated as the Hospital dos Bancários on December $15^{\text {th }}, 1962$. In 1967, with the creation of the National Institute of Social Security (INPS) - which absorbed the functions of the various IAP's in existence, the hospital becomes known as Lagoa Hospital, and passed over to the federal government. In 1970, Doctor's Residency was started at the hospital. On May 24 $4^{\text {th }}, 1973$ the External Patients Unit was inaugurated - including the Emergency Ward, the Pre- and Post-Operatory Clinic, as well as the Pavilion of the Pathological Anatomy Service.

With the implementation of the National Health Program (SUS) in 1990, eleven of the sixteen hospitals belonging to the Ministry of Health in the city of Rio de Janeiro, were municipalized, among them being Lagoa Hospital. Of the five remaining ones, three were promoted to the category of Institutes, under the attribution of proposing health policies for their areas of activity (National Trauma-orthopedic Institute, National Cancer Institute and Cardiology Institute of Laranjeiras); whereas the two remaining ones - the State Employees Hospital and General Hospital of Bonsucesso considered references in the municipal and state health systems, remained under the Ministry of Health.

With the declaration of a state of public calamity in the hospital system of the National Health Program in the municipality of Rio de Janeiro in 2005, Lagoa Hospital was reintegrated into the Ministry of Health. The hospital is currently undergoing complete restructuring. 


\section{Architectonic description:}

The 10-story building stands out in the midst of the scenic view of Rodrigo de Freitas Lagoon and occupies a huge lot confined by the streets, Jardim Botânico and J.J. Seabra, Oliveira Rocha and Epitácio Pessoa Avenue. This construction is perhaps, in the city of Rio de Janeiro, a great example of the single-block hospital typology of the modern period. It further assumes great relevance for having been projected by Oscar Niemeyer, in partnership with the other two representatives of the carioca modern architecture, in its golden age.

Its architectonic details, the "V-shaped" pillar and the arch structure of the auditorium block, reveal great technical and aesthetic diligence. Specially important, the pillar, Niemeyer's creation, as of the launching of the formal collection by International Modernism, was first utilized in this hospital, deserving the attention of the French historian Yves Bruand. Niemeyer would repeat such aesthetic and structural solution of the pillar used in the Lagoa Hospital, which allows for greater spacing between the columns, in some of his other projects, such as the Palace of Agriculture, in São Paulo (1951), a residential building for the district of Hansa, Berlin, Germany (1955) and the headquarters building of the Getúlio Vargas Foundation, in Rio de Janeiro (1955).

The solution of the vertical block, adopted by the architects, distributes the patients' rooms toward the lagoon which receives good ventilation and sunlight in the morning. The operating theaters, as well as the internal doctors' and nurses' residencies were also directed toward the sunlight. The service rooms were directed toward Rua Jardim Botânico, whose façade, to provide protection against the afternoon sun, received a brise-soleil (sun shade) and hollow ceramic bricks. The vertical circulation takes place in a block separate from the building.

\section{Register of Preservation:}

Listed by the State Institute of the Artistic and Cultural Endowments of Rio de Janeiro (INEPAC), since 1990. Case number E-18/001.172/90.

\section{Sources:}

BRUAND, Y. Arquitetura Contemporânea no Brasil. Editora Perspectiva, 1981, São Paulo.

CZAJKOWSKI, J. (Org.) Arquitetura Moderna. Rio de Janeiro: Centro de Arquitetura e Urbanismo, Casa da Palavra, Prefeitura da Cidade do Rio de Janeiro, 2000.

Inventário de Bens Imóveis. Instituto Estadual de Patrimônio Artístico e Cultural do Rio de Janeiro.

LERNER, D. e BITTENCOURT, M. (coords.) Patrimônio Cultural: guia dos bens tombados pelo Estado do Rio de Janeiro, 19652005. Rio de Janeiro: Governo do Estado do Rio de Janeiro, Instituto Estadual de Patrimônio Artístico e Cultural - INEPAC, 2005.

MEMÓRIA da Assistência Médica da Previdência Social no Brasil. Casa de Oswaldo Cruz/Fiocruz, 1983.

MÓDULO, v. 3, n. 14, 1959.

SOUZA, L. Evolução histórica do hospital da Lagoa. Revista do IHGB, Rio e Janeiro, 150 (362): 163-169, jan/mar 1989.

Credits: Daniel Elian (research) and Renato da Gama-Rosa Costa (text and architectonic description). 


\section{AFTER 1930}

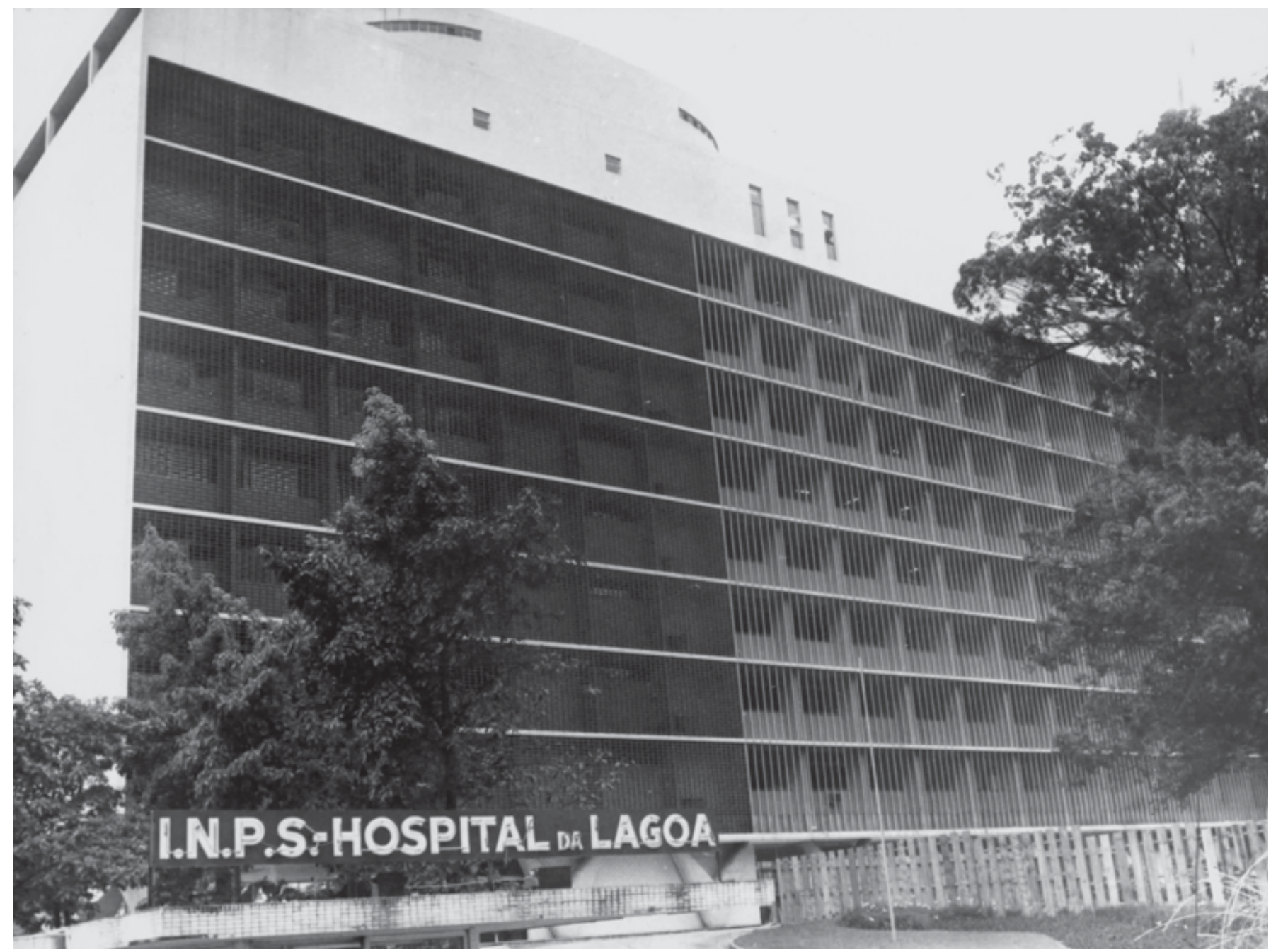

Sul América Hospital, [s.d.]. Correio da Manhã Fund. National Archives 


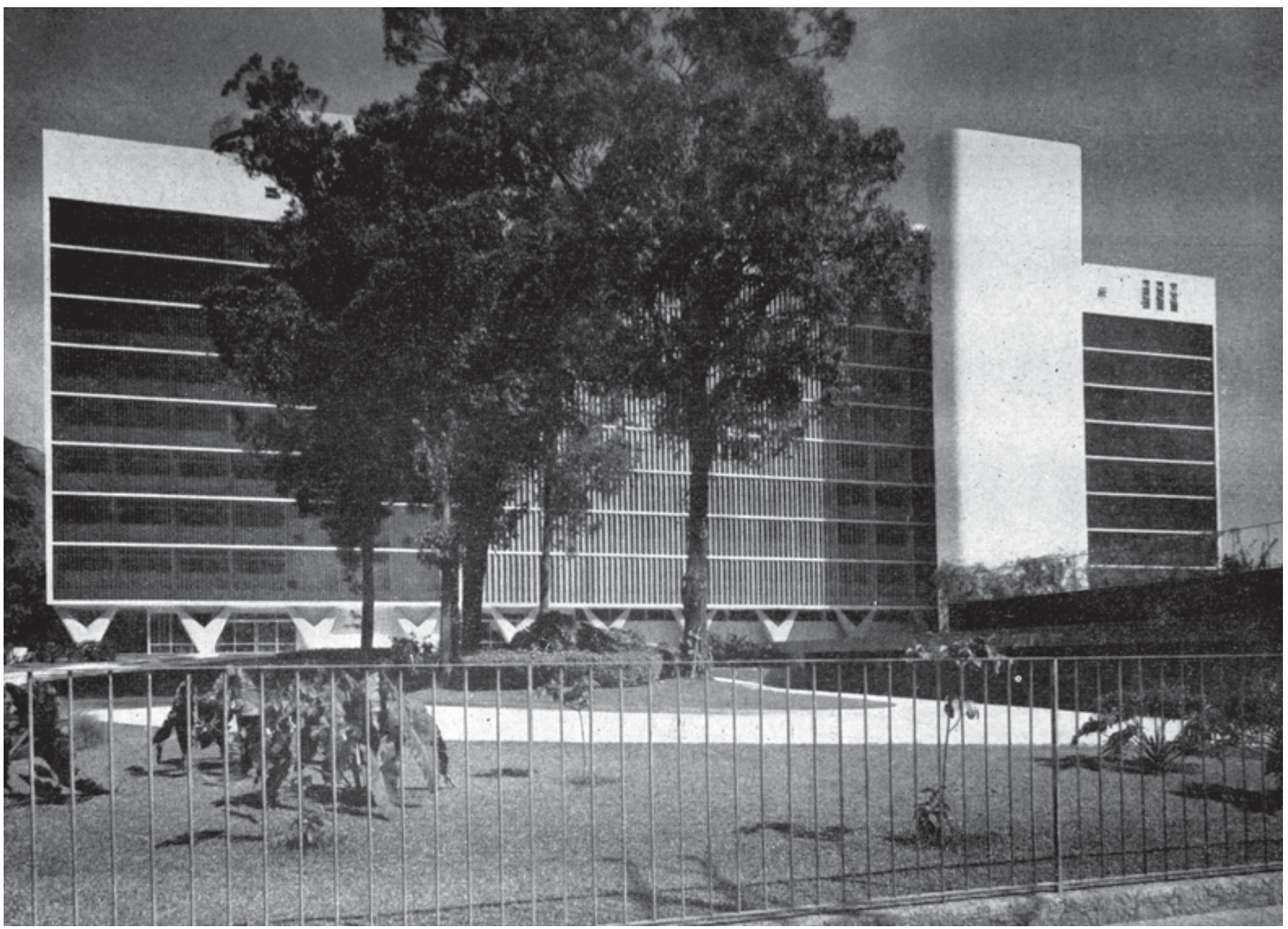

Sul América Hospital - façade. Source: Módulo, v. 3, n. 14, 1959 


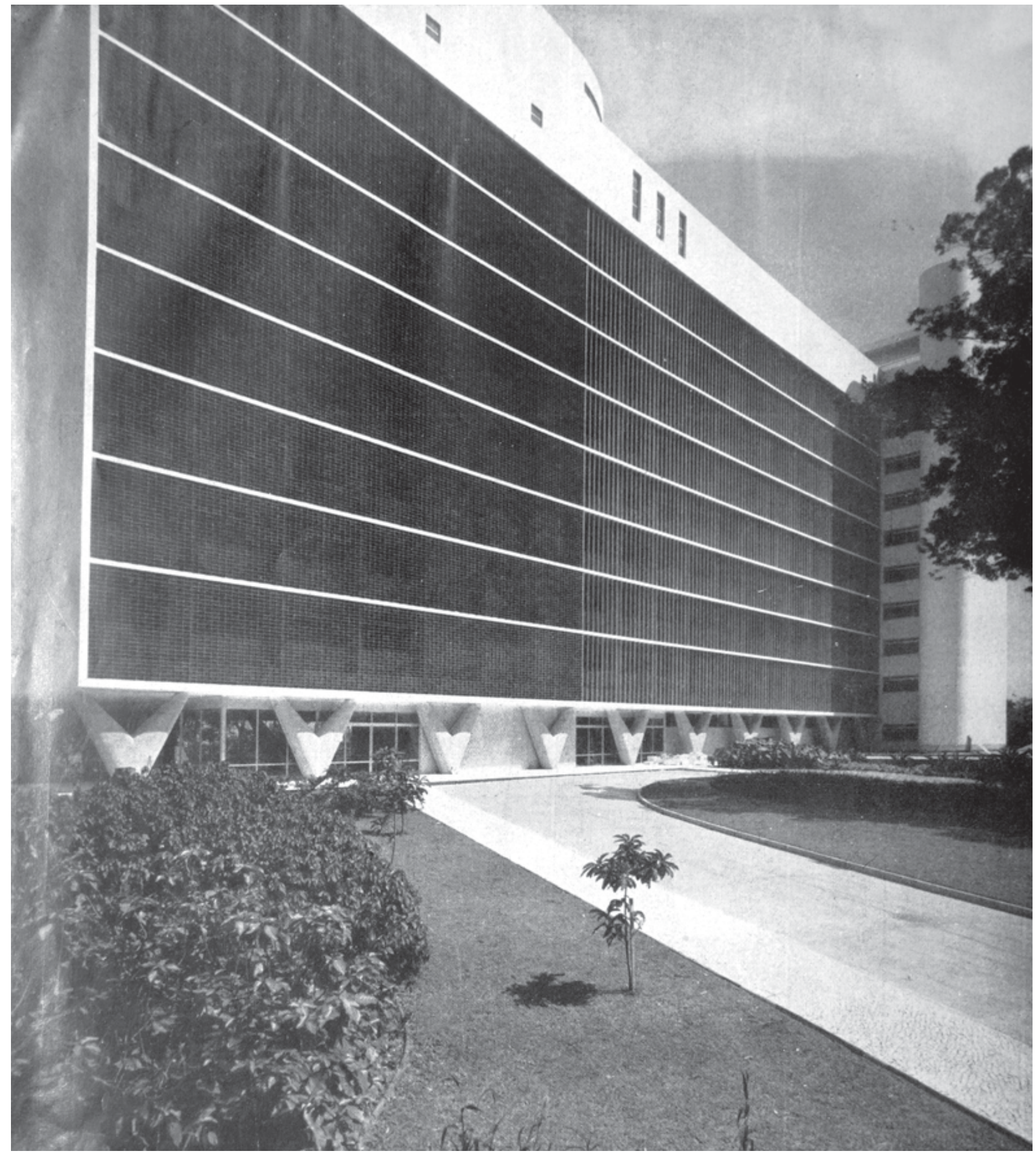

Sul América Hospital - general view. Source: Módulo, v. 3, n. 14, 1959 


\section{Lourenço Jorge Municipal Hospital}

Other Denominations: Lourenço Jorge Medical Center (1955-1958), Lourenço Jorge Hospital-Dispensary (1958-1963), Lourenço Jorge State Hospital (1963-1977), Lourenço Jorge Municipal Hospital (1977-present day)

Location: Barra da Tijuca

Address: Av. Ayrton Senna, 2000

Category: General and Emergency Hospital

Period of Construction: 1996

Proprietor: City Hall of Rio de Janeiro

Author / Constructor: unknown

\section{History:}

The history of the Lourenço Jorge Municipal Hospital goes back to the year 1955 when, by means of Decree no. 12.887, Lourenço Jorge Medical Center was created, subordinate to the Miguel Couto Hospital, in the administration of mayor, Alim Pedro (1954-1955).

The Lourenço Jorge Medical Center functioned initially as a pediatric and clinical out-patient service. At weekends it dealt with cases of near-drowning, when the movement at the beaches of Barra da Tijuca was greater. The name of the Medical Center was given in honor of pneumologist, Lourenço Jorge, assistant of the National Faculty of Medicine, who had developed activities of assistance for the fishing villages existing in the region.

The Decree no. 13.869, of April 24 ${ }^{\text {th }}, 1958$, signed by the then mayor of the Federal District, Francisco Negrão de Lima and the Secretary of Health and Assistance, Dr. Guilherme Romano, transformed the Lourenço Jorge Medical Center into a Hospital-Dispensary, coming to be directly subordinate to the Department of Hospital Assistance, being autonomous from the Miguel Couto Hospital.

In 1960, with the transfer of the federal capital to Brasília, the state of Guanabara was created which covered the whole of the municipality of Rio de Janeiro. At this time, the hospitals belonging to the jurisdiction of the Federal District were handed over to state jurisdiction. Fifteen years later, in 1975, with the fusion of the states of Guanabara and Rio de Janeiro, some of these hospitals returned to being municipal hospitals, among these being the Paulino Werneck Municipal Hospital, while others remained state hospitals.

In October of that year, the First-Aid Service was created - functioning 24 hours per day -, together with the Radiocommunication service. Three years later, on September $18^{\text {th }}, 1963$, it was transformed into a State Hospital, of the old state of Guanabara. Its area of operation was defined as the regions of Estrada das Canoas, Pontal de Sernambetiba, Barra da Tijuca, Alto da Boa Vista, Estrada da Paz, Largo do Anil, Freguesia de Jacarepaguá and Rocinha - which despite being located in the area of coverage of the Miguel Couto Hospital, its inhabitants ended up being attended there because of the facility of transport and service. At this time it operated at Av. Sernambetiba, no. 610.

Its first-aid service was able to attend to adults and children in two shifts, with a continuity of treatment and complementary examinations by means of an agreement with the Miguel Couto Hospital. It maintained, however, emergency services, having an ambulance, medical clinic, pediatrics, a psychiatry and psychology clinic, dental hygiene, hypertension and diabetes programs, with a capacity for serving 800 persons per month in the clinic.

Due to demographic expansion, the increase in the number of traffic accidents in the region and the deficiency in the area of emergency services, it became necessary to construct a new hospital in the region, with greater capacity. A strategic location was chosen between Avenida das Américas and Avenida Ayrton Senna, for the construction of the new hospital, with the capacity to serve the inhabitants of Barra da Tijuca, Jacarepaguá, Recreio dos Bandeirantes and Cidade de Deus. The new building was inaugurated on February 1 1996. 


\section{Register of Preservation:}

Not registered.

\section{Sources:}

Acervo do Hospital.

ASSISTÊNCIA Pública - Guanabara: 80 anos de história. Rio de Janeiro: Superintendência de Serviços Médicos (SUSEME); 1972. mimeo.

http://portalteses.cict.fiocruz.br/transf.php?script=thes_chap\&id=00001104\&lng=pt\&nrm=iso\#nota9, Acessado em 22 de agosto de 2007.

http://www.saude.rio.rj.gov.br/servidor/cgi/private/cgilua.exe/sys/reader/htm/preindexview.htm? editionsectionid= 163\&user=reader, Acessado em 10 de maio de 2007.

Credits: Nathalia Morais (research) and Gisele Sanglard (text) 


\section{Luiza de Marilac College of Nursing}

Other Denominations: Luiza de Marillac College of Nurses (1939-1984); Luiza de Marillac / São Camilo College of Nursing (1984-presente day)

Location: Tijuca

Address: Rua Dr. Satamini, 245

Category: Institution of learning

Period of construction: 60s - XX Century

Proprietor: Ordem Camiliana do Brasil (Camillian Order of Brazil)

Author / Constructor: unknown

\section{History:}

Until the end of the XIX century, the nursing assistance care was executed by the sisters of charity in all of the hospital establishments. These religious women had no theoretical education; their work was carried out based on charity and the practice acquired in taking care of sick people. In 1890, from the creation of the first nursing school of Brazil, the Professional School of Nurses, the nursing of religious aspect practiced by the nurses began to be questioned over its scientific character. Since the beginning of the XX century, several measures were taken in favor of an academic education of the nurses, turning the profession official and institutionalized.

After the arrival of the Republic (1889), the Church lost space and legitimacy in the main fields where it used to be active: education and health. In the latter, practically all assistance care and hospital administration were responsibility of religious people. The São Vicente de Paulo Association was the first congregation to try to graduate their religious members in a standard nursing school, formalizing the knowledge they had, and would guarantee the space, reputation and influence conquered in the field of medical assistance.

The decree no. 20,109 of 06/05/1931, which determined the requirements of institutional equalization and set forth the provisions to legalize the nursing profession, prevented these religious people from carrying out the profession. However, President Getúlio Vargas, in an attempt to maintain an open dialog with the Church, sanctioned on December $26^{\text {th }}, 1932$, the decree no. 22,257 , allowing the sisters of charity, with confirmed practice of at least six years of assistance care, to legally practice the profession under the same rights of the nurses from public health.

In 1931, the São Vicente de Paulo Association enrolled three sisters in the D. Anna Nery School of Nurses; however, they did not graduate. In fact there were difficulties of practical order for the sisters to study in a layman's school, because many activities carried out by them could not be shared with others. It was necessary, then, a center of academic education intended for the education of catholic professionals, with proper location for religious routine. Between 1936 and 1938, there were selected sisters of the same Association whose characteristics better fulfilled the requirements of the selective process of Carlos Chagas Nursing School, in Belo Horizonte. This institution was chosen because it was administered by Laís Moura Netto dos Reys, devout catholic, very respected in the medical environment, granting credibility before the Church by the certainty that the sisters could go on with their religious activities.

On October $25^{\text {th }}, 1938$, the São Vicente de Paulo Association Council appointed Sister Matilde Nina and the provincial Antoinette Clemence Blanchot to gather the Sisters Eugênia Luna and Catarina Cândido Fiusa, newly graduated by the Carlos Chagas Nursing School, with the objective of discussing and presenting proposals for the project of founding its own school. Upon analyzing the legal formalities for such undertaking, they verified the requirements demand of structure and organization similar to the ones at Anna Nery Nursing School of the University of Brazil, considered the official standard. Furthermore, the future school should have a hospital with at least 100 beds, which would work as an area of supervised practical learning. 
By initiative of Sister Matilde Nina (Edmar Arlie Nina) and with the support of provincial Blanchot, work was initiated to found a nursing school that would conjugate the technical-scientific education of nursing with religious activities. Finally on September $5^{\text {th }}, 1939$, the Luiza de Marillac Nursing School was inaugurated, the first catholic entity of Rio de Janeiro dedicated to this area. It received this denomination as a tribute to Santa Luiza de Marillac, founder of the Companhia das Filhas da Caridade, together with Vicente de Paulo, in 1633. At the time of the foundation it received the official name of Luiza de Marillac School of Catholic Nurses; however, in the official act of equalization (1942), the predication "Catholic" would not be authorized.

In order to fulfill all legal requirements, the São Vicente de Paulo Association put available for the new project the building of the Medalha Milagrosa Dispensary and Nursery, located at Rua Dr. Satamini, 237. Created in 1926, the Dispensary worked together with the Luiza de Marillac Nursing School at this address until the decade of the 1960s. As the request for equalization could only be sent to the Ministry of Education and Public Health after having been in operation for two years, not a single nurse graduated by the school could occupy the position of director. Neither could someone graduated by Carlos Chagas Nursing School, who also waited for the verdict on the equalization. Thus, while Sister Matilde Nina did not have her diploma officially registered, the nurse Rosa Maria Leone took over the position of first director of the school.

The first six months of the nursing course were named preliminary period that when concluded authorized the students to receive the brace with the symbol of the School. The students were active not only at the Dispensary but also at infirmaries of the Santa Casa da Misericórdia of Rio de Janeiro, where internship classes were carried out every morning. This internship was carried out at medical and otolaryngology clinics, surgical center and maternity ward, with reduction of three months each. The theoretical part was taught by doctors, in the afternoon, at the amphitheaters of the Santa Casa. The nurses-sisters were responsible for courses of professional ethics; history and nursing techniques. Although it was an acknowledged religious institution, it also accepted the entry of laypeople.

Even after the creation of its own school, the São Vicente de Paulo Association continued making efforts to graduate sisters in standard units, in light that the Luiza de Marillac School of Nurses had still not been officially recognized. For that, in 1939, an official letter was submitted to the Anna Nery School of Nurses so that a specific session for religious women was created on its confines, separating them from the other students, such request was readily attended. On September $22^{\text {nd }}, 1942,10$ nurses from the Association graduated from this institution.

In July, 1940, the School requested equalization in spite not having complied with the two years of operation. However, the request was analyzed and the Luiza de Marillac School of Nurses was equalized to the Anna Nery School of Nurses in view of decree no. 9,100 of March $24^{\text {th }}, 1942$, after two inspections were carried out for this purpose. At the end of the decade, the School began to offer courses in Nursing Assistance in 18 months, following the tendency of other nursing schools that offered courses of short duration.

In 1951, the annexation of the Luiza de Marillac School of Nurses was defined at the Pontifica Universidade Católica (PUC-RJ); such matter only became official on January 04 $4^{\text {th }}, 1953$.

In 1961, the Brazilian Education Basic Tenets Law (LDB no. 4,024) was confirmed, authorizing the organization of technical courses in academic entities, the School included in its program the Nursing Technical Course, with duration of three years. In this same decade it left the building of the Dispensary to work at 245 on the same street. The new building next to the Dispensary, maintained the architectonic characteristics until the 1990s, when it underwent a great internal and external restoration, when an annex building was constructed.

On June 03 ${ }^{\text {rd }}, 1967$, the Luiza de Marillac School of Nurses requested the change of its denomination to Luiza de Marillac College of Nursing, this only happened in 1984. At the time, the College was already under the control of the Sociedade Beneficente São Camilo (São Camilo Beneficence Societies) since 1980, destined by the São Vicente de Paulo Association, which began to only provide service related to assistance care activities. In 1996, the referred to Society focused on hospital works and passed the College to the Camillian Social Union, sector of the Camillian Order of Brazil which focused on educational activities. 


\section{AFTER 1930}

\section{Register of Preservation:}

It is not listed.

\section{Sources:}

BEZERRA, M. A enfermagem e a aliança da Igreja com o Estado: a Escola de Enfermeiras Luiza de Marillac. Rio de Janeiro: UFRJ/ EEAN, 2002. (Dissertação de Mestrado).

Credits: Atiele Azevedo de Lima Lopes (research and text) 


\section{Manoel Arthur Villaboim Integrated Health Center}

Other denominations: Dispensary-Hospital and Municipal Health Center of Paquetá (1933-1950); Manoel Arthur Villaboim Hospital (1950-1966); Manoel Arthur Villaboim Dispensary-Hospital (1966-1980); Manoel Arthur Villaboim Integrated Health Center (1980-present day). Paquetá Hospital.

Location: Paquetá.

Address: Praça Bom Jesus, 40.

Category: General Hospital.

Period of construction: 1950.

Proprietor: City Hall of the City of Rio de Janeiro.

Author / Constructor: Unknown.

\section{History:}

Paquetá Hospital is a fruit of an interaction instituted since 1980 between the old Bichat de Almeida Rodrigues Medical Sanitary Center, which was founded in 1970, and the Manoel Arthur Villaboim Dispensary Hospital, of 1933.

On November $9^{\text {th }}$, 1933, the Dispensary-Hospital/Municipal Health Center of Paquetá was inaugurated; its first Director was Alexandre Cirne, during the administration of the Federal District Mayor Pedro Ernesto. Its construction followed the construction plan of regional polyclinic hospitals and dispensaries, or central and peripheral hospitals, developed by Mayor Pedro Ernesto Batista during his first administration of the Federal Capital, between 1931 and 1934. Out of this same plan, developed by the General Health Department and City Hall Assistance of the Federal District, were included the General Hospital of the plan (currently Pedro Ernesto Hospital), the Méier Health Center (currently Salgado Filho Hospital), the hospitals Jesus, Miguel Couto, Getúlio Vargas, Carlos Chagas and Rocha Faria and the dispensaries of Ilha do Governador (currently Paulino Werneck Municipal Hospital), and Rocha Miranda (currently Carmela Dutra Hospital). The dispensary of Paquetá was located on Rua Furquim Werneck, 180, on the Ilha de Paquetá.

During the administration of Mayor Ângelo Mendes de Moraes (1947-1951), the Health Center was transferred to Rua Pinheiro Freire, where Praça Bom Jesus is today located. The cornerstone of the new hospital was laid in 1947, since the dispensary no longer had the necessary conditions to function in an adequate manner.

As the only health institution on the Island of Ilha de Paquetá, it was finally inaugurated on July $16^{\text {th }}, 1950$, located at Rua Pinheiro Freire, 79/81. In 1948, when it was still under construction, the Hospital, at the request of the Island's residents, had its name modified, becoming known as the Manoel Arthur Villaboim Hospital.

In 1960, with the transfer of the federal capital to Brasília, the State of Guanabara was created encompassing the entire municipality of Rio de Janeiro. During this period, the hospitals belonging to City Hall of the Federal District came to have state jurisdiction. Fifteen years later, in 1975, with the merging of the states of Guanabara and Rio de Janeiro, some of these hospitals returned to the condition of being municipal hospitals - among these the Manoel Arthur Villaboim Integrated Health Center; while others remained state hospitals.

By Decree no. 2946, of December 22 ${ }^{\text {nd }}, 1980$, some institutions were removed from the structures of the General Departments of Hospital Care and Public Health of the Municipal Department of Health, Manoel Arthur Villaboim Municipal Hospital and the Bichat de Almeida Rodrigues Municipal Health Center, creating the Manoel Arthur Villaboim Integrated Health Center, with the aim of consolidating emergency and clinical services.

Currently, the Hospital possesses out-patient departments for care in the basic medical specializations such as Medical Clinic, Pediatrics, Gynecology and Obstetrics, Cardiology, Physical Therapy, Physical Medicine, Nutrition, Mental Health and Odontology. The Emergency Center has 10 beds, tending specifically to cases of Clinical Emergency and small surgical procedures, not being suitable for the performance of major surgeries or more complex cases. Such cases are directed to the mainland, for care at the large Hospitals of the Municipal Health System. 


\section{Register of Preservation:}

It is not listed

\section{Sources:}

ASSISTÊNCIA Pública - Guanabara: 80 anos de história. Rio de Janeiro: Superintendência de Serviços Médicos (SUSEME); 1972. mimeo.

http://www.ilhadepaqueta.com.br/historia.htm, Acessado em 03/07/07.

http://www.saude.rio.rj.gov.br/servidor/cgi/private/cgilua.exe/sys/reader/htm/preindexview.htm?editionsectionid=126 \&user=reader, Acessado em 03/07/07.

Credits: Nathalia Morais (research) and Renato da Gama-Rosa Costa (text). 


\section{Martagão Gesteira Child Welfare and Pediatrics Institute (IPPMG)}

Location: Isle of Fundão.

Address: Rua Marechal Trompovsky, s/n ${ }^{\circ}$.

Category: Pediatrics Hospital.

Period of construction: 1949 - 1953.

Proprietor: Rio de Janeiro Federal University (UFRJ)

Author / Constructor: Staff of architects from the Technical Office of the University of Brazil (EBTU), headed by Jorge Machado Moreira. Landscaping: Roberto Burle Marx.

\section{History:}

The Martagão Gesteira Child Welfare and Pediatrics Institute (IPPMG), the pediatrics hospital of the Federal University of Rio de Janeiro (UFRJ), was the first building of the University City campus of the Isle of Fundão, being inaugurated in 1953. The Institute paid homage with its name to the baiano (Bahia-born) pediatrician Joaquim Martagão Gesteira (18841954), to whom the merit is attributed for obtaining a facility worthy of the pediatrics teaching in Rio de Janeiro, which up to then was being done in improvised and inadequate places.

Considered one of the pioneers of the Brazilian pediatrics, Martagão Gesteira was recognized for his valuable academic production and relative teaching and assistential activities in Bahia, where he headed the Children's Department and collaborated actively for the creation of the "Bahia League against Child Mortality". At invitation of the President Getúlio Vargas, he transferred himself to the Federal District in 1937 to lecture the new subject of Medical Pediatrics Clinic and Child Hygiene. Taking office as the director of the Child Welfare Institute of the National Medicine College of Rio de Janeiro, he installed it initially in a story house rented at the (street) Rua Voluntários da Pátria, later managing to transfer it to the Gaffrée \& Guinle Hospital, from where it would depart to its definite headquarters.

The foundation stone of the building of the Child Welfare Institute was launched in an official ceremony $\mathrm{n}$ the $16^{\text {th }}$ day of October of 1937, with the presence of the President Getúlio Vargas, in a ground contiguous to the College of Medicine, at the (beach) Praia Vermelha. However, on the day following the ceremony, the Minister of Education and Health, Gustavo Capanema, suspended the start of the works, motivated by the decision of transferring the Institute from the National health Department to the recently created University of Brazil. With this, Child Welfare Institute was installed on a provisional basis in a building at the (street) Rua Voluntários da Pátria, No. 98 - already demolished. Later, it occupied, also on a provisional basis, one of the blocks of the Gaffrée \& Guinle Hospital, at Tijuca, which facilities were inaugurated at June $16^{\text {th }}, 1946$.

In the beginning of the following decade, problems with the Hospital's management forced Martagão Gesteira to precipitate the transfer of the Institute to its headquarters building, at the Isle of Fundão, which works had been initiated in 1949, but still weren't finished. Thus, the new and definitive facilities were inaugurated in October 1953.

The Isle of Fundão edification was built complying with a complex program which established the division into four sectors - ambulatory, hospital, milk bank and maternal shelter - which conferred materiality to the precepts defended by Martagão Gesteira. According to the baiano doctor, for the adequate development of the practical and efficient teaching of child welfare, the existence of a healthy "human material" was essential, which was newborns and their mothers/ lactiferous. Thus., one condition essential to the teaching and formation of doctors specialists in extra-uterine child welfare was the construction of a "maternal shelter" close to a "pupilheira" - translation performed by Plácido Barbosa, at the beginning of the XX century, for the French expression ponponnière -, a place where the babies were allocated.

From these precepts, Child Welfare Institute was conceived in three distinct blocks. In Block A, the pediatrics and child welfare ambulatories and doctors' offices were installed - both with examination rooms, class rooms, among others. Block B was intended for the hospital and comprised a three-floor building. On the first floor, he Institute's administrative services (administration, store room, subaltern personnel mess hall and dietetics), the amphitheater and the infant hygiene 
and pathology museum were located. The second floor was intended for the infirmaries, the premature births center, and the children's cafeteria and to the internal recreation. The third floor was intended to the library, the director's cabinet, the doctors' meeting room and a winter garden. Lastly, the "pupilheira", the day care center, the maternal shelter and the child welfare attendants' school were located at Block C.

Since its inauguration, the Institute was provided, further, with a maternal milk bank, and published the (bulletin) Boletim do Instituto de Puericultura - which at the time counted with three annual numbers -, being replaced, in 1964, by the (bulletin) Boletim do Instituto de Puericultura e Pediatria, which circulated until 1969.

Currently, the IPPMG performs actions of assistance, extension and teaching in the field of child and teenager health and develops researches in the mother-child area, working as the headquarters of the Pediatrics Department of the Federal University of Rio de Janeiro.

\section{Architectural Description:}

The project of the Child Welfare Institute was developed in the scope of the general plan of the University City, carried out between 1949 and 1962 by the staff from the Technical Office, headed by Jorge Moreira. The general plan followed the rationalist urbanism model. From the initial project, only five buildings were built, including the Child Welfare Institute.

The architecture of the representative lines of the most pure expression of the carioca modernism exploited the terrain's declivity and is developed in blocks, which number of floors, width and extension follows the needs of the building's function. The rationality of the construction is evidenced in the orthogonality of the arrangement of the blocks and in the ration of spans and materials employed - such as hollowed out bricks and small and square windows or large panes of glass -, creating shadow and protection areas or better exploitation of the sun. The blocks are interconnected and offer internal yards for the conviviality $\mathrm{f}$ patients and employees, in addition to allowing good ventilation and lighting to all the rooms. The orthogonality of the blocks is broken by the counterpoint to the organic landscaping of Burle Marx and by the covering and vaults placed in one of the ends of the central block.

\section{Notes:}

The architectural project received the first place in the category of hospital buildings in the International Exposition of Architecture of the event 'II Bienal Internacional de São Paulo' (1953).

\section{Register of Preservation:}

It is not listed.

\section{Sources:}

AGUIAR, Á.; MENEZES, R. (eds.). História da pediatria brasileira: coletânea de textos e depoimentos. Rio de Janeiro: Sociedade Brasileira de Pediatria, 1996.

CARNEIRO, G. Um compromisso com a esperança. História da Sociedade Brasileira de Pediatria 1910-2000. Rio de Janeiro: Expressão e Cultura, 2000.

CZAJKOWSKI, Jorge (org.). Jorge Machado Moreira. Rio de Janeiro: Centro de Arquitetura e Urbanismo do Rio de Janeiro, 1999. http://www.ippmg.org.br/, acessado em 25 de agosto de 2007.

Instituto de Puericultura da Universidade do Brasil. Jornal do Commercio, Rio de Janeiro, 1953, il.

Instituto de Puericultura da Universidade do Brasil. Revista Paulista de Hospitais, São Paulo, ano V, Volume V, n. 3, março de 1957, p. 23-31, il.

Credits: Guilherme Marcondes e Felipe Abdala (research), Martha Freire (research and text), Gisele Sanglard (text) and Renato da Gama-Rosa Costa (architectural description). 


\section{Miguel Couto Municipal Hospital}

Other denominations: Suburban Regional Hospital of Gávea (1934-1935); Gastão Guimarães Hospital (1935-1936); Miguel Couto General Hospital (1936-1961); Miguel Couto State Hospital (1961-1975); Miguel Couto Municipal Hospital (1975-present day).

Location: Gávea.

Address: Rua Mário Ribeiro, 117.

Category: General Hospital.

Period of construction: 1954-1968 (current building).

Proprietor: City Hall of the City of Rio de Janeiro.

Author / Constructor: Companhia Industrial Construtora of Rio de Janeiro

\section{History:}

The construction of Miguel Couto Hospital followed the plan of construction of regional or central and suburban polyclinic hospitals and dispensaries developed by Mayor Pedro Ernesto Batista in his first administration of the Federal Capital, through the years of 1931 and 1934. In this same plan, elaborated in the General Department of Health and Assistance of the City Hall of the Federal District, were included the General Hospital of the plan (currently Pedro Ernesto Hospital), the Health Center of Méier (currently Salgado Filho Hospital), the Jesus, Getúlio Vargas, Carlos Chagas and Rocha Faria hospitals and the dispensaries of Ilha do Governador (currently Paulino Werneck Municipal Hospital), Ilha de Paquetá (currently Hospital of Paquetá) and Rocha Miranda (currently Carmela Dutra Hospital). Works on these new units of medical-hospital assistance were accompanied by a commission set up especially for this purpose, in which doctors Rodolpho de Abreu Filho, Alcides Pinheiro Marques Carneiro, Alberto Borgerth and Amadeu de Barros Saraiva participated. It was the responsibility of the Companhia Industrial Construtora of Rio de Janeiro, whose owners were architect Luiz Moraes Jr and Archimedes d'Arthagnam Saldanha, to carry out the construction work.

The construction work began on January $06^{\text {th }}, 1934$, with the laying of the cornerstone for the Suburban Regional Hospital of Gávea, which was expected to have 200 beds available. To pay homage to his secretary of health, Pedro Ernesto named the regional hospital as Gastão Guimarães. With the exoneration of Pedro Ernesto by the Getúlio Vargas Administration and with four days to the inauguration, the hospital received the name it has today, to pay homage to Professor Miguel Couto.

On October $26^{\text {th }}, 1936$ the Miguel Couto Hospital was inaugurated with 150 beds, as a polyclinic regional hospital serving the neighborhoods of Leblon, Ipanema, Copacabana, Gávea, Botafogo and Laranjeiras. It offered services in medical, surgical, gynecological and obstetric clinics. There were polyclinics of medicine, surgery, gynecology, obstetrics, pediatrics, otorhinolaryngology, epidermis and syphilis and clinical research laboratories, $\mathrm{x}$-ray and a pharmacy. There were also physiotherapy, odontology, electro-cardiography and basal metabolism departments. These last two were linked to the infirmaries. The emergency services functioned similarly to the Emergency Hospital (curretly Souza Aguiar). Finally, in the inner courtyard, there was the mortuary with a garage and clothes storage area.

On August $17^{\text {th }}, 1948$, Decree no. 9319 incorporated to the hospital, the land of the Federal District City Hall, with an area of 1,198.96 $\mathrm{m}^{2}$ at Rua Mário Ribeiro. In the years of 1954 and 1955, the hospital came to have a new building encompassing the emergency and radiology sector and the service of orthopedics and traumatology, created in 1949. With modern facilities for the period, including rooms of clinic meetings, isolation for cases of infection and specialized operating theaters, these annexes were referred to as the "Bone Palace".

In Carlos Lacerda's administration (1960-1965) a new annex of three floors was constructed and partially inaugurated on September $28^{\text {th }}, 1965$, including the emergency sector, the surgical center and the orthopedics service.

Between 1968 and 1970 during the administration of Negrão de Lima (1965-1970) renovation and modernization works of the old building were performed and new annexes were inaugurated. On December $24^{\text {th }}, 1968$, the secretary of 
Health, Hildebrando Monteiro Marinho, put the surgical center, sterilization center, radiological center, specialization infirmaries and generator room into service. In this work of construction, the emergency sector was also reformed and the hospital got new facilities for the polyclinics, pathological anatomy clinic, director's office, maternity and nursery, infirmary of surgical specializations. As a result of this reform, new beds were became available and the intensive care center underwent extension works. The medical documentation, medical residence and facilities for dressing rooms and entrance of polyclinics were installed in the annex of eight floors, located at Rua Mario Ribeiro.

In 1960, with the transfer of the federal capital to Brasília, the State of Guanabara was created encompassing the entire municipality of Rio de Janeiro. At that time, the hospitals belonging to City Hall of the Federal District came to have state jurisdiction. Fifteen years later, in 1975, with the merging of the states of Guanabara and Rio de Janeiro, some of these hospitals returned to the condition of municipal hospitals - among these being Miguel Couto, while others remained state hospitals.

Nowadays it serves an average of 950 patients per day, maintaining the emergency services; medical clinic; general, vascular and plastic surgery; odontology; otorhinolaryngology; ophthalmology; orthopedics and obstetrics.

\section{Architectonic Description:}

In the first building, built in the decade of 1930, the architectonic language adopted for the hospital complex - and already demolished -, followed the North-American language of art-deco, being gradually altered with the advances of extension works and construction of annexes. The last annex, inaugurated in the decade of 1970, reveals the adoption of a language more typical of the brutalism from São Paulo with emphasis on the use of reinforced concrete. It is worthwhile mentioning that the operating lecture theaters, as well as the rooms for post-operative care, had air conditioning installed, back in 1936, a recently developed system in the buildings of that period, showing that modernity in architecture can express itself in different ways.

\section{Register of Preservation:}

It is not listed.

\section{Sources:}

Anexo do Miguel Couto tem área de $5.700 \mathrm{~m}^{2}$. Jornal do Brasil, Rio de Janeiro, 29 de outubro de 1965.

ASSISTÊNCIA Pública - Guanabara: 80 anos de história. Rio de Janeiro: Superintendência de Serviços Médicos (SUSEME); 1972. mimeo.

Dois novos hospitais. Correio da Manhã, Rio de Janeiro, 7 de janeiro de 1934.

HMMC 70 anos. Capturado em 13 de jun. 2007. Online. Disponível na Internet: http://www.urbicorporate.com.br/mcouto/ 194b50779.jpg

Hospital Gastão Guimarães. O Jornal, Rio de Janeiro, 2 de abril de 1935.

Hospital Miguel Couto. Jornal do Commercio, Rio de Janeiro, 26 de outubro de 1936.

Hospital Miguel Couto. Jornal do Commerciol, Rio de Janeiro, 11 e 12 de Janeiro de 1937.

Negrão e Marinho entregam as obras de reequipamento e reforma do Miguel Couto. Jornal do Brasil, Rio de Janeiro, 25 de dezembro de 1968.

Negrão recebe título de amigo do Hospital Miguel Couto ao inaugurar o bloco E. Jornal do Brasil, Rio de Janeiro, 26 de maio de 1970.

O novo Hospital da Gávea. Correio de Manhã, Rio de Janeiro, 2 de abril de 1935.

RIBEIRO, L. Medicina no Brasil. Imprensa Nacional. Rio de Janeiro, 1940.

Credits: Nathalia Morais (research) and Renato da Gama-Rosa Costa (text and architectonic description). 

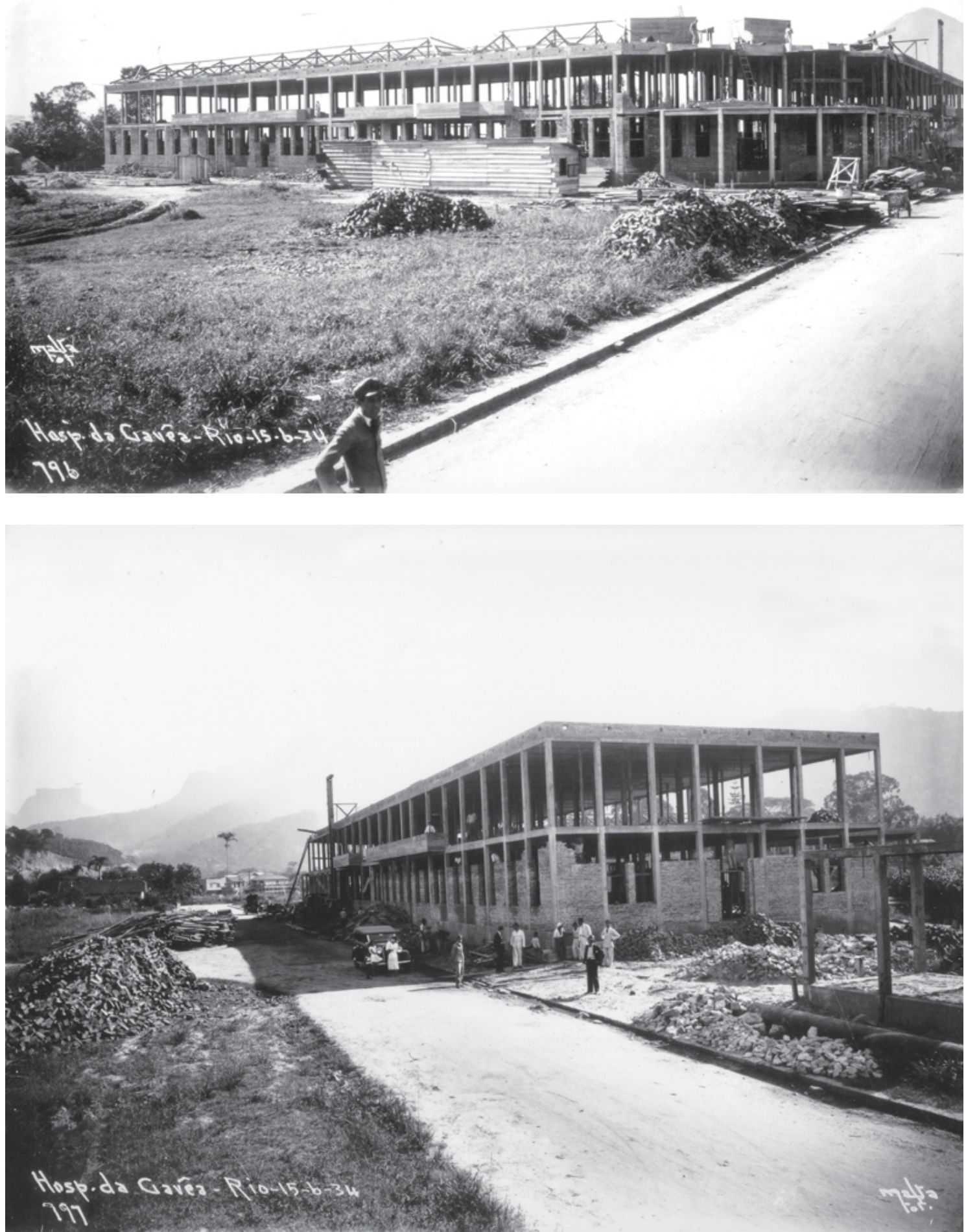

Gávea Hospital. Photo Augusto Malta, 1934. City of Rio de Janeiro General Archives
Gávea Hospital.

Photo Augusto

Malta, 1934. City of

Rio de Janeiro

General Archives 


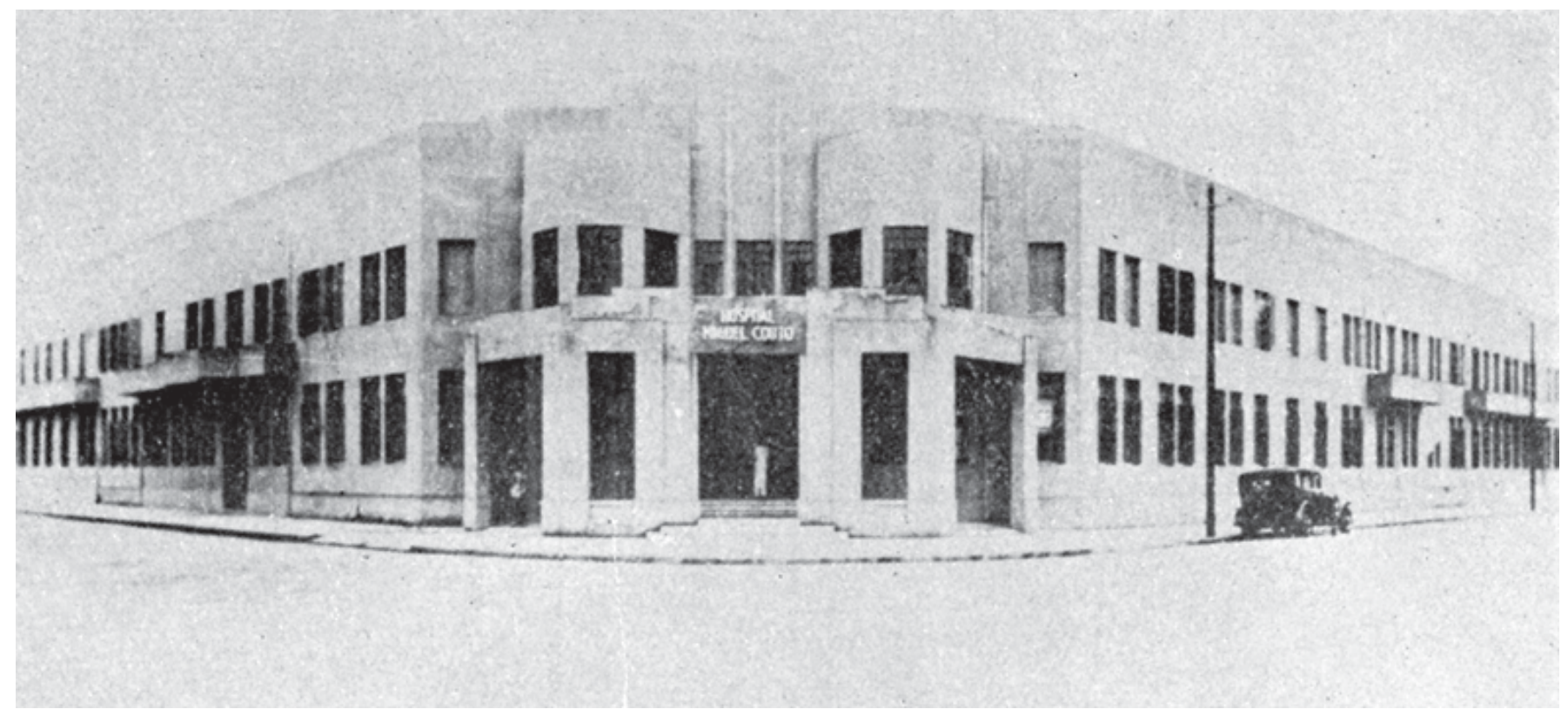

Miguel Couto Hospital, [s.d.]. Source: Ribeiro, 1940 


\section{National Cancer Institute (INCa)}

Other Denominations: Oncology Center (1937-1944); Cancer Institute (1944-1961); National Cancer Institute (1961present day)

Location: Lapa

Address: Praça da Cruz Vermelha, 23.

Category: Specialized Hospital

Period of construction: 1957 (Building headquarters);

Proprietor: Ministry of Health.

Author / Constructor: Jorge Ferreira (Building headquarters); Roberto Nadalutti (Oncology Hospital - INCa II; Luiza Gomes de Lemos Research Center and Santa Rita Hospital - Inca III).

\section{History:}

Literature pertaining to the history of the National Cancer Institute (INCA) highlights the year of 1937 as representing the founding moment of the institution. Although we may point to institutional initiatives in the area as early as the 1920 s - such as, for example, the ones that were developed in the arena of the Leper, Venereal Diseases and Cancer Public Inspection Bureau, on behalf of the National Department of Public Health (DNSP) - it was the creation of the Oncology Center in 1937 which marked the inception of Inca. The Oncology Center was created in the midst of the reform implemented by Minister Gustavo Capanema under the Ministry of Education and Health, by means of Act no. 378, which determined in its article 58, the formation of the Assistance Service Hospital of the Federal District. This service would be formed by the Hospitals Estácio de Sá, São Francisco de Assis and Pedro II. The sole paragraph of this article indicated the creation of the Oncology Center, destined for prophylaxis and the treatment of cancer. (Brazil, act no. 378 of 01/13/1937).

Once the bylaws of the Center had been defined, it was agreed that its headquarters would function in a building annex to the Estácio de Sá Hospital, which was inaugurated in 1938, with the presence of President Getúlio Vargas, Gustavo Capanema and João de Barros Barreto, director of the National Department of Health, being Mario Kroeff designated to run the new center. Its technical service would consist of 40 beds, a polyclinic, surgery, medical dressing and sterilization rooms, radio diagnostic equipment for radiotherapy, characterizing itself as a small center of treatment.

Four years later, in 1941, following the changes ushered in by minister Capanema in the health area; the National Cancer Service (SNC) would be created, along with twelve other national services, under the orientation of the centralizing political structure of the government. The SNC was organized at the Oncology Center of the Estácio de Sá Hospital, maintaining Mario Kroeff as its Director, in addition to staffing 11 assistant doctors. However, in the following year, the physical facilities of the Estácio de Sá Hospital would be ceded to a hospital belonging to the Military Police of the Federal District. As a result, the SNC would be transferred to an old mansion in downtown Rio de Janeiro, and there it remained under precarious working conditions until 1945, when it was transferred to the Gaffrée e Guinle Hospital in the neighborhood of Tijuca. During this interim in 1944, upon the approval of SNC's new regiment which detailed its organizational structure, the denomination of the Oncology Center was altered to Cancer Institute, and the Section of Organization and Control was created (Decree no. 15971 of 07/14/1944).

The eleven years in which the Cancer Institute remained at the Gaffrée e Guinle Hospital represent a period of great development in its activities. In its new headquarters laboratories of clinical analysis and pathological anatomy were inaugurated; a radiotherapy pavilion was constructed and its service rendering capacity expanded to 120 beds for its patients. An important moment in this process of institutional expansion of the SNC dates back to the beginning of the 1950s, when the Cancer Institute was able to expand its budget and technical staff, thus opening the path for new 
activities which the development of medicine and the expansion of its institutional capacity made indispensable. It was in the course of this decade that other significant changes occurred at the institution. With the creation of the Ministry of Health in 1953, the new minister, Miguel Couto Filho, replaced Mario Kroeff as director of the SNC and nominated Antonio Prudente from São Paulo for the position. Prudente physically separated the SNC from the Cancer Institute, transferring the headquarters of the Service to a building occupied by the Ministry of Health in downtown Rio. However, negotiations were under way aiming to transfer to the Union a piece of property belonging to City Hall, located at Praça da Cruz Vermelha, which would be destined for the SNC. The government of Juscelino Kubitschek would make this objective possible, finally inaugurating a new headquarters for the institution in August, 1957, which would be able to meet the necessary demands for its services, which expanded every year.

With the inauguration of the new building, the Institute became equipped with state-of-the-art facilities. It was an 11story single block structure with capacity for 350 beds where specialized services would be set up. More than a mere change of address the new headquarters represented the reinforced pledge of the oncologists of the Institute with its project in relation to cancer. Along with the inauguration of the new building, the Institute elaborated a regiment proposal for its functioning. The document sought to make legal an organization already in existence. It foresaw the division of the Institution into six divisions: Administrative Technical Council; Center of Studies and Teaching; Research and Experimentation Service; Medicine and Surgical Division; Administrative Service and maintenance and Office. The new facilities of the Cancer Institute mark the beginning of a new phase in its history. Well-equipped and with a medical team consisting of more than a hundred people, the Institute characterized itself as the largest institution of its kind in Latin America, exercising multiple activities in the field of control, research and professional qualification.

However, in the following decade, this trajectory of expansion and leadership in the area of cancer control would undergo difficulties as a result of the health policy guidelines adopted in Brazil, which gradually began to prioritize private medical treatment as the solution for the health care problems of the population. In 1968, institutional changes would have a direct impact upon the institutional trajectory of the Institute. Inaugurated at Praça Cruz Vermelha, in Rio de Janeiro, at such moment it had the capacity for 331 beds, and had about 120 doctors and 830 hospital staff working at the institution. The National Campaign for the Control of Cancer was instituted during this year, and the National Cancer Institute would suffer the impact in its trajectory of leadership; that is, it was no longer the main policy articulator in the combat of the illness in the country. In the following year, with the creation of the Medicine and Surgery School Foundation of Rio de Janeiro (FEFIEG), the Institute was incorporated into the Medicine and Surgery School Foundation of Rio de Janeiro, departing from under the organizational structure of the Ministry of Health. During this period, given budgetary and staff reductions, Inca would undergo serious difficulties, and although it returned to the Ministry of Health in 1971, such difficulties extended well into the 1970s.

In 1980, Inca came to be administered jointly by the Ministry of Social Security and the Ministry of Health. This pioneering experience in public health management was the basis for overcoming the financial and administrative difficulties which affected the Institute. The new model allowed for the allocation of new resources for the Institute through resources from the Ministry of Social Security, expanding its areas of medical assistance, teaching and research, and also allowing for the hiring of professionals to supply the grave shortage that it faced in this particular area. In the national arena, in 1983, the activities formerly under the responsibility of the National Division of Chronic-Degenerative Diseases were transferred to Inca and two new centers were created: the National Center for Bone Marrow Transplant (Cemo) and the Reference Center for Children's Tumors. Therefore, this was a period of important internal changes in the institutional sphere, which reassured that Inca would enter the 1990s with a significant role in the country's cancer control policy.

As of this moment a set of initiatives and internal reformulations at the institution sought to address the growing demand and complex specialization in this field of public health action. Among the institutional alterations we may cite: the establishment of the Cancer Control Programs Coordination (Pro-Onco), the incorporation of the Oncology Hospital (currently Inca II, next to the Highway) and the Luiza Gomes de Lemos Research Center (Inca III, in Grajaú). 
The Cancer II Hospital had been constructed in a property donated by Getúlio Vargas to the Brazilian Oncology Institute. The seven story building was inaugurated in 1967, under the name Mathilde von Dollinger da Graça Hospital, and incorporated into Inamps (National Institute of Social Medical Assistance). After its integration into Inca, it became an assistance based unit, concentrating the activities of the Oncologic Gynecology Service of the institution. Cancer II Hospital was exclusively dedicated to the treatment of breast and genital cancer. Constructed in 1956, the Luiza Gomes de Lemos Research Center, of the Social Pioneering Foundation - institution created by Sarah Kubitschek -, only attended to cases of female cancer and was equipped with gynecologic consultation rooms, laboratories of cytology and histopathology and the Cytopathology School for the training of cytotechnologists. In 1977, annex to the Luiza Gomes de Lemos Center, the Santa Rita Hospital was constructed for the treatment of gynecologic cancer, which was also incorporated into Inca (Carmo et alii, 2002, p. 135-138). In 2004, Inca IV joined these new hospitals. Until then denominated the Oncologic Therapeutic Support Center, it functioned in its own building, on Rua Visconde de Santa Isabel, in the district of Vila Isabel. The hospital was dedicated to the palliative care of patients that already had been treated at the Institute, in its new phase it emphasized home care and the qualification and training of professionals.

\section{Architectonic description:}

The building headquarters of the National Cancer Institute is an example of the modern hospital architecture constructed in the 1950s. The project took advantage of a four pavement structure started by City Hall of the Federal District in the 1940s, located at the former praça Vieira Souto, between Carlos Sampaio street and Henrique Valadares avenue. The property and the structure of the unfinished construction, delivered through a decree-law in 1946, adhered to the contour of the square (currently Cruz Vermelha), which made it unique in relation to other contemporary single block hospitals. It has a unique ground floor in relation to the nine floors above, however the implantation did not allow it to adopt the most usual solution for this type of construction, usually done using horizontal foundation - destined for public areas in general -, conjugate a vertical lamina - destined for hospitalization. It is interesting to observe the solutions adopted by this building and the Cruz Vermelha Hospital, located on the opposite side of the square, to adhere to the alignment of the street, defined in the administration of Mayor Pereira Passos (1903-1909). The architectonic solutions adopted by each hospital highlight rather well the different eras under which each one was constructed. Cruz Vermelha adheres to the eclectic aesthetics, with decorative and symbolic references to the institution which it houses (see note). On the other hand, the project for INCa removed all reference and presents elements of the modern hospital architecture which triumphed during the following decades in Brazil. Its façade adopts the brise-soleil (sun breaker) vertical technique to protect against the sun, on the lateral façade facing rua Henrique Valadares, and open verandas for the other ones, with particular effect on the façade which adheres to the curvature of the square. Still its volume and construction materials create a contrast to the other buildings in the vicinity, which makes it stand out from the urban landscape. The author of the project, Jorge Ferreira, was an active architect of hospitals, and was a part of the team of experts in the Construction Work Division of the Ministry of Education and Health, during his entire period as a professional.

A portion of the other buildings associated to INCa, such as INCa II and the Santa Rita Hospital, were designed by another renowned architect of hospitals, Roberto Nadalutti (1922-2005), who specialized in hospital architecture as of the 1950s, after serving at the Special Service of Public Health (SESP) and the Public Health Service, in Washington (EUA). Nadalutti and his partner Oscar Waldetaro and the brother Carlos Nadalutti participated as authors and consultants of many hospital projects in Rio de Janeiro (see notes Beneficência Portuguesa, Pedro II Hospital and Miguel Couto) and throughout Brazil. Nadalutti's architecture also sought to accommodate with quality and modern aesthetics to the challenges imposed by the designs, making use of void elements on the façades, creating areas of transition between the rooms and the exterior. 


\section{Register of Preservation:}

It is not listed.

\section{Sources:}

BODSTEIN, R. (coord). História e Saúde Pública: a política de controle do câncer no Brasil. Rio de Janeiro: PEC/ENSP, 1987.

CARVALHO, A. O Instituto Nacional de Câncer e sua memória: uma contribuição ao estudo da invenção da cancerologia no Brasil. Programa de Pós-Graduação em História Política e Bens Culturais da Fundação Getúlio Vargas. Rio de Janeiro: FGV, 2006. (Dissertação de mestrado)

KROEFF, M. Resenha da luta contra o câncer no Brasil. Rio de Janeiro: Documentário do Serviço Nacional de Câncer, 1947. OLIVEIRA, B.; COSTA, R.; PESSOA, A. Um Lugar para a Ciência: a formação do campus de Manguinhos. Editora Fiocruz. Rio de Janeiro: 2003.

TEIXEIRA, L. e FONSECA, C. De doença desconhecida a problema de saúde pública: o INCA e o controle do câncer no Brasil. Rio de Janeiro: Ministério da Saúde, 2007.

TOLEDO, L. Feitos para curar. Arquitetura hospitalar e processo projetual no Brasil. Rio de Janeiro: ABDEH, 2006.

Credits: Cristina Fonseca and Luiz Antônio Teixeira (research and text) and Renato da Gama-Rosa Costa (architectonic description). 


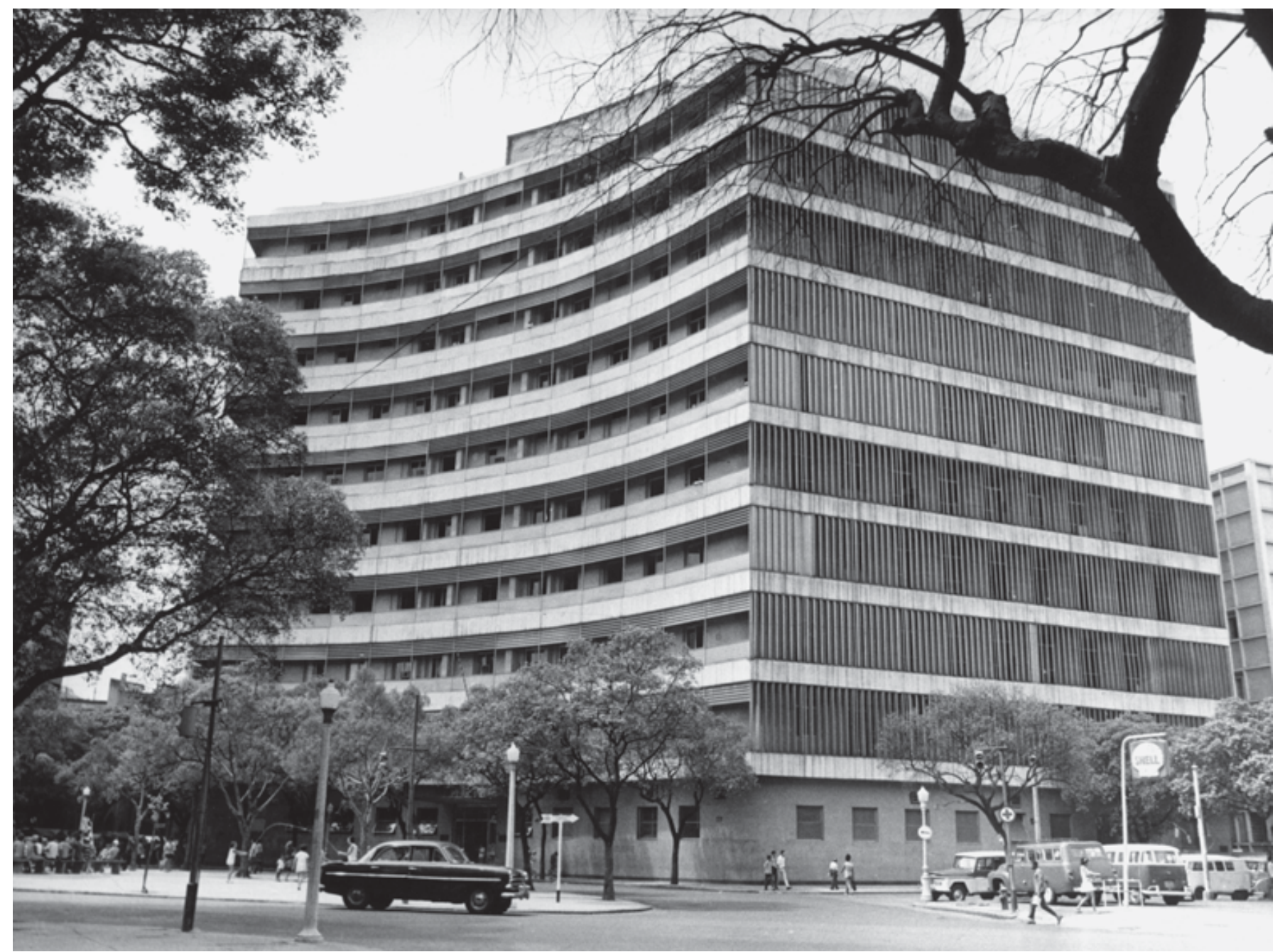

INCa façade, [s.d.]. Correio da Manhã Fund. National Archives 


\section{National Institute of Cardiology}

Other Denominations: Nossa Senhora das Vitórias Hospital (-1974); Laranjeiras Clinics Hospital (1974); Laranjeiras Cardiology Hospital (1974-1990); Nelson Botelho Reis State Institute of Heart Diseases (1990-1994); Laranjeiras Cardiology Hospital (1994-2001); National Institute of Cardiology"(2001- present day).

Location: Laranjeiras.

Address: Rua das Laranjeiras, 374.

Period of construction: 195 ?.

Proprietor: Ministry of Health.

Author / Constructor: J. L. Koch (structural calculation, 1955); Lutz Quaresma and Carvalho Hosken Construction Company (adaptation construction work, 1978-1981); and Ivan Oest and Senge Engenharia (renovation, 1986-1987).

\section{History:}

In the 1920s, as of the promulgation of the Eloy Chaves Act in 1923, the embryo of the Brazilian social security system appeared - with the creation of the Retirement and Pension Credit Unions (CAPs). When Getúlio Vargas came into power in 1930, he modified labor relations in effect and, in regard to the social security issue, the CAPs standard was broken in respect the formation of Retirement and Pensions Institutes (IAPs), tied to the professional categories and linked to policies of the newly created Ministry of Labor, Industry and Commerce. The purpose of the IAPs was to guarantee that particular group of professionals had access to benefits and services - mainly medical services. The first categories to organize their institutes were: mariners (IAPM), in 1933; bankers (IAPB) and merchants (IAPC), in 1934; industrial workers (IAPI), in 1936; stowage (IAPE) and cargo transport employees (IAPETC), in 1938 (Hochman e Fonseca, 1999; 77-78). Many of these IAPs sought to construct hospitals to provide assistance care to their members.

Within the assistance actions maintained by IAPC there is the Nossa Senhora das Vitórias Hospital - which gave rise to the National Institute of Cardiology; Ipanema Hospital and the Casa da Comérciária Pobre (House of the Poor Merchant).

Nossa Senhora das Vitórias Hospital, the surgical hospital of the IAPC, was located in an old two-story building, with multiple small rooms, located on rua Voluntários da Pátria, in Botafogo.

Nossa Senhora das Vitórias Hospital slowly became a reference in cardiology services, especially with the creation of the Graduate Medical School at PUC-Rio in the 1950s, and the organization of the first Specialization Program in Cardiology, directed by Professor Arthur Carvalho de Azevedo, whose practical classes took place at Nossa Senhora das Vitórias Hospital. Certainly these were determinant factors for, in this same period, the areas of general surgery, urology, proctology and gynecology to leave Botafogo and receive their own facilities at a building in Ipanema, where the Ipanema Hospital was created in 1955.

In 1973, Nossa Senhora das Vitórias Hospital could no longer accommodate the large number of patients who sought assistance there. Thus, the director at the time Prof. Hans Dohmann managed for the hospital to be transferred to the Commercial building in Laranjeiras. Between 1973 and 1974 adaptation works were carried out on the old Casa da Comerciaria Pobre in order to receive IAPC's Surgical Clinic. For some years hospital assistance care coexisted with the boarding house, dividing the building into the two functions. New construction were executed between 1979 and 1981 and again between 1986 and 1987, with the removal of the pensioners so that the entire building could house hospital assistance care.

In 1967, all of the institutes that had served the workers were unified under the National Institute of Social Security (INPS), and the Nossa Senhora das Vitórias Hospital became known as Laranjeiras Clinics Hospital and, later, Laranjeiras Cardiology Hospital. In 1974, INPS was divided into three institutes and the hospital becomes administered by the National Social Security Medical Assistance Institute (INAMPS), responsible for the social security health system. With the extinction of INAMPS in 1993, the hospital became associated to the Ministry of Health. 
Under the implementation of the National Health Program (SUS) in 1990, eleven of the seventeen hospitals belonging to the Ministry of Health in the city of Rio de Janeiro, were municipalized, except for the Laranjeiras Cardiology Hospital which became managed by the Government of the State of Rio de Janeiro, receiving the name Nelson Botelho Reis State Institute of Heart Diseases (IEDOC) - this association was maintained until 1994, when the institution was again managed by the Ministry of Health, readopting the old name.Of the five remaining, three were promoted to the category of Institutes, under the condition to propose health policy according to its areas of expertise

National Trauma-orthopedic Institute, National Cancer Institute and Cardiology Institute of Laranjeiras; whereas the three remaining - State Employees Hospital and General Hospital of Bonsucesso - considered references in the municipal and state health systems, remained under the auspices of the Ministry of Health. In 2001, it become known as the National Institute of Cardiology (INC), center of reference of the Ministry of Health for the execution of undergraduate and graduate training and teaching; research - in partnership with the Evandro Chagas Research Institute, Fiocruz - and the formulation of health policies geared toward cardiology.

\section{Architectonic Description:}

It is a typical vertical hospital construction of the time, with base composed of a ground pavement and entresol, out of which emerges the block with 11 pavements, reserved for assistance services. Hospital administration, departments and coordination of support are located in the second pavement. The third floor houses exam services. The fourth floor is dedicated to children's post-operation and from the sixth to the ninth pavements, post-operation for adult patients. Intensive training areas are located in the tenth pavement and the eleventh houses the surgical centers. Fifth pavement concentrates the research area with rooms for researchers and integrated laboratories. Finally, the auditorium and the center of studies were located in the penthouse.

Original construction did not present great architectonic qualities and the renovations that were carried out later emphasized the provision of ever more efficient facilities, leaving the esthetic appeal aside. The facilities of the former pensioners' rooms were advantageously used in the patients' rooms. For every two bed spaces there is a bathroom in the center, with common access.

\section{Register of Preservation:}

It is not listed.

\section{Sources:}

ALBANEZI FILHO, F. (org.). 50 anos de história da cardiologia do Estado do Rio de Janeiro. Rio de Janeiro: SOCERJ; 2005. http://www.incl.rj.saude.gov.br/incl/index.asp, acessado em 08/08/2007.

Credits: Daniel Elian dos Santos (research); Márcio Arnaldo da Silva Gomes (text) and Renato da Gama-Rosa Costa (research, text and architectonic description). 


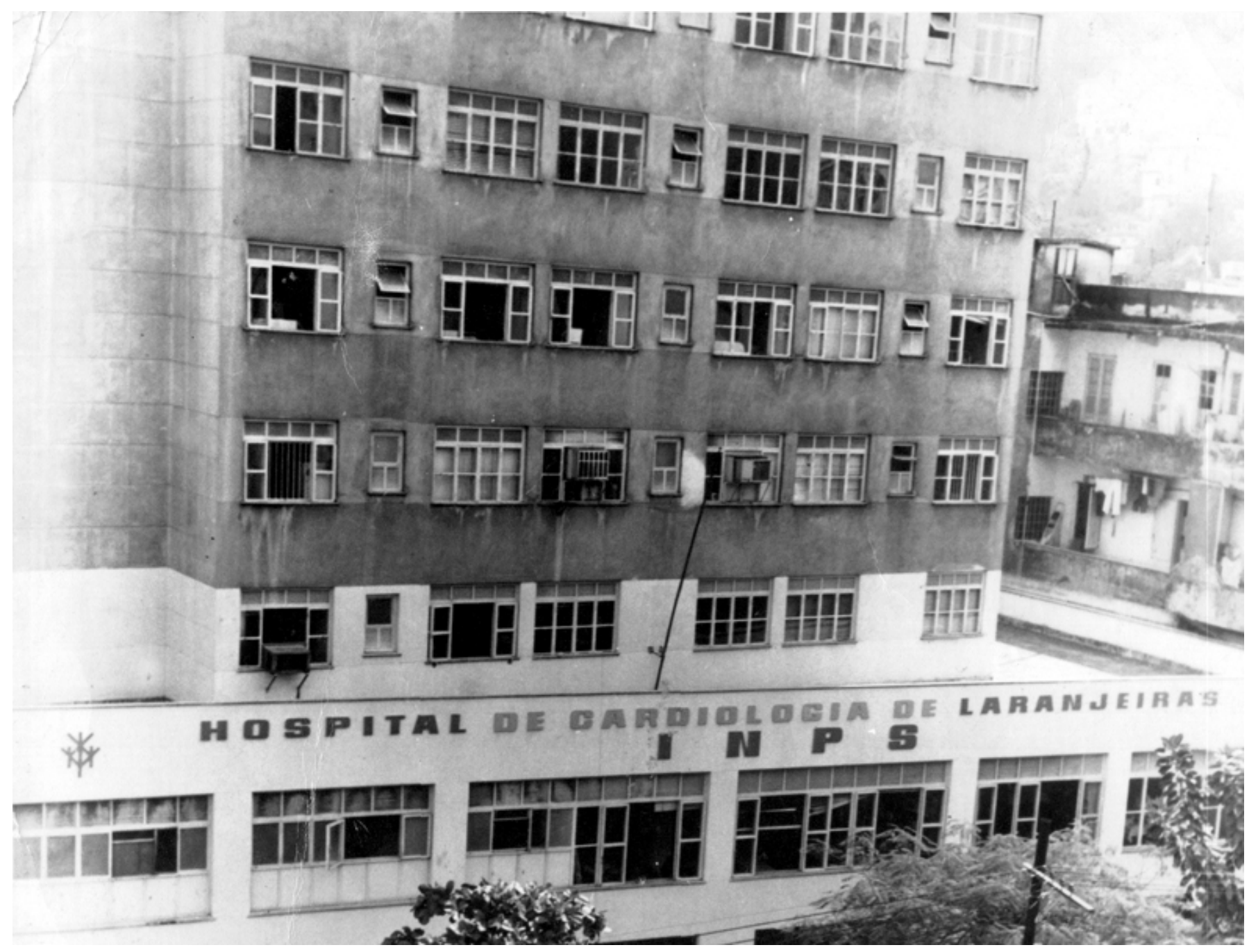

National Institute of Cardiology, [s.d.]. Private Archive 


\section{National Trauma-Orthopedic Institute (INTO)}

Other Denominations: Victims' Central Hospital (1943-1973); Trauma Orthopedics Hospital (1973-1984); Dr. Mário Jorge Trauma Orthopedics Hospital (1984-1994); National Trauma-Orthopedics Institute (1994-present day)

Location: Centro

Address: Rua Washington Luiz, 61

Category: Specialized Hospital

Period of construction: XX Century

Proprietor: Ministry of Health.

Author / Constructor: Unknown

\section{History:}

In the 1920s emerged the embryo of the Brazilian social security system - with the creation of the Retirement and Pension Credit Unions (CAPs) - as of the promulgation of the Eloy Chaves Act in 1923. The arrival of Getúlio Vargas into power in 1930 alters labor relations then in effect and, in relation to the social security issue, the standard of the CAPs was undone for the establishment of the Retirement and Pension Institutes (IAPs), tied to the professional categories and linked to the newly created Ministry of Labor, Industry and Commerce. The objective of the IAPs was to guarantee access to health care for the particular professional category. The first occupations to organize their institutes were: mariners (IAPM), in 1933; bankers (IAPB) and merchants (IAPC), in 1934; industrial workers (IAPI), in 1936; stowage (IAPE) and cargo transport employees (IAPETC), in 1938 (Hochman e Fonseca, 1999; 77-78). Many of these IAPs sought to build hospitals for the health care of its associates. Many of these IAPs sought to build hospitals for the health care of its associates.

The IAPM was destined for the employees of the Brazilian Lloyd Company, which created in 1943, the Victim's Central Hospital, to render assistance care for the employees and associates of the company.

In 1967, all of the institutes which served the workers were consolidated under the National Social Security Institute (INPS), and, in 1973, the Victim's Central Hospital was incorporated into INPS, and specialized in the areas of traumatology and orthopedics, becoming known as the Trauma Orthopedics Hospital. At this moment, the administration of the services was the responsibility of the team at the Bonsucesso General Hospital.

In 1984, it becomes known as the Dr. Mário Jorge Trauma Orthopedics Hospital, in tribute to the first chief of the orthopedics service. This denomination lasts until 1994, at which time it becomes known as the National Trauma-Orthopedics Institute, assuming new functions stemming from the implementation of the National Health Program in 1990.

Of the seventeen hospitals belonging to the Ministry of Health in the city of Rio de Janeiro, eleven were municipalized; and only one - the Cardiology of Laranjeiras - was briefly under state administration. Out of the five remaining, three were elevated into Institutes under the condition to propose health policies in their areas of expertise: National Traumaorthopedics Institute, National Cancer Institute and the Cardiology Institute of Laranjeiras; while the State Employees' Hospital and the Bonsucesso General Hospital, considered references in the municipal and state health systems, were kept under the Ministry of Health.

INTO is considered to be a reference in the specialty in the country, having received, in March, 2006, the highest award for hospital and medical clinic quality in the world granted by the international certifying commission, Joint Commission International.

Since 2006 there is an on-going reform and construction project for INTo's new facilities, which will occupy the building that had belonged to the Jornal do Brasil (Av. Brasil, 500) and was expropriated by the Union, and, in an adjacent property, ceded by the Companhia Docas do Rio de Janeiro (Docks Company of Rio de Janeiro). 


\section{Register of Preservation:}

It is not listed.

\section{Sources:}

HOCHMAN, G. et FONSECA, C. O que há de novo? Políticas de saúde pública e previdência, 1937-45. In: PANDOFI, D. (org.). Repensando o Estado Novo. Rio de Janeiro: Editora FGV; 1999, p. 73-93.

http://www.into.saude.gov.br/, acessado em 19/11/2007

Credits: Renato Menezes (research); Renato da Gama-Rosa Costa and Gisele Sanglard (research and text). 


\section{Noel Nutels Central Public Health Laboratory}

Other denominations: Central Public Health Laboratory (19-1986); Noel Nutels Central Public Health Laboratory (1986-to the present)

Location: Centro.

Address: Rua do Resende, 118

Category: Laboratory of Analysis

Period of construction: unknown

Proprietor: Government of the State of Rio de Janeiro.

Author / Constructor: unknown

\section{History:}

The creation of the Noel Nutels Central Laboratory of Public Health is directly related to the promulgation of State Act no. 1742, of September 9 $9^{\text {th }}, 1946$, which decreed the creation of the Laboratories Division of Public Health, subordinate the Department of Health of the Federal District Office. The new agency was formed by a Central Laboratory; by regional laboratories - with their performance and jurisdiction defined by the Central Laboratory; and by local laboratories installed in health centers, hygiene stations and other sanitary units.

Act 1742 also defined that the director of the Division would accumulate the roles of Central Laboratory chief; and extinguished the Laboratory Service of Public Health and the Studies and Research Service of the Hygiene Division. Among the attributes of the Division, we may cite the following: the realization of laboratory exams for the diagnosis of infectious-contagious diseases, including hystopathology exams; study of etiology on transmitted epidemics and endemic diseases; the realization of exams for the control of biological products, chemicals, drugs, medicines and pharmaceutical specialties and; the production of products and reactives of large consumption in public health. Whereas the Central Laboratory was in charge of the technical direction, establishment of work norms, standardization and control of material usage, demarcation of the competence and dialogue of the various units of the system, as well as organize the standard types of regional laboratories - which performed in determined regions -,approving the work plan of these units.

In 1960, with the transfer of the federal capital to Brasilia, the state of Guanabara is created encompassing the entire municipality of Rio de Janeiro. At this moment, the hospitals and health institutions belonging to city hall of the Federal District were transferred to state jurisdiction. Fifteen years later, in 1975, with the merging of the states of Guanabara and Rio de Janeiro, some of these hospitals returned to the condition of municipal hospitals, while others remained state hospitals - among these was the Central Laboratory of Public Health.

In 1986, in tribute to the doctor and sanitarian Noel Nutels, the institution becomes known as the Noel Nutels Central Laboratory, maintaining its roles related to epidemiology, sanitary and environmental vigilance in health; and medical assistance of high complexity.

Currently, the Laboratory has intensified, under the orientation of the SUS (National Health Program), a decentralization process of its efforts in health, proposing the hierarchization and territorialization of the assistance as of the creation of nine micro regions (Ilha Grande Bay, Mid Paraíba, South Central, Metropolitan I and II, Mountain, Lower Coastal, North and Northeast), with varying degrees of complexity.

\section{Register of preservation:}

It is not listed 


\section{Sources:}

http://www.noelnutels.org/

Credits: Daniel Elian dos Santos (research) and Gisele Sanglard (text). 


\section{Nossa Senhora do Loreto Municipal Hospital}

Location: Ilha do Governador

Address: Estrada Caricó, 26

Category: Pediatric Hospital

Period of construction: 1949-1952

Proprietor: City Hall of Rio de Janeiro

Author / Constructor: unkown

\section{History:}

"The small seed sown in the earth sprouts and soon after will grow into a great tree extending its protective boughs over all the sick school children, sheltering them in its shade, to bring them back to health". These words were used in April of 1949 by Paulo Trigo de Macedo and Joaquim Almeida Cardoso to mark the first steps of the construction of the hospital destined to serve the child population of Ilha do Governador and its surrounding areas. Constructed by the Ministry of Aeronautics, on land it donated, at Estrada do Caricó, no. 26, and equipped and maintained by the city hall of Rio de Janeiro, it received the name Nossa Senhora do Loreto Medical-Pedagogic Center in homage to the patron saint of aviators, being inaugurated with this name on May 31 1952.

By means of Decree no. 1.022, on May 25 $5^{\text {th }}, 1962$ the Center was incorporated into the hospital network of the Health and Assistance Office of the then State of Guanabara. In June of the same year, Service Order no. 39 transformed the institution into a unit dedicated exclusively to children's surgery. In March of 1963, by Decree no. 1.611, the Hospital was integrated into the Medical Services Administration of Guanabara (SUSEME), and came to be called Nossa Senhora do Loreto State Hospital, specialized in medicine and surgery for children.

Throughout the 1960's, the Hospital received various improvements and expansion of its services thanks to the work of the Society of Friends of the Nossa Senhora do Loreto State Hospital, having been a pioneer in the hospital network with regard to the installation of a system of calls via microphone.

In 1960, with the transfer of the federal capital to Brasília, the state of Guanabara was formed which covered the whole of the municipality of Rio de Janeiro. At that time, the hospitals belonging to the jurisdiction of the Federal District were handed over to state jurisdiction. Fifteen years later, in 1975, with the fusion of the states of Guanabara and of Rio de Janeiro, some of these hospitals returned to the condition of municipal hospitals - among them being the Nossa Senhora do Loreto Municipal Hospital, while others remained as state hospitals.

At present it offers services of Pediatrics, Child Development, Pediatric Surgery, Plastic Surgery, Cardiology, Otorhinolaryngology, Hematology, Gastroenterology, Dermatology, Allergies, Physiotherapy, Nutrition, Psychology, Phonoaudiology, Occupational Therapy, Odontology/Orthodontia, Buco-maxilo-facial Surgery, Vaccination, Nursing and Social Services. It also offers three special services: An Asthma Center, Service of Support for Children and Adolescents Victims of Mistreatment (DEDICA) and a Cleft Lip-Palate Center (CEFIL). Internationally recognized, CEFIL is an institute of reference in the multi-discipline treatment of children suffering from cleft lips/palates - popularly called "hare lip".

\section{Register of Preservation:}

It is not listed. 


\section{Sources:}

ASSISTÊNCIA Pública - Guanabara: 80 anos de história. Rio de Janeiro: Superintendência de Serviços Médicos (SUSEME); 1972. mimeo.

http://www.rio.rj.gov.br/pcrj/destaques/cidade_16.htm, Acessado em 03 de julho de 2007.

http://www.saude.rio.rj.gov.br/servidor/cgi/private/cgilua.exe/sys/reader $/$ htm/preindexview.htm?editionsectionid= 143\&user=reader, Acessado em 10 de maio de 2007.

Credits: Nathalia Morais (research) and Martha Freire (text). 


\section{Oscar Clark Municipal Institute of Physical Medicine and Rehabilitation}

Other Denominations: Oscar Clark School Clinic (1930-1940); Oscar Clark Pedagogic Medical Center (1940-1944); Oscar Clark School-Hospital (1944-1962); Rehabilitation Center for the Disabled - Oscar Clark Institute (1962-1975); Oscar Clark Municipal Institute of Physical Medicine and Rehabilitation (1975-present day).

Location: Maracanã

Address: Rua General Canabarro, 345.

Category: Institute of Physical Medicine and Rehabilitation

Period of construction: 1930.

Proprietor: Municipal Public Institution

Author / Constructor: unknown

\section{History:}

In May, 1930, doctor and professor of the College of Medicine Oscar Castelo Branco Clark (1890-1948), founds, in Rio de Janeiro, a philanthropic health center dedicated to preventive infantile medicine - the Oscar Clark School Clinic. This was a concern of Oscar Clark who used to defend his ideas in articles such as "The role of the elementary school"; "The edifice of public health has its base on education" and "Kindergartens" published in the 1940s, in the magazine dedicated to preventive medicine for the education of children, Revista Brasileira de Estudos Pedagógicos. His involvement with this subject made him create the chair of School Clinic in the College of Medicine; in addition to creating the José de Mendonça Hospital-School in the municipality of Araruama, state of Rio de Janeiro, in 1939, in which he also includes education through work.

The principles defended by Oscar Clark were based on a new school of Medicine, with its foundations on maternity wards, nurseries, elementary schools, kindergartens and Hospital-Schools - which, according to him, were efficient instruments in the fight against infant mortality, thus exercising what the author considers humanitarian role, in addition to guarantying the future of the nation, by means of a healthy race. The pedagogy of these schools was based on physiology and psychology, reaching the body and soul of children. His objective would be reached through physical education classes, intellectual instruction and moral education. The target-public of these institutions are children at risk, notably, malnutrition and tuberculosis.

In 1940, the School Clinic was transferred to municipal management and became known as Oscar Clark Pedagogical Medical Center, connected to the Department of School Health and General Office of Education and Culture of City Hall of the Federal District. At this time, it had health assistance services in the areas of pediatrics, ophthalmology, otorhinolaryngology and infirmary for the follow up of children who had been operated.

Four years later, in 1944, the Center is transformed into a School-Hospital, with capacity to hospitalize 150 children. In 1962, the Rehabilitation Center for the Disabled is created receiving the name Oscar Clark Institute. And, in 1975, it is incorporated into the municipal health system.

Currently, the Oscar Clark Municipal Institute of Physical Medicine and Rehabilitation is considered a reference in rehabilitation medicine in the city of Rio de Janeiro and offers polyclinic service to people with physical or sensory deficiency (whether permanent or temporary). Patients are attended by multidisciplinary teams specialized in several areas, such as physiatrists, physiotherapists, neurologists, phonoaudiologists and music therapists. Priority goes to the most serious cases, which are referred by the Municipal health system: amputates and ostomy patients.

The Institute currently maintains two units: the main unit in Maracanã and the unit in Centro. 


\section{Register of Preservation:}

It is not listed.

\section{Source:}

CLARK, O. As políticas dos campos de saúde (escolas-hospitais silvestres). Rio de Janeiro: Gráfico Canton \& Raile; 1936. http://www.afm.org.br/cadeira54.htm, Acessado em 29/08/2007.

http://www.rio.gov.br/pcrj/destaques/oscar_clark.htm , Acessado em 01 de junho de 2007.

http://www.saude.rio.rj.gov.br/servidor/cgi/private/cgilua.exe/web/templates/htm/v2/view.htm?infoid=1641\& editionsectionid=139\&user=reader, Acessado em 10 de maio de 2007;

Credits: Nathália Morais (research) and Gisele Sanglard (text) 


\section{Oswaldo Nazareth Municipal Hospital}

Other denominations: Fishermen's Polyclinic (1941); Praça XV Maternity Hospital (01/21/1974-1999); Oswaldo Nazareth Municipal Hospital (1999-present day).

Location: Centro, Rio de Janeiro - RJ

Address: Praça XV, no. 04, fundos

Category: Maternity and Hospital

Period of Construction: [XX ${ }^{\text {th }}$ Century]

Proprietor: City Hall of the City of Rio de Janeiro

Author / Constructor: unknown

\section{History:}

On March 14 $4^{\text {th }}, 1941$, the federal government created Fishermen's Polyclinic subordinate the Bureau of Game and Fishery of the National Department of Animal Production of the Ministry of Agriculture, funded with resources of the Union (Decree-Law no. 3,118 on 03/14/1941). The institution was installed in the Building of the Federal Fishery Warehouse located at Praça XV de Novembro, no. 4, in downtown Rio de Janeiro.

During the entire Vargas period (1930-1945), the State expanded considerably its intromission in the health and social security sectors with the creation, as of 1933, of the Retirement and Pensions Institutes (IAP's), which incorporated many of the Retirement and Pension Credit Unions (CAP's) that had been created in 1923. Fishermen's Polyclinic and the medical dispensaries installed in the colonies of fishermen emerged amidst a scenario where the State assumed the role of health care provider to the population. Until then, such task was the domain of philanthropic establishments and Santa Casas da Misericórdia.

Fishermen's Polyclinic provided medical, surgical, odontological, pharmaceutical, emergency and social-medical assistance care to professional fishermen and their families, residents in the city of Rio de Janeiro - at the time, Federal District - and the State of Rio de Janeiro.

The Polyclinic was composed of several clinics, dedicated to the following specializations: general medicine, pediatrics, psychiatry, neurology, dermatology and syphilography, surgery, urology, gynecology and obstetrics, ophthalmology, radiology and physiotherapy, odontology and clinical research and anatomopathology. Services were maintained by the Union and all fishermen from Rio de Janeiro were forcibly enrolled in the Polyclinic and there should receive medical care.

A year later the government enacted Decree-Law 5,030, which created the Executive Fishery Committee (CEP), linked to the Ministry of Agriculture, with the function to organize the country's fishing activity into cooperatives. The decree also transferred to CEP the responsibility of maintaining the hospital-medical care services of the polyclinics, clinics and hospitals, amongst them, Fishermen's Polyclinic of Rio de Janeiro.

In 1945, during the presidency of José Linhares (1945), the government extinguished CEP and, as a result, Fishermen's Polyclinic returned to the Bureau of Game and Fishery of the National Department of Animal Production of the Ministry of Agriculture, to where all employees were transferred, to be paid with funds from the Union's General Budget.

With the creation of the Fishery Development Superintendence (SUDEPE) in 1962, a federal autarchy, subordinate the Ministry of Agriculture, Fishermen's Polyclinic became integrated under the competence of this superintendence.

This was the period in which the Brazilian State opted to solve the problems of Public Health through the unification of the health care structures of the IAP's, this attempt started in the 50s and was formalized in 1960 through the Social Security Organic Law under the administration of Juscelino Kubitschek.

In 1967, with the creation of the National Social Security Institute (INPS), it became responsible for the functions of several existing IAP's. In 1973, under this new structure, Fishermen's Polyclinic shifted over to INPS, which had the function to provide health care to all formal employees and autonomous as long as they were taxpayers. 
Under the implementation of the National Health Program (SUS) in 1990, eleven of the seventeen hospitals belonging to the Ministry of Health in the city of Rio de Janeiro were municipalized, among them Fishermen's Polyclinic. Out of the five remaining ones, three were promoted to the category of Institutes, under the condition to propose health policies in their areas of expertise (National Trauma-orthopedic Institute, National Cancer Institute and Cardiology Institute of Laranjeiras); whereas the other two - State Employees Hospital and General Hospital of Bonsucesso - considered references in the municipal and state health systems, remained under the auspices of the Ministry of Health.

In this municipalization process, the Polyclinic was extinct and its building began to house the gynecology and obstetrics services of Lagoa Hospital, having its denomination changed to Praça XV Maternity Hospital, in a move where the location (Praça VX, no. 4/fundos) starts to give meaning to the institution.

By the end of the 90s, with the health municipalization process, Praça XV Maternity Hospital shifted from being a federal unit and became municipal and was reorganized in order to care for high risk pregnancies. Once again the institution formally changed its denomination, and, in 1999, became known as Oswaldo Nazaret Municipal Hospital, however, it is still referred to as Praça XV Maternity Hospital, by both patients and employees.

\section{Register of Preservation:}

It is not listed.

\section{Sources:}

BITENCOURT, F. Hospital dos Servidores do Estado: um patrimônio de saúde, Arquitetura e história. Rio de Janeiro, 2007, FONSECA, C. Saúde no Governo Vargas (1930-1945): dualidade institucional de um bem público. Rio de Janeiro: Editora FIOCRUZ, 2007.

Senado Federal, Decreto-Lei $n^{\circ}$ 3.118, de 14 de Março de 1941.

Senado Federal, Decreto-Lei $n^{\circ}$ 5.030, de 04 de Dezembro de 1942.

Senado Federal, Lei ${ }^{\circ}$ 3.807, de 26 de Agosto de 1960.

Credits: Lidiane Monteiro (research) and Maria Renilda Barreto (research and text). 


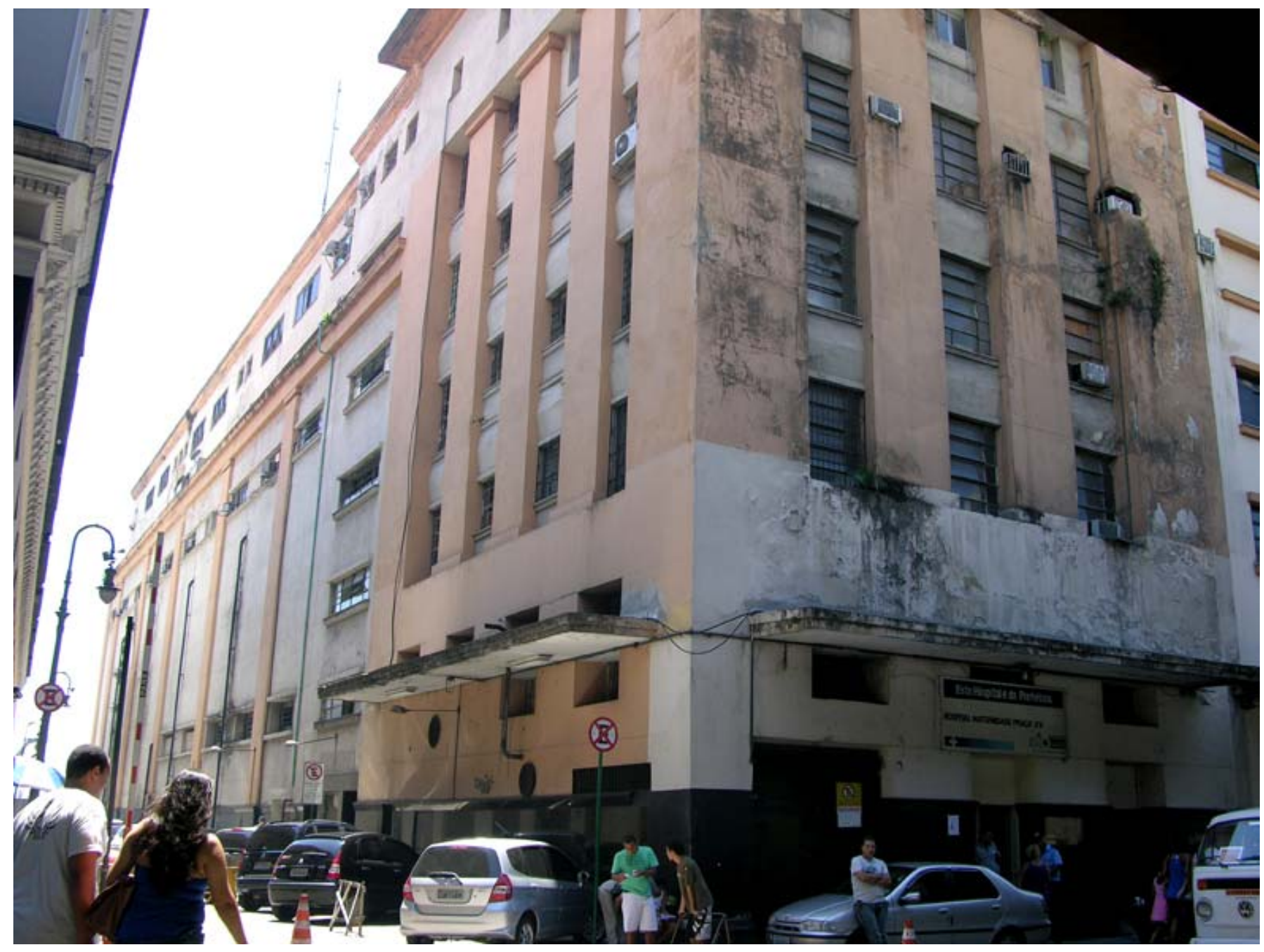

Oswaldo de Nazareth Hospital. Photo Roberto Jesus Oscar \& Vinícius Pequeno de Souza, 2008. Casa de Oswaldo Cruz Archives 


\section{Paulino Werneck Hospital Municipal}

Other Denominations: Ilha do Governador Medical Assistance Center (1914-1933); Ilha do Governador Dispensary (1933-1948); Paulino Werneck Hospital-Dispensary (1948-1951); Paulino Werneck General Hospital (1951-1975); Paulino Werneck Municipal Hospital (1975-present day).

Location: Ilha do Governador

Address: Estrada do Cacuia, 745

Category: General Hospital

Period of construction: 1933-1935

Proprietor: City Hall of Rio de Janeiro

Author / Constructor: Companhia Industrial Construtora do Rio de Janeiro

\section{History:}

The history of the Paulino Werneck Hospital began, when in August of 1914, the Ilha do Governador Medical Assistance Center was created to render assistance to the inhabitants of the region who faced great difficulties of transport and communication, above all, in emergency situations.

The transformation of the Governador Medical Assistance Center into a Dispensary, followed the plan for the construction of regional polyclinic hospitals and central or suburban dispensaries developed by the Mayor, Pedro Ernesto Batista, in his first administration in the Federal District, between the years 1931 and 1934. Included in this same plan, elaborated at the General Department of Health and Assistance of the City Hall of the Federal District, were the general Hospital of the Plan (present Pedro Ernesto Hospital), the Méier Medical Center (present Salgado Filho Hospital), the Jesus, Getulio Vargas, Carlos Chagas and Rocha Faria hospitals and the dispensaries of Ilha de Paquetá (present Paquetá Hospital) and Rocha Miranda (present Carmela Dutra Hospital). The work on these new medical-hospital assistance units was accompanied by a commission formed especially for this purpose, of which doctors Rodolpho de Abreu Fialho, Alcides Pinheiro Marques Carneiro, Alberto Borgerth and Amadeu de Barros Saraiva were members. It was the responsibility of the Companhia Industrial Construtora of Rio de Janeiro, owned by architect Luiz Moraes Jr and Archimedes d'Arthagnam Saldanha, to perform the construction services.

The foundation stone of the Dispensary was laid on September 02 ${ }^{\text {nd }}, 1933$, on land donated to the City Hall of the Federal District by Milton de Carvalho, in the name of the Companhia Geral de Habitações e Terrenos do Jardim Carioca (General Company of Dwellings and Land of Jardim Carioca). Despite the forecast of the mayor, Pedro Ernesto of two months, they were delivered in 1935. Their inauguration took place on August $06^{\text {th }}$ of that same year, with the presence of the mayor, Pedro Ernesto and various personalities from the political world besides the General Director of Municipal Assistance, Gastão Guimarães, and the Director of the Hospital, Romualdo Alves Borges. The Dispensary, open 24 hours, had a clinic service, internment and ambulances, besides a surgery theater, X-ray room, office and an infirmary with a capacity for 40 beds for adults and children.

In July of 1948, the Dispensary was elevated to the category of a Hospital-Dispensary with the name Paulino Werneck; soon afterwards, on October $15^{\text {th }}, 1951$, it was elevated once again in category: the Paulino Werneck General Hospital.

In 1960, with the transfer of the federal capital to Brasília, the state of Guanabara was formed which covered the whole of the municipality of Rio de Janeiro. At that time, the hospitals belonging to the jurisdiction of the Federal District were handed over to the jurisdiction of the state. Fifteen years later, in 1975, with the fusion of the states of Guanabara and Rio de Janeiro, some of these hospitals returned to being municipal hospitals - among them being the Paulino Werneck Municipal Hospital, while others remained as state hospitals. 
At present, the Hospital continues to be a reference for clinical and emergency services for the population of Ilha do Governador and the surrounding areas. Its maternity unit, the only one in Ilha, houses mothers and their children in joint accommodations. The clinic offers orthopedic services along with home visiting programs and cardiology, while in the infirmaries are offered internment for clinical medicine, gynecology, general surgery and orthopedics.

\section{Register of Preservation:}

It is not listed.

\section{Sources:}

ASSISTÊNCIA Pública - Guanabara: 80 anos de história. Rio de Janeiro: Superintendência de Serviços Médicos (SUSEME); 1972. mimeo.

Dispensário da Ilha do Governador. Jornal do Brasil, Rio de Janeiro, 7 de agosto de 1935, p. 12.

Foi inaugurado, solenemente, o Dispensário da Ilha do Governador. Correio da Manhã, Rio de Janeiro, 7 de agosto de 1935, p. 3. Grandes melhoramentos na Ilha do Governador. Correio da Manhã, Rio de Janeiro, 3 de setembro de 1933; p. 5.

http://www.saude.rio.rj.gov.br/servidor/cgi/private/cgilua.exe/sys/reader/htm/preindexview.htm?editionsectionid $=144 \&$ user=reader, Acessado a 03 de outubro de 2007 .

Jornal do Commercio, Rio de Janeiro, 26 de agosto de 1914, p. 5.

Jornal do Commercio, Rio de Janeiro, 3 de setembro de 1933, p. 11.

O Interventor Federal e o Ministro da Marinha visitam, juntos, a Ilha do Governador. Jornal do Brasil, Rio de Janeiro, 3 de setembro de 1933; p. 7.

O Jornal, Rio de Janeiro, 7 de agosto de 1935, p. 3.

RIBEIRO, L. Medicina no Brasil. Rio de Janeiro: Imprensa Nacional, 1940.

Credits: Nathalia Morais (research); Gisele Sanglard (text) 


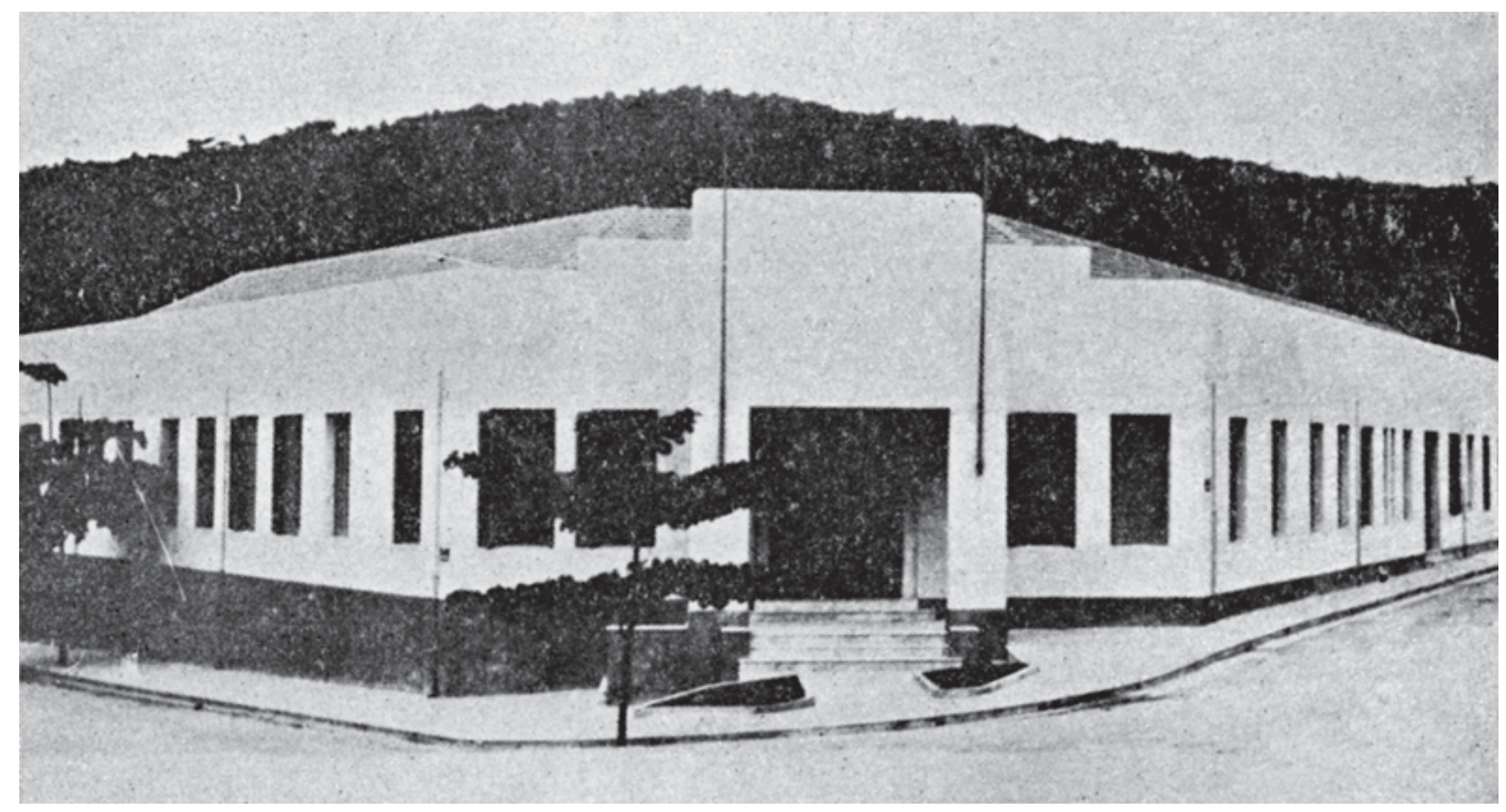

Paulino Werneck Hospital, [s.d.]. Source: Ribeiro, 1940

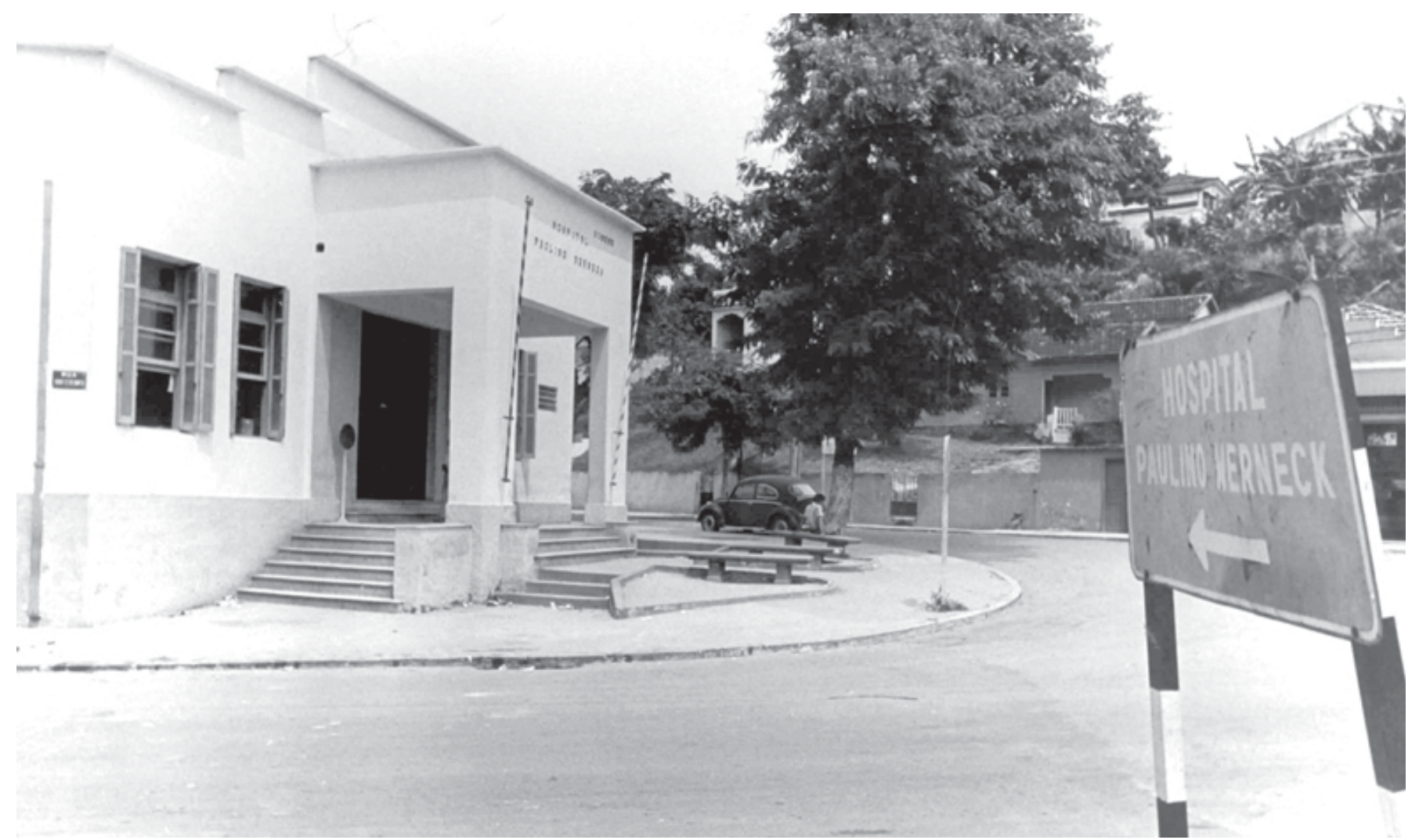




\section{Pedro Ernesto University Hospital}

Other denominations: Polyclinic Hospital (1932-194?); Pedro Ernesto General Hospital (194?-1961); Pedro Ernesto Hospital-School of the Faculty of Medical Sciences of the University of the State of Guanabara (1961-1965); Pedro Ernesto Clinical Hospital of the University of the State of Guanabara (1965-1975); Pedro Ernesto University Hospital (1975present day).

Location: Vila Isabel

Address: Avenida 28 de setembro, 77; Avenida Prof. Manuel de Abreu, 444.

Category: University Hospital

Period of construction: 1938.

Proprietor: University of the State of Rio de Janeiro.

Author / Constructor: Companhia Industrial Construtora do Rio de Janeiro.

\section{History:}

The construction of this hospital followed the hospital plan developed by the Mayor, Pedro Ernesto Batista, in his first administration in the Federal District, between the years 1931 and 1934. The plan foresaw the construction of regional polyclinic hospitals and dispensaries, either in the center or in the suburbs, elaborated at the General Department of Health and Assistance of the City Hall of the Federal District. It included the Méier Medical Assistance Post (present Salgado Filho Hospital), the Jesus, Getúlio Vargas, Carlos Chagas and Rocha Faria hospitals and the dispensaries of Ilha do Governador (present Paulino Werneck Municipal Hospital), of Ilha de Paquetá (present Paquetá Hospital) and of Rocha Miranda (present Carmela Dutra Hospital).

The works on these new medical-hospital assistance units were accompanied by a commission specifically set up for this purpose, in which the doctors, Rodolpho de Abreu Fialho, Alcides Pinheiro Marques Carneiro, Alberto Borgerth and Amadeu de Barros Saraiva participated. The execution of the work was the responsibility of the Companhia Industrial Construtora of Rio de Janeiro, owned by the architect, Luiz Moraes Jr and by Archimedes d'Arthagnam Saldanha.

The Pedro Ernesto Hospital was the most important of the central hospitals, being constructed with a capacity for 700 beds, with a first aid service, outpatient department, nursing, an institute of mechanotherapy and physiotherapy, an institute of pathological anatomy and related services, such as a pharmacy, a clinical research laboratory, among others. Among the clinics, the most important were the surgical, medical, obstetrics, dermatological and the otorrhinolaryngology and ofthalmological clinics.

In 1950, it was inaugurated as a hospital participating in the hospital network of the Department of Health of the Federal District, incorporating medical speciality services transferred there by the city hall, such as the Institute of Neurology, the Helion Povoa Allergy Institute, the Cardiology Institute, a Surgical Center, Surgical Clinic, Gynecological Clinic and the Santa Luzia Clinic for the Blind. In 1962, it became a Hospital-School of the Faculty of Medical Sciences of the University of Estado da Guanabara, and in 1964, a Clinical Hospital.

Up to then, its activities gave exclusive priority to academic issues of teaching and research, with the accompaniment and the study of clinical rarities and diseases in a final stage of evolution. In 1975, as a result of an Agreement signed with the Ministry of Education and Social Welfare, the Pedro Ernesto Hospital adapted its activities to serve the population in general, transforming it into one of the biggest teaching-medical care complexes in the area of health.

Medical care was not free for all the population. The hospital reserved a number of beds proportional to the allocation made by the State Government to the Clinical Hospital, to care for the medical-hospital poor, who would be a kind of patient with rights to internment and outpatient consultations and a discount in the use of medicines and auxiliary diagnosis and treatment services. 
In 1960, with the transfer of the federal capital to Brasília, the Estado da Guanabara was created that included the whole of the municipality of Rio de Janeiro. At that time, the hospitals belonging to the city hall of the Federal District were transferred to state jurisdiction. Fifteen years later, in 1975, with the fusion of the states of Guanabara and Rio de Janeiro, some of these hospitals returned to the condition of being municipal hospitals; while others remained as state ones, this being the case of the Pedro Ernesto Hospital, previously linked to the University of Estado da Guanabara and presently to the University of the State of Rio de Janeiro.

With the creation of the National Institute of Social Welfare (INPS) in 1967, the Institute sought to make agreements with some university hospitals in order to increase the care network to those insured in a system of internment - in this agreement the outpatient and psychiatric services were excluded, the former being incorporated to the network of assistance of the SUS, as from 1974.

In 1975, the Pedro Ernesto University Hospital (HUPE) inaugurated the Adolescents Ward, the first of its kind in Brazil to offer specialized service. In 1991, seeking to follow the same philosophy of attention to a specific age group, it created the Center of Care for the Elderly, which concentrates on uniting together physical, social, psychological and educational aspects of care.

Presently, the HUPE is held as the largest public hospital in operation in the State of Rio de Janeiro, besides being a reference in innumerable medical specialities. Lastly, it presents itself as a sub-regional coordinating center of an information network about adolescents, coordinated by Bireme/OPAS/OMS, among others.

\section{Architectural description:}

It is a five floor building that exploits the language at times recognizable as inspired in the present German modernism, having Erich Mendelsohn as its greatest example, and at other times classified as being inspired in art déco, whose main feature is its curved varandas that project out over the corners and the main entrance. Its architecture also seeks a reference in the European sanatoriums in its therapeutic use of varandas.

\section{Register of Preservation:}

It is not listed.

\section{Sources:}

BARBOSA, F. Instituto de anatomia patológica do Hospital Policlínico. Revista Municipal de Engenheira, Rio de Janeiro, mai. 1938.

COSTA, L. Memorial de um sonho anunciado: a incorporação do Hospital Pedro Ernesto à Faculdade de Ciências Médicas da UEG. Rio de Janeiro, 2004. (Tese de doutorado)

Decreto-Lei n. 8.030, de 3 de outubro de 1945.

Experiência do Hospital de Clínicas da Universidade do Estado do Rio de Janeiro. Revista Paulista de Hospitais, São Paulo, Vol. XXV, n. 7, julho de 1977, p. 293-294.

Credits: Guilherme Marcondes, Felipe Abdala (research) Renato da Gama-Rosa Costa (research, text and architectural description). 


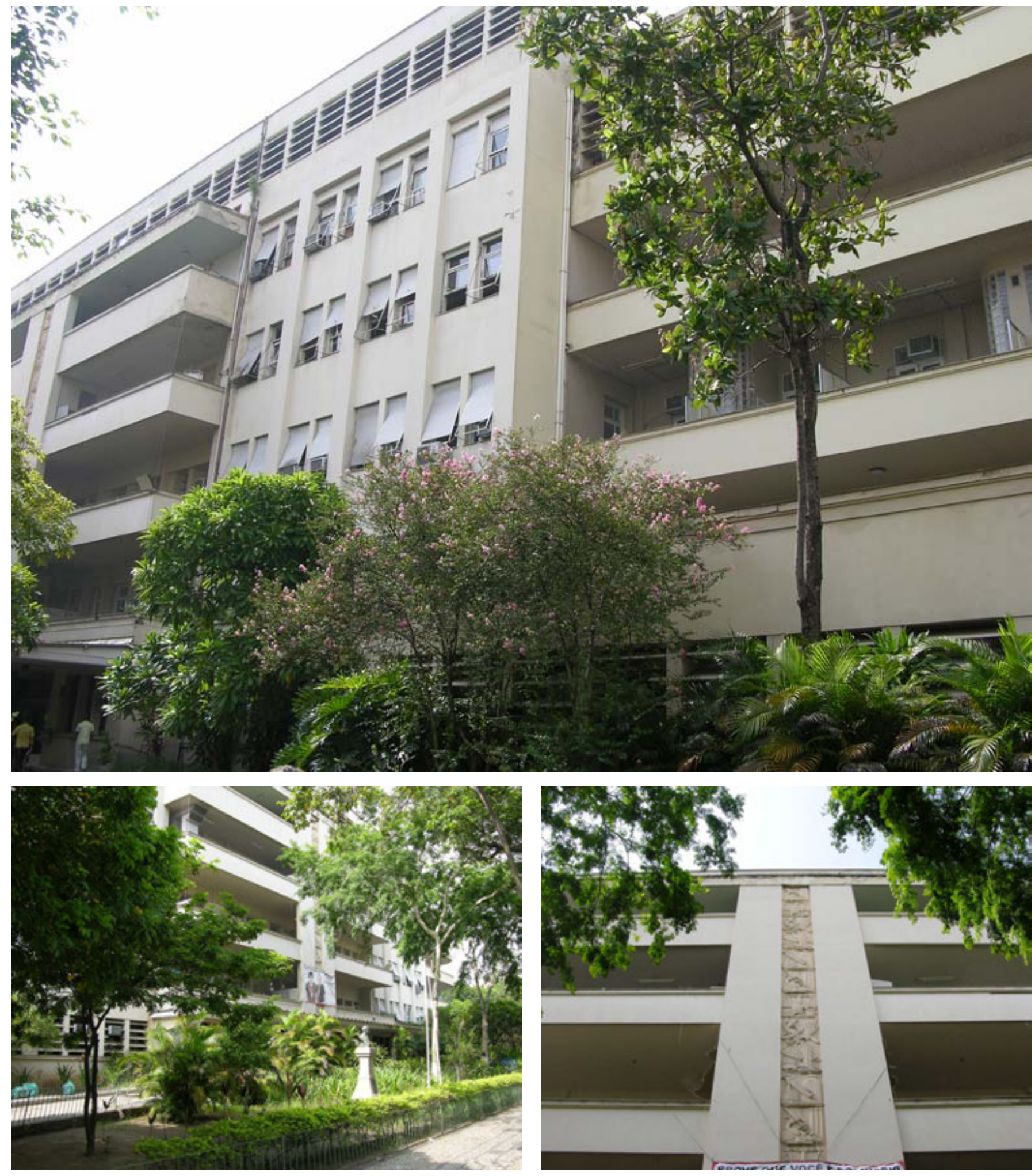

Pedro Ernesto Hospital. Photo Roberto Jesus Oscar \& Vinícius Pequeno de Souza, 2008. Casa de Oswaldo Cruz Archives 


\section{Psychiatry Institute of Rio de Janeiro Federal University (IPUB-UFRJ)}

Other denominations: Psychiatry Institute of Brazil University (1938-1965); Psychiatry Institute of Rio de Janeiro Federal University (1965-present day)

Location: Praia Vermelha

Address: Avenida Wenceslau Brás, no. 71 - (rear).

Category: Research/educational institution

Period of construction: unknown

Proprietor: Federal University of Rio de Janeiro

Author / Constructor: unknown

\section{History:}

The embryo of the present Institute of Psychiatry of the Federal University of Rio de Janeiro goes back to the old Observation Pavilion of the National Asylum for the Mentally Ill, an annex created by decree no. 1.559, of 10/07/1893, which re-organized the Medical/Legal Welfare Service for the Mentally Ill. The work undertaken in this Pavilion was restricted to the procedures of the Faculty of Medicine of Rio de Janeiro, under the direct responsibility of the professor of the discipline of psychiatry and nervous illnesses. The activities carried out there constituted a sort of preliminary evaluation service for the internment of non-paying patients sent by the public authorities. The idea behind this Pavilion followed the French model of psychiatry, which defended treatment in asylum type institutions, the latter also serving as a field for the development of psychiatric science and for the training of professionals.

The classes open to the students of the sixth year of the Faculty of Medicine of Rio de Janeiro were given in the annexes of the Observation Pavilion, counting as a school semester. Although only attendance was required, few students showed interest in the classes, for specialization in mental illnesses was still a cause for uncertainty due to the low salaries and the remote possibility of a cure resulting from such hard work.

Then in the XX century the Observation Pavilion was renamed the Institute of Psychopathology, then subordinate to the Psychopath Welfare Service of the Federal District. On August 03 ${ }^{\text {rd }}, 1938$, due to decree-law no. 591, the referred to institute was transferred to the then called University of Brazil, constituting the IPUB. It is in these first decades that the Rodrigues Caldas Pavilion was also created in the National Asylum for the Mentally Ill, which was later incorporated into the Institute of Psychiatry of the University of Brazil.

With the creation of the IPUB at the end of the 1930's, an institutional space was inaugurated directed exclusively to the scientific investigation of mental illness, making psychiatric science autonomous in relation to the task of formulation and development of a public welfare policy. With regard to the scientific psychiatric field, the French model had already begun to be put aside due to the adoption of the German model for treating the mentally sick, which saw in the constant experimental research, the possibility of a cure, based on the study of mental illnesses as organic illnesses. Insanity became an object to be investigated, a source of knowledge and not only a part of the speech to make official the practice of welfare policies.

This scientific approach followed the psychological paradigms professed by Émil Kraepelin, who associated studies in neuropathology, neurophysiology, serology, genetics and experimental psychology. This combination confirmed the inspiration for the creation of the IPUB from the German Institute for Psychiatric Research (Deutsche Forschungsanstalt für Psychiatrie), founded by the German psychiatrist in 1917. This research arrived in Brazil at the beginning of the XX century by isolated initiatives of doctors such as Juliano Moreira (director of the National Asylum for the Mentally Ill) and Henrique Roxo (as head professor of psychiatry of the Faculty of Medicine of Rio de Janeiro), who travelled constantly to Europe, coming into contact with the new scientific ideas. 
The IPUB had as its first directors illustrious names from the area of psychiatry: Henrique de Brito Belford Roxo (19381946), Maurício Campos de Medeiros (1946-1956) and Adauto Botelho (1956-1958).

During the administration of Henrique Roxo, the Institute maintained the link with the National Asylum for the Mentally Ill, the Rodrigues Caldas Pavilion functioning as an experimental field - material for studies and classes of the Faculty of Medicine of the University of Brazil. This relationship would only be interrupted in 1944, with the transfer of the mentally ill patients to the Juliano Moreira Colony in Jacarepaguá and the Colony of Engenho de Dentro. It was also under his administration that there came into being, in 1942, the Anals of the Institute of Psychiatry, an official entity for publishing the works of the Institute, renamed as the Brazilian Journal of Psychiatry in 1948.

Maurício Campos de Medeiros collaborated with the deepening and valorization of the studies into mental health on suggesting to the Board of the above mentioned faculty, in 1946, a re-organizing of the programs of the discipline of psychiatry, and this began to be offered during two semesters of the fourth year of the medical course, with compulsory attendance, partial tests and a final examination.

Two years at the head of the Institute of Psychiatry of the University of Brazil were sufficient for Adauto Botelho to create an outpatients at the unit, a practice that he had been adopting since 1944, when he began to disseminate the organization of modest mental health outpatient clinics in the city of Rio de Janeiro.

Notwithstanding the fact that, up to the end of the 1950's, the directors of the IPUB had occupied important positions in the federal care service, since its foundation, the institution adopted a posture of consolidating itself as a center of academic excellence, directed toward scientific practice, the production and application of knowledge, fleeing from closer relationships with the establishment and the propagation of public welfare policies.

Being today an auxiliary entity of the Center of Health Sciences (CCS), of the Federal University of Rio de Janeiro (UFRJ), it maintains the identity of its creation, acting as a unit of reference for scientific research and improvement of studies in psychiatry, with post-graduate, extension and specialization courses, in the area of mental health. The educational and welfare activities are financed by the Unified Health System (SUS) and by the Ministry of Education and Culture (MEC).

It has at the present time, two infirmaries divided according to gender and outpatient clinics divided according to age (adults, children/adolescents and the elderly). In 2006, the Institute inaugurated a unit to care for users of toxic substances, including the alcohol and drugs service which had been created 10 years previously. It also administers three units of assisted residence, besides its headquarters at the Campus of the Federal University of Rio de Janeiro (UFRJ), at Praia Vermelha.

\section{Register of Preservation:}

It is not listed.

\section{Sources:}

VENÂNCIO, A. Ciência psiquiátrica e política assistencial: a criação do Instituto de Psiquiatria da Universidade do Brasil. História Ciência e Saúde - Manguinhos, Rio de Janeiro, vol.10, nº.3, set./dez., 2003.

Credits: Atiele Azevedo de Lima Lopes (research and text) 


\section{Raphael de Paula Souza Municipal Hospital}

Other denominations: Curicica Sanatorium (1952-1971); Raphael de Paula Souza Hospital (1971-2002); Raphael de Paula Souza Municipal Hospital (2002-present day).

Location: Jacarepaguá

Address: Estrada da Curicica, 2000

Category: Sanatorium for tuberculous patients.

Period of construction: $1948-1952$

Proprietor: City Hall of the City of Rio de Janeiro

Author / constructor: Sérgio Bernardes

\section{History:}

The Curicica Sanatorium Complex was constructed during the administration of Raphael de Paula Souza (1946-1951) while he was the Director of the National Tuberculosis Service. In order to cope with the large number of tuberculous patients in critical state and requiring hospitalization, it was necessary to construct a hospital of great proportions, somewhere around 24,000 squared meters. Given the immense area available for the construction of the complex, the land of the old Curicica estate was chosen.

The entire construction was accompanied with great expectation, receiving much praise upon its completion, as demonstrated by expressions collected from discourses and reports of the time: "a great work of architecture and sanitary engineering" and "the biggest and most complete sanatorium for the tuberculous in South America".

The first inauguration on January $25^{\text {th }}, 1951$, was symbolic in character and made good use of the presences of Eurico Gaspar Dutra, who would leave the Presidency of the Republic six days later, and of Raphael de Paula Souza himself, who would remain as Director of the National Tuberculosis Service until June $18^{\text {th }}$ of the same year. Some reports attest that the complex began to be occupied on January $2^{\text {nd }}, 1952$, thus this is the date that marks the birth of the institution.

The program for the sanatorium included the capacity for 1,423 beds; accommodations for the director, doctors, staff, nurses, assistants, etc.; an electric plant with capacity for $80 \mathrm{KVA}$; a water treatment station; a complete radiology center; a cafeteria for four thousand meals daily; a laundry; a garbage incinerator, in addition to a freezer.

The complex was composed of 23 services spread out over interlinked pavilions containing a lobby, administration, library, mortuary, infirmaries, medical center, maternity ward, surgical center, laboratory, vivarium, general services, accommodations, house of the director, sewage treatment station and an electricity and power substation.

The Rehabilitation Center was created by Lourival Ribeiro in 1957. The project of the Church was completed on February $10^{\text {th }}, 1958$ and its construction began that same year. Thus, in 1958, the Complex was composed of 16 pavilions, beginning to operate, in addition to the ones already mentioned previously, radiology services, a blood bank, a pathological anatomy department, a dentistry department, a pharmacy, a press office and a physical therapy department, in addition to the Rehabilitation Center.

This center had 20 sectors, and included: a Shoe-repair shop; Watch-repair shop; Radio workshop; Tailoring and Sewing School; Broom and duster making; Typography; Bookbinding; Manual Work; Toy repair and assembly; Furniture making; Weaving and drawing courses, photography, hair salon, adult alphabetization, languages, tachygraphy, typewriting and dental prosthesis.

In 1971, it received the name Raphael de Paula Souza Hospital, in homage from the National Tuberculosis Service to its idealizer. This alteration in nomenclature further indicated a change in the services rendered up to then. Slowly, the sanatorium services gave way to general hospital services. The Church, for example, was deactivated in 1984 and in it was installed the Professor Pereira Filho Center of Studies. In another part of the sanatorium complex was installed the 
Professor Hélio Fraga Center of Reference, created in 1986. And in 2002, the hospital was assigned to the municipality, having, currently, a profile of assistance based on hospitalization and polyclinic treatment, with the capacity for 96 beds.

\section{Architectonic description:}

The project was developed by Sérgio Bernardes, then chief architect of the Architecture section of the National Campaign against Tuberculosis. Work began on May $08^{\text {th }}, 1949$ and the adoption of module architecture utilized a system of prefabricated modules in reinforced concrete, allowing for cost-cutting and speed of work. All of the assembling of the structure, as well as the calculation work, were the responsibility of the chief of the engineering sector of the Campaign, the engineer Julio Coacy Pereira, and the work was under the direction of the engineer Newton Kubrusly.

The architectural program followed the technical premises elaborated by the National Tuberculosis Service, previously approved by the Ministry of Education and Health, whose general recommendations followed the study and the standardization of the construction of Campaign type sanatoriums and dispensaries: efficiency, low cost and economical maintenance, without, however, sacrificing technical and functional qualities.

Although, at the time, the single-block system was already widely in use, the one with pavilions was adopted, more suited for the treatment of pulmonary tuberculosis, due to its better isolation of patients in diverse stages of infection, until they were apt to occupy the facilities of the Rehabilitation Center and prepare for their return to society.

Lastly, according to Lourival Ribeiro, research performed by specialists revealed a high degree of reclusion in ill patients hospitalized in single-block sanatoriums, leading the architect to project the Sanatorium Complex with special characteristics to avoid such a psychological state.

At the inauguration on January $25^{\text {th }}, 1951$, President Eurico Gaspar Dutra demonstrated that the concern in adhering to the recommendations of the program of the National Tuberculosis Service had been fully met, due to the functionality and the flexibility achieved by the project, reinforcing the already established concept at the time, of Brazil modern architectonic school.

\section{Register of Presevation:}

It is not listed.

\section{Sources:}

As comemorações do $1^{\circ}$ Aniversário do Sanatório de Curicica. Revista Brasileira de Tuberculose. Ano $21 . \mathrm{N}^{\circ}$ 145, jan/fev. 1953.

Boletim da Campanha Nacional Contra a Tuberculose. Ano I, n ${ }^{\circ}$ 1, jan., 1952.

DUTRA, G. Discurso. 25 de janeiro de 1951. Transcrito em Inaugurado o Conjunto Sanatorial de Curicica. Revista Brasileira de Tuberculose. Ano 19, Jan/jun., 1951. Pág. 204.

NASCIMENTO, D.; COSTA, R.; PESSOA, A.; MELlO, E. Sanatório de Curicica: um Sérgio Bernardes pouco conhecido. Online. Disponível na Internet: www.vitruvius.com.br

Revista Brasileira de Tuberculose, jan/jun. de 1951, pág. 207.

RIBEIRO, L. O conjunto sanatorial Raphael de Paula Souza. In: Pelos Caminhos da Medicina. Cap. XXIII. Rio de Janeiro, Vecchi, 1976, pág. 174.

Credits: Renato da Gama-Rosa Costa (research, text and architectonic description). 

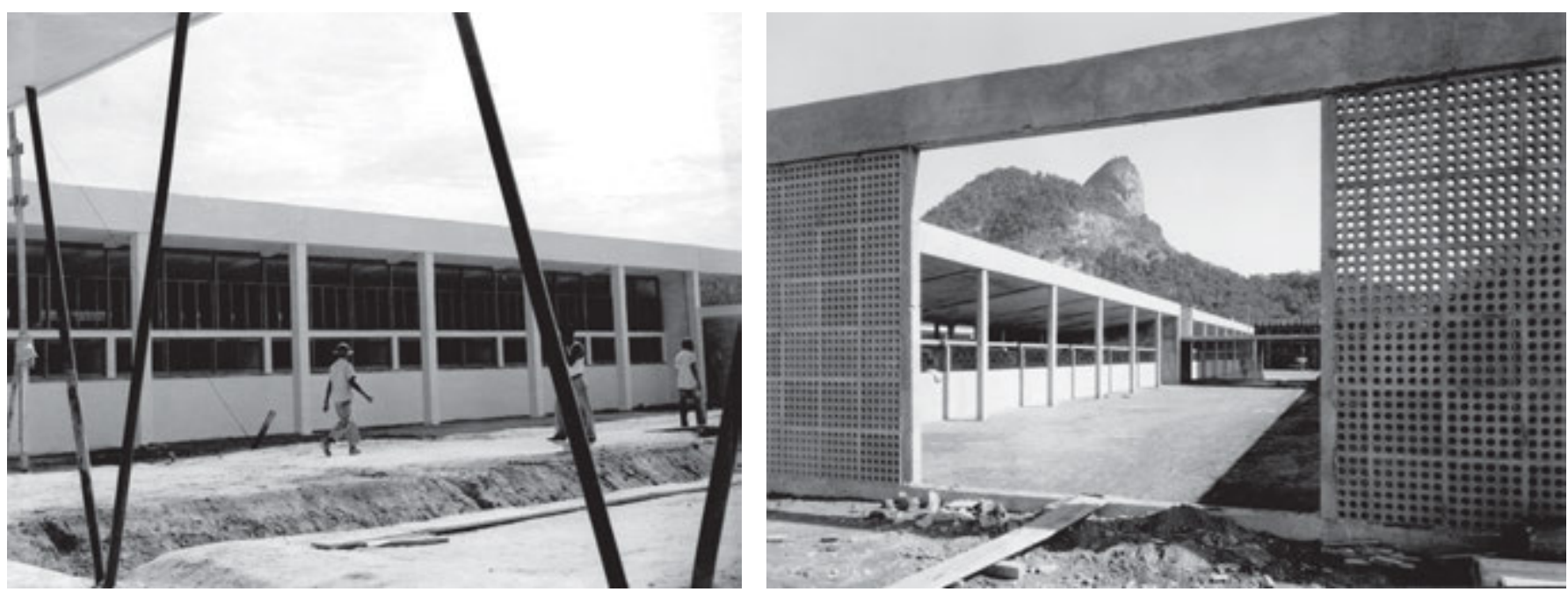

View of Curicica Sanatorium Construction works, [s.d.]. Raphael de Paula Souza Fund. Casa de Oswaldo Cruz Archives

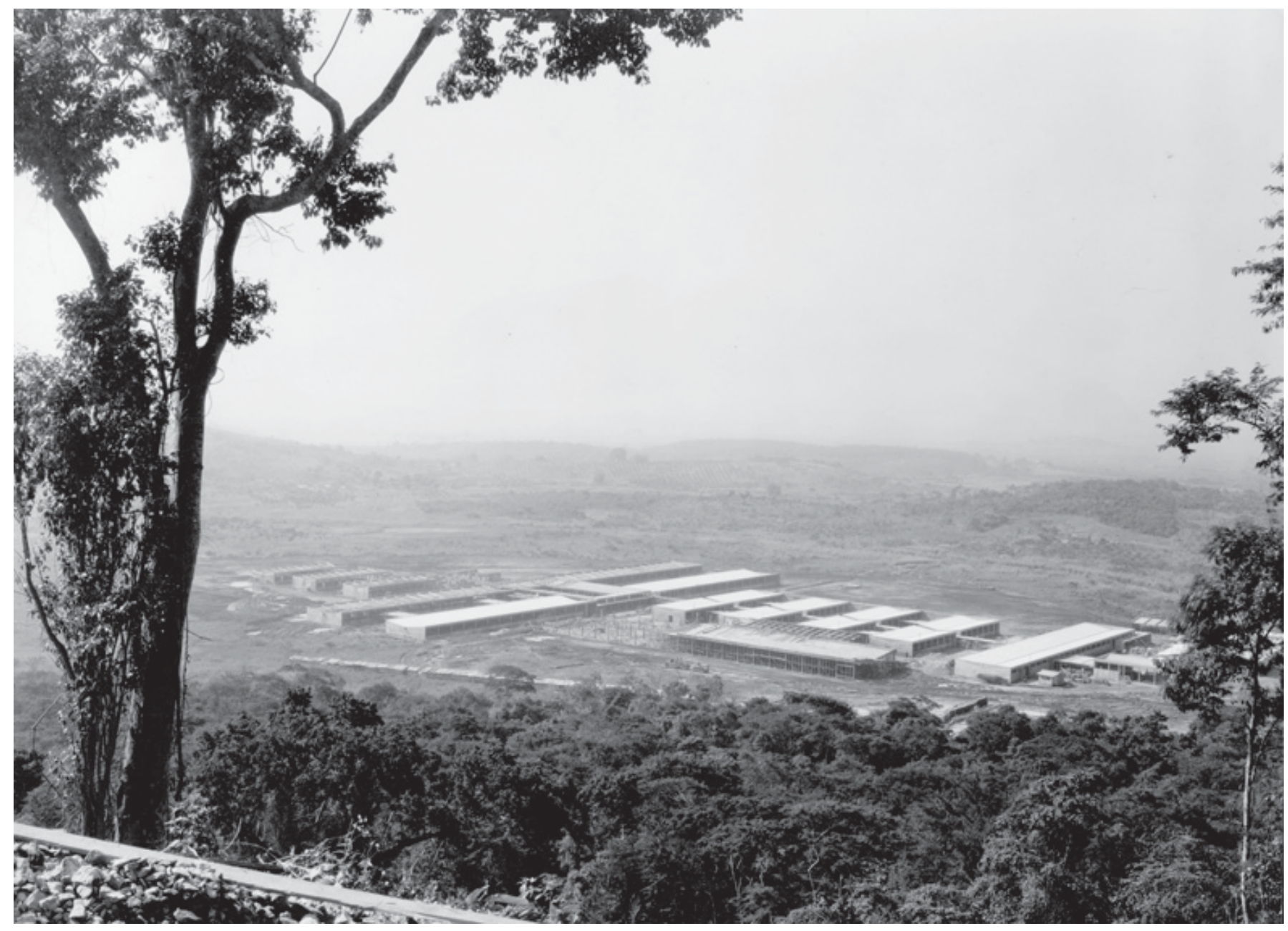

General view of Curicica Sanatorium, [s.d.]. Raphael de Paula Souza Fund. Casa de Oswaldo Cruz Archives 


\section{Rehabilitation Center of the National Cancer Institute.}

Other denominations: Disinfection Center of the Quarantine and Disinfection Inspection Service (1905); General Office of Public Health (1906-1919); National Department of Public Health (1919-1930); Maternal-infant Service of the City Hall of the Federal District (1939-1950); Oswaldo Cruz Health Center (1950-1975); National Tuberculosis Service (1975); Rehabilitation Center of the National Cancer Institute (current).

Location: Downtown

Address: Rua do Resende, 128

Category: Institution of rehabilitation.

Period of construction: 1905.

Proprietor: National Cancer Institute (INCA).

Author/constructor: Luiz Moraes Júnior (architect).

\section{History:}

The General Office of Public Health (DGSP) was created in 1897, subordinate to the Ministry of Justice and Internal Affairs. This office was basically responsible for the coordination of the sanitary services of the fluvial and maritime ports, supervision of medicine and pharmacy practices, studies about infectious-contagious diseases, the organization of demographic-sanitary statistics and for providing assistance to the states. During the administration of Oswaldo Cruz (1903-1909), the DGSP began to incorporate the services of defensive hygiene, sanitation enforcement, the general and specific prophylaxis of contagious diseases and the activities of residential hygiene, without, however, having its own building.

The construction of the headquarters and of the Disinfection Center of the Quarantine and Disinfection Inspection Service started on November 19th 1905 , still under the administration of Oswaldo Cruz and occurred in conjunction with the construction of the architectonic complex proposed by the sanitation doctor for the then Federal Serotherapy Institute, the principal general headquarters for the actions of sanitation reform proposed by the scientist. These actions included the construction of two more disinfection stations - one in Botafogo, to service the south side of the city and another in São Cristóvão, to service the north side. The property chosen to house the central service was Rua do Resende, no. 118 (currently 128).

The works underwent difficulties between 1907 and 1909, with the construction of the ground floor and from 1911 to 1914, when the first and second floors were inaugurated, under the administration of Carlos Seidl (1909-1919). The rapid completion of the works was a result of the very bad conditions of the primitive facilities of the DGSP. The new building contained the repartitions of the General Administration (office, archives, demographic-sanitary section, pharmaceutical section and commission of validity exams); and of the Sanitary Engineering. To the same location would be transferred the Health Enforcement Department, the Museum of Hygiene, the Bacteriology Laboratory and the Superintendence of Prophylaxis Services. With the Public Health Reform of 1919, proposed by Carlos Chagas, targeting a centralized strategy in the actions of national health - which would be applied in the states through conventions - the DGSP began to be known as the National Department of Public Health (DNSP).

Between 1929 and 1930 improvements were made to the headquarters by the administration of Mayor Antonio Prado Junior (1926-1930), with the construction of annexes and the execution of repairs on the main building, with the purpose of amplifying the administrative bodies and the technical development of the DNSP. In 1939, nine years after the extinction of the DNSP, the headquarters was transferred to the municipal sphere, and began to house the maternalinfant services. Much work was performed until the 1950's, when it became known as the Oswaldo Cruz Health Center.

Currently, the building complex houses sectors of the National Cancer Institute, such as the Rehabilitation Center, the Coordination Office of Teaching and Scientific Publishing and the Coordination Office of General Administration. 


\section{AFTER 1930}

\section{Architectonic description:}

The project - first developed with two floors and later another was added, during construction - was given to the same author of the buildings in Manguinhos, Luiz Moraes Júnior, the architect who executed the works for Oswaldo Cruz. Moraes would be responsible for the project of other health related projects, such as the Disinfection Center of Botafogo, the current Rocha Maia Hospital and the building of the College of Medicine in Praia Vermelha. In the architecture of the Administration headquarters there appear some constructive and finishing elements common to the ones utilized by Moraes in other cited projects, such as granite, wood, window and door frames, ornamentation and arrangements. Especially one element, the tower of the façade on Rua do Resende, suggests a preference for the Moorish style, which would be fully utilized in the main building of the then Oswaldo Cruz Institute (currently Fiocruz). This same tower would also appear a crest element of the central tower on the Cruz Family residence, at Botafogo Beach.

The architectonic program for the headquarters develops into three interlinked blocks: the façade to Resende Street more retreated, adding value to the side entrance - , the larger rectangular one, which develops perpendicularly to the street and the back, composed of a smaller rectangle. Its facilities followed what was most advanced at the time, the resemblance to the ones utilized in Manguinhos, demonstrates the extreme care Oswaldo Cruz and Moraes had in their projects.

\section{Register of Preservation:}

Listed by the municipality on September $08^{\text {th }}, 1987$.

\section{Sources:}

CZAJKOWSKI, J. Guia da Arquitetura Eclética no Rio de Janeiro. Rio de Janeiro: Centro de Arquitetura e Urbanismo, 2000.

FALCÃO, E. Oswaldo Cruz Monumenta Histórica: campanhas e inquéritos sanitários. São Paulo: s.n, 1972. v.6. (Brasiliensia Documenta).

OLIVEIRA, B. Da antiga sede da Diretoria Geral de Saúde Pública (DGSP) ao atual Instituto Nacional do Câncer (INCA). História, Ciências, Saúde - Manguinhos, Rio de Janeiro, v.14, n.1, p. 325-346, jan.-mar. 2007.

Credits: Renato da Gama-Rosa Costa (text and architectonic description). 


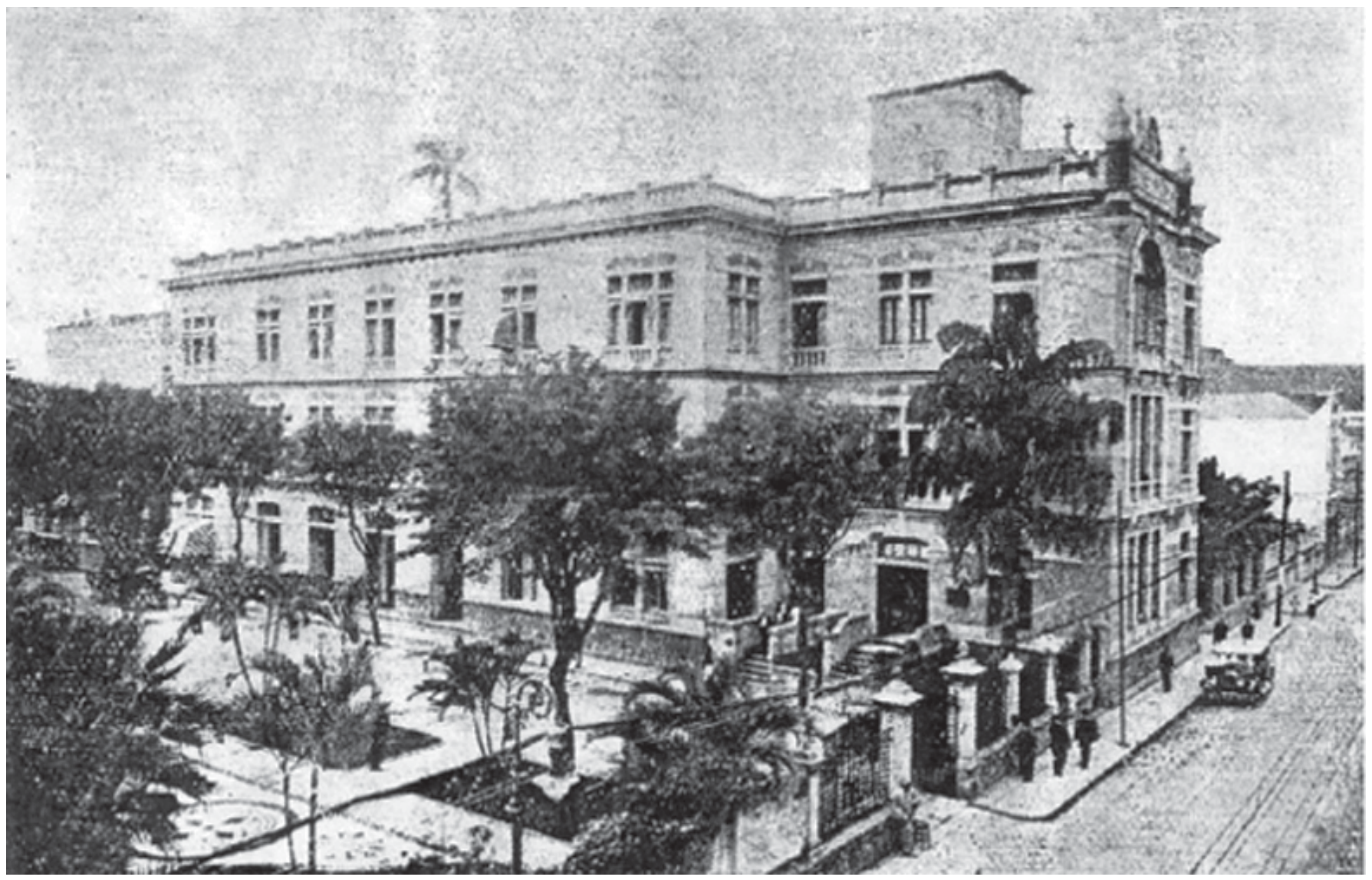

Diretoria Geral de Saúde Pública Centre, [s.d.]. Source: Arquivos de Higiene, 1927

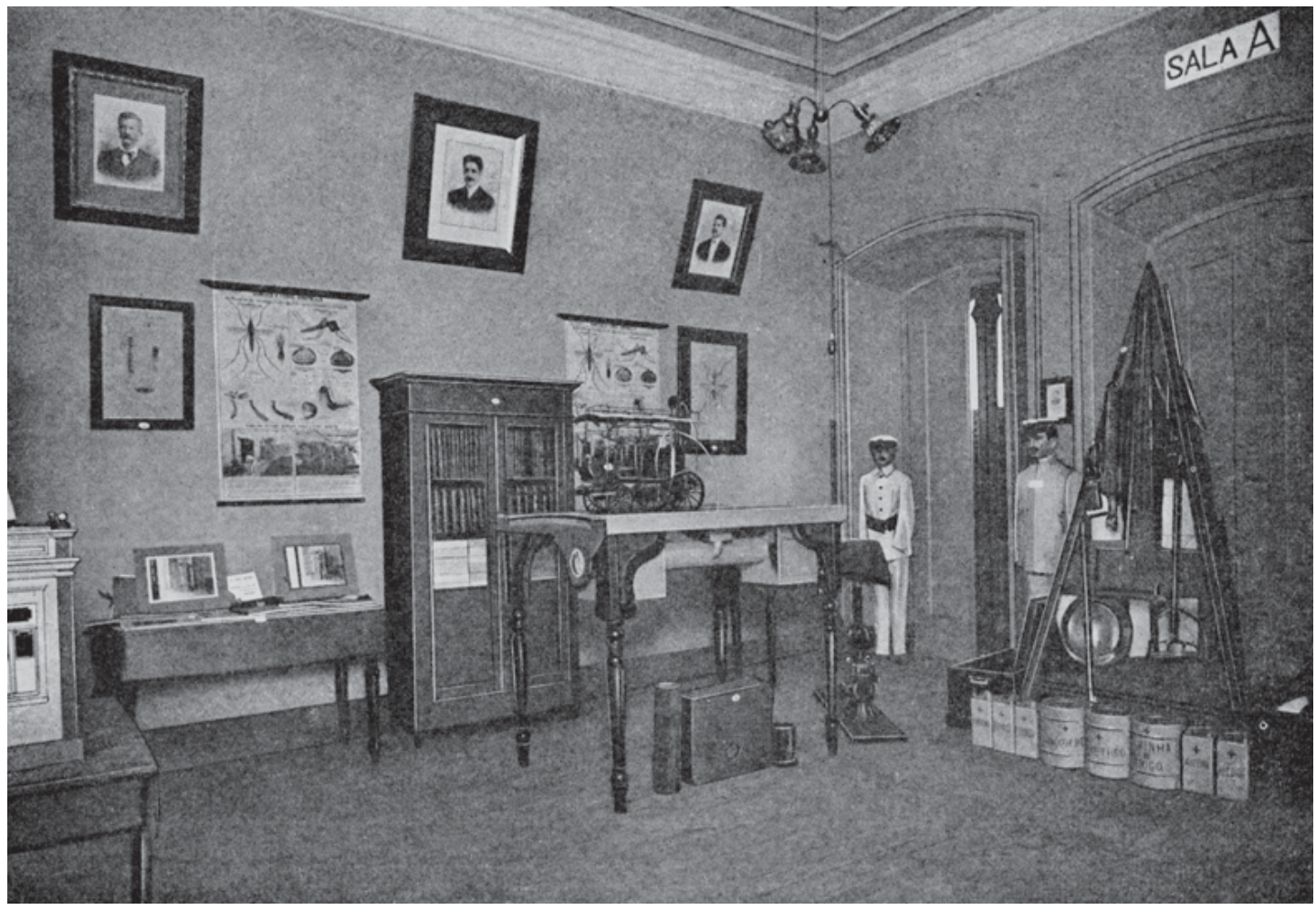




\section{Rocha Faria State Hospital}

Other denominations: Campo Grande Polyclinic Regional Hospital (1933-1940); Rocha Faria Hospital (1940-1975); Rocha Faria State Hospital (1975-present day).

Location: Campo Grande.

Address: Av. Cesário de Melo, no. 3215.

Category: General Hospital.

Period of construction: 1940.

Proprietor: Government of the State of Rio de Janeiro.

Author / Constructor: Companhia Industrial Construtora of Rio de Janeiro

\section{History:}

The construction of Rocha Faria Hospital followed the plan of construction of regional or central and suburban polyclinic hospitals and dispensaries, developed by Mayor Pedro Ernesto Batista in his first administration of the Federal Capital, through the years of 1931 and 1934. In this same plan, administered in the General Management of Municipal Assistance, there was the General Hospital of the plan (currently Pedro Ernesto Hospital), the Assistance Center of Méier (currently Salgado Filho Hospital), the Jesus, Miguel Couto, Carlos Chagas and Getúlio Vargas hospitals and the dispensary of Ilha do Governador (currently Paulino Werneck Municipal Hospital), of Ilha de Paquetá (currently Hospital of Paquetá) and of Rocha Miranda (currently Carmela Dutra Hospital). Works on these new units of medical-hospital assistance were accompanied by a commission comprised especially for such purpose, in which doctors Rodolpho de Abreu Filho, Alcides Pinheiro Marques Carneiro, Alberto Borgerth and Amadeu de Barrol Saraiva participated. It was the responsibility of the Companhia Industrial Construtora of Rio de Janeiro, whose owners were architect Luiz Moraes Jr and Archimedes d'Arthagnam Saldanha, to carry out the construction work.

On August 13 $3^{\text {th }}, 1933$, Getúlio Vargas, president of Brazil at the time, together with the mayor of the Federal District, Pedro Ernesto and the General Director of Municipal Assistance, Gastão de Oliveira Guimarães, laid the cornerstone of Campo Grande Polyclinic Regional Hospital.

However, the hospital was only inaugurated in 1940, already with the name Rocha Faria, with the presence of Getúlio Vargas and the mayor of Federal District, Henrique Dodsworth (1937-1945). On the same date the cornerstone of a pavilion for expanding the service was laid. This pavilion was only ready in 1946, when it was inaugurated by the mayor at that time, Hildebrando de Araújo Góes (1946-1947) and by Samuel Libânio, as General Secretary of Health and Assistance.

In the government of Carlos Lacerda (1960-65) for the State of Guanabara, there arose the plan of constructing a new block in the Hospital, which would be used for Maternity and Emergency Services. This block was inaugurated in 1967 by the governor Negrão de Lima (1965-1970).

In 1960, with the transfer of the federal capital to Brasília, the State of Guanabara was created encompassing the entire municipality of Rio de Janeiro. At this time, the hospitals belonging to City Hall of the Federal District came to have state jurisdiction. Fifteen years later, in 1975, with the merging of the states of Guanabara and Rio de Janeiro, some of these hospitals returned to the condition of municipal hospitals, while others remained state hospitals - among these Rocha Faria.

Tears later, a new Surgical Center, Centers of Intensive Treatment and Post-Anesthetic Recovery and the Auditorium of the Study Center were constructed. There were also constructed new facilities for storing clothes, a laundry and Medical Residence.

Today it is still considered a reference for emergency services in its area of operation. It is one of the few State hospitals to provide an obstetrics service - together with Alberto Schweitzer and Pedro II; besides the medical and surgical clinic specialties; and pediatrics - common to all hospitals of the state health system. 


\section{Architectonic Description:}

From the decade of 1960, many hospitals would undergo reforms and expansion works. The old facilities of these hospitals, in their great majority, constructed in the decade of 1930, by Pedro Ernesto, were obsolete and needed to undergo adaptations to the typology imposed and consolidated, coming from the North-American mono-blocks. A great number of institutions had their old facilities demolished to construct blocks with five, seven or ten pavements. Other received extensions, maintaining the original facilities as in the case of Rocha Faria. The changes in medicine would bring to architecture a formal impoverishment revealed in rectilinear lines, without ornament and of the standard type.

\section{Register of Preservation:}

It is not listed.

\section{Source:}

ASSISTÊNCIA Pública - Guanabara: 80 anos de história. Rio de Janeiro: Superintendência de Serviços Médicos (SUSEME); 1972. mimeo.

Jornal do Commercio, Rio de Janeiro, 07/07/1940, página 6.

SECRETARIA de Estado de Saúde do Rio de Janeiro. Indicadores e Informações em Saúde. In: http://www.saude.rj.gov.br/ informacoes/bancodad.shtml Acessado em 11/10/07.

Credits: Daniel Elian (research) and Renato da Gama-Rosa Costa (text and architectonic description). 


\section{Rocha Maia Municipal Hospital}

Other denominations: Emergency Dispensary of Copacabana (1958-1962); Rocha Maia State Hospital (1962-1975); Rocha Maia Municipal Hospital (1975-present day)

Location: Botafogo

Address: General Severiano, 91.

Category: General Hospital

Period of construction: 1905.

Proprietor: City Hall of the City of Rio de Janeiro

Author / Constructor: Luiz Moraes Jr. (architect)

\section{History:}

The origin of Rocha Maia Municipal Hospital is linked to the Copacabana Emergency Hospital created by Decree no. 13,871, as of April 24 $4^{\text {th }}, 1958$, in the administration of the mayor of the Federal District at the time, Francisco Negrão de Lima. This decree established the Emergency Hospital of Copacabana as subject to the Rescue Service of the Health Care Department. The Emergency Hospital Service of Copacabana was temporarily installed in the building where the Isabel Gusmão Rescue Service Center used to work, at Avenida Nossa Senhora de Copacabana, 151.

Later on, a Committee was created composed of doctors Helson Cavalcanti, Nelson Graça Couto, Durval Vianna and Octávio Pieranti, to study and propose measures to improve the emergency service to people of the south district of Rio, taking into account the conditions of the Copacabana Emergency Hospital and the development of the region in the decades of 50 and 60. Based on this understanding, the implantation of an emergency center became necessary in order to relieve the Souza Aguiar and Miguel Couto Hospitals. The Committee submitted as a suggestion, moving the headquarters of the Emergency Hospital in order to expand and improve the service.

The building located at Rua General Severiano no. 91, designed by the architect Luiz Moraes Júnior, was chosen to be the Disinfection Center of Botafogo. With Service Order no. 34 of May $18^{\text {th }}, 1962$, the Emergency Dispensary of Copacabana was incorporated into the Medical Sanitary unit where the $4^{\text {th }}$ District of Children's Medicine, the $4^{\text {th }}$ District of Tuberculosis and the Cecy Dodsworth Nursery were already operating.

On October 1 1t, 1962 in the presence of the governor of the State of Guanabara, Carlos Lacerda (1960-1965), the Health and Assistance Secretary, Marcelo José de Amorim Garcia and the director of the Dispensary, Octávio Pieranti the facilities of the Emergency Dispensary of Copacabana were inaugurated. The neighborhoods of Copacabana, Leme, Praia Vermelha, Urca, Botafogo, Laranjeiras and Flamengo were included in the area of actuation of the Hospital, which also provided assistance coverage to the waters and beaches of the south district.

In 1960, with the transfer of the federal capital to Brasília, the State of Guanabara was created encompassing the entire municipality of Rio de Janeiro. At that time, the hospitals belonging to City Hall of the Federal District came to have state jurisdiction. Fifteen years later, in 1975, with the merging of the states of Guanabara and Rio de Janeiro, some of these hospitals returned to the condition of municipal hospitals - among these being Rocha Maia, while others remained state hospitals.

On December $6^{\text {th }}, 1976$, the name changed to Rocha Maia Municipal Hospital in honor of the surgeon José da Rocha Maia.

Two great works of expansion of the hospital were performed during its history: one in 1978 and the other in 1988, when the construction of a building was started for the installation of the Emergency Sector and which was concluded at the beginning of 1992 . Some renovated sectors were officially delivered on October $30^{\text {th }}$ and November $6^{\text {th }}, 1992$, such as the pediatrics polyclinics and pharmacy. 
Currently, it has 11 health care units and six polyclinics including a polyclinic of odontology that realizes complete treatment, emergency service in the sector of mental health and a Center of Anonymous Testing with lectures and tests on Aids.

\section{Architectural description:}

The history of the building where Rocha Maia Hospital is located begins in 1904 with its construction as the headquarters of the Disinfection Center of Botafogo and the work was concluded in the following year. Created by Oswaldo Cruz, its facilities served as a model for the actions of the sanitarian doctor which included: Isolation and transport of patients with infectious diseases, such as yellow fever, disinfection of contaminated residences, and service of rat extermination as a prevention against the plague.

Its architecture presents volumetric and constructive aspects very similar to the design created by Luiz Moraes for the building of Horse Stable, component of the Historic Architectonic Assemblage of Manguinhos, of the same period. The Horse Stable in its turn, demonstrates the influence of English architecture with the use of iron, apparent brick and granite as external finishing.

\section{Register of Preservation:}

It is not listed.

\section{Sources:}

Acervo do Centro de Estudos da Unidade hospitalar.

ASSISTÊNCIA Pública - Guanabara: 80 anos de história. Rio de Janeiro: Superintendência de Serviços Médicos (SUSEME); 1972. mimeo.

http://www.saude.rio.rj.gov.br/servidor/cgi/private/cgilua.exe/sys/reader/htm/preindexview.htm?editionsectionid= $131 \&$ user=reader, Acessado em 10 de maio de 2007.

O Globo

OSWALDO Cruz. Monumenta Histórica. Tomo III. Campanhas e Inquéritos Sanitários. São Paulo, 1972.

Credits: Nathalia Morais (research) and Renato da Gama-Rosa Costa (research and architectonic description). 


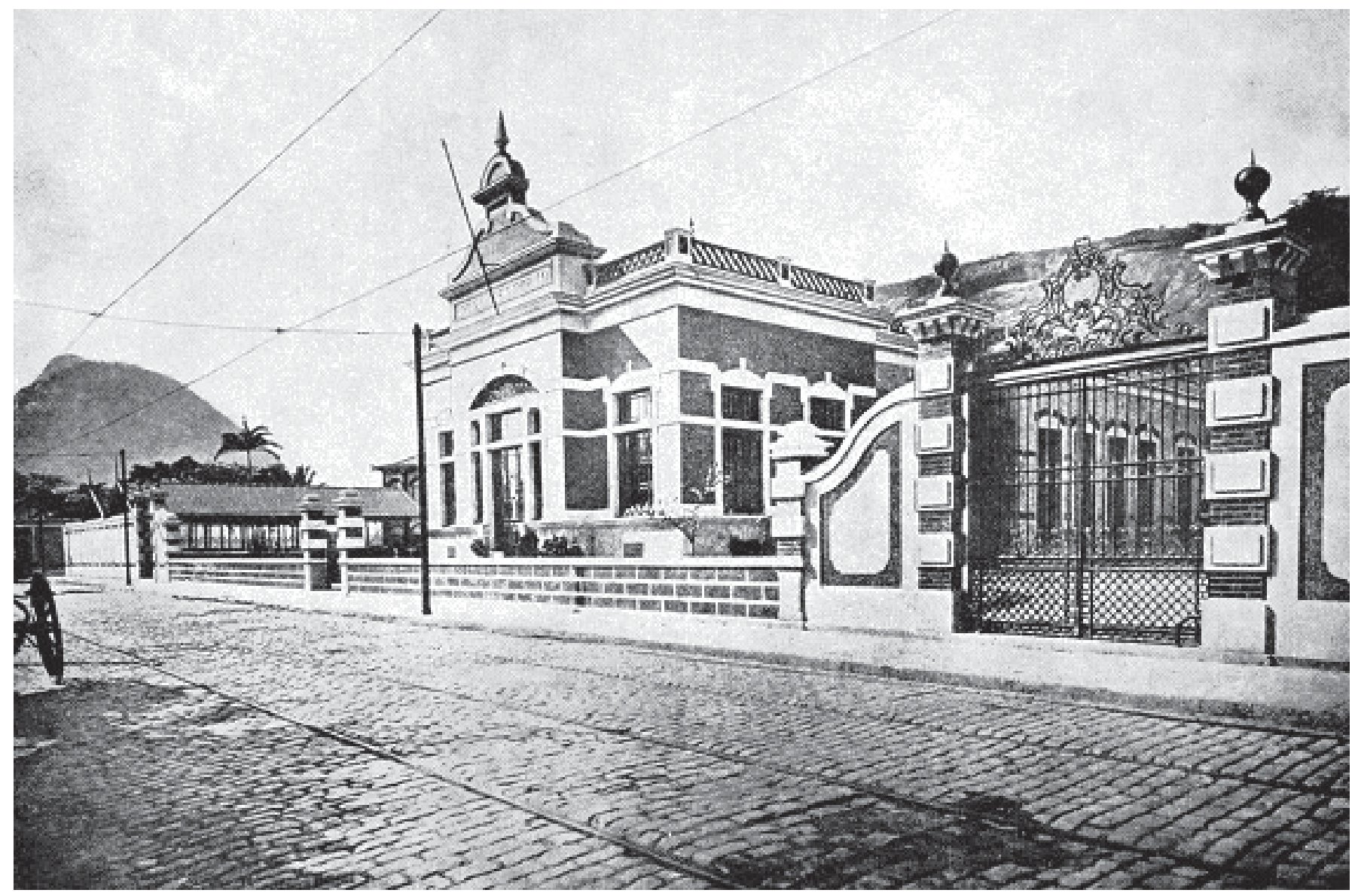

Botafogo Desinfecting Station (Rocha Maia Hospital), [s.d.]. Source: Falcão, 1972 


\section{Salgado Filho Municipal Hospital}

Other denominations: Méier Health Center, Méier Assistance Center and Emergency Assistance Service (1911-1920); Méier Health Center (1920-1934), Méier Dispensary (1934-1951); Salgado Filho Hospital (1951-1975); Salgado Filho Municipal Hospital (1975-present day).

Location: Méier

Address: 370, Arquias Cordeiro, Méier.

Category: General Hospital

Period of construction: 1951.

Proprietor: City Hall of the City of the Rio de Janeiro.

Author / Constructor: Companhia Industrial Construtora of Rio de Janeiro (Méier Dispensary); unknown (current).

\section{History:}

The history of the Salgado Filho Hospital is linked to the creation of the Méier Health Center. Construction began in 1911, during the administration of Mayor Marechal Bento Manual Ribeiro Carneiro Monteiro (1910-1914), and was concluded during the administration of Rivadávia da Cunha Correia (1914-1916) in 1914.

The First World War (1914-1919) brought difficulties in the acquisition of materials destined for the auto-ambulances, affecting the rendering of rescue services to those in need and their transportation to the Health Center (currently Souza Aguiar Hospital). In order to economize such material and prevent the denial of emergency calls, an emergency services organization was created in various areas of the city. Thus, City Hall decided to purchase property from the estate of Francisco José Gonçalves, in the Parish of Nossa Senhora da Conceição in Engenho Novo, at Rua Arquias Cordeiro, with the intention of establishing there the Méier Assistance and Emergency Center, which would operate as the headquarters for the suburban services.

Construction work for the emergency center began on November $26^{\text {th }}, 1914$ and was concluded on July $12^{\text {th }}, 1915$, executed by the Companhia Locativa Construtora. The building housed consultation rooms, an area for the doctors, an equipment sterilizing room and emergency surgery theaters.

In 1916, still under the administration of Mayor Rivadávia Correia, due to the need to expand the building, the Bureau of Works was authorized to initiate construction work of the annexes to the Center, which occurred between March and July of the same year under the supervision of the engineer Carlos Penna, with the assistance of Henrique Vasconcellos.

The work was only completely finished in the administration of Mayor Carlos César de Oliveira Sampaio (1920-1922), with the properly equipped emergency center, initiating activities on October $12^{\text {th }}, 1920$, serving three functions as a Medical-Surgical Emergency Center, Municipal Dispensary and Suburban Dental School Clinic. On the façade of the building was the words: "Public Assistance" and "Municipal Dispensary" at distinct points so that the emergency service center was not confused with the gratuitous medical assistance, each one having its own entrance.

In the center, a specialized consultation room was also created for pediatrics, surgery and obstetrics. For the first time the City Hall of the Federal District organized a dispensary for the poor and a dental clinic, exclusive for students attending municipal schools whose attendance and poverty were checked by the directors or supervisors. It was equipped with 3 auto-ambulances to render emergency services: one small Ford for calls not requiring patient transportation, another with a single bed and the third that could carry more patients. It also had a tram-ambulance, for attending calls from residences, police stations or from streets where the access of the auto-ambulances was difficult. The Center served the areas between the São Francisco Xavier Station, the Central Railway of Brazil, by a dividing line that extended through the streets Jockey-Club, Bom Retiro, Cascadura Station and surrounding areas. 
The transformation of the Méier Health Center into a Dispensary, followed the construction plan of the polyclinic regional hospitals and dispensaries, or central and peripheral, developed by Mayor Pedro Ernesto Batista, during his first administration in the Federal District, between 1931 and 1934, when Méier was chosen for the installation of a large hospital. Out of this same plan, elaborated at the Department of General Health and City Hall Assistance of the Federal District, were included the General Hospital of the Plan (currently Pedro Ernesto Hospital), the Méier Health Center (currently Salgado Filho Hospital), the hospitals Jesus, Getulio Vargas, Carlos Chagas and Rocha Faria and the dispensaries of Ilha de Paquetá (currently Paquetá Hospital) and Rocha Miranda (currently Carmela Dutra Hospital). Work on these new units of medical-hospital assistance were accompanied by a commission specially formed for this purpose, of which participated the doctors Rodolpho de Abreu Fialho, Alcides Pinheiro Marques Carneiro, Alberto Borgerth and Amadeu de Barros Saraiva. The execution of the work was the responsibility of the Companhia Industrial Construtora of Rio de Janeiro, owned by architect, Luiz Moraes Jr and Archimedes d'Arthagnam Saldanha,.

On October $11^{\text {th }}, 1951$, new improvements to the Dispensary were inaugurated, such as an X-ray room, press and police offices, at the same time that a project for the construction of a general hospital was initiated, since the old building constructed in 1920 had become outdated and only had the capacity to attend to 300 people daily in the emergency department and another 300 in the polyclinic. Under Act no. 644, of November 28 ${ }^{\text {th }}, 1951$, the hospital to be constructed on the site of the Dispensary received the name of Salgado Filho. Only on September $6^{\text {th }}, 1952$, under the presidency of Getúlio Vargas (1951-1954) and under the administration of the mayor, João Carlos Vidal, the cornerstone of Salgado Filho Hospital was laid.

Since then, almost nothing had been done in the construction of the hospital until June of 1962, when there was only the skeleton of three floors. It was during the administration of Carlos Lacerda (1960-1965) that the Secretary of Health, Marcelo José de Amorim Garcia, took the initiative to construct four of the eight floors planned, which were inaugurated on March 27 $7^{\text {th }}$, 1963. Since its inauguration, the hospital has been operating with an out-patients clinic, an emergency department, services of pathological anatomy, dermatology, gynecology, cardiology, pediatrics, ophthalmology, physiotherapy, pre-natal care, a mother's club, a lactation center and hydration, with double the capacity in all sectors.

The Secretary of Health under the government of Negrão de Lima (1965-1970), Hildebrando Monteiro Marinho, continued with the initial project, and in 1968 initiated the construction of the 4 remaining floors, thus completing the hospital complex. In 1975, with the merging of the states of Guanabara and Rio de Janeiro, Salgado Filho Hospital switched to the municipal sphere, as a result of the need to reorganize the modus operandi of the municipal public sector in relation to the health care system.

In 1960, with the transfer of the federal capital to Brasilia, the state of Guanabara wa created encompassing the entire municipality of Rio de Janeiro. During this period, the hospitals which had belonged to the City Hall of the Federal District changed to state jurisdiction. Fifteen years later, in 1975, with the merging of the states of Guanabara and Rio de Janeiro, some of these hospitals returned to the municipal sphere - among them being Salgado Filho Hospital; while others remained under the state.

Today it renders emergency services in neurology, pediatrics, gynecology, general medicine, orthopedics, radiology, among others.

\section{Architectonic Description:}

As of the 1960's, many hospitals underwent renovations and expansions. The old facilities of these hospitals, to a great extent constructed in the 1930's, by Pedro Ernesto, were becoming obsolete and needed to undergo adaptations given the imposed and consolidated typology stemming from the North American single-block structures. A great number of institutions had their old facilities demolished, to make way for strips of five, seven or ten floors. Others received annexes, maintaining the original facilities, which were renovated. The change in medicine would bring to architecture a formal impoverishment, revealed in rectilinear lines, without ornament and standardizations. 


\section{Register of Preservation:}

It is not listed.

\section{Sources:}

Aniversário do Posto de Assistência do Méier. Correio da Manhã, Rio de Janeiro, 12 de outubro de 1951.

ASSISTÊNCIA Pública - Guanabara: 80 anos de história. Rio de Janeiro: Superintendência de Serviços Médicos (SUSEME); 1972. mimeo.

ASSISTÊNCIA Pública e Privada no Rio de Janeiro (Brasil) - História e Estatística. Comemoração do Centenário da Independência Nacional. Rio de Janeiro: Typographia do Annuario do Brasil; 1922.

Assistência Suburbana. Jornal do Commercio, Rio de Janeiro, 12 e 13 de outubro de 1920.

Depois de 15 anos será inaugurado o esperado Hospital Salgado Filho. Correio de Manhã, Rio de Janeiro, 27 de março de 1963.

Inaugurado o hospital Salgado Filho. Correio da Manhã, Rio de Janeiro, 28 de março de 1963.

O Rio de Janeiro e os seus problemas de assistência médico-social. Correio de Manhã, Rio de Janeiro, 17 de agosto de 1934. Posto de Assistência do Méier. Jornal do Brasil, Rio de Janeiro, 12 de outubro de 1920.

Um importante melhoramento nos subúrbios. Correio da Manhã, Rio de Janeiro, 12 e 13 de outubro de 1920.

Credits: Nathalia Morais (research) and Renato da Gama-Rosa Costa (text and architectonic description) 


\section{AFTER 1930}

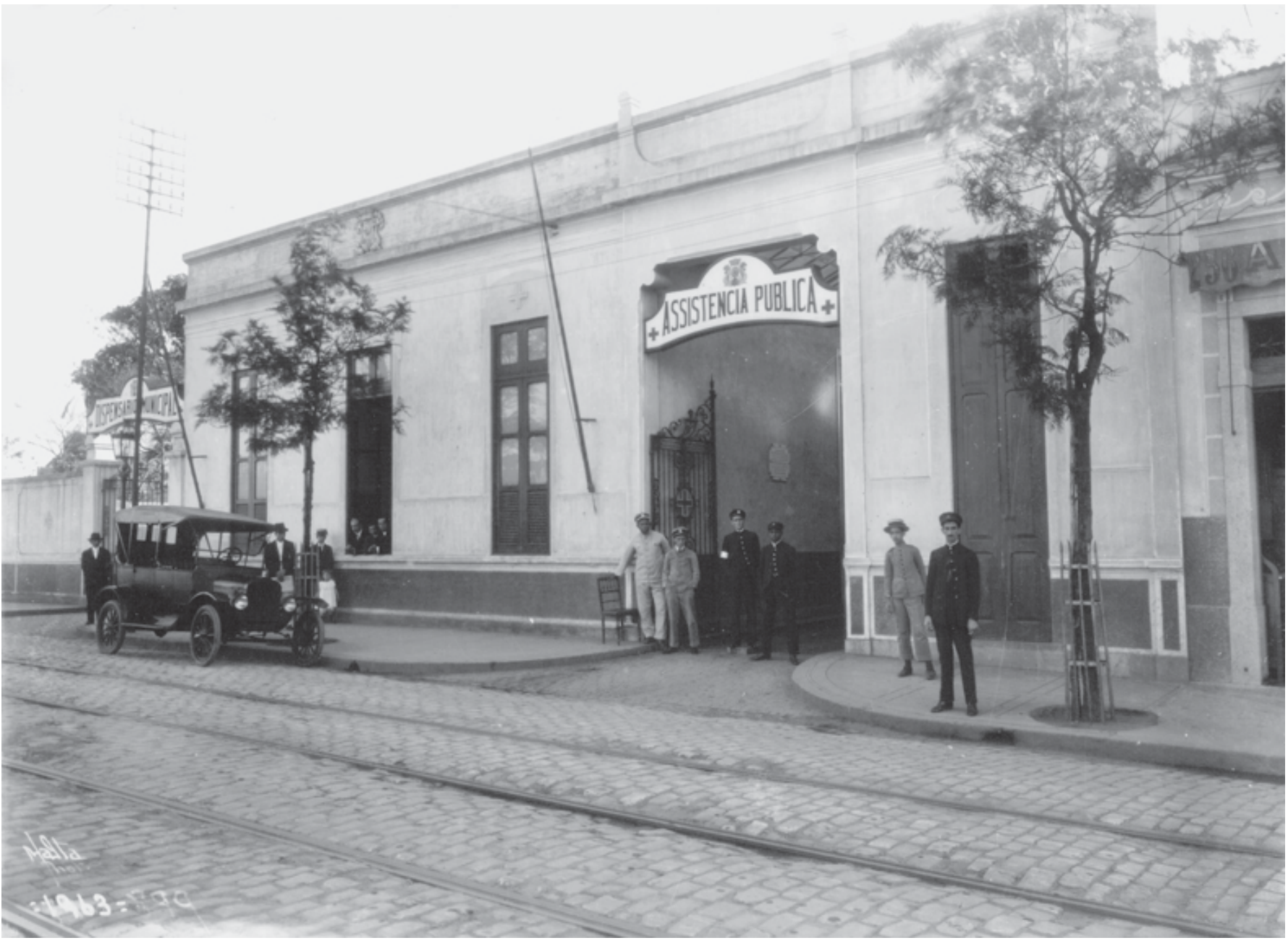

[Dispensary in Méier]. [s.d.]. Photo Augusto Malta. City of Rio de Janeiro General Archives. 


\section{Salles Netto Municipal Hospital}

Other Denominations: Children's Hospital (1947-1951); Toxicology Treatment Center (1951-1961); Salles Netto Rehydration Center (1961-1965); Salles Netto Hospital (1965-present day).

Location: Rio Comprido

Address: Praça Condessa Paulo de Frontin no. 52

Denomination: Pediatric Hospital

Period of construction: 1947

Proprietor: Municipal Public Institution

Author / Constructor: unknown

\section{History:}

The Salles Netto Municipal Hospital is the result of the fusion between two institutions dedicated to the assistance care of children, which were created between 1940 and 1950 in the region of Tijuca.

The oldest of which is the Children's Hospital, inaugurated on October $29^{\text {th }}, 1947$ at Rua Desembargador Isidro no. 144, in Tijuca, by Mayor General Ângelo Mendes de Moraes (1947-1951). It comprised the $7^{\text {th }}$ District of Children's Medicine and its action was orientated to Pediatric Clinic.

The Children's Hospital fitted the model defended by the National Department of Children (DNCr), based on the creation of public equipments - specially the centers for Children's Medicine - dedicated to services of medical assistance and orientation to the little ones, emphasizing prevention and maternal education. The creation of the DNCr in 1940 which aimed to nationalize and standardize the assistance care to the binomial mother-child relationship and combat children's mortality - revealed the central role of the child under the New State, despite having its origins in the maternal movement which had been consolidating in earlier decades.

By initiative of Doctor Salles Netto, then director of the Department of Children's Medicine, the hospital was transferred to Rua Lopes Trovão no. 99, in the São Cristóvão district, on August 29 $9^{\text {th }}, 1951$, when it became known as the Toxicology Treatment Center. On April 13 ${ }^{\text {th }}, 1961$, it received the name Salles Netto Rehydration Center, as a posthumous tribute to the doctor.

Since facilities in São Cristóvão were precarious - there was only one doctor and one academician in each shift - new facilities were sought for the Salles Netto Rehydration Center. The solution was the transfer to the Ludímia Trotta Children's Medicine Center - inaugurated on July 29 $9^{\text {th }}, 1959$, in Rio Comprido, in a building constructed by the Department of Children's Medicine. The construction of the building had been oriented by Doctor João Luiz Sampaio Avilez, head of the $2^{\text {nd }}$ District of Children's Medicine - area where it was located -, with the purpose to house the headquarters of the District, in the ground floor, and a small hospital of children's clinic in the second floor. The Center would offer services of children's medicine, pediatrics, infantile emergency care and others related to children's health.

Thus, Salles Netto Rehydration Center was inaugurated with the presence of Governor Carlos Lacerda (1960-1965), on April $13^{\text {th }}, 1962$, at Condessa Pereira Carneiro square, where it is still located today. At that moment, it operated as an annex of the Children's Medicine Center no. 2 and provided 24h assistance care, with capacity to treat 300 monthly cases of infantile dehydration and hospitalization of 50 children. The Center also had a small surgery room; infirmaries; resting room; oxygen tents; and also provided assistance to cases of eating disorders, notably hunger.

On November $12^{\text {th }}, 1963$, the Laudímia Trotta Children's Medicine Center was incorporated into the Rehydration Center. Two years later, on September $18^{\text {th }}, 1965$, the Salles Netto Rehydration Center became known as Salles Netto State Hospital, taking in consideration the creation of the state of Guanabara in 1960, when the Federal District was transferred to Brasília. During the administration of Negrão de Lima (1965-1971), the hospitalization capacity expanded to 82 beds, and a modern Intensive Treatment Center was installed. 
Due to the fusion of the state of Guanabara with the former state of Rio de Janeiro, in 1975, management of the Hospital was assumed by the municipality of Rio de Janeiro, having its denomination changed to Salles Netto Municipal Hospital.

In the 1990s, the hospital underwent reformulation both in its physical and organizational structure, and was reopened in October, 1992, with a new proposal of assistance care - especially the conditions which would guarantee the presence of the family together with the hospitalized child.

Currently, the hospital is dedicated to the assistance care of children's pathologies of low and medium complexity. It has two infirmaries each with 34 beds, in addition to quarantine beds, and offers assistance in general pediatrics and in the following pediatric specializations: otorhinolaryngology, neurology, pneumology, odontology and nutrition. It also has services of epidemiology, social service, vaccination and pharmacy, in addition to laboratory and radiology exams for diagnostic support.

\section{Register of Preservation:}

It is not listed.

\section{Sources:}

ALBANESI FILHO, F. 50 anos de História da Cardiologia no Estado do Rio de Janeiro. Rio de Janeiro: SOCERJ, 2005.

Correio da Manhã, Rio de Janeiro, 13 de abril de 1962.

http://www.saude.rio.rj.gov.br/servidor/cgi/private/cgilua.exe/sys/reader/htm/preindexview.htm?editionsectionid= $122 \&$ user=reader, Acessado em 10 de maio de 2007.

Jornal do Brasil, Rio de Janeiro, 04 de novembro de 1959.

LEIS DO BRASIL. Rio de Janeiro: Imprensa Nacional.

Credits: Nathalia Morais (research) and Gisele Sanglard and Maria Martha de Luna Freire (research and text). 


\title{
Santa Lúcia Health Center
}

\author{
Location: Botafogo \\ Address: Rua Capitão Salomão, 27 \\ Category: General Hospital \\ Period of construction: 1954 \\ Proprietor: Private Institution \\ Author / Constructor: unknown
}

\section{History:}

The history of the Santa Lúcia Health Center goes back to the year 1947 with the acquisition of a story house of No. 435 of the (street) Rua Voluntários da Pátria, in Botafogo, by the surgeon Guilherme Romano (1914-1995), together with a group of doctors. Its inauguration took place on the day August $13^{\text {th }}$, of that same year.

Guilherme Romano, its owner, had an important political standing in the City Hall of the Federal District and in the scope of the Federal Government on the course of the 1950's, having been General Secretary of Health and Assistance in the administration of the mayors João Carlos Vital (1951-1952) and Joaquim José de Sá Freire Alvim (1958-1960); in addition of director do National Service of Assistance to the Minor, during the second Vargas government, and chairman of the Federal Commission of Supply and Price (COFAP), in the JK period.

In the first decade of operation of the Santa Lúcia Health Center, the maternity ward and services provided to the mother-child assistance were the institution's main activity. The hospital space was intended for women of the carioca elite in a period in which medicine sought to consolidate its position with the feminine public, offering gynecologicalobstetric services in appropriate spaces - the maternity wards. This option comprises a milestone in the history of the institution, preserved up $\mathrm{t}$ this date.

Another important service at Santa Lúcia is the surgical service, and in the beginning, it was its owner who was encharged with performing them. Nowadays, its surgical center is equipped to perform both minor and large surgeries.

In the 1950's, Guilherme Romano, seeking to expand the actions of his Health Center to change it to a general hospital acquired, in 1954, a terrain at the (street) Rua Visconde de Caravelas, No. 126, where a five-floor edifice was built for doctors' Four years later, in 1958, an ambitious project was put into practice - the construction of a new eight-floor edifice, in front of the story house at the (street) Rua Voluntários da Pátria. This new project was motivated by the large search for doctors' offices, opened at the (street) Rua Visconde de Caravelas.

The expansion process continued on the course of the subsequent decades, with the transfer of the institution's entrance to the (street) Capitão Salomão, in 1979. Two years later, a new ambitious project is put into practice: the construction of a new medical center - the Botafogo Medical Center and the Guilherme Romano building, with 18 floors, in the corner of the streets Capitão Salomão e Voluntários da Pátria, intended for the various medical specialities and other activities of the health area.

It is worthwhile to point out in the 1960's decade, the Santa Lúcia Clinic sheltered the Pró-Cardíaco, when the emergency assistance center was forced to leave the premises of the Broadcasters' Hospital, at the (street) Rua David Campista, in Humaitá, due to the closing of the hospital, until it was installed at its own headquarters of the (street) D. Mariana, in 1967. This stay was made possible thanks to the figure of the cardiologist Onaldo Pereira, one of the founders of both s institutions.

Currently, the Santa Lúcia Health Center offers emergency and surgical services, exams and ICU for adults. 


\section{Register of Preservation:}

It is not listed.

\section{Source:}

CLÍNICA Santa Lúcia. Capturado em 17 de ago. 2007. Online. Disponível na Internet: http://clinicasantalucia.com.br/ http://spl.camara.rj.gov.br/spldocs/pl/2004/pl1954_2004_003994.pdf, capturado a 20 de agosto de 2007.

Credits: Gisele Sanglard and Renilda Barreto (research and text) 


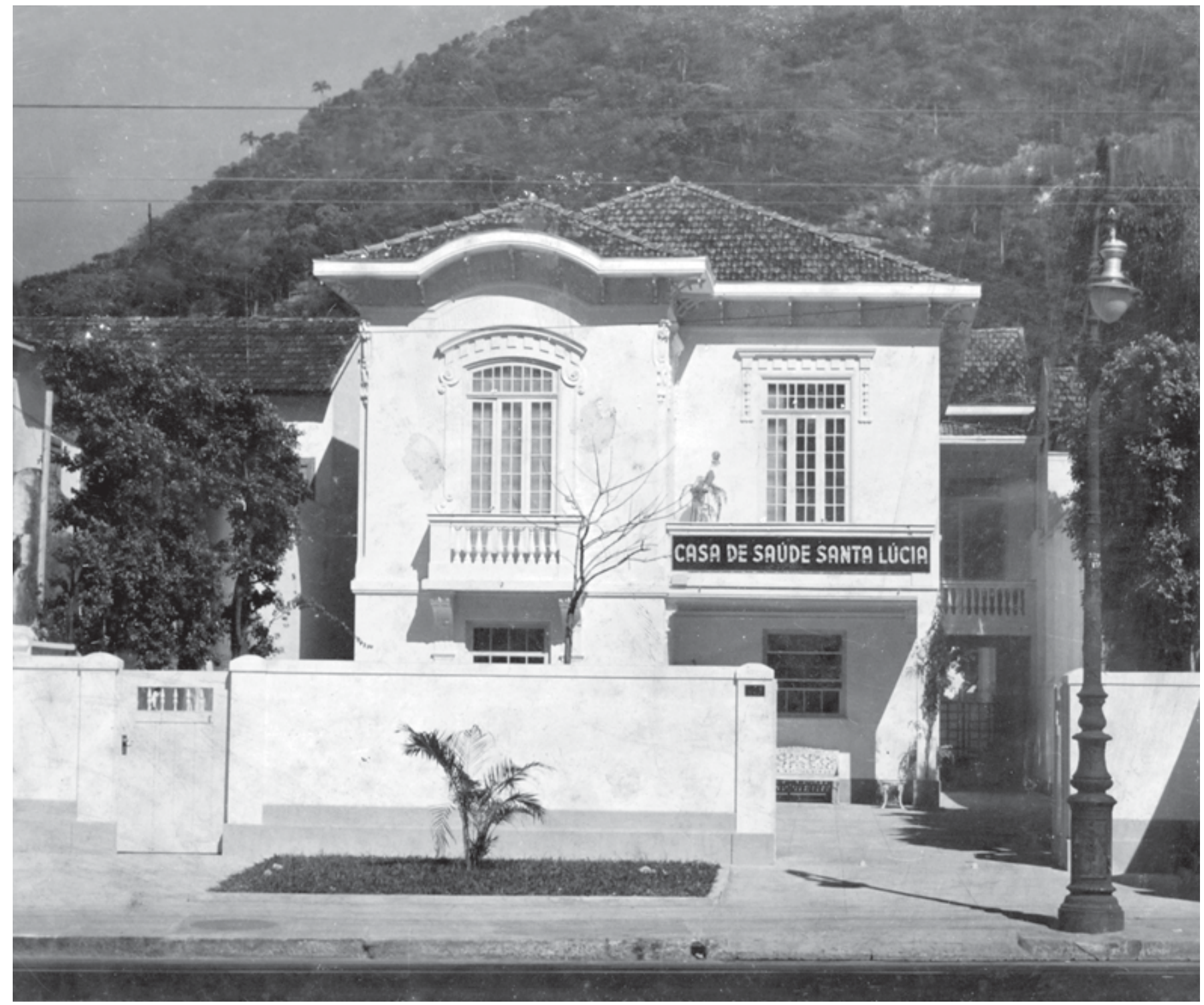

Santa Lúcia Medical Center, 1947. Private Archive 


\section{AFTER 1930}

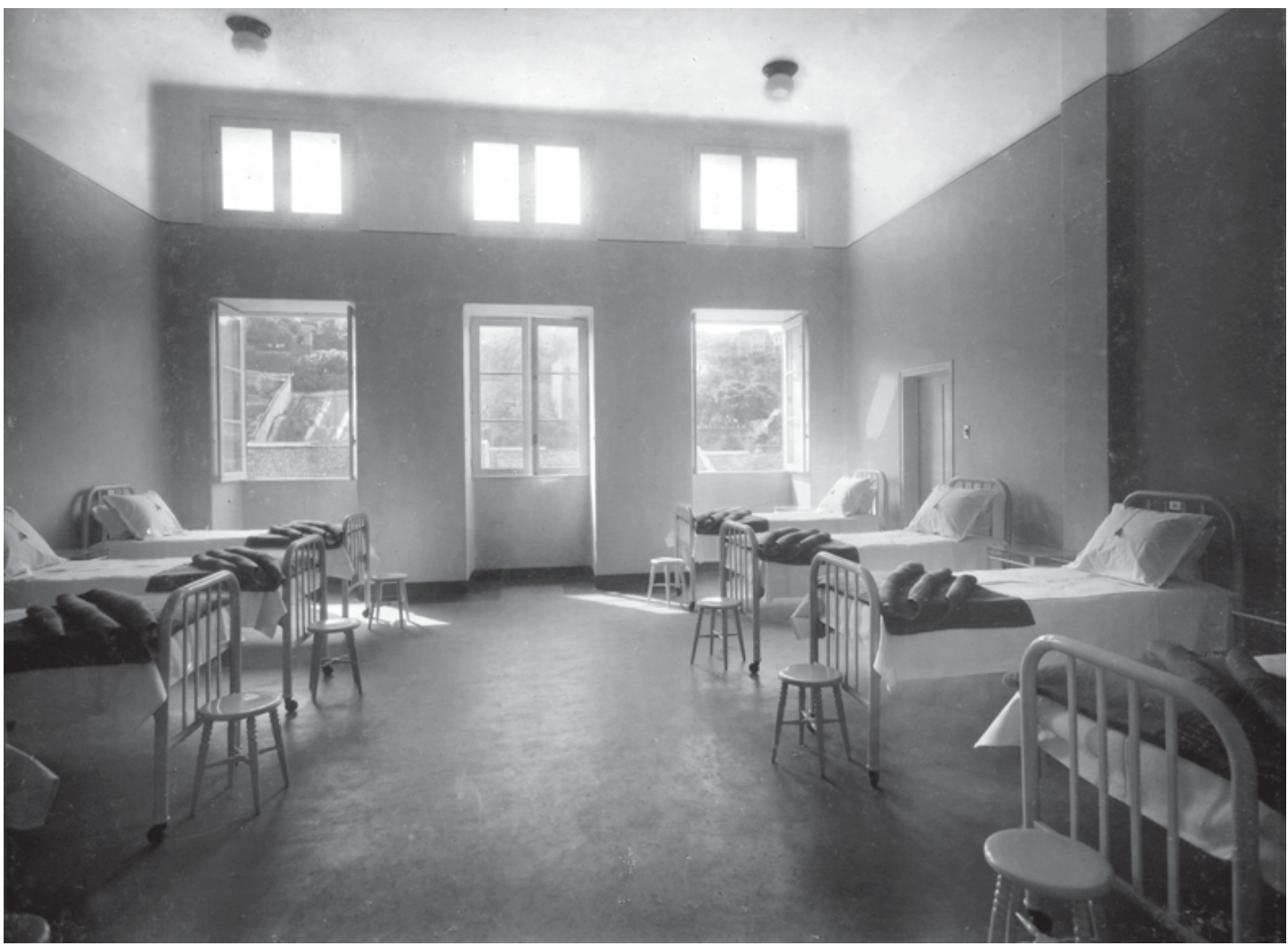

Santa Lúcia Medical Center, 1947. Private Archive

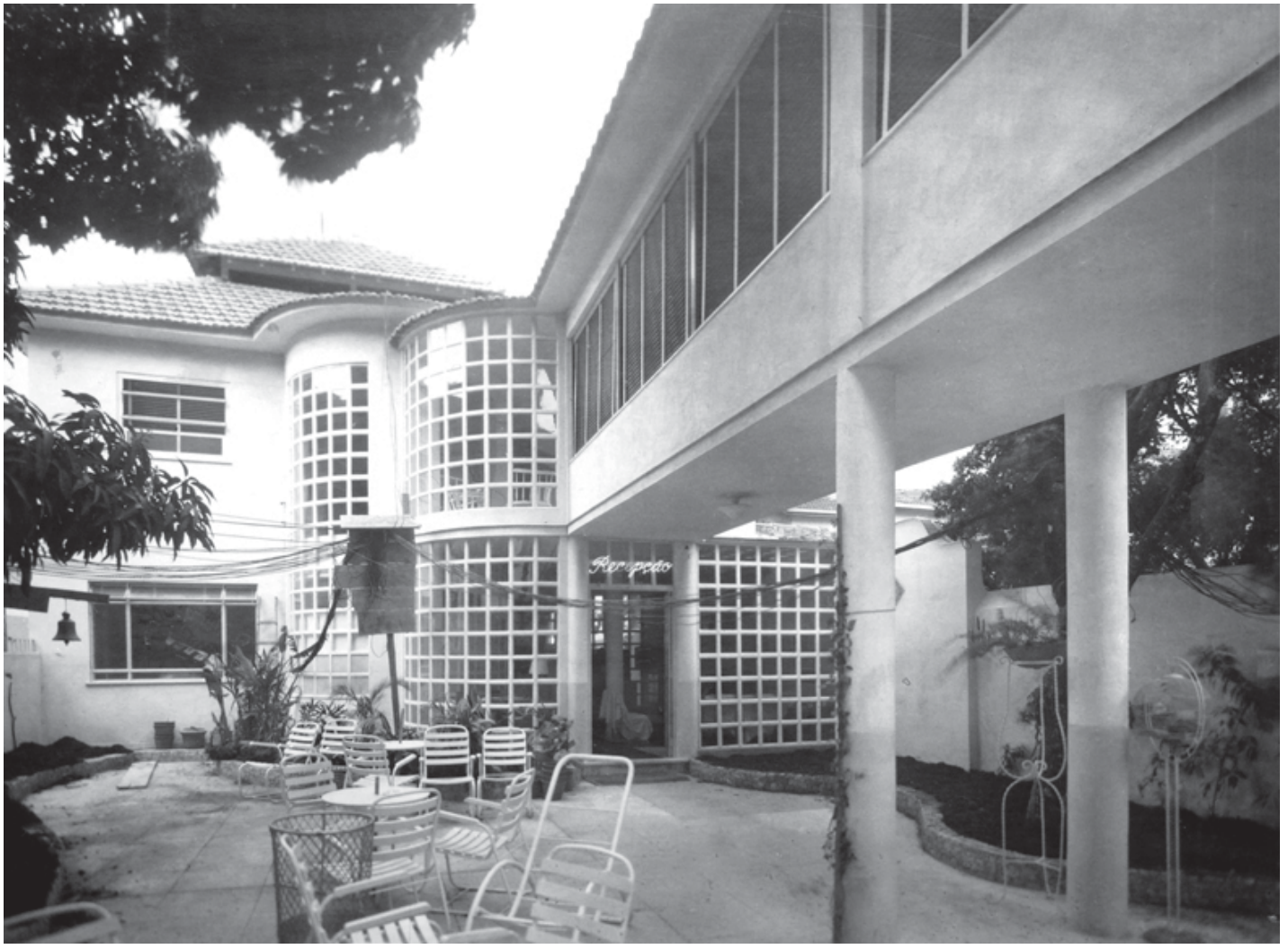

Santa Lúcia Medical Center, 1947. Private Archive 


\section{Santa Maria State Hospital}

Other denominations: Santa Maria Sanatorium and Hospital (1938-1963); Santa Maria State Hospital (1963-present day).

Location: Jacarepaguá

Address: Estrada do Rio Pequeno, no. 656. Taquara.

Category: Tuberculosis Hospital.

Date of construction: 1937.

Proprietor: Federal Government.

Author / Constructor: Division of Works of the Ministry of Education and Health.

\section{History:}

The construction of Santa Maria State Hospital began in 1938 by the Ministry of Education and Health for the fight against tuberculosis. By Decree Law no. 1040, of 1939, it was transferred by the Government to the City Hall of the Federal District and then to the Tuberculosis Department of the Health and Medical Assistance Office being named Santa Maria Sanatorium and Hospital.

The symbolic inauguration was on April 19 ${ }^{\text {th }}, 1943$. It had capacity of 530 beds, but only started to work fully on June $13^{\text {th }}, 1945$ when 26 nurses were relocated from São Sebastião Hospital to there.

Whilst Doctor Flávio Fraga was the director of the hospital, considerable advances in the treatment of tuberculosis were achieved. This is due to the gathering of great specialists in the area that by means of studies and research reached conclusions of world wide acknowledgement. It is worthwhile mentioning that General Ângelo Mendes de Moraes (1947-51), mayor of the Federal District at the time, made several compliments to the hospital, revealing it was superior to all those visited in Europe.

In 1960, with the transfer of the federal capital to Brasília, the State of Guanabara was created encompassing the entire municipality of Rio de Janeiro. At that time, the hospitals belonging to City Hall of the Federal District came to have state jurisdiction. Fifteen years later, in 1975, with the merging of the states of Guanabara and Rio de Janeiro, some of these hospitals returned to the condition of municipal hospitals - among these being Santa Maria, while others remained state hospitals. At this moment, the hospital began to offer, by means of hospitalization, clinical surgical treatment of pulmonary tuberculosis in women that could be successfully treated and surgical treatment for men.

In 1996 the restoration of the hospital began with the hiring of new employees. Between 1998 and 1999 renovation work and a reorganization of one of the wings were undertaken and currently its facilities work with only $30 \%$ of their total capacity. Still, Santa Maria Hospital is a reference in attending to tuberculosis patients also infected with the HIV virus. It also offers complementary exams of bronchoscopy and culture for M. Tuberculosis and small surgical procedures for diagnostic elucidation.

Because it is a reference hospital for the treatment of pulmonary tuberculosis - besides being the only one remaining from the period of combating tuberculosis, Santa Maria Hospital offers, until today, medical and surgical clinical service directed to this disease. It further maintains beds for patients "without therapeutic possibilities" - those who throughout the history of hospitals were considered as "incurable".

\section{Architectonic description:}

The architectonic language adopted for the Santa Maria Hospital is one more example that makes good use of modern formal repertory, but does not follow the corbusian model. Buildings like this - sanatoriums built between the wars and 
catalogued as proto-moderns - have been analyzed in the light of our time as an item constituting the list of good architecture produced in the decade of 1930 and as consequence, being part of the list of goods likely to be listed. Located in a remote region of Jacarepagué, its implantation and volumetry follow the typology of sanatoriums for tuberculosis treatment and stand out in the landscape: a block of five to six pavements formed by the joint of two "Y" formations. The balconies are the main feature of its clean and rational façade and have a therapeutic function: their distribution through several façades is important so that the patients can sunbathe in the morning and get fresh air, throughout the year.

\section{Register of Preservation:}

It is not listed.

\section{Sources:}

ASSISTÊNCIA Pública - Guanabara: 80 anos de história. Rio de Janeiro: Superintendência de Serviços Médicos (SUSEME); 1972. mimeo.

RIBEIRO, L. A luta contra a tuberculose (apontamentos para a sua história). Rio de Janeiro: Editorial Sul-Americana; 1956. SECRETARIA de Saúde do Estado do Rio de Janeiro. Indicadores e Informações em Saúde. In: http://www.saude.rj.gov.br/ informacoes/bancodad.shtml Acessado em 11/10/07.

Credits: Daniel Elian (research) and Renato da Gama-Rosa Costa (text and architectonic description). 


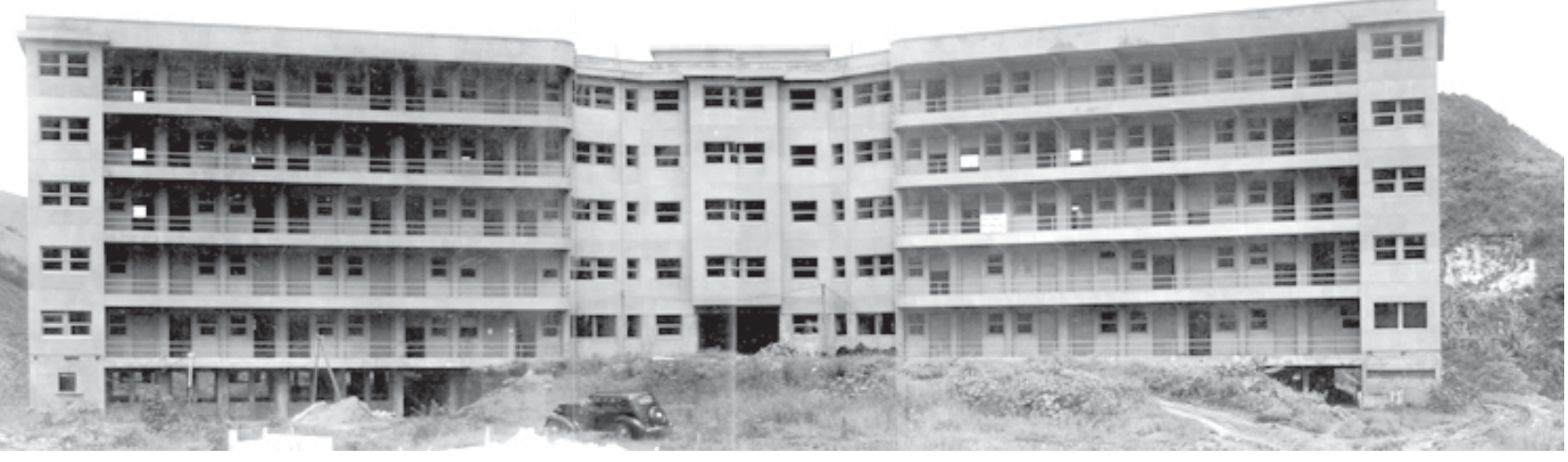

Constructions of the Santa Maria Hospital-Sanatorium, [1938-1943]. Gustavo Capanema Fund. CPDOC/FGV Archives

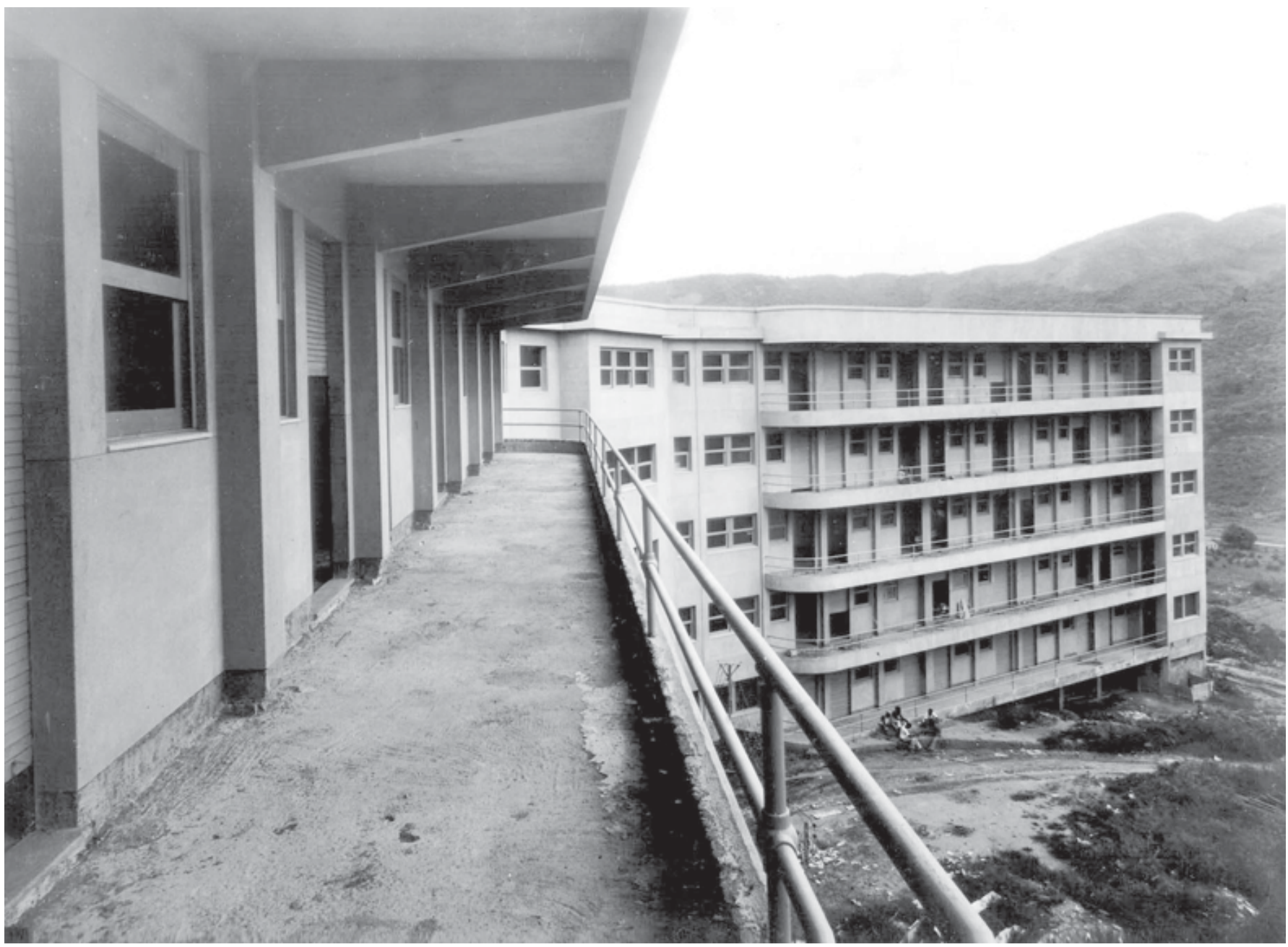

View of Santa Maria Hospital-Sanatorium Construction works, [1938-1943]. Gustavo Capanema Fund. CPDOC/FGV Archives 


\section{São Lucas Hospital}

Other denominations: Arnaldo de Moraes Maternity (1938-1972); São Lucas Hospital (1972-present day).

Location: Copacabana

Address: Travessa Frederico Pamplona, no. 32

Category: General Hospital

Period of construction: 1938

Proprietor: Esho-Amil Network

Author / Constructor: Paulo Antunes Ribeiro

\section{History:}

On April $10^{\text {th }}, 1938$, the Arnaldo de Moraes Maternity Hospital was inaugurated, in Copacabana, adopting the name of its organizer, owner and director.

Arnaldo de Moraes was a doctor and professor of gynecological medicine of the University of Brazil - created in 1937 - the present day Federal University of Rio de Janeiro. Still in the 1930's he began to coordinate the discussion that sought to extrapolate the meaning of gynecology - restricted, up to that time, to the physiopathology of the female genital tract - to relate it to the other sectors of medicine, as well as to deepen the study of the gynecopathies. Moraes undertook various actions to reach the above mentioned objectives, among them being the foundation, in 1936, of the magazine Brazilian Annals of Gynecology and the foundation of the Institute of Gynecology, in 1947.

The maternity unit, understood at that time as the space set aside for the mother-to-be and to childbirth, was also part of the list of concerns of Arnaldo de Moraes. The maternity unit at Rua Frederico Pamplona was designed with a specific purpose and constructed along the lines of the North American "Woman's Clinics", the German "Franeuklinkes", as well as the Argentine maternity hospitals. The building was constructed in two mono-blocks with six floors, connected to a central body and was positioned in such a way as to permit a view of the sea and the forest.

Initially it had 33 rooms and apartments, 17 of which were destined for obstetrics, located on the $3^{\text {rd }}$ and $4^{\text {th }}$ floors; and the others distributed on the $1^{\text {st }}$ and $2^{\text {nd }}$ floors, set aside for the gynecology cases. At the end of the 1940's, the maternity unit had 50 rooms and apartments.

Technological innovation was a differential presented to the public who would come to use the maternity unit: women of the Rio elite. The maternity hospital had elevators interconnecting the various floors, air conditioning equipment in the operating and childbirth rooms, and in the apartments; clinical and anatomo-pathological research laboratories; $\mathrm{X}$-ray rooms; basal metabolism equipment and electrocardiography; anesthesia with gauze; facilities for physiotherapy, such as diathermy, short wave, ultraviolet and infra-red rays; applications of galvanic and faradic electricity; electric scalpels and the Elliot device for local fever, in the treatment of pelvic inflammation.

In 1972 the Arnaldo de Moraes Maternity Hospital became the São Lucas Hospital, administered by SENASA (National Health Insurer). In 1978 the hospital was incorporated by Golden Cross which administered it until 1977, when it was transferred to the IGASE (General Institute of Evangelical Social Welfare) becoming a part of a national medical-hospital assistance network. In October of the year 2000, the São Lucas Hospital was acquired by the Esho-Amil Network.

At the present, São Lucas Hospital occupies an area of 8,830 m², distributed throughout nine floors with 85 apartments and14 wards, making a total of 143 beds. It also has three Intensive Care Units (ICU), with forty beds; a Special Care Unit (SCU) with a capacity for nine beds; a Cardio-intensive Unit with sixteen beds; besides eight operating theaters and an Emergency Unit specialized in medical practice, traumato-orthopedics, cardiology and otorrhinolaryngology.

The hospital serves the population of Rio de Janeiro and other States of the Federation in the specialities of medical practice, surgical medicine and first-aid. 


\section{Architectonic description:}

The current facilities of São Lucas Hospital have few architectonic references of the former maternity ward, built in the 1940s using modern lines expressed in the balconies and in the use of cylindrical volumes. An article written at the time in the Magazine Médico-Social highlighted the "majestic" five story building of "sophisticated architectonic taste" and its position in a "quiet area of the pleasant neighborhood of Copacabana" and close to an "extensive forest". It also highlighted the presence of air conditioning in the facilities of the delivery rooms, operating rooms and nursery.

In constructive terms, the reform undertaken to house São Lucas Hospital added four more floors, maintaining the previous disposition throughout the property, to better position it in relation the morning sun, and the distribution of the two wings for accommodation of the rooms, which is achieved from the vertical access, centralized and until today composed by two elevators and a hall of stairs. The façades were rectified and received revetment in white marble. For two years the hospital has been going through restoration work on its interior and is preparing to undergo a total restoration of its façade in the upcoming years, which will receive mirrored glass and new revetments, according to the contemporary architecture style.

\section{Register of Preservation:}

It is not listed.

\section{Sources:}

A Folha Médica, Rio de Janeiro, 15/04/1938.

Anais Brasileiros de Ginecologia, jan., vol 25, $1^{\circ}$ semestre de 1948, nº 1, p. 1-6.

Brasil-Médico, Rio de Janeiro, 23/04/1938.

Brasil-Médico, Rio de Janeiro, jan.1939 (edição comemorativa).

Informações da Diretoria do Hospital São Lucas fornecidas em 29 de Agosto de 2007.

MATERNIDADE Arnaldo de Moraes. Arquitetura e Urbanismo. jul-ago, 1938.

Revista Médico-Social, Rio de Janeiro, ano I. nº 9, mai. de 1943. pp. 21-23.

Credits: Renato Pereira da Silva and Lidiane Monteiro Ribeiro (research) and Maria Renilda Nery Barreto (text) and Renato da Gama-Rosa Costa (architectonic description). 


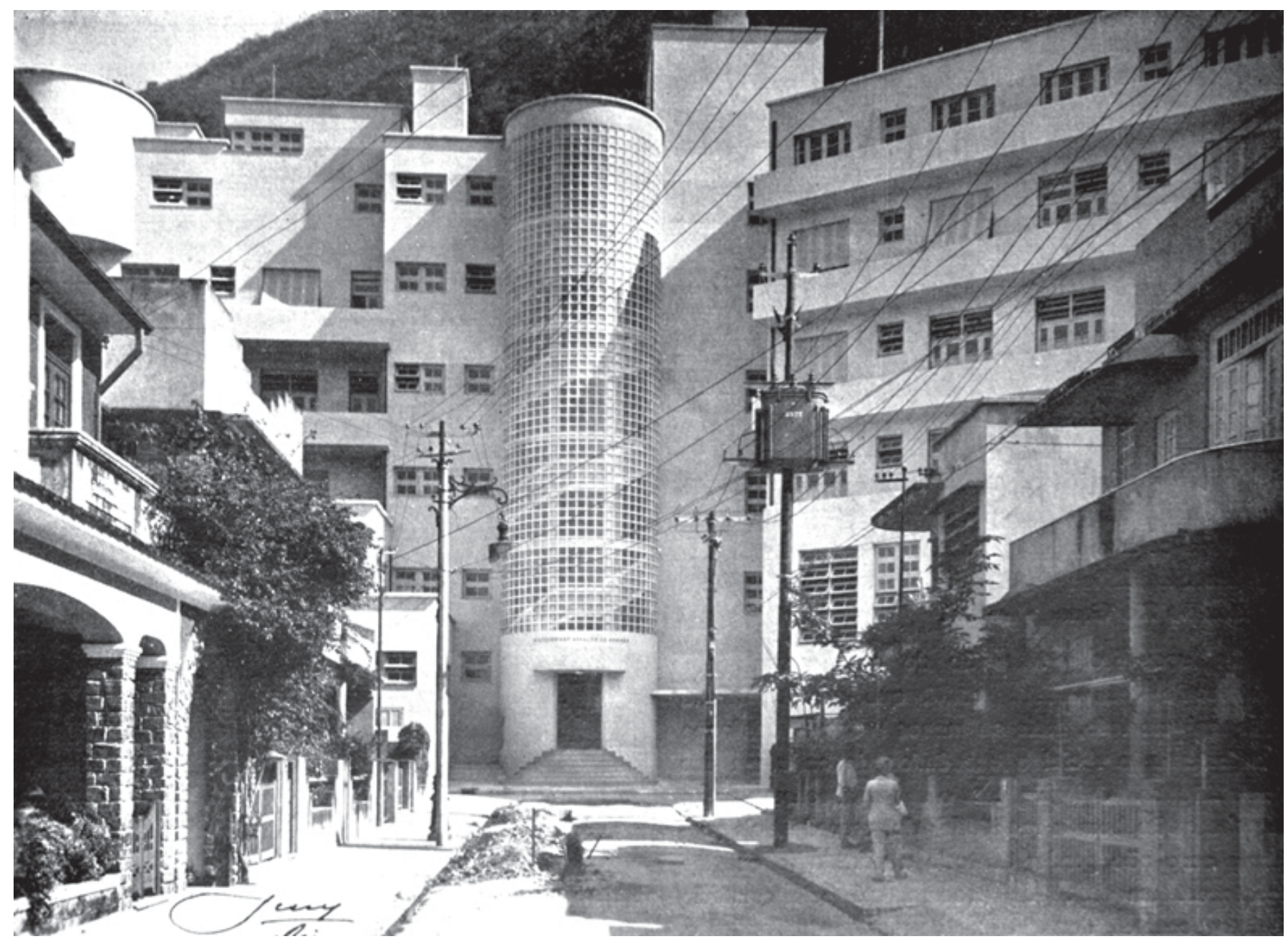

Arnaldo de Moraes Maternity - façade. Source: Arquitetura e Urbanismo, 1938 


\section{AFTER 1930}

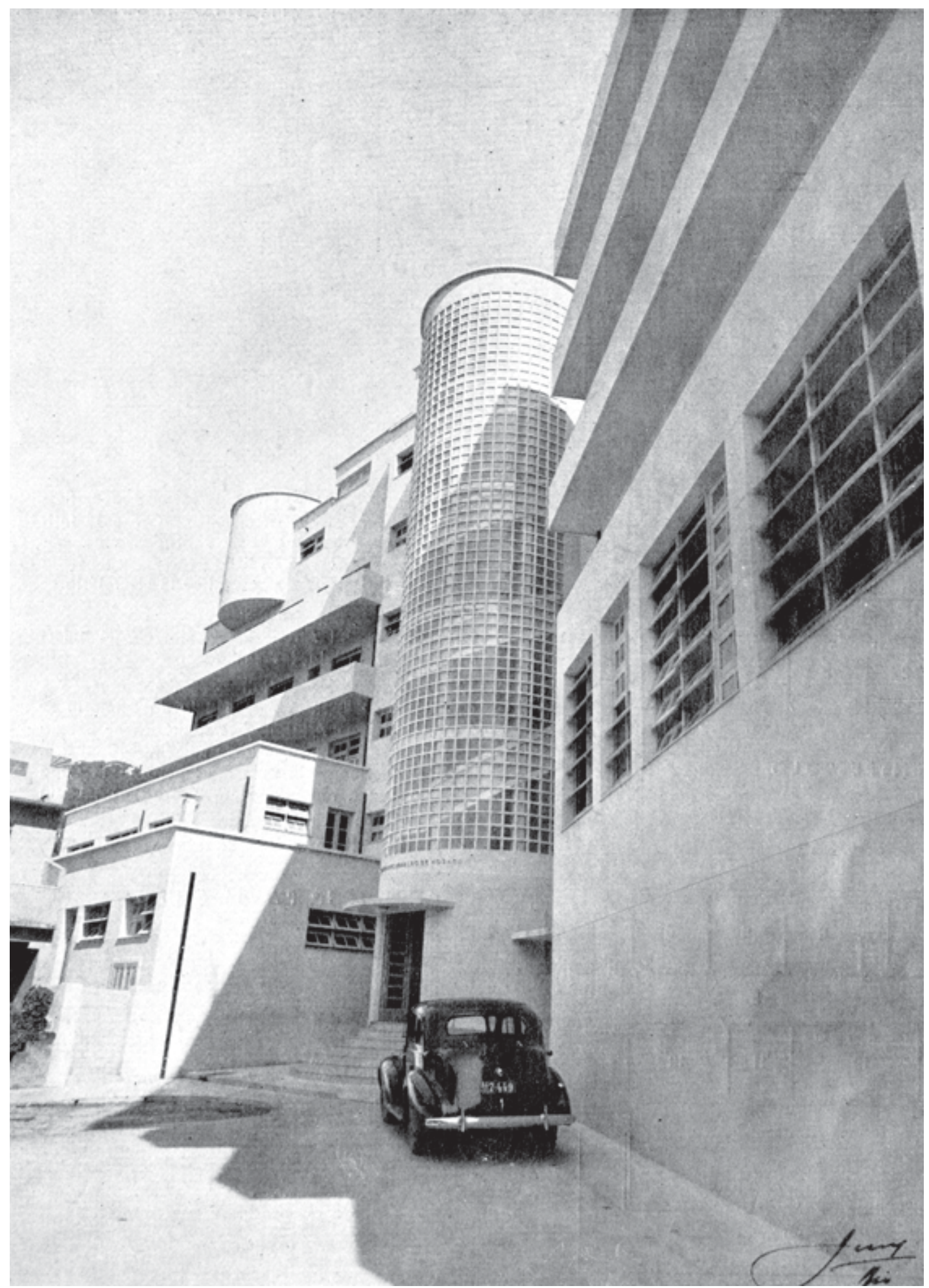

Arnaldo de Moraes Maternity - façade. Source: Arquitetura e Urbanismo, 1938 


\section{São Vicente Clinic}

Other denominations: São Vicente Sanatorium (1933-1942); São Vicente Rest Clinic (1942-1969); São Vicente Clinic (1969-present day)

Location: Gávea

Address: Rua João Borges no. 204

Category: General Hospital

Period of construction: 1969-1970

Proprietor: Private institution

Author / Constructor: Rolf Werther Hutter Architect Associates and Rafael Borges Dutra (constructor)

\section{History:}

The São Vicente Clinic started with the inauguration of a Sanatorium under the same name in a very large house on the corner of Rua Marquês de São Vicente and Adolfo Lutz, in the neighborhood of Gávea. Its proprietors, the cardiologist Genival Londres - who was at the forefront of the creation, in 1941, of the Assistance Service to Cardiovascular Disorders, currently the Aloysio de Castro Institute of Cardiology - and neurologist and psychiatrist Aluízio Marques, created the institution with the mission to provide care for psychiatric, cardiac and elderly patients in need of long term rest. They believed that rest - in the bucolic climate of Gávea - combined with therapy, would be fundamental in the recuperation of the patients. This would be the objective and target-audience of the institution until the end of the 1970's, when there is a perceived alteration in its principles.

The first change suffered by the institution occurred in the 1940's when a business corporation is created with 40 associates - among them Genival Londres, Aluízio Marques and João Borges Filho - for the expansion of the Sanatorium structure. The property for the new headquarters was ceded by João Borges Filho who dismembered it from the inheritance he had received from his father, João Vieira da Silva Borges. Over time, the original property was incremented by the acquisition of other properties contained in the same estate. Under such circumstances, in 1942, the Sanatorium is transformed into the São Vicente Rest Clinic, now located on Rua João Borges, where it is still located today. Its new headquarters was inaugurated on November $12^{\text {th }}, 1949$ and its construction was performed by Construtora Borges Dutra Ltda., under the ownership of Rafael Borges Dutra, who was also an associate member of the Rest Clinic. During this period it maintained a laboratory, electrocardiogram and x-ray machines, in addition to a system of gases for the care of the hospitalized patients.

One of the characteristics of the Clinic, in this first phase, is the low complexity of the polyclinic consultations and the family-run administration, notably of the Londres family who, over time, acquired the greater portion of the institutions' shares.

The transformation of the Rest Clinic into Hospital had Luiz Roberto Londres, who was the son of Genival, as its central figure at the end of the 1960's. During this period, the model of the rest clinic was being replaced, above all, due to the emergence of private insurance plans which made possible the access to technology and all medical specialties under a single location. This was the chosen path followed by another Rest House of the time, belonging to Dr. White, which was transformed into Silvestre Adventist Hospital.

In spite of the paternal resistances, Luiz Roberto continued with his plans of modification of São Vicente with the participation of Carlos Manuel Nunes, who had been responsible for the transformation of Silvestre, and by the surgeon Fernando Paulino - director of the São José Health Center and founder of the São Miguel Heath Center (1947), in Botafogo, recently extinct - who provided technical support and credibility to the project of Luiz Roberto Londres.

The project contained the construction of a surgical center for small and large scale operations, recuperation and otolaryngology procedures' room, infirmaries, central sterilization unit, modernization of the radiology, obstetrics center 
and adult ICU. The surgical center became administered by Fernando Paulino, which as of 1970, had a formed staff consisting of names such as Urbano Fabrini, Antonio Luiz Medina, Geraldo Terreri and Ivan Lemgruber.

The São Vicente transformation process was long and gradual, reflecting in the expansion of its architectonic complex since 1970 which had always been expanded to accommodate new rooms and new specialties of the clinic. Currently, it supports emergency services, cellular therapy and hospitalization; and cardio-intensive and burn Units and ICU. The maternity ward was deactivated in 2000 and, in 2008, it is anticipated the opening of a new unit in Barra da Tijuca breaking ties with Gávea.

\section{Architetonic description:}

São Vicente Clinic, despite the various expansions carried out by the institution to adapt to the new medical specialties, remains faithful to the constructive and formal typology of its original use as a rest home: located at a privileged site and with traditional architecture, which is expressed through the use of ceramic tiles with overhangs; wood-framed windows of four layers, in glass and with Persian blinds; stained glass and a rich set of volumes, with a highlight for accesses, patios and internal gardens, varandas and balconies.

\section{Register of Preservation:}

It is not listed.

\section{Sources:}

CLÍNICA São Vicente. Capturado em 20 de ago. 2007. Online. Disponível na Internet: http://www.clinicasaovicente.com.br/ pt-br/default.asp

MORAES, M. Algumas considerações sobre a história dos hospitais privados no Rio de Janeiro: o caso da Clínica São Vicente. Rio de Janeiro: Casa de Oswaldo Cruz/Fiocruz, 2005 (Dissertação de mestrado) (mimeo)

Credits: Gisele Sanglard (research and final text) and Renato da Gama-Rosa Costa (Architectural description). 


\section{AFTER 1930}

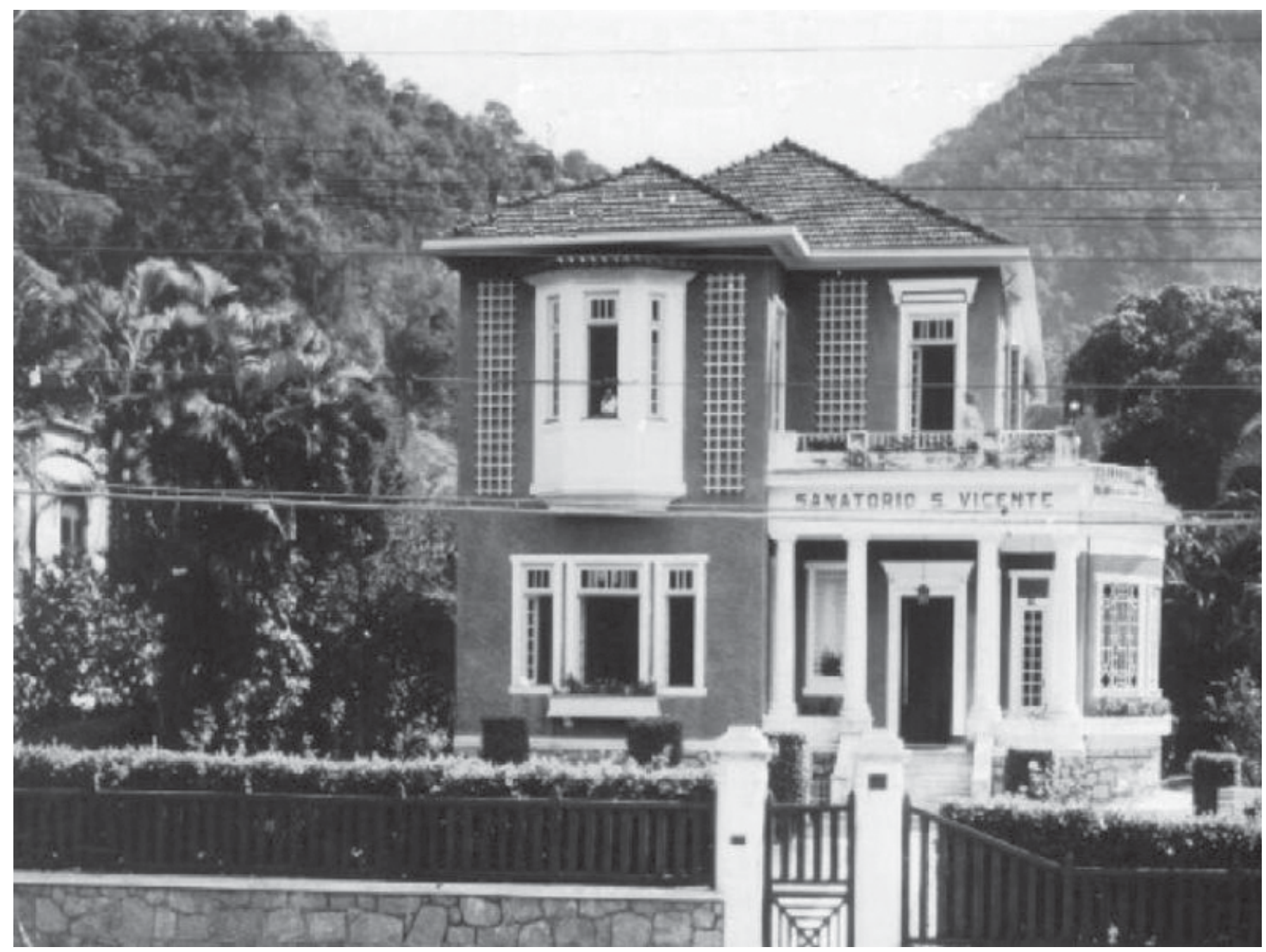

First centre in Marquês de São Vicente Street, 1933. Private Archive 


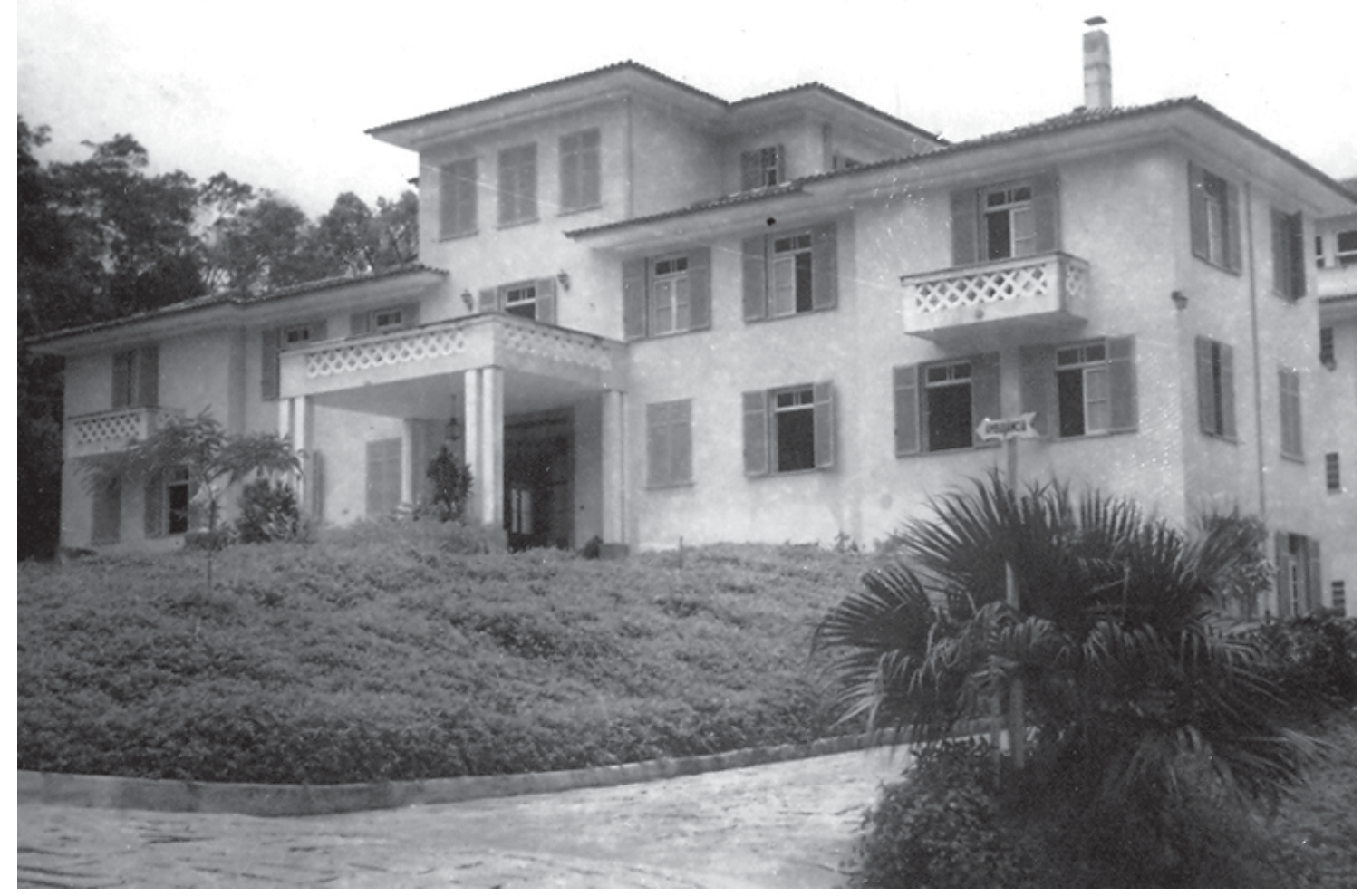

São Vicente Clinic, 1951. Private Archive

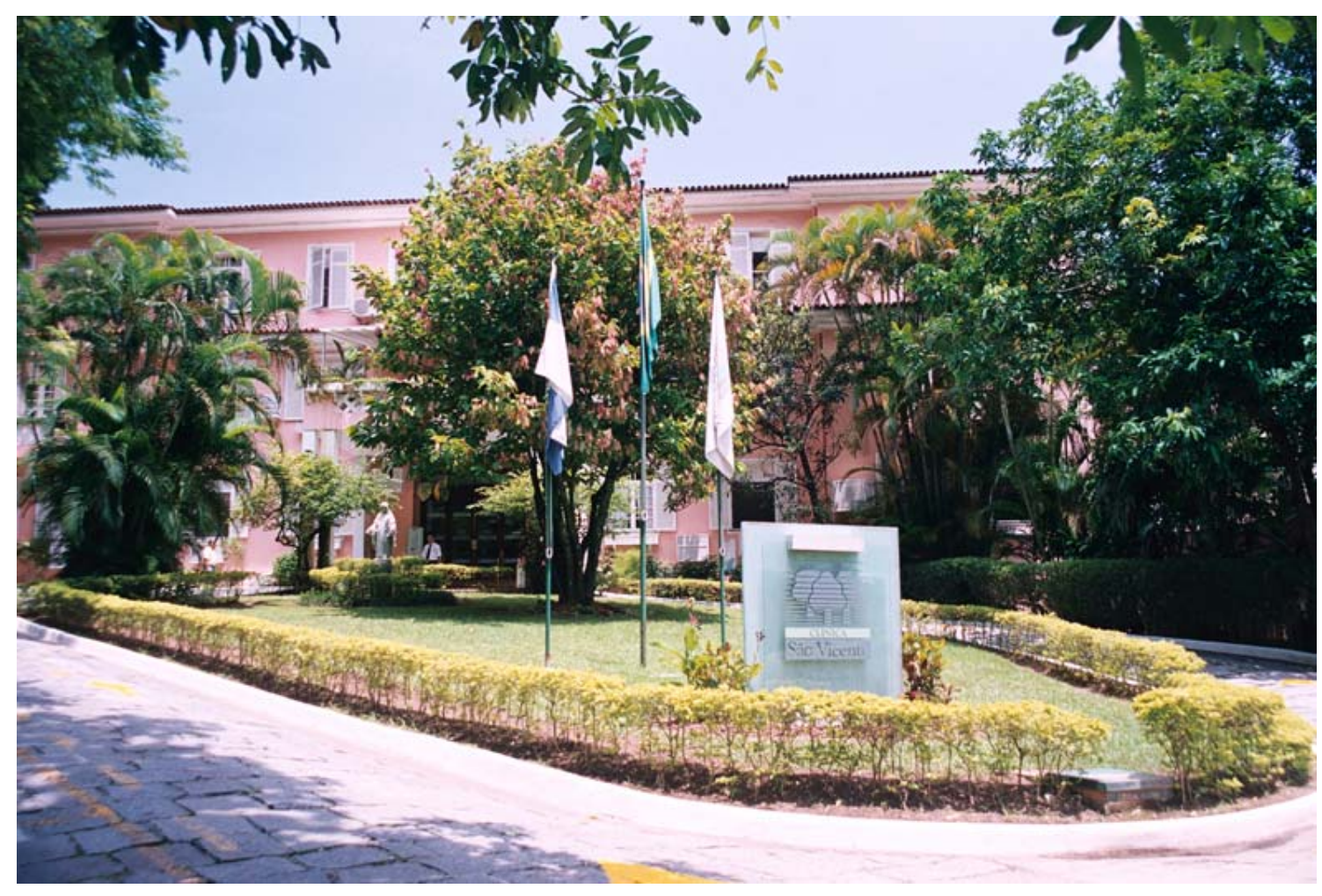

São Vicente Clinic,

[2000]. Private Archive 


\section{Silvestre Adventist Hospital (HAS)}

Other denominations: White Rest Home (1942-1948), Silvestre Sanatorium-Hospital (1948-1950), Silvestre Hospital (1950-1968), Silvestre Adventist Hospital (1968-present day).

\section{Location: Santa Tereza}

Address: Ladeira dos Guararapes, 263.

Category: General Hospital.

Period of construction: 1948-1950; 1977

Proprietor: União Este Brasileira da Igreja Adventista do Sétimo Dia.

Author / Constructor: unknown

\section{History:}

The Silvestre Adventist Hospital (HAS) is part of a network of health institutions established by the Seventh Day Adventist Church (IASD) in 35 countries, making a total of 167 hospitals and 449 clinics. In 1866, Ellen G. White, a North American writer, one of the founders of the IASD, helped to establish the Western Health Reform Institute, in Battle Creek, Michigan, USA, which started off the worldwide medical/missionary project of the denomination, the work of surgeon, philanthropist and inventor, John H. Kellogg being outstanding. The Adventists are noted for their healthy lifestyle, giving value to education and prevention of infirmities and they consider the medical/missionary work as the "right arm" of Evangelism.

The Seventh Day Adventist Church began in Brazil in 1893. However, the first Adventist doctor who arrived in Brazil in 1902, Abel L. Gregory, did not receive permission to practice medicine in Rio de Janeiro and São Paulo. He settled down and opened up a surgery in Taquari, RS.

In Rio de Janeiro, the precursor of the Silvestre Adventist Hospital, the White Rest Home, was inaugurated on November $22^{\text {nd }}, 1942$, with a speech by Clara L. Kienninger, one of the founders of the Anna Nery School of Nursing and representative of the United States for the organization of the war-time blood hospitals. The Clinic was directed by doctor Chester C. Schneider, and functioned until 1948, in the borough of Santa Tereza, at Rua Almirante Alexandrino, 31, in a mansion with 14 rooms and a privileged view of the Federal Capital.

With the purchase of a property at Ladeira dos Guararapes, in 1948, the construction of the Silvestre Sanatorium-/ Hospital was initiated, this being inaugurated on March $12^{\text {th }}, 1950$, and the clinical director was Doctor Galdino N. Vieira. In 1958, in the administration of Edgard M. Berger, the activities of the School of Nursing were started, under the direction of nurse, Júlia Estrela. In 1960, the School of Nursing obtained federal recognition.

In 1962, still in the administration of Edgard Berger, the then Silvestre Hospital began the sale of health bonds.

The need to expand the number of available beds required reforms and expansions of the original building, one taking place in 1963, and another in 1977, when a new seven floor complex was inaugurated.

Its reputation, acquired by the excellence of its medical staff, accredited it for the possible need to care for the sovereign and her entourage, during the visit of queen Elizabeth II to Brazil, in 1968; and for distance heart monitoring of the Pope, João Paulo II and his entourage, on his visit to Brazil in 1980, at the request of the Vatican.

In 1981, the Silvestre Adventist Hospital inaugurated two new consultation centers in Copacabana.

In order to meet the need to expand its network of attendance and to facilitate access to its services, the Hospital inaugurated the Botafogo Medical Center, in a modern building in the borough of Botafogo. Various clinical and diagnostic services are offered there.

In 1998, the Hospital established the Adventist Healthy Living Center (CAVS) in Nova Friburgo, a clinic with 60 beds in an 80 thousand square meter green area. Natural therapy is emphasized and associated with conventional medicine. 
Classified as a large sized private general hospital, it reserves part of its gains for philanthropic purposes. It is connected to and maintained by the East Brazilian Adventist Institution for Prevention and Social Assistance. (IAEBPAS)

\section{Architectural description:}

Different from São Vicente Clinic, in Gávea, the Silvestre Adventist Hospital did not maintain the original formal characteristics of its architecture as a rest home. The adaptations and expansions performed throughout its history have given to the hospital a contemporary look, observed in the new buildings inaugurated in the 1960's and 70's.

The formal language of the White Rest Home, a three floor construction with an elevated basement, denoted protomodern architecture, typical of the 1940's, especially the main entrance, the varandas with rounded lines and the use of typical Copacabana windows. The expansion of 1963 reveals the modern architecture of a general hospital installed in a mono-block building, built upon the foundation of the old clinic. The volumetry adopted highlights the vertical block of six floors, from the base, composed of the ground floor on columns and second and third floors, for administrative use and for the general public, where the parabolic auditorium is the highlight. What makes the façade, in its turn, stand out, are the use of vertical elements for controlling the incidence of the sun and the fire escape, separate from the building, with its own access.

\section{Register of Preservation:}

It is not listed.

\section{Observations:}

A disperse and un-organized reserve of information. Articles about the HAS can be researched in the National Center of Adventist History, at the Adventist University Center of São Paulo in Engenheiro Coelho, SP and at the headquarters of the Brazilian East Union of the IASD.

\section{Sources:}

AZEVEDO, P. O ministério da saúde adventista e o Brasil. Rio de Janeiro: GHAB, 1983.

CHAPMAN. M. Mission of love: a century of Seventh-day Adventist nursing. ASDAN, 2000.

HOSOKAWA, E. Vieram e curaram: a obra médico-missionária da IASD no Brasil. Engenheiro Coelho: UNASP-EC, 2004. VIEIRA, G. Sonhos sonhados, realidades vividas. Santo André: CPB, 1980.

Credits: Elder Hosokawa. (research and text, History Center UNASP SP) and Renato da Gama-Rosa Costa (architectural description). 

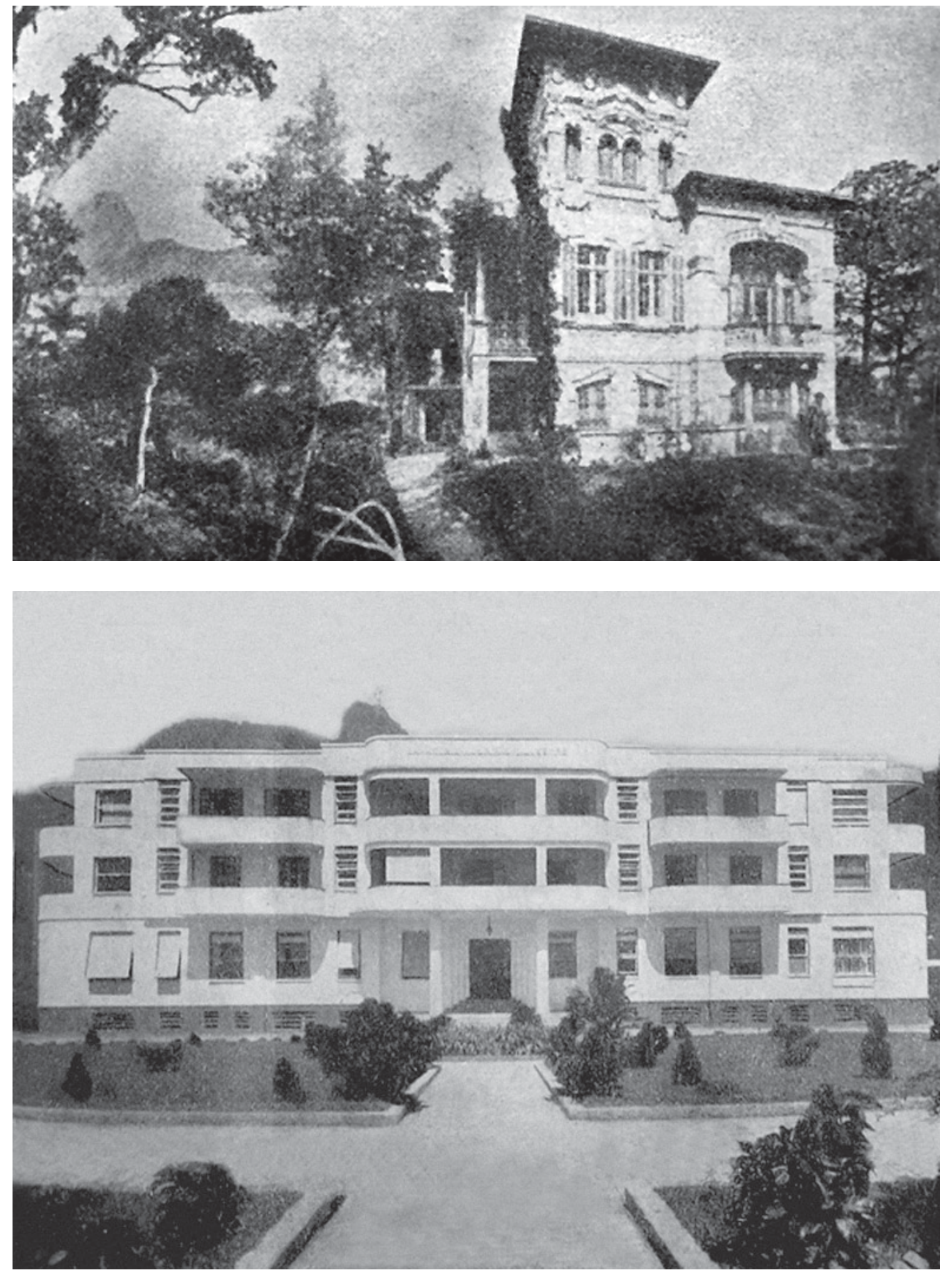

White Resting Home, 1942. East Brazilian Union of the Seventh Day Adventist Church Archives
Silvestre Adventist

Hospital, 1950. East Brazilian Union of the Seventh Day Adventist Church Archives 


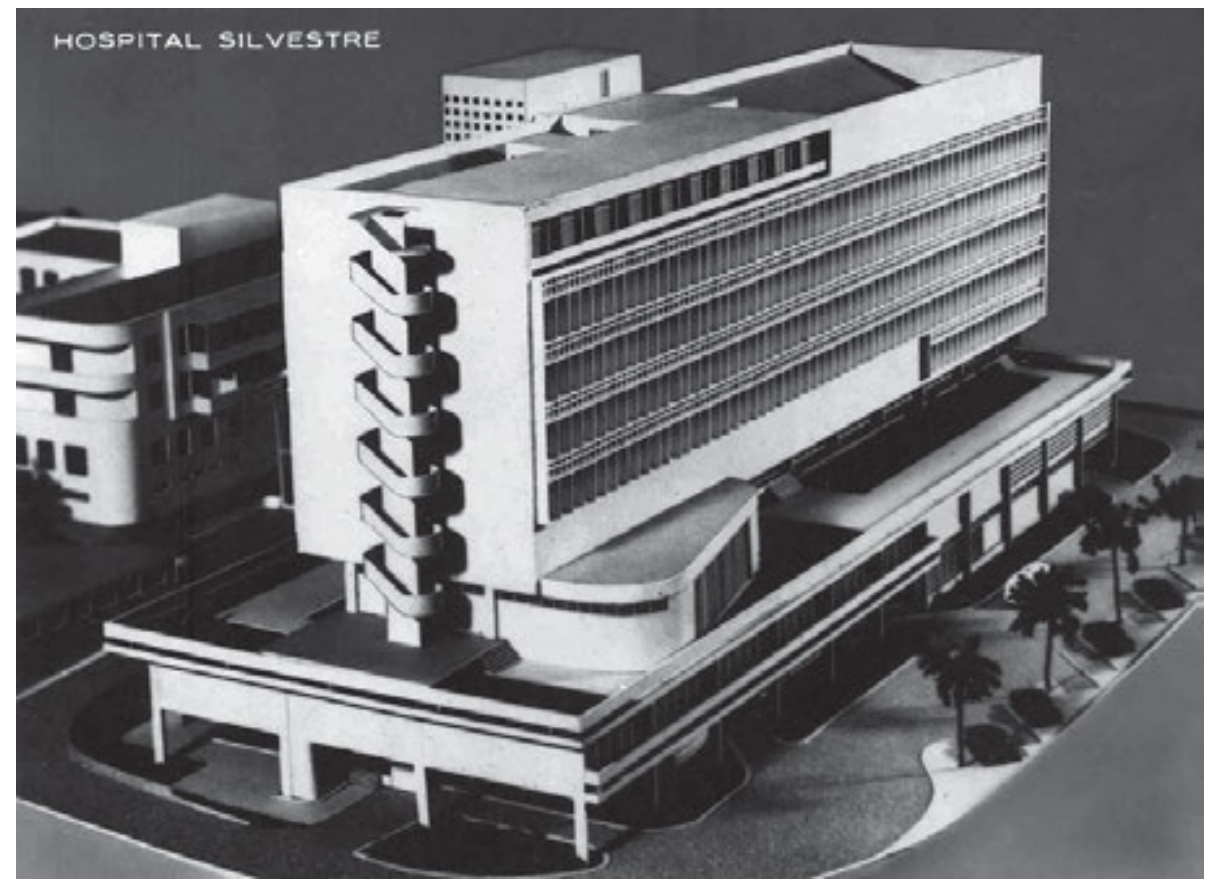

Maquette of Silvestre Adventist Hospital, [1963]. East Brazilian Union of the Seventh Day Adventist Church Archives

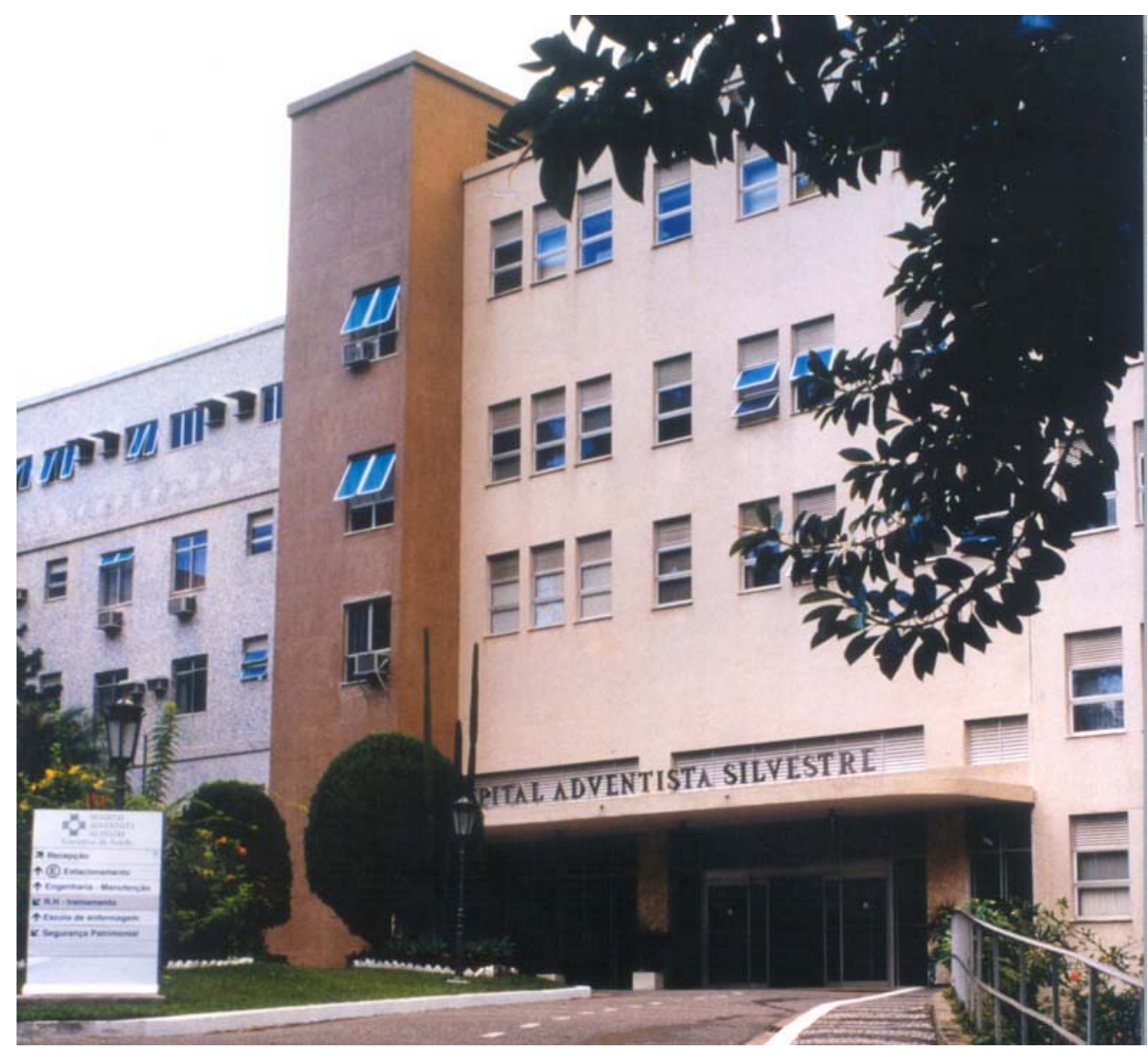

Silvestre Adventist Hospital, 1990. East Brazilian Union of the Seventh Day Adventist Church Archives 


\title{
Servidores do Estado Hospital (State Servants Hospital)
}

\author{
Other denominations: Civil Servant Hospital (1934 - 1938); State Servants Hospital (1938 - present day)
}

Location: Centro

Address: Rua Sacadura Cabral, 178

Category: General Hospital

Period of construction: 1937 - 1947

Proprietor: The Ministry of Heath

Author / Constructor: engineer Dulphe Pinheiro Machado

\section{History:}

Created by the Presidential 24.217 of May 09 ${ }^{\text {th }}, 1934$, the then Civil Servant Hospital had its construction marked by various problems, chiefly of a financial order. Proposed by the Ministry of Labor, Industry and Trade Joaquim Pedro Salgado Filho, idealized by Mário Kroeff and taken over by President Getúlio Vargas, the project was linked to the Special Fund for the Assistance to the Worker, which started to be discounted from the remuneration in 1930. In that same year, a budget was destined for its construction, in a terrain of the (street) Rua Sacadura Cabral.

In the following year, in 1935, a contest was launched for choosing the project, a award which fell to the architect Porto d'Ave. However, the foundation stone of the building was launched only three years later, in June 1937. From that date up to the inauguration in October $28^{\text {th }}, 1947$, more than ten years passed of works being dragged on, a period in which imported equipment was forgotten in Customs. Meanwhile, the original project was modified by the engineer Dulphe Pinheiro Machado, to whom the final authority was awarded, in collaboration with the North-American doctor Felix Lamela, from the Johns Hopkins University, one of the most prestigious public health schools at the time.

On February 23 $3^{\text {rd }}, 1938$ the Institute of Social Security and Assistance of the State Servants (IPASE) was created, by means of Law-Decree No. 288, which receives the encumbrance of managing the hospital under construction. With its link to the IPASE, the Civil Servant Hospital began to be named the State Servants Hospital, having to give medical and dental assistance to its taxpayers and the people from their family.

During its entire construction period, the works were paralyzed several times for lack of resources. The board of directors, responsible for the work, transferred insufficient and variable resources for the development of the construction. Only from 1940, by intermediation of the Civil Service Administrative Department the work started to appear in the General Budget of the Republic, which allowed the works to be accelerated.

The hospital had 600 beds available and would be destined to attending the state civil servants and their family members. The various medical and surgical services, the auxiliary services and the administrative part were distributed throughout its 11 floors: on the first floor, the ambulatories in general and the radiology facility; physiotherapy; radiotherapy; dental services; pharmacy; reception; telephone center and social assistance service. On the $2^{\text {nd }}$ floor the general administration, the management and the other sections of an administrative nature were installed, counting, further, with two infirmaries. On the $3^{\text {rd }}$ floor were the cardiology, neurology and pediatric services. The $4^{\text {th }}$ floor was destined for the medical clinic, with infirmaries, rooms with services, apartments and infirmaries for children. On the $5^{\text {th }}$ and $6^{\text {th }}$ floors were the infirmaries of three to four beds, in addition of attending men and ladies in the specialities of dermatology, otorhinolaryngology, ophthalmology, urology and traumatology. The $7^{\text {th }}$ floor was destined to the gynecology ad obstetrics and the Carmela Dutra Maternity award was inaugurated there, paying homage to the first lady who had just passed away. The $8^{\text {th }}$ floor was destined to the surgery of women and the $9^{\text {th }}$ to the same service for men. On the $10^{\text {th }}$ floor were the mess halls for the doctors, nurses and employees, medical library, auditorium for conferences, material center and general sterilization center. On the $11^{\text {th }}$ floor, the special apartments were located for the President of the 


\section{AFTER 1930}

Republic, State Ministers and Authorities, in addition of the residence of the internal doctors, nursing servants changing room, cold storage rooms, treatment of vegetables, meats and birds in general.

Up to this day, it publishes the (magazine) Revista Médica do HSE which brings the original contributions, or not, on various subjects of medical interest.

The Hospital, on account of its easily accessible location, attends a population not only from the city of Rio de Janeiro but also from the surrounding municipalities. Presently, it has a capacity of 515 beds for internment; its surgical center contains 20 rooms and counts with 50 specialized services. Its ambulatory offers 186 procedure rooms, 5 for surgery and 4 rooms destined to the ophthalmology service.

\section{Architectural Description:}

Its construction meant the full adoption of the North-American model, both in its architecture - the vertical monoblock model - and in the adoption of the internal organization, according to the canons proposed and implemented by the Johns Hopkins University, of Baltimore / USA, such as: the creation of the Information Service, responsible for locating the interned patients; the inauguration of the resident doctors regime for a period of two years; and the centralization of the auxiliary services, such as radiology, clinical analysis laboratory, anesthesia, pathological anatomy, social and diet service, among others.

The North-American influence is perceive also in the adoption of the art déco language, expressed in the cubist elements of the facade; in the details of the frames; the stairs and in the general volumetry and aesthetics, which makes the building unique.

\section{Register of Preservation:}

It is not listed.

\section{Sources:}

HOSPITAL dos Servidores do Estado - um patrimônio de saúde, arquitetura e história. Rio de Janeiro; HSE; 2007.

MORÍNIGO, F. Dos primórdios ao HSE. Revista Médica, n. 35, v. 2. Capturado em 25 de mar. 2007. Online. Disponível na Internet: http://www.hse.ri.saude.gov.br/profissional/revista/35b/primo.asp

SANGLARD, G. et COSTA, R. Hospital dos Servidores do Estado. In: Porto d'Ave - projetos para a saúde, 1920-1940 (catálogo da exposição). Rio de Janeiro: Casa de Oswaldo Cruz/FIOCRUZ, 2007.

Credits: Nathalia Morais and Renato Pereira da Silva (research); and Gisele Sanglard (text and architectural description) 


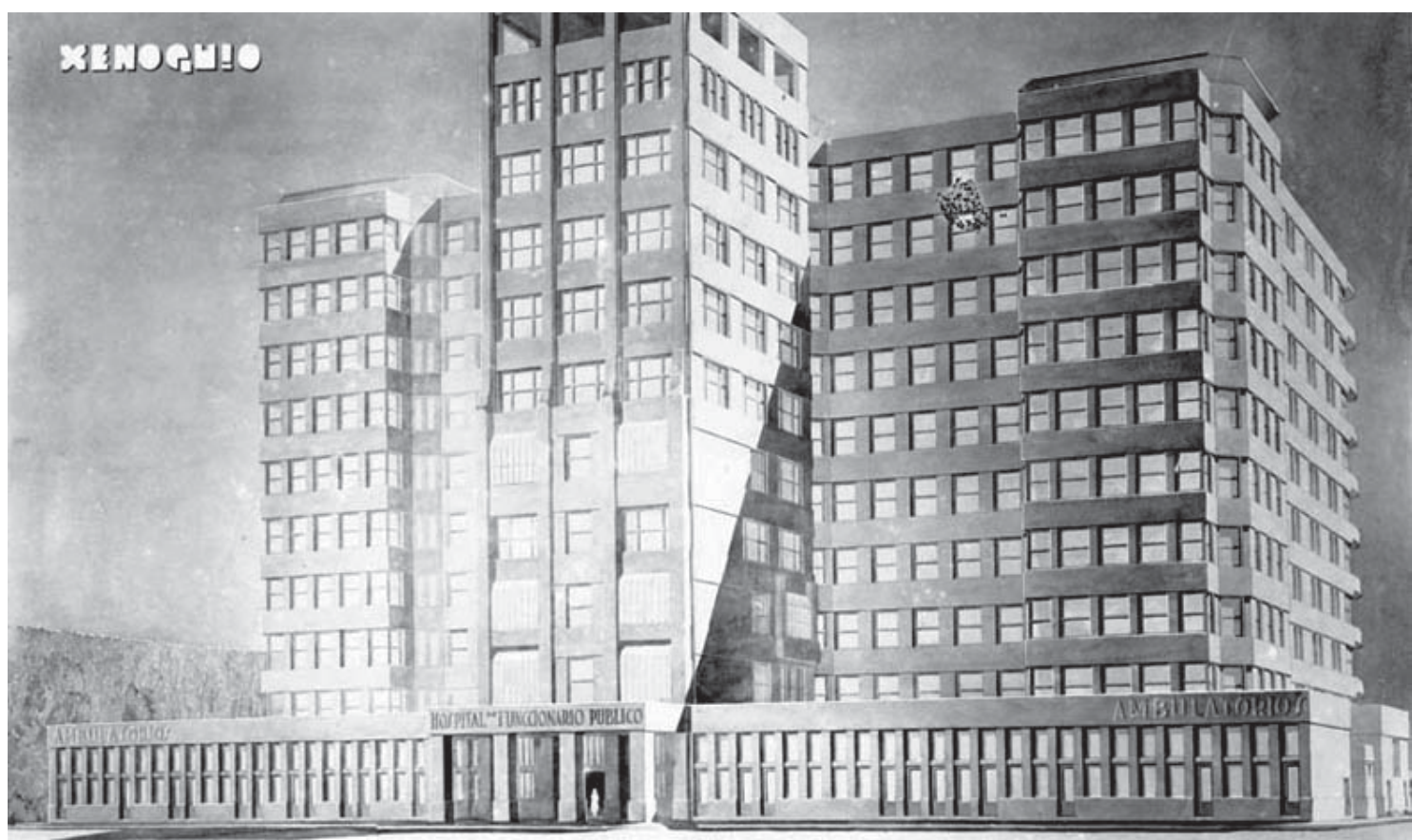

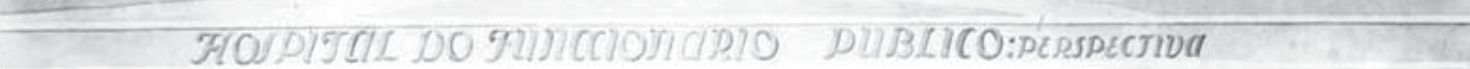

Maquette of Funcinário Público Hospital, Porto d'Ave project, [1935]. Porto d'Ave Fund, Casa de Oswaldo Cruz Archives

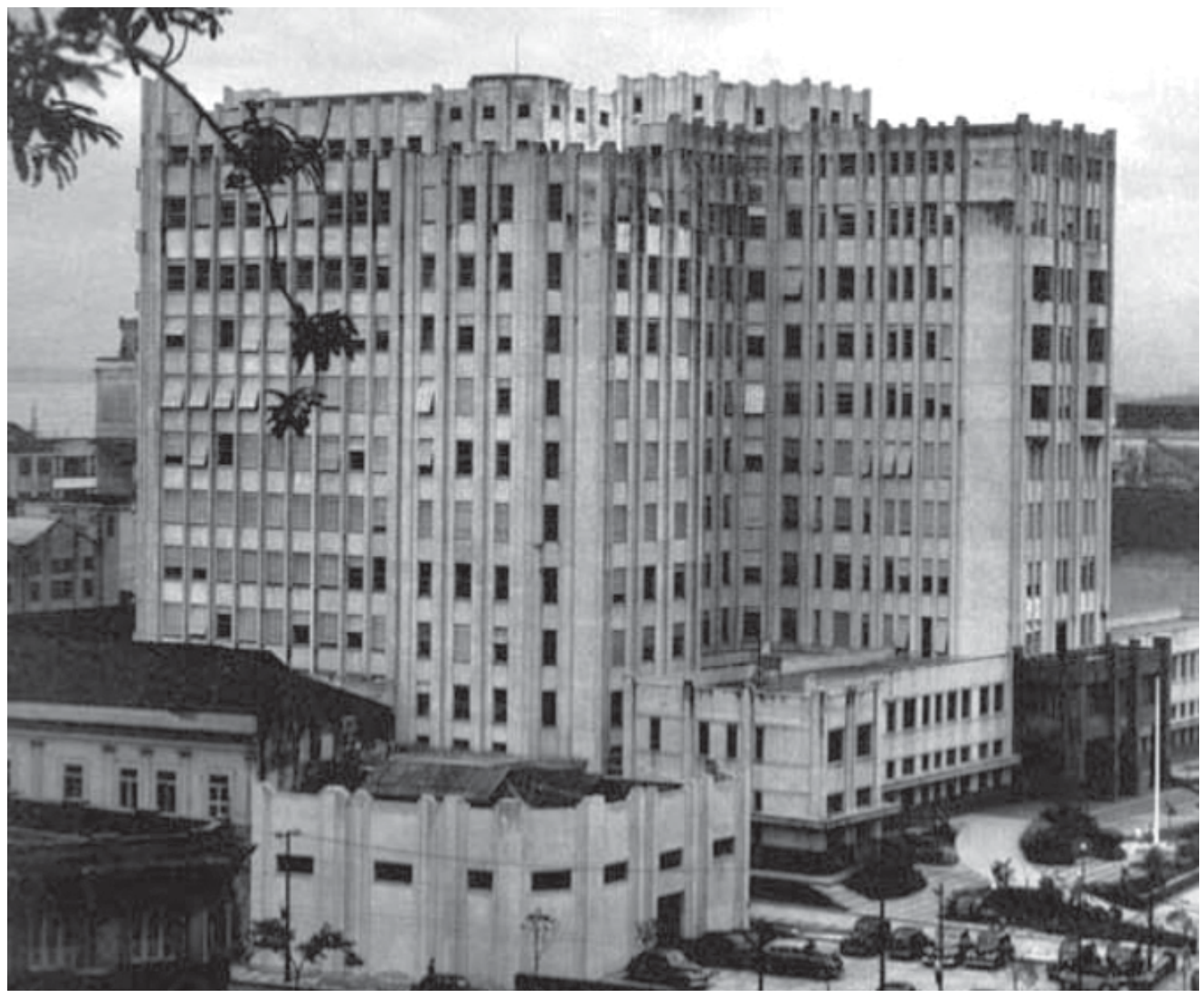

Servidores do Estado Hospital, [195?]. Hospital dos Servidores do Estado Archives 


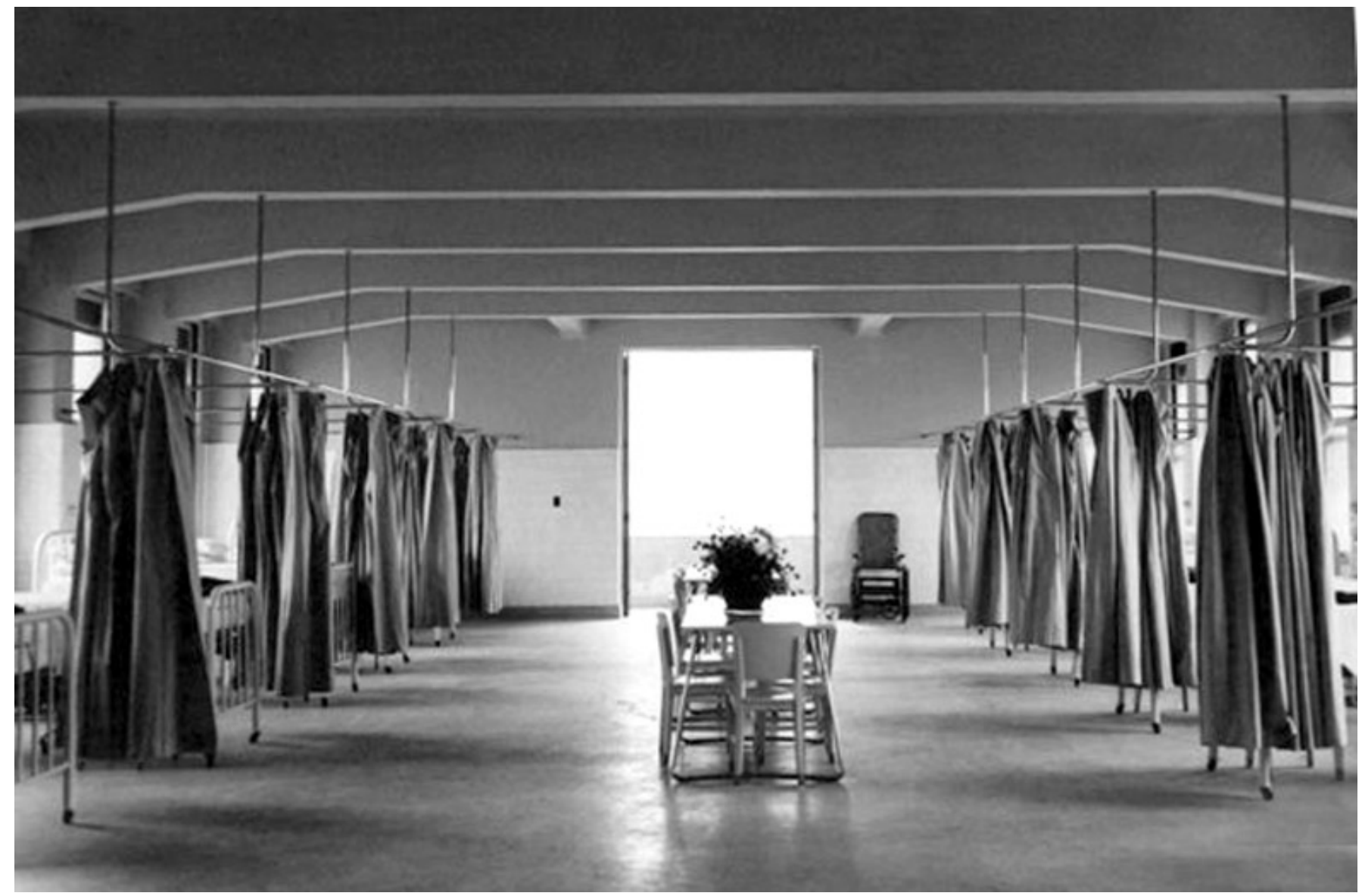

Servidores do Estado Hospital infirmary, [195?]. Hospital dos Servidores do Estado Archives

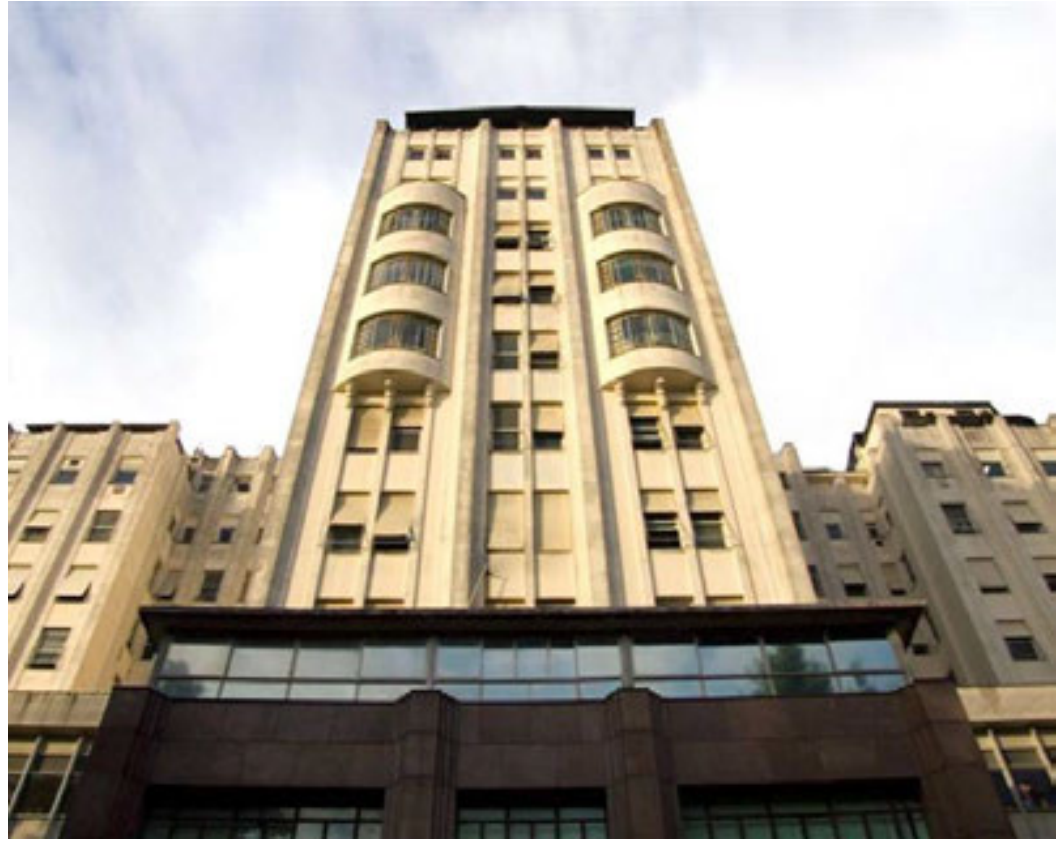

Servidores do Estado Hospital, 2006. Photo Mauro Risch. Hospital dos Servidores do Estado Archives

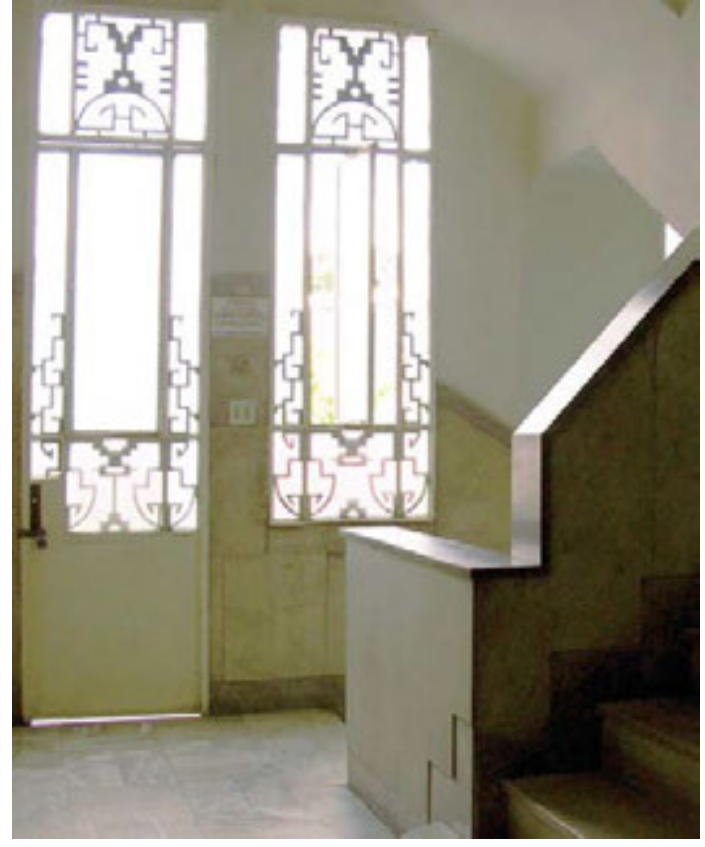

Servidores do Estado Hospital, 2006. Photo Mauro Risch. Hospital dos Servidores do Estado Archives 


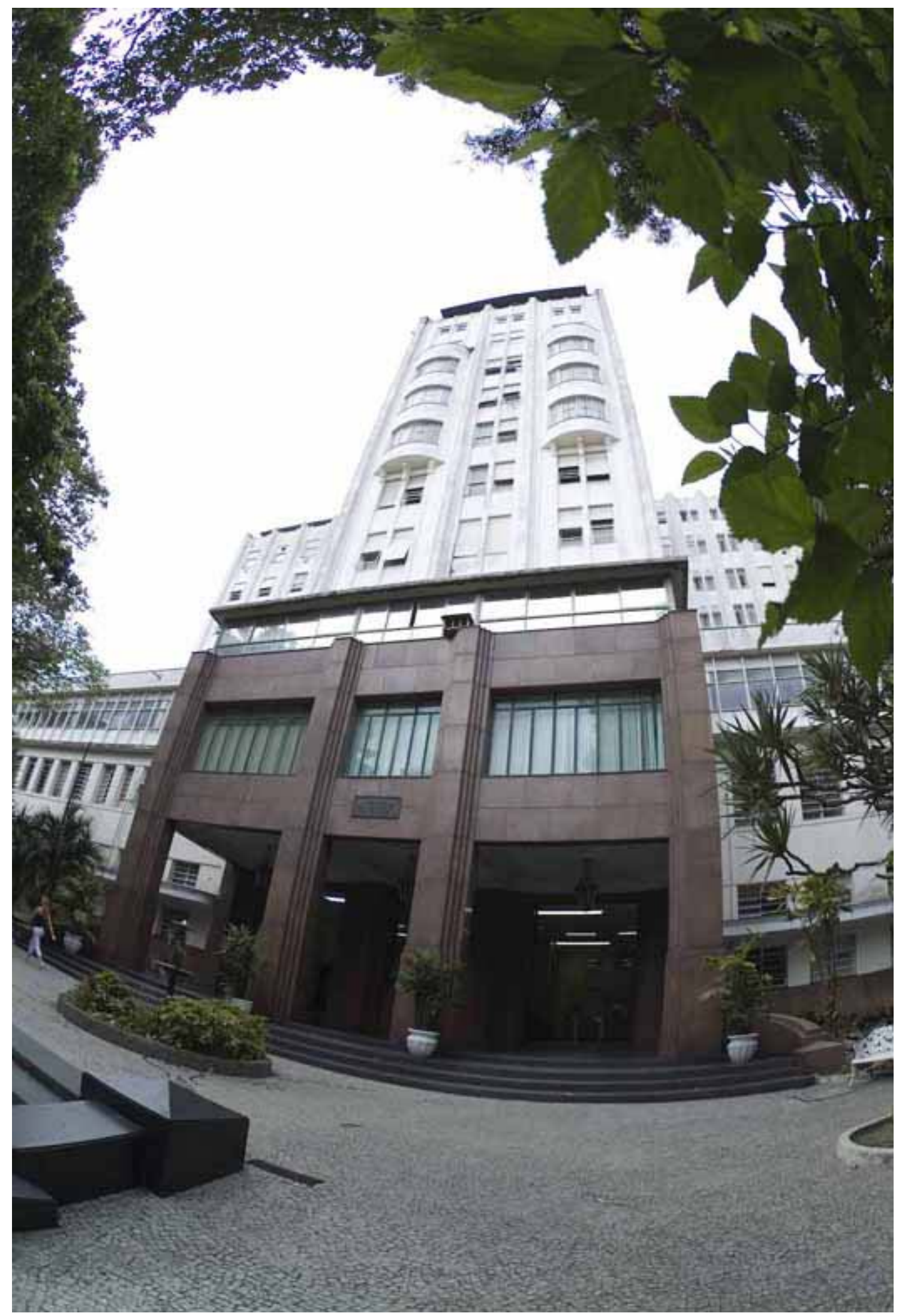

Servidores do Estado Hospital - facade, 2006. Photo Mauro Risch. Source: Hospital dos Servidores do Estado, 2007. 


\section{The Arthur Siqueira Cavalcanti Institute of Hematology}

Other denominations: Blood Bank (1944-); Institute of Hematology (19-)

Location: Downtown

Address: Rua Frei Caneca, 8

Category: Specialized Hospital

Period of construction: 1969

Proprietor: The Government of the State of Rio de Janeiro

Author / Constructor: Escritório Técnico Ary Garcia Roza. Firma Engenharia de Fundação S.A. URBS Imobiliária S.A. Empresa Metropolitana de Construções Metrocon S.A.

\section{History:}

The Arthur Siqueira Cavalcanti Institute of Hematology was created in Rio de Janeiro initially as a Blood Bank, under the administration of Mayor Henrique de Toledo Dodsworth (1937-1945), during World War II. The first headquarters, inaugurated on November $25^{\text {th }}, 1944$, was situated in a building of neoclassic style at Rua Teixeira de Freitas, in Lapa, and used to operate as a blood distribution agency to emergency hospitals in Rio de Janeiro. Its first director and organizer was Doctor Miguel Meira de Vasconcellos.

Arthur de Siqueira Cavalcanti, who was the director during the administration of General Ângelo Mendes de Morais of the Federal District (1947-1951), was the mentor in the transformation of the Blood Bank into the Institute of Hematology, which was named after him.

Act no. 852 of 1956, which was signed by Mayor Negrão de Lima (1956-1958), regulated the denomination change of the Blood Bank to the Institute of Hematology, subordinating it to the General Office of Health and Assistance. The following year, Negrão de Lima promoted the confiscation of buildings located on Rua Frei Caneca, considering them of public utility, so that the new headquarters of the Institute is built there.

Construction work on the building began on March, 1964 in the administration of Carlos Lacerda (1960-1965), however after a period of inaction, resumed in 1967, with some changes in the initial project. The Secretary of Health at the time, Hildebrando Monteiro Marinho, accompanied all stages of the Institute's construction, and insisted that it be finished quickly, to provide the city with what was most modern in the profession, an excellent center of research and training of technicians, and the increment in the service of blood collection, storage and preparation of plasma and derivatives.

During the period of construction work, a Service of Clinical Hematology was temporarily installed in the facilities of the Pedro Ernesto Hospital, belonging to the Institute, which was transferred in 1966, also temporarily to the Aloysio de Casto Cardiology Institute. The definitive headquarters of the Institute was inaugurated on September $29^{\text {th }}, 1969$ - more than ten years, therefore, after the signing of act no. 852 -, in attendance of the Secretary of Health, the Governor of the State and its Benefactor, Arthur de Siqueira Cavalcanti.

Even today the Arthur Siqueira Cavalcanti State Institute of Hematology remains in the same location, and as of 1986, it became known as HEMORIO. Besides operating as a Blood Bank, it maintains a Hematology service both of which are internationally recognized, performing in the fields of assistance, teaching and research and in the technical coordination of HEMORREDE. It also develops the programs "Jovens Salva-Vidas" (Young Life-Rescuers), "Classe Hospitalar" (Hospital Class) and "Círculo de Amigos do Menino Patrulheiro" (Circle of Friends of the Patrol Boy). 


\section{Architectonic Description:}

As of the 1960's, many hospitals underwent restructuring and expansions. The old facilities of these hospitals were obsolete and needed to undergo adaptations to the imposed and consolidated typology coming from North-American mono-blocks. A great number of institutions had their old facilities demolished for the construction of laminas with five, seven or ten floors. Others had annexes built, maintaining the original facilities renovated.

\section{Register of Preservation:}

It is not listed.

\section{Sources:}

http://www.hemorio.rj.gov.br/. Acessado dia 18 de julho de 2007.

SECRETARIA de Estado de Saúde do Rio de Janeiro. Indicadores e Informações em Saúde. In: http://www.saude.rj.gov.br/ informacoes/bancodad.shtml Acessado em 11/10/07.

Credits: Daniel Elian dos Santos (research), Martha Freire (text) and Renato da Gama-Rosa Cosa (architectonic description) 


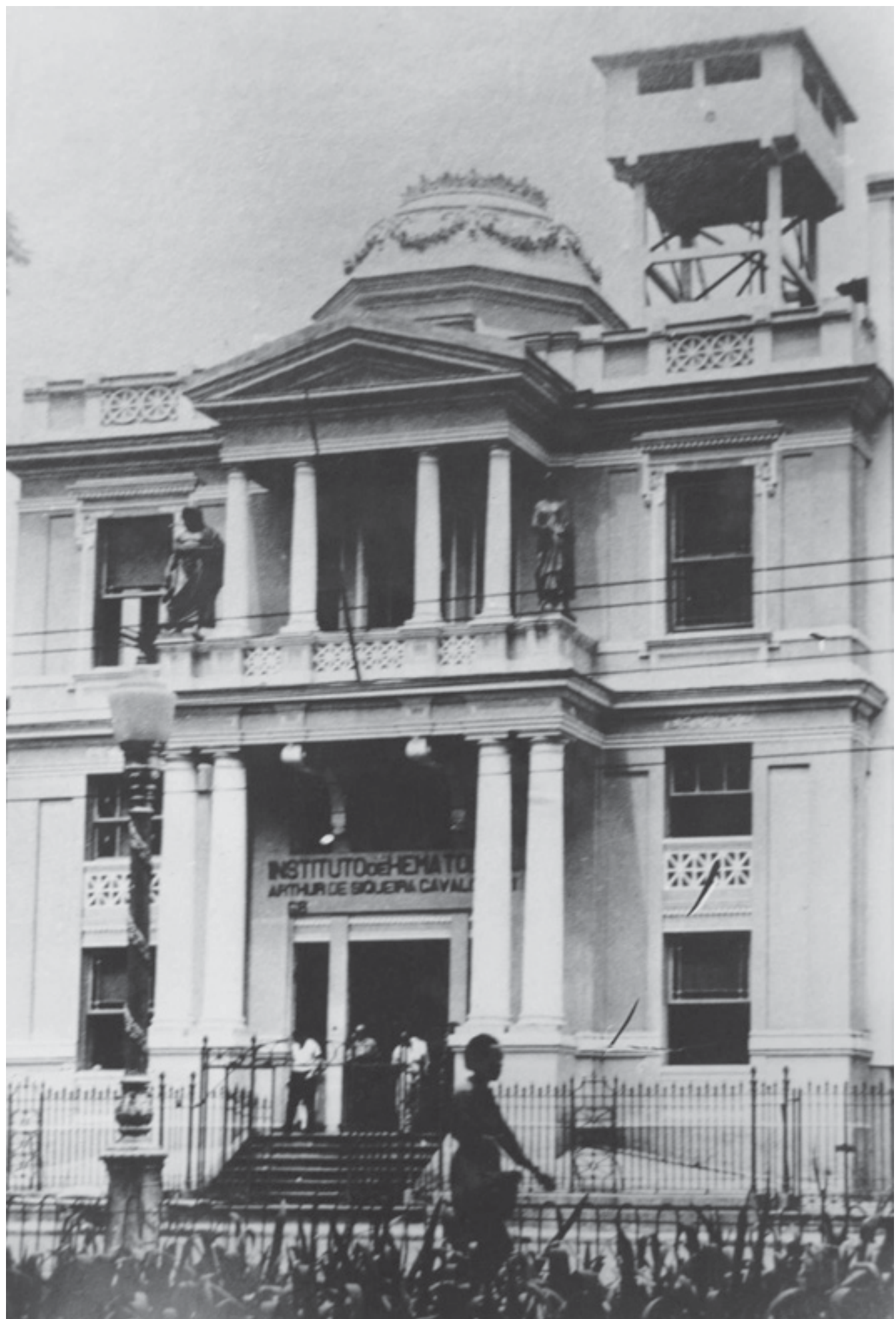

Institute of Hematology, [s.d.]. Private Archive 


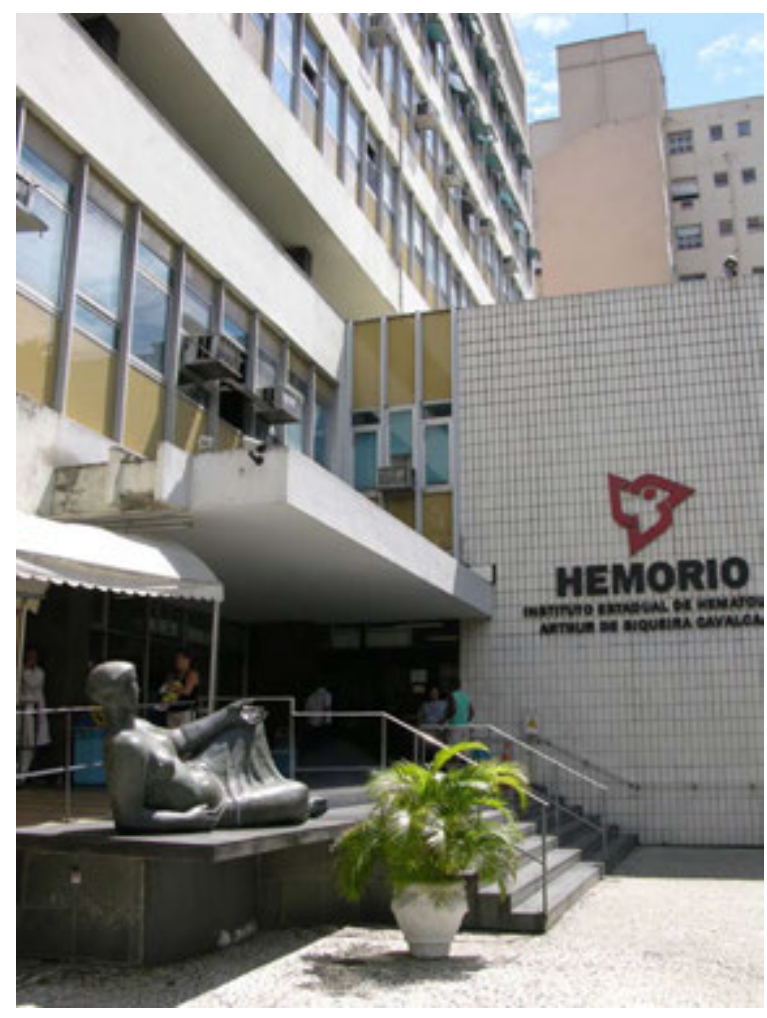

HEMORIO, 2008. Photo Roberto Jesus Oscar \& Vinícius Pequeno de Souza. Casa de Oswaldo Cruz Archives

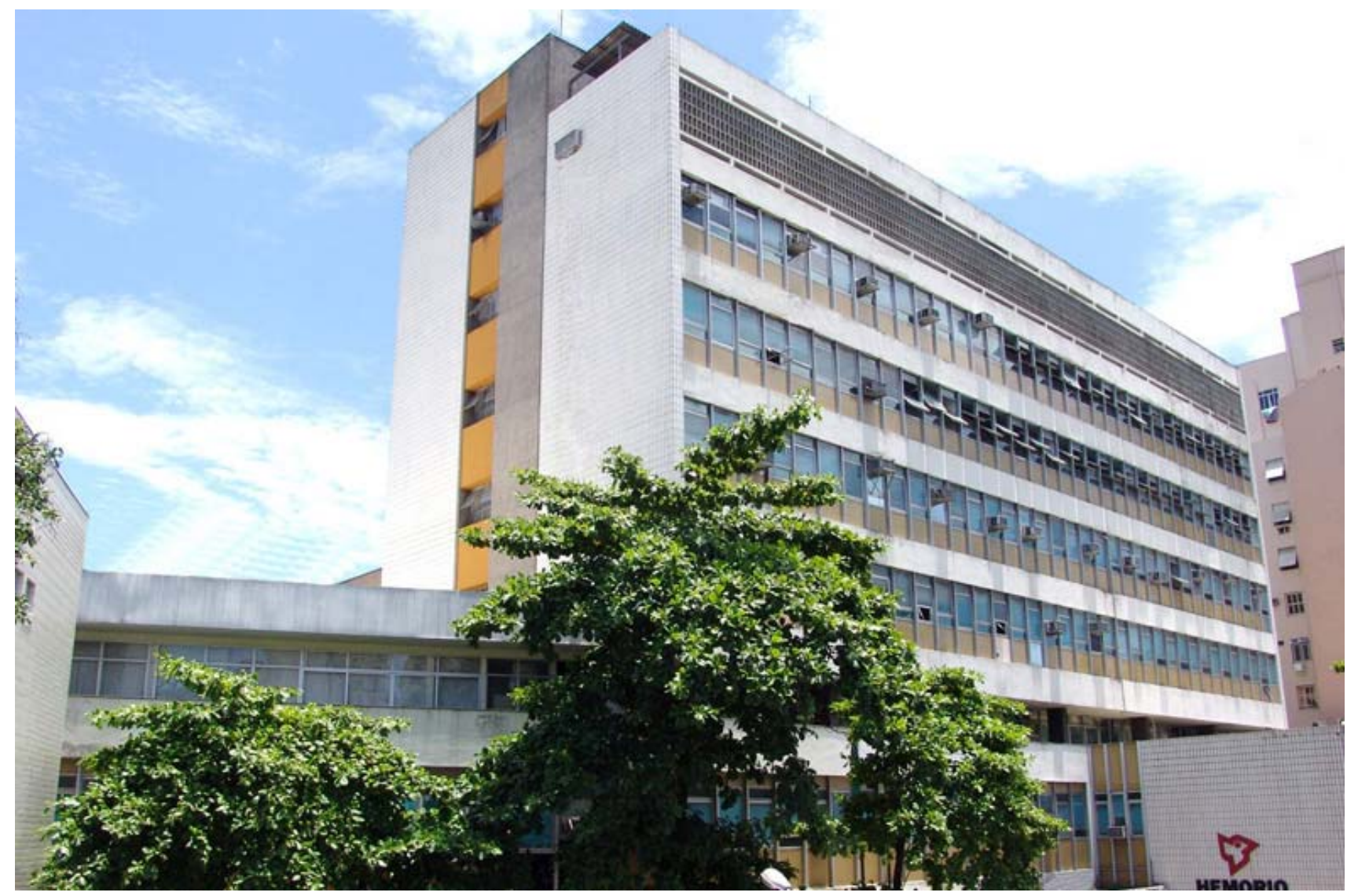

HEMORIO, 2008. Photo Roberto Jesus Oscar \& Vinícius Pequeno de Souza. Casa de Oswaldo Cruz Archives 


\section{University of the State of Rio de Janeiro College of Medical Sciences}

Other denominations: College of Medical Sciences of Rio de Janeiro (1936-1950); University of the Federal District College of Medical Sciences (1950-1958); University of Rio de Janeiro College of Medical Sciences (1958-1961); University of Guanabara State College of Medical Sciences (1961-1975); University of the State of Rio de Janeiro College of Medical Sciences (1975-currently).

Location: Vila Isabel

Address: Rua Professor Manoel de Abreu, 444

Category: Institution of Learning

Period of construction: 1965

Proprietor: University of the State of Rio de Janeiro

Author/constructor: unknown

History:

On December $05^{\text {th }}, 1935$, a group composed by 36 doctors (the majority professors of institutions of higher learning) got together with the purpose of constituting the Congregation of the Business Corporation College of Medical Sciences, a private institution of higher learning created in the confines of the Graffrée-Guinle Foundation. Among the founding doctors were famous names of the national medicine arena at the time: Pedro Ernesto, Álvaro Cumplido de Sant'Anna, Antônio Cardoso Fontes and Rolando Monteiro.

The College of Medical Sciences started working on April $2^{\text {nd }}, 1936$, with an inaugural class by Antônio Cardoso Fontes, who was elected its first director. In the administration until 1940, after his resignation Rolando Monteiro took over the position, and there remained as head of the College's administration for 12 years and was dean of the University of the Federal District, entity to which it was incorporated in 1950.

Working initially at the Gaffrée-Guinle Foundation, located on Rua Mariz e Barros, in the neighborhood of Tijuca, it moved to its first own headquarters on December 23 ${ }^{\text {rd }}$, 1938, at Rua Cadete Ulisses Viana, 35, in São Cristóvão. After three years of service, the official acknowledgement of the institution was solicited by the Congregation of the College of Medical Sciences, conferred by decree no. 5,166, of 01/23/1940.

In 1944, a property was acquired at Rua Fonseca Telles, 121, in the same neighborhood, which had belonged to the Beneficência Espanhola Hospital. The old building was demolished and a new 18-story building was constructed, with the purpose of being the headquarters of the College and its desired clinics hospital.

Before the construction work had been concluded, through the promulgation of Municipal Law no. 547, of 12/04/ 1950, the College of Medical Sciences of Rio de Janeiro was one of the four isolated institutes of higher learning annulled by the University of the Federal District (UDF), together with the College of Economical Sciences of Rio de Janeiro (founded in 1930), the College of Law of Rio de Janeiro (founded in 1935) and the College of Philosophy of the La-Fayette Institute (founded in 1939). The first dean of the newly inaugurated institution was Rolando Monteiro, who assumed on February $15^{\text {th }}, 1952$. He had been the main stimulator behind the creation of the College of Medical Sciences in 1935, and encourager of its institutional development.

In spite of the decree which organized the new university, construction work continued until 1955, when the University of the Federal District was transferred there. In 1957, the acquisition of the shares of the Business Corporation College of Medical Sciences was initiated.

In fact, it was a process of reestablishment for the University of the Federal District, since, in 1935, by municipal decree no. 5,513, of April $4^{\text {th }}$, it was created through the merger of five private institutions of higher learning: Education Institute: School of Sciences; School of Economy and Law; School of Philosophy and Languages and Institute of Arts. This 
university, created by the Intervener of the Federal District, Pedro Ernesto, from the idealization of the Secretary of Education, Anísio Teixeira, lasted for a little while, being extinct in 1939 by decree-law no. 1,063, of January $20^{\text {th }}$.

Until 1962, the students of the College of Medical Sciences had to move around in order to fulfill internships and medical residency in several hospital establishments, such as Santa Casa da Misericórdia of Rio de Janeiro, Cruz Vermelha Hospital, Moncorvo Filho Hospital, and the Pescadores Polyclinic, among others. In the same year, on August $9^{\text {th }}$, Pedro Ernesto General Hospital went to the University which upon the occasion became known as Pedro Ernesto Clinics Hospital.

Still headquartered in São Cristóvão, the distance between the College of Medical Sciences and Pedro Ernesto Hospital began to impair the teaching due to the need to conciliate the theoretical part with the practical activities in the clinical services of the Hospital. In order to by-pass this problem restorations in two buildings on Rua Teodoro da Silva were carried out, granted by the State. Upon the conclusion of the construction work, the College of Medical Sciences was installed there on March $18^{\text {th }}, 1965$.

After being incorporated by the University of the Federal District, the team of professors at the College of Medical Sciences had available some professionals who were contracted by examination and, most of them, at the time professors of the College foundation.

The Congregation of the College of Medical Sciences, as well as of the other learning units, was responsible for the organization and approval of the leaning programs. These procedures continued even after the incorporation; as the University stabilized itself, Basic Institutes were created, in charge of structuring, managing and conducting the learning of their component courses.

The University of the Federal District approved the bylaws of the College of Medical Sciences on December $8^{\text {th }}, 1955$. In 1959, the congregation organized its first curricular reform after the incorporation, executed only in the following year.

Although the development of the university structure and the increase in the demand for academic education in the field of medicine, the College of Medical Sciences, except for the College of Economy, was the one which least attracted students among the four colleges at UDF. Between 1954 and 1956, the total number of students was 600, 601 and 634, respectively. Comparatively, the College of Law attracted during the same period 1800, 1643 and 1608 students. (MANCEBO, 1996:69).

Following the political changes that were happening in the country, the University of the Federal District changed its name several times, consequently changing the complementary denomination of its College of Medical Sciences. By Act no. 909, of 06/16/1958, it became known as the University of Rio de Janeiro (URJ). With the transfer of the Federal District to Brasília, the new capital of the country, it became denominated the University of Guanabara State (UEG), in 1961. In 1975, with the merger of the states of Rio de Janeiro and Guanabara, it received its current title, University of the State of Rio de Janeiro (UERJ).

Currently, the College of Medical Sciences is located outside the UERJ Maracanã campus, carrying out learning and research activities at the Américo Piquet Carneiro Pavilion, in the neighborhood of Vila Isabel. This Pavilion is part of the Biomedical Campus, formed by the buildings Piquet Carneiro and Paulo de Carvalho. In addition, it carries out medical and surgical training at the Pedro Ernesto University Hospital and at the Piquet Carneiro Polyclinic.

The College of Medical Sciences, while it had been an isolated institute, kept the publication of the journal Raios X, founded in 1949 by Rolando Monteiro and Agamémnon Parente Moraes. As part of the University of Guanabara State, it published its research work and circulated news through the magazine Revista da Universidade do Estado da Guanabara.

\section{Register of Preservation:}

It is not listed. 


\section{Sources:}

CARNEIRO, A. Breve Histórico do Hospital de Clínicas da Faculdade de Ciências Médicas. Revista da Universidade do Estado da Guanabara, Rio de Janeiro, ano 1, nº. 1, mar. 1963. p. 27-30.

MANCEBO, D. Da gênese aos compromissos. Uma História da UERJ. Rio de Janeiro: Ed. UERJ, 1996.

PARDAL, Paulo. UERJ - Apontamentos sobre sua origem. Rio de Janeiro: UERJ, 1990.

Credits: Atiele Azevedo de Lima Lopes (research and text) 


\section{Glossary}

In this glossary the reader will find specific definitions about health institutions that used to and continue to be a part of everyday healthcare.

Hospital Shelter: Semi-hospital institution designed for short-term patient care.

Hospital Hostel: Semi-hospital institution designed for admission of patients for up to 24 hours.

Outpatient Clinic: A place where assistance is provided, without hospital admission. It is a service designed to diagnose and treat patients without admitting them to a hospital.

Nursing Home: Institution of social assistance, normally maintained by philanthropic institutions, aimed at helping poor, elderly or retired people, who do not have a place to live and are not helped by others, providing them home, food and hygienic and health care.

Nursing care: Activity performed by one or more nursing professionals aimed at improving and protecting health and aiding in the recovery and rehabilitation of sick people.

Home care: Activity performed by one or more nursing professionals at the patient's home.

Hospital care: Activities performed by one or more health professionals which involves admission to a hospital. This is performed at general hospitals, also known erroneously as polyclinics and in specialized hospitals, treating both admitted patients and people using outpatient services, with a higher proportion of medical care as opposed to social work. This represents all the medical and social assistance upon which the Hospital is based, whatever its specialization or type.

Medical care: Activities performed by a physician to promote and protect patient health and help recovery and rehabilitation of sick people.

Medical and social assistance: Social Assistance activities in which medical care is the principal aspect. It covers hospital and emergency medical care. Thus, it includes all institutions that exercise or maintain medical and social care, which may be professional or technical, such as help and support to patients. It is not considered as official charitable work.

Emergency medical care: A set of actions taken by institutions with objectives similar to hospitals or complementary to hospital care, such as: clinics or polyclinics or independent infirmaries, dispensaries, independent outpatient clinics, spas (hydro-mineral, thermal, climatic), nursing homes, hospital shelters and hostels. This is the specific area of social service. 
Public Health Authority: Qualified authority within the health care area with legal powers to establish regulations and issue licenses (authorizations) and perform inspections.

Rest home: Institution destined to the recuperation of patients with physical or mental stress, with no organic injuries.

Proprietary hospital: General or specialized for-profit hospital.

Convalescence Clinic: Institution to where sick patients with reduced needs for medical and nursing care are transferred.

Clinic: Institution or hospital service whose purpose is to diagnose and treat patients within a single specialty.

Farm colony: Farm establishment where some prisoners serve their jail sentences and do agricultural work. It is also a place where mentally disturbed people are treated.

Disinfectory: Hospital establishment where the disinfecting of certain diseases is performed.

Dispensary: Not-for-profit establishment where poor sick people receive free medical treatment, social assistance, medicine and clothing.

Hospital constructions: follow the following types: pavilion type or with several buildings, single structure, mixed type, main building. In the pavilion system the different buildings are connected by galleries or covered floors or by underground corridors, which do not affect the landscaping nor the surface esthetics. The single building type, as already mentioned, includes the whole hospital in a single structure.

Infirmary Wards: 1 . Included in this category are establishments which offer less than 25 beds for medical care. 2. Rooms containing accommodations for 4, 5 or more patients. In the general hospital the infirmaries must have no more than 8 beds. It is a section of the hospital designed to lodge three or more patients.

Basic Medical Specialties: There are four basic specialties: general medicine, surgery, gynecology-obstetrics and pediatrics.

Critical (Strategic) Medical Specialties: medical specialties which are particularly important in a particular geographical area because of certain ailments common in the area or difficulties in access to more sophisticated establishments.

Asylum: home where poor or sick people live and are treated for free; hospital. It is also a hospital used for treatment or lodging sick or mental disturbed people.

Surgical Hospitals: this includes establishments specializing in trauma and orthopedics, ear, nose and throat disorders, ophthalmology, gynecology, cancer, work injuries and other surgical specialties.

Medical Hospitals: These are establishments specializing in: mental and neural diseases, tuberculosis, leprosy, isolation (and other contagious diseases), general medicine, cardiology, pediatrics, venereal diseases and other medical specialties. 
Polyclinical Hospitals: Hospital establishments dealing with several specialties including general medicine, surgery and others.

Base Hospital: Its purpose is to perform medical and public health activities and serve as the coordination center and integration of the medical and hospital services in a particular area, and also must be qualified to provide more diversified specialized assistance, as well as provide basic and specialized training for hospital personnel.

\section{Teaching Hospital or School Hospital: see University Hospital}

District or Regional Hospital: This type of institution performs public health activities and provides more complete medical assistance, in conjunction with Public Health units and Local Hospitals.

Specialized Hospital: A single-purpose institution aimed at providing health care in a certain specialty or related specialties. Example: tuberculosis, cardiology, venereal diseases, etc. or to certain restricted groups of diseases that are considered as related specialties. They are divided into four groups: maternities and nurseries, medical hospitals, surgical hospitals, hospitals for chronic or incurable diseases, convalescence hospitals.

General Hospital: A multi-purpose hospital aimed at providing medical assistance in the following specialties: general medicine, pediatrics, gynecology-obstetrics, surgery and others. It receives all or many types of sick people with different ailments. Typical examples are the 'Public Charity Hospitals'(Santas Casas da Misericórdia) and certain public hospitals and emergency hospitals. It receives visits of patients in need of general or specialized clinical resources. They are classified into the following categories: Public Health Units, Local or Community Hospitals, Regional or District Hospitals, Base Hospitals, BasicLevel Teaching Hospitals.

Local or Community Hospital: these are hospitals which, as a part of their medical, clinical, surgical, obstetrical and pediatric assistance program, assists public health personnel, according to the availability of their staff and equipment.

University Hospital: A base hospital used to provide basic and continuing training to doctors and professionals in this area. A University Hospital or Teaching Hospital is a center of hospital-type assistance maintained by universities, normally used as base for apprenticeship of students from courses like Nursing and Medicine.

Hospital: Establishment designed to provide inpatient health care to the population and which may also provide outpatients and other services. Hospital classification is based on size: small (25 to 49 beds), medium (50 to 149 beds), large (150 to 500 beds) and very large (more than 500 beds). It admits patients for diagnoses and medical treatment, in addition to assisting those who do not require hospitalization. It also works toward the social recovery of the patients, in addition to providing public health education, basic and on-going training of hospital personnel, making surveys and performing medical research.

Public Health Unit: (Medical and Public Health Unit, Mixed-Activity Unit, Integrated Health Unit) is one which provides medical care including hospitalization for clinical and urgent surgeries, obstetrics and public health ailments. 
Proprietary Institutions: These are institutions which seek to earn a profit or distribute dividends.

Non-Profit Institutions: These institutions do not seek to earn profits, distribute dividends or other financial advantages, and which assist, for the most part, a certain number of patients (associates, people with specific health insurance coverage, members of charitable institutions, etc).

Philanthropic institutions: These institutions allocate all their income to providing free medical and social assistance and makes available at least one-third of their beds for free medical care for the general public.

Public Institution: Institution belonging to a government entity.

Semi-Hospital Institution: An institution where social assistance is more important than medical care.

Private Institution: Institution belonging to a private organization.

Non-Official or Private Institutions: These institutions can be divided into philanthropic, non-profit, for profit. In the first group are charitable institutions, those free medical assistance, those belonging to churches, brotherhoods, foundations and other corporations. Non-profit institutions, similarly, like philanthropic institutions, are maintained by corporations, industrial plants or employee organizations; are those run by cooperatives, professional associations, schools or universities, charities, community chests, religious orders, etc., in other words, organizations which do not distribute dividends or profits, and whose income is destined exclusively to the medical and social objectives, to maintain, improve and expand the respective institutions; for the benefit of health care. Among the for-profit institutions are proprietary hospitals, hospitals run by physicians, common stock and limited liability companies, with the purpose of exercising an industrial or commercial activity; of a firm, corporation, etc.

Official or governmental institutions: These may be run by the federal, state and municipal governments and belong to or run by the Army, Navy, Air Force, Police Department, Fire Department, Public Health Department, Public Social Assistance Entities, Federal and State Universities, etc.

Clinical institute: An institution whose purpose is to provide diagnoses, treatment and perform research.

Boarding School: School where students not only study, but also live with their schoolmates in lodgings normally attached to the main building. The institution may board its students only on weekdays (from Monday to Friday) or also over the weekends.

Maternity: Department of a Hospital which take cares of women giving birth, relating both to medical care and hospitalization at the time of childbirth. It may also refer to a Hospital dedicated exclusively to this activity.

Nosocomy: A place where patients are received for treatment; a synonym for Hospital.

Pavilion: a separate or attached construction where one or more types of hospital services are performed.

Polyclinic: hospital that offers medical care in several medical specialties.

Public Health Clinic: Public medical care facility 
Preventorium: An establishment where people are admitted who have been exposed to any kind of disease-causing agent, until it can be verified that they have contracted the disease or not. It is an institution which boards children of persons with tuberculosis or leprosy people, to take them out of the contagious environment.

Emergency Hospital: Hospital for urgent medical assistance.

Health Care Establishment Networks: A group of health care establishments, organized by region and specialty, by level of complexity, qualified to solve all health problems of the population within its area.

Sanatorium: Buildings to where people with tuberculosis, leprosy or mental disorders were sent, thus remaining completely isolated from society. As a general rule, they were located in high and airy places, providing a special contact with nature.

Medical social services: Service provided to patients and his/her families aimed at removing social problems which interfere with the patient's treatment and his/her reintegration into the community.

Social service: a group of experts who seek to use community resources to promote the reintegration of individuals or groups in need of assistance to the social environment.

\section{Bibliography}

DICIONÁRIO Barsa da Língua Portuguesa. São Paulo: Barsa Planeta, 2005.

DIVISÃO e Organização Hospitalar. Assistência Médica e Social. Arquivos de Higiene, Rio de Janeiro, vol. 13, 1943.

MINISTÉRIO da Saúde. Departamento Nacional de Saúde. História e Evolução dos Hospitais. 2a ed. Rio de Janeiro, 1965.

. Agência Nacional de Vigilância Sanitária (ANVISA). Glossário de termos comuns nos serviços de saúde do Mercosul. Capturado em 17 out. 2007. Online. Disponível na Internet:

http://e-legis.anvisa.gov.br/leisref/public/showAct.php?mode=PRINT_VERSION\&id=6

Wikipédia. A Enciclopédia livre. Capturado em 29 de jan. 2008. Online. Disponível na Internet: http:// pt.wikipedia.org 